\title{
CONTRIBUIÇÕES PARA UMA TEORIA DA DISCRIMINAÇÃO NAS RELAÇÕES DE TRABALHO
}

Tese de Doutorado apresentada à Banca Examinadora da Faculdade de Direito da Universidade de São Paulo, como exigência parcial para a obtenção do título de Doutor em Direito, sob orientação da Prof ${ }^{a}$. Dr ${ }^{\mathrm{a}}$. Walküre Lopes Ribeiro da Silva

\section{FACULDADE DE DIREITO DA USP}

SÃO PAULO, 2010 


\section{RESUMO}

O principal objetivo da pesquisa é revelar e examinar os principais elementos encontrados nas condutas discriminatórias nas relações de trabalho, como alicerce de uma teoria da discriminação nas relações de trabalho. A tese extraiu conceitos e princípios antidiscriminatórios mediante a identificação e estudo dos componentes das práticas discriminatórias. As conclusões da investigação foram baseadas no direito antidiscriminatório geral, bem como no direito antidiscriminatório laboral. A pesquisa tem início na busca das origens da expressão discriminação, dentro de seu sentido pejorativo, como tratamento diferenciado ilícito. Posteriormente, faz uma avaliação do significado e do alcance do dever de tratamento igualitário, bem como demonstra a natureza destacada das normas antidiscriminatórias. É procedida a identificação dos componentes de uma prática discriminatória através do exame detalhado de suas principais características. Igualmente são apresentados os mais interessantes conceitos doutrinários, normativos e jurisprudenciais sobre a discriminação laboral, bem como as modalidades discriminatórias mais comuns. Dos componentes apresentados são colhidos alguns princípios antidiscriminatórios laborais envolvidos, tanto materiais como processuais. Por fim, é abordada a complexa e preocupante situação da discriminação praticada contra trabalhadores migrantes, em face de ser uma modalidade que tem vislumbrado crescentes dificuldades no seu combate. Como conclusão da pesquisa, é proposto um conceito de prática discriminatória nas relações do trabalho.

Palavras-chave: Discriminação. Relações do Trabalho. Conceito. Conduta discriminatória. Princípios antidiscriminatórios. Trabalhadores Migrantes. 


\section{ABSTRACT}

The main objective of the study is to uncover and examine the principal elements found in discriminatory conduct in work relationships, as a foundation of a theory of work relation discrimination. This thesis extracted concepts and antidiscrimination principles by identifying and studying the components of discriminatory practices. The investigation's conclusions were based on both general and labor antidiscrimination law. The study begins with a search for the origins of the expression discrimination, in its pejorative sense, as illicit differentiated treatment. Later, it evaluates the meaning and scope of the duty of equal treatment, as well as it demonstrates the outstanding nature of the antidiscrimination norms. Next, in the study, the identification of components of discriminatory practices is done through a detailed examination of their main characteristics. The most interesting, doctrinaire, normative and jurisprudential concepts are presented in the same manner, which are related to work discrimination as well as to the most common discriminatory modalities. Some labor antidiscrimination principles, both material and procedural, result from the concepts here presented. Finally, the complex and preoccupying situation of the discrimination practiced against migrating workers is addressed, in light of the fact that this is a modality of discrimination which has become ever more difficult to combat. As a final conclusion of this study, a concept of discriminatory practice is proposed in work relations.

Keywords: Discrimination. Work Relationship. Concept. Discriminatory practice. Antidiscrimination principles. Migrating workers. 


\section{RÉSUMÉ}

Le principal objectif de la recherche est révéler et examiner les principaux éléments trouvés dans les conduites discriminatoires sur les relations de travail, comme le fondement d'une théorie de la discrimination sur les relations de travail. La thèse a extrait des concepts et principes antidiscriminatoires moyennant l'identification et étude des composantes des pratiques discriminatoires. Les conclusions de la recherche ont été basées sur le droit antidiscriminatoire général, ainsi que sur le droit antidiscriminatoire du travail. La recherche a du début dans la recherche des origines de l'expression discrimination, dans son sens péjoratif, car un traitement illégal différentiel. Ultérieurement, il fait une évaluation de la signification et de l'obligation d'égalité de traitement ainsi que démontre la nature détachée des normes antidiscriminatoires. Est procédée identification des composantes d'une pratique discriminatoire par l'examen détaillé de leurs principales caractéristiques. Également sont présentés les plus intéressants concepts doctrinaux, normatifs et jurisprudentiels sur la discrimination dans le domaine du travail, ainsi que les modalités discriminatoires plus communes. Des composantes présentées sont récoltés certains principes antidiscriminatoires au travail, tant matériels et procédurales. Finalement, c'est abordé la complexe et préoccupante situation de la discrimination pratiquée contre les travailleurs migrants, en raison d'être une modalité qui a aperçu de croissantes difficultés dans son combat. Comme conclusion de la recherche, est proposé un concept de pratique discriminatoire dans les relations du travail.

Mots-clés: Discrimination. Relations du travail. Concept. Pratique discriminatoire. Principes antidiscriminatoires. Travailleurs migrants. 


\section{SUMÁRIO}

INTRODUÇÃ

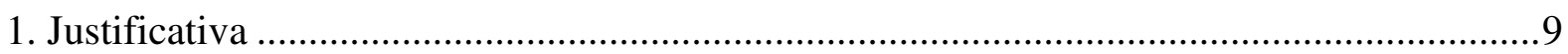

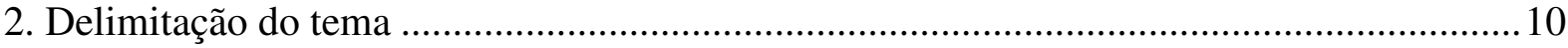

3. Metodologia e Técnicas de Pesquisa............................................................................. 17

1. A PALAVRA DISCRIMINAÇÃO

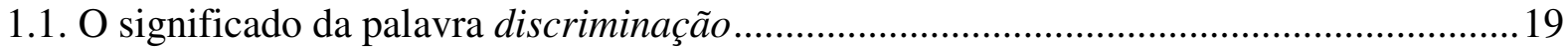

1.2. A palavra discriminação no mundo jurídico..................................................................24

1.3. O uso da palavra discriminação no ordenamento jurídico brasileiro ................................. 31

2. DIFERENÇA ENTRE TRATAMENTO DESIGUAL E TRATAMENTO

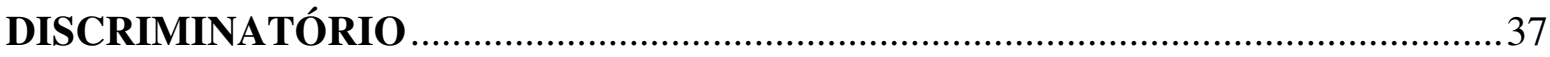

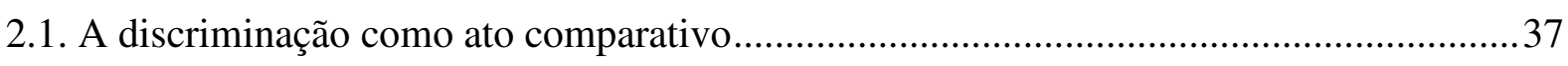

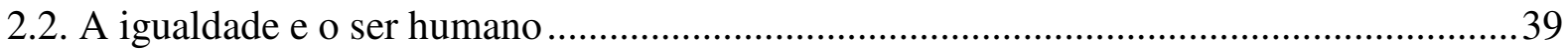

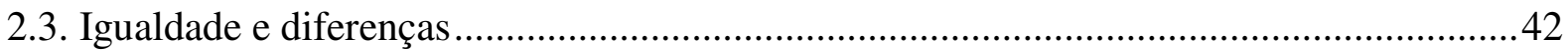

2.4. A igualdade e a sua importância no direito constitucional e na estruturação do

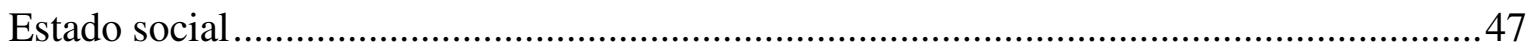

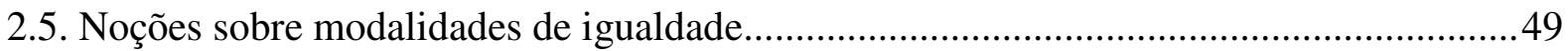

2.6. A igualdade e o combate à discriminação dentro da visão do direito norteamericano: as perspectivas da antidiferenciação e da antissubordinação ...........................59

2.7. A igualdade como princípio violado por um ato discriminatório ...................................63

3. NATUREZA JURÍDICA DAS NORMAS ANTIDISCRIMINATÓRIAS .....................69

3.1. A qualidade diferenciada das normas antidiscriminatórias no direito internacional ........69

3.2. As normas antidiscriminatórias como normas de direito fundamental ............................. 71

3.3. A proibição da discriminação como objetivo do Estado brasileiro...................................79

3.4. A prevalência das normas antidiscriminatórias como expressão da dignidade da

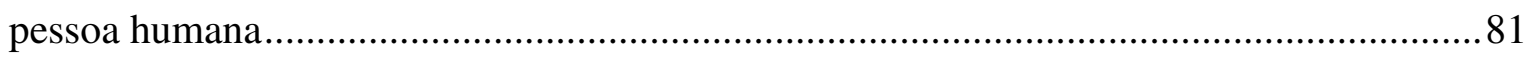

3.5. A proibição da discriminação como direito fundamental nas relações de trabalho ...........82

4. SUJEITOS E EFEITOS DO ATO DISCRIMINATÓRIO ............................................ 88

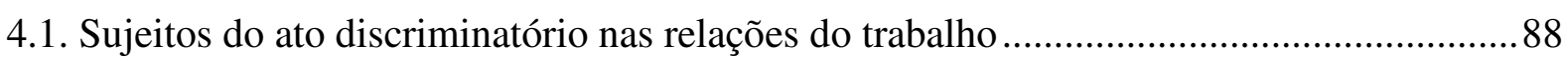

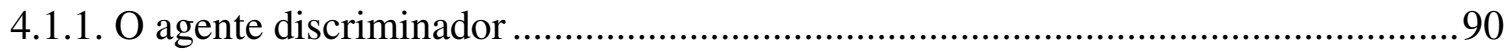

4.1.2. A vítima da prática discriminatória.......................................................................94

4.1.3. O modelo de comparação................................................................................... 97

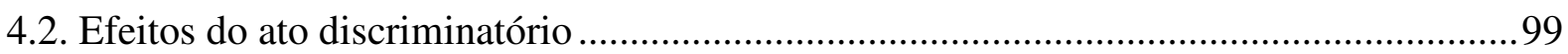




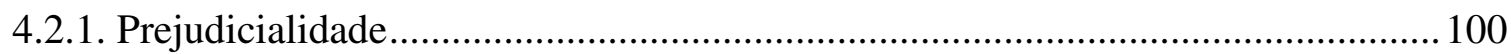

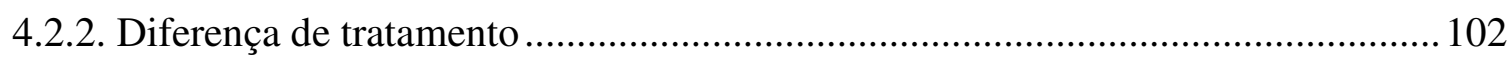

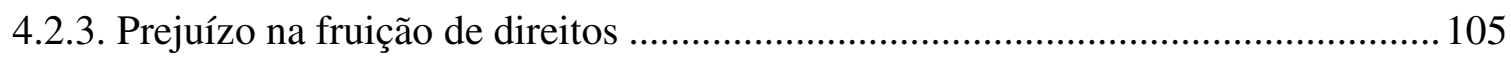

5. A MOTIVAÇÃO DE UM ATO DISCRIMINATÓRIO ............................................... 116

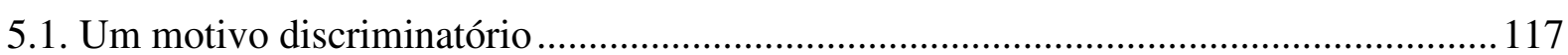

5.2. A importância da motivação na conceituação de discriminação .....................................119

5.2.1. As funções do motivo ................................................................................... 124

5.2.2. Os testes de validade constitucional de medidas diferenciadoras......................... 126

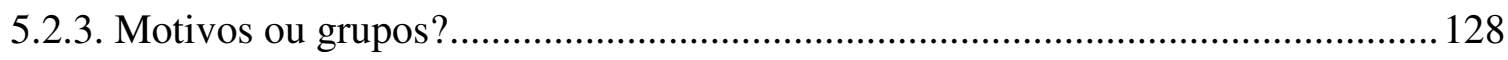

5.3. Taxatividade ou exemplificidade nos motivos previstos em normas positivadas .......... 131

5.3.1. Identificação dos modelos de proteção antidiscriminatória em relação aos

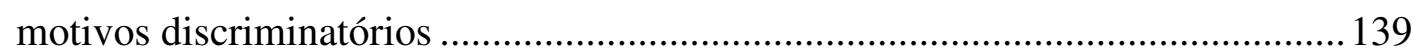

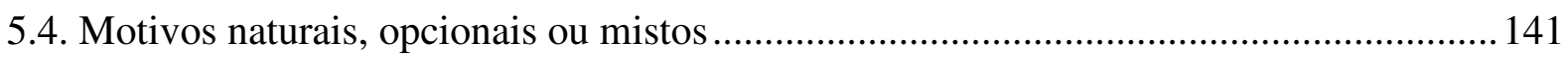

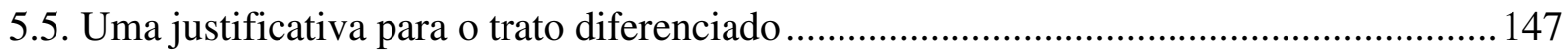

5.5.1. A teoria do business necessity e suas limitações................................................. 148

5.5.2. A Bona Fide Occupational Qualification - BFOQ ............................................... 160

5.5.3. Razoabilidade e proporcionalidade do trato diferenciado...................................... 163

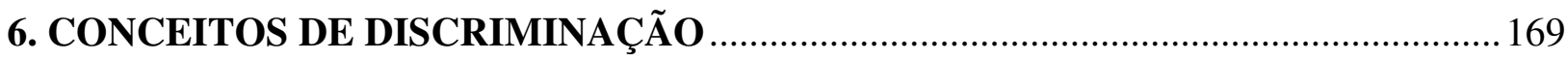

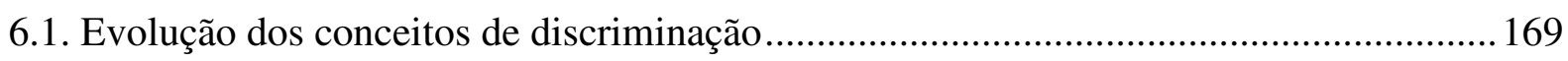

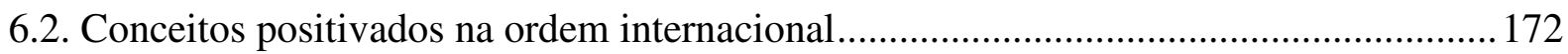

6.2.1. O conceito de discriminação da Convenção 111 da OIT ...................................... 173

6.2.2. O conceito da Convenção relativa à luta contra as discriminações na esfera do ensino

6.2.3. O Conceito da Convenção Internacional sobre todas as formas de eliminação da discriminação racial

6.2.4. O conceito da Convenção sobre a eliminação de todas as formas de discriminação contra as mulheres

6.2.5. O conceito da Declaração sobre a eliminação de todas as formas de intolerância e discriminação fundadas na religião ou nas convicções

6.2.6. O conceito da Declaração sobre o direito e a responsabilidade dos indivíduos, grupos ou órgãos da sociedade de promover e proteger os direitos humanos e liberdades fundamentais universalmente reconhecidas

6.2.7. Convenção sobre os Direitos da Criança .

6.2.8. O conceito da Convenção interamericana para a eliminação de todas as formas

6.3. Conceitos positivados na ordem interna de outros Estados 


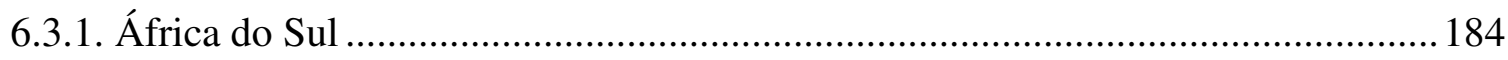

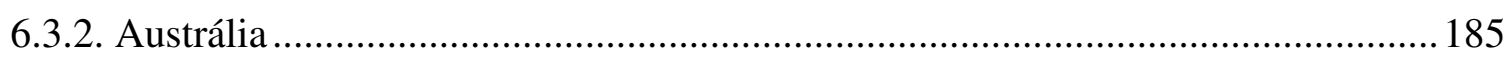

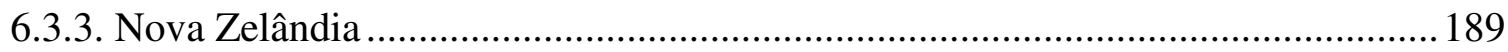

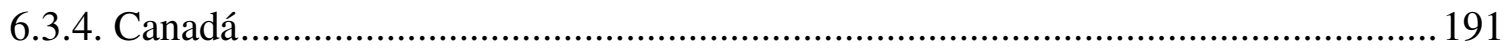

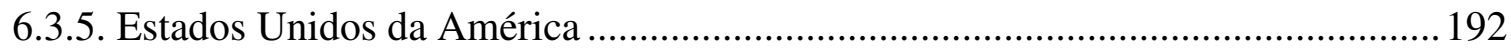

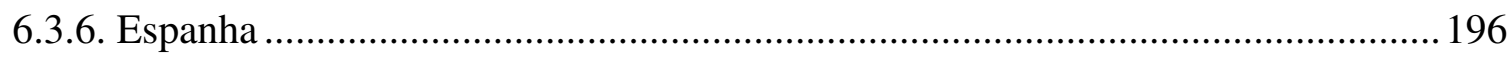

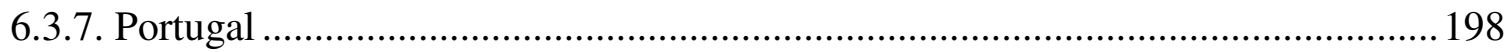

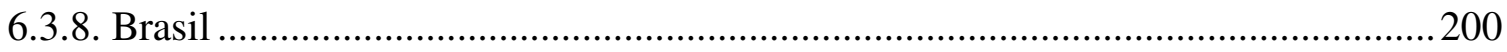

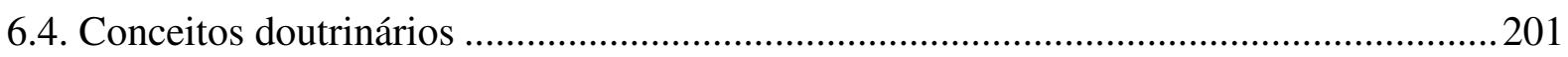

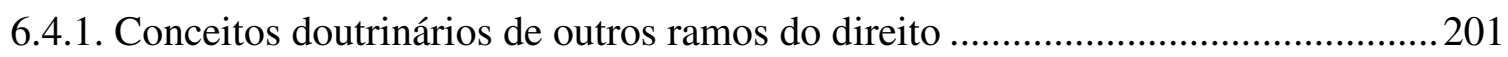

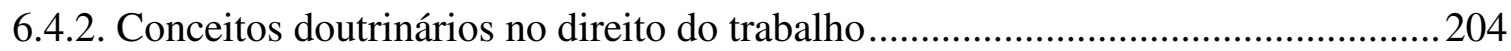

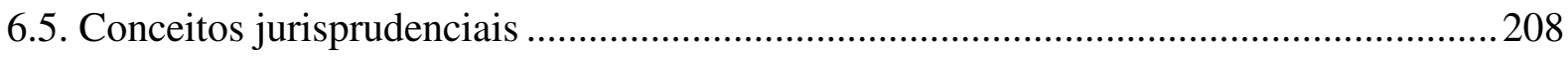

6.5.1. Suprema Corte dos Estados Unidos da América .................................................209

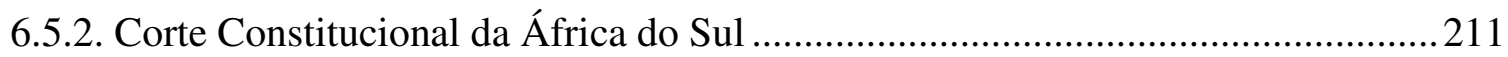

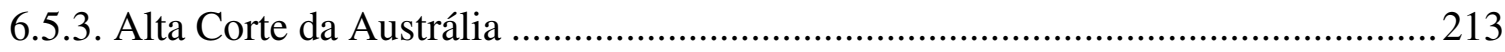

6.5.4. Tribunal de Justiça da União Européia .................................................................2214

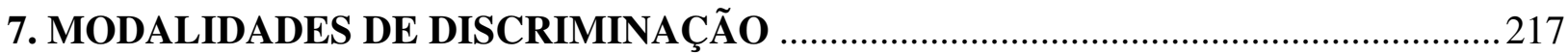

7.1. Classificação das discriminações pela intencionalidade ……….......................................217

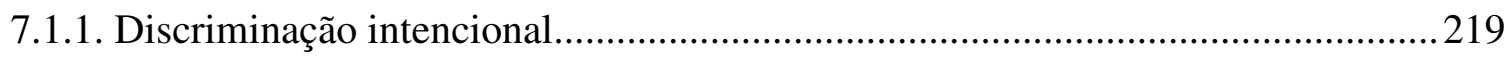

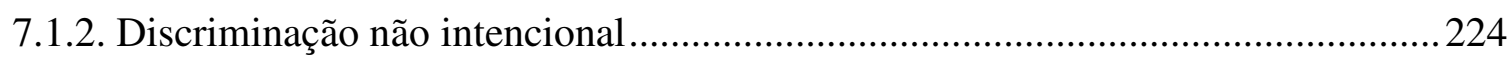

7.2. Classificação das discriminações pela prejudicialidade.................................................238

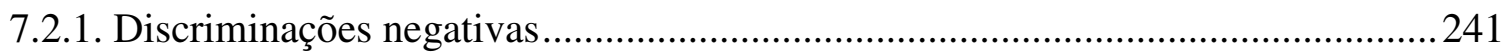

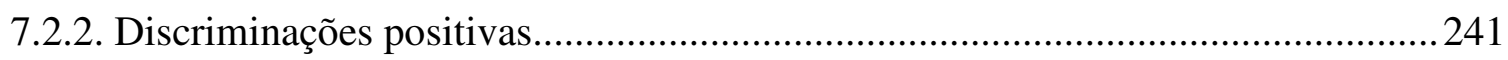

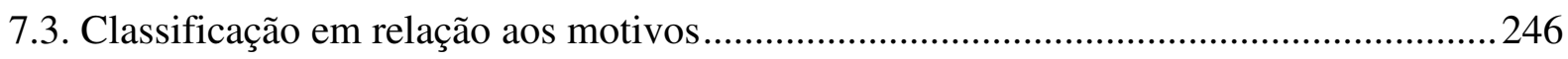

7.4. Classificação em relação à posição das partes envolvidas................................................247

7.5. Classificação quanto ao momento da prática do ato discriminatório.................................249

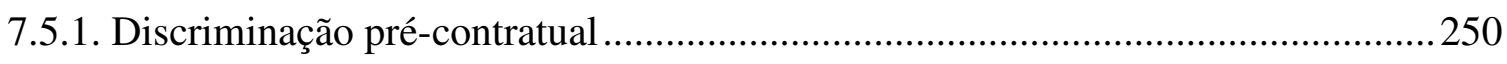

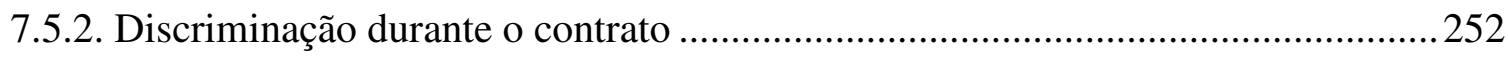

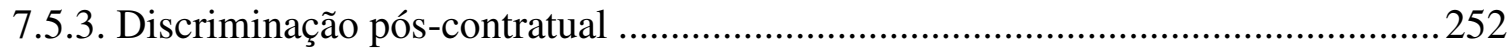

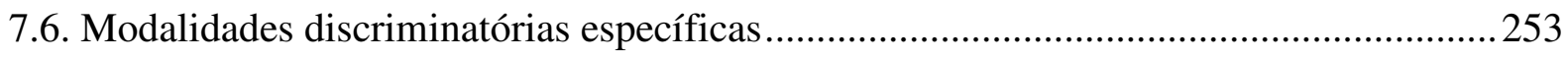

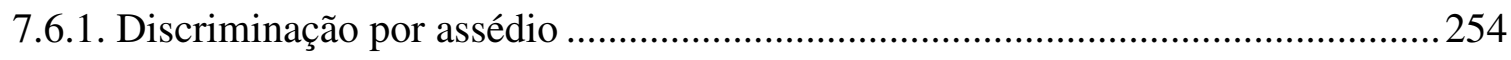

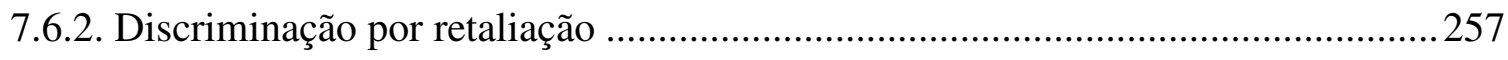

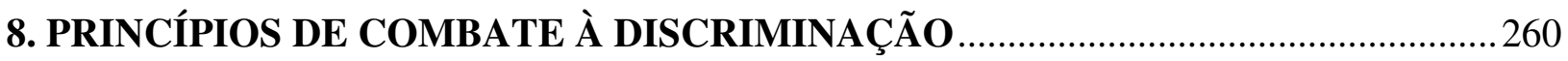

8.1. A proibição da discriminação nas relações do trabalho ..................................................260

8.2. O princípio da igualdade como presunção de medida justa.............................................262

8.3. A imprescritibilidade das violações discriminatórias ......................................................264 
8.4. Os aspectos processuais mais importantes nas questões discriminatórias nas

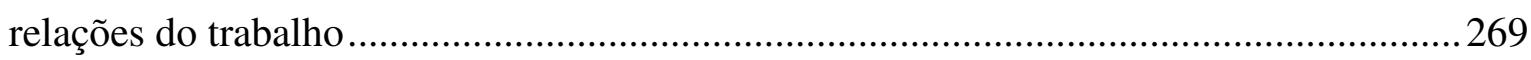

8.4.1. O ônus da prova nas questões discriminatórias ..................................................2271

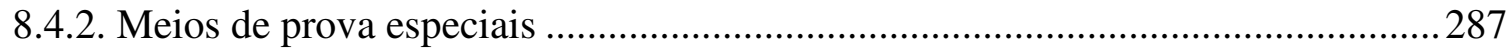

8.4.3. Meios de reparação dos atos discriminatórios ...................................................229

9. DISCRIMINAÇÕES CONTRA OS TRABALHADORES MIGRANTES....................298

9.1. Breve histórico e atualidades dos fenômenos migratórios ............................................299

9.2. As condições especiais dos diversos tipos de trabalhadores migrantes ..........................302

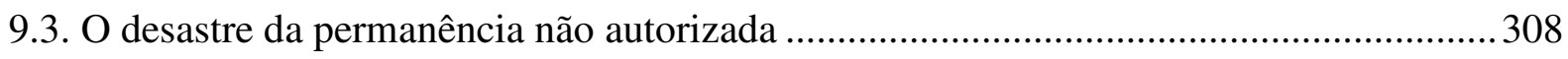

9.4. Proteção internacional do trabalhador migrante .......................................................... 315

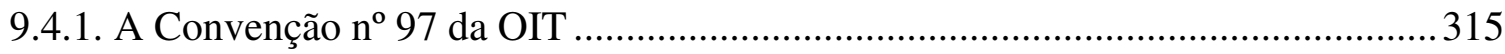

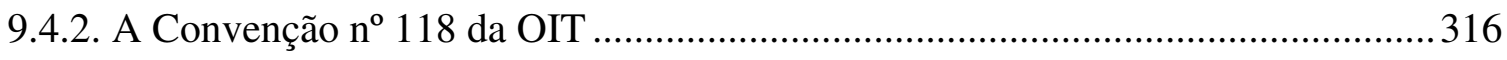

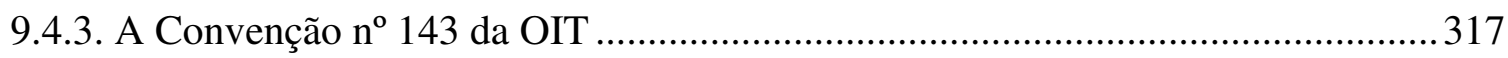

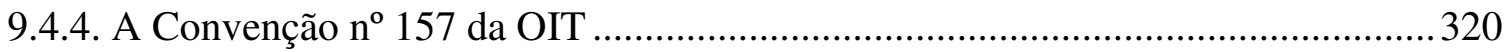

9.4.5. A Convenção sobre Direitos dos Trabalhadores Migrantes e de suas Famílias da Organização das Nações Unidas ................................................................... 320

9.4.6. Declaração Sócio Laboral do Mercosul ................................................................... 323

9.5. O ordenamento jurídico brasileiro e o trabalhador migrante ......................................... 324

9.6. A tensão crescente entre dois direitos: o direito individual de ir e vir e o direito dos

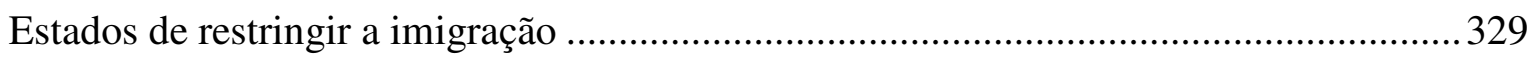

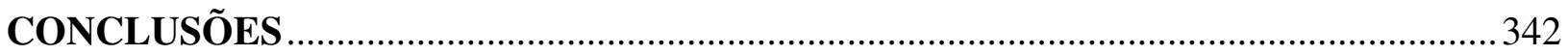

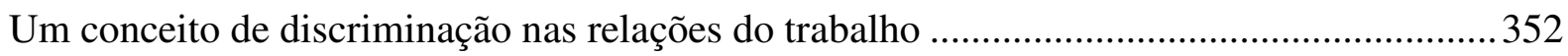

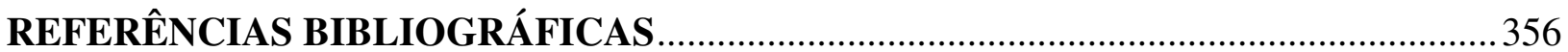




\section{INTRODUÇÃO}

\section{Justificativa}

O direito laboral brasileiro necessita solidificar mais conceitos sobre a discriminação nas relações do trabalho. O Brasil é uma nação constituída por grandes diferenças e mantém uma cultura elitista com tratamento discriminatório bastante arraigado, lamentavelmente visto por muitos com a falsa ideia de uma democracia racial, a qual, de fato, não existe.

As disparidades de renda e de condições de trabalho entre brancos e negros, bem como entre homens e mulheres, são escandalosas segundo os dados do IBGE nas últimas constatações da PNAD - Pesquisas Nacional por Amostragem de Domicílios. Esses são apenas dois grupos estudados pelas análises demográficas; no entanto, muitos outros grupos são continuamente discriminados, sem receber qualquer atenção da doutrina a respeito. A Organização Internacional do Trabalho reconheceu vários avanços do Brasil sobre o tema no seu relatório de 2007 sobre a discriminação no mundo, no entanto aponta que a prática de tratamento diferenciado em vários aspectos no nosso país ainda é elevada ${ }^{1}$.

O tema em questão é extremamente controvertido na doutrina brasileira, a qual deve se debruçar, com a necessária profundidade, sobre as questões discriminatórias nas relações do trabalho. No entanto, o volume de pesquisas doutrinárias existentes no nosso país a respeito da discriminação nas relações do trabalho é muitíssimo reduzido em proporção ao volume de discriminações constatadas nas análises demográficas e nos relatos da Organização Internacional do Trabalho. Por outro lado, as questões discriminatórias não possuem um aprofundamento teórico mais destacado na doutrina laboral brasileira. E, para agravar ainda mais a dificuldade no combate à discriminação, nosso ordenamento possui uma legislação pouco eficiente e muito mal elaborada para tratar com maior efetividade tais questões, deixando de reconhecer expressamente modalidades discriminatórias consolidadas nos ordenamentos europeus desde os anos setenta, e.g. a discriminação por impacto adverso ou indireta.

\footnotetext{
${ }^{1}$ ORGANIZAÇÃO INTERNACIONAL DO TRABALHO. Equality at work: tackling the challenges. Global Report under the follow-up to the ILO Declaration on Fundamental Principles and Rights at Work. Disponível em: <http://www.ilo.org/wcmsp5/groups/public/---dgreports/---dcomm/--webdev/documents/publication/wcms_082607.pdf>. Acesso em: 29 dez. 2008.
} 
Mas não é só isso. Não obstante os dados demográficos e sociais apontarem quadros de exclusão social motivados por fatores raciais e sexuais exemplificados, a baixíssima procura das cortes laborais para discussão de tais temas é absolutamente desproporcional à realidade das diferenças encontradas na estrutura social brasileira. Não bastasse tal grave situação, outros fatores, como a obesidade, a aparência pessoal, o fato de ser reclamante em processo trabalhista, a condição de ex-presidiário, portador do vírus HIV, orientação sexual e origem regional, entre tantos outros, são motivações discriminatórias não previstas nos nossos diplomas legais. Apesar de poucos, são crescentes os questionamentos judiciais sobre tais situações discriminatórias, as quais pedem posturas totalmente inovadoras dos profissionais da área jurídica para enfrentar adequadamente tais complexas questões. A intensa mutabilidade das formas discriminatórias é verificada por estudos internacionais, que revelam discriminações crescentes contra pessoas com hábitos não saudáveis (tabagistas e obesos) e trabalhadores muito qualificados, demonstrando que os fenômenos discriminatórios são extremamente dinâmicos.

Quando tais questões são submetidas ao Poder Judiciário, acabam por ser enfrentadas sem a devida profundidade teórica exigida para um tema fundamental de direitos humanos e os profissionais jurídicos acabam notando o desamparo da doutrina especializada sobre o tema. É importante discutir e entender esta contradição, em um ambiente tão discriminatório não acompanhado pelo Poder Judiciário especializado, demonstrando o descompasso entre a realidade danosa e a limitada bagagem jurídica sobre o tema.

\section{Delimitação do tema}

O objetivo primordial da tese é desenvolver contribuições para uma teoria sobre a discriminação nas relações do trabalho. A proposição de elementos para uma teoria sobre a discriminação nas relações do trabalho envolve muitas questões, em especial as questões conceituais e os elementos existentes nos atos discriminatórios. A investigação pretende pesquisar os conceitos de discriminação previstos na doutrina e nos diplomas legais, internos e internacionais, universo bastante vasto e variado. Deles, em confronto com as diversas correntes doutrinárias existentes sobre o tema, pretende extrair conceitos fundamentais e elementos comuns, para que, ao final, consiga estabelecer um conceito de um ato discriminatório nas relações do trabalho, seus componentes e suas características. 
É de crucial importância para a elaboração de uma teoria a classificação das condutas discriminatórias em face do amplo universo já constatado e em decorrência da dinamicidade das manifestações de condutas discriminatórias.

Destacar elementos para a elaboração de uma teoria da discriminação nas relações do trabalho exigirá uma profunda análise dos componentes dos atos discriminatórios. Este ponto é fundamental para caracterizar se determinado fato é, efetivamente, uma conduta discriminatória ou o exercício regular e legítimo dos poderes do empregador. Com efeito, para que haja a caracterização é necessário saber se presentes estão os componentes de um ato discriminatório, entre eles a desigualdade de trato, o prejuízo da conduta adotada, bem como sua motivação, e a adequação desta com as necessidades do empregador.

Por fim, apontar elementos que são envolvidos na construção de uma teoria pressupõe a constatação e a descrição de princípios e presunções de discriminação, aspectos essenciais para a solução de situações complexas. Efetivamente, situações discriminatórias controvertidas exigem a aplicação de diversos e sistemáticos questionamentos, para ser alcançada uma conclusão mais segura sobre a conduta a ser examinada. A adoção de presunções e testes de avaliação são expedientes muito comuns usados pela Suprema Corte dos Estados Unidos da América nos célebres casos em que apreciou processos relativos à discriminação nas relações do trabalho, inclusive uma sequência de testes.

Conceituar precisamente o que seja discriminação não é tarefa simples, uma vez que a própria expressão discriminação é relativamente recente. De fenômeno considerado como quebra de trato isonômico, tal qual a discriminação era amplamente considerada antes da Segunda Grande Guerra, ao longo destes anos ganhou inúmeros conceitos e recebeu a atenção de muitos estudos pelos mais diversos motivos. No entanto, um estudo preliminar constata, com facilidade, a existência de inúmeros e diferenciados conceitos de discriminação nas relações do trabalho, alguns voltados para determinadas finalidades ou situações específicas, outros muito complexos baseados em decisões jurisprudenciais de várias cortes de outros países. Pode ser tomado como exemplo o conceito de discriminação por impacto adverso formulado pela Suprema Corte dos Estados Unidos da América ou discriminação indireta pela Corte da União Europeia, aspecto pouquíssimo tratado no nosso país e que guarda umbilical relação com os dados acima revelados. A definição exata do que, efetivamente, seja um ato discriminatório, leva a uma controvérsia muito 
ampla, muitas vezes fomentada pela sua motivação, o que acaba por desviar de um conceito mais genérico, coerente com todas as formas de discriminação.

Verifica-se nos dias atuais uma grande proliferação de conceitos sobre discriminação nas relações de trabalho. Com efeito, desde o Tratado de Versalhes em 1919, passando pelo surgimento da Convenção 111 (1958), que proclama como discriminação a quebra da igualdade de tratamento entre empregados não justificável, até a definição objetiva mais recente do sofisticado conceito de discriminação indireta, consagrado pela Diretiva 2002/73 da União Europeia, verifica-se um panorama extremamente dinâmico dentro de um relativo curto período de tempo.

Essa rápida e profunda evolução, muitas vezes liderada pela própria jurisprudência de alguns países, bem como a arrojada jurisprudência do Tribunal da então Comunidade Econômica Europeia, alterou várias vezes, de forma substancial, o conceito de discriminação no trabalho. Hoje, no final da primeira década do Século XXI, os conceitos de trinta anos atrás no final dos anos 70 e começo dos anos 80 já se encontram totalmente superados.

A doutrina estrangeira debate com muita intensidade os conceitos sobre discriminação no trabalho, o que a doutrina nacional somente agora começa a discutir. $\mathrm{O}$ interesse da pesquisa está na procura de um conceito de discriminação sustentável pelo fato de enunciar uma violação de um direito fundamental, cuja aplicação deva ser a mais imediata e a mais abrangente possível. Do conceito único de discriminação aos tipos de discriminação, como já citadas as teorias do disparate treatment e disparate impact enunciadas pelas decisões da Suprema Corte norte-americana, ou pelos conceitos de discriminação positiva, negativa ou indireta utilizados na União Europeia, a pesquisa coleta e analisa os mais variados conceitos de discriminação para procurar enunciar um conceito simples, prático e de maior aplicabilidade possível.

No plano legislativo nacional, praticamente não há definição no ordenamento pátrio do que seja discriminação e isso vem promovendo equivocadas considerações sobre o tema. Com efeito, a mais importante norma legal sobre discriminação no trabalho, a Lei 9.029/95, não se preocupa em dizer o que é discriminar, apenas expõe a proibição e algumas sanções. Nesse sentido, a Lei 9.799/99 é bem mais feliz e detalhada, mas trata somente das questões de discriminação feminina. Tal imprecisão acaba por levar o intérprete a uma enorme dificuldade para verificar a existência, ou não, de uma situação de discriminação no Brasil. A doutrina não tem convergido para um conceito amplamente 
aceito e, quando o faz, acaba sendo influenciada por focos de situações motivacionais específicas.

A Organização das Nações Unidas tem uma grande preocupação com o tema e vem promovendo a criação de normas internacionais antidiscriminatórias para diversos motivos (raça, gênero, educação, etc.). A Convenção 111 da Organização Internacional do Trabalho, por sua vez, é um marco importante merecendo um estudo muito detalhado, em face de o conceito de discriminação abranger a disparidade de tratamento não justificável, sendo este ponto de extrema importância para a definição de um conceito de discriminação. A teoria do business necessity apresentada pela delegação inglesa na Conferência de 1958, que veio marcar profundamente a referida Convenção, é de extrema importância também. Ela permite diferenciar situações reais de discriminação ou de necessidade do empregador, algumas delas muito próximas e com separações muito tênues, sendo de fundamental importância para o julgador poder apreciar determinado fato concreto a ele apresentado. Nesse sentido, é de crucial importância o aprofundamento na referida teoria para entender o que seja ou não permitido. Mais ainda, para o acusado de discriminação se defender, quando são formuladas exceções de defesa contra atos discriminatórios como a Bona Fide Occupational Qualification - BFOQ, um meio de defesa contra alegações de atos discriminatórios que tem ampla aceitação no ordenamento e na jurisprudência norte-americanas e são praticamente desconhecidas no nosso país.

As convenções para procurar eliminar diversas formas de discriminação trazem conceitos muito interessantes e merecem especial atenção posto que, para atendimento de determinadas situações específicas, as normas internacionais acabam por apresentar importantes novidades. Como exemplo, a Convenção Interamericana para a Eliminação de Todas as Formas de Discriminação Contra as Pessoas Portadoras de Deficiência, adotada na Cidade de Guatemala, em 7 de junho de 1999, enuncia em seu artigo 2o, alínea "b", a preocupação de não ser considerada como discriminatória a postura diferenciativa dos Estados signatários que venha a promover a integração social ou o desenvolvimento pessoal dos portadores de deficiência, procurando assim excluir da caracterização como atitude discriminatória as atitudes promocionais em favor dos portadores de deficiência. Neste aspecto, as ações afirmativas, também conhecidas como discriminações positivas, têm uma destacada relevância.

Assim, a pesquisa também procurou realizar uma análise de normas internas de vários países sobre a discriminação no trabalho, procurando levantar suas raízes, a 
evolução verificada, as normas vigentes e, principalmente, seus objetivos. Igualmente será importante analisar as tendências verificadas na elaboração de normas antidiscriminatórias, para tentar traçar pontos de convergência em um panorama de muita disparidade legislativa.

Neste particular, o papel das Diretivas europeias é extremamente importante, posto que assinala tendências fundamentais que orientam os Estados-Membros a adequarem seus ordenamentos internos a tais normas, e adaptá-las para a realidade nacional de cada um. A trilogia das Diretivas aprovadas em 2000/2002 já promove seus frutos com a promulgação de diversos diplomas legislativos europeus sobre o tema, baseados nas diretivas acima, mas adaptados para as necessidades localizadas de cada Estado-membro, ampliando e atualizando um vasto universo de conceitos sobre discriminação laboral.

Insta ainda lembrar a grave situação verificada em todos os países europeus pelas populações migrantes de origem extracomunitária e que tem gerado situações extremamente delicadas de discriminação coletiva e sistemática. A segunda metade da primeira década do Século XXI tem revelado, nos países europeus, uma tendência extremamente restritiva da imigração, com posturas que provocam grandes controvérsias entre os especialistas.

Se a disparidade de conceitos sobre a discriminação traz dificuldades para trabalhar com o tema, a falta de uma estrutura teórica mais organizada sobre a discriminação nas relações do trabalho prejudica, e muito, a apreciação judicial de tais questões. A limitada envergadura doutrinária e jurisprudencial sobre o tema em nosso país traz uma grande dificuldade na análise e qualificação de uma determinada conduta como discriminatória, em alguns casos gerando graves equívocos. Tal problema vem sendo enfrentado pelos advogados, juízes e procuradores do trabalho, quando se deparam com uma situação de tratamento desigual. Em alguns casos os profissionais jurídicos sequer conseguem tomar consciência de que a situação por eles examinada se trata, na verdade, de um ato discriminatório já reconhecido e classificado como tal em conceitos já consolidados na doutrina e nos ordenamentos externos mais avançados.

É necessário agregar os elementos mais comuns presentes na apontada vastidão de conceitos sobre a discriminação, para que seja possível formular alicerces de uma estrutura teórica sobre a discriminação no trabalho. As construções normativas, doutrinárias e jurisprudenciais também geram uma série de presunções sobre a proibição da discriminação e discutíveis ideias. Uma teoria deverá ter a mesma aproximação para atuar 
tanto nas situações de tratamento desigual evidente, como tratamentos desiguais, por exemplo, e a natureza prejudicial da atitude diferenciadora. Outro componente possui ampla discussão dentro da doutrina se é ou não elemento obrigatório para conceituação de discriminação: o motivo do ato diferenciador. E dentro dele, surge, ainda, uma série de questões importantíssimas, como a taxatividade ou exemplificidade dos motivos previstos nas normas legais, a classificação dos motivos como naturais ou opcionais e a existência de motivos mais delicados que merecem maior atenção ou um prisma diverso para sua observação e análise.

Como já colocado anteriormente, verifica-se atualmente a adoção da terminologia discriminação indireta ou reflexiva em ambientes doutrinários europeus, ou de impacto adverso, pela terminologia norte-americana. A doutrina externa já classifica atos discriminatórios como negativos e positivos. Com efeito, determinados atos e posturas no combate à discriminação são de extrema importância e pedem uma reflexão mais aprofundada. Mecanismos que venham a proibir expressamente a discriminação assumem posturas de natureza exclusivamente proibitiva e, quase sempre, com caráter repressor, procurando impedir a prática de uma discriminação. Porém, outras atitudes de combate à discriminação agem mediante a prática de tratamento diferenciado de cunho positivo para reparar outras discriminações já consolidadas, mediante atitudes promocionais, como as ações afirmativas, hoje sob intenso questionamento dentro do panorama científico nacional. Assim, é possível exemplificar dois importantes critérios de diferenciação das condutas discriminatórias.

Por outro lado, a pesquisa analisa profundamente a relação do direito do trabalho com a proibição da discriminação. As relações de trabalho são marcadas por acentuada desigualdade de tratamento entre o contratante dos serviços e os trabalhadores, principalmente em face dos traços subordinativos que até pouco existiram e que começam a sofrer profundas alterações em face da mudança dos paradigmas do trabalho humano com as novas formas introduzidas pelas transformações econômicas, tecnológicas e sociais vividas nos últimos anos. No entanto, cabe verificar quais os reflexos desta desigualdade diante da proibição de discriminação nas relações do trabalho. O fenômeno da igualdade formal liberal do Século XVIII foi contraposto pelo direito do trabalho que se baseou nas desigualdades de fato. A discussão sobre a igualdade no direito do trabalho acaba por analisar o problema do exercício legítimo do poder do empregador e suas limitações pela proibição de discriminação. A obrigação de não discriminar é um princípio aplicável não 
somente às relações de trabalho, mas também a qualquer outra relação jurídica. Trata-se, portanto, da classificação de um direito constitucional laboral inespecífico, mas pode ser exercitado pelos sujeitos das relações de trabalho, no seu âmbito, por adquirirem um conteúdo ou dimensão laboral superveniente, sendo o titular desse direito o trabalhador assalariado ou o empresário, na qualidade de sujeitos de uma relação de trabalho ${ }^{2}$. Pode ser a aplicação da teoria da eficácia externa ou eficácia em relação a terceiros dos direitos, liberdades e garantias ${ }^{3}$, reconhecida pela doutrina alemã como Drittwirkung der Grundrechte.

A tese analisa essa complexa relação decorrente da interação entre o direito do trabalho e o direito constitucional aplicado às relações do trabalho, ainda mais em um mundo de grandes transformações nas novas formas de trabalho humano. A discussão que envolve o antagonismo entre a obrigação de não discriminar e a liberdade contratual do empregador ou contratante de serviços invade a seara da limitação da autonomia privada. A conceituação de discriminação implica, necessariamente, em limitações ao poder diretivo do empregador ou contratante. Ele somente pode ser ultrapassado quando a decisão diferenciadora for dotada de proporcionalidade, explicadas pela necessidade justificável da atividade empresarial. A intervenção estatal na proibição da discriminação relativiza o poder de o empregador dirigir suas atividades empresariais e é fundamento para grandes questionamentos que a tese deverá enfrentar. Como consequência, ao empregador vem sendo constituído pela jurisprudência externa o ônus de justificação, valorando a racionalidade e o bom senso, exigindo um motivo legítimo ou uma adequada justificação das decisões concernentes à gestão da mão de obra. Essa discussão implica a construção do princípio já consolidado na Europa e nos Estados Unidos da América da inversão do ônus da prova em processos judiciais ou administrativos que envolvam discriminação, quando os prejudicados integram grupos historicamente discriminados.

A tese, após analisar todos os aspectos acima apontados, apresenta e defende um conceito de um ato discriminatório essencialmente voltado para as relações de trabalho. Este conceito procura, assim, contribuir cientificamente para o estudo e o combate da discriminação nas referidas relações.

\footnotetext{
${ }^{2}$ PALOMEQUE LÓPEZ, Manuel Carlos. O direito constitucional à igualdade e à não discriminação por razão de gênero nas relações de trabalho em Espanha. Revista do Instituto Goiano de Direito do Trabalho, Goiânia, ano 7, n. 9, p. 95, nov. 2001.

${ }^{3}$ CANOTILHO, Joaquim José Gomes. Direito constitucional e teoria da Constituição. 6. ed. Coimbra: Almedina, 2002. p. 1270.
} 


\section{Metodologia e Técnicas de Pesquisa}

Em face da amplitude do trabalho e dos conceitos envolvidos, vários são os métodos de abordagem para as exigências da pesquisa. Será utilizado o método dedutivo quando forem extraídas conclusões de conceitos gerais do direito constitucional aplicáveis ao direito do trabalho. O método indutivo será adotado quando da análise dos sistemas de proteção contra a discriminação forem extraídas conclusões gerais. Em alguns tópicos será utilizado, também, o método dialético, expondo-se posições contrastantes, mas procurando elaborar uma síntese como conclusão da pesquisa realizada.

Os métodos de procedimento serão a dogmática jurídica, o método comparativo para os conceitos encontrados em outros ordenamentos, o método histórico para análise cronológica dos fatos envolvidos e o método sociológico para compreensão dos fenômenos discriminatórios nas relações de trabalho.

Quanto às técnicas de pesquisa, adota-se tanto a consulta de fontes primárias (tratados internacionais, leis nacionais, normas jurídicas comunitárias, decisões judiciais, portarias, decretos, acordos coletivos de trabalho, etc.) quanto a consulta de fontes secundárias e a utilização da análise de dados quantitativos. 


\section{A PALAVRA DISCRIMINAÇÃO}

Definir o que seja discriminação dentro da ciência jurídica não é uma tarefa simples. Isso porque tal palavra teve, no meio jurídico, uma aparição relativamente recente no direito internacional. Somente em 1948 ela teve sua primeira aparição em um documento internacional de alcance global. No direito brasileiro não foi diferente o uso da expressão discriminação para fins jurídicos é mais recente ainda. O sentido da expressão, como um tratamento diferenciado e prejudicial, somente veio a figurar no nosso ordenamento jurídico em 1968 e, em termos constitucionais, apenas com a Constituição Federal de 1988.

Como adiante poderá ser visto, trata-se de uma definição demasiadamente complexa, não somente por ser relativamente recente, como também por possuir conceituação extremamente dinâmica nos últimos sessenta anos. Vários conceitos para a discriminação foram se sucedendo nos tratados internacionais, como também em constituições e legislações de muitos países e, também, na doutrina e jurisprudência. Entre todos eles verifica-se uma constante e significativa variação em um curto período de tempo. Há quem considere que a palavra discriminação tenha se desvirtuado ou excessivamente estendido seu significado, como faz George Rutherglen ${ }^{4}$. Esse jurista norte-americano ressalta que o conceito de discriminação empresta sua definição a um vasto campo do direito norte-americano, sendo, o ramo que trata da discriminação no emprego, um conceito inacabado 5 .

A complexidade da conceituação deve ser enfrentada pela pesquisa. E tal desafio tem início com a análise da palavra discriminação, o que gerará importantes reflexões sobre seu real sentido. As indagações são variadas: quais são seus sentidos, como ela foi e vem sendo utilizada no universo jurídico e qual o caminho percorrido desde sua aparição até o presente significado. Essas são indagações importantes para um dos objetivos da pesquisa e para estabelecer um conceito de discriminação nas relações do trabalho. Não basta somente compreender o seu significado, também, mas como esse significado veio a

\footnotetext{
${ }^{4}$ RUTHERGLEN, George. Discrimination and discontents. Virginia Law Review, feb. 1995, no 81, p. 117. Lexis Nexis. Disponível em: <http://www.lexisnexis.com/us/Inacademic/results/docview/docview.do?docLinkInd=true\&risb=21_T7345 684975\&format=GNBFI\&sort=RELEVANCE\&startDocNo=1\&resultsUrlKey=29_T7345684979\&cisb=2 2_T7345684978\&treeMax=true\&treeWidth $=0 \& c s i=7361 \&$ docNo=1>. Acesso em: 08 set. 2009.

${ }^{5}$ Id. Ibid., p. 117.
} 
ser empregado juridicamente, tanto no direito internacional, como no direito norteamericano (onde surgiu a ideia de distinção desfavorável) e no direito brasileiro.

\subsection{O significado da palavra discriminação}

A origem da palavra discriminação é extremamente interessante e merece ser bem analisada, tendo em vista que permite uma boa introdução sobre o seu significado e uma melhor compreensão do seu alcance.

A primeira aparição da palavra discriminação, no sentido de tratamento diferenciado de pessoas, ocorreu nos Estados Unidos da América em meados do Século XIX e ganhou alcance universal a partir da segunda metade do Século XX, coincidindo com a projeção hegemônica daquele país no cenário político internacional. Assim, é imprescindível uma análise mais profunda da palavra na língua inglesa, a fonte para sua adoção no ramo jurídico. Também haverá uma análise da mencionada palavra na língua francesa, a qual, para alguns, teria sido a fonte para sua utilização na língua portuguesa.

As origens atribuídas para a palavra discriminação estão situadas em uma área próxima da língua latina, merecendo uma breve análise etimológica, mediante as descrições de diversos etimologistas, tanto da língua inglesa, como da francesa, da portuguesa e, também, da língua latina.

Iniciando tal panorama pela língua inglesa, o filólogo britânico Ernest Weekley atribui a sua origem à palavra latina discriminare, entendendo como significado dessa palavra o de dividir ${ }^{6}$. O filólogo britânico Walter Skeat atribui a origem a diversas palavras latinas correlatas ${ }^{7}$, entre elas a palavra discriminate, que teria o sentido de dividir ou colocar uma diferença entre alguma coisa. Já a palavra latina discriminatus com origem no verbo discriminare, também significa dividir ou separar. Quanto à palavra latina discrimen, entende o referido estudioso que significa separar ou colocar um espaço entre duas coisas. E também indica que a palavra discriminação teria origem na palavra discernire, com o sentido de separação.

\footnotetext{
${ }^{6}$ WEEKLEY, Ernest. A concise etymological dictionary of modern english. London: Secker \& Warburg, 1952. p. 122, v. discriminate.

${ }^{7}$ SKEAT, Walter W. An etymological dictionary of english language. Oxford: Clarendon Press, 1961. p. 172.
} 
O dicionário etimológico norte-americano Online Etimology Dictionary ${ }^{8}$ informa que a palavra discriminação tem seu primeiro registro na língua inglesa em 1628. Porém, no sentido de expressão de um tratamento diferenciado e prejudicial, teve sua aparição no ordenamento jurídico daquele país somente em 1866. A referida expressão, sem o sentido de tratamento diferenciado e prejudicial foi e ainda é usada pelo direito e por outros ramos científicos, como a estatística e a economia.

Thilo Ramm faz um importante estudo sobre a origem da mencionada palavra na língua inglesa e aponta que ela possui dois diferentes sentidos naquele idioma ${ }^{9}$. Nesse mesmo sentido e aprofundando a posição anterior, Egbert Vierdag aponta que a palavra discriminação tem um sentido neutro, ou seja, diferenciar entre coisas ou seres, sendo uma expressão utilizada em termos acadêmicos, ressaltando a utilização por Francis Bacon em 1626 e Thomas Malthus em 1789, além de textos literários como o do autor britânico William Prynne em 1628, na obra The Unloveliness of Lovelockes ${ }^{10}$. O referido autor, no entanto, revela que existe um segundo sentido para a expressão discriminação, de cunho pejorativo, que significa discriminar contra alguém ou alguma coisa, ou seja, fazer uma distinção desfavorável. Aponta o autor que esse segundo sentido é o mais utilizado atualmente e, em algumas línguas como o alemão, o francês, o russo e o holandês, somente há a possibilidade do uso dessa palavra nesse sentido negativo.

Owen M. Fiss, um importante jurisfilósofo norte-americano, aponta que o atual contexto da palavra discriminação recebe uma conotação emocional em função de seu significado, lembrando que a palavra tem um sentido original de diferenciação ou de separação $^{11}$.

Thilo Ramm, no entanto, aponta que, nos Estados Unidos da América, nos anos 70, a palavra discriminação adquire um outro sentido: a palavra discrimination ganha o significado de reverse discrimination ${ }^{12}$. Esse significado traz uma forma de discriminação

\footnotetext{
${ }^{8}$ ONLINE Etimology Dictionary. Disponível em: $<$ http://www.etymonline.com/index.php?search=discrimination\&searchmode=none $>$. Acesso em: 20 jul. 2009.

${ }^{9}$ RAMM, Thilo. Discrimination: international development and remarks of legal theory. In: AARON, Benjamim et al. Discrimination at employment: a study of six countries by the Comparative Labour Law Group. Stockholm:Almqvist \& Wiksell International, 1978. p. 17.

${ }^{10} \mathrm{VIERDAG}$, Egbert. W. The concept of discrimination in international law. The Hague: Martinus Nijhoff, 1973. p. 48.

${ }^{11}$ FISS, Owen M. Groups and the Equal Protection Clause. Philosophy and Public Affairs, n. 5, p. 109, 1976. Yale Law School. Disponível em: http://www.law.yale.edu/faculty/fisspublications.htm>. Acesso em: 13 set. 2009.

${ }^{12}$ RAMM, Thilo. op. cit., p. 17.
} 
mais recente, que fundamenta as ações afirmativas ou ações positivas. Elas são medidas determinadas para remediar discriminações historicamente consolidadas contra determinados grupos, procurando deliberadamente dar tratamento preferencial a tais grupos para corrigir situações anteriores.

$\mathrm{Na}$ língua inglesa, a palavra discriminação é mencionada como originária da palavra latina discrimen, que por sua vez derivou da palavra latina discernire. O renomado dicionário New Webster da língua inglesa também afirma a mesma origem, com o significado originário de distinguir. O célebre dicionário aponta que a palavra latina possui o prefixo dis, que significa diferença; e a raiz crimen, que exprime o sentido de acusar, cernir, peneirar ou separar cuidadosamente ${ }^{13}$. O mesmo dicionário aponta que o verbo discriminar significa distinguir de outros pela observação de diferenças, perceber distinções, discernir, separar, selecionar, observar ou notar diferenças e assinalar uma diferença ou distinção ${ }^{14}$.

O educador e jurista norte-americano Charlton T. Lewis, autor de renomado dicionário da língua latina escrito no Século XIX, aponta que a palavra latina discrimen teve origem na palavra discerno, que veio de cerno, cujo sentido é de separar ou dividir as coisas em dois grupos distintos entre si, tendo como sinônimos latinos as palavras differentia, discrepantia, diversitas e distantia ${ }^{15}$. Também enuncia o referido autor que a palavra latina acima tem como significado inserir um espaço entre, instituir um intervalo, uma divisão e uma separação, revelando que ambas as expressões têm como objetivo demonstrar uma distinção ou descrever um ponto decisivo ou crítico em determinada ação. $\mathrm{E}$ analisando a palavra discrimen, o mencionado autor ainda aponta que o adjetivo discriminalis significa aquilo que serve para dividir ou apartar, bem como o substantivo discriminatim para caracterizar uma diferença ou distinção. E ainda prossegue com o substantivo discriminatio, que significa o contraste entre pensamentos opostos e que o verbo discrimino significa dividir, apartar, separar, distinguir e dividir em partes ${ }^{16}$.

Ainda na língua inglesa, o tradicional dicionário American Heritage Dictionary, aponta como origem etimológica as palavras latinas discriminare (verbo) e os substantivos

\footnotetext{
${ }^{13}$ THATCHER, Virginia S.; McQUEEN, Alexander. The new webster encyclopedic dictionary of the english language. New York, Grolier Inc., 1969. v. 1, p. 247, v. discriminate.

${ }^{14}$ Id. Ibid.

${ }^{15}$ LEWIS, Charlton T. A latin dictionary: founded on Andrew's edition of Freund's Latin Dictionary. Oxford:Clarendon Press. First Edition 1879 - Impression 1984. p. 589, v. discrimen.

${ }^{16}$ Id. Ibid.
} 
discriminat e discrimen, que significam distinguir ${ }^{17}$. O referido dicionário aponta como sinônimas da forma intransitiva do verbo discriminar as expressões fazer uma distinção clara, distinguir e diferenciar. Como forma transitiva, teria como significado receber pontos de distinção de, bem como para servir como ponto de diferenciação.

Na língua francesa, a origem da palavra discriminação não é muito diferente da língua inglesa.

A referida palavra na língua francesa, importantíssima para o direito internacional que a universalizou, recebeu uma atenção especial do jurista belga Marc Bossuyt. Esse autor cita que alguns dos principais dicionários da língua francesa do início do Século XX mencionam discriminação como ato de discernir, de distinguir, como uma ação de separar e de classificar separadamente duas coisas ou seres que podem ser confundidos ${ }^{18}$. O autor conclui que a palavra discrimination não é encontrada nos antigos dicionários da língua francesa, tendo pesquisado dicionários dos anos de 1873 e 1877, onde não foi encontrada a palavra.

Oscar Bloch e Walter Wartburg, etimologistas da língua francesa, no mesmo sentido dos filólogos da língua inglesa acima citados, afirmam que a palavra discriminação tem origem na palavra latina discriminatio e no verbo discriminare, ambas com o mesmo sentido $^{19}$. Atribuem a data de 1877 para o uso da palavra discriminant na língua francesa e o verbo discriminer tão somente em 1948. Albert Danzat, Jean Dubois e Henri Mitterand apontam que a origem seria encontrada nas palavras discriminans, discriminare $e$ decrimen, com o significado de ponto de separação ${ }^{20}$. Segundo os referidos filólogos, a palavra discriminação na língua francesa teria sido utilizada pela primeira vez em 1870, a palavra discriminatório em 1950 e o verbo discriminar em 1897.

No mesmo sentido, os filólogos franceses Ernout e Meillet, que produziram um interessante estudo sobre as origens das palavras na língua latina, apontam que a palavra discrimen tem origem na palavra latina cerno, que gerou a palavra discerno, que tem como

\footnotetext{
${ }^{17}$ AMERICAN HERITAGE DICTIONARY. Rev. ed. of American Heritage dicitionary of english language. New College ed. 1976. p.404.

${ }^{18}$ BOSSUYT, Marc. L'interdiction de la discrimination dans le droit International des droits d'homme. Bruxelas: Étabilissements Émile Bruylent, 1976. p. 8.

${ }^{19} \mathrm{BLOCH}$, Oscar. Dictionnaire étymologique de la langue française. 8. ed. Paris: Presses Universitaires de France, 1989. p. 196.

${ }^{20}$ DANZAT, Albert; DUBOIS, Jean; MITTERAND, Henri. Dictionnaire étymologique et historique du français. Paris: Larousse, 1993. 1993. p. 226, v. discriminant.
} 
significado decidir ${ }^{21}$. Eles apontam que o significado da palavra discrimen na língua latina era separar ou criar um intervalo entre duas coisas.

Dentro da língua portuguesa a origem é bem próxima das duas línguas anteriormente vistas.

Os etimologistas da língua portuguesa apontam as mesmas origens das línguas inglesa e francesa, apenas com pequenas variações no sentido original. Antonio Geraldo da Cunha aponta que a origem é da palavra latina discrimimen, que significa linha divisória e discernimento, possuindo origem inicial na palavra discernire ${ }^{22}$. Aponta o referido autor que a palavra discriminação teria sido utilizada pela primeira vez no nosso país em 1881, com origem na língua francesa. Também, segundo o referido autor, a palavra discriminador teria origem em 1899 e o verbo discriminar, em 1833.

José Pedro Machado, filólogo lusitano, afirma que a palavra discrime teria origem na palavra latina discrimen, significando o que separa, linha de demarcação e ponto de separação $^{23}$. Afirma o referido autor que as figurações da palavra também apontam para diferença, distinção, decisão, determinação e posição crítica de determinada situação. $\mathrm{E}$ conclui afirmando que a palavra discriminação tem origem em uma figura de retórica da palavra latina discriminatione, que também significa separação, bem como que o verbo discriminare tem o sentido de pôr à parte, separar, dividir e distinguir.

O padre Raphael Bluteau, que elaborou a clássica obra Vocabulário Portuguez e Latino no ano de 1713, em Portugal, aponta que a palavra discriminado advém da palavra latina discriminare, que traz o significado de dividir, apartar ou distinguir ${ }^{24}$. A palavra discrimen encontra diversos significados na língua latina, como estabelecer uma linha divisória, separar, criar intervalo, consignar sinal distintivo, diferença, distinção, distinguir, discernir, decisão, sentença decisiva, expectativa, momento decisivo, situação crítica e perigo grave $e^{25}$.

\footnotetext{
${ }^{21}$ ERNOUT, A.; MEILLET, A. Dictionnaire étymologique de la langue latine: histoire de mots. 4. ed. Paris: C. Klincksieck, 1959. p. 115, v. cerno.

${ }^{22}$ CUNHA, Antonio Geraldo da. Dicionário etimológico Nova Fronteira da língua portuguesa. 2. ed. Rio de Janeiro: Ed. Nova Fronteira, 1982. p. 269, v. discrimen.

${ }^{23}$ MACHADO, José Pedro. Dicionário etimológico da língua portuguesa. 6. ed. Lisboa: Livros Horizonte, 1990. v. 2, p. 345, v. discriminação e discriminar.

${ }^{24}$ BLUTEAU, Raphael. Vocabulário portuguez e latino. Edição facsimilada. Hildesheim: Georg Olms Verlag, 2002. v. 3, p. 244, v. discriminado.

${ }^{25}$ FARIA, Ernesto. Dicionário escolar latino-português. Revisão de Ruth Junqueira de Faria. 5. ed. Rio de Janeiro:FENAME, 1975. p. 318, v. discrimen.
} 
No moderno e célebre dicionário “Aurélio", de autoria do Prof. Aurélio Buarque de Holanda Ferreira, o verbo discriminar tem origem no latim discriminare, entendendo como tal as atitudes de diferençar, distinguir, discernir, separar, especificar, extremar e estabelecer diferença ${ }^{26}$. Já o verbete discriminação do referido dicionário aponta para os sentidos de ato ou efeito de discriminar, faculdade de distinguir ou discernir, discernimento, separação, apartação, segregação, bem como definições para a física, economia e da discriminação genética como aquela em que haveria a recusa de emprego ou a cobertura pessoal de seguro por informações genéticas obtidas. Ao final do verbete, o referido dicionário afirma que a discriminação racial seria sinônimo de segregação racial.

O Dicionário de Sinônimos e Antônimos da Língua Portuguesa aponta que discriminação tem como sinônimos distinção, diferença, destrinça, separação, discernimento e discrime, não apontando, entretanto, para o sentido de tratamento diferenciado de pessoas ou segregação ${ }^{27}$.

Feitas tais considerações sobre a origem da palavra discriminação em alguns idiomas importantes para o seu estudo, será abordada agora suas origens dentro do universo jurídico.

\subsection{A palavra discriminação no mundo jurídico}

Miguel Rodriguez-Piñero e Maria Fernanda Fernandez apontam que a palavra discriminação no universo jurídico teve duas fontes. A primeira teve origem na economia, onde a expressão significa a venda de determinado produto no mesmo momento com preços diferentes segundo diversos critérios, sem possuir um sentido negativo, mas neutro $^{28}$. O dicionário Oxford Dictionary of Business English aponta que price discrimination é a venda dos mesmos produtos para mercados distintos com preços diferentes, geralmente por organizações detentoras de monopólios, sendo uma palavra de uso na economia ${ }^{29}$.

\footnotetext{
${ }^{26}$ FERREIRA, Aurélio Buarque de Holanda. Novo Aurélio século XXI: o dicionário da língua portuguesa. 3. ed. Rio de Janeiro: Nova Fronteira, 1999. p. 690.

${ }^{27}$ FERNANDES, Francisco. Dicionário de sinônimos e antônimos da língua portuguesa. 3. ed. rev. e ampl. por Celso Pedro Luft. Porto Alegre:Globo, 1980.

${ }^{28}$ RODRIGUEZ-PIÑERO, Miguel; FERNANDEZ LOPEZ, Maria Fernanda. Igualdad y discriminación. Madrid:Tecnos, 1986. p. 85.

${ }^{29}$ OXFORD UNIVERSITY PRESS. Oxford dictionary of business english. Oxford: Oxford University Press, 1994. p. 319, v. price discrimination.
} 
Os supracitados autores espanhóis apontam que a referida expressão migrou da terminologia econômica para a jurídica, mais especificamente para as primeiras leis que tratavam de regulação de $\operatorname{preços}^{30}$. Tais normas procuravam, principalmente, coibir atitudes de eliminação da concorrência, qualificando a discriminação de preços como atitude legalmente vedada mas, ainda assim, uma expressão neutra. A palavra discriminação, segundo os referidos autores, é transportada mais adiante do direito econômico para o direito internacional, com referência a termos econômicos e na igualdade de trato, mais especificadamente no trato igual de Estados, como um princípio daquela ciência jurídica. Com isso, tornou-se uma expressão cada vez mais familiar naquele ramo ainda que sem a dimensão atual ${ }^{31}$.

A segunda fonte, que implica em segundo sentido, teve origem nos Estados Unidos da América. Em 1866 o Congresso dos Estados Unidos promulgou a 14 ${ }^{\text {a }}$ Emenda Constitucional, a qual prevê a igual proteção das leis a todos os cidadãos, bem como estipula que todas as pessoas não poderiam perder seus bens e a sua liberdade sem o devido processo legal ${ }^{32}$. A referida Emenda Constitucional advém do período pós-guerra civil, período caracterizado por uma grande reforma legislativa com a intenção de proteger os direitos dos negros americanos nascidos naquele país, recém saídos da escravidão. Era a chamada Reconstruction Era Civil Rights Legislation ${ }^{33}$.

Nesse espeque, foram promulgados vários diplomas sobre os direitos humanos de primeira dimensão, lá conhecidos como direitos civis. Merece destaque a introdução do parágrafo 1981 no Código Federal, mais especificamente no título 42, capítulo 21, subcapítulo I, sendo que a alínea "c" da referida norma já utilizou a expressão discriminação dentro do contexto de que fosse proibida sua prática não governamental ${ }^{34}$. A lei foi aprovada em março de 1866, mas somente foi promulgada em nove de abril daquele ano, depois de ter sido derrubado o veto presidencial do então Presidente Andrew Jackson.

\footnotetext{
${ }^{30}$ ESTADOS UNIDOS DA AMÉRICA. Clayton Antitrust Act. St. Olaf College - legal texts. Disponível em: $<$ http://www.stolaf.edu/people/becker/antitrust/statutes/clayton.html>. Acesso em: 20 jul. 2009.

${ }^{31}$ Op. cit. pp. 86-87.

${ }^{32}$ ESTADOS UNIDOS DA AMÉRICA. Constituição, $14^{\mathrm{a}}$ Emenda Constitucional, 1866, no sítio FINDLAW - For legal professionals. Disponível em: <http://caselaw.lp.findlaw.com/data/constitution/amendment14/>. Acesso em: 21 jul. 2009.

${ }^{33}$ BELTON, Robert; AVERY, Dianne. Employment discrimination law. 6. ed. St. Paul: West Publishing Co., 1999. p. 29.

${ }^{34}$ ESTADOS UNIDOS DA AMÉRICA. Código Federal. Título 42, Capítulo 21, Subcapítulo I, § 1981. Disponível em: <http://uscode.law.cornell.edu/uscode/html/uscode42/usc_sec_42_00001981----000-.html>. Acesso em: 21 jul. 2009. (c) Protection against impairment. The rights protected by this section are protected against impairment by nongovernmental discrimination and impairment under color of State law.
} 
A palavra discriminação, a partir de 1866, passou a ser largamente utilizada tanto por textos legais e, um pouco mais adiante, também por decisões judiciais dentro daquele país. Já nesse período, a palavra discriminação assumiu o sentido internacionalmente conhecido, que seria uma discriminação contra determinada pessoa ou grupo e não uma discriminação entre determinadas pessoas ou grupos, fazendo referência a um tratamento desigual com caráter de prejudicialidade e de natureza injusta.

As discussões surgidas com o novo diploma constitucional reforçaram o uso da palavra discriminação. No sentido de diferenciação, a decisão do caso Paul v. Virginia ${ }^{35}$, julgado em $1^{\circ}$ de novembro de 1869 , condenou a prática de alguns estados de elevarem as taxas operacionais de empresas de seguros, alegando a Suprema Corte norte-americana que a prática de exigência de taxas discriminatórias para empresas de seguros de outros estados contrariava a cláusula de privilégios e imunidades da seção $n^{\circ} 4$ da Constituição daquele país.

Porém, com o sentido de prática negativa de tratamento diferenciado de pessoas, a aparição da palavra discriminação é verificada no caso Strauder v. West Virginia (100 US 303), julgado em $1^{\circ}$ de março de 1880. A referida decisão aponta que a $14^{\mathrm{a}}$ emenda procurou proteger a raça emancipada ao derrubar qualquer possibilidade de discriminação legal contra os negros, proibindo qualquer ato que implique a inferioridade legal dentro da sociedade civil $^{36}$. O caso envolveu uma discussão sobre a possibilidade de os negros do Estado da Virgínia Ocidental participarem de julgamentos como jurados, situação expressamente proibida pela legislação daquele Estado.

O conceituado dicionário jurídico norte-americano Black's aponta que a expressão discriminação tem origem no direito constitucional e significa o efeito provocado por um estatuto, o qual confere vantagens particulares para uma classe arbitrariamente selecionada em um grande número de pessoas, no mesmo patamar de tratamento, sendo que não há distinção razoável em favor dos escolhidos ${ }^{37}$. O mesmo verbete do tradicional dicionário jurídico aponta também para a situação de tratamento injusto, recusa ou negação de

\footnotetext{
${ }^{35}$ SUPREMA CORTE DOS ESTADOS UNIDOS DA AMÉRICA. Paul v. Virginia, 75 U.S. (8 Wall.) 168 (1869). Findlaw. Disponível em: $<$ http://caselaw.lp.findlaw.com/scripts/getcase.pl?court=US\&vol=75\&invol=168>. Acesso em: 13 set. 2009.

${ }^{36}$ SUPREMA CORTE DOS ESTADOS UNIDOS DA AMÉRICA. Strauder v. West Virginia, 100 US 303 (1880). Disponível em: <http://www.law.cornell.edu/supct/html/historics/USSC_CR_0100_0303_ZS.html>. Acesso em: 21 jul. 2009.

${ }^{37}$ BLACK, Henry Campbell. By the publisher's editorial staff. Black's Law Dictionary. 6. ed. St. Paul: West Publishing Co., 1990. p. 467, v. Discrimination.
} 
vantagens normais a determinadas pessoas por causa de sua raça, sexo, idade, nacionalidade ou religião, bem como a falta de tratamento igualitário entre todas as pessoas, sem distinção razoável que possa ser identificada.

Como se vê, diante das colocações acima, a expressão teria sido cunhada em duas fontes jurídicas distintas, uma do direito econômico, que passou para o direito internacional, e outra do direito interno norte-americano. Curiosamente, as duas fontes acabaram se encontrando dentro do direito internacional, porém, a segunda fonte possui uma proximidade muito maior com o conceito atual.

A palavra discriminação ganhou a dimensão atualmente conhecida por meio de sua utilização pelo direito internacional, dentro do contexto utilizado pela legislação e jurisprudência norte-americanas. O crescimento do papel político e militar dos Estados Unidos durante o século XX, como uma potência dominante, influenciou sobremaneira a adoção da expressão nos diplomas internacionais, principalmente após as duas grandes guerras.

O governo norte-americano trouxe de seus conceitos internos a noção de discriminação para a sua prática diplomática do início do Século XX. Nesse período e especialmente após a primeira guerra mundial, a preocupação com o tema da discriminação contra minorias, como parte dos temas de proteção dos direitos humanos, ajudou a divulgar a palavra da língua inglesa pelo mundo. Nesse período, com a projeção dos Estados Unidos da América no cenário político mundial e a disseminação da língua inglesa dentro da diplomacia, abolindo a exclusividade da língua francesa nesse ambiente até então consagrada, a referida expressão foi se internacionalizando gradativamente.

A palavra discriminação no direito internacional tinha uso restrito aos documentos internacionais anglo-americanos, como bem cita E. W. Vierdag ${ }^{38}$. Ele aponta que o artigo III, do Tratado Hay-Pauncefote, concluído em 1901, mencionava que não dever haver discriminação contra qualquer nação ou seus cidadãos, a respeito das condições de tráfego sobre o canal que os Estados Unidos da América iria construir no Panamáa ${ }^{39}$.

O Presidente Woodrow Wilson utilizou o termo discriminação no seu discurso ao Congresso Nacional norte-americano em 2 de abril de 1917, quando solicitou ao Poder

\footnotetext{
${ }^{38}$ VIERDAG, Egbert. W. op. cit. p. 49.

${ }^{39}$ UNIVERSITE DE MONTREAL. LexUM. Canado-American Treaties. Disponível em: $<$ http://www.lexum.umontreal.ca/ca_us/en/cus.1901.147.en.html>.
} 
Legislativo daquele país autorização para declarar guerra à Alemanha ${ }^{40}$. Posteriormente, em outras oportunidades, já no pós-primeira grande guerra, especialmente na conferência de Versalhes, externalizou sua preocupação com a discriminação das minorias dentro do novo desenho de fronteiras dado à Europa após o conflito. A língua francesa, até então dominante no ambiente diplomático, descrevia o mesmo fenômeno como tratamento diferenciado (traitement différentiel), mesmo para as finalidades econômicas já citadas. Também a língua francesa, nessa época, utilizava outras expressões como distinções, distinções odiosas, distinções maliciosas ou arbitrárias, como bem cita E. W. Vierdag ${ }^{41}$.

Nesse período, segundo o mencionado autor holandês, fora da esfera de atuação norte-americana, não havia uso geral da expressão discriminação, somente em alguns textos esparsos. Ela foi registrada na versão francesa do artigo 18, I, do instrumento de Mandato Britânico da Palestina, redigido pela Liga das Nações em 1922, sendo utilizado conjuntamente com tratamento diferenciado, provavelmente uma tradução do texto, originalmente em inglês, para a língua francesa.

É importante registrar que dois documentos internacionais da época, redigidos na língua francesa, adotaram expressamente a palavra discriminação. O primeiro foi o célebre Tratado de Paz, elaborado na cidade de Versalhes na França, em 1919. Tal norma, no seu artigo 104, $\S 5^{\circ}$, ao tratar da complicada questão da cidade de Danzig, menciona que nenhuma discriminação deverá ser praticada naquela cidade, para prejuízo dos nacionais poloneses e outras pessoas de origem ou de língua polonesa ${ }^{42}$. Nele, a expressão discriminação é utilizada com o significado muito próximo do atual. Em outro documento, bastante relevante para a época, porém com nítidos traços de uma tradução para o francês de um texto original em língua inglesa, o termo discrimination integrou o artigo 5 da Declaração Internacional dos Direitos do Homem, adotada em 1929 pelo Instituto de Direito Internacional, na sua reunião na cidade de Nova York ${ }^{43}$.

Somente após o final da segunda grande guerra em 1945, com o surgimento da Organização das Nações Unidas, e o papel de destaque dos Estados Unidos da América no

\footnotetext{
${ }^{40}$ THE HISTORY PLACE. The World War I. Text of President Wilson's Speech. Disponível em: <http://www.historyplace.com/worldhistory/firstworldwar/us-wilson-war-decl.htm>. Acesso em: 21 jul. 2009.

${ }^{41}$ Op. cit. p. 49.

${ }^{42}$ SCRIBD. Tratado de Versalhes. Disponível em: <http://www.scribd.com/doc/11553826/Traite-deVersailles-1919>. Acesso em: 21 jul. 2009.

${ }^{43}$ INSTITUT DE DROIT INTERNATIONAL. Déclarations. Disponível em: <http://www.idiiil.org/idiF/resolutionsF/1929_nyork_03_fr.pdf>. Acesso em: 20 jul. 2009. L'égalité prévue ne devra pas être nominale mais effective. Elle exclut toute discrimination directe ou indirecte.
} 
cenário internacional, a palavra discriminação passou a ser utilizada em termos universais. Vários autores reconhecem que a referida expressão somente alcança caráter geral dentro do Direito Internacional com a prática anglo-americana. Marc Bossuyt reconhece que somente passa a ser uma expressão amplamente utilizada dentro do direito internacional após 1945, ainda que a Carta das Nações Unidas não a tenha adotado e, principalmente, em 1948, pela Declaração Universal dos Direitos do Homem ${ }^{44}$. Tais diplomas, segundo o autor belga, exerceram uma influência capital, do ponto de vista da terminologia, sobre as convenções internacionais posteriores, ajudando a consagrá-la.

A Carta das Nações Unidas foi um documento de amplitude global, que prega em seu primeiro artigo o respeito pelos direitos do homem e pelas liberdades fundamentais para todos os seres humanos, sem distinções de qualquer espécie. Marc Bossuyt explica que a versão original continha a expressão sem distinção de qualquer espécie, conforme os trabalhos preparatórios para a redação do texto ${ }^{45}$. A versão francesa somente continha a expressão distinção, porém, a versão inglesa, mediante emendas apresentadas pelo Brasil, República Dominicana e México, segundo o autor sem explicação lógica, já continha o termo discriminação. O espanto do autor decorre do fato de a versão em língua espanhola conter a expressão distinção. Ao final, prevaleceu a redação original utilizando a expressão distinção tanto nas versões francesa e inglesa, podendo ser deduzido que, para os autores da referida carta, as referidas palavras tinham o mesmo significado.

A Declaração Universal dos Direitos do Homem, por seu turno, teve a adoção de ambas as expressões em seu texto nas duas línguas, só que assimetricamente. No artigo $2^{\circ}$, no parágrafo primeiro, refere-se a sem distinção alguma. No entanto, no artigo $7^{\circ}$, utiliza a expressão distinção e discriminação no mesmo artigo, sendo que a versão inglesa utiliza três vezes a expressão discriminação e a versão francesa duas vezes somente, com a utilização da expressão distinção somente uma só vez, ao passo que a versão inglesa do referido artigo não usa nenhuma vez. Marc Bossuyt aponta que a referida versão na língua inglesa veio com as três menções da comissão de redação e recebeu uma emenda australiana para sua retirada. A discussão da emenda teve a participação decisiva de Eleanor Roosevelt, integrante da comissão, que preferia a expressão discriminação por considerar uma mudança importante, ao contrário de René Cassin, que entendia que as

\footnotetext{
${ }^{44}$ BOSSUYT, Marc. op. cit. p. 12.

${ }^{45}$ Id. Ibid., p. 13.
} 
expressões tinham o mesmo significado. A emenda foi retirada, permanecendo as três expressões contendo discriminação, na versão inglesa e duas na versão francesa ${ }^{46}$.

A partir do uso dessa importantíssima declaração internacional, a expressão discriminação passou a ser constantemente utilizada em vários documentos internacionais, em especial na Convenção sobre os refugiados (1951), na Convenção que criou o Estatuto dos Apátridas (1954). Porém, o maior destaque deve ser dado para a Convenção $\mathrm{n}^{\circ} 111$, da Organização Internacional do Trabalho, de 1958, a qual, em seu artigo $1^{\circ}$, parágrafo primeiro, traz uma importante definição do que seja discriminação. Posteriormente, foi adotada a expressão também na Convenção da UNESCO contra a discriminação no ensino em 1960 e na Convenção Internacional sobre a eliminação de todas as formas de discriminação racial, de 1965, também da ONU, ambas trazendo definições particulares e aplicáveis do que era a discriminação e como tais normas a tratavam. Progressivamente, outros textos de abrangência global passaram a utilizar a expressão, como a Convenção para Eliminação de todas as formas de discriminação contra a mulher, de 1979, bem como a Convenção Internacional sobre a Proteção dos Direitos de Todos os Trabalhadores Migrantes e dos Membros das suas Famílias, firmada em 1990.

No plano europeu, a Convenção Europeia dos Direitos do Homem, de 1951, adota a expressão distinção na versão em língua francesa e discriminação na versão em língua inglesa. A Carta Social Europeia adota a expressão discriminação em seu preâmbulo, tanto para a versão em língua francesa como para a inglesa.

No continente americano, a Declaração Americana dos Direitos e Deveres do Homem, de 1948, contém nas versões na língua espanhola e inglesa a expressão distinção, não obstante a influência norte-americana na constituição e na condução da Organização dos Estados Americanos. Já a Convenção Interamericana de Direitos Humanos, firmada em 1969, adota a expressão discriminação ao contrário do documento anterior, utilizando a expressão já então consagrada no direito internacional.

Insta destacar, no entanto, que nos pactos da ONU de 1966 as posições sobre a terminologia adotada foram conflitantes. No pacto de direitos civis e políticos, foi utilizada a expressão distinção nas duas versões em língua inglesa e francesa, ao passo que no pacto de direitos econômicos, sociais e culturais foi utilizada a expressão discriminação, motivada por uma emenda subscrita pela Argentina, Itália e México, aprovada por 76 votos

\footnotetext{
${ }^{46}$ BOSSUYT, Marc. op. cit. p. 17.
} 
a favor da emenda, contra 2 votos e 13 abstenções $^{47}$. E entre os grandes tratados internacionais, foi a última utilização da palavra distinção, uma vez que, posteriormente, e de modo definitivo, a expressão discriminação passou a ser prevalecente no direito internacional, tanto em normas globais como regionais e mesmo de menor abrangência.

A palavra discriminação, a partir de 1945, veio paulatinamente a ser consagrada como uma palavra amplamente utilizada no direito internacional, passando a integrar diversos textos internacionais e também textos internos de muitos países, especialmente as constituições e diplomas infraconstitucionais que procuram combater tal prática. Com essa consagração, a palavra discriminação passou a ter uma utilização universal já nos anos de 1950 e 1960. Isto se deve também à ênfase no seu combate dado tanto pelas Nações Unidas, como pelas organizações regionais e tantos outros documentos do direito internacional, tornando-se seu combate uma preocupação global.

Mais recentemente, alguns autores como George Rutherglen, discutem que o conceito de discriminação foi sendo alterado dentro do direito norte-americano, porém permaneceu incompleto até a presente data por não atender às necessidades de efetividade da reparação dos atos de desigualdade no trabalho ${ }^{48}$. O referido autor conclui seu trabalho apontando que as leis e as decisões judiciais deixaram o conceito intacto, porém sem um formato, necessitando de uma revisão para que o conceito não seja abandonado, mas venha a atender outras necessidades de igualdade no trabalho ${ }^{49}$.

\subsection{O uso da palavra discriminação no ordenamento jurídico brasileiro}

Como pode ser visto, a palavra discriminação, como expressão de um ato de distinção desfavorável, tem uso mais recente no direito internacional e no direito constitucional de vários países, sendo uma expressão adotada nas principais constituições elaboradas a partir da segunda metade do Século XX.

No Brasil não é diferente, sendo consagrado seu uso mais tardiamente ainda.

Nos textos constitucionais brasileiros, somente na Carta de 1988 é que a expressão discriminação é utilizada com o sentido atual. Nas Constituições anteriores, quase sempre era utilizada a expressão discriminação como especificação ou separação, para finalidades

\footnotetext{
${ }^{47}$ BOSSUYT, Marc. op. cit., p. 20.

${ }^{48}$ RUTHERGLEN, George. op. cit., p. 117.

${ }^{49}$ Id. Ibid., p. 147.
} 
administrativas ou tributárias, sendo que a expressão foi utilizada com tais finalidades nas Constituições de 1891 (artigo $1^{\circ}$, $\S \S 1^{\circ}$ e $5^{\circ}$ das disposições transitórias); no artigo $6^{\circ}$ das disposições transitórias da Constituição de 1934 e no artigo 13 das disposições transitórias da Constituição de 1946.

Insta destacar que, na Constituição de 1937, em várias passagens, foi utilizada a expressão discriminação ou discriminar próximo ao sentido ora pesquisado, porém com finalidades tributárias. No artigo 32, alínea "a", é mencionada a expressão discriminações e desigualdades entre Estados e Municípios, no seguinte sentido: Art. 32 - É vedado à União, aos Estados e aos Municípios: a) criar distinções entre brasileiros natos ou discriminações e desigualdades entre os Estados e Municípios ${ }^{50}$.

No mesmo sentido, no artigo 34 daquele texto constitucional, novamente surge a expressão discriminação como tratamento diferenciado entre portos de um e de outro Estado. Na alínea "b" do artigo seguinte, o texto coloca que é vedado aos Estados, ao Distrito Federal e aos Municípios, estabelecer discriminação tributária ou de qualquer outro tratamento entre bens ou mercadorias por motivo de sua procedência ${ }^{51}$.

Como é possível observar, ainda que voltado o texto para finalidades tributárias, a adoção da expressão discriminação tem um sentido muito semelhante ao pesquisado, como a proibição de tratamento diferenciado tributário entre determinados entes da administração pública. No artigo 32, “a”, é curioso notar que a expressão discriminação vem acompanhada, inicialmente, da expressão criar distinções entre brasileiros natos. Mais adiante e na mesma alínea, a expressão discriminações vem acompanhada da conjunção ou antes de mencionar desigualdades entre os Estados e os Municípios. Nesse tópico, o texto constitucional elaborado pelo jurista Francisco Campos deixa claro que criar distinções e desigualdades não são sinônimos de discriminações. Ao que parece, o mencionado jurista utilizou no referido texto constitucional, o qual serviu de alicerce jurídico para a ditadura de inspiração corporativo-fascista do Estado Novo, uma noção muito próxima do significado atual da expressão discriminação.

O texto constitucional de 1988 usa em vários artigos e disposições a expressão discriminação em consonância com o sentido universal e atual. Ela foi apelidada pelo Deputado Ulysses Guimarães, o Presidente da Assembleia Constituinte (mais precisamente

\footnotetext{
${ }^{50}$ BRASIL. Constituição dos Estados Unidos do Brasil (de 10 de novembro de 1937). Presidência da República. Casa Civil. Subchefia para assuntos jurídicos. Disponível em: <http://www.planalto.gov.br/ccivil_03/Constituicao/Constituiçao37.htm>. Acesso em: 22 jul 2009.

${ }^{51}$ Id. Ibid.
} 
um Congresso Constituinte), de constituição cidadã. Por seu cunho de resgate do Estado de Direito e ao procurar banir as terríveis ocorrências do regime de exceção que a antecedeu, teve grandes preocupações com o tema. Merece destaque o fato de que a atual Constituição estabelece como um dos objetivos da República Federativa do Brasil no artigo $3^{\circ}$, inciso IV, promover o bem de todos, sem preconceitos de vários tipos e quaisquer outras formas de discriminação, referindo-se como dado complementar aos preconceitos ali mencionados.

Não bastasse tal aparição de destaque no texto, a expressão discriminação é utilizada em várias outras passagens, como no artigo $5^{\circ}$, XLI, o qual menciona que qualquer discriminação atentatória dos direitos e liberdades fundamentais será punida pela lei, no rol de direitos e garantias da Constituição Federal de 1988. Não menos importante, o artigo $7^{\circ}$, XXXI, no rol de direitos dos trabalhadores, proíbe qualquer discriminação para salários e critérios de admissão. Em outra passagem, uma norma de direito fundamental estabelecida na proteção da criança e do adolescente, o artigo 227 coloca ambos sob proteção de qualquer forma de discriminação.

Outras passagens também utilizam a expressão, em especial no artigo 71, alterado pela Emenda Constitucional $n^{\circ} 10 / 1996$, mas com o significado de especificação das despesas ali previstas.

O atual texto constitucional foi bastante inovador e, até mesmo, ousado, em utilizar a palavra discriminação como um dos objetivos da República Federativa do Brasil e enunciar a proibição de discriminação em diversos aspectos. O texto atual dá a necessária importância conferida pelo direito internacional ao combate da discriminação em diversos setores da vida humana, ao alinhar as relações internacionais do Brasil com a prevalência dos direitos humanos (artigo $4^{\mathrm{o}}$, inciso II). Assim, procurou estar em sintonia com as declarações e tratados internacionais contra a discriminação que o Brasil ratificou antes da promulgação da Carta.

Em termos de legislação infraconstitucional, a aparição do lexema discriminação no sentido de tratamento diferenciado e prejudicial acompanha a evolução constitucional do país.

A Consolidação das Leis do Trabalho utiliza várias vezes a palavra discriminação ou discriminar, no entanto sem o sentido de tratamento diferenciado, mas com o sentido de especificação ou indicação precisa. Com efeito, os artigos $68,105,370,550,570$, e 832, § 
$5^{\circ}$, utilizam a palavra discriminação para o tal sentido e, em muitos casos tratam de alterações legislativas posteriores. Somente a introdução do artigo 373-A, pela Lei 9.799, de 26 de maio de 1999, acresceu ao texto consolidado a palavra discriminação. A alteração veio inovar a Consolidação das Leis do Trabalho, ao empregar a expressão discriminação como tratamento diferenciado, até mesmo descrevendo como tal as condutas reprovadas pela norma.

No Código Civil de 1916, tal qual o texto consolidado, o verbo discriminar assume o mesmo sentido das normas constitucionais e infraconstitucionais anteriores, tendo aparição nos artigos 626 e 1671 daquele Código, revogado pela Lei 10.406/2002.

O primeiro diploma legal a se preocupar com a discriminação por raça ou cor da pele foi a Lei 1.390, de 3 de julho de 1951, também conhecida como Lei Affonso Arinos, em homenagem ao destacado parlamentar e constitucionalista mineiro que foi o autor da proposição legislativa. O referido diploma não utilizou em nenhum momento a palavra discriminação, mas a expressão preconceito de raça ou de cor para diversas situações discriminatórias. O referido diploma foi atualizado pela Lei 7.437, de 20 de dezembro de $1985^{52}$, passando a regular a questão praticamente com os mesmos dizeres da lei anterior, sem qualquer alteração significativa.

Em 9 de julho de 1968 foi sancionada a Lei 5.473/68, cujo primeiro artigo dispõe que seriam nulas as disposições e providências que, direta ou indiretamente, criassem discriminações entre brasileiros de ambos os sexos, para o provimento de cargos sujeitos à seleção. A referida norma legal é uma das primeiras utilizações da palavra discriminação, exatamente para fins trabalhistas, no sentido de tratamento diferenciado e prejudicial para o provimento de cargos e de vagas em empresas privadas. A justificativa para o projeto do então Deputado Nélson Carneiro, conforme o Projeto de Lei n ${ }^{\circ} 3.232 / 65$, apresentado em 31 de agosto de 1965, concluía pela existência de discriminação das mulheres ao perceberem salário inferior, bem como nas dificuldades de acesso ao trabalho, pretendendo que o referido diploma colocasse fim a essa odiosa e injusta discriminação ${ }^{53}$.

A Lei 7.716, de 5 de janeiro de 1989, sancionada sob a vigência da atual Constituição, passou a tratar como crimes de preconceito de raça e cor os atos previstos na Lei 7.437, sendo que o texto original do primeiro artigo não empregava a palavra

\footnotetext{
${ }^{52}$ BRASIL. Lei 7.437, de 20.12.1985. Senado Federal. Disponível em: <www.senado.gov.br>. Acesso em: 22 jul. 2009.

${ }^{53}$ CONGRESSO NACIONAL. Diário do Congresso Nacional. Brasília, Seção I, 12 out. 1965. p. 8381.
} 
discriminação, apesar de definir vários crimes com um extenso rol de tipos penais e utilizar a referida palavra somente no artigo 20 quando se referia à prática, indução ou incentivo à discriminação. Somente com a alteração deste diploma dado pela Lei 9.459, de 15 de maio de 1997 , o artigo $1^{\circ}$ passou a enunciar que serão punidos os crimes de discriminação ou preconceito de raça, cor, etnia, religião ou procedência nacional ${ }^{54}$.

A Lei 7.853 , de 24 de outubro de $1989^{55}$, que visava regular o apoio às pessoas portadoras de deficiência, usou a palavra discriminação no sentido de tratamento diferenciado e prejudicial, sendo que logo no primeiro artigo é feita uma aproximação da proibição da discriminação com os valores básicos da igualdade de tratamento e da dignidade da pessoa humana. $\mathrm{O}$ parágrafo segundo, do artigo $1^{\circ}$, enuncia a preocupação contra as discriminações e os preconceitos sofridos pelos portadores de deficiência.

Em 1995 foi sancionada a Lei $9.029^{56}$, de 13 de abril de 1995, uma das mais importantes normas legais que trata da discriminação no trabalho no Brasil. Ela adotou expressamente a existência de prática discriminatória e o ato discriminatório pelos empregadores, apresentando sanções trabalhistas, administrativas e até mesmo penais, em caso da prática dos tipos penais ali estabelecidos. E a Lei 9.799, de 26 de maio de 1999, alterou a Consolidação das Leis do Trabalho ao instituir importantes definições sobre discriminação, porém, aplicando-as para os casos de discriminação contra as mulheres.

No plano dos tratados internacionais os quais o Brasil ratificou, o primeiro tratado onde consta a palavra discriminação é a Convenção no 111 da Organização Internacional do Trabalho. Este diploma foi aprovado na $42^{\mathrm{a}}$ reunião da Conferência Internacional do Trabalho, realizada em Genebra no ano de 1958, ingressando sua vigência no plano internacional em 15 de junho de 1960. No Brasil, ela foi aprovada pelo Congresso Nacional por meio do Decreto Legislativo $\mathrm{n}^{\circ}$ 104, de 24 de novembro de 1964, foi ratificada em 26 de novembro de 1965 e, promulgada pelo Decreto $\mathrm{n}^{\mathrm{o}} 62.150$ em 19 de janeiro de $1968^{57}$.

A palavra discriminação poderia ter ingressado no nosso ordenamento jurídico anteriormente, conforme previsão expressa da Convenção que criou o Estatuto dos

\footnotetext{
${ }^{54}$ BRASIL. Lei 7.716 de 5 de janeiro de 1989, alterada pela Lei 9.459, de 15 de maio de 1997. Presidência da República. Casa Civil. Subchefia para assuntos jurídicos. Disponível em: $<$ http://www.planalto.gov.br/ccivil_03/Leis/L7716.htm>. Acesso em: 22 jul. 2009.

${ }^{55}$ BRASIL. Lei 7.853 de 24 de outubro de 1989. Presidência da República. Casa Civil. Subchefia para assuntos jurídicos. Disponível em: <http://www.planalto.gov.br/ccivil_03/Leis/L7853.htm>. Acesso em: 22 jul. 2009.

${ }^{56}$ BRASIL. Lei 9.029 de 13 de abril de 1995. Presidência da República. Casa Civil. Subchefia para assuntos jurídicos. Disponível em: <http://www.planalto.gov.br/ccivil_03/Leis/L9029.htm>. Acesso em: 22 jul. 2009.

${ }^{57}$ SÜSSEKIND, Arnaldo. Convenções da OIT. São Paulo: LTr, 1994. p. 243.
} 
Apátridas, uma convenção internacional para proteção das pessoas que não eram consideradas seus nacionais por nenhum Estado. Essa Convenção foi firmada em 1954, mas somente ingressou no ordenamento jurídico nacional pelo Decreto $\mathrm{n}^{\circ} 4.246$, de 22 de maio de 2002, que promulgou a referida convenção.

Em 1969, mais precisamente desde 4 de janeiro daquele ano, encontra-se em vigência no Brasil a Convenção Internacional sobre a Eliminação de Todas as Formas da Discriminação Racial, celebrada em 21 de dezembro de $1965^{58}$, diploma de grande relevância internacional. Em 18 de dezembro de 1979, a Assembleia das Nações Unidas aprovou a Convenção sobre a Eliminação de Todas as Formas de Discriminação contra a Mulher ${ }^{59}$. Tal norma somente entrou em vigor em nosso país em $1^{\circ}$ de fevereiro de 1984 , com o Decreto 89.460, de 20 de março de 1984.

A Convenção Interamericana de Direitos Humanos, que está vigente no Brasil desde 9 de novembro de 1992, quando foi publicado o Decreto 678/92, prevê que não poderá ser aceita qualquer forma de discriminação, adotando como um princípio dentro daquele texto.

Essas foram as principais manifestações do direito positivo pátrio que mencionam a palavra discriminação, ficando claro que desde 1964 a expressão já era usada na esfera laboral com a finalidade de caracterizar um tratamento diferenciado prejudicial não justificado, mas que depois de 1988, com o advento da Constituição Federal promulgada naquele ano, a palavra discriminação consolidou-se no cenário jurídico nacional, com o sentido que é objeto deste estudo. Não obstante tal constatação, a aparição da palavra na Constituição de 1937, no sentido de tratamento diferenciado, não deixa de ser surpreendente, na medida em que, nessa época, o panorama do direito internacional sequer havia consolidado a referida palavra para tal finalidade, somente para outros sentidos, como acima apontados.

\footnotetext{
${ }^{58}$ NAÇÕES UNIDAS. Convenção internacional sobre a eliminação de todas as formas de discriminação racial (1968). Biblioteca Virtual de Direitos Humanos. Universidade de São Paulo. Disponível em: $<$ http://www.direitoshumanos.usp.br/counter/Onu/Minorias_discriminacao/texto/texto_1.html >. Acesso em: 22 jul. 2009. Adotada pela Resolução n. ${ }^{\circ}$ 2.106-A da Assembleia das Nações Unidas, em 21 de dezembro de 1965. Aprovada pelo Decreto Legislativo n. ${ }^{\circ} 23$, de 21.6.1967. Ratificada pelo Brasil em 27 de março de 1968. Entrou em vigor no Brasil em 4.1.1969. Promulgada pelo Decreto n. ${ }^{\circ}$ 65.810, de 8.12.1969. Publicada no D.O.U. de 10.12.1969.

${ }^{59}$ NAÇÕES UNIDAS. Convenção sobre a eliminação de todas as formas de discriminação contra as mulheres (1979). Biblioteca Virtual de Direitos Humanos. Universidade de São Paulo. Disponível em: <http://www.direitoshumanos.usp.br/counter/Onu/Mulher/texto/texto_3.html>. Acesso em: 22 jul. 2009. Adotada pela Resolução n. ${ }^{\circ}$ 34/180 da Assembleia das Nações Unidas, em 18 de dezembro de 1979. Aprovada pelo Decreto Legislativo n. ${ }^{\circ}$ 93, de 14.11.1983. Ratificada pelo Brasil em $1^{\circ}$ de fevereiro de 1984 (com reservas). Promulgada pelo Decreto n. ${ }^{\circ} 89.460$, de 20.3.1984.
} 


\section{DIFERENÇA ENTRE TRATAMENTO DESIGUAL E TRATAMENTO DISCRIMINATÓRIO}

\subsection{A discriminação como ato comparativo}

Como pôde ser observado no capítulo anterior, a palavra discriminação traz consigo, desde suas origens, seu principal significado que é a ideia de estabelecer uma diferença, uma desigualdade. No caso das relações de trabalho, a discriminação estabelece um tratamento diferenciado entre trabalhadores ou grupos de trabalhadores. Ao realizar a diferenciação, tal ato quebra a complexa e fundamental norma de tratamento igual entre os seres humanos, uma norma que, muitas vezes, é vislumbrada como expressão da própria justiça.

Assim, o primeiro componente que pode ser extraído para uma definição de discriminação é a existência de um comportamento que importe em trato desigual de pessoas ou grupos de pessoas. A igualdade tem sentido exatamente oposto ao sentido da desigualdade que resulta em diferença. $\mathrm{O}$ ato discriminatório traz consigo uma distinção ilegítima que promove diferenças entre duas pessoas ou entre dois grupos. Essencialmente, discriminar é, no dizer de Lyon-Caen ${ }^{60}$, distinguir pessoas ou grupos, negando-lhes um tratamento igual em relação a outras pessoas ou a outros grupos.

Um tratamento igual depende, essencialmente, de um elemento de comparação com outra pessoa ou grupo, pois no ensinamento de Bobbio, dizer que "alguém é igual" é algo sem sentido ${ }^{61}$. A conceituação de igualdade depende do estabelecimento de uma relação comparativa com alguma outra pessoa ou grupo, que servirá como um modelo de comparação. A proposição de igualdade somente será válida se afirmar que alguma coisa é igual a outra coisa. São necessários dois elementos para o estabelecimento de uma relação de comparação.

Portanto, é possível concluir que, para ser concretizada uma afirmação de igualdade ou de discriminação, é necessária a existência de uma relação comparativa. Essa relação comparativa pode ser realizada entre uma pessoa e outra, entre uma pessoa e um grupo ou mesmo entre um grupo e uma pessoa. Portanto, para que haja a caracterização

\footnotetext{
${ }^{60}$ LYON-CAEN, Antoine. L'égalité et la loi en droit du travail. Droit Social, Paris, n. 1, p. 73 janv. 1990.

${ }^{61}$ BOBBIO, Norberto. Igualdad y libertad. Tradução para o castelhano de Pedro Aragón Rincón. Barcelona: Ed. Paidós Ibérica, 1993. p. 54.
} 
diferenciadora, necessário será a existência de um modelo sobre o qual possa ser estabelecida uma relação comparativa.

Quando se afirma a existência de uma igualdade entre dois elementos, procura-se estabelecer uma relação entre eles, identificando-se, pelo menos, uma propriedade comum entre os seus componentes analisados. No caso das pessoas, elas devem ser iguais em alguma característica, em algum fator, já que os homens são, ao mesmo tempo, iguais e desiguais, sem haver contradição entre as duas proposições, como bem frisou Pontes de Miranda $^{62}$. Os componentes da igualdade e, também, da discriminação possuem, essencialmente, um caráter relacional e não um caráter individual, como bem assegura Oscar Sarlo ${ }^{63}$. O exame desse relacionamento entre os dois elementos será fundamental para análise de determinada conduta, para classificá-la como discriminatória.

Assim, para sustentar a afirmação de que alguém está sendo discriminado, necessário será demonstrar que esta pessoa ou grupo está recebendo um tratamento diferenciado em relação a alguém. O resultado da análise da comparação para definir se o tratamento dado a um e a outro é mais favorável ou não, configura questão que adiante será mais profundamente analisada, por ser um outro componente do ato discriminatório. No entanto, a falta do componente específico de diferenciação importa em reconhecer que a consideração de discriminação fica completamente afastada.

Cabe assinalar, todavia, que a quebra da igualdade, por si só, não significa exatamente uma prática discriminatória. Um vasto grupo de tratamentos diferenciados pode ser permitido e aceito pelo direito como tratamentos juridicamente aceitos ${ }^{64}$, ainda que diferenciadores, sendo tão somente um dos componentes de um ato discriminatório. Mas certamente, como questão inicial para a análise sobre a existência de um ato discriminatório depende, essencialmente, da constatação de um tratamento diferenciado comparativamente a alguém. Sem a presença desse ato diferenciador, não é possível constatar uma discriminação.

Nesse sentido, a posição de Ricardo de Paula Alves é bem clara: a discriminação pressupõe uma comparação e uma diferenciação entre o tratamento dado a uma pessoa em

\footnotetext{
${ }^{62}$ MIRANDA, Francisco Cavalcanti Pontes de. Comentários à Constituição de 1967, com a Emenda $n^{o} 1$ de 1969. 2. ed. São Paulo: Ed. Revista dos Tribunais, 1970. t. 4, p. 671.

${ }^{63}$ SARLO, Oscar. La igualdad y sus garantias. In: SARLO, Oscar; BLANCO, Andrés (Coord.). El princípio de igualdad en la teoría del derecho y la dogmática jurídica. Montevideo: Fundación de Cultura Universitaria, 2008. p. 31-32.

${ }^{64}$ LYON-CAEN, Antoine. op. cit., p. 73.
} 
relação ao tratamento oferecido a outra pessoa ${ }^{65}$. Egbert Vierdag aponta que cada forma de tratamento desigual requer uma comparação e, consequentemente, um padrão de comparação, classificando os grupos distinguidos e situando-os dentro de suas respectivas posições legais ${ }^{66}$.

Então, conclui-se que a discriminação tem como seu primeiro componente essencial a existência de um tratamento diferenciado comparativo com alguma outra pessoa ou determinado grupo. Qualquer análise do ato discriminatório dependerá, então, desse primeiro questionamento, para que, posteriormente, sejam analisados outros componentes.

Esse elemento de comparação recebe a denominação latina de tertium comparationis ou um elemento de comparação, adotando-se a expressão de RodriguezPiñero e Fernández López ${ }^{67}$, tal qual o faz Canotilho ${ }^{68}$, como sendo a situação concreta na qual se encontram outros cidadãos ou grupos de cidadãos como termo de comparação daquele que denuncia a desigualdade ${ }^{69}$. Esse elemento forma, junto com o fato e a norma, a reunião dos elementos mínimos para que seja realizada uma análise concreta sobre a existência, ou não, de tratamento igual.

\subsection{A igualdade e o ser humano}

A clássica expressão todos são iguais perante a lei, adotada em muitos diplomas legais e constitucionais, é paradoxal.

Com o avanço da tecnologia genética, está cientificamente demonstrado que os seres humanos são diferentes entre si. Eles possuem características genéticas próprias, com identidade própria e diversa de todos os demais. Tais características são elementos identificadores de cada ser humano como sendo ele, e tão somente, ele próprio. Quando se menciona o dever de igualdade entre os homens, pode parecer contraditório que devam ser juridicamente considerados iguais, quando não existe ser humano igual a outro.

\footnotetext{
${ }^{65}$ ALVES, Ricardo de Paula. Considerações sobre o princípio de não-discriminação em direito comunitário: novas perspectivas em relação ao direito laboral. Revista de Direito do Trabalho. São Paulo, n. 101, p. 110, jan./mar. 2001.

${ }^{66}$ ALVES, Ricardo de Paula. op. cit., p. 44.

${ }^{67}$ RODRIGUEZ-PIÑERO, Miguel; FERNANDEZ LOPEZ, Maria Fernanda. op. cit., p. 47.

${ }^{68}$ CANOTILHO, Joaquim José Gomes. op. cit., p. 1280.

${ }^{69}$ QUEIROZ, Cristina M. M. Direitos fundamentais. Coimbra: Coimbra Ed., 2002. p. 111.
} 
Cada ser humano possui um número infinito de características pessoais, de caráter natural e que, em tese, o acompanharão por toda a vida, como o sexo, cor da pele, cor dos olhos, etc. Assim deve ser posicionado até hoje como uma verdade. No entanto, ela tem seu final próximo. Os mais recentes avanços da medicina permitem alterações profundas no ser humano mediante tratamentos e intervenções a ponto de transformar drasticamente tais características naturais, servindo como exemplo as cirurgias plásticas até mesmo para transformação de sexo. Ainda são características inelegíveis por serem naturais, porém sua imutabilidade cada dia mais é desafiada pela medicina.

Outras características humanas são adotadas voluntariamente durante a evolução da vida, baseada na plena liberdade que cada ser humano deve ter na designação de seus destinos e nas suas opções de vida e de conduta. Por ser um direito humano da mais alta importância, são características que não são perenes e que podem ser escolhidas pelo ser humano, em função de sua liberdade. Opinião política, estado civil, religião, filiação sindical, entre tantas outras, estão entre as características humanas elegíveis e, portanto, são características sociais.

Para que alguém seja considerado como "igual” a outro, somente o poderá ser em poucos aspectos. Não é possível que um ser humano seja totalmente igual a outro, nem mesmo em face de uma clonagem, já que ela não permite que sejam reproduzidas as características obtidas pela liberdade do ser humano conduzir seus caminhos. Não será possível que alguém consiga reunir em dois seres humanos idênticas características; cada ser humano será diferente de outro e de todos os demais.

Mais ainda, cada ser humano integra uma infinidade de diferentes grupos sociais, com distintas condições econômicas, sociais e culturais que o cercam e com ele interagem. Assim, fica claro que as condições de vida dos seres humanos são, efetivamente, condições desiguais, variando de pessoa a pessoa ou de grupo para grupo. Luigi Ferrajoli aponta que as diferenças são fundadas na diversidade de identidades pessoais, no entanto, as desigualdades advêm das diferenças sociais, como aquelas baseadas em critérios econômicos e culturais ${ }^{70}$. Ou seja, a humanidade integra um universo de diferenças e desigualdades.

\footnotetext{
${ }^{70}$ FERRAJOLI, Luigi. La igualdad y sus garantias. In: SARLO, Oscar; BLANCO, Andrés (Coord.). El princípio de igualdad en la teoría del derecho y la dogmática jurídica. Montevideo: Fundación de Cultura Universitaria, 2008. p. 9.
} 
Neste panorama de diversidades humanas, até pode soar contraditório falar que os homens devam ser iguais, que devam possuir as mesmas condições e as mesmas oportunidades de vida, que todos devam merecer o mesmo respeito e dividir, entre si, de forma proporcional, as cargas de sacrifícios e de vantagens que a sociedade lhes proporcione. Se são desiguais, porque torná-los iguais? O fato concreto é que reina a diversidade e a desigualdade, restando a igualdade como uma meta, um dever-ser, para oferecer plenas condições a todos. Esta igualdade vislumbrada é uma opção escolhida pela humanidade como elemento necessário para uma convivência pacífica e para que tenhamos um sistema político equilibrado e estável, com características democráticas.

Neste panorama, Luigi Ferrajoli indica que nossas diferenças devem ser iguais, ou seja, uma convenção no sentido de que todos nós somos iguais, temos o mesmo valor e dignidade, definindo o princípio da igualdade como o igual valor associado a todas as diferenças de identidade que fazem de cada pessoa um indivíduo diverso das outras e de cada indivíduo uma pessoa como todas as outras ${ }^{71}$. E arremata afirmando que o princípio da igualdade foi estabelecido porque somos diferentes e desiguais.

A indagação sobre o que é ser igual e o que é ser diferente para seres humanos é uma questão complexa. Martin Heidegger preocupou-se com a questão analisando sob o prisma filosófico sobre a busca por uma resposta para a pergunta ontológica do $\operatorname{ser}^{72}$.

O notável filósofo alemão aponta a identidade no pensamento ocidental representada pela fórmula $\mathrm{A}=\mathrm{A}$ como a suprema lei de pensar, mencionando que $\mathrm{A}$ é igual a A, e que um A é igual a outro A. Mas segundo ele, a correta forma de pensar é que A é A, isso significa que cada A é ele mesmo. E aclara seu raciocínio afirmando que cada A mesmo é consigo mesmo o mesmo, realizando na preposição "com" uma mediação, uma vinculação, uma síntese, uma união em sua unidade. Heidegger rechaça a ideia de que a identidade possa ser entendida, ao modo ocidental, como unidade, como uma mera permanência de um momento abstrato. A identidade é o mútuo pertencer entre o ente (o homem) e o ontos (o ser). Heidegger menciona que o homem é o ente, no entanto, como o Dasein, tem um trato privilegiado com o ser, porque é o único capaz de perguntar-se por ele e estabelecer uma mútua pertinência entre o ente e o ser, relação que constitui a mesmidade da identidade. Assim, conclui que a fórmula do princípio de identidade supõe,

\footnotetext{
${ }^{71}$ FERRAJOLI, Luigi. op. cit., p. 9.

${ }^{72}$ HEIDEGGER, Martin. O que é isto: a filosofia? Identidade e diferença. Trad. Ernildo Stein. Petrópolis: Vozes, 2006. p. 38-52.
} 
ao mesmo tempo, uma relação especial e necessária entre o homem e o ser no sentido de que todo A é consigo mesmo o mesmo ${ }^{73}$.

Já quando trata da diferença, Heidegger aponta que a essência do ser está na diferença com o ente, não que a diferença seja uma propriedade do ser, mas que o ser se constitui na mútua pertinência com o ente que lhe interroga e ele supõe, pois que ambos se constituem na diferenciação ${ }^{74}$. É o outro modo de ser ele mesmo. Oscar Sarlo, mencionando as lições de Vattimo, também recorda que a expressão latina diferre implica um movimento tanto no espaço como no tempo (diferir), o que nos conduz tanto no distinto ou separado, como no diferido (atrasado ou postergado) ${ }^{75}$. Somos o que somos naquele determinado tempo, em outro, podemos mudar, pressupondo que a identidade deva ocorrer no mesmo espaço e ao mesmo tempo.

E sobre a diversidade, Sarlo aponta os dizeres de Heidegger no sentido de que a mesmidade do mesmo supõe a diversidade, na qual cada mesmidade ou cada mesmo é diverso dos demais, apontando que a experiência do ser é única, é o mesmo consigo mesmo e portanto diversa de qualquer outra ${ }^{76}$. Expõe Sarlo que o sujeito não pode ser repetido, eis que pode ser igual a outros em muitos aspectos, no entanto, sua identidade está radicada na sua própria mesmidade que o torna único. Ser o mesmo significa ser ele e nada mais que ele mesmo, afastando qualquer ideia de pluralidade ${ }^{77}$.

Portanto, qualquer discussão sobre o tratamento dado a seres humanos deve levar em conta que a humanidade é essencialmente formada pela diversidade de características dos seres humanos. Diante desta constatação, resta indagar como buscar a efetividade de uma ordem de igualdade, diante da certeza científica de que os seres humanos possuem uma diversidade e vivem na desigualdade de diversas condições de vida.

\subsection{Igualdade e diferenças}

O ser humano é possuidor de características próprias naturais ou sociais, que torna cada um diferente de outro ser. Sobre essa realidade de fato, a humanidade, ao longo de sua história, vem evoluindo a ponto de exigir um tratamento igual a todos os homens. Mas

\footnotetext{
${ }^{73}$ HEIDEGGER, Martin. op. cit., p. 38.

${ }^{74}$ Id., loc. cit.

${ }^{75}$ Id. Ibid., p. 25.

${ }^{76}$ Id., loc. cit.

${ }^{77}$ Id., loc. cit.
} 
vem a indagação de como um trato igual pode ser efetivado sobre um universo de diversidade. Ainda resta o questionamento sobre em que ponto a igualdade poderá dialogar com a diversidade humana no sentido de ser harmonizado este paradoxo, para obter uma maior igualdade entre os seres humanos.

Conceber um modelo de igualdade sem a consideração das diferenças entre os seres humanos é conceber um modelo débil, dotado de quase nenhuma efetividade. Com efeito, o exemplo apresentado por Dworkin, quando começa a discutir duas teorias gerais de igualdade distributiva e apresenta um exemplo curioso, demanda uma reflexão interessante ${ }^{78}$.

O jurisfilósofo norte-americano narra como exemplo o desejo de um pai de razoável patrimônio que pretenda elaborar um testamento, possuindo cinco filhos. $\mathrm{O}$ primeiro é deficiente visual e depende de elevados gastos para sua sobrevivência, o segundo é uma pessoa de hábitos perdulários com preferências caras, um terceiro com pretensões políticas e que também tem aspirações dispendiosas, um quarto um poeta com necessidades humildes e um quinto um escultor que trabalha com material caro. Uma distribuição de seu patrimônio no seu testamento, se pretender a igualdade de bem-estar de seus filhos, necessariamente dependerá de uma distribuição desigual.

O bem-estar de cada um dos herdeiros depende das suas características pessoais; algumas são justas, outras nem tanto. Algumas características como a deficiência visual, necessariamente pedem mais recursos, possuindo uma justificativa razoável para um tratamento desigual em termos da quantidade de recursos disponibilizados. Outras características possuem demandas de recursos igualmente dispendiosas, cuja justificação fica muito mais dificultada em função da duvidosa necessidade, sendo fatores pessoais que podem influenciar na decisão da destinação da herança. O exemplo aponta que, dependendo do critério que serve de prisma para a análise da questão, a distribuição igual nem sempre é a mais justa.

O que pode ser extraído do exemplo é que características pessoais podem justificar uma distribuição desigual de recursos para que necessidades ou vantagens sejam implementadas. Tais características serão fundamentais no exame do acerto, ou não, das medidas diferenciadoras. As diferentes características de cada um dos filhos podem, portanto, influir decisivamente em uma medida que venha a distribuir recursos distintos,

\footnotetext{
${ }^{78}$ DWORKIN, Ronald. Sovereign virtue: the theory and practice of equality. Cambridge: Harvard University
} Press, 2002. p. 5. 
sendo que as necessidades e o bem-estar de cada um podem levar ao entendimento de que uma distribuição igual de recursos não seja propriamente uma medida mais justa.

Luigi Ferrajoli estabelece uma classificação de quatro modelos distintos de configuração jurídica, não exatamente sobre a igualdade, mas sobre a diferença para, daí, extrair uma interessante análise sobre a igualdade, principalmente na complexa questão da igualdade de gênero ${ }^{79}$.

O primeiro modelo é aquele baseado na indiferença jurídica das diferenças, sendo esse o modelo mais antigo, caracterizado pela opressão das diversas identidades pela força $^{80}$. O segundo modelo é baseado na distinção jurídica das diferenças, bem como na valorização de algumas identidades e desvalorização de outras. Esse modelo possui uma característica pela qual as identidades valorizadas conferem a seus titulares a condição de status privilegiado e uma base de um falso universalismo baseado sobre sujeitos privilegiados, sendo que outros status assumem características discriminatórias ${ }^{81}$.

O terceiro modelo estabelecido pelo jurista italiano é o da homologação jurídica das diferenças, modelo pelo qual elas são valorizadas e negadas. Isso ocorre não porque essas diferenças são concebidas como valores e outras como desvalores, mas porque todas resultam desvalorizadas e ignoradas em nome de uma abstrata afirmação de igualdade ${ }^{82}$. Tais diferenças seriam reprimidas e violadas, em um quadro de uma homologação, neutralização e integração geral. Seria um modelo que escamotearia as diferenças entre os grupos, sendo todos vislumbrados como iguais, penalizando as diversidades em comparação com o modelo dominador e traduzindo-se em falta de efetividade da norma de igualdade.

O quarto modelo é bem diferente que os demais por realizar uma configuração jurídica das diferenças, promovendo uma igual valoração jurídica delas, baseada no princípio normativo de igualdade nos direitos fundamentais, bem como em um sistema de garantias capaz de assegurar sua efetividade ${ }^{83}$. Assevera o célebre jurisfilósofo que a igualdade nos direitos fundamentais é o igual direito de todos da afirmação e da tutela da própria identidade, em virtude de um igual valor associado a todas as diferenças que

\footnotetext{
${ }^{79}$ FERRAJOLI, Luigi. Igualdad y diferencia: derechos y garantias: la ley del más débil. Trad. de Perfecto Andrés Ibañez y Andrea Greppi. 3. ed. Madrid: Trotta, 2002. p. 73.

${ }^{80}$ Id. Ibid., p. 74.

${ }^{81}$ Id., loc. cit.

${ }^{82}$ Id. Ibid., p. 75.

${ }^{83}$ Id., loc. cit.
} 
fazem de cada pessoa um indivíduo diverso de todos os demais e cada indivíduo uma pessoa como as demais ${ }^{84}$.

E arremata tal classificação apontando que as diferentes identidades podem ser reconhecidas e valorizadas na mesma medida. Deve ser tomado como partida o fato de que os fatores de desigualdade pesam nas relações sociais como violação da norma sobre a igualdade, ao contrário da proclamação da abstrata igualdade ${ }^{85}$. E assim, não devem ser somente elaboradas as formulações normativas de direitos, como também as suas garantias de efetividade.

Retomando as considerações de Heidegger sobre a diferença e a diversidade como características do ser humano, podemos associá-las ao pensamento de Ferrajoli e ao exemplo citado de Dworkin, para elaborar uma consideração mais profunda sobre a igualdade.

As diferenças são inerentes ao ser humano e não podem ser deixadas de lado, elas são a essência de diferenciação do ser humano sobre os demais seres humanos, posto que o homem tem o condão de ter consciência e questionar a si próprio. Não é possível entender como modelo de igualdade efetiva aquela baseada na desconsideração da diversidade humana, posto que haverá um tratamento geral a situações distintas. O exemplo de Dworkin nos abre esta possibilidade. Em termos de igualdade de condições de vida e bemestar, a distribuição rigorosamente igual dos recursos pode não ser efetivamente a forma mais justa, dependendo de como seja analisada esta distinção, principalmente pela sua finalidade.

Uma maior efetividade da norma geral de igualdade somente pode ser alcançada se o próprio direito reconhecer e valorizar as diferenças, abandonando-se a igualdade centrada em modelos ideais, geralmente concebidos dentro das categorias dominantes de seres humanos. Ferrajoli destaca que os inspiradores desses modelos gerais são os homens brancos, cidadãos, proprietários e instruídos. Uma norma de igualdade, segundo o referido autor, deverá considerar que os diferentes devem ser respeitados e tratados como iguais, respeitando, tutelando e garantindo as diferenças para que se atinja uma igualdade mais efetiva $^{86}$.

\footnotetext{
${ }^{84}$ FERRAJOLI, Luigi. op. cit., p. 76.

${ }^{85}$ Id Ibid.

${ }^{86}$ Id. Ibid. p. 79.
} 
Uma norma de igualdade mais efetiva deve, antes de tudo, reconhecer as diferenças entre os seres humanos, valorizando-as a ponto de receber um tratamento jurídico de reconhecimento, proteção e manutenção mediante garantias não somente voltadas para a manutenção da igualdade, mas também para a manutenção das diferenças. Elas compõem a natureza humana que é o objeto da proteção dos direitos humanos, para preservar a integridade física e moral do ser humano, procurando proporcionar-lhe todas as possibilidades de desenvolvimento pessoal na busca de sua felicidade. Ignorar as diferenças entre as pessoas é violar a essência do ser humano, a sua identidade pessoal e a sua potencialidade de desenvolvimento, e traduz-se em uma negativa da condição de pessoa humana.

E são essas diferenças, quando desconsideradas ou anuladas por qualquer atitude, que motivam o ato discriminatório. São tais características especiais, principalmente aquelas que diferem a pessoa de um grupo dominante, que são os fatores discriminatórios mais recorrentes e os mais severos. A discriminação certamente ocorrerá em função das diferenças que compõem a identidade da pessoa. A proibição de discriminação que não levar em conta as diferenças, a ponto de valorizá-las e preservá-las, será uma norma antidiscriminatória despida de efetividade.

O tratamento igual deve ser realizado pela sociedade como uma forma de torná-la mais justa, com maiores chances e oportunidades para todos, indistintamente. Tal igualdade somente será atingida com maior efetividade quando removidos os obstáculos ao reconhecimento da integralidade da condição humana da pessoa discriminada, sendo tais obstáculos exatamente as diferenças. As diferenças não podem ser reprimidas ou mesmo desconsideradas. Somente a sua plena afirmação trará melhores efeitos contra as práticas discriminatórias, afastando-as como obstáculo e transformando-as em componente comum e valorizado.

A igualdade, segundo Ferrajoli, consiste no igual valor das diferenças como elementos constitutivos da identidade pessoal, assegurada pelo caráter universal dos direitos fundamentais ${ }^{87}$. A igualdade não é um estado mas um dever-ser na visão de Bobbio $^{88}$. Esta meta somente será alcançada se as diferenças forem respeitadas e valorizadas, constituindo-se em um direito à identidade do ser humano e que os

\footnotetext{
${ }^{87}$ Id. Ibid., p. 84.

${ }^{88}$ BOBBIO, Norberto. A era dos direitos, Trad. Carlos Nélson Coutinho. Rio de Janeiro: Campus, 1992. p. 29.
} 
componentes desta identidade não sejam obstáculos ao seu desenvolvimento e suas realizações em busca da felicidade pessoal.

Assim, é possível concluir que a concretização da igualdade efetiva passa, necessariamente, pelo reconhecimento das diferenças que compõem a diversidade humana. A igualdade depende da diferença, porque somente seremos efetivamente iguais quando formos tratados de modo igual naquilo que cada pessoa é, na sua essência e por sua opção própria, sem correr o risco de perder a sua identidade.

\subsection{A igualdade e a sua importância no direito constitucional e na estruturação do Estado social}

A igualdade não apenas é um princípio jurídico importante, mas o eixo estruturante da ordem jurídica que venha a constituir um Estado social. Esse Estado pretende, em sua essência, promover uma transformação social traduzindo-se a igualdade em uma síntese axiológica de uma organização estatal que vise combater as desigualdades sociais.

Paulo Bonavides destaca que a igualdade é o centro medular do Estado social e de todos os direitos de sua ordem jurídica ${ }^{89}$. Segundo o referido constitucionalista, a igualdade compõe um eixo ao redor do qual gira toda a concepção estrutural do Estado democrático contemporâneo. Ela assume importância singular dentro do direito constitucional, qualificando-o como o direito chave e o direito guardião do Estado social ${ }^{90}$.

Robert Alexy aponta que toda a teoria da igualdade fática é um programa para repartição dos bens a serem partilhados em uma sociedade ${ }^{91}$, sendo que tal programação dependerá da interpretação de como o Estado deva promover meios para criar na sociedade a igualdade fática ${ }^{92}$. E para tanto deverá adotar desigualdades jurídicas, entre as quais menciona a promoção de grupos com o significado de tratar outros de forma desigual. Para criar igualdades reais, segundo o jurista alemão, deve ser aceita a desigualdade jurídica ${ }^{93}$ quando comenta a jurisprudência do Tribunal Constitucional de seu país. E assim, conclui, apresentando o que chama de paradoxo da igualdade, quando os princípios da igualdade

\footnotetext{
${ }^{89}$ BONAVIDES, Paulo. Curso de direito constitucional. 24. ed. São Paulo: Malheiros, 2009. p. 376.

${ }^{90}$ Id. Ibid.

${ }^{91}$ ALEXY, Robert. Teoria de los derechos fundamentales. 3. reimpr. Trad. para o espanhol de Ernesto Garzón Valdés. Madrid:Centro de Estúdios Políticos e Constitucionales, 2002. p. 411.

${ }^{92}$ Id. Ibid., p. 401-402.

${ }^{93}$ Id. Ibid., p. 404.
} 
jurídica e da igualdade de fato acabam sendo unidos em um princípio superior de igualdade.

Joaquim José Gomes Canotilho explica que o princípio da igualdade também pode significar induções ao Estado para obtenção de melhores oportunidades e condições reais de vida ${ }^{94}$. A igualdade também traduz, segundo o referido constitucionalista, uma política de justiça social, alicerçada na ideia de igual dignidade social, com imposições constitucionais tendentes à efetivação dos direitos econômicos, sociais e culturais. A igualdade nesse sentido não somente funciona apenas como fundamento antropológicoaxiológico contra discriminações objetivas ou subjetivas, mas também como princípio jurídico-constitucional impositivo de compensação das desigualdades de oportunidades e como princípio sancionador da violação da igualdade por comportamentos omissivos por parte do Estado.

Fica claro que o direcionamento estatal para um Estado social, em busca da igualdade fática, tem amparo na igualdade como o elemento estruturante de ações estatais, ou a quem ele delegar, que visam eliminar, ou pelo menos atenuar, desigualdades mediante a promoção de ações positivas. A igualdade se traduz, também, em base axiológica de um grupo de direitos fundamentais os quais visam reduzir as desigualdades de fato, que são os direitos sociais. Entre eles, com amplo destaque, se encontram os direitos trabalhistas, onde o direito a não ser discriminado no âmbito das relações de trabalho é um dos mais importantes componentes.

Carlos Roberto Siqueira Castro assinala que a Constituição brasileira de 1988, atualmente vigente, tem a igualdade como princípio fundamental com a magnitude de valor protagonista no cenário jurídico constitucional a todos os demais direitos e garantias individuais e coletivos que integram a extensa relação de direitos fundamentais $^{95}$. E ainda completa que a igualdade assume o eixo central do projeto constituinte de transformação social.

Desse modo, podemos concluir pela destacada importância da igualdade como elemento axiológico dos direitos sociais, incluindo-se aqui os direitos trabalhistas, restando demonstrado o peso jurídico do princípio. A busca da igualdade justifica várias medidas

\footnotetext{
${ }^{94}$ CANOTILHO, Joaquim José Gomes. op. cit., p. 430.

${ }^{95}$ CASTRO, Carlos Roberto Siqueira. A constituição aberta e os direitos fundamentais: ensaios sobre o constitucionalismo pós-moderno e comunitário. Rio de Janeiro: Forense, 2003. p. 360.
} 
estatais e não estatais de cunho positivo, as quais criam ou se baseiam em desigualdades, procurando reparar outras desigualdades reais ou históricas.

\subsection{Noções sobre modalidades de igualdade}

Como já foi assinalado, um ato discriminatório viola, essencialmente, um dos principais sustentáculos da democracia representativa, o princípio da igualdade. Pinho Pedreira afirma que a discriminação é o aspecto negativo da igualdade ${ }^{96}$. Quando se pratica uma discriminação, em regras gerais, necessariamente está sendo negado um trato igual a determinada pessoa ou grupo de pessoas. Mas o princípio de igualdade tem outras dimensões. Luciano Ventura afirma que, no direito italiano, a igualdade vem operando cada vez mais em novas modalidades e que, no curso dos últimos anos, acumulou-se uma massa de novos dados que merecem ser estudados em seu conjunto para mensuração da extensão deste princípio ${ }^{97}$.

Para melhor compreensão do ato discriminatório, é necessário um estudo mais aprofundado do princípio da igualdade, das diferentes concepções consolidadas desde a primeira geração de direitos fundamentais, bem como das concepções mais atuais da igualdade no direito contemporâneo.

A história da humanidade, em sua maior parte, sempre foi caracterizada pela diferenciação entre os seres humanos e os diferentes tratamentos que os dominados recebiam dos dominadores, com inequívocas desigualdades. A desigualdade entre os homens sempre foi ordenada pelas sociedades humanas, sendo que, nos aproximados seis mil anos de história da civilização humana, somente nos últimos duzentos anos a ideia de que todos os homens seriam juridicamente iguais passou a ser considerada e mais ardorosamente defendida. No entanto, até hoje, essa ideia longe está de ser razoavelmente efetivada.

Antes das revoluções liberais, prevalecia a noção de que os seres humanos deveriam receber tratamentos diversos como um desígnio natural, por serem reconhecidos em condições jurídicas diferentes. Tal situação, juridicamente consolidada, prevaleceu em grande parte da história humana. Nos dias atuais, infelizmente, o estabelecimento de diferenças jurídicas entre os seres humanos ainda é prevista em alguns ordenamentos.

\footnotetext{
${ }^{96}$ PEDREIRA, Luiz de Pinho. O princípio da igualdade de tratamento. LTr: revista legislação do trabalho, São Paulo, ano 60, n. 4, p. 445, abr. 1996.

${ }^{97}$ VENTURA, Luciano. Il principio di eguaglianza nel diritto del lavoro. Milano: Giuffré, 1984. p. 36.
} 
A ideia de igualdade entre os homens é tão antiga como a sociedade humana, ainda que não tenha evoluído como fosse desejável. Somente a partir da segunda metade do Século XX podemos afirmar que exista um patrimônio jurídico da humanidade, o qual não aceita mais qualquer tipo de tratamento jurídico diferenciado. A Declaração Universal dos Direitos do Homem, de 1948, tem como abertura em seu primeiro artigo a solene afirmação de que todas as pessoas nascem livres e iguais em dignidade e em direitos.

Luigi Ferrajoli qualifica a supressão das diferenças de tratamento jurídico como uma grande conquista da humanidade, no sentido de que todos os seres humanos são iguais em direitos, independentemente de suas diferenças ${ }^{98}$. Não há como deixar de ser considerada como uma conquista obtida mediante ações de violenta ruptura com os sistemas diferenciadores que sempre exerceram o poder por muitos séculos. A positivação do reconhecimento dessa igualdade perante o ordenamento jurídico foi uma grande conquista, sem dúvida, para que todos os homens recebessem um mesmo tratamento. Até as revoluções liberais, com destaque para as considerações que fundamentaram a independência dos Estados Unidos da América ${ }^{99}$ e a revolução francesa ${ }^{100}$, ambas no Século XVIII, a existência de tratamentos diferenciados estabelecidos em normas jurídicas, para diferentes classes de pessoas, foi regra dominante.

Como exemplos, a escravidão ou a sociedade estamental, com fundamentos jurídicos, filosóficos e religiosos, demonstra a prevalência, durante boa parte da história da humanidade, de sistemas diferenciadores de seres humanos que permitiam a existência de privilégios de nascença e regalias de classe. Outros sistemas, que permitiam a escravidão, eram mais drásticos ao aproximá-los de objetos e animais, negando-lhes qualquer reconhecimento jurídico como ser humano. Ainda que alguns sistemas jurídicos falassem em igualdade, essa era totalmente relativizada com amplas autorizações para diferenciação dos homens. Tais sistemas jurídicos favoreciam a formação e a conservação de desigualdades jurídicas tão drásticas como as apontadas.

\footnotetext{
${ }^{98}$ FERRAJOLI, Luigi. op. cit., p. 14.

${ }^{99}$ ESTADOS UNIDOS. Declaração de independência. "Nós temos por evidentes em si mesmas as seguintes verdades: todos os homens foram criados iguais e dotados pelo criador de certos direitos inalienáveis.". Embaixada dos Estados Unidos da América no Brasil. Disponível em: <http://www.embaixadaamericana.org.br/index.php?action=materia\&id=645\&submenu=106\&itemmenu=110>. Acesso em: 04 ago. 2009.

${ }^{100}$ FRANÇA. Declaração dos direitos do homem e do cidadão - 1789. Biblioteca Virtual de Direitos Humanos, Universidade de São Paulo. Disponível em: <http://www.direitoshumanos.usp.br/index.php/Documentos-anteriores-à-criação-da-Sociedade-dasNações-até-1919/declaracao-de-direitos-do-homem-e-do-cidadao-1789.html>. Acesso em: 04 ago. 2009. Art. 10 "Os homens nascem e são livres e iguais em direitos"
} 
As rupturas das revoluções liberais tiveram como meta jurídica consolidar uma igualdade jurídica ideal, ou seja, meramente de caráter formal, como aquela em que todos os seres humanos são iguais em direitos ou deveres diante da ordem jurídica existente. E mesmo assim, os referidos ordenamentos jurídicos possuíam grandes lacunas mantidas até os dias atuais, servindo como exemplo as condições jurídicas dos estrangeiros, os quais não recebem o mesmo tratamento jurídico dos nacionais na imensa maioria dos ordenamentos jurídicos vigentes, principalmente dos países centrais mais desenvolvidos. Eles possuem melhores condições políticas, econômicas e sociais para efetivação da plenitude dos direitos fundamentais dos estrangeiros que os Estados periféricos, no entanto, em uma escolha política lamentável, e cada dia mais excludente, reservam somente aos seus cidadãos a efetivação dos direitos e obrigações estabelecidas pelos seus ordenamentos.

A conquista da igualdade formal, apesar de ter sido uma grande ruptura com sistemas políticos e religiosos dominantes durante milênios, somente promoveu um pequeno avanço ao dissolver as desigualdades jurídico-formais. No entanto, se tal instituição veio promover a derrubada da desigualdade formal, significando um grande avanço para a burguesia contra a antiga classe dominante, tal conquista resultou em um instrumento inútil para a solução ou amortização das desigualdades reais, principalmente as de cunho social. Ao se proclamar a igualdade jurídica entre os homens, certas relações jurídicas de cunho social como as relações do trabalho, discutidas em um prisma de igualdade formal, somente resultaram em maior disparidade de resultados reais. Não há como conceber a existência de idênticas condições para uma aceitável contratação de obrigações em ambientes onde a dependência econômica e a desigualdade social eram estarrecedoras. A igualdade formal-liberal aplicada aos contratos nada mais é que um instrumento de dominação humana dos mais poderosos sobre os mais débeis, promovendo a intensificação das desigualdades sociais.

Porém, alguns avanços puderam ser notados. Um dos exemplos é que a igualdade jurídica formal não ficou restrita somente à igualdade diante do ordenamento jurídico, no sentido de que ela se tornasse uma exigência na aplicação do direito de forma igual a todos. A feição jurídica da igualdade também se voltou contra o legislador, que se viu diante da igualdade como um freio contra atitudes legislativas que promovessem a desigualdade jurídica. Canotilho explica que a igualdade na criação do direito é uma igualdade na própria lei, ao passo da fórmula liberal que seria de igualdade diante da lei. 
Trata-se de uma exigência de igualdade destinada ao legislador, para que a norma legal trate igualmente os cidadãos, a ponto de exigir do próprio legislador a igualdade relativamente a seu conteúdo, citando Castanheira Neves ${ }^{101}$. Nesse sentido, discorre Cristina M. M. Queiróz ${ }^{102}$, ao afirmar que a igualdade atuará como fundamento principal positivo de controle de racionalidade e/ou razoabilidade das leis, ainda que não único, bem como servirá como instrumento ao serviço de uma técnica de construção da "fundamentação" da decisão judicial.

As graves distorções sociais do sistema capitalista incipiente encontraram amplo amparo jurídico na igualdade formal para consolidar uma verdadeira tragédia humana. A igualdade formal potencializou as desigualdades de fato e demonstrou a face mais nefasta do incipiente capitalismo instalado. Fábio Konder Comparato expressa muito bem a situação da igualdade formal nesse período, traduzindo a igualdade jurídica como uma pomposa inutilidade para uma legião de trabalhadores, compelidos a se empregarem nas empresas capitalistas $^{103}$. Mesmo Jean Jacques Rousseau já havia mencionado essa possibilidade em sua clássica obra Do Contrato Social, na qual citava que, diante de maus governos, a igualdade formal era aparente e ilusória, que manterá o pobre na miséria e o rico dentro daquilo que chama de usurpação ${ }^{104}$. O referido autor ainda aponta em sua nota especial do final do capítulo IX, cuja primeira edição foi publicada em 1762, que tal modalidade de igualdade é útil aos possuidores de bens e inútil para quem não possui nada, não havendo qualquer possibilidade de avanço no Estado social, destacando que este somente é vantajoso para a sociedade quando todos tenham alguma coisa e ninguém tenha nada demais.

A teórica igualdade de tratamento aplicada a situações extremamente desiguais passou a suscitar ideias revisionistas das estruturas sociais então existentes, mediante ideologias bastante inovadoras que pregavam a total ruptura com os padrões do capitalismo liberal, atingindo grande profusão na Europa do Século XIX. Ainda que essas novas ideias não obtivessem pleno êxito na reforma de uma sociedade gravemente doente, em face das crescentes desigualdades sociais, o questionamento formulado pelos grupos menos favorecidos deixou claro que a igualdade formal não tinha como prosseguir. Carlos Roberto Siqueira Castro destacou que a classe operária foi se conscientizando das

\footnotetext{
${ }^{101}$ CANOTILHO, Joaquim José Gomes. op. cit., p. 426-427.

${ }^{102}$ QUEIROZ, Cristina M. M. op. cit., p. 111.

${ }^{103}$ COMPARATO, Fábio Konder. A afirmação histórica dos direitos humanos. 4. ed. rev. e atual. São Paulo: Saraiva, 2005. p. 52.

${ }^{104}$ ROUSSEAU, Jean Jacques. Du contrat social. Paris: Éditions Sociales, 1963. p. 77.
} 
manipulações urdidas pelo sistema de economia burguesa, notadamente da pregação de irrestrita defesa do direito de propriedade e de irrestrita liberdade de contratar, o que a cada dia aumentava a exploração das massas trabalhadoras desamparadas ${ }^{105}$.

As exigências sociais decorrentes das chagas do capitalismo liberal proclamavam a existência de direitos que não seriam alicerçados sobre a igualdade formal dos seres humanos. Ao contrário, esses novos direitos deveriam, em síntese, reconhecer as distorções sociais e, baseando-se nelas, construir uma nova ordem jurídica. Nessa, as diferenças gerariam tratamentos jurídicos diferenciados, com o intuito de promover uma atenuação das desigualdades de fato para a aproximação crescente da igualdade de fato.

Os direitos sociais são instrumentos para a compensação das desigualdades reais, deixando-se de reconhecer a igualdade jurídico-formal para gerar novas desigualdades jurídicas. Elas foram criadas para que favorecessem os operários e empregados, visando um interesse geral de uma sociedade mais justa em termos reais, segundo Chaïm Perelman ${ }^{106}$.

Jorge Miranda aponta que, na concepção social, a igualdade é a concreta igualdade de agir e, a liberdade, a própria igualdade voltada para a ação, traduzindo-se os direitos de índole social num direito geral à igualdade ${ }^{107}$. E arremata dizendo que o resultado almejado é a possibilidade de uma liberdade igual para todos, construída por meio da correção das desigualdades $^{108}$.

A conquista dos direitos sociais durante o Século XIX e no início do Século XX tem como fundamento o combate às desigualdades de fato, sendo a igualdade como um axioma que fundamenta uma atividade positiva do Estado ou de seus escolhidos para tal responsabilidade. Ou seja, o ordenamento jurídico criou desigualdades com a intenção de atingir a maior igualdade material possível entre os seres humanos. E tais desigualdades jurídicas geradas são fundamentadas no reconhecimento de que o bem-estar da sociedade depende, essencialmente, de um maior equilíbrio social, sendo um instrumento de sua obtenção.

Abandona-se o critério individualista e adota-se uma atuação mais intensa do princípio da solidariedade humana segundo Fábio Konder Comparato, onde as carências e

\footnotetext{
${ }^{105}$ CASTRO, Carlos Roberto Siqueira. op. cit., p. 376.

${ }^{106}$ PERELMAN, Chaïm. Égalité et valeurs. L'Égalité. Bruxelas: Bruylant, 1971. p. 324-326.

${ }^{107}$ MIRANDA, Jorge. Manual de direito constitucional. 3. ed. Coimbra: Coimbra Ed., 2000. t. 4, p. 102-103.

${ }^{108}$ Id. Ibid., p. 104.
} 
as necessidades dos menos favorecidos são responsabilidades de todos os integrantes de um grupo social. Procura-se, assim, mediante uma compensação de bens e vantagens entre as classes sociais, socializar-se os riscos da existência humana para que as condições sociais de todos os seres humanos possam, progressivamente, se tornarem mais equânimes ${ }^{109}$. Adota-se uma atitude crítica sobre a ordem social e econômica com a consciência da necessidade de modificação das condições vigentes, criando-se novas condições mediante a transformação das estruturas de domínio e da produção, como meio de realização para todos os homens.

A ciência jurídica então se voltou ao trato de duas desigualdades, uma de origem jurídico-formal, prevalecente antes das revoluções liberais do Século XVIII, e outra de cunho substancial, verificada na evolução histórica da humanidade. Não é possível vislumbrar que as desigualdades reais tenham alguma perspectiva de serem totalmente eliminadas, muito ao contrário. A discussão sobre a ação de uma sociedade igualitária é cada vez mais atual e pertinente, eis que as desigualdades reais vêm sendo incrementadas pelos perversos efeitos do neoliberalismo e da globalização, gerando grandes e concentrados acúmulos de renda e riquezas nas mãos de poucos, tanto nos países centrais como nos periféricos.

A adoção de um sistema gerador de desigualdades que procure obter a igualdade teve um significativo avanço e até um relativo sucesso. Cabe ressaltar que, mais recentemente, as desigualdades fáticas tenham se acentuado e, ideologicamente, tais ideias de equalização social tenham se esmorecido nos últimos tempos, como bem assinala Ronald Dworkin ${ }^{110}$.

A igualdade substancial possui algumas maneiras específicas de concretização, merecendo aqui mencionar três formas de igualdade com base na classificação do jurista britânico Bob Hepple: a igualdade de oportunidades, a igualdade de resultados e a igualdade na dignidade humana ${ }^{111}$. Aponta o mencionado autor que essas três concretizações da igualdade substancial constituem a base para o trabalho decente defendido pela Organização Internacional do Trabalho.

A primeira forma se baseia no reconhecimento da existência de grupos humanos historicamente prejudicados, ainda que amparados por uma nova ordem de direitos de

\footnotetext{
${ }^{109}$ COMPARATO, Fábio Konder. op. cit., p. 64.

${ }^{110}$ DWORKIN, Ronald. op. cit., p. 1.

${ }^{111}$ HEPPLE, Bob. Igualdad, representación y participación para un trabajo decente. Revista Internacional del Trabajo, Genebra, v. 120, n. 1, p. 7-12, 2001.
} 
cunho modificador da estrutura social. Eles continuaram a experimentar desigualdades fáticas de modo mais acentuado por estarem menos aptos a buscar sua promoção social, sem a perspectiva de melhorias, em muitos casos experimentando a exclusão social.

Certas situações sociais, principalmente para determinados grupos sociais, atingiram altos graus de desfavorecimento, nos quais foi constatada a ineficácia da promoção da igualdade mediante políticas gerais e abrangentes de redução das desigualdades. Tais grupos necessitam de uma proteção especial, em respeito às suas condições peculiares em comparação com outros grupos sociais. Para tais grupos, são necessárias considerações especialíssimas, criando-se maiores desigualdades comparativamente com a generalidade social existente, procurando resgatá-los das condições adversas e promover sua inclusão dentro da sociedade em condições de competitividade com os demais integrantes.

John Rawls aponta que a sociedade é interpretada como um empreendimento cooperativo para a maior vantagem de todos, mediante o estabelecimento de regras públicas que autorizem os comportamentos de seus integrantes ${ }^{112}$. Afirma que as desigualdades não justificáveis devem ser reparadas mediante compensações, sendo que o princípio da diferença determina que, para que todas as pessoas sejam tratadas igualitariamente, a sociedade deve dar mais atenção àqueles com menos dotes inatos e aos oriundos de posições sociais menos favorecidas, procurando proporcionar uma genuína igualdade de oportunidades ${ }^{113}$.

A teoria de Rawls é liberal, posto que não reprime a existência de desigualdades sociais e econômicas, mas procura direcioná-las para que privilegiem a todos, proporcionalmente aos integrantes menos afortunados da sociedade. As desigualdades são instituídas de uma forma que não é proposta qualquer revisão da estrutura social, dentro de uma visão próxima à do utilitarismo.

Esse é um conceito baseado em uma ideia de competitividade na sociedade humana. Bobbio afirma que toda a vida social é uma competição para a obtenção de bens escassos ${ }^{114}$. Essa sociedade competitiva possui características mais próximas de uma típica sociedade capitalista liberal, onde, a sobrevivência e o desenvolvimento da pessoa humana são competições desenvolvidas dentro de uma sociedade.

\footnotetext{
${ }^{112}$ RAWLS, John. Uma teoria da justiça. Trad. Almino Pisetta e Lenita M.R. Esteves. 1. ed. 2. tir. São Paulo: Martins Fontes, 2000. p. 90.

${ }^{113}$ Id. Ibid., p. 107.

${ }^{114}$ BOBBIO, Norberto. Igualdad y libertad, cit., p. 31.
} 
Procurando fazer uma analogia com os esportes, que também são práticas competitivas, a ideia de igualdade de oportunidades pressupõe uma igualdade de chances para todos atingirem seu objetivo, para que o maior número de participantes possa ser vencedor nessa competição. A preocupação é voltada essencialmente para a possibilidade de iguais oportunidades de êxito pessoal. O seu maior objetivo é poder obter uma maior igualdade nos resultados. Para as pessoas que integram grupos historicamente prejudicados na sociedade, criam-se desigualdades absolutamente artificiais, reconhecendo-se em tais regras que, inequivocamente, os integrantes de grupos prejudicados não terão os mesmos desempenhos dos grupos mais privilegiados.

Tais desigualdades dentro dessa doutrina igualitária inserem os integrantes desse grupo em um ponto de partida da competição em situação mais favorável que os demais integrantes da sociedade. A situação é bastante semelhante a um jogador mais qualificado que, ao participar de uma disputa com outro competidor com qualidades bem inferiores, oferece uma vantagem ao último no início da competição, para que haja uma efetiva disputa. A expressão popular lambuja reflete com fidelidade tal artificialismo, uma vantagem no início da prova para que ela seja bem disputada, procurando diminuir a vantagem técnica do competidor mais capacitado. E, dentro da atividade competitiva do desenvolvimento da vida humana, o que se espera não é a igualdade de oportunidades na partida da competição, com uma largada em igualdade de condições, mas sim uma igualdade de oportunidades no resultado final da prova, para que os integrantes desses grupos menos privilegiados, que terão desempenho presumivelmente inferior, tenham oportunidade de obter êxito tal qual os demais melhor estruturados. Trata-se de uma concepção mais solidária e comunitária da sociedade, segundo o escólio de Norberto Bobbio $^{115}$.

A segunda vertente de igualdade substancial se encontra na igualdade de resultados. Ela pressupõe que mesmo havendo um trato aparentemente igualitário com atitude neutra, isento de intenções maléficas, se ele gerar resultados desiguais, fere a igualdade substantiva. Essa modalidade de igualdade tem origem em uma forma extremamente importante de discriminação, dentro das demais formas atualmente verificadas, pois tratase da discriminação chamada indireta pela terminologia europeia ou discriminação por impacto adverso como considerada pela terminologia norte-americana, além de outros

\footnotetext{
${ }^{115}$ Id. Teoria geral da política. Trad. Daniela Beccacia Versiani. Rio de Janeiro: Campus, 2000. p. 302.
} 
exemplos citados por Hepple ${ }^{116}$. Trata-se de uma prática ou regra aparentemente neutra, que traz consequências adversas injustificáveis para determinada pessoa ou grupo de pessoas.

A igualdade de resultados pressupõe que, não obstante seja neutra determinada atitude ou prática por parte de determinada autoridade ou empregador, não poderá gerar prejuízos se não houver justificativa razoável para tal medida. Ainda que tal medida seja neutra, ou mesmo positiva, caso seus resultados sejam revelados como nefastos para determinados grupos, ela não pode ser aceita. O que importa nessa modalidade de igualdade é que o resultado obtido com determinada medida, não obstante seja neutra ou mesmo de boa-fé, o resultado desigual proporcionado a invalida completamente.

A terceira vertente da igualdade substancial é a igualdade na dignidade da pessoa humana. Trata-se de uma consideração de igualdade que se baseia na preservação dos iguais valores da dignidade da pessoa humana, ou seja, sua própria dignidade, a autonomia e o seu valor como tal. Fábio Konder Comparato vislumbra no raciocínio de Kant a afirmação de que a humanidade como espécie e cada ser humano em sua individualidade são propriamente insubstituíveis; não têm equivalentes, não podem ser trocados por coisa $\operatorname{alguma}^{117}$.

Ingo Wolfgang Sarlet define a dignidade da pessoa humana da seguinte forma:

"a qualidade intrínseca e distintiva de cada ser humano que o faz merecedor do mesmo respeito e consideração por parte do Estado e da comunidade, implicando, neste sentido, um complexo de direitos e deveres fundamentais que assegurem a pessoa tanto contrato e qualquer ato de cunho degradante e desumano, como venham a lhe garantir as condições existenciais mínimas para uma vida saudável, além de propiciar e promover sua participação ativa e corresponsável nos destinos da própria existência e da vida em comunhão com os demais seres humanos" ${ }^{, 18}$.

J.J. Gomes Canotilho explica o conteúdo do princípio da dignidade da pessoa humana em uma teoria de cinco componentes. No último deles, o célebre constitucionalista estabelece que se firma na igualdade dos cidadãos e se expressa na mesma dignidade social e na igualdade de tratamento normativo ${ }^{119}$. Assim, fica claro que a dignidade da

\footnotetext{
${ }^{116}$ HEPPLE, Bob. op. cit., p. 9.

${ }^{117}$ COMPARATO, Fábio Konder. op. cit., 3. ed. 2003, p. 21.

${ }^{118}$ SARLET, Ingo Wolfgang. Dignidade da pessoa humana e direitos fundamentais. 2. ed. Porto Alegre: Livr. do Advogado, 2002. p. 62.

${ }^{119}$ CANOTILHO, Joaquim José Gomes. Direito constitucional. 6. ed. Coimbra: Almedina, 1993. p. 363.
} 
pessoa humana depende, essencialmente, de ser respeitada a mesma dignidade social a todos os seres humanos. No mesmo sentido, Jorge Miranda aponta que a dignidade de cada pessoa reporta-se a todas e a cada uma das pessoas, sendo uma dignidade individual e concreta, na qual a pessoa vive uma relação comunitária, o que implica o reconhecimento por cada pessoa, da igual dignidade das demais pessoas ${ }^{120}$. Todos os homens devem respeitar e todos os homens devem ser respeitados em sua integral e mesma dignidade social, segundo o referido constitucionalista lusitano ${ }^{121}$.

A igualdade na dignidade da pessoa humana pressupõe que nenhum ato que venha a prejudicá-la ou aniquilá-la possa ser aceito, salvo justificação muito intensa e defensável, mediante a um rigoroso questionamento. Cristina Queiroz se apoia nas noções de Kant sobre a dignidade humana para explicar que a igualdade atingiu sua universalização nas revoluções contra as monarquias tradicionais. Afirma a jurista portuguesa que a noção de dignidade kantiana de cada ser humano deveria ser traduzida na dignidade igual de todos os homens nos novos Estados constituídos, em especial sobre os direitos civis e políticos $^{122}$. Ou seja, a todos indistintamente deve ser dispensado um tratamento igual em função de uma mesma dignidade de todos os homens. O conceito kantiano estabelecido no Século XVIII merece uma retificação para os tempos atuais, no sentido de estender o respeito à dignidade humana a todos os direitos que integram o rol de direitos inerentes à pessoa humana.

Esse é um ponto chave para compreensão desta visão sobre a igualdade. A todos os seres humanos deve ser reconhecida a mesma dignidade, a mesma consideração como pessoa humana detentora de direitos, independentemente de sua situação na sociedade, como sustentáculo fundamental do Estado Democrático.

Juan Maria Bilbao Ubillos afirma, com clareza, que a discriminação possui um caráter vexatório e pejorativo, e leva a uma estigmatização de determinado grupo social, geralmente marginal da sociedade ou vulnerável, impedindo de fato a realização e o pleno exercício de seus direitos ${ }^{123}$. A discriminação, segundo o constitucionalista espanhol, afeta

\footnotetext{
${ }^{120}$ MIRANDA, Jorge. op. cit., p. 183.

${ }^{121}$ Id. Ibid., p. 189.

${ }^{122}$ QUEIROZ, Cristina M. M. op. cit., p. 106.

${ }^{123}$ BILBAO UBILLOS, Juan Maria. Prohibición de discriminación y relaciones entre particulares. Teoria y Realidad Constitucional, Madrid, n. 18, p. 154, 2006.
} 
a própria dignidade da pessoa, pois as pessoas discriminadas não são tratadas como pessoas diferentes, mas inferiores, deixando de merecer o mesmo respeito ${ }^{124}$.

Quando se nega essa dignidade, discrimina-se uma pessoa, que sofrerá uma desconsideração como pessoa humana, inserindo-a em uma situação como um ser humano de segunda classe. Nessa situação não lhe é conferido o mesmo trato em condições de manter a mesma dignidade dos demais seres humanos que integram o modelo de comparação anteriormente mencionado.

Por fim, cabe ressaltar a exposição de Sandra Fredman sobre quatro modelos alternativos de valores que informam o princípio da igualdade, tal qual a referida autora vislumbra na legislação do Reino Unido. O primeiro reside na dignidade e no valor individual, o segundo na restituição, o terceiro na redistribuição e o quarto na democracia efetiva $^{125}$. A referida autora expõe, no mesmo artigo, que uma quarta geração de igualdade caminha no sentido de que são instituídas obrigações para promoção de igualdade destinadas aos empregadores e para os agentes públicos, ao invés de uma conduta abstencionista da prática discriminatória. Esse novo conceito de igualdade traz consigo o valor da democracia efetiva, estimulando que os membros de grupos atingidos pela discriminação venham a participar diretamente dos processos decisórios impostos por empregadores e agentes públicos. Tais medidas integrativas estabelecem uma maior representatividade das minorias, promovendo uma participação destinada a suplementar as dificuldades culturais de assimilação das minorias pelos grupos majoritários, estabelecendo uma relação dinâmica entre os dominados e a cultura dominante ${ }^{126}$.

\subsection{A igualdade e o combate à discriminação dentro da visão do direito norte- americano: as perspectivas da antidiferenciação e da antissubordinação}

A discussão sobre a discriminação no direito norte-americano é extremamente profunda, na medida em que aquele país apresenta uma intensa litigiosidade envolvendo a discriminação nas relações do trabalho, a ponto de o direito sobre a discriminação nas relações de trabalho ser quase um ramo autônomo do direito individual do trabalho. Os

\footnotetext{
${ }^{124}$ BILBAO UBILLOS, Juan Maria. op. cit., p. 154.

${ }^{125}$ FREDMAN, Sandra. Equality: A new generation? Industrial Law Journal. June 2001, volume 30, Número 2, ILJ 2001.30(145), Oxford: Oxford Journal Press, p. 6. Lexis Nexis. Disponível em: $<$ http://www.lexisnexis.com/us/lnacademic/results/docview/docview.do?risb=21_T7244461488\&treeMax= true \&sort=BOOLEAN\&docNo=11\&format=GNBFULL\&startDocNo=1\&treeWidth=0\&nodeDisplayNam $\mathrm{e}=\& \mathrm{cisb}=22 \_$T7244461490\&reloadPage $=$false $>$. Acesso em: 31 ago. 2009.

${ }^{126}$ Id. Ibid., p. 10 .
} 
motivos são conhecidos: trata-se de um país que vive até os presentes dias um conflito racial com persistentes efeitos de uma longa dominação branca sobre uma vasta população negra, em face da escravidão, bem como a prática de atitudes discriminatórias contra imigrantes.

Roger Raupp Rios, um estudioso sobre a discriminação no direito brasileiro, traz um relato interessante sobre as duas principais perspectivas do direito norte-americano, o que chama de direito da antidiscriminação: as perspectivas da antidiferenciação e da antissubordinação $^{127}$. A terminologia das duas perspectivas é adotada por Ruth Colker, que reconhece dois princípios em sua exposição, para facilitar a exploração das forças e fraquezas dos modelos sobre discriminação por raça e por sexo ${ }^{128}$. Roger Raupp Rios afirma que as duas perspectivas permitem a compreensão do debate peculiar ao direito da antidiscriminação, indicando as perspectivas dominantes e concorrentes no desenvolvimento das categorias jurídicas do direito da antidiscriminação.

$\mathrm{Na}$ perspectiva da antidiferenciação, segundo Colker, não é apropriado tratar pessoas distintamente com base em uma visão individualista sobre raça ou sexo, posto que tal prisma abandona a visão do contexto social importante para uma análise de uma situação discriminatória $^{129}$. Por outro lado, a referida perspectiva foca tão somente o efeito específico da alegada discriminação em pessoas vistas de modo isolado, ao invés de grupos.

Roger Raupp Rios destaca que esse modelo rejeita tratamentos diferenciados, baseando-se na ótica do agente discriminador, apresentando-se como uma manifestação radical da igualdade formal enquanto proibição da instituição de qualquer distinção fundada nos critérios proibidos de diferenciação ${ }^{130}$. E acrescenta que esse modelo não se funda no reconhecimento das diferenças dos indivíduos discriminados, sendo irrelevante a diferença, principalmente quando possui dificuldades no estabelecimento do modelo de comparação $^{131}$. Sérgio Campos critica essa perspectiva, apontando que ela possui uma

\footnotetext{
${ }^{127}$ RIOS, Roger Raup. Direito da antidiscriminação: discriminação direta, indireta e ações afirmativas. Porto Alegre: Livr. do Advogado, 2008. p. 32.

${ }^{128}$ COLKER, Ruth. Anti-subordination above all: sex, race, and equal protection. New York University Law Review, Dec. 1986, $\mathrm{n}^{\mathrm{o}}$ 61, p. 1003-1066, p. 1005. Lexis Nexis. Disponível em: $<$ http://www.lexisnexis.com/us/lnacademic/results/docview/docview.do?docLinkInd=true\&risb=21_T7334 $624754 \&$ format=GNBFI\&sort=BOOLEAN\&startDocNo=1\&resultsUrlKey=29_T7334624759\&cisb=22_T $7334624758 \&$ treeMax $=$ true $\&$ treeWidth $=0 \&$ csi $=7351 \&$ docNo=11>. Acesso em: 13 jan. 2009.

${ }^{129}$ Id., loc. cit.

${ }^{130}$ RIOS, Roger Raup. op. cit., p. 33.

${ }^{131}$ Id. Ibid., p. 34.
} 
visão puramente transacional, sem avaliação do contexto estrutural dentro da sociedade em que a discriminação atua ${ }^{132}$.

O jurisfilósofo Owen Fiss aponta que essa perspectiva invoca uma "cegueira" do aplicador da lei em relação ao fator em questão, promovendo uma proteção igual das leis muito mais voltada para o aspecto formal. Tal posição pede uma posição mais neutra do julgador, com uma jurisprudência muito mais mecânica e um processo decisório muito mais tecnocrático, para constatar se há superinclusão ou infrainclusão ${ }^{133}$. O referido autor também aponta que essa perspectiva mais individualística permite que as regras sejam apreciadas com uma maior possibilidade de certeza sobre sua aplicação, não são muito dependentes de contextos probatórios ou julgamentos de diversos aspectos, bem como não estão sujeitas a variações com o passar do tempo ${ }^{134}$.

Dentro desse conceito, fica claro que uma proposta igualitária "rasa", sem ou com mínima conexão com o contexto fático, constitui uma proposta igualitária de cunho individualista, sem permissão de qualquer tratamento diferenciado, em especial aqueles destinados a corrigir reiteradas posições prejudiciais aquilatadas e trazidas do passado. É uma perspectiva avessa às ações afirmativas e medidas de cunho igualitário que venham a criar desvantagens para corrigir tratamentos diferenciados persistentes dentro do meio social. Tal perspectiva permite que situações fáticas de dominação social de um grupo por outro persistam impunemente, sem exigir providências jurídicas em sentido contrário.

A segunda perspectiva em questão é a antissubordinativa, que vem reprimir tratamentos jurídicos que promovam situações de subordinação social. A primeira noção que essa perspectiva clama, é o reconhecimento da existência de condições sociais e como elas afetam a pessoa dentro do contexto social, segundo a colocação de Sergio Campos. Esse autor menciona que essa perspectiva tem uma visão diferenciada da sociedade, mirando sua visão para uma noção de castas sociais, não na forma tradicional, mas sim dentro de uma metáfora, pela qual é avaliada a situação de uma pessoa dentro de um grupo e os reflexos de tratamento em uma estrutura social que fere os princípios éticos de uma sociedade com igual proteção ${ }^{135}$.

\footnotetext{
${ }^{132}$ CAMPOS, Sergio J. Subordination and the fortuity of our circumstances. University of Michigan Journal of Law Reform, n. 41, Primavera 2008, p. 591. Lexis Nexis. Disponível em: <http://www.lexisnexis.com/us/lnacademic/search/homesubmitForm.do>. Acesso em: 13 set. 2009.

${ }^{133}$ FISS, Owen M. op. cit., p. 120.

${ }^{134}$ Id. Ibid., p. 121.

${ }^{135}$ CAMPOS, Sergio J. op. cit., p. 594.
} 
Owen Fiss relata a existência de uma relação de subordinação do grupo afrodescendente em relação ao grupo dominante dos brancos, implicando em redução de poder político; ainda que outros grupos também sofram a mesma situação naquele país, porém com menor intensidade ${ }^{136}$. O referido autor adota a expressão "casta" como forma de demonstrar a intensidade do despojamento político que o grupo dos afro-descendentes sofre, como resultado de uma reiterada prática de negação de direitos dentro do contexto norte-americano ${ }^{137}$. O uso da expressão "casta" advém da ideia de que o grupo desfavorecido possui fortes restrições para livrar-se da referida subordinação, com nítido caráter de imutabilidade social, segundo Sergio Campos ${ }^{138}$.

A perspectiva da antissubordinação condena como indevida toda forma discriminatória que seja intencional ou neutra, tornando ambas proscritas segundo o mandamento de igualdade geral, desde que venham a perpetuar determinada hierarquia, segundo Ruth Colker ${ }^{139}$. A perspectiva da antissubordinação tem início na detecção da existência de subordinação gerada pela sociedade contra determinado grupo. Por outro lado, importa também constatar de que modo tal hierarquização social inflige danos para o grupo social.

Constatadas tais situações, a referida perspectiva admite a adoção de medidas de contenção ou de desfazimento das situações subordinativas, por meio de políticas públicas e privadas para geração de uma igualdade substancial que venha a quebrar a dominação hierárquica. A falta de uma ação nesse sentido é que configura a existência de tratamento desigual. O princípio da igualdade, nessa perspectiva, pede uma atuação mais pró-ativa, solicitando uma visão de futuro sobre a existência de situações subordinativas, principalmente na elaboração das leis.

Segundo Owen Fiss, a cláusula de proteção igual fornece ao Poder Judiciário uma plataforma textual que pode emitir declarações sobre o significado da igualdade, para dar forma ao ideal de igualdade. Nesse aspecto, as declarações sobre a igualdade são vistas como integrantes do direito e atuam no papel fundamental de formatar a moralidade popular e a efetiva expressão da igualdade ${ }^{140}$.

\footnotetext{
${ }^{136}$ FISS, Owen M. op. cit., p. 154.

${ }^{137}$ Id. Ibid., p. 152.

${ }^{138}$ CAMPOS, Sergio J. op. cit., p. 596-597.

${ }^{139}$ COLKER, Ruth. op. cit., p. 1007.

${ }^{140}$ FISS, Owen M. op. cit., p. 173.
} 
Assim, a noção de igualdade trazida pela perspectiva da antissubordinação é uma atuação ativa dos meios regulatórios fundada em um conteúdo substancial ao direito da antidiscriminação, por meio da superação das situações subordinativas mediante medidas concretas e não somente neutras. Roger Raupp Rios lembra, com muita profundidade, que tal perspectiva conduz a uma das funções mais caras dos direitos fundamentais nas democracias contemporâneas - a proteção das minorias ${ }^{141}$. Ela será feita mediante uma atenção à situação dos grupos subordinados, por meio da análise de uma consideração de um prejuízo a ser suportado por um grupo subordinado.

\subsection{A igualdade como princípio violado por um ato discriminatório}

O tema da igualdade é extremamente fundamental, não somente para as questões que envolvem o tratamento diferenciado de pessoas, mas, também, para todo o direito, por ser um aspecto crucial da estruturação de um sistema político e jurídico, como fundamento de muitos institutos jurídicos. No entanto, como se percebe, não se trata apenas de um valor, mas de um princípio jurídico especial, como um dos elementos estruturantes do Estado de direito, da democracia representativa. Também a igualdade é regente de muitos aspectos da ordem jurídica, principalmente dentro do Estado Social. Desde um ideal contra as diferenças da vida humana no planeta até elemento para um controle da constitucionalidade de normas infraconstitucionais, a igualdade é um elemento de ponderação fundamental na compreensão jurídica de diversos fatos.

A igualdade, ao longo da civilização humana, vem sendo considerada como um valor que pode ser confundido até mesmo com a própria justiça, sendo uma forma de expressão desta. Chaïm Perelman aponta que uma característica de nossa civilização desde o Século XVIII é a insistência com que, cada vez mais, a igualdade é apresentada como substitutivo de justiça ${ }^{142}$.

As noções sobre justiça como sinônimo de igualdade são destacadas por Aristóteles como o justo é o igual $^{143}$, assim ponderado como um meio termo estabelecido entre extremos desproporcionais, ou a igualdade como essência da própria justiça distributiva ${ }^{144}$.

\footnotetext{
${ }^{141}$ RIOS, Roger Raup. op. cit., p. 41.

${ }^{142}$ PERELMAN, Chaïm. Ética e direito. Trad. Maria Ermantina Galvão. São Paulo:Martins Fontes, 1996. p. 227.

${ }^{143}$ ARISTÓTELES. Ética a Nicômacos. Trad. Mário da Gama Kury. 4. ed. Brasília: Ed. Universidade de Brasília, 2001. p. 95.

${ }^{144}$ Id. Ibid., p. 109.
} 
A máxima do tratamento igual dos iguais e do tratamento desigual dos desiguais se perfaz pela distribuição proporcional dos méritos a cada um e pela proporção inversa do mal que cada um deva receber ${ }^{145}$. Esse pensamento aristotélico, que se baseia na proporcionalidade geométrica (a soma do primeiro e do terceiro elemento estão da mesma forma que a soma do segundo e do quarto, entre quatro elementos), fundamenta o direito constitucional mais moderno que procura estabelecer os meios de concretizar a igualdade e promover a correção de disparidades de ordem material e social.

Bobbio também ressalta a noção da igualdade como algo próximo da justiça ${ }^{146}$. Já Kelsen analisa a igualdade como uma das expressões da justiça no direito natural, por muitas vezes ser assim comparada; no entanto, critica tal posicionamento ao afirmar que a igualdade nada mais é que a consequência lógica da generalidade da norma ${ }^{147}$. Jorge Miranda aponta que pensar em igualdade é pensar em justiça na linha da análise aristotélica, retomada pela escolástica e por todas as correntes posteriores, de Hobbes a Rousseau, de Marx a Rawls, é redefinir as relações entre pessoas e entre normas jurídicas $^{148}$.

Perelman também toca no mesmo sentido, apontando que o tratamento igualitário tem uma consideração muito próxima à de um tratamento justo, indicando que a noção de igualdade é, necessariamente, uma noção muito próxima à de justiça ${ }^{149}$.

Diante desta peculiar condição da igualdade, fica claro que qualquer tratamento diferenciado tende bastante, mas não necessariamente significa, em caráter preliminar e em uma visão menos apurada, a um tratamento com contornos de injustiça em face da quebra da igualdade.

Esse ponto traz, fundamentalmente, a noção de que a igualdade é sempre presumida como atitude correta, porque tende a ser justa ou que a justiça está mais próxima. Essa presunção pode conduzir o intérprete do fato alegado a uma conclusão de que tal fato seja considerado como discriminatório, sendo uma indicação como anteriormente já foi visto. Nesta análise, somente em casos excepcionais, mediante justificativa proporcionalmente inversa à da gravidade da distinção, poderá entender como autorizada tal diferenciação. Nesse sentido, Perelman destaca um dos pontos mais importantes sobre a igualdade e a

\footnotetext{
${ }^{145}$ ARISTÓTELES. op. cit., p. 97.

${ }^{146}$ BOBBIO, Norberto. Teoria geral da política, cit., p. 311.

${ }^{147}$ KELSEN, Hans. A justiça e o direito natural. Trad. João Baptista Machado. Coimbra: Almedina, 2001. p. 93.

${ }^{148}$ MIRANDA, Jorge. op. cit., p. 221.

${ }^{149}$ PERELMAN, Chaïm. op. cit., p. 214.
} 
análise dos tratamentos diferenciados, apontando que a igualdade não tem que ser justificada, pois é presumida justa, mas a desigualdade deve ser justificada, tem conotação de arbitrária e, portanto, mais parece injusta ${ }^{150}$. Tal posicionamento vai reger vários aspectos sobre uma atitude discriminatória, principalmente sobre as questões da prova da discriminação em Juízo.

A igualdade não é somente considerada como um valor, mas também um princípio de natureza relacional e constitui um dos princípios estruturantes dos direitos fundamentais, segundo Canotilho ${ }^{151}$. Para o referido constitucionalista, a igualdade é um pressuposto para a uniformização do regime das liberdades individuais a favor de todos os sujeitos de um ordenamento jurídico, sendo assim, indissociável da própria liberdade individual $^{152}$.

O princípio da igualdade possui uma aplicação bastante ampla, sendo que nas situações de discriminação resta irremediavelmente violado. Muito já se falou em doutrina e jurisprudência que o princípio da igualdade e o princípio da proibição de discriminação são verso e reverso da mesma moeda, e que toda discriminação é uma violação do princípio da igualdade e vice-versa. No entanto, a afirmação de que toda violação do princípio de igualdade incorre em discriminação é afirmação que não pode ser aceita. A violação de igualdade é gênero, onde a discriminação é uma de suas espécies.

Lyon-Caen aponta que uma distinção não constitui, necessariamente, uma discriminação e, portanto, ela contraria a igualdade jurídica, mas na condição de que essa seja compreendida como uma igualdade na lei. E nessa esteira afirma que as regras para não discriminar não têm o mesmo significado, nem o mesmo alcance de uma regra de igualdade jurídica ${ }^{153}$. No entanto, segundo o autor francês, é possível uma aproximação entre os dois princípios.

O princípio da proibição de discriminação não é, exatamente, a única expressão negativa do princípio da igualdade, mas uma de suas derivações, com uma situação extremamente específica, muito além da obrigação de trato igual. Trata-se de um princípio negativo que impõe uma abstenção de determinada prática, dirigido contra o Estado e os particulares. Como pode ser visto, o princípio da igualdade é extremamente amplo, com muitas faces e várias utilizações, por ser um princípio estrutural dos sistemas jurídicos

\footnotetext{
${ }^{150}$ PERELMAN, Chaïm. op. cit., p. 214.

${ }^{151}$ CANOTILHO, Joaquim José Gomes. op. cit., p. 426.

${ }^{152}$ Id. Ibid.

${ }^{153}$ LYON-CAEN, Antoine. op. cit., p. 73.
} 
atualmente vigentes. Oscar Sarlo aponta que as violações da igualdade podem ocorrer tanto por atitudes discriminatórias, como por atitudes injustas, posto que a igualdade se conecta com dois campos: o da justiça e o da nãodiscriminação ${ }^{154}$.

Gilmar Ferreira Mendes define, com base na doutrina alemã, que a isonomia tanto pode ser vista como exigência de tratamento igualitário (Gleichbehanlungsgebot), como proibição de tratamento discriminatório (Ungleichbehanlungsverbot) ${ }^{155}$. A primeira concepção corresponde à situação da violação do trato igual de um modo geral, porém a proibição do tratamento discriminatório vai mais além. A discriminação não é somente uma violação de trato isonômico como também uma violação qualificada da igualdade, correspondente a uma situação específica de alguns componentes especiais que não são encontrados na violação do trato igual. A discriminação possui uma valoração negativa destacada, na feliz colocação de Rodriguez-Piñero e Fernandez López ${ }^{156}$.

No mesmo sentido, o argentino Hugo Roberto Mansueti destaca que nem todo trato desigual resultará em trato discriminatório; este somente ocorrerá quando o ato venha atingir um determinado trabalhador que pertença a um grupo caracterizado por um caráter e, por conta dessa pertinência, haja um resultado prejudicial ${ }^{157}$.

Luís Gabriel Martínez Rocamora faz uma distinção mais precisa sobre a norma de igualdade e a proibição da discriminação. O referido autor aponta que o princípio geral de igualdade veda o arbítrio, ou seja, um comportamento empresarial desigual desfundamentado. Porém, caracteriza a proibição da discriminação como uma proibição de caráter "forte", cuja constatação pede uma justificativa muito mais rigorosa e intensa ${ }^{158}$. E conclui que o princípio geral de igualdade possui uma face de neutralidade, ao passo que a proibição de discriminar apresenta um objetivo unilateral crítico e corretor, que pede uma maior intensidade do direito constitucional para impregnar de senso igualitário as relações laborais ${ }^{159}$.

Thilo Ramm expõe com muita propriedade as questões sobre fatores naturais e sociais que envolvem a discriminação, sendo que os primeiros não podem ser mudados, ao

\footnotetext{
${ }^{154}$ SARLO, Oscar. op. cit., p. 29.

${ }^{155}$ MENDES, Gilmar Ferreira. Direitos fundamentais e controle de constitucionalidade. 2. ed. São Paulo: Celso Bastos, 1999. p. 48.

${ }^{156}$ RODRIGUEZ-PIÑERO, Miguel; FERNANDEZ LOPEZ, Maria Fernanda. op. cit., p. 65.

${ }^{157}$ MANSUETI, Hugo Roberto. Discriminación Laboral e integración normativa. Revista de Direito do Trabalho, São Paulo, ano 33, n. 125, p. 259, jan/mar. 2007.

${ }^{158}$ MARTÍNEZ ROCAMORA, Luis Gabriel. Decepciones empresariais y principio de igualdade. Barcelona:Sedes Editorial, 1998. p. 98.

${ }^{159}$ Id. Ibid., p. 99.
} 
contrário do segundo grupo. No entanto, quando a discriminação atinge determinada pessoa por um fator elegível, de escolha pessoal, o jurista alemão afirma claramente que a discriminação deixa de ser uma questão apenas de violação da igualdade e passa a ser um problema da preservação da liberdade do ser humano em tomar decisões de caráter individual $^{160}$.

Daniele Lochak aponta que a discriminação não pode ser definida tão somente como a violação do princípio da igualdade, cujo alcance é cada vez mais leve ${ }^{161}$. E conclui no mesmo texto que qualquer diferença ou desigualdade de tratamento não é necessariamente uma discriminação, posto que apenas aparenta ser ilegítima, demandando uma análise mais precisa sobre este aspecto.

A exemplificação acima nos traz outra diferenciação importante entre a discriminação e a violação da igualdade. A discriminação não somente afeta a igualdade de tratamento, que é necessária também, porém vai bem além da violação de trato igual como medida de justiça. A discriminação afeta profundamente o exercício e plenitude da realização humana na fruição de outros direitos de caráter fundamental e essenciais para o desenvolvimento regular da existência pessoal em condições idênticas aos demais seres humanos. A vítima da discriminação tem ameaçada e, muitas vezes, destruída a sua própria essência como pessoa, principalmente a sua individualidade, que pode ser prejudicada em muitos sentidos. Assim, a proteção contra a discriminação não somente pretende preservar a obrigação de trato igual, mas também todo o patrimônio jurídico da pessoa humana, no respeito de sua igual dignidade e igual valor social em relação a todas as demais.

Como bem coloca Lyon-Caen, atrás de toda regra que proíbe uma discriminação é descoberta uma igualdade compensadora ${ }^{162}$. Portanto, toda regra antidiscriminatória tem uma natureza compensatória, mas muitas não têm intenção de dissolver o fato que gera a discriminação, apenas reprimi-la, nunca preveni-la.

E tal ameaça a direitos fundamentais, dentro de uma relação profundamente hierarquizada como as relações de emprego, mantida sob o manto da subordinação e da dependência econômica, solicita-nos muito maior atenção. As relações de trabalho não são somente relações bilaterais de prestação de serviços e pagamento de valores, mas também, relações de profunda implicação social. A sobrevivência e a realização de um enorme

\footnotetext{
${ }^{160}$ RAMM, Thilo. op. cit., p. 507.

${ }^{161}$ LOCHAK, Daniele. Réflexions sur la notion de discrimination. Droit Social, Paris, n. 11, p. 779, nov. 1987.

${ }^{162}$ LYON-CAEN, Antoine. op. cit., p. 74.
} 
contingente de seres humanos são regulados por tais relações. Qualquer medida que venha a ameaçar, ou minimizar os direitos fundamentais, deve ser analisada com muito cuidado, mormente as relações estabelecidas em situações tão peculiares e delicadas, como são as relações trabalhistas. 


\section{NATUREZA JURÍDICA DAS NORMAS ANTIDISCRIMINATÓRIAS}

\subsection{A qualidade diferenciada das normas antidiscriminatórias no direito internacional}

Como visto no capítulo anterior, o ato discriminatório não é somente uma quebra de igualdade. Vai mais além e leva a vítima a uma situação de falta de tratamento digno em relação à sua pessoa, desqualificando-a perante os modelos de comparação e os demais seres humanos.

Pôde ser afirmado, sem qualquer questionamento de qualquer espécie, que as normas que proíbem a discriminação visam proteger os direitos humanos. Mas não é somente isso, elas possuem uma consideração especial, mesmo entre as normas de direitos humanos.

A criação e a efetivação de normas contra a discriminação é um fenômeno recente. Como foi visto no primeiro capítulo, a consideração da discriminação como um ato grave contra os direitos do homem no direito internacional somente teve alcance global a partir de meados do Século XX, mais precisamente com a Declaração Universal dos Direitos do Homem, em 1948. A partir daí, podemos afirmar com toda a certeza que o combate à discriminação de seres humanos passou a integrar as agendas das discussões globais e regionais sobre a proteção dos direitos do homem. E com isso, houve o rápido surgimento de normas antidiscriminatórias, em especial as normas globais e regionais da segunda metade do Século XX.

O processo de generalização da proteção aos direitos humanos no plano internacional desencadeou-se com a Declaração Universal dos Direitos do Homem. Cançado Trindade aponta que, exatamente em função do segundo grande conflito mundial, havia a necessidade de solução de graves problemas com o surgimento das normas internacionais de proteção dos direitos do homem ${ }^{163}$. Nesse sentido, também opinam Celso Lafer $^{164}$ e Norberto Bobbio ${ }^{165}$.

\footnotetext{
${ }^{163}$ TRINDADE, Antonio Augusto Cançado. A proteção internacional dos direitos humanos e o Brasil. 2. ed. Brasília: Ed. Universidade de Brasília, 2000. p. 23.

${ }^{164}$ LAFER, Celso. A reconstrução dos direitos humanos: um diálogo com o pensamento de Hannah Arendt. São Paulo: Cia das Letras, 1988. p. 150-166.

${ }^{165}$ BOBBIO, Norberto. A era dos direitos, cit., p. 49.
} 
$\mathrm{O}$ direito internacional foi o precursor do combate à discriminação em todo o mundo, em função dos horríveis acontecimentos do segundo grande conflito mundial. A consideração da discriminação como ato extremamente grave contra a pessoa humana irradiou-se da Declaração Universal para vários tratados internacionais extremamente importantes, provocando a sua universalização. Esse processo de irradiação também atingiu declarações de direitos do homem de caráter regional, bem como as Constituições internas e Declarações de direitos humanos de diversos Estados.

Não é necessário mencionar os atos discriminatórios verificados durante a Segunda Grande Guerra e o impacto global que tais atos perpetraram. Rapidamente, logo após a Declaração universal, vários tratados internacionais exclusivamente voltados para o combate da discriminação passaram a ser celebrados. Em pouco mais de cinquenta anos de existência autônoma, as normas antidiscriminatórias internacionais vieram a receber um status especial dentro dos direitos humanos de caráter internacional.

Dentro do direito internacional, alguns autores reconhecem que as normas internacionais que protegem os seres humanos da discriminação têm caráter especial e destacado. André de Carvalho Ramos relata a classificação dos tratados internacionais feita por Villán Durán, no âmbito das Nações Unidas, destacando quatro principais grupos de normas de direito internacional: os tratados gerais de direitos humanos, tratados sobre temas específicos, tratados que protegem certas categorias de pessoas e os tratados contra a discriminação ${ }^{166}$. Alberto do Amaral Júnior também destaca que as convenções que tratam de várias modalidades de discriminação compõem um grupo especial de convenções especiais. O referido autor justifica a divisão em relação às normas de caráter geral, posto que, ainda que as normas gerais tratem o homem como um ser abstrato e que mereça tratamento igual sem qualquer discriminação, as convenções especiais focalizam as especificidades e diferenças entre os seres humanos, fatores que justificaram o tratamento particularizado sob pena de se cometer injustiça ${ }^{167}$.

Após a Declaração Universal dos Direitos do Homem, vários tratados de caráter global passaram a cuidar mais profundamente da discriminação, reafirmando o caráter universal de sua proibição. No entanto, eles procuraram ser mais específicos a determinadas circunstâncias discriminatórias, com enorme importância na definição de

\footnotetext{
${ }^{166}$ RAMOS, André de Carvalho. Teoria geral dos direitos humanos na ordem internacional. Rio de Janeiro: Renovar, 2005. p. 52-53.

${ }^{167}$ AMARAL JÚNIOR, Alberto do. Introdução ao direito internacional público. São Paulo: Atlas, 2008. p. 448.
} 
conceitos sobre a discriminação. Cronologicamente, podemos destacar como um dos principais tratados a Convenção $\mathrm{n}^{\circ} 111$ da OIT, de 1958, o tratado pioneiro que se preocupou em definir um ato discriminatório. Logo após, em 1960, a Convenção relativa à luta contra as discriminações na esfera do ensino foi aprovada pela Conferência Geral da Organização das Nações Unidas para a Educação, a Ciência e a Cultura. Em 1965, a Organização das Nações Unidas aprovou a Convenção sobre a eliminação de todas as formas da discriminação racial, uma demanda extremamente importante para uma época conturbada com conflitos regionais e algumas manifestações de cunho racista na Europa. Porém, somente em 1979 a Assembleia das Nações Unidas aprovou a Convenção sobre a eliminação de todas as formas de discriminação contra a mulher.

Como vimos, a preocupação das organizações internacionais, em especial das Nações Unidas, foi erigir documentos internacionais de grande importância, voltados para coibir as práticas discriminatórias em diversos setores ou proteger determinados grupos que sofriam mais severamente os efeitos da discriminação. A preocupação das Nações Unidas tem origem na sua constituição, por meio da Carta das Nações Unidas, a qual traz em seu preâmbulo seus objetivos, entre eles promover a igualdade de direitos entre os homens e mulheres. Como bem assevera Marc Bossuyt, trata-se de um motivo excepcional e tema prioritário da Carta das Nações Unidas ${ }^{168}$. Essa organização tem uma grande preocupação com o tema, inclusive instituindo uma sub-comissão específica para cuidar da prevenção da discriminação e a proteção dos direitos humanos.

Não poderia ser diferente. A discriminação é um ato de extrema gravidade ao deixar de reconhecer a integralidade da condição humana de determinada pessoa ou grupo de pessoas. $\mathrm{O}$ ato discriminatório desmantela todo o sistema de proteção de direitos da pessoa humana, exigindo uma situação especial de proteção. Por outro lado, não obstante seja uma grave situação, os casos de discriminação infelizmente foram e continuam sendo muito comuns em qualquer lugar do planeta.

A prática reiterada de reconhecimento de determinados direitos de grande importância para a paz e para o progresso da humanidade conduzem a proibição de discriminação ao nível de um jus cogens, ou seja, uma norma de direito internacional geral que reflita um valor vital para a sociedade internacional que os Estados venham compartilhar, na definição de Alberto do Amaral Júnior ${ }^{169}$. Tal condição estipula que

\footnotetext{
${ }^{168}$ BOSSUYT, Marc. op. cit., p. 60.

${ }^{169}$ AMARAL JÚNIOR, Alberto do. op. cit., p. 110.
} 
qualquer tratado que permita a discriminação seja considerado internacionalmente nulo. $\mathrm{O}$ artigo 53 da Convenção de Viena sobre tratados internacionais declara expressamente a nulidade dos tratados que demonstrem conflito com uma norma imperativa de direito internacional geral, assim qualificando-a como norma que é aceita e reconhecida pela comunidade internacional dos Estados ${ }^{170}$.

O jurista neozelandês Warwick McKean defende que a igualdade dos indivíduos é um elemento de jus cogens, na medida em que as regras que proíbem a discriminação compõem um corpo de direitos cuja não observância por tratados pode afetar a essência do sistema legal internacional, tornando-se normas nulas ${ }^{171}$. O referido jurista ainda sustenta que o genocídio e a escravidão, apesar de exemplos extremos, são práticas discriminatórias que importam em violação da igualdade e são reiteradamente condenadas pelo direito internacional. Mais ainda, McKean menciona que a proibição de discriminação, em especial a racial, integra o rol dos direitos humanos básicos, cuja proteção é considerada um elemento de jus cogens ${ }^{172}$. E complementa descrevendo a decisão da Corte Internacional de Justiça do célebre caso Barcelona Traction, cuja decisão reconheceu que os atos de genocídio, escravidão e discriminação ofendem os direitos humanos como um todo, e geram obrigações internacionais erga omnes contra a efetivação de tais práticas ${ }^{173}$.

Como pode ser observado, o ato discriminatório, dentro do direito internacional, é considerado como uma das mais reprováveis condutas, estando situado ao lado de práticas que este ramo do direito internacional repudia com energia. Essa situação, em especial, deixa claro que a proteção contra a discriminação se posiciona entre uma das mais importantes normas de proteção dos direitos da pessoa humana, reconhecidamente por um grande número de tratados internacionais, pelos costumes internacionais, pela prática do direito internacional e até mesmo como fundamento de todo um sistema internacional de proteção dos direitos do homem. Como bem assevera Marc Bossuyt, a proibição da discriminação aparece, assim, como o princípio fundamental dos direitos do homem ${ }^{174}$.

No direito internacional do trabalho, a proibição da discriminação atinge, com maior intensidade ainda, a consideração de jus cogens. A Declaração da Organização

\footnotetext{
${ }^{170}$ CONVENÇÃO DE VIENA SOBRE TRATADOS INTERNACIONAIS. Ministério das Relações Exteriores do Brasil. Disponível em: <http://www2.mre.gov.br/dai/dtrat.htm>. Acesso em 25 ago. 2009.

${ }^{171}$ MCKEAN, Warwick. Equality and discrimination under international law. Oxford:Clarendon Press, 1983. p. 277.

${ }^{172}$ Id. Ibid., p. 282.

${ }^{173}$ Id. Ibid., p. 283.

${ }^{174}$ BOSSUYT, Marc. op. cit., p. 226.
} 
Internacional do Trabalho sobre os Princípios e Direitos Fundamentais no Trabalho, aprovada na sessão de 18 de junho de 1998, durante sua 86 ${ }^{\text {a }}$ reunião anual, afirma nas suas considerações iniciais que a garantia dos princípios e direitos fundamentais no trabalho é expressão de seus princípios fundamentais gozando de apoio e reconhecimento universais, buscando assim sua aplicação universal ${ }^{175}$. Os referidos direitos fundamentais no trabalho, assim reconhecidos pela própria Declaração, definem, em seu artigo $2^{\circ}$, que são princípios fundamentais a todos os membros da organização, ainda que não tenham ratificado a respectiva declaração aprovada, no sentido de respeitar, promover e tornar efetivos os seguintes aspectos:

a) liberdade sindical e o reconhecimento efetivo do direito de negociação coletiva;

b) a eliminação de todas as formas de trabalho forçado ou obrigatório;

c) a abolição efetiva do trabalho infantil; e

d) a eliminação da discriminação em matéria de emprego e ocupação. ${ }^{176}$

A referida declaração menciona em seu item 1 que os Estados que se incorporaram livremente à referida organização aceitaram os seus princípios e se compromissaram com os direitos enunciados em sua Constituição e na Declaração de Filadélfia. A declaração também afirma que os integrantes da organização, ao decidirem pela filiação, se comprometeram a esforçar-se para lograr êxito em atingir os objetivos gerais da organização em toda sua medida de possibilidades e atendendo a condições específicas. A declaração ainda menciona expressamente que os princípios e direitos ali estabelecidos foram desenvolvidos na forma de direitos e obrigações específicas, em convenções que tenham sido reconhecidas pela declaração como fundamentais, tanto dentro como fora do âmbito da OIT.

A mencionada declaração pode parecer sem efeito vinculante, por sua natureza, no entanto seus dizeres apontam exatamente o contrário. A declaração, logo no seu início, expressa a vontade da organização para que determinado grupo de normas por ela geradas tenham caráter universalista, tornando-se aplicáveis a qualquer trabalhador, em qualquer local do planeta, independentemente de adesão do Estado em que esse trabalhador preste seus serviços. Ela adota o conceito da universalidade de tais direitos e princípios, pelo

\footnotetext{
${ }^{175}$ DECLARAÇÃO DA OIT sobre os Princípios e Direitos Fundamentais no Trabalho e seu Seguimento. Tradução de Edílson Alkmin Cunha. Brasília: Escritório da OIT.

${ }^{176}$ Declaração da OIT idem apud.
} 
motivo de que também estão previstos em outros documentos internacionais de direitos humanos.

O jurista peruano Mario Pasco Cosmópolis destaca que a Declaração da OIT constitui um ponto histórico e implica uma quebra formal com os critérios que eram observados para a adoção de convenções internacionais relacionadas ao trabalho. Tais direitos são reconhecidos com uma natureza anterior e superior a qualquer outra norma, de tal importância que dispensam reconhecimento formal ou adoção expressa por cada Estado, através do processo de ratificação de convenções. Segundo o jurista peruano, a referida declaração possui efeito vinculante por si mesma ${ }^{177}$.

Oscar Ermida Uriarte destaca claramente o jus cogens da referida Declaração como o coração do sistema jurídico dos direitos humanos, e que possui as seguintes características: a) obriga a todos os estados, independentemente de ratificações ou qualquer outra forma de reconhecimento nacional; b) tem efeito erga omnes, enquanto não se dirige só aos Governos, mas também aos indivíduos; c) pode ser reclamado por qualquer pessoa ou Estado, mesmo à margem de todo vínculo convencional ou ratificação; d) é universal e não internacional no sentido tradicional dessa expressão; e e) possui multiplicidade de fontes ${ }^{178}$. O notável autor uruguaio ainda vai mais além e anuncia que a posição da OIT oferece à comunidade internacional uma espécie de cláusula social universal, que pode ser referência para diversos tipos de acordos, bem como para organismos e países que se ocupem do comércio internacional.

Um indicativo da importância da proibição da discriminação é o fato de que a Convenção 111 da OIT é uma das convenções mais ratificadas até a presente data, segundo os dados da própria organização, com 169 ratificações entre 177 membros ${ }^{179}$.

Desse modo, então, a proibição de discriminação é uma norma que possui um status diferenciado dentro do direito internacional, com muito maior intensidade ainda no direito internacional do trabalho. Tal condição posiciona as normas antidiscriminatórias

\footnotetext{
${ }^{177}$ PASCO COSMÓPOLIS, Mario. Tendências constitucionais em matéria trabalhista. Associação de Magistrados da Justiça do Trabalho da $4^{a}$ Região $\quad$ AMATRA IV. Disponível em: $<$ http://www.amatra4.org.br/Comunicacao/Artigos/1460>. Acesso em: 23 nov. 2008.

${ }^{178}$ ERMIDA URIARTE, Oscar. Derechos laborales e comércio exterior. Ponencia presentada al V Congreso Regional Americano de Derecho del Trabajo y de la Seguridad Social, Lima 2001. Universidad de la República. Facultad de Derecho. Instituto de Derecho del Trabajo y Seguridad Social. Disponível em: $<$ http://www.rau.edu.uy/universidad/inst_derecho_del_trabajo/derlabermida.htm>. Acesso em: 23 ago. 2008.

${ }^{179}$ ORGANIZAÇÃO INTERNACIONAL DO TRABALHO. Ilolex. Base de dados de documentos da OIT. Disponível em: <http://www.ilo.org/ilolex/english/newratframeE.htm>. Acesso em: 08 set. 2009.
} 
dentro do direito internacional em uma posição de destaque, motivo pelo qual a sua violação, na esfera internacional, dependa de uma justificativa muito forte acompanhada de outros aspectos igualmente importantes. Essa qualidade especial da norma antidiscriminatória no direito internacional é refletida, também, dentro do direito interno, em especial no direito constitucional mais moderno.

\subsection{As normas antidiscriminatórias como normas de direito fundamental}

Se o direito internacional teve a preocupação de elevar a proibição da discriminação a um nível tão elevado de proteção dentro do direito internacional dos direitos humanos, tal posicionamento teve reflexos importantes nos ordenamentos internos do período após a Segunda Grande Guerra. A proibição da discriminação é considerada como norma fundamental na maioria dos ordenamentos jurídicos vigentes no planeta.

Como já observado, a proibição da discriminação dentro do direito internacional teve sua primeira aparição em termos globais a partir da Declaração Universal dos Direitos do Homem, em 1948. Logo após, muitos tratados internacionais de alcance global passaram a tratar com maior profundidade o assunto, ocorrendo o mesmo fato com a legislação interna de diversos Estados, em especial algumas Constituições promulgadas na segunda metade do Século XX. É certo que a questão terminológica deve ser ponderada, eis que, muitas normas legislativas, ainda que não utilizassem a expressão discriminação, utilizavam expressões similares.

Sua consideração como norma de direito fundamental é clara em diversas constituições do pós-Segunda Grande Guerra, merecendo a demonstração de alguns exemplos.

A Constituição italiana, que entrou em vigor em $1^{\circ}$ de janeiro de 1948 , assinala em seu artigo $3^{\circ}$ um mandamento de igualdade mais sofisticado, mencionando que todos os cidadãos italianos possuem a mesma dignidade social e são iguais perante a lei, proibindo distinções por sexo, raça, língua, religião, opinião política e condições pessoais e sociais ${ }^{180}$.

\footnotetext{
${ }^{180}$ ITALIA. Costituzione della Reppublica Italiana. Corte Costituzionale. Disponível em: $<\mathrm{http}: / /$ www.cortecostituzionale.it/istituzione/lacorte/fontinormative/lacostituzione/costituzione_principii.a sp>. Acesso Acesso em: 25 ago. 2009. Art. 3. Tutti i cittadini hanno pari dignità sociale e sono eguali davanti alla legge, senza distinzione di sesso, di razzi, di lingua, di religione, di opinioni politiche, di condizioni personali e sociali.è compito della Repubblica rimuovere gli ostacoli di ordine economico e sociale, che, limitando di fatto la libertà e l'eguaglianza dei cittadini, impediscono il pieno sviluppo della persona umana e l'effettiva partecipazione di tutti i lavoratori all'organizzazione politica, economica e sociale del Paese.
} 
Observou-se, também, que a expressão distinções era a expressão preferida da língua francesa nos tratados internacionais ao se referir à discriminação.

A Constituição alemã, de 1949, expõe em seu artigo $3^{\circ}$, de modo bem claro, que todos os homens são iguais perante a Lei, que homens e mulheres possuem os mesmos direitos e que o Estado favorece o estabelecimento dos mesmos direitos para homens e mulheres, atuando sobre a eliminação das desigualdades existentes. E deixa bem claro que ninguém pode ser prejudicado ou privilegiado por causa do seu sexo, da sua descendência, da sua raça, da sua língua, da sua terra materna e da sua origem, da sua religião, das suas ideias religiosas ou políticas, bem como por causa da sua incapacidade ${ }^{181}$. A norma alemã tem uma característica muito interessante, ao afirmar que ninguém pode ser prejudicado ou privilegiado pelos fatores ali estabelecidos, utiliza de forma ímpar a descrição de um ato discriminatório, motivada, certamente, pela falta de universalização da expressão discriminação.

Ambas as constituições citadas, importantíssimas para o estudo dos direitos fundamentais, preocupam-se com a discriminação, e adotam expressões similares. Há de ser ponderado que a expressão discriminação somente passou a ser universal a partir de 1948. Ambas são textos do período de redemocratização desses dois importantes países europeus, que durante a guerra mantiveram regimes totalitários, com desastrosas violações de direitos humanos e discriminações institucionalizadas.

Já nos anos setenta, duas constituições possuem definições interessantes da proibição da discriminação, advindas de dois países que instituíram regimes democráticos em substituição à longa dominação de caráter neo-fascista.

A Constituição portuguesa de 1976 possui uma norma de proibição da discriminação bastante interessante. $\mathrm{O}$ artigo 13 da carta política portuguesa é dividido em dois itens: o primeiro menciona a igualdade perante a lei e a mesma dignidade social. Já o segundo fala sobre a discriminação, e não utiliza a referida expressão mas a existência de privilégios, benefícios, prejuízos ou privações de qualquer direito ou isenção de qualquer

\footnotetext{
${ }^{181}$ ALEMANHA. Deutscher Bundestag. Disponível em: <http://www.bundestag.de/dokumente/rechtsgrundlagen/grundgesetz/gg_01.html>. Acesso em 25 ago. 2009. Artikel 3. (1) Alle Menschen sind vor dem Gesetz gleich. (2) Männer und Frauen sind gleichberechtigt. Der Staat fördert die tatsächliche Durchsetzung der Gleichberechtigung von Frauen und Männern und wirkt auf die Beseitigung bestehender Nachteile hin. (3) Niemand darf wegen seines Geschlechtes, seiner Abstammung, seiner Rasse, seiner Sprache, seiner Heimat und Herkunft, seines Glaubens, seiner religiösen oder politischen Anschauungen benachteiligt oder bevorzugt werden. Niemand darf wegen seiner Behinderung benachteiligt werden.
} 
dever em razão de ascendência, sexo, raça, língua, território de origem, religião, convicções políticas ou ideológicas, instrução, situação econômica, condição social ou orientação sexual $^{182}$.

A referida norma da Constituição lusitana parece ter se inspirado na Constituição italiana quando menciona a regra geral de igualdade, utilizando-se da expressão dignidade social, que é importantíssima para a definição da discriminação. Por outro lado, é uma norma mais extensa e dividida em dois itens, sendo que no segundo adota a técnica da Constituição alemã, porém de forma mais ampla e detalhada, em definir uma norma geral antidiscriminatória, baseada em ações prejudiciais ou constitutivas de privilégios. E quando o faz, apresenta um rol interessante de motivações.

A Constituição espanhola de 1978 é extremamente interessante, porque adota a expressão discriminação de forma bem clara, apontando a sua regra básica de igualdade em duas previsões: a primeira relativa à igualdade geral e uma segunda previsão ao proibir a discriminação nos termos ali estabelecidos. Ela afirma que os espanhóis são iguais ante a lei, sem que possa prevalecer discriminação alguma por razão de nascimento, raça, sexo, religião, opinião ou qualquer outra condição ou circunstância pessoal ou social ${ }^{183}$. Essa norma é extremamente sintética e, ao contrário da portuguesa, adota uma cláusula geral de proibição de discriminação por qualquer motivo.

Por fim, na análise de diversos textos constitucionais, merece destaque a Constituição da República da África do Sul. Aquele país vivenciou uma das maiores tragédias da história da humanidade, o regime do apartheid. O novo texto constitucional, promulgado em 1996, trata a questão da igualdade de seus cidadãos de forma bem extensa e com muita profundidade, dividida em cinco itens. No primeiro aponta a regra geral de igualdade diante da lei e igual proteção dos benefícios da lei. No segundo item, fala sobre a fruição igual de todos os direitos e liberdades, bem como da promoção da igualdade mediante a realização de medidas especiais para fruição integral dos direitos. No terceiro

\footnotetext{
${ }^{182}$ PORTUGAL. Constituição da República Portuguesa. Tribunal Constitucional. Disponível em: $<$ http://www.tribunalconstitucional.pt/tc/crp.html\#art13>. Acesso em 25 ago. 2009. 1. Todos os cidadãos têm a mesma dignidade social e são iguais perante a lei. 2. Ninguém pode ser privilegiado, beneficiado, prejudicado, privado de qualquer direito ou isento de qualquer dever em razão de ascendência, sexo, raça, língua, território de origem, religião, convicções políticas ou ideológicas, instrução, situação económica, condição social ou orientação sexual.

${ }^{183}$ ESPANHA. Constitución Española. Ministerio de la Presidencia. Boletim Oficial del Estado. Disponível em: <http://www.boe.es/aeboe/consultas/enlaces/documentos/ConstitucionCASTELLANO.pdf>. Acesso em 25 ago. 2009.

Los españoles son iguales ante la ley, sin que pueda prevalecer discriminacion alguna por razon de nacimiento, raza, sexo, religion, opinion o cualquier otra condicion o circunstancia personal o social.
} 
tópico vem a proibição da discriminação voltada para o Estado contra os motivos ali relacionados, como raça, gênero, sexo, gravidez, estado civil, origem étnica ou social, cor da pele, orientação sexual, idade, deficiência, religião, consciência, credo, cultura, língua e nascimento. No quarto tópico, a norma proíbe a discriminação realizada por particulares de modo injusto em relação a outros particulares, pelo mesmo motivo do terceiro tópico. $\mathrm{O}$ quinto tópico aponta que toda a discriminação é injusta até que seja reconhecida como justa $^{184}$.

A norma sul-africana é extensa e complexa, mas tal característica é compreensível em função de um país que ainda vive os reflexos de um passado sombrio em face de uma ordem de cunho explicitamente racista, tal qual a dominação branca impôs durante muitos anos. A preocupação da norma constitucional sul-africana está voltada contra várias formas de discriminação e de tratamento desigual. Ela caracteriza uma das mais recentes formas de expressão do princípio da proibição de discriminação nas constituições. Insta ponderar ainda que se trata da Constituição de um país africano, promulgada em 1996, após um complexo processo de mudança de poder naquele país, cujas características são mais delicadas por ser dotado de onze línguas oficiais, e que ainda enfrenta enormes desigualdades sociais.

Assim, o princípio da proibição de discriminação é expresso em praticamente todas as constituições mais recentes, com caráter de norma de direito fundamental, abrindo o rol de direitos para proteção da pessoa humana. Trata-se de um princípio extremamente abrangente que estrutura toda a proteção dos direitos da pessoa humana previstos nas normas constitucionais mais modernas. O princípio da proibição da discriminação, como foi visto nos cinco exemplos acima citados, não se confunde com o dever de igualdade e possui uma condição especial, com destaque em relação aos demais direitos fundamentais e de proteção da pessoa humana.

Se a tendência global de destaque para as normas antidiscriminatórias é verificada em muitas constituições, na atual Constituição brasileira a proibição contra a discriminação assume destaque ainda mais elevado.

\footnotetext{
${ }^{184}$ REPÚBLICA DA ÁFRICA DO SUL. Constitutional Court of South Africa. Disponível em: <http://www.constitutionalcourt.org.za/site/constitution/english-web/ch2.html>. Acesso em 25 ago. 2009.
} 


\subsection{A proibição da discriminação como objetivo do Estado brasileiro}

Como foi visto no primeiro capítulo, a proibição de discriminação, no sentido de vedar as distinções não justificáveis, somente passou a ser expressa na atual Constituição, promulgada em 1988. Antes da atual norma, com exceção da norma de 1937, a expressão discriminação sequer figurou entre as demais cartas políticas.

Se a Constituição de 1988 foi inovadora ao tratar da discriminação dentro do panorama das Constituições brasileiras, foi extremamente audaciosa na forma do tratamento contra a discriminação. A carta de 1988 deixou de considerar a proibição da discriminação como apenas uma norma de direito fundamental, elevá-la ao nível de um dos objetivos fundamentais da República Federativa do Brasil, ao lado de outros extremamente importantes para um Estado social e democrático de direito, como uma sociedade livre e justa, o desenvolvimento nacional e a erradicação da pobreza e das desigualdades sociais.

O inciso IV do artigo $3^{\circ}$ da Constituição Federal de 1988, antes mesmo do artigo $5^{\circ}$, o qual enuncia os direitos e garantias fundamentais, aponta que:

\footnotetext{
Art. $3^{\circ}$ Constituem objetivos fundamentais da República Federativa do Brasil:

I - construir uma sociedade livre, justa e solidária;

II - garantir o desenvolvimento nacional;

III - erradicar a pobreza e a marginalização e reduzir as desigualdades sociais e regionais;

IV - promover o bem de todos, sem preconceitos de origem, raça, sexo, cor, idade e quaisquer outras formas de discriminação.
}

José Afonso da Silva destaca o caráter inovador da atual carta, no sentido de trazer, pela primeira vez, um rol de objetivos fundamentais do Estado, como base de prestações positivas que venham concretizar a democracia econômica, social e cultural, com o intuito de, na prática, efetivar a dignidade da pessoa humana ${ }^{185}$. Como já mencionado anteriormente, a igualdade deixou de ser um princípio na carta de 1988 para receber o status de eixo coordenador de todo o sistema político e jurídico, tornando-se um direito principal, de abertura a todos os demais direitos fundamentais. Celso Ribeiro Bastos

\footnotetext{
${ }^{185}$ SILVA, José Afonso. Curso de direito constitucional positivo. 22. ed. São Paulo: Malheiros, 2003. p. 105106.
} 
assinala que a igualdade é o mais vasto dos princípios constitucionais, que informa e condiciona todo o direito ${ }^{186}$.

O terceiro artigo da nossa atual constituição vai mais além. Ele estabelece quais são os objetivos fundamentais, ou seja, o Estado brasileiro deve ter como objetivos aqueles ali estabelecidos, os quatro incisos de caráter igualitário e, por último, a proibição da discriminação de qualquer espécie. Mas não é somente no artigo terceiro que a proibição da discriminação se encontra prevista. Muitas outras normas de caráter fundamental reafirmam a importância do combate à discriminação em diversos setores da sociedade brasileira, reafirmando esse compromisso em outras passagens.

A proibição de discriminação reaparece em diversas normas da carta, como anteriormente demonstrado. Destaca-se, inicialmente, o artigo $5^{\circ}$, XLI, que menciona que qualquer discriminação atentatória dos direitos e liberdades fundamentais será punida pela lei. No rol de direitos laborais, o artigo $7^{\circ}$, incisos XXX e XXXI, proíbe expressamente qualquer discriminação para salários e critérios de admissão, bem como outras ações discriminatórias contra os portadores de deficiência. Não bastasse isso, em outra passagem, uma norma de direito fundamental estabelecida na proteção da criança e do adolescente, o artigo 227 coloca ambos sob proteção de qualquer forma de discriminação.

Insta destacar ainda o artigo $4^{\circ}$, inciso II, da carta política, que prevê a prevalência dos direitos humanos como um dos regentes das relações internacionais de nossa república e promove a conexão do texto constitucional com todas as previsões internacionais contra a discriminação. Assim, fica perfeitamente harmonizado todo este rol de proteções contra a discriminação do texto constitucional com a preocupação global de seu combate.

Ou seja, uma simples análise de nosso texto constitucional nos permite afirmar, com segurança, que a proibição da discriminação recebe o status de direito fundamental da mais alta importância dentro do rol de direitos fundamentais na ordem jurídica brasileira. A proibição da discriminação, manifestada em várias passagens da carta política, afigura-se como um poderoso instrumento efetivador do princípio da igualdade material, procurando realizá-lo, integrando-o definitivamente.

\footnotetext{
${ }^{186}$ BASTOS, Celso Ribeiro. Curso de direito constitucional. 17. ed. São Paulo: Saraiva, 1996. p.169.
} 


\subsection{A prevalência das normas antidiscriminatórias como expressão da dignidade da pessoa humana}

Pudemos observar nos tópicos anteriores que a proibição da discriminação é norma geral imperativa dentro do direito internacional a ponto de ser considerada um jus cogens e, como tal, tornar nulas quaisquer disposições em tratados que venham a contrariá-la. Também alcança o rol da proteção máxima que o direito confere aos seres humanos, tal qual a proteção contra a escravidão e o genocídio, que são as manifestações discriminatórias mais violentas conhecidas na humanidade. Trata-se de um princípio que fundamenta a constituição de diversas organizações internacionais, concebe uma série de tratados internacionais específicos e ações internacionais para a defesa dos seres humanos em sua igual dignidade.

Se no direito internacional a proibição de discriminação assume um caráter de destaque, no direito constitucional não pode receber outro tratamento. Os textos constitucionais mais recentes colocam a proibição da discriminação com importância destacada dos demais direitos fundamentais, geralmente como uma norma condicionadora ou informadora do rol de direitos fundamentais, principalmente quando o abre como um direito-chave, na expressão de Paulo Bonavides, anteriormente mencionada. O direito constitucional mais moderno encontra na proibição de discriminação, em diversos textos, um dos componentes mais ativos e importantes da igualdade a ser atingida.

E no direito constitucional brasileiro a proibição de discriminação atinge ainda mais o caráter de direito fundamental da mais alta grandeza. Não é somente considerada um direito, mas, também, tem formalmente reconhecido o nível de um objetivo fundamental da República ao lado de outros objetivos também de caráter igualitário e que guardam relação direta com o fato social da discriminação.

A conjunção de tais fatores permite concluir que a proibição da discriminação é uma das mais importantes normas de proteção da pessoa humana. Ela recebe dentro do direito uma qualificação especial, como integrante do princípio da igualdade: é um instrumento de defesa da igualdade substancial, voltado contra qualquer praticante da discriminação, sejam em relações públicas ou privadas, contra o Estado e contra os particulares.

Essa assertiva permite concluir que a proibição da discriminação atinge um status diferenciado e superior em relação aos demais direitos fundamentais. Ela visa tutelar não 
somente a efetivação da igualdade material, porém algo que vai mais além e de maior importância ainda: garantir o efetivo exercício dos demais direitos fundamentais. Por tal motivo, a norma antidiscriminatória tem caráter de norma de direito fundamental em posição superior aos demais direitos fundamentais, eis que visa, basicamente, protegê-los e assim propiciar a existência digna do ser humano em sua plenitude.

Tal consideração é extremamente importante, na medida em que, quando discutida alguma medida que pretenda, direta ou indiretamente, colidir com a proibição da discriminação, esta terá um valor superior a qualquer outro direito fundamental, com exceção dos direitos essenciais asseguradores da existência humana (vida, sobrevivência, saúde, etc.). Um ato discriminatório não atingirá somente a igualdade de tratamento, mas, também, a fruição de outros direitos de caráter fundamental, traduzindo em redução da dignidade social que cada ser humano deva ter.

\subsection{A proibição da discriminação como direito fundamental nas relações de trabalho}

Se a proibição da discriminação atinge o ápice do rol de direitos fundamentais para qualquer ser humano, não seria de forma diferente sua destacada importância dentro do direito do trabalho.

No plano internacional, a proibição da discriminação compõe um dos direitos fundamentais do trabalho, conforme estabelecido na Declaração da Organização Internacional do Trabalho sobre os Princípios e Direitos Fundamentais no Trabalho, de 1998. Com tal qualificação, a proibição da discriminação é reconhecida como um direito trabalhista fundamental da mais alta importância, válido universalmente, não dependendo da aceitação formal do Estado integrante da OIT, com efeito erga omnes para os Estados e os particulares.

No plano interno, configura um dos mais importantes direitos da pessoa humana, de acordo com o nosso texto constitucional, sendo um direito de altíssimo grau de importância dentro do ordenamento jurídico pátrio, por ser correlato aos direitos fundamentais e ser um dos objetivos do Estado brasileiro.

A proibição da discriminação não somente é um direito; mais que isso, é um princípio constitucional de ampla envergadura e que vem atuar como instrumento para blindar, ou pelo menos tentar tal intenção, contra as atitudes que venham a se tornar um menoscabo a direitos da pessoa. Como bem coloca Hugo Mansueti, os problemas trazidos 
pela discriminação pertencem ao gênero das relações humanas e sua essência não é patrimônio exclusivo de qualquer região do mundo jurídico ${ }^{187}$. E complementa o referido jurista argentino que a proteção contra a discriminação pertence a todas as áreas jurídicas que visam a proteção do ser humano em seu duplo caráter de ente espiritual e físico, tanto na existência individual, como em suas relações com outras pessoas e instituições.

Atualmente, a proteção contra a discriminação atinge diversos setores jurídicos, sendo que o direito laboral foi o ramo que mais se preocupou com a discriminação, em especial nos países anglo-saxões. O britânico Nicholas Bamforth destaca que a discriminação sempre teve um foco mais destacado nas relações trabalhistas no Reino Unido, no entanto, a proteção contra a discriminação ganhou uma consideração de questão constitucional cada vez mais abrangente ${ }^{188}$. Segundo o referido autor, as questões discriminatórias têm atuado em variados setores naquele país, como no direito criminal, nos contextos imigratórios, no direito de família e de propriedade, além de outros ramos jurídicos $^{189}$. No entanto, ele conclui apontando que, apesar de sua contextualização constitucional, uma questão discriminatória ocorrida não deve ser vista exclusivamente pelo direito constitucional como um todo, mas também pelo direito do trabalho e suas relações com outros ramos do direito ${ }^{190}$.

A proibição da discriminação, pelo seu caráter abrangente e como instrumento protetor de todos os outros direitos, envolve questões que abrangem o direito constitucional. No entanto, tem uma caracterização muito mais detalhada e específica dentro do direito do trabalho, sendo reconhecida como um princípio específico do direito do trabalho.

Manuel Carlos Palomeque López afirma que os direitos constitucionais laborais têm origem específica ou razão de ser exclusiva ou principal no âmbito das relações do trabalho. Seriam, segundo o referido autor, direitos constitucionais especificadamente laborais e, portanto, direitos constitucionais laborais específicos. Os titulares desses direitos seriam os trabalhadores assalariados ou os empresários, na qualidade de sujeitos de uma relação trabalhista ${ }^{191}$. O jurista espanhol afirma, por outro lado, que outros direitos constitucionais de caráter geral e, por isso, não especificadamente laborais, podem ser

\footnotetext{
${ }^{187}$ MANSUETI, Hugo Roberto. op. cit., p. 266.

${ }^{188}$ BAMFORTH, Nicholas. Conceptions of anti-discrimination law. Oxford Journal of Legal Studies, v. 24 , n. 4, p. 696, Dec. 2004.

${ }^{189}$ Id. Ibid., p. 694.

${ }^{190}$ Id. Ibid., p. 698-699.

${ }^{191}$ PALOMEQUE LÓPEZ, Manuel Carlos. op. cit., p. 95.
} 
exercitados pelos sujeitos das relações do trabalho, no seu âmbito, por adquirirem um conteúdo ou dimensão laboral superveniente, produzindo uma impregnação laboral de titularidade geral ou inespecífica. Assim, seriam direitos constitucionais laborais inespecíficos $^{192}$.

Ainda que possa parecer um direito laboral inespecífico, a proibição da discriminação é, efetivamente, um direito constitucional laboral específico. Tal conclusão pode ser vislumbrada em face do reconhecimento expresso da OIT como um direito fundamental do trabalho, bem como da opinião doutrinária de diversos juristas.

Historicamente, a proibição da discriminação conta dentro da OIT como um de seus princípios elementares. A Declaração de Filadélfia, de 1944, que estabeleceu os objetivos e os princípios da Organização, deixa claro em seu item II que a Justiça Social deve ser realizada a todos os seres humanos de qualquer raça, crença ou sexo, o bem-estar material e a igualdade de oportunidades ${ }^{193}$.

Com efeito, a consideração da proibição da discriminação como um princípio do direito do trabalho é consagrada por vários juslaboralistas, merecendo maior destaque a consideração do recém-falecido Américo Plá Rodriguez, um grande autor sobre os princípios do direito do trabalho. O grande mestre uruguaio afirmava que a proibição de discriminação é um direito fundamental do direito laboral e que se encontra na mesma base dos direitos humanos porque protege o homem em qualquer circunstância ou condição ${ }^{194}$.

A mesma opinião é comungada por Pinho Pedreira, para quem a proibição de discriminação arbitrária é princípio do direito do trabalho, como consequência de outro princípio do direito laboral - o direito de igualdade de tratamento dos iguais em identidade de circunstâncias ${ }^{195}$.

Alfredo J. Ruprecht também destaca a não discriminação como princípio do direito do trabalho, em face de várias aparições em convenções e tratados internacionais, em especial a figuração no próprio Tratado de Versalhes, que previa a igualdade de retribuição

\footnotetext{
${ }^{192}$ PALOMEQUE LÓPEZ, Manuel Carlos. op. cit., p. 95.

${ }^{193}$ ORGANIZAÇÃO INTERNACIONAL DO TRABALHO. Constituição Sítio do Escritório no Brasil. Disponível em: <http://www.oitbrasil.org.br/info/download/constituicao_oit.pdf>. Acesso em 08 set. 2009.

${ }^{194}$ PLÁ RODRIGUEZ, Américo. Nuevos aportes sobre la proteción a la intimidad del trabajador. In: RIBEIRO, Lélia Guimarães Carvalho; PAMPLONA FILHO, Rodolfo (Coords.). Direito do trabalho: estudos em homenagem ao Prof. Luiz de Pinho Pedreira da Silva. São Paulo: LTr, 1998. p. 203.

${ }^{195}$ PEDREIRA, Luiz de Pinho. Discriminação indireta. LTr: revista legislação do trabalho, São Paulo, ano, 65, n. 4, p. 402, abr. 2001.
} 
sem distinção de idade, sexo, estado, religião ou ideias políticas ${ }^{196}$. Afirma o referido jurista que o fundamento do princípio está em que todos os homens têm os mesmos direitos, razão pela qual se devem fazer distinções por questões alheias ao trabalho em si mesmo $^{197}$.

Qualquer dúvida sobre a proibição da discriminação entre particulares é solvida pela Declaração da OIT e pela Convenção 111 daquela organização. A norma antidiscriminatória se contrapõe à liberdade contratual do empregador, sendo que a aplicação mais intensa do princípio da igualdade leva inevitavelmente à anulação da autonomia privada deste ${ }^{198}$. Esta é respeitada, mas bastante restrita, como adiante poderá ser visto, eis que certas modalidades diferenciadoras podem ser aceitas de forma legítima.

A proibição da discriminação pela intervenção estatal ou negociada relativiza o poder do empregador de dirigir suas atividades empresariais, limitando o racionalismo da economia de mercado, porém sem desconsiderá-la, na visão de Hugo Barreto Ghione ${ }^{199}$. O mandamento legal que proíbe determinadas formas de contratação ou de desfazimento de determinados contratos importa, decisivamente, em aumento dos custos da empresa, já que o empregador não poderá contratar ou manter o contrato com quem deseja, cuja escolha tende a recair no trabalhador menos oneroso ou mais rentável para a empresa.

Há importantes estudos econômicos realizados sobre o impacto da discriminação e das políticas antidiscriminatórias, inclusive sobre a sua efetividade. Marco Fugazza faz um detalhado estudo sobre as teorias econômicas que envolvem a discriminação e conclui que são necessários esforços para colher informações e detectar situações discriminatórias. Ele também aponta, em um precioso estudo para a OIT, que a efetividade das políticas estatais antidiscriminatórias depende, inclusive, de tais informações para sua correção ou percepção social, como também para melhor ajustamento do problema que causa muitas tensões na sociedade ${ }^{200}$.

A proibição da discriminação e a autonomia privada se opõem frontalmente, no entanto, as limitações da autonomia privada, segundo Guilherme Machado Dray, devem ter

\footnotetext{
${ }^{196}$ RUPRECHT, Alfredo J. Os princípios do direito do trabalho. Trad. para o português de Edílson Alkmin Cunha. São Paulo: LTr, 1995, p. 102.

${ }^{197}$ Id., loc. cit.

${ }^{198}$ VENTURA, Luciano. op. cit., p. 19.

${ }^{199}$ GHIONE, Hugo Barreto. El derecho a la igualdad y la no discriminación en derecho del trabajo: una revisión crítica. Derecho Social Latinoamérica, N. 4-5, p. 44, 2008.

${ }^{200}$ FUGAZZA, Marco. La discriminación racial. Teorias, hechos y planos políticos. Revista Internacional del Trabajo, Genebra, v. 122, n. 4, p. 593, 2003.
} 
origem nas ações que venham a incorrer em desvalor da dignidade humana do trabalhador $^{201}$. Portanto, o limite para o direito do empregador será estabelecido em toda atitude em que a pessoa humana no caso concreto, e a humanidade por via reflexa, estejam ameaçados, mesmo que o referido ato esteja dentro dos limites fixados pelos poderes do empregador. A possibilidade de violação à dignidade da pessoa humana impõe limitações às atitudes do empregador, mesmo que possam estar dentro de seus poderes. O jurista lusitano complementa que fica de um lado a dignidade humana a ser respeitada e, de outro, a autonomia privada. Assim, conclui que o princípio da igualdade no direito do trabalho deve ser um princípio aberto e dinâmico, sujeito a apreciações de cada situação fática apresentada, agindo a igualdade entre os parâmetros da autonomia do empregador e da dignidade da pessoa humana ${ }^{202}$.

Atualmente, não restam dúvidas sobre a aplicação do princípio da proibição da discriminação nas relações de trabalho, inclusive intervindo sobre os contratos de trabalho. A célebre teoria da aplicação dos direitos fundamentais aos particulares, conhecida no direito alemão como Drittwirkung der Grundrechte, teve origem no assentamento jurisprudencial da corte superior trabalhista alemã, no sentido de que uma norma coletiva não poderia estabelecer salários distintos para as trabalhadoras em comparação com os trabalhadores abrangidos pela norma, como bem coloca Thilo Ramm ${ }^{203}$. A teoria legal do drittwirkung permitiu que o Poder Judiciário trabalhista alemão pudesse declarar cláusulas contratuais como inconstitucionais, limitando a liberdade de contratação coletiva com respaldo nos direitos fundamentais da pessoa humana.

O direito do trabalho impõe limitações por meio da legislação à liberdade de contratação do trabalho. Gino Giugni aponta que tais limitações geralmente são destinadas a uma proteção física do trabalhador e raramente teriam o propósito de proteger a liberdade pessoal do trabalhador como ser humano e integrante de comunidades ${ }^{204}$. Felizmente, tais cláusulas vêm se tornando cada vez mais comuns em diversas modalidades de contratação, demonstrando que a proteção ao trabalho não somente é destinada a questões específicas da prestação ao trabalho, mas, também, de proteção à pessoa do trabalhador e à expressão de sua dignidade fora do trabalho, desde que tais medidas, de algum modo, possam afetá-la.

\footnotetext{
${ }^{201}$ DRAY, Guilherme Machado. O princípio da igualdade no direito do trabalho. Coimbra: Almedina, 1999. p. 183. 
A proteção contra a discriminação não envolve somente a limitação do poder de contratar, mas também a intervenção no mercado de trabalho, pretendendo que este se torne menos injusto ao alterar a dinâmica de valoração do trabalho humano. Nesse sentido, John Donohue assinala que os defensores das ações positivas começaram a procurar a solução idealizada do mercado e incrementá-lo com uma noção de justiça social mais abrangente $^{205}$. O referido economista e jurista indica que, na visão da igualdade construída pelas ações afirmativas, as ordens da norma jurídica são definidas, não mais como algum paradigma abstrato do mercado, mas já considerando as etapas que seriam necessárias para definir uma noção mais refinada de justiça ${ }^{206}$.

Vislumbra-se, portanto, que a proteção contra a discriminação vai bem mais além do que uma limitação ao empregador - é uma norma que também pretende moldar o próprio mercado de trabalho. Ela procura valorizar o trabalho humano, principalmente aquele prestado pelos integrantes das categorias mais prejudicadas pela discriminação.

\footnotetext{
${ }^{205}$ DONOHUE, John J., III. Employment discrimination law in perspective: three concepts of equality. Michigan Law Review, Ann Arbor, v. 92, n.8, p.2583-612, Aug. 1994. Lexis Nexis, Disponível em: $<$ http://www.lexisnexis.com/us/lnacademic/auth/checkbrowser.do?ipcounter $=1 \&$ cookieState $=0 \&$ rand $=0.72$ 14586677334796\&bhcp=1>. Acesso em: 31 ago. 2009.

${ }^{206}$ Id. Ibid.
} 


\section{SUJEITOS E EFEITOS DO ATO DISCRIMINATÓRIO}

Neste capítulo, a investigação centrará seu foco em alguns componentes do ato discriminatório, procurando assim definir os elementos necessários para fundamentar uma proposta de um conceito de discriminação nas relações do trabalho. Já foi possível perceber que o ato discriminatório importa em uma diferenciação, que viola o dever do igual tratamento das pessoas. Mas o ato discriminatório não somente é integrado por uma diferenciação de tratamento. Outros componentes são essenciais para a classificação de determinada conduta, como discriminatória, nas relações do trabalho.

Este capítulo dá início a uma análise dos componentes do ato discriminatório, tratando dos sujeitos do ato discriminatório, bem como do contexto da prejudicialidade de seus efeitos. São componentes que devem ser detectados e observados para a análise da efetiva existência de uma prática discriminatória. Os referidos componentes devem ser analisados com maior profundidade para fundamentar uma concepção mais contemporânea de um ato discriminatório. Caberá, portanto, averiguar sua pertinência, a justificativa como um componente essencial e suas principais características.

\subsection{Sujeitos do ato discriminatório nas relações do trabalho}

Danièle Lochak estabelece que o primeiro elemento da noção de discriminação está centrado nas pessoas ou grupos que foram objeto de uma diferença de tratamento ${ }^{207}$. Pode parecer uma tarefa fácil compreender quem são os atores de um fenômeno discriminatório nas relações do trabalho, mas trata-se de um equívoco.

A doutrina clássica sobre a discriminação aponta que, necessariamente, existem três sujeitos que integram uma relação discriminatória. Um agente discriminador, uma vítima da discriminação e um terceiro, conhecido como elemento de comparação na expressão de Rodriguez-Piñero e Fernández López ${ }^{208}$, já mencionado no segundo capítulo.

O jurista argentino Mario Ackerman sustenta, dentro de uma visão mais clássica da discriminação nas relações do trabalho, que é estabelecida uma relação triangular entre três sujeitos: o empregador que discrimina, o trabalhador ou a trabalhadora discriminada e o

\footnotetext{
${ }^{207}$ LOCHAK, Daniele. op. cit., p. 779.

${ }^{208}$ RODRIGUEZ-PIÑERO, Miguel; FERNANDEZ LOPEZ, Maria Fernanda. op. cit., p. 47.
} 
trabalhador ou trabalhadora não discriminante ativo, mas passivo, favorecido pela discriminação $^{209}$. O modelo de Ackerman pode ser aceito como ponto de partida, principalmente na contextualização do formato triangular que deverá ser inicialmente adotado. Todavia, a crítica que pode ser feita sobre seu modelo é que ele está muito mais voltado para uma situação comum de discriminação fundada em uma estruturação empresarial típica. O modelo de Ackerman está longe de abranger a totalidade de possibilidades que um ato discriminatório pode envolver, como podemos perceber nos dias atuais.

Os fenômenos discriminatórios possuem uma casuística muito rica e variada, com constante e intensa renovação. A cada dia novas modalidades de discriminação vão surgindo, segundo o relatório do Diretor Geral da OIT, publicado no ano de 2007, sobre a igualdade no trabalho e a luta global pela igualdade de oportunidades. O referido documento aponta o crescente surgimento de novas formas de discriminação nas relações do trabalho, que são somadas aos motivos discriminatórios já arraigados na sociedade ${ }^{210}$. A discriminação nas relações do trabalho é um fenômeno extremamente dinâmico, com o constante surgimento de novas modalidades discriminatórias.

As relações do trabalho também passam por profundas mutações, abandonando os modelos tradicionais de uma produção centralizada para um sistema produtivo integrado por novos atores, que configuram um sistema de empresa-rede, assim qualificado o processo de exteriorização da produção mais recente, conforme aponta Mario Garmendia Arigón e Gustavo Gauthier ${ }^{211}$. Essa profunda modificação dos meios de produção influencia, decisivamente, a composição da relação discriminatória.

Deste modo, adotando-se a estruturação triangular de Mario Ackerman como ponto inicial, é possível realizar uma análise dos sujeitos do ato discriminatório, muito mais voltada para a nova realidade laboral, onde novas modalidades de trabalho e novos atores laborais passam a integrar os vértices deste cada vez mais complexo formato, podendo, em algumas situações, passar de um triângulo a um autêntico polígono.

\footnotetext{
${ }^{209}$ ACKERMAN, Mario E. La negociacion colectiva como instrumento para la aplicación del Convenio 111 de la OIT. Revista do Ministério Público do Trabalho, Brasília, ano 10, n. 19, p. 49, mar. 2000.

${ }^{210}$ ORGANIZAÇÃO INTERNACIONAL DO TRABALHO. Equality at work: Tacking the challenges. Global Report under the follow-up to the ILO Declaration on Fundamental Principles and Rights at Work. Disponível em: <http://www.ilo.org/wcmsp5/groups/public/---dgreports/---dcomm/--webdev/documents/publication/wcms_082607.pdf>. Acesso em: 22 set. 2009.

${ }^{211}$ GARMENDIA ARIGÓN, Mario; GAUTHIER, Gustavo. Tercerizaciones. Montevideo; Fundación de Cultura Universtiária, 2008. p. 36.
} 


\subsubsection{O agente discriminador}

$\mathrm{O}$ agente discriminador é autor, direto ou indireto, do ato discriminatório, sendo o seu sujeito ativo. Essa atividade discriminatória não demanda, necessariamente, ser praticada por uma determinada ação. Uma modalidade discriminatória laboral consagrada na doutrina e jurisprudência conhecida como discriminação por impacto adverso ou também conhecida como discriminação indireta pela terminologia Europeia, é desencadeada por uma postura neutra ou omissiva. O discriminador é o sujeito ou sujeitos que possuem a capacidade de praticar determinado ato discriminatório, por ação ou omissão, contra determinada pessoa, que será a vítima da prática discriminatória.

Como pode ser observado no modelo clássico acima referido, de modo geral e automático é transferida esta condição de agente ao empregador, procedimento muitas vezes balizado por uma estrutura tradicional de prestação do trabalho humano, a da empresa tradicional que realiza em suas dependências todas as atividades necessárias para a finalidade produtiva. No entanto, uma apreciação mais detalhada dos fenômenos discriminatórios atuais solicita uma vigorosa expansão sobre o reconhecimento da capacidade de um agente discriminador.

Em primeiro lugar, deve ser considerado que o agente discriminador não precisa ser, necessariamente, um único agente. A existência de mais de um agente em uma relação discriminatória passa a ser cada vez mais comum. São vários exemplos que podem ilustrar esta afirmação, mas a situação do trabalho terceirizado, bem como a prática de contratação de gestões de recursos humanos externas, pode desencadear um procedimento discriminatório por ação de mais de um agente.

O empregador, sem sombra de dúvidas, é o agente mais comum. No entanto, esta exclusividade da consideração do empregador como agente discriminador deve ser revista. Um novo modelo de relações discriminatórias pede uma nova moldura, ajustada às novas formas de trabalho humano prestado, respondendo ao processo de integração de novos atores nas relações de trabalho. É possível citar os exemplos do tomador ou contratante de serviços terceirizados, o contratante de serviços autônomos ou de trabalho avulso, além de outras pessoas ou empresas que integram indiretamente a relação de trabalho, atuando em nome do empregador e interferindo, decisivamente, nas relações trabalhador-empresa.

É certo que esta ampliação desencadeia uma complexa, e quase infinita, enumeração de agentes discriminadores atuando em nome do empregador. Tal situação 
decorre do fato de que a relação empresarial vem agregando novos personagens que tomam decisões, agem ou interagem com as vítimas, sem integrarem diretamente a relação de trabalho. Fenômenos como a terceirização, a fragmentação da atividade produtiva, a redução da própria empresa, o aumento dos contratos de prestação de serviços e tantas outras modalidades de trabalho humano incorporam novos personagens nesta relação, personagens que atuam em decisões-chave que podem se tornar atos discriminatórios.

Sobretudo, em especial, a gigantesca e dramática expansão da terceirização sobre as atividades produtivas, em especial nos países periféricos, modifica decisivamente o conceito de agente discriminador. $\mathrm{O}$ tomador de serviços age diretamente como se fosse o próprio empregador, tomando decisões importantes que podem estar revestidas por um contexto discriminatório, no entanto, não é ele o empregador formal. Não se pode afastar o questionamento no sentido de que uma relação terceirizada também é uma relação discriminatória. Um trabalhador terceirizado, sob as ordens de um preposto de um determinado tomador, pode ser e muitas vezes é a mais frágil vítima de uma prática discriminatória. Tal prática é facilitada pelo fato de a vítima não integrar o quadro de empregadores regulares de uma empresa, atuando na condição precária de empregado terceirizado ou temporário, sofrendo também os efeitos da pulverização da categoria sindical. Assim, se encontra alijado das poucas garantias do trabalho, por prazo indeterminado, prestado diretamente ao tomador.

Mas a preocupação com o alargamento do conceito de agente discriminador não termina aí. Prestadores de serviços diversos, com ou sem nenhuma vinculação mais duradoura com determinada empresa, podem ser vítimas de práticas discriminatórias decorrentes da relação de emprego, mediante ações discriminatórias praticadas por agentes não integrantes da relação. Um empregador, atualmente, utiliza muitas pessoas para relacionar-se com prestadores de serviços ou mesmo candidatos a um emprego típico.

O melhor exemplo pode ser fornecido pelos agentes de recursos humanos contratados para a seleção e recrutamento de trabalhadores, para o trabalho com ou sem vínculo empregatício. Esta atividade é extremamente comum, geralmente prestada por empresas especializadas, contratadas exclusivamente para tal atividade. Seus procedimentos e métodos para seleção e recrutamento podem praticar, com ou sem interferência do empregador ou contratante destinatário, atos discriminatórios extremamente graves. 
Não é necessário recordar que os procedimentos de seleção e treinamento são ambientes extremamente férteis para práticas discriminatórias. Neste caso, a prática discriminatória pode advir de um selecionador de mão de obra, sem intenção discriminatória, em alguns casos sem o conhecimento ou participação do futuro empregador ou tomador. No entanto, determinada prática, ainda que neutra, poderá levar a efeitos danosos, atraindo a responsabilidade desse futuro empregador sobre qualquer reparação a ser buscada diante da prática discriminatória verificada. Esse agente discriminatório não tem qualquer participação na relação de trabalho ou de emprego; no entanto, é um agente efetivo e em um momento crítico na contratação, que pode gerar responsabilidade ao contratante e para a agência, conforme destaca Luca Ratti ${ }^{212}$.

No entanto, não pode ficar restrita a condição de agente discriminatório somente ao empregador e seus contratados. Sem o consentimento do empregador, mas em decorrência da ausência de uma política interna de prevenção de tais ocorrências, um trabalhador pode ser vitimado por uma prática discriminatória que partiu de um colega de trabalho. $\mathrm{O}$ melhor exemplo atual desta complexa situação é o bullying, prática infelizmente cada vez mais comum em diversos setores da sociedade, principalmente no trabalho. Trata-se de uma prática de atos intimidatórios ou ofensivos na frente de outros colegas, promovendo uma desvalorização da pessoa dentro do ambiente. David Yamada aponta como melhor definição para o bullying no trabalho aquela formulada por Gary Namie e Ruth Namie, como os repetidos maus tratos de caráter intencional e com riscos à saúde praticados por um ou mais empregados ${ }^{213}$.

O bullying é prática reconhecidamente considerada como discriminatória pela Equal Employment Opportunity Comission - EEOC, agência do governo norte-americano responsável pela aplicação das normas legais contra a discriminação no trabalho ${ }^{214}$. A referida agência considera que os autores das práticas de assédio, nele incluso o bullying,

\footnotetext{
${ }^{212}$ RATTI, Luca. Agency work and the idea of dual employership: a comparative perspective. Comparative Labor Law \& Policy Journal. N ${ }^{\circ}$ 30, Verão 2009, p. 835-874, p. 869. Lexis Nexis. Disponível em: $<$ http://www.lexisnexis.com/us/lnacademic/results/docview/docview.do?docLinkInd=true\&risb=21_T7498 438386\&format=GNBFI\&sort=RELEVANCE\&startDocNo=1\&resultsUrlKey=29_T7498438398\&cisb=2 2_T7498438397\&treeMax=true\&treeWidth=0\&csi=7381\&docNo=1>. Acesso em: 04 out. 2009.

${ }^{213}$ YAMADA, David. C. Human Dignity and American Employment Law. University of Richmond Law Review, $\mathrm{n}^{\mathrm{o}}$ 43, Janeiro 2009, p. 523-569, p. 531. Lexis Nexis. Disponível em: <http://www.lexisnexis.com/us/lnacademic/results/docview/docview.do?docLinkInd=true\&risb=21_T7342 949468\&format=GNBFI\&sort=RELEVANCE\&startDocNo=1\&resultsUrlKey=29_T7342949472\&cisb=2 2_T7342949471\&treeMax=true \&treeWidth=0\&selRCNodeID=46\&nodeStateId=411en_US, $1 \&$ docsInCate gory $=380 \& c s i=143888 \&$ docNo=19>. Acesso em: 15 set. 2009.

${ }^{214}$ EQUAL EMPLOYMENT OPPORTUNITY COMISSION. Harassment. Disponível em: <http://www.eeoc.gov/types/harassment.html>. Acesso em: 09 set. 2009.
} 
podem ser o chefe, supervisor, colega de trabalho ou mesmo uma pessoa não integrante da empresa. A responsabilidade sobre os efeitos da discriminação, no entanto, recai sobre o empregador, que tem o dever de manter um bom ambiente de trabalho para cada um dos trabalhadores.

Infelizmente, tal prática vem se tornando cada vez mais comum entre colegas de trabalho, que acabam por hostilizar determinada pessoa, muitas vezes por características pessoais ou por estereótipos, qualificada como um gravíssimo problema de discriminação. A hostilidade demonstrada pelos sócios no caso Price Waterhouse v. Hopkins é um claríssimo exemplo desta situação. Os sócios da empresa entenderam que a autora daquela ação, a Sra. Ann Hopkins, apesar de excelente desempenho profissional ao longo de vários anos de serviços prestados, foi rejeitada em uma candidatura a sócia da empresa por não possuir aparência tipicamente feminina, como aquela formatada dentro dos padrões culturais dos agentes discriminadores. Ela foi considerada textualmente nos votos "com aparência de macho" ou mesmo recebendo sugestões para "que ela fizesse um curso de charme" 215 . No Reino Unido, Bob Hepple e outros autores relatam uma pesquisa realizada em 1996, que apurou que uma em cada oito pessoas naquele país teria sofrido algum tipo de bullying nos últimos cinco anos ${ }^{216}$.

Os agentes discriminatórios, por outro lado, podem ser colegas de profissão, mas empregados em outras empresas, que por força do trabalho interagem com a vítima. Um exemplo, que infelizmente vem ocorrendo com maior frequência, é a prática de racismo entre atletas de futebol. No calor da competição e da disputa, passam a se ofender, ou muitas vezes com o apoio da torcida adversária, com conotação discriminatória, principalmente de cunho racista. Na Europa, a prática de atos desta natureza tem provocado punições severas por parte dos administradores do esporte, inclusive com duras punições aos clubes cujas torcidas pratiquem ofensas aos seus próprios atletas ou oponentes. Os danos decorrentes dessas práticas possuem origem em uma relação laboral extremamente complexa e não deixam de ser atos discriminatórios praticados em decorrência da prestação de trabalho humano.

Por outro lado, a prática discriminatória pode vir de clientes ou de contratantes de serviços. Um exemplo muito claro dessa prática é o constante assédio sofrido por

\footnotetext{
${ }^{215}$ ROTHSTEIN, Mark A.; LIEBMAN, Lance. Employment law. 3. ed. New York: The Foundation Press, 1994. p. 252. Price Waterhouse v. Hopkins 490 U.S. 228 (1989).

${ }^{216}$ HEPPLE, Bob; COUSSEY, Mary; CHOUDHURY, Tufyal. Equality: a new framework. Portland: Hart Publishing, 2000. p. 39.
} 
professores em salas de aula, sendo vítimas de cada vez mais comuns agressões verbais de alunos, quando não, agressões físicas com severos ferimentos. Tal forma de tratamento é expressamente considerada como uma forma de discriminação nas diretivas 2000/43 e 2000/78 da União Europeia. Situação semelhante vem ocorrendo, com frequência crescente e assustadora, em clubes e associações esportivas, principalmente aqueles causados por sócios de tais agremiações que contrata, direta ou indiretamente, a vítima da discriminação.

Nos casos acima apontados, os agentes discriminatórios não são empregados, tampouco prepostos ou contratados dos empregadores, mas a prática discriminatória tem origem em função do exercício das obrigações contratadas. E se o empregador não toma as medidas cabíveis e razoáveis para sua eliminação ou, pelo menos, redução ou atenuação de tais práticas, acaba se tornando responsável, por omissão, pelos danos da discriminação.

Portanto, diante de tais considerações, é possível considerar o agente discriminador como sendo as seguintes pessoas:

a) o empregador, tomador ou contratante de serviços;

b) aquele que age em nome do empregador, podendo ser seu preposto, contratado ou indicado por este para desempenhar determinada atividade que seja de interesse da empresa;

c) o terceiro que, apesar de não integrar direta ou indiretamente a relação de trabalho, nem integrar o quadro de pessoas contratadas pelo empregador ou tomador de serviços, por causa desta relação interage com a vítima, promovendo práticas discriminatórias contra ela.

Assim, o espectro de agentes discriminatórios passa a ser extremamente amplo, alguns inclusive que não participam das atividades desenvolvidas na relação de trabalho, mas que possuem contato com a vítima em função das obrigações assumidas na celebração do contrato de trabalho. Tal amplitude é fundamental para afastar uma visão mais tradicional de que somente o empregador pode ser um agente de um ato discriminatório.

\subsubsection{A vítima da prática discriminatória}

A diversidade de figurantes como vítimas de um ato discriminatório não difere muito da diversidade de agentes discriminatórios. A vítima é toda aquela pessoa que sofreu determinada prática discriminatória, foi privada de um direito ou sofreu tratamento 
prejudicial diferenciado, em função da relação de trabalho. Para sua qualificação, não deve importar quem seja o agente discriminatório. A consideração da vítima de um ato discriminatório está mais ligada à natureza da relação de trabalho prestada do que da condição do agente discriminador. Se, em função desta relação e, no cumprimento das obrigações advindas da relação de trabalho com ela contratada, sofrer uma prática discriminatória, será considerada vítima de uma discriminação ocasionada pela relação de trabalho.

A vítima pode ser tanto uma pessoa como também determinado grupo de pessoas. Assim, a prática discriminatória pode receber um foco individual ou coletivo, dependendo do número de vítimas envolvidas. No caso das relações do trabalho a vítima pode ser tanto um trabalhador como um grupo de trabalhadores que, ao partilharem a mesma situação, poderão experimentar, efetiva ou potencialmente, uma situação de diferenciação de tratamento. Ou seja, o grupo de trabalhadores que será considerado a vítima da prática deverá possuir e receber os mesmos efeitos das diferenciações.

Nessa situação, é possível vislumbrar trabalhadores com ou sem vínculo empregatício, avulsos, parceiros rurais, prestadores de serviços autônomos, parasubordinados, trabalhadores temporários, representantes comerciais, trabalhadores terceirizados, trabalhadores genuinamente cooperados, entre tantos outros. Também poderão estar incluídos entre as possibilidades de vítimas os trabalhadores vinculados a outros empregadores distintos dos agentes discriminatórios, mas que em face das obrigações contratadas possuem contato ou interagem com terceiros que venham a adotar práticas discriminatórias. Essa situação é comum nos trabalhos de subempreita e prestação de serviços especializados, entre outros.

Por outro lado, a vítima da discriminação pode ser um trabalhador que, ainda que não seja o detentor de determinada característica pessoal ou social ou alguém relacionado a uma pessoa que possua determinada característica e que seja suficiente para influenciar um comportamento discriminatório, esteja dentro ou fora do ambiente de trabalho. Seria o caso da vítima indireta, ou seja, por conta de um relacionamento que a vítima tenha com determinada pessoa que possua determinada característica, recaia sobre ela o efeito discriminatório por proximidade ou afinidade.

Um exemplo dessa situação é um trabalhador nacional cujo cônjuge seja estrangeiro, natural de um país que esteja em conflito bélico com o país onde o trabalhador nativo esteja prestando serviços. As situações de conflito armado, notoriamente, trazem 
hostilização contra os nacionais do outro país beligerante ou mesmo aqueles a eles relacionados. A potencialidade da ocorrência de uma discriminação nas relações de trabalho é evidente.

Podem ser incluídas aí, também, situações comuns como uma empregada doméstica cujo cônjuge ou filho tenha sido detido ou condenado criminalmente, ou mesmo que esteja cumprindo pena privativa de liberdade. Quando tal informação chega ao conhecimento do empregador doméstico, pode sofrer represálias ou mesmo ser dispensada por tal situação. Outro exemplo, mais comum do que se pode imaginar, é o caso de dois trabalhadores irmãos contratados pela mesma empresa. Um deles é dispensado por justa causa e o outro, ainda que não tenha qualquer participação na falta grave do irmão, acaba também sendo dispensado, mesmo imotivadamente, sofrendo os efeitos da discriminação causada pelo ato de seu irmão.

Portanto, a vítima de uma discriminação pode ser considerada aquela pessoa ou o grupo de pessoas que:

a) seja empregado ou prestador de serviços do agente discriminador;

b) em função da sua relação de trabalho, mantenha contato com determinado agente discriminador;

c) que possua relacionamento com outra pessoa detentora de características as quais tragam para ela um tratamento diferenciado ocasionado por tal condição.

Diante da posição acima, é possível considerar que a vítima de uma prática discriminatória laboral esteja bem além da figura do empregado ou prestador de serviços. Qualquer trabalhador que tenha determinado relacionamento com um agente discriminador, por força de uma relação de trabalho, pode se tornar uma vítima. Também poderá ser considerada vítima qualquer pessoa que, em virtude de relacionamento de ordem matrimonial, familiar ou de qualquer natureza com outra pessoa, receba os impactos discriminatórios em face do referido relacionamento, ainda que alheio ao ambiente de trabalho. 


\subsubsection{O modelo de comparação}

O modelo de comparação é um sujeito necessário dentro da relação discriminatória. Como anteriormente já mencionado no segundo capítulo, sendo a discriminação um ato diferenciador, sua caracterização também depende de um ato comparativo, já que a obrigação é o dever do trato igual. A igualdade pressupõe uma relação de comparação com determinada pessoa ou grupo de pessoas, para caracterizar sua existência, assim como a diferenciação.

Para a análise de uma situação de discriminação, deve ser escolhido um modelo de comparação. Esta escolha pode recair sobre uma pessoa ou grupo de pessoas, que possua a mesma característica que efetivamente importa para a análise ou na mesma situação fática que a vítima, para que seja procedido um processo comparativo.

Escolher um elemento de comparação não é tarefa tão simples. Sandra Fredman aponta que a escolha do modelo de comparação envolve um complexo julgamento de valores, para apontar se as diferenças entre a suposta vítima e o modelo de comparação são relevantes ou não ${ }^{217}$. Somente as características ou situações relevantes são importantes no resultado do processo comparativo, segundo a referida autora sul-africana e professora no Reino Unido.

Marie-Thérèse Lanquetin destaca que a comparação de um assalariado com outro assalariado não tem se mostrado eficaz como a prova de uma situação discriminatória ${ }^{218}$. A autora francesa revela que a Câmara Social da Corte de Cassação francesa tem procurado estabelecer comparações com o grupo ao qual o interessado pertença, ainda que individualmente busque a prova da distinção desfavorável, analisando a situação entre grupos.

Luís Gabriel Martínez Rocamora cita que os requisitos dos termos de comparação devem ser três: deve ser lícito, concreto e adequado ${ }^{219}$. Isso significa, segundo o autor espanhol, que o termo de comparação não pode ser baseado em um critério ilegal, bem como deve haver uma identificação entre a decisão empresarial e o modelo de comparação. E como meio de adequação, aponta que deve ser tomado um juízo de identidade pelo qual

\footnotetext{
${ }^{217}$ FREDMAN, Sandra. Discrimination law. Oxford: Oxford University Press, 2002. p. 98.

${ }^{218}$ LANQUETIN, Marie-Thérèze. La preuve de la discrimination:l'apport du droit communautaire. Droit Social, Paris, n. 5, p. 437, maio 1995.

${ }^{219}$ MARTÍNEZ ROCAMORA, Luis Gabriel. op. cit., p. 157-158.
} 
é definido um grau de semelhança, por meio de uma análise valorativa das circunstâncias ou critérios que se consideram suficientes para o questionamento da prática diferenciadora.

A quebra da igualdade pode ocorrer tanto do trato desigual entre iguais (iguais em determinado fator decisivo para a análise do ato discriminatório) ou pelo trato igual entre desiguais em um fator relevante. Um exemplo para demonstrar uma atitude discriminatória na última possibilidade é a imposição de determinados ônus no trabalho entre duas pessoas distintas, sendo que para uma delas, em função de determinada característica, o peso da sanção se torna desproporcional em relação ao modelo de comparação.

O modelo de comparação, necessariamente, deve possuir um vínculo de identidade com a vítima, e ela, em função da situação diferenciadora, poderá ser beneficiada, ao contrário da vítima. O que destacará como condição para figuração como modelo de comparação é que, de algum modo, no ponto que interessa para a atitude desafiada, possam ser comparáveis as situações da vítima e do modelo de comparação, principalmente se o modelo de comparação for beneficiado com a medida. Se não houver essa possibilidade de comparação, este vínculo de identidade, não poderá ser considerada como existente a prática discriminatória. A maior dificuldade está em encontrar, ou mesmo escolher, quem seja o correto modelo de comparação, tarefa difícil, que pode prejudicar bastante a alegação de discriminação.

Uma vez havendo a possibilidade da comparação, seu exame pode ser formulado, verificando duas possibilidades: o trato desigual entre iguais e o trato igual entre desiguais, já que ambas as fórmulas permitem a existência de uma prática discriminatória.

O elemento de comparação pode ser tanto um trabalhador como um grupo de trabalhadores, desde que possuam, em relação à vítima, características de identidade no critério que orientou a atitude desafiada. Situações absolutamente distintas, que sequer permitam o estabelecimento de uma relação comparativa, não podem ser analisadas como uma atitude discriminatória. O importante dentro do estabelecimento da relação comparativa é firmar que, em relação à vítima, houve tratamento diferenciado, baseada no mesmo critério.

Esse aspecto é extremamente tormentoso e tem levado a grandes celeumas dentro dos conflitos que envolvem a discriminação. A análise do modelo de comparação tem levado a grandes problemas para o reconhecimento da discriminação por orientação sexual 
no Reino Unido, segundo Sandra Fredman ${ }^{220}$. Como naquele país a discriminação é considerada somente por motivos expressos, entre eles por motivos de sexo, a referida autora aponta que, de acordo com a legislação vigente e a jurisprudência firmada naquele país, um homem homossexual somente pode reclamar sobre uma discriminação de acordo com o Sex Discrimination Act, se demonstrar que recebeu tratamento menos favorável que uma mulher homossexual, mas não poderá invocar um tratamento dado a um homem heterossexual $^{221}$.

Outro problema também crucial para a questão é a inexistência de um modelo de comparação. Se não existir a figura pessoal de um elemento de comparação, a apreciação da questão não poderá ser prejudicada. Caso típico desta situação é a discriminação perpetrada contra gestantes. Nessas situações, devem ser tomados elementos imaginários padronizados, como modelos comuns de pessoas que possuam as mesmas características da pessoa suposta vitimizada pela discriminação, para uma análise. Figuras como o cidadão médio podem auxiliar na comparação quando inexistente uma pessoa que, efetivamente, apresente as características necessárias para figurar como o do modelo de comparação.

\subsection{Efeitos do ato discriminatório}

Como já pôde ser visto no terceiro capítulo, a proteção contra a discriminação é extremamente intensa, reputando tal ato como uma das mais graves formas de atentado contra a pessoa humana. Isso porque as consequências de um ato discriminatório são extremamente graves, retirando da vítima da discriminação certas possibilidades e certos direitos que poderia usufruir livremente, caso não ocorresse o ato discriminatório. Mais do que isso, o ato discriminatório revela, ainda que não tenha nenhum prejuízo mensurável, a falta de trato da mesma dignidade de ser humano entre os seus agentes passivos e os demais seres humanos. O estudo dos efeitos do ato discriminatório é extremamente importante, na medida em que permite detectar a existência de uma prática discriminatória, bem como avaliar sua extensão e gravidade.

A importância do efeito do ato discriminatório permite reconhecer, em primeiro lugar, se determinada prática é considerada discriminatória. Por outro lado, pode também

\footnotetext{
${ }^{220}$ MARTÍNEZ ROCAMORA, Luis Gabriel. op. cit., p. 98.

${ }^{221}$ Smith v. Gardner Merchant [1998] 3 All ER 852 (CA).
} 
auxiliar decisivamente na definição de qual tipo de discriminação é praticada. Como já mencionado no texto, atitudes neutras podem, em um primeiro momento, podem revelar-se inofensivas; no entanto, se constatados efeitos adversos, podem ser consideradas como atitudes discriminatórias. Tal modalidade de discriminação longe está de possuir a mesma transparência de atitudes mais agressivas, sendo formas sorrateiras, muitas vezes de difícil percepção. Nesse sentido, Miguel Rodriguez-Piñero e Maria Fernanda Fernández López destacam essa função do estudo do efeito do ato discriminatório, deixando claro que o resultado não pode ser omitido na avaliação da existência da discriminação, permitindo constatar discriminações ocultas, encobertas ou discriminações indiretas ${ }^{222}$.

\subsubsection{Prejudicialidade}

No primeiro capítulo pudemos observar que a palavra discriminação tem vários significados. No caso da discriminação no trabalho, a expressão discriminação possui um significado negativo, o qual expressa a prática de um ato de distinguir com uma finalidade prejudicial. O resultado do ato discriminatório causa prejuízos de alguma espécie para a vítima e, por tal motivo, é repudiado com tanta energia pelo direito em geral, bem como pelo direito do trabalho em particular, sendo considerado um princípio deste.

A existência de um resultado prejudicial à vítima impõe a realização de instrumentos jurídicos para protegê-la dos danos advindos. A inexistência de algum elemento prejudicial não permite entender determinada conduta como discriminatória propriamente dita. Em um sentido geral desenvolvido neste texto, é possível estabelecer que um ato discriminatório implica um tratamento diferenciado e que este tratamento tenha por efeito causar determinado tipo de dano à vítima do ato discriminatório.

Esse resultado prejudicial pode ser manifestado de muitas formas, mas em todas elas a pessoa ou grupo discriminado sofre algum resultado negativo, um gravame, um dano, seja mensurável ou potencial. As diferentes formas de resultados da prática discriminatória importam na formulação de diversos conceitos descritivos de discriminação no direito internacional e nos direitos internos de diversos países, dependendo do objetivo da norma como mecanismo protetor. Os conceitos positivados até a presente data podem variar desde o reconhecimento de um tratamento diferenciado ou uma privação de direitos, como privação de condições e, até mesmo, de elementos

\footnotetext{
${ }^{222}$ RODRIGUEZ-PIÑERO, Miguel; FERNANDEZ LOPEZ, Maria Fernanda. op. cit., p. 155.
} 
essenciais para a sobrevivência humana. $\mathrm{O}$ ato discriminatório apresenta, como consequência, um fato que posiciona a pessoa, ou o grupo envolvido, em situação de desvantagem em comparação com o modelo adotado. Trata-se basicamente de um fato que, uma vez controverso, deve ser demonstrado de alguma forma.

Todavia, a noção de desvantagem é muito vaga e imprecisa, possuindo suas imperfeições. Os efeitos de um ato discriminatório são extremamente variados nas normas antidiscriminatórias, sendo um dos componentes de maior variação. Porém, entre todas elas um elemento comum é observado, que é a descrição de uma situação desvantajosa para a pessoa que foi vítima da discriminação. A preposição contra na descrição do sentido da discriminação como apontado no primeiro capítulo, em oposição à preposição entre utilizada no sentido "neutro", distingue, com maior precisão, o resultado desvantajoso para a pessoa que recebeu os impactos da discriminação. Ela, normalmente, é reconhecida como "vítima" ou pessoa que "sofreu" um ato discriminatório.

Maria Fernanda Fernández López ressalta que o tratamento pejorativo, assim expressamente considerado, pode se manifestar de diversas formas, conforme o que chama de ampla casuística do Tribunal de Justiça da Comunidade Europeia, citando a privação de um direito, sua redução ou o seu não reconhecimento ${ }^{223}$. A referida autora destaca, adicionalmente, que não são requeridos muitos formalismos sobre a demonstração do fato e seu relacionamento com as normas antidiscriminatórias.

Marzia Barbera destaca bem que a discriminação deve ser compreendida como um ato que possua uma situação de fato efetivamente danosa, devendo ser remediada exatamente dentro da natureza da desvantagem causada ao sujeito discriminado ${ }^{224}$.

Desta forma, fica claro que todo o ato discriminatório deverá resultar em um prejuízo à vítima. Talvez tal afirmação possa parecer óbvia, mas certas diferenças de tratamento podem resultar em vantagem para a pessoa envolvida e, como tal, não pode ser considerada como ato discriminatório. E neste específico caso, serve como exemplo a existência de ações afirmativas, medidas de cunho explicitamente diferenciatório, que visam resgatar discriminações sistemáticas ou pretéritas, cujos efeitos do passado ainda persistem, mediante a criação de desigualdades para reparar danos já ocorridos. Em muitos

\footnotetext{
${ }^{223}$ FERNÁNDEZ LÓPEZ, Maria Fernanda. La prohibición de discriminación en el marco internacional y en el derecho de la Unión Europea. Revista de Derecho Social Latinoamérica, Buenos Aires, n. 2, p. 74, 2007.

${ }^{224}$ BARBERA, Marzia. Discriminazione ed eguaglianza nel diritto del lavoro. Milano: Giuffré, 1991. p. 97.
} 
casos, elas são reconhecidas como discriminações positivas, expressão utilizada por Jorge Miranda $^{225}$, entre outros autores, principalmente os europeus.

Feitas tais considerações, cabe agora adentrar, com maior profundidade, em uma averiguação dos efeitos do ato discriminatório. A demonstração das diferentes possibilidades será realizada pela apresentação de um rol extraído de diversas normas antidiscriminatórias descritivas vigentes, que externalizam a preocupação das modalidades de dano que cada norma procurou proteger.

\subsubsection{Diferença de tratamento}

Como já foi mencionado anteriormente, a primeira norma internacional que veio a descrever um ato discriminatório foi a Convenção 111 da OIT. Em seu primeiro artigo, a referida norma estabelece que um ato discriminatório é composto pelo rol de condutas por ela estabelecido e pelos motivos ali apontados, que tenha por efeito destruir ou alterar a igualdade de oportunidade ou de tratamento em matéria de emprego ou profissão ${ }^{226}$.

Inicialmente cumpre ponderar o que seja a expressão tratamento. Egbert Vierdag faz uma importante análise sobre o termo tratamento, para os efeitos do direito internacional. Ele destaca a definição de tratamento como sendo uma ação social, adotando a definição de Max Weber, e estabelece as seguintes formas:

a) ação pela qual se procura criar, modificar ou nulificar direitos ou obrigações de um indeterminado número de matérias juridicamente previstas pelos órgãos de um sistema jurídico ao qual esteja subordinado;

b) ação pela qual se procura determinar ou modificar determinados direitos ou obrigações previstas em matérias juridicamente previstas ou determinar ou modificar as condições pelas quais uma matéria juridicamente protegida usufrui direitos e executa obrigações;

\footnotetext{
${ }^{225}$ MIRANDA, Jorge. op. cit., t. 4, Direitos fundamentais, p. 225.

${ }^{226}$ ORGANIZAÇÃO INTERNACIONAL DO TRABALHO. Convenção 111. Sítio do escritório no Brasil. Disponível em: <http://www.ilo.org/public/portugue/region/ampro/brasilia/info/download/conv_111.pdf>. Acesso em: 16 set. 2009.
} 
c) ações não previstas nas hipóteses anteriores ainda que contenham uma regra jurídica, até que a ação possa ser considerada nos termos de conformidade ou violação do direito $^{227}$.

E conclui o referido autor holandês que o tratamento desigual importa na possibilidade de conceder ou negar um ou mais direitos a uma determinada pessoa, ou mesmo a imposição de uma obrigação ou obrigações sobre uma determinada pessoa, resultando em quatro situações distintas ${ }^{228}$ :

a) a recusa de um direito que é concedido a outros;

b) a diminuição de um direito que é integralmente concedido a outros;

c) a imposição de uma obrigação que não é imposta a outros;

d) a imposição de uma obrigação que não é imposta com a mesma intensidade para os outros.

Não deixa dúvidas a Convenção 111 da OIT no sentido de que o objeto de proteção da proibição da discriminação é evitar que seja destruída ou alterada a igualdade de oportunidades ou de tratamento em matéria de emprego ou de profissão. Esse é o bem maior protegido, mediante a proibição das condutas descritas no artigo $1^{\circ}$.

A igualdade de oportunidades ou de tratamento é um dos princípios da Organização Internacional do Trabalho, estabelecidos na Declaração de Filadélfia de 1944, em seu artigo $\mathrm{II}^{229}$, reafirmada pela Declaração sobre os Princípios e Direitos Fundamentais no Trabalho de 1998.

O caráter inovador da Convenção 111 decorre de uma norma que foi pioneira ao definir uma situação discriminatória no plano global, inclusive explicitando os efeitos que visava coibir. Maria Fernanda Fernández López reconhece que a Convenção 111 serviu de norte para orientar várias normas antidiscriminatórias posteriores ${ }^{230}$.

A manutenção da igualdade de tratamento e de oportunidades foi a forma encontrada pela Convenção 111 para atender aos anseios de uma norma de alcance global que previsse e tratasse a discriminação nas relações do trabalho, visando não somente a proteção do emprego, mas também da profissão.

\footnotetext{
${ }^{227}$ VIERDAG, Egbert. op. cit., p. 32.

${ }^{228}$ Id. Ibid., p. 44.

${ }^{229}$ ORGANIZAÇÃO INTERNACIONAL DO TRABALHO. Ilolex. Declaração de Filadélfia. Disponível em: <http://www.ilo.org/ilolex/english/constq.htm>. Acesso em: 16 set. 2009.

${ }^{230}$ FERNÁNDEZ LÓPEZ, Maria Fernanda. op. cit., p. 67.
} 
Marzia Barbera ressalta que a discriminação não somente causa uma desigualdade de tratamento, mas também é uma conduta que produz uma desigualdade de oportunidades. A autora italiana destaca que a conduta discriminatória é coincidente com um procedimento de redistribuição de chances entre os sujeitos avantajados e os sujeitos discriminados, ou seja, a discriminação é um processo que transversalmente reatribui, de modo desigual, as oportunidades de acesso a um determinado bem ${ }^{231}$.

A Convenção 111 da OIT não é uma norma que tão somente proíbe determinada conduta. Ela também tem por objetivo a reparação das violações de trato igual mediante a instauração de uma política de igualdade de tratamento, conforme seu segundo artigo, um dado extremamente importante. Assim, fica claro que o objetivo da referida norma é uma atuação ampla na proibição da discriminação e, ao mesmo tempo, na conduta positiva da concretização da igualdade de oportunidades.

Nesse sentido, Miguel Rodriguez-Piñero e Maria Fernanda Fernández López destacam que, dentro da política de combate à discriminação da então Comunidade Europeia, o significado de igualdade de tratamento e de oportunidades não somente é um meio de proibição da discriminação, porém vai mais além, é um meio fundamental para assegurar a eliminação das discriminações, mas com amplitude para permitir desigualdades com vantagens ${ }^{232}$.

Como bem aponta Warwick McKean, a elaboração do texto da Convenção 111 tinha por objetivo observar a necessidade de conceitos mais flexíveis, em face da grande variação das situações das diversas nações integrantes da organização ${ }^{233}$. O referido jurista neozelandês ressalta que o termo inicialmente adotado pela Sub-Comissão de experts sobre a discriminação (distinção adversa) gerou muitas dúvidas principalmente pelos governos dos membros integrantes, sobre o que efetivamente significaria tal expressão ${ }^{234}$. E ainda, a Convenção 111 estabeleceu que a combinação do primeiro com o quinto artigo da referida Convenção, não somente trouxe grande contribuição para a compreensão da expressão discriminação, como também excluiu da consideração como prática discriminatória qualquer medida que venha a incentivar a igualdade de oportunidades e de tratamento, ainda que promova distinções, permitindo, assim, a realização de medidas de ações afirmativas.

\footnotetext{
${ }^{231}$ BARBERA, Marzia. op. cit., p. 97.

${ }^{232}$ RODRIGUEZ-PIÑERO, Miguel; FERNANDEZ LOPEZ, Maria Fernanda. op. cit., p.153.

${ }^{233}$ MCKEAN, Warwick. op. cit., p. 124.

${ }^{234}$ Id. Ibid., p. 126.
} 
Como já demonstrado, a referida Convenção recebeu 174 adesões, um número extremamente elevado. Isso demonstra como foi positiva a preocupação original de seus redatores.

A Convenção 111 estabeleceu um padrão para normas antidiscriminatórias, tornando-se uma referência dentro do âmbito laboral que até a presente data não deixa de ser respeitada. Claude Rossillion esclarece que os efeitos da Convenção 111 estão circunscritos a situações prejudiciais exclusivamente laborais, em um extenso rol de atividades laborais envolvidas ${ }^{235}$. No entanto, novas considerações sobre os efeitos discriminatórios passaram a ser adotados nas normas posteriores.

A situação de tratamento diferenciado é muito pertinente para amparar certas situações, as quais não parecem revestidas de caráter danoso, mas são, pela sua própria essência, atentatórias contra a dignidade do ser humano.

Como exemplo, podemos adotar a suposição de um regime de separação social absoluta de determinados grupos em função da cor da pele. São separados por escolas, facilidades públicas, hospitais e todos os meios de vida necessários. Supondo-se que, para cada um deles, sejam dadas as mesmas condições sociais, em absoluta igualdade, poder-seia imaginar como aceitável tal separação, mesmo ausente qualquer prejuízo aparente nos meios materiais?

A resposta negativa se impõe, pois mesmo que sejam tratados de forma igual e em paridade plena de condições os dois grupos, o ato de separar, por si só, significa um gravame social tão drástico e absolutamente desafiador da dignidade da pessoa humana integrante do grupo segregado, que merece ser desconstituído em face do ato de separar, ainda que não sejam verificados prejuízos imediatos ao grupo separado. Tal situação, já ocorrida muitas vezes na humanidade, pode ser resolvida somente pela consideração de diferença de tratamento, ainda que não haja prejuízo material aparente.

\subsubsection{Prejuízo na fruição de direitos}

Henrik Carl Nielsen destaca que um dos mais complexos conceitos de direitos humanos no plano internacional é o conceito de discriminação, principalmente aquele que

\footnotetext{
${ }^{235}$ ROSSILLION, Claude. La OIT y la eliminación de la discriminación en el empleo. Medellin, Revista de la Facultad de Derecho y Ciencias Políticas de la UPB, n. 76, primer semestre, 1987.
} 
pretende descrever o fenômeno discriminatório ${ }^{236}$. Tal situação decorre das dificuldades que os documentos de direito internacional tiveram para enfrentar o tormentoso tema, bem como tratar de situações discriminatórias mais abrangentes. A pioneira norma da OIT estava restrita exclusivamente ao plano do trabalho humano.

A primeira Convenção internacional no âmbito das Nações Unidas que tratou do tema da discriminação era uma norma específica sobre o combate à discriminação na educação. A Convenção relativa à luta contra as discriminações na esfera do ensino foi adotada em 14 de dezembro de 1960, pela Conferência Geral da Organização das Nações Unidas para a Educação, a Ciência e a Cultura.

A referida norma estabelece em seu artigo $1^{\circ}$ que é compreendida como discriminação toda distinção, exclusão, limitação ou preferência fundada na raça, na cor, no sexo, no idioma, na religião, nas opiniões políticas ou de qualquer outra índole, na origem nacional ou social, na posição econômica ou o nascimento, que tenha por finalidade ou por efeito destruir ou alterar a igualdade de tratamento na esfera do ensino ${ }^{237}$. Porém, além de adotar uma descrição muito próxima da Convenção 111 da OIT, a referida norma é mais específica ainda em apontar situações práticas discriminatórias pontuais, que são as seguintes:

a) excluir uma pessoa ou um grupo de acesso aos diversos graus e tipos de ensino;

b) limitar a um nível inferior a educação de uma pessoa ou de um grupo; c) instituir ou manter sistemas ou estabelecimentos de ensino separados para pessoas ou grupos;

d) inserir uma pessoa ou um grupo em uma situação incompatível com a dignidade humana.

A referida norma adota a expressão tenha por finalidade ou por efeito destruir ou alterar a igualdade de tratamento na esfera do ensino, mas foi mais além e procurou definir situações discriminatórias específicas dentro do âmbito da educação, exatamente porque a noção geral é um tanto quanto abrangente.

Em 1965 as Nações Unidas aprovaram outro documento internacional de crucial relevância para o combate à discriminação, a Convenção Internacional para Eliminação de

\footnotetext{
${ }^{236}$ NIELSEN, Henrik Karl. The concept of discrimination in ILO Convention $\mathrm{N}^{\circ} 111$. International and Comparative Law Quarterly, v. 43, n. 4, p.827, out. 1994.

${ }^{237}$ ORGANIZAÇÃO DAS NAÇÕES UNIDAS. Convenção relativa à luta contra as discriminações na esfera do ensino. Biblioteca Virtual de Direitos Humanos da USP. Disponível em: $<$ http://www.direitoshumanos.usp.br/index.php/Direito-a-Educação/convencao-relativa-a-luta-contra-asdiscriminacoes-na-esfera-do-ensino.html>. Acesso em: 21 set. 2009.
} 
todas as Formas de Discriminação Racial, adotada pela Resolução $\mathrm{n}^{\circ}$ 2.106-A da Assembleia das Nações Unidas em 21 de dezembro de 1965. Como seu título aponta, ela tem uma aplicação extremamente ampla e não menos importante, uma vez que pretende eliminar toda e qualquer forma de discriminação racial em todos os ramos da atividade humana. E para tanto, ela apresenta um conceito descritivo da discriminação diferente das mencionadas Convenções, cujos dizeres merecem ser transcritos:

Para fins da presente Convenção, a expressão "discriminação racial" significará toda distinção, exclusão, restrição ou preferência baseada em raça, cor, descendência ou origem nacional ou étnica que tenha por objeto ou resultado anular ou restringir o reconhecimento, gozo ou exercício em um mesmo plano (em igualdade de condição) de direitos humanos e liberdades fundamentais nos campos político, econômico, social, cultural ou em qualquer outro campo da vida pública ${ }^{238}$.

O conceito adotado pela referida convenção é bem diferente da Convenção sobre a discriminação na educação, no que tange aos efeitos. A referida norma adotou que o efeito da discriminação seria a prática que tem por objeto anular ou restringir o reconhecimento, gozo ou exercício em um mesmo plano (em igualdade de condição) de direitos humanos e liberdades fundamentais nos campos político, econômico, social, cultural ou em qualquer outro campo da vida pública. Trata-se de um conceito que narra um efeito não circunscrito, não somente à falta de igualdade de tratamento, mas ao cerceamento do gozo ou exercício de direitos humanos e liberdades fundamentais em todo e qualquer campo da vida pública.

Trata-se de um conceito extremamente amplo e ao mesmo tempo preciso. Seu objetivo é procurar evitar práticas que procuravam anular, ou pelo menos mitigar, os direitos fundamentais de raças minoritárias. Warwick McKean aponta que a referida Convenção foi o mais radical instrumento adotado até então no campo do combate à discriminação, sendo o primeiro documento internacional dirigido para assegurar plenamente e em condição de igualdades os direitos humanos e as liberdades fundamentais, com caráter vinculativo explícito para as partes ${ }^{239}$.

Marie-Thérèse Lanquetin destaca que a Convenção racial da ONU inova no sentido de ser necessária, para a consideração da discriminação, a ocorrência de um determinado

\footnotetext{
${ }^{238}$ ORGANIZAÇÃO DAS NAÇÕES UNIDAS. Convenção Internacional para Eliminação de todas as formas de Discriminação Racial. Biblioteca Virtual de Direitos Humanos da USP. Disponível em: $<$ http://www.direitoshumanos.usp.br/index.php/Prevenção-contra-a-Discriminação-e-Proteção-dasMinorias/convencao-internacional-sobre-a-eliminacao-de-todas-as-formas-de-discriminacao-racial1968.html>. Acesso em: 21 set. 2009.

${ }^{239}$ MCKEAN, Warwick. op. cit., p. 165.
} 
fato que demonstre um resultado objetivo da distinção verificada, sem se preocupar ou levar em consideração as intenções do autor da discriminação ${ }^{240}$.

Esse conceito sobre os efeitos de proteção dos direitos humanos e liberdades fundamentais pode e deve ser transportado para dentro do direito do trabalho, como meio de ampliar o conceito da Convenção 111 da OIT.

$\mathrm{O}$ ato discriminatório nas relações de trabalho não deve ficar circunscrito aos efeitos verificados dentro da própria relação de trabalho. A proteção contra a discriminação laboral deve estar atenta para a defesa de direitos da pessoa da vítima, que sejam exercidos fora do ambiente laboral, mas por ele ameaçados ou anulados. Em especial, a proteção contra a discriminação por opinião política, a discriminação religiosa e a invasão na vida privada da vítima são modalidades que não procuram prevenir liberdades a serem exercidas dentro da relação de trabalho. As liberdades sindicais, de credo e a liberdade de opção de vida são exercidas fora do ambiente de trabalho, mas podem ser obstruídas pela atitude discriminatória no trabalho.

A inovação da referida norma é não restringir a conceituação da discriminação ao âmbito do tema tratado, mas que, ao procurar dar uma proteção mais abrangente, busque a proteção da vítima da discriminação contra seus efeitos reflexos em todas as esferas da vida humana. Esse é um ponto essencial que uma norma antidiscriminatória nas relações do trabalho não pode deixar de lado.

Em 18 de dezembro de 1979 a Assembleia das Nações Unidas aprovou a Convenção sobre a eliminação de todas as formas de discriminação contra a mulher. Esse texto também apresenta uma definição descritiva de discriminação, com os seguintes dizeres, em seu artigo $1^{\text {o: }}$ :

Para fins da presente Convenção, a expressão "discriminação contra a mulher" significará toda distinção, exclusão ou restrição baseada no sexo e que tenha por objeto ou resultado prejudicar ou anular o reconhecimento, gozo ou exercício pela mulher, independentemente de seu estado civil, com base na igualdade do homem e da mulher, dos direitos humanos e liberdades fundamentais nos campos político, econômico, social, cultural e civil ou em qualquer outro campo ${ }^{241}$.

\footnotetext{
${ }^{240}$ LANQUETIN, Marie-Thérèse. La discrimination à raison du sexe en droit international et communautaire. Droit Social, Paris, n. 12, p. 808, dez. 1998.

${ }^{241}$ NAÇÕES UNIDAS. Convenção internacional sobre a eliminação de todas as formas de discriminação contra a mulher. Biblioteca Virtual de Direitos Humanos. Universidade de São Paulo. Disponível em:
} 
A definição de discriminação trazida pela referida Convenção guarda proximidades com a definição trazida pela Convenção sobre eliminação de todas as formas de discriminação racial, uma vez que a Comissão das Condições Femininas da ONU manifestou para a Assembleia Geral o interesse de uma norma semelhante àquela adotada em $1965^{242}$.

E como efeito da discriminação, aponta a proteção do ato que venha a prejudicar ou anular o reconhecimento, gozo ou exercício pela mulher, independentemente de seu estado civil, com base na igualdade do homem e da mulher, dos direitos humanos e liberdades fundamentais nos campos político, econômico, social, cultural e civil ou em qualquer outro campo.

É inevitável a comparação com a Convenção contra a discriminação racial, eis que a Convenção contra a discriminação da mulher amplia ainda mais a proteção, na medida em que pretende defender os direitos da mulher em qualquer campo da vida humana, enumerando, de forma exemplificativa, os campos onde a norma tenha a intenção de atuar com maior ênfase. A ampliação é constatada no sentido de que a Convenção para eliminação da discriminação racial menciona para qualquer outro campo da vida pública, ao passo que a norma contra a discriminação feminina não restringe esta amplitude à vida pública, mas também à vida privada, acertadamente.

Como foi possível observar dos exemplos acima, houve, ao mesmo tempo, uma ampliação da proteção contra a discriminação e uma maior precisão na descrição dos efeitos da discriminação nas duas normas das Nações Unidas, a segunda adotada mais de vinte anos após a concepção da Convenção 111 da OIT.

A evolução da conceituação dos efeitos da discriminação é extremamente rápida, com alterações significativas conforme as normas antidiscriminatórias foram sendo aprovadas, em períodos de tempo relativamente curtos. As diretivas europeias contra a discriminação no trabalho são um bom exemplo da evolução na conceituação da discriminação em diversos aspectos.

O primeiro documento europeu que tratou precisamente da discriminação nas relações de emprego foi a Diretiva 76/207, texto esse voltado contra a discriminação por

$<$ http://www.direitoshumanos.usp.br/index.php/Direitos-da-Mulher/convencao-sobre-a-eliminacao-detodas-as-formas-de-discriminacao-contra-a-mulher.html>. Acesso em: 21 set. 2009.

${ }^{242}$ MCKEAN, Warwick. op. cit., p. 189. 
gênero, para procurar regulamentar as disposições do Tratado da Comunidade Econômica Europeia (art. 119) que proíbem expressamente a distinção de salários por gênero.

A Diretiva 76/207 é um texto que por sua natureza de diretiva, tem como finalidade orientar as normas internas dos Estados membros da então Comunidade, hoje União Europeia. Seus dizeres não foram muito específicos sobre os efeitos, apenas aponta a proteção da igualdade de tratamento nas relações de emprego, destacando a proteção antidiscriminatória nas condições de acesso, nos critérios de seleção, em qualquer ramo de atividade ou hierarquia profissional, no treinamento ou preparação para o trabalho e na dispensa $^{243}$. Essa norma se preocupou em definir determinados atos nos quais os atos discriminatórios estavam proscritos.

No ano 2000 foram editadas duas novas diretivas sobre a discriminação laboral, atendendo às disposições do Tratado de Amsterdam, celebrado em 1997 e em vigor desde 01.05.1999. Esse tratado trouxe uma nova concepção sobre a proteção contra a discriminação dentro da União Europeia, focando o combate à discriminação por diversos outros motivos além do gênero. Em função da ampliação do foco na luta contra a discriminação foram adotadas duas novas diretivas, as de número 2000/43 e 2000/78.

A primeira trata da discriminação racial definindo que, para os efeitos daquela norma, entende-se por princípio da igualdade de tratamento a ausência de qualquer discriminação, direta ou indireta, em razão da origem racial ou étnica ${ }^{244}$. Essa definição procura explicar o princípio da igualdade de tratamento como a ausência de discriminação pelos motivos ali apontados. É revelação de um marco no objetivo da norma manter a igualdade de tratamento como a inexistência de qualquer discriminação.

Já no seu segundo artigo, no item 2, a referida diretiva trouxe uma definição completamente diversa das proporcionadas nos diplomas internacionais mencionados. Ela optou pela seguinte definição dos efeitos da discriminação: seja objeto de tratamento menos favorável que aquele que é, tenha sido ou possa vir a ser dado a outra pessoa em situação comparável $^{245}$. A referida norma aponta como efeito discriminatório o tratamento diferenciado desfavorável comparativamente com outra pessoa (o elemento de comparação), sendo uma definição simples e extremamente abrangente.

\footnotetext{
${ }^{243}$ UNIÃO EUROPEIA. Diretiva 76/207. EURLEX. Disponível em: <http://eurlex.europa.eu/LexUriServ/LexUriServ.do?uri=CELEX:31976L0207:PT:HTML>. Acesso em: 21 set. 2009.

${ }^{244}$ UNIÃO EUROPEIA. Diretiva 2000/43. EURLEX. Disponível em: <http://eurlex.europa.eu/LexUriServ/LexUriServ.do?uri=CELEX:32000L0043:PT:HTML>. Acesso em: 21 set. 2009.

${ }^{245}$ Id. Ibid.
} 
Por seu turno, a Diretiva 2000/78 trouxe um conceito bastante semelhante, mas voltado para suas finalidades que são a proteção contra a discriminação religiosa, da deficiência, da idade ou da orientação sexual ${ }^{246}$. Ambas as normas do ano de 2000 têm um aspecto interessante que é a consideração do assédio como forma de discriminação, definindo o que seja essa grave conduta, porém deixando uma abertura da especificação do assédio para as legislações nacionais.

Em 2002 a União Europeia decidiu renovar sua normatização sobre a discriminação por gênero, editando a diretiva 2002/73. Essa importante norma seguiu a tendência das duas diretivas de 2000, produzindo definições não existentes na Diretiva 76/207. Sua definição dos efeitos da discriminação é a mesma das duas diretivas anteriores, mas esclarece, em especial, alguns aspectos importantes.

O primeiro deles é que conceitua como efeito da discriminação, a situação desvantajosa da vítima do ato discriminatório, tanto na discriminação direta como indireta (segundo o termo que expressamente adota), conforme seu artigo segundo ${ }^{247}$, o qual deu nova redação à descrição da Diretiva 76/207. Por outro lado, define como efeitos discriminatórios tanto o assédio, como o assédio sexual, promovendo a definição descritiva das duas modalidades. E também, seguindo o exemplo das diretivas anteriores, qualifica a instrução para a discriminação como prática discriminatória.

As diretivas foram editadas como normas orientadoras para que os estadosmembros promovessem, no âmbito interno, a criação de novas normas que seriam balizadas pelas diretivas.

Portugal adotou os princípios das diretivas Europeias em 2002, mediante uma alteração no Código de Trabalho da República Portuguesa, o qual recebeu nova redação dos artigos 23 a 32 pelo recente texto da Lei $n^{\circ}$ 7/2009. Ela manteve as mesmas denominações das diretivas Europeias (tratamento menos favorável), no entanto, a nova Lei estabelece, no seu artigo 24 , algumas descrições de tratamento diferenciado ${ }^{248}$, como

\footnotetext{
${ }^{246}$ UNIÃO EUROPEIA. Diretiva 2000/78. EURLEX. Disponível em: <http://eurlex.europa.eu/Notice.do?val=237068:cs\&lang=pt\&list=432017:cs, 257961:cs,237068:cs, \&pos=3\&page=1\& nbl=3\&pgs=10\&hwords=\&checktexte=checkbox\&visu=\#texte>. Acesso em: 21 set. 2009 .

${ }^{247}$ UNIÃO EUROPEIA. Diretiva 2002/73. EURLEX. Disponível em: <http://eurlex.europa.eu/Notice.do?val=275217:cs\&lang=pt\&list=275217:cs,\&pos=1\&page=1\&nbl=1\&pgs=10\&hwo $\mathrm{rds}=\&$ checktexte $=$ checkbox $\&$ visu $=\#$ texte $>$. Acesso em: 21 set. 2009.

${ }^{248}$ PORTUGAL. Lei $\mathrm{n}^{\circ}$ 7/2009. Diário da República Eletrónico. Disponível em: >http://dre.pt/pdf1sdip/2009/02/03000/0092601029.pdf>. Acesso em: 21 set. 2009 Acesso em: 21 set. 2009 Acesso em: 21 set. 2009 Acesso em: 21 set. 2009 Acesso em: 21 set. 2009.
} 
ser privilegiado, beneficiado, prejudicado, privado de qualquer direito ou isento de qualquer dever em função dos motivos ali proibidos (são listados vinte motivos).

No mesmo sentido, a Lei Orgânica 3/2007 espanhola segue os mesmos conceitos de adversidade (tratamento de modo menos favorável que outra situação comparável ${ }^{249}$ ). A legislação italiana referente à discriminação de pessoas com deficiência, a Lei 67/2006, aponta a mesma situação de desfavorecimento em comparação com a situação de outra pessoa na mesma situação ${ }^{250}$. No mesmo sentido atua o Decreto Legislativo no 216 , de 9 de julho de 2003, que trata de outras modalidades de discriminação ${ }^{251}$.

No Reino Unido, a norma antidiscriminatória vigente relativamente à discriminação por gênero aponta a mesma descrição da diretiva 2002/73 (tratamento menos favorável comparativamente a um homem). O Sex Discrimination Act foi editado em 1975, mas sofreu alterações por parte da norma Europeia. Por outro lado, a referida norma expressa como aspecto específico da discriminação a política que implique na redução proporcional da participação de mulheres na atividade produtiva, que não possa ser justificada e que venha provocar detrimento à igualdade de oportunidades das mulheres ${ }^{252}$. No mesmo sentido de definição caminha a lei britânica de proteção contra a discriminação racial $^{253}$ e a lei de proteção contra a discriminação de deficientes ${ }^{254}$.

Já na França, a Lei 2008-496, que alterou o Código de Trabalho daquele país, instituiu os artigos 1132-1 a 1132-4, que tratam da discriminação no trabalho de modo bem diverso, em comparação com os demais ordenamentos relatados. A referida norma destaca que ninguém pode ser excluído de um processo de seleção, de acesso a determinada atividade de estágio, de um período de formação dentro de uma empresa, bem como nenhum trabalhador pode receber sanções, ser dispensado ou receber qualquer outra

\footnotetext{
${ }^{249}$ ESPANHA. Lei Orgânica 3/2007. Boletin Oficial del Estado. Disponível em: $<$ http://www.boe.es/aeboe/consultas/bases_datos/doc.php?coleccion=iberlex\&id=2007/06115>. Acesso em: 21 set. 2009.

${ }^{250}$ ITÁLIA. Lei 67/2006. Webacessibile.org. Disponível em: <http://webaccessibile.org/normative/legge-672006/>. Acesso em: 21 set. 2009.

${ }^{251}$ ITÁLIA. Decreto legislativo n. 219, de 9 de julho de 2003. La Consiglieri di Paritá Provinciale di Torino. Disponível em: <http://www.consiglieraparitatorino.it/allegati/2003_DL216.pdf>. Acesso em: 21 set. 2009.

${ }^{252}$ REINO UNIDO. Sex Discrimination Act. OPSI - Office of Public Sector Information. Disponível em: $<$ http://www.opsi.gov.uk/RevisedStatutes/Acts/ukpga/1975/cukpga_19750065_en_2\#pt1-11g1>. Acesso em: 21 set. 2009.

${ }^{253}$ REINO UNIDO. Race Relations Act. OPSI - Office of Public Sector Information. Disponível em: <http://www.opsi.gov.uk/RevisedStatutes/Acts/ukpga/1976/cukpga_19760074_en_2\#pt1-11g1>. Acesso em: 21 set. 2009.

${ }^{254}$ REINO UNIDO. Disability Discrimination Act. OPSI - Office of Public Sector Information. Disponível em: <http://www.opsi.gov.uk/acts/acts1995/ukpga_19950050_en_2\#pt2-pb1-11g4>. Acesso em: 21 set. 2009.
} 
medida discriminatória direta ou indireta, notadamente em matéria de remuneração, de medidas de aproveitamento ou distribuição de ações, formação, reclassificação, afetação, qualificação, classificação, promoção profissional, mutação ou renovação de contrato pelos motivos expostos naquele diploma legal ${ }^{255}$.

A descrição francesa é minuciosa e detalhada sobre diversas medidas que importam em desvantagem das vítimas, bem como vantagens indevidamente concedidas a elementos de comparação. Ela afasta a descrição mais simples adotada nas diretivas Europeias e parte para uma declaração mais precisa e típica de situações discriminatórias.

Fora do contexto europeu, duas normas merecem destaque. No Canadá, a discriminação nas relações do trabalho é prevista pela lei de direitos humanos daquele país (Canadian Human Rights Act), de 1985, a qual estabelece, no seu artigo $7^{\circ}$, que uma prática discriminatória no emprego consiste em recusar-se a empregar ou manter o emprego de uma pessoa; bem como, no curso do contrato, tratar de modo diferenciado e prejudicial uma pessoa em relação a outro empregado ${ }^{256}$. A referida norma, no seu artigo $8^{\circ}$, também estabelece como efeitos discriminatórios a divulgação de formulários para um emprego ou qualquer propaganda ou entrevista que venha expressar limitações conforme os motivos proibidos naquele diploma. $\mathrm{O}$ artigo $9^{\circ}$ considera prática discriminatória aquela que exclua ou suspenda o trabalhador de uma determinada organização, bem como de alguma forma limite, segregue, classifique ou então prive o trabalhador de oportunidades de emprego, ou limite tais oportunidades, por pertencer a determinada organização que trate de uma norma coletiva relativa ao trabalhador. E o artigo $10^{\circ}$ da referida norma ainda aponta que são práticas discriminatórias a adoção ou prática de políticas, bem como inserir em normas coletivas que tratem de recrutamento, seleção, promoção, treinamento, aprendizagem, transferência ou qualquer outra matéria que trate de uma relação de emprego ou de uma proposta de emprego, que prive ou tenda a privar uma pessoa ou uma classe de pessoas de quaisquer oportunidades em um motivo proibido de discriminação. Já o artigo 11 relata que é uma prática discriminatória o estabelecimento de salários diferenciados entre homens e mulheres, empregados no mesmo estabelecimento, que desempenhem trabalho de igual valor.

\footnotetext{
${ }^{255}$ FRANÇA. Código do Trabalho. Lei 2008-496. Lexinter.net. Disponível em: <http://www.lexinter.net/Legislation5/JURISOC2/chapitre_ii_principe_de_non_discrimination.htm>. Acesso em: 21 set. 2009.

${ }^{256}$ CANADA. Canadian Human Rights Act. Department of Justice of Canada. Disponível em: <http://laws.justice.gc.ca/PDF/Statute/h/h-6.pdf>. Acesso em: 21 set. 2009.
} 
A legislação da República da África do Sul descreve com maiores detalhes as situações discriminatórias envolvidas em uma conceituação prévia, e procura especificar algumas práticas gerais que importam em discriminação utilizando-se do conceito de employment policy or practice (política ou prática de emprego). A Lei Employment Equity Act, aprovada em 1998, estabelece em seu artigo $6^{\circ}$ que são discriminatórias as atitudes previstas na definição de tais atos, baseada nos vinte motivos listados ${ }^{257}$. Os procedimentos de trabalho afetados por uma ação discriminatória, caso recebam influência de um dos motivos apontados na referida norma são os seguintes: procedimentos de seleção, publicidade de um emprego, ou critérios de seleção; compromissos e processo de designação de compromissos; classificação ou gradação no emprego; remuneração, benefícios do emprego, bem como termos e condições de emprego; designações de trabalho; ambiente de trabalho e facilidades; treinamento e desenvolvimento; sistemas de avaliação de desempenho; promoção; transferência; rebaixamento; medidas disciplinares diversas da dispensa e a dispensa. A referida norma aponta que qualquer tratamento diferenciado em um dos atos acima poderá ser considerado discriminatório. Além disso, são consideradas como atitudes discriminatórias, segundo a referida norma sul-africana, as práticas de assédio, bem como testes médicos e psicométricos.

No Brasil, não há nenhuma norma legal interna que defina quais sejam os efeitos da discriminação em uma relação de emprego. No entanto, a Lei 9.799/99, de autoria da Deputada Rita Camata, adicionou o artigo 373-A ao artigo 373 da Consolidação das Leis do Trabalho, vedando, por serem discriminatórias, as seguintes práticas contra as mulheres por parte dos empregadores, com exclusão daquelas que são destinadas a corrigir o acesso da mulher ao mercado do trabalho:

Art. 373-A. Ressalvadas as disposições legais destinadas a corrigir as distorções que afetam o acesso da mulher ao mercado de trabalho e certas especificidades estabelecidas nos acordos trabalhistas, é vedado:

I - publicar ou fazer publicar anúncio de emprego no qual haja referência ao sexo, à idade, à cor ou situação familiar, salvo quando a natureza da atividade a ser exercida, pública e notoriamente, assim exigir;

II - recusar emprego, promoção ou motivar a dispensa do trabalho em razão do sexo, idade, cor, situação familiar ou estado de gravidez, salvo quando a natureza da atividade seja notória e publicamente incompativel;

\footnotetext{
${ }^{257}$ REPÚBLICA SUL-AFRICANA. Department of Labour. Employment Equity Act, n. 55 - 1998. Disponível em: $\quad<$ http://www.labour.gov.za/downloads/legislation/acts/employment-equity/Act\%20\%20Employment\%20Equity.pdf>. Acesso em: 21 set. 2009.
} 
III - considerar o sexo, a idade, a cor ou situação familiar como variável determinante para fins de remuneração, formação profissional $e$ oportunidade de ascensão profissional;

IV - exigir atestado ou exame, de qualquer natureza, para comprovação de esterilidade ou gravidez, na admissão ou permanência no emprego;

$V$ - impedir o acesso ou adotar critérios subjetivos para deferimento de inscrição ou aprovação em concursos, em empresas privadas, em razão de sexo, idade, cor, situação familiar ou estado de gravidez;

VI - proceder o empregador ou preposto a revistas intimas nas empregadas ou funcionárias.

Apesar de não ser uma descrição geral, os apontamentos feitos pela Lei 9.799/99 são pormenorizados para coibir determinadas situações potencialmente discriminatórias.

Uma rápida visita a diversos conceitos positivados de discriminação no trabalho permite concluir que existe um universo muito amplo de efeitos relacionados à prática discriminatória nas relações de trabalho. Uma das tendências, a qual é seguida pela União Europeia, é bastante simplista e define o efeito pela prejudicialidade de tratamento sem maiores detalhes. Outra tendência, verificada em outros países, é uma descrição minuciosa das situações laborais que são afetadas por um ato discriminatório. As duas tendências são frontalmente divergentes, não sendo possível avaliar qual das duas poderá prevalecer no futuro. 


\section{A MOTIVAÇÃO DE UM ATO DISCRIMINATÓRIO}

O estudo do motivo de uma diferenciação é fundamental para concluir se ela tem ou não natureza discriminatória. Certamente, entre todos os componentes do ato discriminatório, a discussão sobre o motivo e todos os elementos a ele relacionados são questionamentos fundamentais para a consideração sobre uma conduta discriminatória nas relações do trabalho.

Como já pôde ser observado em diversas normas constitucionais e internacionais mencionadas anteriormente, a proibição da discriminação é sempre relacionada a um ou mais fatores ou fundamentos, que são os motivos. Alguns são comuns praticamente a todas as normas antidiscriminatórias, como a raça e o gênero. Por outro lado, alguns outros são menos recorrentes, ficando aqui o exemplo da Constituição portuguesa de 1976, que destaca a instrução como fator discriminatório expressamente proibido ${ }^{258}$. Naquele capítulo, foi possível observar, em seis diferentes constituições - um rol distinto de motivos, para cada uma - como fundamentos para qualificação de determinada conduta como discriminatória.

A grande maioria das normas antidiscriminatórias possui uma relação própria de motivos, quando não centrada no combate a um único motivo. Como exemplo desta última tendência, a Convenção sobre a eliminação de todas as formas da discriminação racial das Nações Unidas, de 1965, trata especificadamente de um motivo e suas variantes; no caso citado, a discriminação racial.

É possível notar diferentes tendências de normatização dos motivos de discriminação proibidos. Algumas normas são mais específicas, com um relacionamento detalhado, como a Constituição portuguesa de 1976 e a Constituição Sul-Africana de 1996. Outros textos constitucionais adotam posturas mais sintéticas, como a Constituição espanhola de 1976, que apesar de arrolar poucos motivos em comparação com a norma constitucional do estado vizinho da península ibérica, traz consigo um critério muito interessante e importante no estudo da discriminação, ao mencionar que qualquer outra condição ou circunstância pessoal ou social também não autoriza a prática de um ato discriminatório. Tal característica também é encontrada, não de modo tão feliz, na carta

\footnotetext{
${ }^{258}$ Capítulo $3^{\text {o }}$, item 3.2 .
} 
política brasileira de 1988 , em seu artigo $3^{\circ}$, inciso $\mathrm{IV}^{259}$. Ou seja, as referidas normas proíbem a discriminação, por qualquer motivo, esteja ele objetivamente previsto ou não. Trata-se tal característica de uma tendência mais recente, no entanto já prevista pela Declaração Universal dos Direitos do Homem, pelos Pactos da ONU de 1966 e por algumas normas internacionais regionais, como a Declaração Americana de Direitos e Deveres do Homem, de 1948.

No entanto, algumas posturas diferenciadoras nas relações de emprego, ainda que explícitas e tomadas com fundamento em fatores expressamente proibidos, com inegável caráter prejudicial, podem ser autorizadas como posturas legítimas. As exceções previstas em alguns ordenamentos específicos sobre a discriminação abrem um campo vasto, porém muito delicado e tormentoso, ao confrontar a motivação do ato diferenciador contra a necessidade de sua aplicação na atividade empresarial. Este, certamente, talvez seja o aspecto mais controvertido e tratado nas questões judiciais que versam sobre as posturas discriminatórias, sendo um aspecto fundamental no estudo da discriminação nas relações do trabalho.

Portanto, nota-se que é absolutamente necessário, ainda que sucintamente, um estudo mais aprofundado do motivo de uma discriminação para compreender, efetivamente, o que seja um ato discriminatório. Outros questionamentos surgem com sua análise, não menos importantes e decisivos. No transcorrer do capítulo será necessário indagar se a presença de um motivo é requisito essencial para qualificar determinado ato como sendo um ato discriminatório. Como já foi apontado anteriormente, um ato discriminatório possui uma diferenciação em relação ao tratamento desigual, por possuir uma qualificação mais intensificada. A existência de um motivo em um ato discriminatório pode permitir distingui-lo de um ato de tratamento anti-isonômico.

\subsection{Um motivo discriminatório}

Podemos dizer com segurança que a totalidade das normas antidiscriminatórias descritivas possui determinada estrutura comum: é considerada discriminatória uma conduta que provoque determinado tipo de dano, se praticada em decorrência de um

\footnotetext{
${ }^{259}$ BRASIL. Constituição Federal de 1988. Presidência da República. Legislação. Disponível em: $<$ www.planalto.gov.br>. Acesso em 29 set. 2009. Art. $3^{\circ}$ Constituem objetivos fundamentais da República Federativa do Brasil: IV - promover o bem de todos, sem preconceitos de origem, raça, sexo, cor, idade e quaisquer outras formas de discriminação.
} 
determinado motivo arrolado pela norma que a proíbe. Na língua portuguesa é normalmente expressado este terceiro componente como motivo pelo ordenamento jurídico e pela doutrina, ou seja, a razão que motivou determinada diferenciação. A doutrina em língua francesa também adota a mesma expressão, ainda que promova certa confusão com a expressão critérios. Na língua inglesa, principalmente na terminologia britânica, a expressão grounds of parece ser mais precisa porque significa um fundamento, ou uma base, para determinada conduta. Nos Estados Unidos da América é mais comum a expressão basis of, para relacionar os motivos proibidos.

Determinada conduta diferenciadora foi praticada por um agente, causando algum prejuízo a determinada pessoa. Constatadas tais situações, resta perguntar: com base em que fator foi tomada determinada atitude? A pergunta procurará explicar o motivo da conduta e, como será visto mais adiante, se é justificável tal conduta em face do fundamento adotado. O motivo será o elemento determinante para saber por qual razão foi adotada aquela conduta.

Quando se menciona um determinado motivo, é possível compreendê-lo como uma razão que teria impulsionado determinada conduta diferenciadora. Isso permite trazer uma ideia de intencionalidade, ou seja: se alguém cometeu determinado ato, por qual motivo assim teria agido? Tem início um delicado e perigoso relacionamento entre motivo e intencionalidade, que necessita ser imediatamente desfeito.

O perigo reside no fato de que a intencionalidade de uma prática discriminatória não é elemento necessário para sua consideração, situação pacífica na doutrina sobre a discriminação. Como já foi visto anteriormente, a prática de uma discriminação por efeito adverso, ou discriminação indireta, dispensa qualquer intenção prejudicial. Trata-se de um conceito amplamente reconhecido dentro do direito positivado de muitos países, bem como da doutrina e da jurisprudência. Para sua consideração, basta apenas que seja constatado o ato prejudicial e analisar se sua prática é justificável.

Assim, utilizar a expressão fundamento da discriminação, ou discriminação com base em determinada característica ou fator, seria uma definição mais feliz. No entanto, a expressão motivo está muito arraigada dentro da doutrina europeia continental ${ }^{260}$, devendo ser aceita. Por outro lado, o termo motivo é utilizado por várias normas antidiscriminatórias internas e internacionais, estando internacionalmente consagrada.

\footnotetext{
${ }^{260}$ RODRIGUEZ-PIÑERO, Miguel; FERNANDEZ LOPEZ, Maria Fernanda. op. cit., p. 171.
} 
No entanto, cabe deixar bem claro que não pode ser aceita a noção de motivo como propósito discriminatório. Miguel Rodriguez-Piñero e Maria Fernanda Fernández López ${ }^{261}$ apontam que tal termo não deve ser entendido em um sentido subjetivo, que venha a concorrer com um elemento intencional, o que jamais poderá ser levado em conta na apreciação de uma prática discriminatória.

Os motivos nada mais são do que determinadas categorias específicas de características pessoais, as quais são analisadas dentro do contexto discriminatório, isolada ou conjuntamente. As referidas categorias reunidas por determinadas características conduzem à averiguação do fundamento da atitude diferenciadora discutida, com a finalidade de saber se determinada decisão, ainda que involuntariamente, provocou diferenças prejudiciais no tratamento ou atingiu desproporcionalmente determinado grupo que possua tal característica.

Essa característica ou situação pessoal pode atrair determinada conduta por parte de um agente discriminador, sendo o elemento desencadeador de uma relação discriminatória. Os motivos são fatores que determinada pessoa porta ou opta por adotar, cuja presença traz contra si um tratamento diferenciado. A avaliação do referido fator para constatação de uma atitude discriminatória é essencial, especialmente nas relações de trabalho.

\subsection{A importância da motivação na conceituação de discriminação}

Marc Bossuyt sustenta que o motivo de uma discriminação é um elemento essencial na sua caracterização ${ }^{262}$, porque exprime as razões pelas quais a diferenciação foi preferida ao invés de uma igualdade de tratamento. O célebre autor belga, cuja pesquisa tem ampla receptividade no direito europeu, destaca que o motivo possui uma relevante utilidade para examinar a consistência da proibição da discriminação no direito internacional, porque o motivo é posto defronte à norma internacional que proíbe a discriminação ${ }^{263}$. Hugo Mansueti aponta que o motivo figura no conceito descritivo da Convenção 111, razão pela qual deve constar como elemento necessário para a conceituação, desde que um trabalhador integre um dos grupos mencionados na referida previsão normativa ${ }^{264}$. Marie-

\footnotetext{
${ }^{261}$ RODRIGUEZ-PIÑERO, Miguel; FERNANDEZ LOPEZ, Maria Fernanda. op. cit., p. 171.

${ }^{262}$ BOSSUYT, Marc. op. cit., p. 40

${ }^{263}$ Id. Ibid., p. 65.

${ }^{264}$ MANSUETI, Hugo Roberto. op. cit., p. 259.
} 
Thérèse Lanquetin qualifica o motivo como o problema-chave da discriminação, permitindo saber se é uma discriminação ou uma diferenciação ${ }^{265}$.

Miguel Rodriguez-Piñero e Maria Fernanda Fernandez López, por seu turno, afirmam categoricamente a possibilidade de a expressão conduzir à existência de um elemento intencional. Ela pode remeter à ideia de que não é imprescindível avaliar os motivos sobre os quais se baseiam um tratamento diferenciado, nem tampouco a falta de intenção poderia ser uma escusa ou motivo para excluir qualquer responsabilidade do agente $^{266}$. Na mesma esteira, Rosemary Hunter e Elaine Shoben, entre tantos autores que se filiam a essa corrente, apontam que a discriminação indireta torna irrelevante a verificação de um motivo, na medida em que necessita tão somente apurar se determinado grupo foi desproporcionalmente afetado ${ }^{267}$.

Egbert Vierdag se filia à corrente de que os motivos integram, necessariamente, a definição de discriminação ${ }^{268}$. E o faz mediante justificativas bastante pertinentes que merecem ser analisadas. Em primeiro lugar, o jurista holandês aponta que uma norma que enumere alguns motivos para a discriminação a clarifica e, assim, auxilia o intérprete a ter maior precisão sobre o que seja discriminação e avaliar mais detalhadamente se há ou não natureza discriminatória em determinada conduta ${ }^{269}$. Mas outra situação apontada pelo referido autor, muito particularizada com a discussão da discriminação nas relações de trabalho, indica a indispensabilidade da análise dos motivos.

Um motivo pode indicar que determinada conduta seja ou não considerada discriminatória. A possibilidade aqui destacada se deve a uma razão muito especial na análise das condutas discriminatórias: a de que uma determinada conduta, ainda que possua como fator decisivo um motivo proibido, assim mesmo não seja discriminatória. Uma das possibilidades citadas pelo autor holandês é a existência de medidas especiais de proteção, assim reconhecidas pela Convenção 111 da OIT e pela Convenção racial da ONU. Elas seriam medidas de cunho equitativo e aplicação efetiva de justiça distributiva,

\footnotetext{
${ }^{265}$ LANQUETIN, Marie-Thérèse. La discrimination à raison du sexe en droit international et communautaire, cit., p. 808.

${ }^{266}$ RODRIGUEZ-PIÑERO, Miguel; FERNANDEZ LOPEZ, Maria Fernanda. op. cit., p. 171.

${ }^{267}$ HUNTER, Rosemary C.; SHOBEN, Elaine W. Disparate impact discrimination: american oddity or internationally accepted concept? Berkeley Journal of Employment and Labor Law. No 19 , 1998 , p. 109. Lexis Nexis. Disponível em: $<$ http://www.lexisnexis.com/us/Inacademic/results/docview/docview.do?docLinkInd=true\&risb=21_T7498 $584904 \&$ format=GNBFI\&sort=RELEVANCE\&startDocNo=1\&resultsUrlKey=29_T7498584911\&cisb=2 $2 \_$T7498584910\&treeMax $=$true $\&$ treeWidth $=0 \& c s i=248045 \&$ docNo $=4>$. Acesso em: 04 out. 2009.

${ }^{268}$ VIERDAG, Egbert. op. cit., p. 61.

${ }^{269}$ Id. Ibid., p. 108.
} 
as quais venham a reparar situações discriminatórias, pela adoção de medidas diferenciadoras que favorecem grupos historicamente prejudicados. Entre elas, é possível considerar as ações afirmativas ou discriminações positivas, como definidas no capítulo anterior.

Para saber se a medida é de cunho positivo, ou seja, de cunho reparador, necessariamente deverá tal exame passar, e de forma profunda, pelo motivo da diferenciação adotada e do nexo entre ela e o motivo da discriminação historicamente consolidada.

Entretanto, medidas discriminatórias somente podem ser avaliadas com maior precisão se analisadas dentro de um contexto de relação entre a necessidade do meio adotado e a finalidade visada com a conduta diferenciadora. Trata-se de um juízo de razoabilidade que deve ser formulado entre a medida diferenciadora, os fins ao qual se destina e os meios que foram tomados. Esse juízo de razoabilidade não pode ser tomado sem que seja levado em conta o fundamento da atitude diferenciadora. Os três elementos os motivos, os meios e os fins - são os componentes do juízo de razoabilidade, segundo a lição de Luis Roberto Barroso ${ }^{270}$.

O motivo, analisado isoladamente, não permite concluir que a medida diferenciadora seja considerada uma discriminação, como bem observa Rémy Hernu ${ }^{271}$. A consideração da finalidade de uma medida questionada como discriminatória é defendida por Roger Raupp Rios, que aponta a necessidade deste exame, principalmente para medidas legislativas que tenham conteúdo ou efeito discriminatório ${ }^{272}$. Com efeito, muitas normas antidiscriminatórias são elaboradas visando proibir um motivo de discriminação tão somente, ficando os exemplos das Convenções das Nações Unidas para eliminação da discriminação por raça ou feminina. Em muitos ordenamentos, são elaboradas normas antidiscriminatórias específicas para determinada modalidade ou determinado motivo. Saber o motivo da diferenciação importa, em alguns casos, saber qual norma será aplicável.

Por outro lado e com muito maior ênfase nas discriminações nas relações de trabalho, certas atitudes podem ser diferenciadoras, quando explicitamente tomadas com

\footnotetext{
${ }^{270}$ BARROSO, Luis Roberto. Razoabilidade e isonomia no direito brasileiro. In: VIANA, Márcio Túlio; RENAULT, Luiz Otávio Linhares (Coords.). Discriminação. São Paulo: LTr, 2000. p. 30.

${ }^{271}$ HERNU, Rémy. Principe d'égalité et principe de non-discrimination dans la jurisprudence de la Cour de Justice des Communautés Européennes. Paris: L.G.D.J., 2003. p. 261.

${ }^{272}$ RIOS, Roger Raup. op. cit., p. 104.
} 
base em determinado motivo proibido e, assim mesmo, serem juridicamente aceitas. Um dos princípios da discriminação nas relações de trabalho envolve a consideração de que certas medidas, ainda que sejam efetivamente discriminatórias, devem ser permitidas em função de uma determinada necessidade da atividade laboral envolvida ou de determinada necessidade da atividade desenvolvida pelo empregador ou contratante. Este princípio foi explicitamente considerado pela Convenção 111 da OIT e, depois de seu surgimento, praticamente todas as normas antidiscriminatórias laborais descritivas destacam esta possibilidade. Consolida-se, assim, um dos princípios da discriminação nas relações de trabalho: certas necessidades do trabalho ou da atividade do empreendimento autorizam posturas que importam em diferenciações aceitas por motivos tradicionalmente proibidos nas normas discriminatórias.

Egbert Vierdag aponta que essa peculiaridade é mais fácil de ser visualizada nas relações do trabalho, eis que a razoabilidade de tais distinções baseadas em motivos proibidos pode ser mais facilmente demonstrada nesta modalidade de relação ${ }^{273}$. É o caso da necessidade da atividade empresarial ou business necessity, adicionada ao texto da Convenção 111 por uma emenda da delegação britânica. Essa relação de razoabilidade mencionada pelo referido autor somente poderá ser analisada se for feito um profundo estudo sobre o motivo da diferenciação e sua efetiva necessidade para a atividade empresarial.

Essa possibilidade nas relações do trabalho, ampla, se comparada com outras possibilidades muito mais estreitas em outras áreas jurídicas que também tratam da discriminação, torna absolutamente indispensável que, dentro das relações de trabalho, seja inevitável, e absolutamente essencial, a análise dos motivos da discriminação discutida. Marzia Barbera assevera que o fundamento da racionalidade do tratamento preferencial será constituído pela diversidade das situações consideradas ${ }^{274}$, apontando a existência de uma regra de não arbitrariedade ${ }^{275}$. A existência do arbítrio na decisão que tem efeitos discriminatórios é matéria recorrente na doutrina europeia e será analisada com maior profundidade no final do capítulo. A análise da existência de um juízo de razoabilidade na conduta diferenciadora, para a discussão de sua possibilidade, ou não, envolverá o motivo ou os motivos alegados.

\footnotetext{
${ }^{273}$ VIERDAG, Egbert. op. cit., p. 111.

${ }^{274}$ BARBERA, Marzia. op. cit., p. 97.

${ }^{275}$ Id., loc. cit.
} 
Por fim, há de ser considerado que, em alguns ordenamentos jurídicos, as proibições sobre discriminação recaem sobre motivos específicos enumerados pela norma jurídica, enquanto outros possuem um sistema extremamente aberto ou ainda cláusulas enumerativas não limitativas. Nos sistemas jurídicos de previsão expressa dos motivos discriminatórios, a análise do motivo é absolutamente essencial para a qualificação de determinada conduta como discriminatória. Se não for encontrada a conduta dentro do grupo de motivos proibidos, a conceituação como discriminatória será afastada. Como os sistemas totalmente abertos são muito raros, fica claro que a análise do motivo também se torna um elemento essencial para a consideração sobre a discriminação. As discussões na Suprema Corte dos EUA sobre a discriminação tomam como ponto de partida o fato de o trabalhador envolvido pertencer a determinado grupo a ser protegido pela lei antidiscriminatória laboral federal daquele país. Pertencer a um determinado grupo é um fator importantíssimo para a discussão da conduta empresarial questionada, indicando como aquela Corte irá avaliar a questão.

E essa relação de pertinência envolve o próprio motivo do questionamento da conduta. O fato de o envolvido pertencer a determinado grupo, em razão de alguma característica pessoal, é o motivo da discussão da conduta discriminatória decorrente de um impacto desproporcionalmente desvantajoso para os integrantes do referido grupo. Nos casos de discriminação por efeito adverso ou por discriminação indireta, o ponto chave da sua definição é que determinada prática neutra de um empregador que afeta desproporcionalmente um grupo, colocando-o em situação de desvantagem em comparação com os demais. A relação entre causa e efeito da medida não intencional, bem como a necessidade e a justificação da medida tomada, deve ser criteriosamente analisada como razoável. Para tanto, as características do grupo envolvido e as necessidades do empregador são inevitavelmente ponderadas no questionamento envolvido. Nesse sentido, a decisão do caso Ontario Human Rights Commission \& O'Malley v. Simpsons-Sears Ltd. pela Corte Suprema do Canadá foi claríssima em apontar que uma prática neutra "tem um efeito discriminatório baseado em determinado motivo sobre um ou um grupo de empregados que receberam a imposição, por conta de determinada característica do empregado ou do grupo" ${ }^{, 276}$. A decisão acima ilustra bem que a discussão sobre a intencionalidade do ato discriminatório fica afastada, mas a análise do motivo é

\footnotetext{
${ }^{276}$ SUPREMA CORTE DO CANADÁ. Université du Montréal. Judgments of the Supreme Court of Canada. Disponível em: <http://csc.lexum.umontreal.ca/en/1985/1985rcs2-536/1985rcs2-536.pdf>. Acesso em: 06 out. 2009.
} 
fundamental para a caracterização da discriminação, mesmo sendo caso de discriminação por impacto adverso.

Portanto, é possível concluir que a análise do motivo é absolutamente indispensável, ao menos nas discriminações ocorridas nas relações do trabalho, para avaliar a ocorrência de uma conduta discriminatória. Assim, não resta outro caminho, principalmente dentro do estudo da discriminação laboral, senão se posicionar ao lado da corrente doutrinária estabelecida por Vierdag e Bossuyt, entre outros autores, no sentido de que o motivo é componente essencial para a conceituação de discriminação.

\subsubsection{As funções do motivo}

O motivo de um ato discriminatório possui algumas funções importantíssimas para a consideração de uma conduta como discriminatória. Marc Bossuyt faz uma classificação válida para os motivos, de acordo com suas funções, apontando duas possibilidades: as funções materiais e as funções procedimentais dos motivos de um ato discriminatório ${ }^{277}$. Danièle Lochak aponta que, numa discussão judicial sobre a discriminação, dois aspectos são essenciais no debate: a existência de um motivo legítimo e a prova ${ }^{278}$.

A função material do motivo dentro da análise sobre a conduta discriminatória é indiscutível, em especial nas discriminações ocorridas dentro das relações laborais, pelos fundamentos acima apontados.

Em primeiro lugar, e talvez sua função mais importante, o juízo de ponderação pede, necessariamente, o motivo da conduta sob análise. Com o conhecimento do motivo e recebendo a justificativa de quem praticou o ato diferenciador, será possível fazer a ponderação se aquela determinada característica é relevante e suficientemente justificadora para ensejar a prática diferenciadora. A possibilidade de exceções, que permitam uma conduta diferenciadora, torna o motivo do ato discriminatório um componente chave para verificar se há razoabilidade na conduta sob análise.

Todavia, especialmente nos sistemas antidiscriminatórios positivados com rol de motivos expresso e taxativo, o motivo do ato discriminatório é absolutamente essencial para saber se determinada conduta diferenciadora se encaixa dentro da previsão normativa. Este é um debate muito delicado quando são tratadas as discriminações em sistemas

\footnotetext{
${ }^{277}$ BOSSUYT, Marc. op. cit., p. 64.

${ }^{278}$ LOCHAK, Daniele. op. cit., p. 788.
} 
fechados, servindo como exemplo o sistema de proteção antidiscriminatória laboral do Reino Unido. Sandra Fredman chama a atenção para as dificuldades vividas no sistema britânico, apontando que, ainda que a legislação daquele país seja sofisticada, bem como os motivos discriminatórios venham aumentando nos últimos anos, principalmente com a incorporação da Carta Europeia de Direitos Humanos em 1998, a cobertura normativa está longe de ser considerada completa ${ }^{279}$. Segundo a referida autora, várias situações discriminatórias deixam de ser atendidas, promovendo a exclusão de importantes $\operatorname{grupos}^{280}$.

As exceções permitidas nas normas discriminatórias nas relações laborais são extremamente delicadas. Danièle Lochak destaca que essa interessante questão é a que mais preocupa, na medida em que a existência de motivos autorizados pode suprimir a efetiva proteção da discriminação ${ }^{281}$.

Assim, fica claro diante desses dois exemplos, que os motivos possuem uma função material essencial na discussão da existência de um ato discriminatório, o que reforça ainda mais a tese da imprescindibilidade de sua consideração dentro do contexto discriminatório sob análise.

Por outro lado, os motivos possuem uma inquestionável função procedimental de caráter essencial, sendo decisiva sua relevância dentro dos processos nos quais são questionadas condutas diferenciadoras.

Certos motivos, pela gravidade que traduzem e pela importância do tipo de discriminação que pretendam combater, apontam para determinadas condutas diferenciadoras como "suspeitas", expressão explicitamente adotada pela Suprema Corte dos Estados Unidos. Diferenciações baseadas na raça dos envolvidos, por exemplo, atraem para a questão discriminatória uma atenção maior do julgador, levando-o a suspeitar dos atos diferenciadores como discriminatórios, até que seja provado o contrário. Motivos delicados levam o julgador a adotar presunções de práticas discriminatórias até que seja demonstrada a sua inexistência, possuindo importantes reflexos sobre a designação do ônus da prova.

\footnotetext{
${ }^{279}$ FREDMAN, Sandra. Discrimination law, cit., p. 69.

${ }^{280}$ Id. Ibid., p. 70.

${ }^{281}$ LOCHAK, Daniele. op. cit., p. 788.
} 
O exame da questão discriminatória gerou no direito norte-americano um sistema de análise pelo qual a Suprema Corte daquele país criou parâmetros de controle da constitucionalidade de medidas diferenciadoras.

\subsubsection{Os testes de validade constitucional de medidas diferenciadoras}

Determinados motivos de práticas diferenciadoras ensejaram um sistema de avaliação da sua constitucionalidade pela Suprema Corte dos Estados Unidos da América. Tais práticas podem ser postas sob questionamento judicial com base na equal protection doctrine, um princípio que proíbe as discriminações e a subjugação de pessoas e grupos em face da comunidade ${ }^{282}$. O sistema de avaliação permite a análise e o agrupamento das decisões de acordo com uma compreensão sistematizada, mediante parâmetros de controle nelas empregadas, segundo Roger Raupp Rios ${ }^{283}$.

O caso Korematsu v. United States ${ }^{284}$ deixou claro um entendimento da Suprema Corte dos Estados Unidos, em 1944, no sentido de que todas as limitações legais que reduzam os direitos civis de um único grupo racial são imediatamente $\operatorname{suspeitas}^{285}$. O voto condutor do Juiz Hugo Black ainda mencionou que a afirmação acima não significa dizer que todas as limitações são inconstitucionais; no entanto, para tais questões, a limitação deve ser submetida ao mais minucioso e rígido exame. Ou seja, a suspeição do motivo racial que envolve a decisão importa em uma análise muito mais profunda de todos os elementos envolvidos. A decisão realiza um rígido exame para ser verificada a questão da validade da conduta discutida diante das proibições legais de discriminação por aquele específico motivo.

O sistema de avaliação tem por base o motivo da discriminação e, dependendo do motivo ou da situação, podem ser adotados três critérios de controle: o rational relationship test (teste da relação de racionalidade), o strict scrutiny test (o padrão de rigoroso controle de constitucionalidade) e o intermediate scrutiny test (o padrão intermediário de constitucionalidade). Dependendo da motivação adotada para a medida diferenciadora, a Corte promove um determinado tipo de controle, seja ele mais rigoroso

\footnotetext{
${ }^{282}$ TRIBE, Laurence H. American constitutional law. 2. ed. Mineola: The Foundation Press, 1988. p. 1515.

${ }^{283}$ RIOS, Roger Raup. O princípio da igualdade e a discriminação por orientação sexual. São Paulo: Ed. Revista dos Tribunais, 2002. p. 71.

${ }^{284}$ Toyosaburo Korematsu v. United States, 323 U.S. 214 (1944).

${ }^{285}$ SUPREMA CORTE DOS ESTADOS UNIDOS DA AMÉRICA. Findlaw. Disponível em: $<$ http://caselaw.lp.findlaw.com/scripts/getcase.pl?court=US\&vol=323\&invol=214>. Acesso em: 30 set. 2009.
} 
(strict scrutiny), o controle intermediário (intermediate scrutiny test) e o sistema mais brando (rational relationship test). Dependendo do teste, o interessado deverá demonstrar que a medida diferenciadora seja extremamente necessária, com um objetivo relevante e que dependa de determinado grau de justificação. No grau mais rigoroso, se encontram as medidas diferenciadoras que são motivadas por critérios raciais, ou que afetem minorias.

Fica claro, portanto, que o motivo tem um papel fundamental para orientar qual procedimento judicial será adotado pela Corte daquele país para apreciação dos casos que envolvam discriminação. Dependendo do motivo, a análise sobre sua constitucionalidade terá tratamento diferenciado. Eduardo Appio revela que, desde a adoção dos testes acima, o teste mais rigoroso (Strict Scrutiny) declarou todas as leis inconstitucionais desde o caso Korematsu, e, por esta razão, o debate prévio sobre qual será o nível do teste a ser aplicado à lei se converte na principal questão dessas disputas ${ }^{286}$. Assim, a discussão sobre o teste, questão absolutamente procedimental, diante das tendências da Corte, passa a ter uma função procedimental praticamente equiparada à função material do motivo.

Steven Kaminshine comenta as primeiras decisões da Suprema Corte norteamericana sobre discriminação após o advento da lei dos direitos civis aprovada em 1964, principalmente as decisões proferidas nos dois célebres casos que firmaram duas importantes teorias sobre discriminação. O referido autor destaca que nessas decisões a motivação foi crucial $^{287}$. Tal fato ocorreu em face de aquela Corte tomar como base para a discriminação a noção de afetação por uma prática neutra ou deliberada contra um grupo protegido, por possuir determinada característica. Ambas as teorias daquela corte construídas no início dos anos 70, nos célebres casos Griggs v. Duke Power Co. e McDonnell Douglas v. Green adotam, como ponto central da discussão, a noção de grupo protegido, sendo este o motivo para a avaliação das posturas empresariais discutidas nas referidas ações e, daí, concorrer todo um sofisticado esquema de testes para apuração de que tais condutas não eram de natureza discriminatória.

Os motivos de uma prática diferenciadora não somente têm um papel fundamental na questão material da discriminação, como também na situação processual da questão que

\footnotetext{
${ }^{286}$ APPIO, Eduardo. Direito das minorias. São Paulo: Ed. Revista dos Tribunais, 2008. p. 212.

${ }^{287}$ KAMINSHINE, Steven J. Disparate treatment as a theory of discrimination: the need for a restatement, not a revolution. Stanford Journal of Civil Rights \& Civil Liberties. Stanford. No 1 . Novembro 2005, p. 8. Lexis Nexis. Disponível em: <http://www.lexisnexis.com/us/lnacademic/results/docview/docview.do?docLinkInd=true\&risb=21_T7509 823010\&format=GNBFI\&sort=RELEVANCE\&startDocNo=1\&resultsUrlKey=29_T7509823022\&cisb=2 2_T7509823021\&treeMax $=$ true \& treeWidth $=0 \&$ selRCNodeID $=25 \&$ nodeStateId=411en_US, $1 \&$ docsInCate gory $=850 \& \mathrm{csi}=303824 \& \operatorname{doc} \mathrm{No}=2>$. Acesso em: 06 out. 2009.
} 
envolva a discriminação. Dependendo do motivo, podem resultar em determinado tipo de desfecho, conforme a rigidez do sistema de avaliação adotado.

\subsubsection{Motivos ou grupos?}

Um debate cada vez mais intenso é centrado na discussão de que o fundamento para a caracterização de uma discriminação deva ser baseado em um determinado motivo, assim considerado uma característica pessoal ou o fato de a pessoa discriminada pertencer a determinado grupo social.

Para a caracterização de uma discriminação direta, ou considerada nos EUA como disparate treatment, basta contextualizar que determinada pessoa, ou grupo, foi discriminada por um dos motivos previstos na sétima seção da Lei dos Direitos Civis de 1964. Porém, a consideração de uma discriminação por efeito adverso, naquele país conhecida como disparate impact, requer a comprovação de que determinada prática empresarial, ainda que neutra e não intencional, tenha repercutido de forma desfavorável ou tenha provocado um dano desproporcional para um determinado grupo.

No Canadá, a Suprema Corte daquele país tem debatido sobre o papel da discriminação como violação da dignidade da pessoa humana, quando verificado um tratamento diferenciado que coloque o envolvido em posição desvantajosa dentro da sociedade canadense, como resultado de um tratamento diferenciado substantivo comparativamente analisado entre a pessoa em questão e outros, fundados em uma ou mais características pessoais $^{288}$. Daphne Gilbert critica a decisão do processo judicial Law v. Canada, cujo fundamento caracterizou uma doutrina daquela Corte.

A referida autora assevera que esta decisão dificultou ainda mais o reconhecimento da discriminação. Ela aponta que a Corte aliou a exigência de uma diferenciação baseada em determinado motivo ao fato de o envolvido pertencer a um grupo historicamente em desvantagem naquela sociedade e, ainda, se houve violação da dignidade da pessoa humana na ação diferenciatória ${ }^{289}$.

\footnotetext{
${ }^{288}$ SUPREMA CORTE DO CANADA. Law v. Canada (Minister of Employment and Immigration) [1999] 1 S.C.R. 497, 170 D.L.R. (4th) 1 [Law]. Université de Montréal. Judgments of the Supreme Court of Canada. Disponível em: <http://csc.lexum.umontreal.ca/en/1999/1999rcs1-497/1999rcs1-497.html>. acesso em: 08 out. 2009.

${ }^{289}$ GILBERT, Daphne. Time to Regroup: Rethinking Section 15 of the Charter. McGill Law Journal, $\mathrm{N}^{\circ} 48$, p. 627-649, dezembro de 2003. Lexis Nexis. Disponível em: <http://www.lexisnexis.com/us/lnacademic/results/docview/docview.do?docLinkInd=true\&risb=21_T7498
} 
A crítica da referida autora canadense reside no fato de que a relação que enumera os motivos pode ter suas vantagens, mas o foco voltado para um determinado grupo onde a parte envolvida tenha dividido uma história de marginalização e vulnerabilidade social vem por afastar a neutralidade dos motivos para se aproximar de um resultado pragmático obtido por meio da contextualização dos grupos envolvidos. Ela aponta ainda que, para alcançar maior sutileza na apreciação da discriminação discutida, a Corte irá analisar concretamente qualquer violação da dignidade dos indivíduos do grupo. Por fim, ainda assinala que as discussões centradas em grupos são muito mais fáceis de serem compreendidas do que baseadas em motivos, principalmente as situações de discriminações complexas, traçando todos os contornos necessários para a solução da questão $^{290}$.

A Corte canadense, ao decidir uma questão discriminatória de outro importante feito, no qual o nome das partes foi mantido em sigilo, estabeleceu que a enumeração de motivos corresponde à delimitação de determinados grupos de pessoas que dividem características pessoais similares, sendo que tal forma pode encapsular muitos grupos de pessoas que foram expostas a uma conduta proibida. No entanto, tal fato sociológico não transfere a um requisito de que o envolvido tenha que identificar determinado grupo que sofreu ou que pode sofrer potencialmente a mesma discriminação. Afirmou a Corte canadense, na referida decisão, que a escolha de um grupo é uma medida conveniente para entender e descrever a ação discriminatória, no entanto ela não pode ser transformada ao nível de argumento legal. Entendeu a Corte que o fato de pertencer a determinado grupo não é necessariamente pré-condição para ser encontrada uma discriminação ${ }^{291}$.

A discussão é extremamente interessante e muito complexa, na medida em que ruma para aspectos sociológicos, antropológicos, psicológicos e filosóficos. A discussão reforça ainda mais o importante papel dos grupos e a utilidade deste complexo debate, principalmente no que tange às situações de estigmatização social, estereótipos, preconceito e hostilidade social contra determinado grupo. Porém, é importante frisar que a caracterização da discriminação se faz, basicamente, pelo motivo envolvido, sendo tais análises sociais elementos auxiliares importantes, mas nunca autônomos.

557915\&format=GNBFI\&sort=RELEVANCE\&startDocNo=1\&resultsUrlKey=29_T7498557924\&cisb=2

2_T7498557918\&treeMax $=$ true \&treeWidth $=0 \& c s i=152738 \& d o c N o=3>$. Acesso em: 04 out. 2009.

${ }^{290}$ Id. Ibid., p. 634.

${ }^{291}$ SUPREMA CORTE DO CANADA. B v. Ontario (Human Rights Commission), [2002] 3 S.C.R. 403, 2002 SCC 66. Université de Montréal. Judgments of the Supreme Court of Canada. Disponível em: <http://csc.lexum.umontreal.ca/en/2002/2002scc66/2002scc66.html>. Acesso em: 08 out. 2009. 
Tais características pessoais poderão ser comuns a outros membros da sociedade e a experiência desse grupo podea ser extremamente importante para a contextualização da discriminação. Servirão tais elementos para auxiliar a mensuração da gravidade da medida em discussão e a sua relevância social. Como bem coloca Roger Raupp Rios, tais avaliações permitem analisar com maior precisão situações reconhecidamente incontestes como racismo, sexismo e homofobia, caminhando também para hipóteses mais recentes e ainda não muito bem definidas, como discriminação estética, por obesidade ou utilização de aparelhos oculares ${ }^{292}$.

Mas o referido jurista aponta que a aludida análise é apenas um dos componentes utilizados pelos testes da Suprema Corte dos EUA para a avaliação de classificações suspeitas (strict scrutiny). A discussão, com o rigor adotado para tais situações, aborda a questão de o grupo sujeitar-se histórica e intencionalmente a tratamento desigual praticado pela maioria; se é vítima de um processo de estigmatização; se é objeto de preconceito e hostilidade difusos; se recebe tratamento desigual em face de estereótipos; se constitui parcela minoritária e pouco expressiva; se tem características imutáveis e constituintes de sua identidade e se apresenta, como motivo de discriminação, uma característica irrelevante para sua participação positiva na sociedade ${ }^{293}$.

No entanto, não pode a situação de uma pessoa em um grupo substituir o motivo na contextualização, posto que o motivo em si é o elemento comum a todos que constituem o grupo em questão. O motivo envolvido tem uma característica nuclear no tema em debate, sendo que todas as indagações e respostas envolvidas orbitam em torno do motivo, demonstrando sua importância.

Mais ainda, no campo das relações de trabalho, o motivo, que determina a presença de determinada pessoa dentro de um grupo, é um aspecto fundamental para a análise da permissibilidade da conduta questionada. No entanto, o retrato social do grupo ao qual a pessoa pertença é muito importante também, principalmente na contextualização de discriminações laborais que não tragam prejuízos à vida laboral do discriminado, mas tenha reflexos exógenos, que o prejudique perante o seu grupo social. A realidade da discriminação religiosa no trabalho é um bom exemplo. Nessas situações, o contexto do grupo servirá como um meio importante de auxílio para compreensão do dano causado

\footnotetext{
${ }^{292}$ RIOS, Roger Raup. op. cit., p. 55.

${ }^{293}$ Id., loc. cit.
} 
pela conduta discriminatória no ambiente de trabalho, ou nas situações em que tal conduta também reflita fora dele.

\subsection{Taxatividade ou exemplificidade nos motivos previstos em normas positivadas}

Uma questão emerge de uma simples observação das normas antidiscriminatórias. Algumas apresentam definições enumerando os motivos pelos quais se proíbe a discriminação, outras são abertas, não contendo qualquer enumeração e outras demonstram o rol de motivos, mas deixam claro que são motivos exemplificativos e que não é permitida a discriminação de qualquer outro motivo. A observação traz consigo uma dúvida extremamente importante: quais são as diferenciações permitidas e quais são as diferenciações proibidas?

Esta resposta pode ser a solução de um grande número de controvérsias que emergem das questões discriminatórias, principalmente nas relações do trabalho. Como foi apontado anteriormente, o relatório global da OIT sobre a igualdade no trabalho destaca que novas modalidades de discriminação surgem no planeta, destacando as formuladas no estilo de vida do trabalhador e sua relação com a saúde (o exemplo de pessoas obesas e fumantes). Tais formas relatam a extrema dinamicidade que a discriminação laboral assume em todo o globo, principalmente em relação aos motivos das práticas discriminatórias.

O debate sobre a discriminação de trabalhadores tabagistas ganha muito mais corpo com a vigência da Lei 13.541/2009, do Estado de São Paulo que, em termos gerais, proíbe o tabagismo em diversos locais públicos, inclusive nos ambientes de trabalho ${ }^{294}$. O comportamento de certos empregadores e a adoção da referida norma legal como pretexto para práticas discriminatórias contra trabalhadores tabagistas será uma realidade a ser enfrentada nos tribunais laborais.

A questão é muito intrigante, eis que, reiteradamente, são constatadas atitudes discriminatórias fundadas em aspectos importantes, mas dificilmente previstos em normas antidiscriminatórias. Situações de discriminação contra portadores do vírus HIV, exdetentos, pessoas de aparência fora dos padrões convencionais (a questão da "boa aparência”), reclamantes na Justiça do Trabalho e homossexuais, entre tantos outros casos,

\footnotetext{
${ }^{294}$ ESTADO DE SÃO PAULO. Lei 13.541/2009. Sítio Lei Antifumo. Disponível em: <http://www.leiantifumo.sp.gov.br/usr/share/documents/legislacao.pdf>. Acesso em: 16 out. 2009.
} 
possuem baixíssima ou nenhuma proteção positiva contra a discriminação. No primeiro caso, portar o vírus HIV encabeça a lista dos motivos pelos quais a Justiça do Trabalho é mais procurada no país para questões discriminatórias, no entanto, não existe qualquer proteção normatizada para tal motivo discriminatório. Alguns motivos podem parecer irrelevantes, mas se eles forem fundamento para prejuízo de uma situação laboral, não podem deixar de ser considerados. A questão mais preocupante surge quando se constata uma prática discriminatória, cuja motivação não possua qualquer previsão normativa que a proíba.

O primeiro aspecto que deve ser levado em conta é a gravidade da prática discriminatória. Como foi visto no terceiro capítulo, a proteção contra a discriminação é elevada a uma dimensão especial dentro das normas sobre direitos humanos. A proteção contra a discriminação visa o pleno e irrestrito gozo de tais direitos, reconhecendo-se a plena e universal igualdade do ser humano no seu exercício. Assim, o cerne da proteção contra a discriminação é encontrado na defesa da plenitude da condição humana, conferindo a ela um tratamento na mesma proporção de dignidade de qualquer outra pessoa neste planeta. $\mathrm{O}$ objetivo nuclear dessa proteção é preservar o direito à igualdade $\mathrm{e}$ a integralidade do ser humano contra privações de qualquer espécie causadas por tratamentos diferenciados injustificáveis. Ocorrendo discriminação, há efetivamente quebra da igualdade, seja por qual motivo for, prejudicando a fruição de determinado direito.

O foco das normas antidiscriminatórias é a preservação dessa integralidade de condições e direitos do ser humano, utilizando-se do mandamento de igualdade. Assim, a norma protetora não pode apontar que a defesa nela prevista é aplicável somente para determinados tipos de diferenciações injustificadas. É inconcebível um rol taxativo para um instrumento tão importante; seria um verdadeiro freio à realização da igualdade substancial. A proteção da fruição dos direitos humanos pede uma blindagem jurídica total contra as discriminações. Essa proteção não é imutável. Bobbio aponta que os direitos humanos, enquanto direitos históricos, são mutáveis, suscetíveis de transformação e ampliação $^{295}$.

A utilização de um modelo geométrico pode ajudar a compreensão do problema. Podemos imaginar o mundo dos fatos discriminatórios como um plano típico lançado no espaço, sendo tal plano infinito. Sobre ele, existe um semiplano paralelo que seria o plano

\footnotetext{
${ }^{295}$ BOBBIO, Norberto. A era dos direitos, cit., p. 32.
} 
das normas jurídicas protetoras contra a discriminação. Como semiplano ele é finito, possui dimensões definidas. Se o plano e o semiplano são paralelos, ou seja, nunca se encontram, não haverá linha de intersecção. Por serem paralelos, para cada ponto do plano poderá sair uma linha perpendicular que atingirá em situação igualmente perpendicular determinado ponto do semiplano das normas, havendo uma relação entre o fato e a norma.

Se as normas contidas no respectivo semiplano refletem os fatos da existência humana do plano infinito dos fatos, podemos supor que cada norma contida no semiplano encontra um respectivo fato, encontrado diante da ligação perpendicular estabelecida entre o fato e a norma. O mundo dos fatos é infinito e o mundo das normas é finito. Ou seja, nem sempre haverá, para cada fato existente no plano, uma norma correspondente no semiplano.

Essa falta de correspondência que o modelo geométrico proposto pode ilustrar revela um grave problema. Se adotada a taxatividade, para certas situações de discriminação não haveria correspondente proteção normativa da pessoa humana. Se a proteção da pessoa humana deve ser integral, posto que a existência de uma discriminação resulta em uma profunda corrosão do patrimônio jurídico desse ser humano, a proteção contra a discriminação deve ter como finalidade proteger todas e quaisquer situações discriminatórias existentes no plano dos fatos e não alcançadas pela norma jurídica protetora, suprindo esta falta de correspondência entre fato e norma. Se essa proteção não for integral, abrem-se as portas para um gravíssimo risco. O fato de não existir proteção jurídica integral contra a discriminação, coloca sob ameaça todo o sistema de proteção dos direitos humanos que é estruturado em uma rede de direitos interdependentes e indivisíveis. A quebra de uma parte do sistema de proteção dos direitos humanos compromete todo o sistema, como reconhecido na Declaração de Viena, em 1993, em seu artigo $5^{\circ}$, no sentido de que todos os direitos humanos são universais, indivisíveis, interdependentes e inter-relacionados ${ }^{296}$.

Portanto, não é possível compreender um sistema universal de proteção contra a discriminação que atue em caráter parcial, apenas voltado para determinados motivos discriminatórios e ineficaz para outros. Se a discriminação compromete decisivamente os

\footnotetext{
${ }^{296}$ DECLARAÇÃO E PROGRAMA DE AÇÃO DE VIENA. Conferência Mundial sobre Direitos Humanos. Organização das Nações Unidas. Ministério Público Federal. Procuradoria Federal dos Direitos do Cidadão. Legislação. Disponível em: <http://pfdc.pgr.mpf.gov.br/legislacao-pfdc/direitoshumanos/Declarac255eo\%20e\%20Plano\%20de\%20Ac255eo\%20-\%20Viena.pdf>. Acesso em: 07 out. 2009.
} 
direitos humanos, qualquer quebra não pode ser permitida. Por ser um instrumento de proteção de direitos em caráter universal, a proibição da discriminação deverá ser flexível em relação à sua motivação, para atingir esse objetivo, na opinião de Aaron Fellmeth ${ }^{297}$.

Mais ainda, os direitos humanos possuem uma força expansiva, integrada por normas finalistas com vocação para irradiar todo o ordenamento jurídico, procurando exatamente manter o poder de efetividade, na lição de Pérez Luño ${ }^{298}$. O referido autor aponta que, nos casos de dúvida, a interpretação deve ser a favor da proteção dos direitos fundamentais, concebendo que o processo hermenêutico tende a maximizar e otimizar a força expansiva e a eficácia dos direitos fundamentais em seu conjunto, possui um caráter positivo e dinâmico e contempla o sistema de direitos e liberdades fundamentais como um todo unitário ${ }^{299}$.

Não é por outro motivo que os principais tratados gerais de direitos humanos, em nível global ou regional, procuram estabelecer certos motivos de modo exemplificativo, destacando somente os principais. Os tratados costumam prever, além dos principais motivos, uma cláusula aberta para quaisquer outras formas de discriminação. Marc Bossuyt destaca que a Declaração Universal dos Direitos do Homem aparentemente deixava uma enumeração limitativa dos motivos para a discriminação. Já a Declaração Americana dos Direitos e Deveres do Homem teria adotado os quatro motivos constantes na Carta das Nações Unidas, bem como a expressão ou qualquer outro fator, sendo o primeiro texto internacional a adotá-la, ao deixar claro que a indicação ali realizada era puramente indicativa $^{300}$.

O Pacto Internacional de Direitos Civis e Políticos, em seu artigo 26, estabelece que:

Artigo 26 - Todas as pessoas são iguais perante a lei e têm direito, sem discriminação alguma, a igual proteção da lei. A este respeito, a lei deverá proibir qualquer forma de discriminação e garantir a todas as pessoas proteção igual e eficaz contra qualquer discriminação por motivo de raça, cor, sexo, língua, religião, opinião política ou de outra

\footnotetext{
${ }^{297}$ FELLMETH, Aaron. Human rights: nondiscrimination as a Universal Human Right. The Yale Journal of International Law, $\mathrm{n}^{\mathrm{o}}$ 34, Verão 2009, p. 588-595. Nexis Lexis. Disponível em: $<$ http://www.lexisnexis.com/us/lnacademic/results/docview/docview.do?docLinkInd=true\&risb=21_T7498 424111\&format=GNBFI\&sort=RELEVANCE\&startDocNo=1\&resultsUrlKey=29_T7498424114\&cisb=2 2_T7498424113\&treeMax $=$ true \& treeWidth=0\&csi=172860\&docNo=11>. Acesso em: 04 out. 2009.

${ }^{298}$ PÉREZ LUÑO. Antonio E. Derechos humanos, Estado de derecho y Constitución. 7. ed. Madrid: Tecnos, 2001. p. 315.

${ }^{299}$ Id. Ibid., p. 316.

${ }^{300}$ BOSSUYT, Marc. op. cit., p. 44.
} 
natureza, origem nacional ou social, situação econômica, nascimento ou qualquer outra situação. ${ }^{301}$

Já a Convenção Americana de Direitos Humanos, conhecida como Pacto de San José da Costa Rica, aponta o mesmo princípio, em seu artigo $1^{\circ}, \S 1^{\circ}$, no sentido de que:

\$1. Os Estados Membros nesta Convenção comprometem-se a respeitar os direitos e liberdades nela reconhecidos e a garantir seu livre e pleno exercício a toda pessoa que esteja sujeita à sua jurisdição, sem discriminação alguma, por motivo de raça, cor, sexo, idioma, religião, opiniões políticas ou de qualquer natureza, origem nacional ou social, posição econômica, nascimento ou qualquer outra condição social. ${ }^{302}$

Já a Convenção Europeia de Direitos Humanos de 1950 destaca, em seu artigo 14, que o gozo dos direitos e liberdades é assegurado sem quaisquer distinções por qualquer fundamento, enumerando os motivos ali apontados e deixando cláusula aberta ao final para qualquer outra situação $o^{303}$.

O texto da Carta Africana dos Direitos Humanos e dos Povos, também conhecida como Carta de Banjul, possui uma cláusula explicitamente aberta, cuja redação é a seguinte:

Artigo $2^{\circ}$ - Toda pessoa tem direito ao gozo dos direitos e liberdades reconhecidos e garantidos na presente Carta, sem nenhuma distinção, nomeadamente de raça, de etnia, de cor, de sexo, de língua, de religião, de opinião política ou de qualquer outra opinião, de origem nacional ou social, de fortuna, de nascimento ou de qualquer outra situação ${ }^{304}$.

Fica bem claro que, entre todas as principais normas internacionais de proteção dos direitos humanos, os motivos são relacionados de forma explicitamente indicativa, com

${ }^{301}$ ORGANIZAÇÃO DAS NAÇÕES UNIDAS. Pacto Internacional dos Direitos Civis e Políticos. Biblioteca de Direitos Humanos da USP. Disponível em: <http://www.direitoshumanos.usp.br/index.php/SistemaGlobal.-Declarações-e-Tratados-Internacionais-de-Proteção/pacto-internacional-dos-direitos-civis-e-

politicos.html>. Acesso em: 07 out. 2009.

${ }^{302}$ ORGANIZAÇÃO DOS ESTADOS AMERICANOS. Convenção Americana dos Direitos Humanos. Biblioteca de Direitos Humanos da USP. Disponível em: <http://www.direitoshumanos.usp.br/index.php/OEA-Organização-dos-Estados-Americanos/convencaoamericana-de-direitos-humanos-1969-pacto-de-san-jose-da-costa-rica.html>. Acesso em: 07 out. 2009.

${ }^{303}$ CONVENÇÃO EUROPEIA DOS DIREITOS HUMANOS. Corte Europeia dos Direitos Humanos. Disponível em: <http://www.echr.coe.int/nr/rdonlyres/d5cc24a7-dc13-4318-b4575c9014916d7a/0/englishanglais.pdf>. Acesso em: 07 out. 2009.

${ }^{304}$ CARTA AFRICANA DE DIREITOS HUMANOS E DOS POVOS. Organização da Unidade Africana. Biblioteca de Direitos Humanos da USP. Disponível em: $<$ http://www.direitoshumanos.usp.br/index.php/Documentos-n\%C3\%A3o-Inseridos-nasDelibera\%C3\%A7\%C3\%B5es-da-ONU/carta-africana-dos-direitos-humanose-dos-povos-carta-debanjul.html>. Acesso em: 07 out. 2009. 
expressa permissão para a adoção de outros motivos. Cristaliza-se, assim, a existência de um princípio internacional no sentido de que a relação de motivos é meramente indicativa e não taxativa. Somente é taxativa quando a norma expressamente menciona, principalmente para situações específicas e especiais, como o caso da Convenção para eliminação de todas as formas de discriminação racial. Os principais doutrinadores sobre a discriminação no direito internacional seguem essa linha, entre eles Marc Bossuyt ${ }^{305}$, Egbert Vierdag ${ }^{306}$ e Warwick McKean $^{307}$, e também alguns constitucionalistas como Rodriguez-Piñero e Fernández López ${ }^{308}$.

No caso das relações de trabalho, a situação não é diferente. A Convenção 111 da OIT é uma norma que possui uma relação de motivos cuja concepção é interessante. Warwick McKean destaca que certos motivos receberam a atenção da norma por serem geralmente reconhecidos a ponto de solicitarem uma proteção especial ${ }^{309}$. O jurista neozelandês afirma que, no entanto, alguns motivos como a língua, idade, cidadania e filiação sindical foram deixados de lado da relação, atitude que recebeu críticas de alguns dos participantes, traduzindo esse autor como uma atitude desapontadora por parte do texto final $^{310}$.

No entanto, o texto da Convenção 111, por ser normogenético, concebido para estimular a criação de novos diplomas legais nos Estados ratificadores, deixou aberta a possibilidade de serem incluídos outros motivos, após amplo diálogo social envolvendo os representantes de trabalhadores e empregadores, além de outros grupos. Efetivamente, a Convenção 111 enfrentou a enorme dificuldade de ser uma norma pioneira concebida em uma conferência instalada em um ambiente com interesses muito divergentes. Ela tratou de um assunto muito delicado e de mínima aceitação em uma época na qual, praticamente, quase não se falava em proteção da discriminação laboral. Por tal razão, a cláusula de abertura do texto deixou ao Estado-membro a possibilidade de adicionar outros motivos de seu interesse, desde que a referida inclusão fosse discutida com os interessados. Marzia Barbera comenta a referida norma, ressaltando que a abertura dada pelo item " $b$ " do primeiro artigo da referida Convenção caracteriza o rol de motivos como não taxativo ${ }^{311}$.

\footnotetext{
${ }^{305}$ BOSSUYT, Marc. op. cit., p. 60.

${ }^{306}$ VIERDAG, Egbert. op. cit., p. 128.

${ }^{307}$ MCKEAN, Warwick. op. cit., p. 145.

${ }^{308}$ RODRIGUEZ-PIÑERO, Miguel; FERNANDEZ LOPEZ, Maria Fernanda. op. cit., p. 177.

${ }^{309}$ MCKEAN, Warwick. op. cit., p. 124.

${ }^{310}$ Id. Ibid., p. 73.

${ }^{311}$ BARBERA, Marzia. op. cit., p. 94.
} 
Mas a discriminação laboral, na visão da OIT, não é regulada somente pela referida Convenção, sendo importante destacar alguns exemplos de outras normas protetoras contra a discriminação laboral. A Convenção 98 da OIT, celebrada em 1949, na 32a reunião da Conferência Internacional do Trabalho, é uma norma autenticamente antidiscriminatória, que visa coibir a discriminação motivada pela atuação sindical. Seu artigo $1^{\circ}$ destaca a proibição da discriminação contra atos fundados na filiação sindical ou participação na ação sindical ${ }^{312}$. A Convenção $n^{\circ} 19$ (1925) trata da igualdade de trato entre estrangeiros e nacionais para questões de acidentes de trabalho ${ }^{313}$. A Convenção $n^{\circ} 66^{314}$, de 1935 (já retirada de vigência), proibia a diferença de trato entre trabalhadores nacionais e trabalhadores migrantes. A Convenção $n^{\circ} 105^{315}$ (1957) estabelece uma proibição contra o trabalho escravo e um dos motivos da escravidão é aquele resultante de uma discriminação racial, social, nacional ou religiosa. No mesmo ano a entidade se preocupava com medidas discriminatórias contra as populações indígenas, prescrevendo tratamento idêntico para tais povos na Convenção n ${ }^{\circ} 107^{316}$. O artigo 14 da Convenção $n^{\circ} 117^{317}$ (1962) aponta para a proibição de discriminação por motivos de raça, cor, sexo, credo, associação a uma tribo ou filiação sindical ${ }^{318}$.

Os exemplos acima mencionados demonstram que a OIT, historicamente, procura coibir discriminações pelos mais diversos motivos, sendo um ponto muito destacado da instituição o combate contra qualquer forma de discriminação, procurando, muitas vezes, atingir determinado problema discriminatório com normas específicas, voltadas para determinada situação discriminatória. Esse posicionamento histórico institucional demonstra que qualquer motivo de discriminação laboral deve ser coibido, não obstante não esteja explicitamente demonstrado na Convenção principal ( $\left.n^{\circ} 111\right)$, mas em face dos vários outros motivos estabelecidos em suas normas.

Por fim, outro aspecto importante também trilha a favor do entendimento de que os motivos de uma norma discriminatória geral não são limitados, salvo quando assim a norma estabelecer. Muitas discriminações ocorrem por mais de um motivo, podendo tal

\footnotetext{
${ }^{312}$ ORGANIZAÇÃO INTERNACIONAL DO TRABALHO. Convenção no 98 . Escritório da OIT Brasil. Disponível em: <http://www.oitbrasil.org.br/download/convencao98.pdf>. Acesso em: 08 out. 2009.

${ }^{313}$ ORGANIZAÇÃO INTERNACIONAL DO TRABALHO. Ilolex Database of International Labour Standards. Disponível em: <http://www.ilo.org/ilolex/english/convdisp1.htm>. Acesso em: 08 out. 2009. ${ }^{314}$ Id. Ibid.

${ }^{315}$ Id. Ibid.

${ }^{316}$ Id. Ibid.

${ }^{317}$ Id. Ibid.

${ }^{318}$ Id. Ibid.
} 
situação ser chamada como discriminação por motivos múltiplos, mistos ou mesmo discriminação interseccional, como relata Roger Raupp Rios ${ }^{319}$. Trata-se de fenômenos discriminatórios que envolvem vários motivos e que serão adiante relatados com maior profundidade. Tais situações, em destaque a situação feminina, que sempre associa um determinado fator ao gênero, potencializando seus efeitos. Tais discriminações ocorrem porque a vida é carregada de situações e experiências multifacetadas em que uma pessoa não integra somente um grupo, sendo que cada fator potencializa ainda mais o efeito discriminatório.

Nessas situações, fica claro que considerar a discriminação ocorrida por um motivo que esteja devidamente positivado e desconsiderar outro, com a mesma ou maior gravidade na influência da conduta discriminatória, justamente porque não está previsto em norma antidiscriminatória, é um absoluto contrasenso. Com efeito, é impensável aceitar tal situação quando o interesse maior é evitar ou reparar o tratamento diferenciado.

Fazer depender o reconhecimento de uma prática discriminatória de um aspecto formal da norma positivada seria a negativa da importância de sua proibição e dos danos que essa prática causa na sociedade. E reconhecer uma discriminação somente com base na previsão normativa é um risco muito grande. Como bem aponta a canadense Dahpne Gilbert, ao defender os critérios formulados por grupos, as reivindicações complexas da discriminação são muito mais fáceis de descobrir quando se centra sobre certos grupos, no entanto essas sutilezas podem se perder na rigidez dos motivos enumerados nas normas antidiscriminatórias $^{320}$. Não se pode permitir, no combate à discriminação, que uma função que mais se assemelha a uma função procedimental tome importância superior comparativamente com a própria essência da discriminação, que é a negação da condição humana de uma pessoa, em cotejo com as demais.

Deste modo, somente resta entender que toda norma antidiscriminatória possui uma enumeração exemplificativa dos motivos discriminatórios, salvo quando expressamente se referir que o rol é taxativo, não permitindo outro motivo além dos designados.

\footnotetext{
${ }^{319}$ RIOS, Roger Raup. Direito da antidiscriminação: discriminação direta, indireta e ações afirmativas, cit., p. 59 .

${ }^{320}$ GILBERT, Daphne. op. cit., p. 634.
} 


\subsubsection{Identificação dos modelos de proteção antidiscriminatória em relação aos motivos discriminatórios}

De acordo com o exposto, as posturas das normas antidiscriminatórias podem ser distintas ao tratar da previsão de motivos. Algumas podem ser abertas, outras mais estritas, sendo importante uma classificação e distinção entre elas. Sandra Fredman concebeu uma classificação das formas de tratamento dos motivos nas normas antidiscriminatórias que, apesar de interessante, parece ser incompleta e, deste modo, não pode ser integralmente adotada. Tais diferenças clamam também diferentes posturas do intérprete na consideração da discriminação e, assim, merecem uma reflexão mais aprofundada.

A referida autora menciona três tipos de sistemas legais de proteção contra a discriminação: uma totalmente aberta, com uma previsão geral de observância da igualdade; uma segunda, de caráter restrito, com uma enumeração taxativa dos motivos que pretender proteger; uma terceira, intermediária, que possua um rol de motivos, mas que especifica que tal lista não é exaustiva ${ }^{321}$. A conceituação de Fredman não pode ser adotada integralmente. Verifica-se, claramente, a existência de dois grupos principais e dentro de um deles, uma subdivisão muito sutil, mas de extrema importância para o intérprete das normas.

São verificados, inicialmente, dois grupos bastante distintos.

O primeiro é composto pelas normas totalmente abertas, sem qualquer definição de motivos, estando ausente qualquer arrolamento. É o caso da Constituição norte-americana que, em sua $14^{\mathrm{a}}$ emenda, assegura a todos um direito geral de igualdade diante da obrigação de que o Estado não pode negar a ninguém dentro de sua jurisdição a igual proteção das leis. Tal estruturação assegura que o sistema jurídico garante a igualdade do cidadão, deixando totalmente para o intérprete, quando não há lei ou norma inferior que o regule, analisar e aplicar quais os motivos que entenda como relevantes para qualificar determinado comportamento como discriminatório. Quando não regulado, o legislador entrega totalmente o poder desta classificação ao intérprete. No caso dos Estados Unidos da América, a Lei de direitos civis regula a abertura da norma, enumerando alguns motivos, e algumas outras normas tratam especificamente de um ou outro motivo especial. Tal sistema permite entender que fica designado ao intérprete estabelecer os limites da proteção antidiscriminatória, quando não houver regulação específica.

\footnotetext{
${ }^{321}$ FREDMAN, Sandra. op. cit. p. 67-68.
} 
O segundo grupo seria composto das normas antidiscriminatórias que enumeram os motivos. Ou seja, tal grupo difere do primeiro, na medida em que um contém uma relação e o outro não possui qualquer relação, deixando em aberto para o intérprete ou legislação regulatória estabelecer quais os parâmetros de fundamento para a discriminação.

Dentro do segundo grupo, encontramos três sub-grupos bastante distintos, com diferenças sutis, porém relevantes ao ponto de serem diferenciados.

O primeiro sub-grupo é composto por aquelas previsões que possuem uma condição explícita no sentido de que quaisquer outros motivos podem ser adotados, possuindo uma cláusula expressa de abertura. É o caso do Pacto Internacional dos Direitos Civis e Políticos em seu artigo 26, a situação da Convenção Americana em seu artigo $1^{\circ}$, § $1^{\circ}$, a situação da Convenção Europeia de Direitos Humanos em seu artigo 14, bem como da Carta Africana de Direitos Humanos e dos Povos em seu artigo $2^{\circ}$. Como pode ser visto, abrange a grande maioria dos tratados gerais de direitos humanos, que preveem certos motivos, mas deixam uma cláusula aberta, designando as expressões $e$ toda e qualquer forma de discriminação, notadamente, motivos como, entre outros exemplos. É o caso também de algumas normas constitucionais antidiscriminatórias, sendo exatamente o caso brasileiro no artigo $3^{\circ}$, IV, bem como no artigo 14 da Constituição espanhola. Essas normas possuem uma visão aberta, ou seja, destacam os motivos que não permitem um tratamento diferenciado, abrangendo qualquer outro motivo, desde que observadas as condições de relevância e pertinência com o ato desafiado e a necessidade do agente. Essa forma de previsão ainda passa ao intérprete grande possibilidade de qualificar condutas como antidiscriminatórias, ainda que não sejam formalmente previstas.

O segundo sub-grupo é constituído por uma postura das normas antidiscriminatórias que possuem um rol de motivos, mas não mencionam qualquer cláusula de abertura do seu sistema de proteção. Este é o meio adotado pela Convenção 111 da OIT, que não possui uma cláusula aberta, assim como as normas antidiscriminatórias da Constituições portuguesa e alemã. Elas não possuem uma previsão taxativa, no entanto, como anteriormente demonstrado e com os fundamentos explicitados no tópico anterior, devem ser compreendidos como um rol exemplificativo, posto que somente as normas limitadas devem ser interpretadas restritivamente.

Para finalizar, o terceiro sub-grupo é composto de uma previsão explícita que somente permite considerar como discriminação os motivos expressamente previstos na normatização, afastando os demais. As normas do mencionado sub-grupo proíbem o 
intérprete de estender qualquer aplicação para motivos não previstos, deixando exclusivamente a cargo do legislador a escolha da proteção antidiscriminatória. É o caso do sistema antidiscriminatório do Reino Unido, o qual estabelece explicitamente que somente os motivos previstos nas normas internas podem ser tomados em conta. É o sistema adotado pelas convenções internacionais contra a discriminação racial e contra a discriminação feminina das Nações Unidas, cujo propósito é a defesa dos motivos explícitos. E é o caso também de algumas convenções da OIT, servindo como exemplo a Convenção ${ }^{\circ} 98$, que trata da discriminação por filiação e participação sindical.

Como é possível verificar, o sistema brasileiro deve ser enquadrado no primeiro sub-grupo do segundo grupo - o das normas com motivos enumerados e com cláusula aberta expressa. Isso decorre, especificadamente, pela previsão do artigo $3^{\circ}$, IV, da Constituição, que proíbe qualquer forma de discriminação, bem como pelos tratados gerais de direitos humanos de que o Brasil é parte, os quais possuem a mesma previsão aberta.

\subsection{Motivos naturais, opcionais ou mistos}

Os motivos discriminatórios possuem características que os distinguem. Determinados motivos, aparentemente, possuem características de influência perene sobre a pessoa ou sobre os grupos envolvidos em um ato discriminatório, principalmente os fatores de nascença, que não são opcionais. Já outros motivos possuem características transitórias, que podem ou não ter influência definitiva sobre a pessoa ou sobre o grupo envolvido e estão associados a uma opção da pessoa ou grupo.

O tema do presente sub-capítulo ganha extrema relevância na medida em que a jurisprudência da Suprema Corte norte-americana destaca que determinado motivo foi adquirido por nascença e, portanto, é de natureza definitiva ${ }^{322}$. Tal situação se torna extremamente importante na medida em que os referidos motivos, por serem inatos, orientam aquela Corte para que proceda a uma análise mais detalhada e profunda sobre o tratamento diferenciado questionado, aplicando, no caso do motivo raça, o rígido regime do strict scrutiny.

Por outro lado, as situações discriminatórias mais comuns nos dias atuais não são compostas por um único motivo, mas uma agregação de diversos motivos, os quais

\footnotetext{
${ }^{322}$ RIOS, Roger Raup. Direito da antidiscriminação: discriminação direta, indireta e ações afirmativas, cit., p.
} 55. 
influenciam decisivamente uma decisão empresarial relativamente a um empregado ou a um grupo. O fenômeno da interseccionalidade, tão bem exemplificado por Kimberlé Crenshaw, revela que nos casos das mulheres negras dos EUA os motivos associados potencializam uma situação de exclusão social e de subordinação desse grupo estabelecido dentro da intersecção. Esse grupo interseccional, diferentemente das mulheres brancas e dos homens negros, podem promover uma reconceituação do motivo raça, como uma aliança entre homens e mulheres de $\operatorname{cor}^{323}$. Por outro lado, a possibilidade de discriminação por motivos mistos é um aspecto importantíssimo no estudo das ações discriminatórias.

Hector Hugo Barbagelata divide os motivos em grupos específicos ${ }^{324}$. O jurista uruguaio especifica que o primeiro grupo seria caracterizado pela raça, assim englobando raça, cor da pele, ascendência nacional ou origem social, entendendo que tais definições são formuladas em diversos diplomas internacionais e, muitas vezes, uns se sobrepõem aos outros. O segundo grupo seria composto pelo sexo, afirmando ser uma motivação clássica, abordando uma preocupação sobre a discriminação por orientação sexual, mas não afirmando claramente que ela esteja perfeitamente encaixada dentro do referido grupo. $\mathrm{O}$ terceiro grupo de Barbagelata é composto por opiniões políticas ou orientações religiosas, aí servindo como um porto para diversos motivos relacionados a opções políticas ou religiosas $^{325}$.

Thilo Ramm faz uma classificação dos motivos segundo fatores naturais ou sociais, classificação muito interessante e de grande conteúdo prático. A primeira categoria seria composta pelo sexo, raça, origem étnica, cor da pele, que são qualidades trazidas pelo nascimento ou marcadas pelo sinal da imutabilidade, não sendo caracterizadas pelo elemento vontade, por parte de seu portador $^{326}$. O referido autor aponta que tais motivos revelam graves formas de discriminação, já que atentam contra uma situação que foge do controle da pessoa discriminada, havendo uma reação mais forte contra tais discriminações, eis que elas podem colocar todo o bem-estar da sociedade em risco ${ }^{327}$.

\footnotetext{
${ }^{323}$ CRENSHAW, Kimberlé. Mapping the Margins: Intersectionality, Identity Politics, and Violence Against Women of Color. Stanford Law Review. Julho 1991. No 43, p. 1299. Lexis Nexis. Disponível em: $<$ http://www.lexisnexis.com/us/lnacademic/results/docview/docview.do?docLinkInd=true\&risb=21_T7543 680835\&format=GNBFI\&sort=BOOLEAN\&startDocNo=51\&resultsUrlKey=29_T7543680839\&cisb=22_ T7543680838\&treeMax=true \&treeWidth=0\&csi=7353\&docNo=53>. Acesso em: 18 out. 2009.

${ }^{324}$ BARBAGELATA, Hector-Hugo. Los Convenios 100, 111 e 156 ratificados por la Ley $\mathrm{n}^{\circ} 16.063$ e a eliminação da discriminação na matéria de emprego e ocupação. Cuadernos. Facultad de Derecho y Ciencias Sociales, Montevideo, n. 15, p. 152, 1990.

${ }^{325}$ Id. Ibid., p. 153-154.

${ }^{326}$ RAMM, Thilo. Discrimination: international development and remarks of legal theory, cit., p. 506-507.

${ }^{327}$ Id., loc. cit.
} 
Já para o segundo grupo, o jurista alemão aponta os fatores sociais como categorias marcadas pelo caráter da mutabilidade e pela possibilidade de escolha ${ }^{328}$. Com efeito, por opção da pessoa, pode ser adotada a religião, estado civil, opinião política, adesão a determinada entidade sindical, entre tantos outros que são fatores que podem levar a um ato discriminatório. A discriminação sobre tais fatores atua como um fator de pressão contra tais opções ${ }^{329}$. Segundo o autor, a questão deixa de ser tão somente de violação da igualdade de tratamento, mas passa a ser uma questão contra a liberdade pessoal de determinadas condutas, sendo um risco para a moldura do pluralismo social, com repercussões políticas ${ }^{330}$.

A definição de Thilo Ramm é extremamente interessante, mas pode trazer problemas em futuro não muito distante, mormente porque formulada em 1978. Aspectos como o sexo e cor da pele, como exemplos, são características que podem ser desafiadas pelas evoluções tecnológicas da medicina como permanentes, em face das cirurgias e tratamentos transexuais, bem como técnicas desenvolvidas para alteração da cor da pele. No entanto, o melhor aspecto da classificação de Thilo Ramm é o fator de distinção entre os dois grupos, que é a possibilidade de opção de possuir, ou não, determinado motivo. As discriminações fundadas nesses dois motivos possuem resultados distintos, principalmente tratando-se de relações do trabalho. O segundo grupo traz consigo a noção de um atentado com uma repercussão igualmente importante, o cerceamento da liberdade pessoal.

O próprio Thilo Ramm reconhece algumas vulnerabilidades de sua classificação, ao admitir que esta distinção é algumas vezes difícil de ser executada e nem sempre pode ser interpretada literalmente. Ele menciona, como exemplo, o problema do fator idade como sendo uma situação complexa, continuamente alterada, mas que não pode ser modificada por decisão pessoal. O referido jurista aponta que essa diferenciação não pode ser tão rígida e estanque, na medida em que uma série de fatores sociais, econômicos, científicos, entre outros, podem alterar significativamente a posição de inalterável para opcional. Tais distinções dependem de uma série de fatores como a estrutura social, a sua flexibilidade e, principalmente, se existe competição que seja efetivamente a base real para mudanças ${ }^{331}$.

Em que pesem as dificuldades apontadas, a classificação de Thilo Ramm é o melhor modelo encontrado. Em primeiro lugar, ela é elaborada sobre os efeitos da

\footnotetext{
${ }^{328}$ RAMM, Thilo. Discrimination: international development and remarks of legal theory, cit., p. 506-507.

${ }^{329}$ Id. Ibid., p. 507.

${ }^{330}$ Id., loc. cit.

${ }^{331}$ Id., loc. cit.
} 
discriminação sobre o discriminado, possuindo um critério sem uma definição muito precisa, mas que pode se amoldar perfeitamente a uma sociedade em profunda transformação.

Um aspecto que vem causando cada vez maior celeuma nas discussões sobre discriminação laboral é a situação discriminatória que envolve mais de um motivo. Uma decisão empresarial nem sempre é tomada exclusivamente por um determinado motivo, mas baseada em diversos fatores, opiniões e levando em conta vários dados para obter a melhor rentabilidade possível. Um ato discriminatório pode ter origem em uma decisão com múltiplos fundamentos, sendo que um deles poderá apresentar efeitos discriminatórios.

Tal situação pode ocorrer desde uma sobreposição de fatores discriminatórios e seus efeitos potencializados, como bem apontou Kimberlé Crenshaw, quando menciona as difíceis situações de interseccionalidade. Julissa Reynoso assinala que o conceito de interseccionalidade foi definido como a opressão que surge da combinação de várias formas de discriminação que, conjuntamente, produzem uma incomparável forma de discriminação em relação às diferenciações por um único motivo ${ }^{332}$.

A preocupação sobre essa possibilidade discriminatória assume especial relevância internacional. A Declaração de Durban, extraída da terceira convenção sobre o racismo da ONU em 2001, toca nesse ponto, ainda que o texto aprovado mencione o problema de forma tímida. Lindgren Alves ressalta que aquela declaração, por problemas de ordem política, conseguiu cunhar a expressão "formas correlatas de intolerância" como uma expressão acomodatícia para se referir às discriminações múltiplas ou agravadas ${ }^{333}$.

Essa situação, em particular, pede uma análise mais detalhada, eis que um dos motivos pode ser ilegítimo, ainda que outro possa ser permitido, mas o impacto dos motivos agregados irá provocar um efeito danoso diferenciado e mais agravado, em comparação a um motivo isolado.

A Suprema Corte do Canadá já enfrentou tal questão: ao apontar as questões sobre motivos múltiplos ou interseccionais, teceu um comentário que merece destaque. A

\footnotetext{
${ }^{332}$ REYNOSO, Julissa. Perspectives on intersections of race, ethnicity, gender, and other grounds: Latinas at the Margins. Harvard Latino Law Review. $N^{\circ}$ 7, p. 64-73. Lexis Nexis. Disponível em: $<$ http://www.lexisnexis.com/us/Inacademic/results/docview/docview.do?docLinkInd=true\&risb=21_T7543 $680835 \&$ format $=$ GNBFI\&sort=BOOLEAN\&startDocNo=1\&resultsUrlKey=29_T7543680839\&cisb=22_T 7543680838\&treeMax=true\&treeWidth=0\&csi=221805\&docNo=22>. Acesso em: 08 out. 2009.

${ }^{333}$ ALVES, J. A. Lindgren. A conferência de Durban contra o racismo e a responsabilidade de outros. Revista Brasileira de Política Internacional, Rio de Janeiro, ano 45, n. 2, p. 207, 2002.
} 
referida Corte afirmou que determinadas categorias de motivos podem se sobrepor, causando histórica exclusão com base tanto em motivo de raça como de gênero, idade e deficiência ou qualquer outra combinação ${ }^{334}$. A referida decisão ainda assinalou, em um voto dissidente que, ainda que existam dois motivos proibidos de discriminação combinados, o intérprete pode acabar ignorando a complexidade da sobreposição e caracterizar a discriminação por um motivo ou outro, apesar de a proteção ser voltada para ambos os motivos. O referido voto destaca que podem existir múltiplos níveis de discriminação, mas não poderão ser acompanhados do mesmo número de proteções. Segundo a decisão, existem situações nas quais uma pessoa sofra discriminação por mais de um motivo, mas somente um é proibido, exigindo cautela para caracterizar a discriminação ou desprover a pessoa humana de qualquer proteção.

A mesma Corte, no já citado caso Law v. Canada $^{335}$, ressaltou que não há razão, a princípio, para que uma causa discriminatória apresentada com base na intersecção de motivos não possa ser compreendida como uma situação análoga aos motivos envolvidos na carta de direitos e liberdades do Canadá, ou mesmo sua síntese. Efetivamente, para serem enfrentadas tais situações, o intérprete deverá demonstrar certa parcela de arrojo para se desprender da formalidade dos motivos singularmente apreciados e procurar a aplicação dos contextos combinados, extremamente mais complexos em comparação com os motivos apreciados isoladamente. O que não poderá haver, certamente, é a separação de cada situação - essa é a pior tática possível para enfrentar a questão posta em análise.

As questões de multiplicidade de motivos de discriminação são situações extremamente complexas, tanto no aspecto material como procedimental. É possível existir agregação de motivos discriminatórios ilegítimos ou a mais complexa situação que pode ser encontrada - a agregação de motivos proibidos e motivos legítimos na mesma situação discriminatória. Nesse último caso, a existência de fatores de natureza diversa gera uma grande controvérsia, principalmente quando levados para questões judiciais, como a decisão do caso canadense Canada v. Mossop bem apontou. Certamente, cada interessado irá procurar destacar o fator que lhe interessa para sua defesa em Juízo e, nessa situação, o

\footnotetext{
${ }^{334}$ SUPREMA CORTE DO CANADÁ. Université du Montréal. Judgments of the Supreme Court of Canada. Canada (Attorney General) v. Mossop, [1993] I S.C.R. 554. Disponível em: $<$ http://csc.lexum.umontreal.ca/en/1993/1993rcs1-554/1993rcs1-554.html>. Acesso em: 09 out. 2009.

${ }^{335}$ SUPREMA CORTE DO CANADÁ. Law v. Canada (Minister of Employment and Immigration) [1999] 1 S.C.R. 497, 170 D.L.R. (4th) 1 [Law]. Université de Montréal. Judgments of the Supreme Court of Canada. Disponível em: <http://csc.lexum.umontreal.ca/en/1999/1999rcs1-497/1999rcs1-497.html>. Acesso em: 09 out. 2009.
} 
debate se intensifica muito, cabendo ao julgador ter um extremo cuidado para não prejudicar direitos ou se exceder na proibição da conduta.

A Suprema Corte dos Estados Unidos da América enfrentou uma questão judicial envolvendo motivos discriminatórios e não discriminatórios no rumoroso caso Price Waterhouse v. Hopkins ${ }^{336}$. O processo envolveu uma situação de motivos mistos para a recusa da promoção, como sócia da empresa, da funcionária Ann Hopkins, que moveu uma ação contra a referida empresa. A decisão proferida pela Corte, por meio do voto condutor da Juíza Sandra O'Connor, estabeleceu que nessas situações somente é aceitável uma ação desta natureza se o autor demonstrar a existência de prova direta do motivo discriminatório. Não é preciso dizer que tal decisão limitou drasticamente a oportunidade do aforamento de ações, uma vez que designou o pesado ônus da prova ao empregado.

O Congresso norte-americano reagiu à postura conservadora da Suprema Corte daquele país diante da referida decisão, promulgando uma alteração na lei dos direitos civis, que prescreveu no artigo $703(\mathrm{~m})^{337}$ que uma prática ilegal é estabelecida quando a parte demonstrar que os motivos ali listados desencadearam a prática empresarial questionada, ainda que outros fatores também a tenham motivado. A norma aprovada em 1991 revogou em parte o precedente exarado no voto da referida Juíza. Somente em 2003 a Suprema Corte procurou reformar o entendimento exposto no caso Hopkins, por meio da decisão do caso Desert Palace Inc. v. Costa ${ }^{338}$, no qual revogou o entendimento do precedente anterior, criando novas regras para o ônus da prova em tais situações. Neste último precedente, a decisão do júri foi no sentido de que o motivo gênero tenha sido preponderantemente apresentado como elemento de prova no caso, ainda que outros fatores legítimos tenham influenciado as condições desfavoráveis de trabalho a que aquela autora tenha sido submetida.

Assim, é possível constatar o complexo universo das questões judiciais que envolvam mais de um motivo para a discriminação. Elas solicitam do julgador uma atenção muito mais intensa sobre cada aspecto envolvido, bem como a avaliação conjunta

\footnotetext{
${ }^{336}$ SUPREMA CORTE DOS ESTADOS UNIDOS DA AMÉRICA. Cornell University Law School. Supreme Court Collection. Price Waterhouse v. Hopkins. 490 U.S. 228, 1989. Disponível em: <http://www.law.cornell.edu/supct/html/historics/USSC_CR_0490_0228_ZC.html>. Acesso em: 09 out. 2009.

${ }^{337}$ ESTADOS UNIDOS DA AMÉRICA. Civil Rights Act. Equal Employment Opportunity Comission. Disponível em: <http://www.eeoc.gov/policy/vii.html>. Acesso em: 09 out. 2009.

${ }^{338}$ SUPREMA CORTE DOS ESTADOS UNIDOS DA AMÉRICA. Cornell University Law School. Supreme Court Collection. Desert Palace Inc. v. Costa. 539 U.S. 90 (2003). Disponível em: http://www.law.cornell.edu/supct/html/02-679.ZS.html>. Acesso em: 09 out. 2009.
} 
da situação da alegada vítima e do ambiente social que ela integre. Somente assim poderá o julgador caracterizar, com maior precisão, se houve ou não atitude discriminatória. Nesse caso, prevalecerá o contexto discriminatório se houver demonstração razoável de que tal motivo tenha sido um fator importante na decisão, ainda que não seja o único.

\subsection{Uma justificativa para o trato diferenciado}

A proibição da discriminação é um princípio considerado como norma de direitos fundamentais da mais alta importância dentro do direito do trabalho. Suas violações comprometem não somente a obrigação de trato igual de todos os seres humanos, mas falta com o necessário respeito à igual dignidade de cada um, colocando em risco a fruição de outros direitos de caráter fundamental.

Não obstante o destaque da proibição discriminatória seja colocado ao nível mais elevado de importância dentro dos princípios do direito do trabalho, tal proibição não constitui uma regra absoluta e inflexível. Ainda que seja verificada uma situação diferenciadora, promovendo tratamento desigual juridicamente por motivo não aceito nem todas as situações diferenciadoras podem ser proscritas - não pode ser considerada uma proibição absoluta.

Existe uma possibilidade de que um tratamento diferenciado prejudicial possa ser admitido pelo direito do trabalho, fundado em certas necessidades do trabalho ou da própria atividade executada pelo empregador, as quais autorizam o comportamento diferenciador. Trata-se de uma exceção ao princípio da proteção contra a discriminação e sempre deve ser vislumbrada como tal, não obstante seja um princípio do direito antidiscriminatório. Nem todo direito fundamental é absoluto; em certas situações sua desconsideração ou quebra podem ser necessárias, em atendimento a outra proteção jurídica igualmente importante.

Certamente, esse é um dos mais polêmicos e cruciais temas sobre a discriminação laboral. Ele reconhece a existência de uma fresta na qual a porta da proteção contra a discriminação laboral seja vulnerada. Nesse momento, a investigação atinge seu ponto mais delicado; portanto, deve se debruçar atentamente sobre essa questão. Ela está intrinsicamente ligada ao motivo e, por tal modo, deve ser apreciada como um item dos motivos da discriminação. 


\subsubsection{A teoria do business necessity e suas limitações}

O direito a não ser discriminado é um direito fundamental da mais alta relevância dentro da ordem jurídica, como pode ser constatado no capítulo 3. No entanto, como outros direitos fundamentais, não é absoluto. Carlos Roberto Siqueira Castro afirma que praticamente inexiste direito individual ou coletivo absoluto, ou de fundamentação absoluta, isto é, revestido de ilimitação plena ${ }^{339}$. O referido autor ainda aponta que a grande maioria das liberdades individuais consubstancia liberdades sociais, que devem ser exercidas em sociedade, devendo receber limitações para que toda a sociedade as usufrua. José Carlos Vieira de Andrade assinala que não é novidade afirmar que os direitos fundamentais não são absolutos, nem mesmo ilimitados ${ }^{340}$. Robert Alexy qualifica essa limitação como evidente ${ }^{341}$.

A doutrina sobre os direitos fundamentais expressa uma grande preocupação sobre a sua aplicabilidade e suas restrições ou choques com outros direitos fundamentais. A proibição da discriminação, como norma de direito fundamental e como direito humano, deve ser aplicada de modo mais efetivo e concreto possível, para a realização de seus objetivos. Ela procura manter o tratamento igual entre as pessoas, a proteção contra atitudes que venham a desconsiderar a dignidade da pessoa humana ou ameaçar a realização de outros direitos humanos da pessoa do trabalhador ou prestador de serviços. $\mathrm{O}$ direito a não ser discriminado não pode correr o risco de ser esvaziado ou depender de requisitos formais para ser efetivamente exercido. Deve, ao contrário, receber a proteção de uma norma de direito fundamental para se tornar a mais efetiva proteção possível.

No entanto, a norma antidiscriminatória está entre o rol de normas constitucionais que possui uma função social, na medida em que, atuando conjuntamente com outras normas de caráter fundamental, complementa-as e condiciona-as em uma ordem de respeito mútuo de direitos. A ordem constitucional procura construir uma unidade jurídica em torno de um propósito constitucional de consolidar uma ordem unificada, segundo Peter Häberle ${ }^{342}$. A existência de um direito ilimitado, segundo o referido autor, poderia colocar em discussão esse processo de unificação. E a constituição espera, segundo

\footnotetext{
${ }^{339}$ CASTRO, Carlos Roberto Siqueira. op. cit., p. 62.

${ }^{340}$ ANDRADE, José Carlos Vieira de. Os direitos fundamentais na Constituição portuguesa de 1976. 2. ed. Coimbra: Almedina, 2001. p. 275.

${ }^{341}$ ALEXY, Robert. op. cit., p. 267.

${ }^{342}$ HÄBERLE, Peter. La libertad fundamental en el Estado constitucional. Trad. Carlos Ramos, Jürgen Saligmann e César Landa. San Miguel: Fondo Editorial de La Pontificia Universidad Catolica del Peru, 1997. p. 103.
} 
Häberle, que sejam otimizados os seus direitos fundamentais, sem que se corra o risco de serem pervertidos por uma exceção ${ }^{343}$.

A complexa discussão sobre os limites imanentes dos direitos fundamentais é extremamente importante para o tema. Os limites estabelecidos pela norma constituem restrições constitucionais ao programa normativo do preceito em questão, segundo José Carlos Vieira de Andrade $^{344}$. O referido autor admite a possibilidade de estes limites estarem implícitos no ordenamento constitucional. Canotilho assevera que o reconhecimento dos limites imanentes é muito problemático, mas sua admissibilidade é justificada, no contexto sistemático da constituição, em nome da salvaguarda de outros direitos ou bens ${ }^{345}$. O constitucionalista português se refere a eles ao ponderar que são justificados em virtude da existência de limites originários ou primitivos, os quais se impõem a todos os direitos, estando o poder restritivo de tais limites sujeito a averiguações de outros princípios, entre eles o da proporcionalidade ${ }^{346}$.

Robert Alexy enuncia que as restrições aos direitos fundamentais podem ser de ordem externa, na qual não há nenhuma relação necessária entre o conceito do direito e da restrição ${ }^{347}$, assim como pode ser ordem interna, na qual não existem duas coisas, mas uma só, o direito com um determinado conteúdo, substituindo-se a restrição do direito por um limite $^{348}$. Peter Häberle afirma que os conflitos entre os direitos fundamentais são resolvidos no interior do direito mesmo (von innen her), sendo os limites implícitos à sua essência $^{349}$.

A norma de direito fundamental da proteção contra a discriminação, não obstante ser uma norma da mais alta proteção dentro do direito como um todo, e do direito do trabalho, em particular, pode vir a colidir com outros direitos, principalmente os direitos da empresa ou contratante de serviços, bem como de terceiros. Efetivamente, a proteção contra a discriminação atua dialeticamente com o direito de o empregador contratar e exercer a atividade empresarial com liberdade. No entanto, em certas situações, a proteção do valor da igualdade e dignidade humana pode impor sacrifícios ou riscos de tal ordem ao empregador, como também a terceiros, que o elevado nível de proteção constitucional da

\footnotetext{
${ }^{343}$ HÄBERLE, Peter. op. cit., p. 105.

${ }^{344}$ ANDRADE, José Carlos Vieira de. op. cit., p. 282-284.

${ }^{345}$ CANOTILHO, Joaquim José Gomes. Direito constitucional e teoria da Constituição, cit., p. 1261.

${ }^{346}$ Id. Ibid., p. 1264.

${ }^{347}$ ALEXY, Robert. op. cit., p. 268.

${ }^{348}$ Id. Ibid., p. 269.

${ }^{349}$ Id. Ibid., p. 120.
} 
norma antidiscriminatória terá que se curvar, para que não seja inviabilizada a atividade empreendida.

A proteção contra a discriminação laboral não pode vir a trazer impactos ao empregador ou ao contratante de serviços, a ponto de tornar inviável sua atividade produtiva, nem provocar riscos de danos de ordem significativa a terceiros, colocando em risco seus direitos da maior importância como, por exemplo, a vida ou sua integridade física. O respeito incondicional do direito de igualdade não pode causar danos ao patrimônio jurídico de outros. Como bem assevera Häberle, os direitos fundamentais possuem uma função social, tomando-se por base a realidade social, caracterizando-se por uma ponte entre o ser e o dever, a ponto de justificar uma intervenção, sem que se tenha em mente uma relativização ${ }^{350}$, que deva ser solucionada por uma ponderação entre os interesses na busca de um equilíbrio, como um princípio imanente à Constituição ${ }^{351}$.

No artigo 29 da Declaração Universal dos Direitos do Homem há uma limitação aos próprios direitos ali estabelecidos, na medida em que tais direitos devam respeitar direitos alheios e as necessidades da moral, da ordem pública e do bem-estar de uma sociedade democrática, nem contrariar os objetivos e princípios das Nações Unidas ${ }^{352}$.

Artigo 29 - 1. Todo ser humano tem deveres para com a comunidade, na qual o livre e pleno desenvolvimento de sua personalidade é possível. 2. No exercício de seus direitos e liberdades, todo ser humano estará sujeito apenas às limitações determinadas pela lei, exclusivamente com o fim de assegurar o devido reconhecimento e respeito dos direitos e liberdades de outrem e de satisfazer as justas exigências da moral, da ordem pública $e$ do bem-estar de uma sociedade democrática. 3. Esses direitos e liberdades não podem, em hipótese alguma, ser exercidos contrariamente aos objetivos e princípios das Nações Unidas.

Fica claro que o próprio sistema de direitos humanos reconhece limites às aplicações dos direitos estabelecidos na Declaração. Jorge Miranda ainda afirma que a expressão justas exigências é um apelo a um conceito de justiça ou a uma ponderação ética avaliadora dos preceitos de Direito positivo que envolva limites dos direitos. Segundo o constitucionalista lusitano, transparece a ideia de proporcionalidade em algumas vertentes, o reconhecimento de uma moral social de modo a observar o correto funcionamento das

\footnotetext{
${ }^{350}$ ALEXY, Robert. op. cit., p. 108.

${ }^{351}$ Id. Ibid., p. 121.

${ }^{352}$ DECLARAÇÃO UNIVERSAL DOS DIREITOS DO HOMEM. Biblioteca Virtual de Direitos Humanos da USP. Disponível em: <http://www.direitoshumanos.usp.br/index.php/Sistema-Global.-Declarações-eTratados-Internacionais-de-Proteção/declaracao-universal-dos-direitos-humanos.html>. Acesso em: 12 dez. 2009.
} 
instituições, atingir a todos os componentes de um bem-estar social e não somente alguns, e de estarem restritos os limites aos de uma sociedade democrática ${ }^{353}$.

Podemos conceber alguns fundamentos para uma limitação à proteção contra a discriminação dentro do direito em geral, em especial dentro do direito internacional. Tais limitações são formuladas pelos conceitos de justificação para a restrição das normas antidiscriminatórias pela proporcionalidade. Também as limitações são projetadas pela moral social e pelo correto funcionamento das instituições, com o intuito de promover o bem-estar geral e observar os fundamentos de uma sociedade democrática. É possível, assim, extrair os limites imanentes da norma antidiscriminatória geral, baseada nos aspectos acima citados, que podem balizar toda a restrição de aplicação de uma norma antidiscriminatória.

A questão ganha mais intensidade ainda dentro do direito do trabalho. Uma das mais importantes concepções sobre a proibição da discriminação dentro do direito do trabalho é a da Convenção 111 da OIT, que traz na sua estipulação de direito à proteção contra a discriminação laboral um limite expresso ao estabelecer em seu item 2, do primeiro artigo, o seguinte:

2. Qualquer distinção, exclusão ou preferência, com base em qualificações exigidas para um determinado emprego, não são consideradas como discriminação.

Trata-se de uma norma restritiva à norma de proteção contra a discriminação. A referida delimitação à proteção discriminatória integra a própria conceituação de discriminação laboral, ao estabelecer um princípio no sentido de que os tratamentos diferenciados necessários para uma determinada atividade não podem ser considerados discriminatórios. Por estar inserido expressamente na conceituação de discriminação da referida norma internacional, ele está consolidado como integrante da descrição de discriminação. Não custa lembrar que a Convenção $n^{\circ} 111$ constitui uma das normas fundamentais da OIT, conforme a Declaração de 1998, uma norma de conteúdo nuclear da proteção contra a discriminação no trabalho.

A exclusão apresentada na referida norma foi introduzida no texto mediante uma emenda apresentada pela representação do governo britânico perante o comitê encarregado de elaborar a proposta de texto para a Conferência Internacional do Trabalho. A emenda

\footnotetext{
${ }^{353}$ MIRANDA, Jorge. op. cit., t. 4, p. 302-304.
} 
tomou como base discussões sobre discriminação no trabalho naquele país e as necessidades do empregador para as exigências de determinado emprego, como bem destaca Henrik Karl Nielsen ${ }^{354}$. Foi uma emenda com apresentação de uma cláusula de exceção à regra geral, demonstrando que sua interpretação sempre deverá ser feita em caráter restritivo. Warwick McKean, ao analisar os relatórios da referida comissão, aponta que em 1957, na $40^{a}$ sessão, o comitê já havia se preocupado com a falta de clareza da definição de discriminação sobre a aplicabilidade para os casos de diferenciação objetiva baseada nas genuínas necessidades de diferentes tipos de emprego ${ }^{355}$. Esclarece o referido autor neozelandês que a minuta da Convenção introduziu que distinções a respeito do acesso a determinado emprego baseadas em requisitos inerentes não deveriam ser consideradas como discriminações.

A referida exclusão foi aprovada no texto final da Convenção $\mathrm{n}^{\circ} 111$ e influenciou diversas normas antidiscriminatórias laborais. A possibilidade se tornou um princípio dentro do direito antidiscriminatório laboral, no sentido de que as reais e efetivas exigências de um determinado emprego não podem constituir um motivo para a discriminação, como destaca Rodríguez-Piñero e López Fernández, classificando o tema como clássico $^{356}$. O sentido que a exceção traz para a regra geral pressupõe, então, a noção de um requisito essencial de justificação por parte de quem a utiliza, com significativas consequências para inúmeras questões que envolvem a discussão da conduta discriminatória, principalmente sobre a prova judicial de sua existência.

A exceção, perfeitamente justificável pela doutrina dos direitos fundamentais, incorre em uma substantiva e explícita limitação da proteção contra a discriminação. Ela abre uma significativa possibilidade para que o empregador ou contratante de serviços venha a adotar uma postura diferenciadora, bastando que a justifique adequadamente dentro de suas necessidades. Não é preciso destacar que, nas principais discussões sobre práticas discriminatórias nas relações do trabalho, uma vez existente determinada conduta diferenciadora, o empregador ou contratante de serviços, para se esquivar de uma responsabilização sobre uma conduta discriminatória, irá se apoiar sobre tal complexo argumento.

\footnotetext{
${ }^{354}$ NIELSEN, Henrik Karl. op. cit., p. 845.

${ }^{355}$ MCKEAN, Warwick. op. cit., p. 125.

${ }^{356}$ RODRIGUEZ-PIÑERO, Miguel; FERNANDEZ LOPEZ, Maria Fernanda. op. cit., p. 97.
} 
A exceção pressupõe a ideia de que uma determinada necessidade do trabalho justifique a adoção de uma postura diferenciadora, desde que haja uma relação direta entre a necessidade de um determinado emprego (não para todos os empregados, mas sim para aquela específica atividade, conforme expressamente aponta o texto convencionado) e o motivo pelo qual foi tomada a postura diferenciadora. Haverá, portanto, a exposição de uma determinada razão pela qual a conduta diferenciadora possa ser explicada.

Abre-se uma porta para uma discussão extremamente delicada e complexa. Danièle Lochak ressalta que, apuradas as situações de diferenciação e o critério adotado para a distinção, entra em cena um novo elemento para análise - a justificação ou a ausência de justificação da distinção operada e a sua adequação ou a sua não adequação ao objetivo perseguido pelo ato diferenciador ${ }^{357}$. A autora francesa traz, como outros autores, a noção de que a discriminação é uma diferenciação de tratamento arbitrário, cuja definição reconhece ser complexa ${ }^{358}$.

Marek Nowicki expõe que a diferença de tratamento somente não será discriminatória, para os efeitos da Convenção Europeia de Direitos Humanos, se ela possuir um objetivo legítimo e uma justificativa razoável, assim considerada se ela possua um legítimo propósito e se há razoável relação de proporcionalidade entre os meios empregados e os objetivos a serem realizados ${ }^{359}$. Henrik Karl Nielsen destaca que o artigo 26 do Pacto Internacional de Direitos Civis e Políticos, que trata da discriminação, como anteriormente apontado, tem como objetivo primordial a proibição das discriminações que não possam ser explicadas mediante critérios objetivos e razoáveis, sendo que o elemento nuclear do referido artigo 26 é o arbítrio ${ }^{360}$.

Canotilho explica que existe uma violação arbitrária da igualdade jurídica quando a disciplina jurídica: 1) não se basear em um fundamento sério; 2) não tiver um sentido legítimo; 3) estabelecer uma diferenciação jurídica sem um fundamento razoável $^{361}$. E o célebre constitucionalista aponta que a necessidade de valoração ou de critérios de qualificação, bem como a necessidade de encontrar "elementos de comparação"

\footnotetext{
${ }^{357}$ LOCHAK, Daniele. op. cit., p. 780.

${ }^{358}$ Id., loc. cit.

${ }^{359}$ NOWICKI, Marek Antoni The European Convention of Human Rights: prohibition of discrimination. Saint Louis-Warsaw Transatlantic Law Journal, 1999, p. 28. Lexis Nexis. Disponível em: <http://www.lexisnexis.com/us/lnacademic/results/docview/docview.do?docLinkInd=true\&risb=21_T7498 643639\&format=GNBFI\&sort=RELEVANCE\&startDocNo=26\&resultsUrlKey=29_T7498643642\&cisb= 22_T7498643641\&treeMax=true\&treeWidth=0\&csi=156973\&docNo=34>. Acesso em: 04 dez. 2009.

${ }^{360}$ NIELSEN, Henrik Karl. op. cit., p. 831.

${ }^{361}$ CANOTILHO, Joaquim José Gomes. Direito constitucional e teoria da Constituição, cit., p. 428.
} 
subjacentes ao caráter relacional do princípio da igualdade implicam: 1) a insuficiência do "arbítrio" como fundamento adequado de "valoração" e de "comparação"; 2) a imprescindibilidade da análise da "natureza", do "peso", dos "fundamentos" ou "motivos" justificadores de soluções diferenciadas; 3 ) insuficiência da consideração do princípio de igualdade como um direito de natureza apenas "defensiva" ou "negativa"362.

Marzia Barbera destaca que o direito à igualdade deriva da regra da não arbitrariedade da diferença de tratamento, desta vez enquanto medida da racionalidade da exceção à regra geral de parificação ${ }^{363}$. Rodríguez-Piñero e López Fernández também caracterizam a discriminação como uma desigualdade não razoável ${ }^{364}$. E para confirmar a carga de importância que a doutrina europeia deposita sobre a noção do arbítrio, Hueck e Nipperdey ressaltam que o empregador pode agir de acordo com pontos de vista gerais e seguir as regulamentações que ele mesmo adotou, no entanto, não deve excetuar arbitrariamente um trabalhador de tais regras, posto que seria arbitrário o trato desigual em casos semelhantes por causas não objetivas ${ }^{365}$.

Roberto Pessi ressalta que será proibido o tratamento diferenciado que não tenha uma razoável justificação, sendo que o controle deverá voltar-se para as razões do ato supostamente discriminatório e não para o resultado propriamente dito, ainda que o juízo de razoabilidade participe e seja necessariamente envolvido no efeito do ato ${ }^{366}$. Selene Mize aponta que a legislação neozelandesa que trata da discriminação laboral, a Human Rights Act, de 1993 e emendada em 2001, adota a expressão boas razões (good reasons) para que um empregador venha a estabelecer um tratamento diferenciado baseado em um requisito para um trabalho específico ${ }^{367}$. A autora aponta uma decisão da Suprema Corte daquele país destacando que os critérios para uma boa razão devem ser bem restritos, que

\footnotetext{
${ }^{362}$ CANOTILHO, Joaquim José Gomes. Direito constitucional e teoria da Constituição, cit., p. 429.

${ }^{363}$ BARBERA, Marzia. op. cit., p. 97.

${ }^{364}$ Id. Ibid., p. 66.

${ }^{365}$ HUECK, Alfred; NIPPERDEY, H.C. Compendio de derecho del trabajo. Trad. M. Rodríguez Piñero e Luís Enrique de la Villa. Madrid: Editorial Revista de Derecho Privado, 1963. p. 164.

${ }^{366}$ PESSI, Roberto. Lavoro e discriminazione femminile. In: LAVORO e discriminatione: Atti dell'XI Congresso Nazionale de Direito Del Lavoro Gubbio, 3-5 Giugno 1994. Milano: Giuffrè, 1996. p. 44.

${ }^{367}$ MIZE, Selene. Indirect discrimination reconsidered. New Zealand Law Review. № 1, 2007, p. 47. Lexis Nexis. 070051\&format=GNBFI\&sort=RELEVANCE\&startDocNo=26\&resultsUrlKey=29_T7456070057\&cisb= 22_T7456070056\&treeMax $=$ true $\&$ treeWidth $=0 \& c s i=241402 \&$ docNo=44 2909.2009>. Acesso em: 29 set. 2009 .
} 
somente podem ser qualificados como necessidades empresariais, mas nunca conveniências empresariais ${ }^{368}$.

O cerne de toda e qualquer discussão de tratamento igual em geral, bem como a discussão específica da discriminação nas relações do trabalho, em particular, são travados sobre o eixo da noção de arbítrio. Ele pode ser considerado como a ausência de justificação razoável para implementação da medida diferenciadora. Adota-se o conceito, portanto, como um limite da proibição da discriminação nas relações do trabalho, no sentido de que as medidas diferenciadoras que possam ser justificadas mediante os critérios de proporcionalidade não podem ser proibidas.

No entanto, tais limites devem ser analisados mediante rigoroso exame, para que não seja esvaziada a proteção, cuja importância já foi destacada. Este será o principal elemento e o núcleo de uma defesa contra uma acusação de prática discriminatória, como aponta Karthy Govender ${ }^{369}$, ao se referir ao termo unfairness, que pode ser razoavelmente interpretado como sinônimo de arbítrio. Assim, constata-se que várias normas antidiscriminatórias estabelecem explicitamente suas exceções. A exceção do business necessity é uma das mais comuns, prevista na Convenção 111 da OIT e em outros diplomas legais, certamente o mais utilizado argumento de defesa nas alegações de prática discriminatória.

Robert Belton e Dianne Avery afirmam que as cortes norte-americanas trataram o business necessity como propriamente uma defesa, recebendo o empregador o ônus da prova e o ônus da persuasão. Entre as decisões dos casos Griggs (1971) e Wards Cove (1989), os referidos autores destacam que foi um dos mais importantes temas tratados pela Suprema Corte dos EUA, promovendo a articulação de diversos padrões decisórios em casos envolvendo discriminação laboral ${ }^{370}$. No entanto, Mack Player, reconhecido autor estadunidense sobre a discriminação laboral, diverge da referida opinião ao assinalar que o business necessity não é propriamente uma defesa; é mais um elemento de legalidade do

\footnotetext{
${ }^{368}$ PESSI, Roberto. op. cit., p. 48.

${ }^{369}$ GOVENDER, Karthy. The developing equality jurisprudence in South Africa. Michigan Law Review First Impressions. Janeiro 2009, $\mathrm{n}^{\mathrm{o}}$ 107, p. 122. Lexis Nexis. Disponível em: $<$ http://www.lexisnexis.com/us/lnacademic/results/docview/docview.do?docLinkInd=true\&risb=21_T7510 801140\&format=GNBFI\&sort=RELEVANCE\&startDocNo=226\&resultsUrlKey=29_T7510801147\&cisb =22_T7510801146\&treeMax=true \& treeWidth=0\&csi=7346\&docNo=233 >. Acesso em: 05 dez. 2009.

${ }^{370}$ BELTON, Robert; AVERY, Dianne. op. cit., p. 201.
} 
que exatamente uma justificação completa para discussão da ilegalidade de uma classificação $^{371}$.

Na decisão proferida no caso Griggs v. Duke Power $C o{ }^{372}$, uma das decisões mais importantes sobre discriminação nas relações do trabalho em todos os tempos, a Suprema Corte dos EUA definiu que o business necessity é a pedra de toque nas discussões em que a postura e as condições do empregador devem ser levadas em conta. Tal menção leva a entender que o business necessity era, até então, um elemento chave nas decisões sobre discriminação laboral. A referida decisão indica que a prática diferenciadora deve estar relacionada com o desempenho da atividade laboral, caso contrário será considerada discriminatória. A partir da decisão acima, Robert Belton e Dianne Avery apontam que as cortes de um modo geral adotaram uma interpretação mais restritiva sobre tal condição, afirmando que a prática colocada em discussão deveria ser demonstrada como essencial à atividade empresarial ${ }^{373}$.

Tal postura prevaleceu até a decisão do caso Wards Cove Packing Co. v. Atonio ${ }^{374}$. Nela, a decisão proferida, em uma apertada maioria de cinco em nove juízes, entendeu que a Corte havia interpretado equivocadamente no caso Griggs e nos julgamentos posteriores sobre a alocação do ônus da prova em casos de discriminação por efeito adverso. Robert Belton afirma que a alteração de posicionamento feita pela Suprema Corte no caso Wards Cove ocorreu em face da formação de uma maioria conservadora na composição daquele tribunal, que visava redefinir a doutrina exposta no caso Griggs, manipulando as questões de ônus da prova, maioria essa que guardava objeções às ações afirmativas ${ }^{375}$. Alan Freeman destaca que a campanha presidencial de Ronald Reagan foi explicitamente contrária às políticas de Ações Afirmativas e, como estratégia de ação contra tais ações por parte daquele governo conservador, foram nomeados juízes manifestamente contrários a

\footnotetext{
${ }^{371}$ PLAYER, Mack. Employment discrimination law. St. Paul:The West Group, 1988. p. 279.

${ }^{372}$ SUPREMA CORTE DOS ESTADOS UNIDOS DA AMERICA. Griggs v. Duke Power Co. 401 US 424, 91 S. Ct. 849, 28 L. Ed.2d 158. Cornell University Law School. Supreme Court Collection. Disponível em: <http://www.law.cornell.edu/supct/html/historics/USSC_CR_0401_0424_ZS.html>. Acesso em: 13 out. 2009.

${ }^{373}$ Id., loc. cit.

${ }^{374}$ SUPREMA CORTE DOS ESTADOS UNIDOS DA AMÉRICA. Wards Cove Packing Co. v. Atonio. 490 US 642, 109 S. Ct. 2115, 104 L. Ed.2d 733. Cornell University Law School - Legal Information Institute. Disponível em: <http://www.law.cornell.edu/supct/html/historics/USSC_CR_0490_0642_ZO.html>. Acesso em: 13 out. 2009.

${ }^{375}$ BELTON, Robert. Causation and burden-shifiting doctrines in employment discrimination law revisited: some thoughts on Hopkins and Wards Cove. Tulane Law Review, v. 64, n. 6, p. 1364, June 1990.
} 
elas $^{376}$. A decisão do caso Wards Cove, claramente, era uma forma de reverter jurisprudência favorável à caracterização da discriminação laboral.

A controvertida decisão levou o Congresso daquele país, de maioria democrata naquela época, a reagir contra a postura conservadora e alterar o Civil Rights Act após uma autêntica guerra legislativa. A alteração legislativa aprovada promoveu a inclusão de uma nova subseção ao artigo 703 do título sétimo da referida norma federal, para expressamente declarar que somente é reconhecida uma prática ilegal de emprego baseada em efeito adverso se o autor demonstrar que o réu utiliza a prática para causar um efeito adverso com base nos motivos ali expostos, e que o réu não consiga demonstrar que a prática em discussão é relacionada com o trabalho no cargo em questão e consistente com a necessidade do emprego ${ }^{377}$. Com o novo diploma, caberá ao empregador o ônus de provar o business necessity ou qualquer outro fator excludente da discriminação por impacto adverso. Foi resgatada, ainda que parcialmente, a postura do caso Griggs, porém por via legislativa. O texto legal adotado aponta que o autor deverá demonstrar o impacto adverso da medida diferenciadora tomada, cabendo ao réu demonstrar que a prática questionada é relacionada com o cargo em questão e consistente com a necessidade do negócio ${ }^{378}$.

O tema é extremamente complexo e levou a Equal Employment Opportunity Comission - EEOC, agência federal do governo norte-americano, incumbida pelo Civil Rights Act de implementar a igualdade de condições de trabalho naquele país, a estabelecer uma série de diretrizes relacionadas às necessidades do empregador em diversos tópicos relacionados à discriminação no trabalho. A adoção de sistemas de testes científicos para admissão de empregados passou a ser regulada (foi a questão central do caso Griggs), mediante um extenso rol de procedimentos para validação de tais procedimentos, além de outras diretrizes estipuladas para tais alegações.

Em 1972, a Corte do $10^{\circ}$ Circuito Federal, no caso Spurlock v. United Airlines Inc. ${ }^{379}$, uma questão sobre discriminação racial, estabeleceu parâmetros para contratação de empregados, de acordo com as necessidades da atividade de trabalho. Nele, a referida

\footnotetext{
${ }^{376}$ FREEMAN, Alan. Antidiscrimination law: the view from 1989. Tulane Law Review, v. 64, n. 6, p. 1408 , June 1990. Foram nomeados por Ronald Reagan os Juízes O'Connor, Scalia, Rehnquist e Kennedy.

${ }^{377}$ FRIEDMAN, Joel W.; STRICKLER Jr., George M. The law of employment discrimination. 5. ed. New York: Foundation Press, 2001. p. 232.

${ }^{378}$ ESTADOS UNIDOS DA AMÉRICA. The Civil Rights Act. Equal Employment Opportunity Comission. SEC. 2000e-2. [Section 703]. Disponível em: <http://www.eeoc.gov/policy/vii.html>. Acesso em: 13 out. 2009.

${ }^{379}$ OPEN JURIST. 475 F2d 216 Spurlock v. United Airlines Inc 475 F.2d 2165 Fair Empl.Prac.Cas. 17, 5 Empl. Prac. Dec. P 7996. Disponível em: <http://openjurist.org/475/f2d/216>. Acesso em: 13 out. 2009.
} 
corte apontou que quando um determinado emprego requer uma pequena quantidade de habilidade e treinamento $e$ as consequências da contratação de um trabalhador desqualificado são insignificantes, as cortes devem examinar atentamente qualquer padrão prévio ao emprego ou critério o qual venha a discriminar minorias. No caso em questão, o empregador tem um pesado ônus de demonstrar para a corte que seus critérios para admissão são relacionados ao trabalho. Por outro lado, quando o emprego claramente requer um alto grau de habilidade e altos riscos econômicos e humanos estão envolvidos na contratação de um candidato desqualificado, a obrigação processual do empregador é proporcionalmente menor para demonstrar que tais critérios são relacionados ao trabalho, citando as diretrizes da EEOC. A referida decisão ainda menciona que o trabalho de um piloto de uma empresa aérea é um trabalho de alto risco financeiro e de vidas humanas, sendo evidente o alto interesse dos clientes da empresa aérea para que a empresa tenha os pilotos com melhor habilitação e treinamento. Assim, a mencionada decisão estipula, claramente, que as cortes devem agir com o máximo cuidado antes de exigirem que uma determinada empresa baixe seus padrões de admissão para uma determinada função qualificada.

A discussão do business necessity enfrenta algumas questões extremamente importantes. Ela trata, essencialmente, de alguns aspectos que merecem ser destacados, como foi descrito na decisão do caso Zamlen v. City of Cleveland ${ }^{380}$. Nesse processo, a Corte federal proferiu uma decisão baseada em alguns elementos interessantes para analisar os termos da defesa. Tratava-se de um processo que continha uma alegação de discriminação por motivo de gênero, no qual um grupo de bombeiros do sexo feminino questionava alguns testes que estariam, segundo a pretensão veiculada, discriminando as mulheres no posto de bombeiros. A defesa alegou que as decisões foram tomadas em testes que avaliaram que as necessidades da função estabeleciam restrições para as autoras atuarem como bombeiros.

A referida decisão tomou uma estratégia para a avaliação do caso, consistente em alguns pontos. O primeiro foi no sentido de definir os diferentes ônus da prova. No caso, cabia às autoras demonstrarem que os testes tiveram impacto adverso sobre seu grupo e, ao empregador, que os testes são relacionados com as exigências do trabalho. $\mathrm{O}$ segundo

\footnotetext{
${ }^{380}$ ALTLAW. Barbara ZAMLEN; Charleen Cuffari; Sharon Pirosko; Leana Adkins; Jennifer Garuccio; Concetta K. Zingale; and Diane Horne, Plaintiffs-Appellants, v. The CITY OF CLEVELAND, DefendantAppellee, George V. Voinovich, Defendant. 53 Fair Empl.Prac.Cas. 70; 906 F.2d 209; 59 USLW 2026; 30 Fed. R. Evid. Serv. 555. Disponível em: <http://www.altlaw.org/v1/cases/499660>. Acesso em: 13 out. 2009.
} 
tópico a ser enfrentado é a adequação dos procedimentos de validação das medidas que levaram à postura diferenciadora e sobre a falha em demonstrar capacidade aeróbica para o exercício da função. Nessa parte, a decisão enfrentou se havia adequação do teste exigido dentro das diretrizes da EEOC, bem como se tais critérios eram válidos como elementos diferenciadores. Por fim, o teste proferido pela decisão avaliou se havia uma alternativa menos restritiva que a limitação imposta e discutida em Juízo. A decisão entendeu que as autoras não lograram êxito em demonstrar que havia uma alternativa menos restritiva. $\mathrm{Na}$ somatória de todos os elementos acima apontados, a referida decisão entendeu que o teste formulado pela autoridade mantém relacionamento paralelo com as tarefas exigidas de um bombeiro para desempenhar sua função. A autoridade municipal demonstrou uma correlação direta entre os melhores resultados do teste e um melhor desempenho da função, demonstrando a justificação da municipalidade e a falta de fundamento da irresignação das autoras.

Como ficou claramente demonstrado, a discussão promovida pela decisão em questão tomou como base a existência da necessidade das exigências formuladas para a função, bem como se elas tinham relação direta com o desempenho do trabalho e se não havia uma alternativa menos danosa para a exclusão das autoras da função de bombeiro. Ou seja, a decisão tomou como fundamento uma avaliação de proporcionalidade da medida adotada pela municipalidade.

São situações extremamente complexas que, dependendo do motivo questionado da alegada discriminação, irão demandar uma solução distinta, posto que pode envolver o valor, em si, do motivo em questão. Casos como os de funções religiosas que demandem a professar determinada crença para seu exercício, por um lado, e funções que efetivamente exijam determinada condição pessoal ou habilidade afastando a deficiência humana para aquela função, por outro, demandarão para sua análise as necessidades do cargo e as condições da pessoa que se diz discriminada.

É possível concluir que o business necessity é uma importantíssima ferramenta de avaliação de uma conduta alegada como discriminatória, na qual é realizada uma análise de ponderação entre os meios adotados para o tratamento diferenciado e as finalidades perseguidas pela atividade laboral. A submissão a essa análise permitirá classificar se uma conduta é, ou não, discriminatória, segundo os elementos verificados e trazidos ao Juízo. Para tais situações, fica extremamente claro que a existência de um motivo para a conduta diferenciadora, ainda que em tese, é ponto essencial para a análise acima exigida. 
O que se pode concluir é que a discussão comporta uma profunda análise da função, como ela é desempenhada e os requisitos essenciais e inafastáveis para seu exercício. Igualmente, a situação posta em questão irá indagar se a exclusão por motivo da necessidade da função não teria uma solução alternativa menos danosa. São requisitos que não podem ser tecidos de modo genérico - para cada situação caberá uma avaliação rigorosa e profunda das necessidades envolvidas e das possibilidades de cada pessoa envolvida.

\subsubsection{A Bona Fide Occupational Qualification - BFOQ}

Uma das formas de defesa mais importantes em face de alegações de discriminação no trabalho no direito norte-americano é a Bona Fide Occupational Qualification, que é amplamente reconhecida por doutrinadores e pela jurisprudência pela sua sigla $B F O Q$. Trata-se de uma exceção expressa à previsão de discriminação positivada no artigo 703, “e” (1), do Civil Rights Act, a qual menciona que não será ilegal uma prática de contratar diretamente empregados, ou por meio de agências de empregos, com base nos motivos proibidos, em certas situações onde a religião, sexo ou origem nacional é uma qualificação vocacional de boa fé, necessária para a operação normal de determinado negócio ou empreendimento ${ }^{381}$.

Trata-se explicitamente de uma modalidade pela qual o empregador efetivamente promova uma justificativa de determinada prática diferenciadora intencional, relacionada a um motivo proibido. O empregador, uma vez questionado, poderá afirmar que efetuou tal prática, geralmente por motivo de sexo, estribado em uma qualificação ocupacional razoavelmente necessária para a operação normal de um determinado negócio ou empreendimento. Katie Manley explica que o memorando interpretativo que se refere à BFOQ, a destaca como "limitada exceção" à proibição de discriminação e explica que aos

\footnotetext{
${ }^{381}$ ESTADOS UNIDOS DA AMÉRICA. Civil Rights Act. Equal Employment Opportunity Comission. SEC. 2000e-2. [Section 703]. Disponível em: <http://www.eeoc.gov/policy/vii.html>. Acesso em: 13 out. 2009. Notwithstanding any other provision of this subchapter, (1) it shall not be an unlawful employment practice for an employer to hire and employ employees, for an employment agency to classify, or refer for employment any individual, for a labor organization to classify its membership or to classify or refer for employment any individual, or for an employer, labor organization, or joint labormanagement committee controlling apprenticeship or other training or retraining programs to admit or employ any individual in any such program, on the basis of his religion, sex, or national origin in those certain instances where religion, sex, or national origin is a bona fide occupational qualification reasonably necessary to the normal operation of that particular business or enterprise,.
} 
empregadores é concedido um limitado direito para discriminarem, mas mediante uma razão que seria a qualificação ocupacional de boa fé s $^{382}$.

Tal forma de defesa possui um regramento por parte da EEOC, por meio de uma série de diretrizes codificadas como 29 C.F.R. $\$$ 1604.2(b) que trazem uma série de detalhadas orientações sobre como pode ser adotada uma BFOQ por motivos de sexo. Tais diretrizes são extremamente importantes e orientam o empregador como agir corretamente para considerar tal exceção destinada a justificar uma prática diferenciadora. $\mathrm{O}$ ônus da prova, segundo o precedente e as regras procedimentais estabelecidas no caso McDonnell Douglas v. Green ${ }^{383}$, é do empregador para articular e demonstrar motivos que justifiquem a prática diferenciadora.

A BFOQ difere da alegação de business necessity em alguns aspectos, como bem demonstra Stephen Befort ${ }^{384}$. O referido autor afirma que a BFOQ difere do business necessity por possuírem diferentes finalidades. A BFOQ está posicionada como uma defesa afirmativa em casos de discriminação explícita, ao passo que o business necessity tem maior relação com os casos de discriminação não intencional, sendo um meio de auxílio da Corte em saber se determinada prática é ou não discriminatória. Befort menciona que o ônus da prova possui regime diverso, ao estabelecer ao empregador uma justificativa muito mais precisa que o business necessity, de modo que a BFOQ possui uma margem muito estreita para as justificativas, em comparação com a forma de defesa do business necessity, mormente quando trata toda uma classe.

Befort relata também que o business necessity, por seu turno, é satisfeito somente se demonstrada sua relação com o trabalho. A BFOQ demandará uma justificativa muito mais densa para demonstrar que a prática diferenciadora seja indispensável e essencial para as atividades empresariais do empregador. O business necessity, segundo o referido autor, abrange questões além da estreita amplitude de apreciação como o desempenho no

\footnotetext{
${ }^{382}$ MANLEY, Katie. The BFOQ Defense: Title VII's Concession to Gender Discrimination. Duke Journal of Gender Law \& Policy. Janeiro 2009, $\mathrm{n}^{\mathrm{o}}$ 16, p. 169-210. Lexis Nexis. Disponível em: $<$ http://www.lexisnexis.com/us/lnacademic/search/journalssubmitForm.do>. Acesso em: 29 set. 2009.

${ }^{383}$ SUPREMA CORTE DOS ESTADOS UNIDOS DA AMÉRICA. FindLaw. McDonnell Douglas Corp. $v$. Green, $411 \quad$ U.S. 792 (1973). Disponível em: $<$ http://caselaw.lp.findlaw.com/scripts/getcase.pl?court=US\&vol=411\&invol=792>. Acesso em: 13 out. 2009.

${ }^{384}$ BEFORT, Stephen F. BFOQ Revisited: Johnson Controls Halts the Expansion of the Defense to Intentional Sex Discrimination. Ohio State Law Journal, n. 52, 1991, p. 10-11. 1991. Lexis Nexis. Disponível em: <http://www.lexisnexis.com/us/lnacademic/search/journalssubmitForm.do>. Acesso em: 04 out. 2009.
} 
trabalho, segurança no local de trabalho e preocupações sociais com proteção ambiental e, em certo grau, sobre os custos com determinada prática.

Alguns casos tratados com a referida modalidade de defesa são extremamente importantes. Merece destaque a decisão do caso Wilson v. Southwest Airlines Co $^{385}$, cuja decisão qualificou como discriminatória uma política de marketing de uma empresa aérea regional que utilizava o sexo feminino em grande evidência. A estratégia de marketing procurava denominar a empresa como a empresa aérea do amor e com uma campanha publicitária destinada a atrair o público de jovens executivos, auferindo grande preferência no concorrido mercado do transporte aéreo no sul dos Estados Unidos. A empresa afirmou que a política de ampla utilização feminina era essencial para sua imagem, o que foi rejeitada pela Corte federal, que entendeu que a essência da empresa era o transporte aéreo e não sua imagem, não acolhendo a alegação de BFOQ.

Outro caso que promoveu um intenso debate em função dessa modalidade de defesa foi o caso International Union, United Automobile, Aerospace and Agricultural Implement Workers of America, UAW v. Johnson Controls, Inc. ${ }^{386}$, um rumoroso e complexo processo sobre discriminação. Trata-se de um processo movido pelo sindicato profissional contra a referida empresa fabricante de produtos para automóveis, no caso em questão, baterias. A ação questionava uma política empresarial que proibia a presença de mulheres que estivessem grávidas ou tivessem a capacidade de engravidar de trabalhar em uma linha de produção de baterias, posto que poderiam ter contato excessivo com o chumbo. Segundo dados da empresa, o contato com o chumbo utilizado nas baterias poderia afetar significativamente os fetos. A política da empresa foi judicialmente questionada pelo sindicato, com base no título VII, na medida em que discriminava de modo geral as mulheres, impondo restrições ao seu direito de engravidar em troca da manutenção no emprego. A Suprema Corte entendeu que a política da empresa era de fato discriminatória, rejeitando a aplicação da BFOQ, na medida em que sua capacidade de engravidar não poderia ser um fator para que fosse discriminada, uma vez que sua gravidez não afetaria a

\footnotetext{
${ }^{385}$ CORTE DISTRITAL DOS ESTADOS UNIDOS, DISTRITO NORTE DO ESTADO DO TEXAS. 1981, 517 F. Supp. 292.

386 SUPREMA CORTE DOS ESTADOS UNIDOS DA AMÉRICA. 1991. International Union, United Automobile, Aerospace and Agricultural Implement Workers of America, UAW v. Johnson Controls, Inc. 499 US 187, 111 S. Ct. 1196, 113 L. Ed. 2d. 158. Cornell University Law School. Supreme Court Collection. Disponível <http://www.law.cornell.edu/supct/html/historics/USSC_CR_0499_0187_ZS.html>. Acesso em: 13 out. 2001.
} 
capacidade de exercer suas obrigações de trabalho, conforme estabelece a lei de proteção à gravidez no trabalho (Pregnant Discrimination Act).

Friedman e Stickler ${ }^{387}$ enumeram três contextos em que a exceção da BFOQ foi utilizada com sucesso em questionamentos judiciais: a) em casos de autenticidade do negócio, citando o exemplo de uma garçonete de origem chinesa para laborar em um restaurante chinês autêntico; b) nos em que a privacidade dos clientes de determinada atividade exijam pessoas de determinado sexo, como enfermeiras em determinados tipos de hospitais, cuja essência do negócio seja determinado tipo de atendimento ou a busca de determinada terapia; c) em casos de segurança, onde a presença feminina pode, de certo modo, comprometer toda a segurança de uma atividade, citando o caso Dothard $v$. Rawlinson $^{388}$, em que foi mantida a exigência de contratação exclusiva de homens para a segurança de um presídio no Alabama, que poderia ser comprometida com a atuação feminina como guarda em um presídio masculino, prejudicando sua eficiência na defesa do complexo penitenciário e dos demais companheiros.

Como pode ser visto, trata-se de um meio de defesa extremamente complexo e restrito, no qual é estabelecida uma afirmação de uma prática discriminatória, mas impondo, a quem a alega, o difícil ônus de provar que tal discriminação era absolutamente necessária e essencial para a obtenção das finalidades da atividade exercida pelo empregador. Trata-se de uma forma de defesa mais específica e mais difícil de ser comprovada que o business necessity, por adotar o reconhecimento explícito de uma prática diferenciadora.

\subsubsection{Razoabilidade e proporcionalidade do trato diferenciado}

Já caminhando para a conclusão do complexo tema sobre a justificação de determinada prática diferenciadora, foi possível extrair da jurisprudência norte-americana, como também na Europa, que uma prática diferenciadora pode ser considerada lícita se demonstrada uma justificativa razoável e pertinente às necessidades do agente discriminador.

Portanto, é possível estabelecer, como um dos princípios do direito da proibição da discriminação, que uma determinada conduta pode deixar de ser considerada

\footnotetext{
${ }^{387}$ FRIEDMAN, Joel W.; STRICKLER Jr., George M. op. cit., p. 171.

${ }^{388}$ SUPREMA CORTE DOS ESTADOS UNIDOS DA AMÉRICA. Dothard v. Rawlinson, 433 US 321, 97

S. Ct. 2720, 53 L.Ed.2d 786 (1977).
} 
discriminatória se for demonstrada pelo acusado de praticar uma discriminação, de modo claro e inequívoco, uma justificativa razoável e proporcional para a diferenciação formulada. Assim, o exame da caracterização de determinada conduta como discriminatória passa pelos controles de razoabilidade ou proporcionalidade, como muitas outras supostas violações de direitos fundamentais são submetidas.

O princípio da razoabilidade é um princípio do direito do trabalho, como assim definiu Américo Plá Rodriguez, em sua clássica obra sobre os princípios do direito do trabalho $^{389}$. O referido jurista uruguaio aponta que as relações trabalhistas devem ser regidas pela razão, impondo uma ação dentro do razoável, e não arbitrariamente, destacando que razão é a antítese do arbítrio.

Peter Häberle mencionou que os limites essenciais admissíveis postos aos direitos fundamentais devem ser determinados mediante a composição de um equilíbrio que tem como ponto de referência o sistema objetivo dos valores da Constituição ${ }^{390}$. Manuel Carlos Palomeque López aponta também o necessário equilíbrio (equilíbrio e limitações recíprocas para ambas as partes no contrato de trabalho) entre o exercício do poder de direção do empresário e o âmbito das liberdades constitucionais do trabalhador ${ }^{391}$. Em prosseguimento, o referido autor espanhol aponta a existência de uma "modulação" de direitos fundamentais que deverá ser produzida em medida estritamente imprescindível, indicando, tal qual Häberle, o caminho da proporcionalidade para a solução da controvérsia.

Luis Gabriel Martínez Rocamora destaca que a permissibilidade da desigualdade passa, segundo a jurisprudência do Tribunal Constitucional Espanhol, pela justificativa objetiva e razoável ${ }^{392}$. Segundo o referido autor, aquela Corte, em diversos julgados, demanda a apreciação de uma relação da finalidade e dos efeitos da medida, mantendo-se uma relação razoável de proporcionalidade entre os meios empregados e a finalidade perseguida $^{393}$.

Afirma o referido autor espanhol que é razoável a explicação que seja constitucionalmente admissível, sem colidir com o sistema de valores consagrado no texto fundamental ou mesmo vulnerá-lo, desde que seja suficiente e real para atingir o fim

\footnotetext{
${ }^{389}$ PLÁ RODRIGUEZ, Américo. Princípios de direito do trabalho. Trad. de Wagner D. Giglio. 3. tir. São Paulo: LTr; Ed. da Universidade de São Paulo, 1994. p. 251.

${ }^{390}$ HÄBERLE, Peter. op. cit. p. 109.

${ }^{391}$ PALOMEQUE LÓPEZ, Manuel Carlos. op. cit., p. 96.

${ }^{392}$ MARTÍNEZ ROCAMORA, Luis Gabriel. op. cit., p. 160.

${ }^{393}$ Id., loc. cit.
} 
perseguido $^{394}$. E o juízo de proporcionalidade deverá ser estabelecido de modo que a medida de diferenciação medida proporcionada a um meio adequado aos fins perseguidos $^{395}$. Ricardo de Paula Alves aponta claramente que o controle de proporcionalidade é de suma importância, assim como o controle que deve ser exercido pelo Juiz dos dados oferecidos pela realidade ${ }^{396}$.

A australiana Amelia Simpson ${ }^{397}$ destaca uma decisão da Alta Corte da Austrália ${ }^{398}$, órgão judiciário máximo de interpretação constitucional daquele país, que revela a existência de um conceito universal de discriminação emanado de uma variedade de contextos constitucionais e legislativos. A referida decisão aponta que a análise envolve uma comparação na qual um tratamento diferenciado requer o exame da relevância, conveniência e permissibilidade da distinção verificada, podendo existir questões de graus de aceitação, dependendo de cada situação.

Assim, temos a clara noção de que os critérios de razoabilidade e proporcionalidade são absolutamente fundamentais para o exame de uma conduta diferenciadora. Eles permitem, assim, diante da necessária análise, concluir se há uma conduta discriminatória.

Há uma questão preliminar importante, que é a utilização simultânea das expressões razoabilidade e proporcionalidade, para o mesmo princípio. Juan Cianciardo estuda o que intitula como o princípio da razoabilidade, ao destacar a utilização indistinta em sua obra dos conceitos de razoabilidade e proporcionalidade ${ }^{399}$. O referido autor assevera que as diferenças entre os vocábulos é pouco importante, ao explicar que razoabilidade tem origem no direito anglo-saxão e a proporcionalidade, no direito europeu continental. Luis Roberto Barroso ${ }^{400}$ também adota a expressão razoabilidade para o mesmo princípio, e destaca a origem do princípio no direito anglo-saxão. Robert Alexy adota a expressão máxima de proporcionalidade, como deduzida do princípio da proporcionalidade ${ }^{401}$. Da

\footnotetext{
${ }^{394}$ MARTÍNEZ ROCAMORA, Luis Gabriel. op. cit., p. 161.

${ }^{395}$ Id. Ibid., p. 161.

${ }^{396}$ ALVES, Ricardo de Paula. op. cit., p. 123.

${ }^{397}$ SIMPSON, Amelia. The high court's conception of discrimination: origins, applications, and implications. The Sidney Law Review, n. 29, p. 272, Jun. 2007. Lexis Nexis. Disponível em: $<$ http://www.lexisnexis.com/us/lnacademic/results/docview/docview.do?docLinkInd=true\&risb=21_T7590 411324\&format=GNBFI\&sort=BOOLEAN\&startDocNo=1\&resultsUrlKey=29_T7590411329\&cisb=22_T 7590411328\&treeMax=true\&treeWidth=0\&csi=224646\&docNo=4>. Acesso em: 31 ago. 2009.

${ }^{398}$ ALTA CORTE DA AUSTRALIA. Bayside City Council (2004) 216 CLR 595 at 629-30. Disponível em: $<$ http://www.austlii.edu.au/au/cases/cth/HCA/2004/19.html>. Acesso em: 14 set. 2009.

${ }^{399}$ CIANCIARDO, Juan. El principio de razonabilidad. Buenos Aires: Editorial Ábaco de Rodolfo Depalma, 2004. p. 23, nota $\mathrm{n}^{\circ} 7$.

${ }^{400}$ BARROSO, Luis Roberto. op. cit., p. 28.

${ }^{401}$ ALEXY, Robert. op. cit., p. 112.
} 
mesma forma Paulo Bonavides prefere a expressão proporcionalidade, tomando como base a expressão alemã verhältnismässigkeit, assim como Häberle, pois fundamenta sua explicação na vasta doutrina germânica empregada nas suas célebres considerações ${ }^{402}$. A adoção da expressão proporcionalidade parece mais adequada à sua utilização dentro do direito brasileiro, ainda que controversa.

Bonavides explica que o princípio da proporcionalidade possui três elementos, conteúdos parciais ou sub-princípios que governam a sua composição. No primeiro aponta que é a pertinência ou aptidão (Geeignetheit) que, citando a expressão de Zimmerli, seria "o meio certo para levar a cabo um fim baseado no interesse público" ${ }^{403}$. Cianciardo, por sua vez, o denomina como o sub-princípio da adequação, também conhecido como um sub-princípio de idoneidade. O sub-princípio exige uma finalidade para uma determinada medida, bem como a sua adequação para o alcance desse propósito ${ }^{404}$. Bonavides afirma que tal princípio constitutivo se confunde até mesmo com a vedação do arbítrio (Übermassverbot).

O segundo sub-princípio, no que Cianciardo e Bonavides convergem ${ }^{405}$, seria o da necessidade (Erforderlichkeit), também conhecido por Cianciardo como juízo de indispensabilidade. Nele se examina se a medida adotada é a menos restringente das normas de direito fundamental entre as normas igualmente eficazes ${ }^{406}$. Paulo Bonavides aduz que o mencionado sub-princípio pressupõe que a medida seja efetivamente necessária. Esta análise, segundo Cianciardo, irá tratar de três questões específicas deste sub-princípio, que seriam a possibilidade do juízo de necessidade, o juízo de eficácia e a eleição da medida necessária ${ }^{407}$. Bonavides procura explicar o sub-princípio pela expressão de Xavier Philippe, na qual "de dois males faz-se mister escolher o menor", entrando em discussão o meio empregado e sua dosagem para a finalidade pretendida ${ }^{408}$.

Por fim, Cianciardo expõe que o juízo de proporcionalidade em sentido estrito procura saber se a medida guarda uma relação razoável com o fim que se procura alcançar, mediante um balanço entre vantagens e desvantagens ${ }^{409}$. Luis Roberto Barroso define a proporcionalidade estrita como o reconhecimento de que o valor promovido pela

\footnotetext{
${ }^{402}$ BONAVIDES, Paulo. op. cit., p. 392.

${ }^{403}$ Id. Ibid., p. 396.

${ }^{404}$ Id. Ibid., p. 62.

${ }^{405}$ Id. Ibid., p. 397.

${ }^{406}$ Id. Ibid., p. 79.

${ }^{407}$ Id., loc. cit.

${ }^{408}$ Id., loc. cit.

${ }^{409}$ Id. Ibid., p. 93.
} 
desequiparação seja mais relevante do que foi sacrificado pela atitude diferenciadora ${ }^{410}$. Bonavides destaca a expressão de Pierre Müller, na qual a escolha recai sobre o meio ou os meios que, no caso específico, levarem mais em conta o conjunto de interesses em jogo ${ }^{411}$. Ou seja, a proporcionalidade em sentido estrito avaliará, necessariamente, qual o maior valor que deve ser protegido.

Assim, tal modelo de controle da limitação do direito fundamental da proibição da discriminação se encaixa dentro dos requisitos adotados pela jurisprudência da Alta Corte da Austrália ${ }^{412}$, bem como na decisão do caso Zamlen v. City of Cleveland $^{413}$, mencionada no item 5.5.1. Como destacado anteriormente, tal juízo de controle irá fazer a ponderação dos conflitos postos no caso prático, exigindo, do julgador, uma técnica de pesos de todos os referidos elementos, para verificação da existência de uma postura discriminatória.

Resta ponderar que a tarefa acima narrada não é das mais fáceis. Pela controvérsia estabelecida, fica muito claro que elementos secundários ou adjacentes à questão principal assumem papel de destaque. O conteúdo da prova e a forma da apresentação da prova em Juízo assumem papel primordial na solução das lides que envolvem discriminação, o que deveria estar restrito a um papel instrumental. Tal afirmação tem fundamento na própria importância que as Cortes judiciais, principalmente as norte-americanas, dão à questão do ônus da prova.

Ultrapassada a tormentosa questão da prova, que será melhor analisada no final desta investigação, fica claro que a discussão do tema e a avaliação pelos critérios da proporcionalidade sofrem uma forte influência valorativa. Luciano Ventura obtempera que as decisões sobre a legitimidade de uma atitude diferenciadora à luz de uma racionalidade não muito bem definida e emanada, segundo Ferrara, provêm do senso comum de juízos constitucionais, que coincidem com o senso comum da classe de juristas de uma determinada geração ${ }^{414}$. Assim, destaca Ventura, adota-se um senso comum que pode trazer muitas contradições ${ }^{415}$, promovendo intensas polêmicas sobre a jurisprudência.

A proibição da discriminação destina-se a obter a igualdade substantiva dos seres humanos, ainda mais na proteção das minorias contra o governo da maioria. Como bem pontua Peter Häberle, muitos são os intérpretes situados na posição que antecede a

\footnotetext{
${ }^{410}$ BONAVIDES, Paulo. op. cit., p. 34.

${ }^{411}$ Id. Ibid., p. 398.

${ }^{412}$ Vide nota $\mathrm{n}^{\mathrm{o}} 136$.

${ }^{413}$ Vide nota $\mathrm{n}^{\circ} 119$ deste mesmo capítulo.

${ }^{414}$ VENTURA, Luciano. op. cit., p. 36.

${ }^{415}$ Id., loc. cit.
} 
interpretação constitucional do juízes, por serem todas as forças pluralistas públicas também intérpretes da Constituição ${ }^{416}$. Assim, segundo o jurista alemão, o processo de interpretação da Constituição é realizado por um círculo cada vez mais ampliado, sendo que esta esfera pública pluralista desenvolve força normatizadora, levando a Corte Constitucional a interpretar a Constituição em correspondência com a sua atualização pública $^{417}$.

Tais influências valorativas na interpretação da proibição da discriminação são verificadas pelos caminhos percorridos pelas Cortes constitucionais sobre o tema. Um bom exemplo é o norte-americano, em determinado período, como na Corte Warren, que demonstrou uma postura bastante audaciosa sobre as questões discriminatórias, sucedida pela Corte Burger, com perfil semelhante. Na sequência veio a Corte Rehnquist, em 1986, que demonstrou uma postura bem diferente, com interpretações bem restritivas das normas antidiscriminatórias, ao contrário das duas Cortes antecessoras.

A interpretação de determinada conduta à luz de critérios não muito bem claros e rigidamente definidos podem, ou não, justificar determinada postura diferenciadora. A imprecisão de tais critérios demonstra a dificuldade de ser estabelecido um conceito mais preciso sobre a discriminação. Mais ainda, tais julgamentos de valor dependem da época em que são proferidos, dos conceitos sociais valorativos de uma sociedade pluralista e do contexto dos relacionamentos humanos vigentes. Muito mais ainda, um mundo do trabalho em permanente crise, com a corrosão dos valores protetivos do trabalho humano em favor da eficiência econômica do neoliberalismo, compromete mais ainda o princípio da proporcionalidade, podendo solapar o sentido da proteção do tratamento igualitário e, via de consequência, dos valores humanos do trabalho.

\footnotetext{
${ }^{416}$ HÄBERLE, Peter. Hermenêutica constitucional. Trad. Gilmar Ferreira Mendes. Porto Alegre: Sérgio Antonio Fabris Editor, 2002. Reimpressão, p. 41.

${ }^{417}$ Id., loc. cit.
} 


\section{CONCEITOS DE DISCRIMINAÇÃO}

O presente capítulo irá tratar dos diversos conceitos de discriminação em geral, e de discriminação laboral em particular. Tais conceitos foram apresentados nos últimos sessenta anos desde que a expressão discriminação foi utilizada na Declaração Universal dos Direitos do Homem, para denominar diferenciações proibidas. Durante este relativamente curto período de tempo, a definição do que seja discriminação sofreu profundas alterações, demonstrando uma dinamicidade peculiar na sua evolução.

O capítulo irá demonstrar o histórico, os principais e os mais interessantes conceitos de discriminação, tanto no direito positivo interno e de outros países, bem como na doutrina e jurisprudência. A pesquisa doutrinária e jurisprudencial irá acompanhar a pesquisa sobre os conceitos das normas positivadas, demonstrando, igualmente, uma rápida evolução nos seus termos.

\subsection{Evolução dos conceitos de discriminação}

Os conceitos sobre a discriminação em geral, e sobre a discriminação laboral em particular, sofreram gigantesca transformação durante um relativamente curto período de tempo. É possível estabelecer algumas fases dos conceitos antidiscriminatórios, posto que certos períodos podem ser delimitados por tendências e posturas características de cada época.

A primeira fase que pode ser facilmente definida é aquela em que houve a afirmação da expressão discriminação, com o significado verificado na investigação, na qual a expressão começou a ser aceita em termos universais. Inicialmente, a expressão experimentou algumas tímidas aparições em alguns tratados e documentos internacionais, com maior visibilidade somente após o primeiro grande conflito mundial. A referida expressão era utilizada mais intensamente dentro dos Estados Unidos da América, principalmente após a Guerra de Secessão, com sua aparição nas leis que tratavam da reconstrução do país.

Tratava-se de uma fase em que a expressão discriminação estava muito longe de possuir o atual alcance. Ela procurava sua afirmação dentro do direito internacional, apesar de consagrada no direito norte-americano, ainda que lá tivesse diversos significados. Essa 
fase de afirmação era caracterizada pela utilização conjunta da expressão discriminação com a expressão distinção, ora uma ora outra. A Declaração Universal dos Direitos do Homem, em 1948, demonstra muito bem essa tendência. A expressão discriminação não havia se afirmado isoladamente dentro do texto - nas duas versões divulgadas as expressões se alternavam para expressar a mesma conduta.

A principal característica dessa fase está centrada no fato de que a expressão discriminação era uma novidade e sua definição positivada ainda não existia. Nessa primeira fase, não havia uma conceituação específica do que fosse uma discriminação por uma norma positivada. A expressão constava nos documentos como uma prática expressamente proibida pelos motivos ali apontados, só que as normas não procuravam descrever o que seria, efetivamente, uma conduta discriminatória.

Nesse período, ainda que a referida expressão fosse tratada como sinônimo da expressão distinção, mas com tendência de universalização através da sua figuração na Declaração Universal de Direitos do Homem, não possuía um conceito definido. Esta fase transcorreu em uma época caracterizada pela preocupação da afirmação dos direitos humanos, na qual uma declaração de cunho universal foi realizada conjuntamente com algumas declarações e tratados regionais de proteção de direitos do homem. A Declaração Americana dos Direitos e Deveres do Homem, adotada alguns meses antes da Declaração Universal (abril de 1948), não menciona a expressão discriminação, apenas proscrevendo a conduta de distinção em seu artigo $2^{\circ}$, com uma previsão de motivos explicitamente não taxativa $^{418}$. A Convenção Europeia de Direitos do Homem, de 1950, por sua vez, utilizava a expressão distinção para a versão em língua francesa e a expressão discriminação para a versão em língua inglesa, em seu artigo 14, conforme o relato de Marc Bossuyt ${ }^{419}$.

É possível afirmar que uma nova fase surge em 1958, com a Convenção 111 da Organização Internacional do Trabalho. Este foi um diploma extremamente audacioso para seu tempo, posto que nenhuma norma de cunho universal havia ainda adotado uma descrição da conduta discriminatória. A convenção não somente adotou a expressão

\footnotetext{
${ }^{418}$ DECLARAÇÃO AMERICANA DOS DIREITOS E DEVERES DO HOMEM. IX Conferência Internacional Americana em Bogotá. Biblioteca Virtual de Direitos Humanos da USP. Disponível em: $<$ http://www.direitoshumanos.usp.br/index.php/OEA-Organização-dos-Estados-Americanos/declaracaoamericana-dos-direitos-e-deveres-do-homem.html>. Acesso em: 20 out. 2009. Artigo $2^{\circ}$. Todas as pessoas são iguais perante a lei e têm os direitos e deveres consagrados nesta Declaração, sem distinção de raça, língua, crença, ou qualquer outra.

${ }^{419}$ BOSSUYT, Marc. op. cit., p. 18.
} 
discriminação como também consolidou sua definição laboral em termos precisos, inaugurando uma nova fase, a das normas com conceitos descritivos.

É bem verdade que a primeira fase não foi definitivamente encerrada com o surgimento da Convenção 111 da OIT, posto que esta norma tinha uma aplicação restrita ao mundo laboral. Mesmo depois de sua aparição, algumas outras normas de cunho universal ainda utilizavam a expressão distinção. Marc Bossuyt aponta que na preparação da Carta Social Europeia, de 1961, como dos pactos das Nações Unidas de 1966, travaramse debates sobre a terminologia a ser adotada ${ }^{420}$. Mas o caráter inovador da Convenção 111 da OIT impulsionou outras normas internacionais a descreverem quais condutas seriam consideradas discriminatórias.

Fica claro que há uma distinção evidente entre as duas fases. Na primeira, não havia uma consolidação da expressão discriminação, muito menos uma descrição positivada da conduta. A tendência dos conceitos descritivos foi reforçada pela Convenção relativa à luta contra as discriminações na esfera do ensino, de 1960, que apresentou um conceito descritivo do que é discriminação dentro da esfera do ensino. Warwick McKean aponta que este diploma buscou, conforme a expressão adotada pela UNESCO, "uma básica e permanente fonte de inspiração" ${ }^{421}$ na Declaração Universal, nas minutas dos Pactos Internacionais de Direitos Humanos, na Convenção 111 da OIT e no trabalho da Comissão de Direitos Humanos da ONU. A nova fase foi marcada pela adoção da Convenção Internacional sobre a Eliminação de Todas as Formas de Discriminação Racial, de 1965, que também apresentou um conceito descritivo do que seja discriminação.

Esta fase foi caracterizada por conceitos descritivos de uma conduta discriminatória mediante extensas definições que, no entanto, vieram a ser suplantadas por uma terceira fase.

A União Europeia sempre demonstrou extrema preocupação com a questão da discriminação laboral por motivo de gênero, principalmente após o Tratado de Amsterdam. Este tratado contém uma importante alteração na Constituição da União Europeia, em seu artigo $2^{\circ}$, item 7 , introduzindo o artigo 6-A na antiga Constituição. Ela passou a se preocupar com a discriminação laboral por outros motivos, além do motivo do gênero ${ }^{422}$.

\footnotetext{
${ }^{420}$ I BOSSUYT, Marc. op. cit., p. 18.

${ }^{421}$ MCKEAN, Warwick. op. cit., p. 132. O referido autor se refere ao documento $\mathrm{n}^{\mathrm{o}} 11 / \mathrm{C} 15$, parágrafos $14 \mathrm{e}$ 18-20 da UNESCO.

${ }^{422}$ EUROPEAN CENTRAL BANK. Home Page. Legal framework. Tratado de Amsterdão. Disponível em: <http://www.ecb.europa.eu/ecb/legal/pedf;Amsterdam_pt.pdf>. Acesso em: 20 out. 2009.
} 
Após a celebração deste novo tratado, foi produzido um novo corpo de normas antidiscriminatórias, gerando importantes Diretivas que foram transpostas para os ordenamentos internos dos Estados-membros. As Diretivas 2000/43, 2000/78 e 2002/73 formam uma trilogia caracterizada por uma série de semelhanças e importantíssimas novidades.

As três normas apresentam uma conceituação descritiva do que seja discriminação, com base na jurisprudência do Tribunal de Justiça da Comunidade Europeia, caracterizada pela definição precisa de dois tipos de discriminação, segundo a terminologia por elas utilizada: a discriminação direta e a indireta. Por outro lado, as novas diretivas adotam um conceito relativamente simples para definir os efeitos da discriminação, afirmando que uma pessoa é discriminada ao ser objeto de tratamento menos favorável comparativamente com outra pessoa ou grupo. Por fim, as referidas normas estabelecem que o assédio de modo geral e o assédio sexual em particular passaram a ser consideradas atitudes discriminatórias. Tais normas comunitárias desencadearam a criação de uma série de normas antidiscriminatórias nos ordenamentos internos dos Estados-membros, dentro das linhas gerais traçadas pelas referidas Diretivas. Tais normas comunitárias e as respectivas normas internas constituem, atualmente, uma nova forma descritiva da discriminação, caracterizada pela simplicidade e abrangência. Por outro, elas trazem a descrição precisa de modalidades de discriminação já reconhecidas pelas Cortes europeias, principalmente aquelas consolidadas em uma riquíssima jurisprudência constituída naquele continente.

Assim, tais características peculiares levam à caracterização de uma nova fase dos conceitos discriminatórios, marcada pelos elementos das descrições de algumas condutas tipicamente discriminatórias amplamente reconhecidas pela jurisprudência sobre o tema e um conceito muito amplo sobre os efeitos da discriminação verificada. Esta nova fase é caracterizada pela constituição de diversas modalidades de discriminação.

\subsection{Conceitos positivados na ordem internacional}

Como já foi colocado no tópico anterior, existem dois tipos de normas, no que tange à previsão das condutas discriminatórias: normas antidiscriminatórias simplesmente proibitivas e normas discriminatórias descritivas. Caberá a esta parte da investigação tão somente se debruçar sobre as normas discriminatórias descritivas, posto que somente elas procuram conceituar o que seja efetivamente uma discriminação. 


\subsubsection{O conceito de discriminação da Convenção 111 da OIT}

A primeira norma que descreve objetivamente o que seja uma discriminação no direito internacional é, justamente, uma norma que descreve a discriminação laboral. A Convenção 111, aprovada na $42^{\mathrm{a}}$ Reunião da Conferência Internacional do Trabalho em Genebra em 1958, entrou em vigor no plano internacional em 15.06.1960. A referida Convenção aponta seu conceito de discriminação da seguinte forma:

Art. 1 - 1. Para os fins da presente convenção o termo "discriminação"
compreende:
a) toda distinção, exclusão ou preferência fundada na raça, cor, sexo,
religião, opinião política, ascendência nacional ou origem social, que
tenha por efeito destruir ou alterar a igualdade de oportunidade ou de
tratamento em matéria de emprego ou profissão;

b) qualquer outra distinção, exclusão ou preferência que tenha por efeito destruir ou alterar a igualdade de oportunidades ou tratamento em matéria de emprego ou profissão que poderá ser especificada pelo Membro interessado depois de consultadas as organizações representativas de empregadores e trabalhadores, quando estas existam, e outros organismos adequados.

2. As distinções, exclusões ou preferências fundadas em qualificações exigidas para um determinado emprego não são consideradas como discriminação.

3. Para os fins da presente convenção as palavras 'emprego' $e$ 'profissão' incluem o acesso à formação profissional, ao emprego e às diferentes profissões, bem como às condições de emprego. ${ }^{423}$

Trata-se de um conceito pioneiro e, por tal motivo, revela algumas imperfeições. Ao se basear em seu preâmbulo na Declaração Universal dos Direitos do Homem, deveria se ater a um conceito que visasse eliminar todas as formas de discriminação. Mas como já foi apontado no $5^{\circ}$ capítulo, o texto da Convenção acabou ficando restrito a alguns motivos, sendo que vários outros motivos comuns na esfera laboral deixaram de ser abordados.

O texto da referida Convenção se caracteriza por estipular que os atos discriminatórios podem ser uma distinção, exclusão ou preferência. Os dois últimos verbos poderiam estar incluídos na descrição do primeiro, mas há de ser relevado que, no direito internacional da época, ainda era largamente utilizada a expressão distinção. No campo dos

\footnotetext{
${ }^{423}$ ORGANIZAÇÃO INTERNACIONAL DO TRABALHO. Sítio do escritório da OIT em Brasília. Disponível 
motivos a Convenção falhou em apontar uma das causas mais comuns de discriminação nas relações laborais, relacionada ao exercício da liberdade sindical, ainda que tal tema já fosse previsto na Convenção nº 98, de 1948.

Por fim, é importante destacar que o texto da Convenção 111 não leva em consideração o objetivo do ato discriminatório, mas apenas seu efeito. Tal disposição vem a consagrar que não há qualquer interesse na apuração da intenção do empregador na prática discriminatória, desprezando completamente esse elemento. Para sua caracterização, basta a verificação concreta dos resultados especificados na norma.

E conclui seu conceito expondo que a discriminação tem por resultado a diferença de tratamento ou prejuízo à igualdade de oportunidades no emprego e na profissão. Esta caracterização é interessante pela sua abrangência, no entanto, ela fica restrita aos efeitos discriminatórios consolidados no ambiente de trabalho, sem tratar de repercussões fora dele, ainda que lá praticados. Esta situação não pode ser deixada de lado, principalmente nos casos de discriminação por motivos opcionais ou sociais, uma vez que a discriminação atinge, principalmente, a respectiva liberdade relacionada ao motivo da conduta.

No entanto, apesar das falhas acima apontadas, somente pode merecer elogios o conceito da Convenção 111. Ele foi elaborado em uma época em que a doutrina sobre o tema era extremamente rara e restrita a temas genéricos de discriminação. Nessa época não havia uma jurisprudência mais consistente a respeito do tema da discriminação laboral, bem como sobre os direitos humanos em geral. A Convenção 111 foi concebida mediante a pesquisa sobre algumas experiências de direito interno de alguns Estados integrantes da conferência, bem como das experiências dos representantes de trabalhadores e empregadores. Eles levaram seus principais conceitos e dúvidas e algumas definições já existentes, como a complexa situação do business necessity.

Em um balanço entre as falhas e os acertos do conceito envolvido, somente pode ser considerado um saldo positivo, ponderando-se o fato de ter sido uma norma pioneira, bem como a época e o contexto mundial em que a norma foi elaborada. Basta ressaltar que, em termos brasileiros, o conceito de discriminação laboral elaborado pela referida Convenção é a melhor norma descritiva da discriminação em vigor em nosso país, apesar de ser uma norma cinquentenária. 


\title{
6.2.2. O conceito da Convenção relativa à luta contra as discriminações na esfera do ensino
}

O conceito da Convenção relativa à luta contra as discriminações na esfera do ensino $^{424}$ guarda certa semelhança com o conceito da Convenção 111 da OIT, no entanto possui algumas características peculiares. No seu primeiro artigo, expõe que são consideradas discriminações as seguintes condutas:

\begin{abstract}
Artigo 1 - \$1. Aos efeitos da presente Convenção, se entende por discriminação toda distinção, exclusão, limitação ou preferência fundada na raça, na cor, no sexo, no idioma, na religião, nas opiniões políticas ou de qualquer outra índole, na origem nacional ou social, na posição econômica ou o nascimento, que tenha por finalidade ou por efeito destruir ou alterar a igualdade de tratamento na esfera do ensino, e, em especial:

a) excluir uma pessoa ou um grupo de acesso aos diversos graus e tipos de ensino;

b) limitar a um nível inferior a educação de uma pessoa ou de um grupo; c) a reserva do previsto no artículo no artigo 2 da presente Convenção, instituir ou manter sistemas ou estabelecimentos de ensino separados para pessoas ou grupos;

d) colocar uma pessoa ou um grupo em uma situação incompativel com a dignidade humana.
\end{abstract}

$\$ 2$. Aos efeitos da presente Convenção, a palavra " ensino" se refere em seus diversos tipos e graus, e compreende o acesso ao ensino, ao nivel e à qualidade desta e as condições em que se dá.

O primeiro parágrafo enumera que são consideradas situações discriminatórias as distinções, exclusões, limitações ou preferências (incluiu a situação de limitação, além da previsão da Convenção 111 da OIT). A norma também tem uma finalidade específica, a proteção contra a discriminação no ensino, assim é uma norma de aplicação restrita a determinada atividade. Como pode ser observada, a previsão dos efeitos é assemelhada com a proteção da Convenção 111 da OIT, com a exceção de alguns tópicos estabelecidos em destaque, para enumerar algumas possibilidades discriminatórias, entre elas:

a) exclusão de uma pessoa ou grupo a determinada forma de ensino;

b) limitar uma pessoa ou grupo a um nível inferior de educação (situações que violam a igualdade de oportunidades na educação);

\footnotetext{
${ }^{424}$ ORGANIZAÇÃO DAS NAÇÕES UNIDAS. Convenção Relativa à Luta Contra as Discriminações na Esfera do Ensino. Adotada pela Assembleia Geral em 14.12.1960. Disponível em: $<$ http://www.direitoshumanos.usp.br/index.php/Direito-a-Educação/convencao-relativa-a-luta-contra-asdiscriminacoes-na-esfera-do-ensino.html>. Acesso em: 20 out. 2009.
} 
c) a exclusão da consideração de discriminação das situações previstas no artigo 2 do texto convencionado, como as unidades de ensino para grupos específicos e as unidades de ensino particulares;

d) a colocação de uma pessoa ou grupo em situação incompatível com a dignidade humana.

A enumeração das circunstâncias da discriminação pela referida convenção é importante porque expressamente exclui situações comuns específicas e, por outro lado, procura dar ênfase à caracterização de outras situações peculiares da discriminação na educação.

Mas, entre elas, o que mais chama a atenção e vai orientar muitos entendimentos sobre a discriminação é o item "d", no qual menciona que, ainda que todas as situações sejam igualmente tratadas, não será aceita a conduta que venha a deixar uma pessoa ou grupo em situação incompatível com a dignidade humana. Tal referência aborda um efeito que toda e qualquer discriminação acaba por violar. Ao promover o trato desigual, o ato discriminatório não fará a consideração da igual dignidade dos seres humanos, ao considerar os desfavorecidos como pessoas que não possuem a sua dignidade no mesmo patamar dos demais.

Esta Convenção foi firmada em 1960, dois anos após a aprovação da Convenção 111 da OIT e trouxe algumas evoluções importantes. No entanto, o reconhecimento da incompatibilidade da discriminação com o respeito à dignidade humana, foi uma importante resposta a certas situações diferenciadoras que, não obstante conferirem as mesmas condições de ensino a diferentes grupos, não permitiam sua integração, em especial a segregação no ensino.

\subsubsection{O Conceito da Convenção Internacional sobre todas as formas de eliminação da discriminação racial}

A Convenção Internacional sobre todas as formas de eliminação da discriminação racial foi celebrada em 1965, e seu texto foi preparado durante um longo período. Em 1962, a Assembleia Geral das Nações Unidas solicitou para o Conselho Econômico e Social daquela entidade a elaboração de uma minuta de uma declaração e uma convenção para eliminação de todas as formas de discriminação racial. Na Assembleia Geral de 1963 foi proclamada uma declaração de eliminação de todas as formas de discriminação racial 
que não utiliza expressamente a expressão discriminação. Tal declaração foi um instrumento preparatório para o reconhecimento de um princípio de proibição da discriminação e para a elaboração de uma convenção posterior.

O trabalho de preparação da Convenção seria complexo, posto que deveria possuir efeito vinculante sobre seus signatários, e foi objeto de muitas discussões prévias, principalmente por parte da delegação do Reino Unido. Os representantes britânicos lograram êxito em aprovar uma emenda que retirava as expressões obrigação e cumprimento da referida Convenção, como destaca McKean ${ }^{425}$. Insta ponderar que, na época em que o documento foi assinado, estava em plena vigência o regime de apartheid na África do Sul, e ainda, o regime colonialista ainda persistia no continente africano e em outros continentes, muitos deles ainda sob o domínio da Coroa britânica.

O documento tem foco em um determinado motivo nuclear e outros motivos paralelos e próximos. Porém, sua aplicação seria voltada para todos os setores da vida humana, exatamente para prever a proibição da discriminação em qualquer esfera e em qualquer ramo da sociedade. Ou seja, um motivo restrito e uma aplicação extremamente ampla.

O texto da referida Convenção assinala que discriminação racial é considerada para os fins daquele documento nas seguintes situações:

Artigol $^{\circ}$

§1. Para fins da presente Convenção, a expressão "discriminação racial" significará toda distinção, exclusão, restrição ou preferência baseada em raça, cor, descendência ou origem nacional ou étnica que tenha por objeto ou resultado anular ou restringir o reconhecimento, gozo ou exercício em um mesmo plano (em igualdade de condição) de direitos humanos e liberdades fundamentais nos campos político, econômico, social, cultural ou em qualquer outro campo da vida pública.

\$2. Esta Convenção não se aplicará às distinções, exclusões, restrições e preferências feitas por um Estado-Membro entre cidadãos e não cidadãos.

§3. Nada nesta Convenção poderá ser interpretado como afetando as disposições legais dos Estados Membros, relativas à nacionalidade, cidadania e naturalização, desde que tais disposições não discriminem contra qualquer nacionalidade particular.

§4. Não serão consideradas discriminação racial as medidas especiais tomadas com o único objetivo de assegurar o progresso adequado de certos grupos raciais ou étnicos ou de indivíduos que necessitem da proteção que possa ser necessária para proporcionar a tais grupos ou indivíduos igual gozo ou exercício de direitos humanos e liberdades

\footnotetext{
${ }^{425}$ MCKEAN, Warwick. op. cit., p. 155.
} 
fundamentais, contanto que tais medidas não conduzam, em consequência, à manutenção de direitos separados para diferentes grupos raciais e não prossigam após terem sido alcançados os seus objetivos.

O conceito adotado pela referida Convenção é semelhante ao da Convenção 111 da OIT, de 1958, e da Convenção sobre a discriminação no ensino, de 1960. No que tange à motivação, a Convenção aponta alguns motivos que orbitam sobre a discriminação racial. Contudo, no item "2" do primeiro artigo, exclui as diferenciações entre nacionais e não nacionais dentro do seu âmbito de proteção, o que resultou em uma profunda limitação na sua aplicabilidade, lamentavelmente.

Como efeito da prática discriminatória, a referida norma aponta que tem objeto ou resultado anular ou restringir o reconhecimento, gozo ou exercício em um mesmo plano (em igualdade de condição) de direitos humanos e liberdades fundamentais nos campos político, econômico, social, cultural ou em qualquer outro campo da vida pública. Como é uma norma de ampla abrangência, aponta como consequência as restrições de direitos e liberdades fundamentais em qualquer campo da vida pública. A referida Convenção tem um rol de motivos restrito; no entanto, possui uma série de efeitos extremamente abrangente, diante das suas necessidades.

Por outro lado, o conceito de discriminação acima apontado exclui as medidas temporárias que, ao apresentarem diferenciações, procurem medidas para assegurar o progresso de grupos étnicos ou raciais que necessitem de medidas especiais. Ou seja, a norma pretende excluir de sua consideração, como discriminatória, as práticas que atuem no sentido promocional dos grupos ou raças. McKean aponta que estas previsões incorporam a noção de medidas temporárias, não como exceção, mas como corolário necessário às proteções discriminatórias, fundindo os dois conceitos de discriminação em um único, situado no interior do princípio da igualdade ${ }^{426}$. O mesmo autor ainda ressalta que esta Convenção foi o mais radical instrumento adotado até então, e foi o primeiro instrumento internacional geral que previu medidas práticas especiais para assegurar a plena e igual fruição de direitos humanos e liberdades fundamentais, com caráter vinculante para as partes signatárias ${ }^{427}$.

\footnotetext{
${ }^{426}$ MCKEAN, Warwick. op. cit., p. 159.

${ }^{427}$ Id. Ibid., p. 165.
} 
Como bem ressalta Ingrid Cyfer, ao comentar a aludida Convenção, o modelo repressivo se volta para o passado, mas a promoção da igualdade visou o futuro, procurando construir uma cultura de tolerância que venha minimizar gradativamente a necessidade da repressão ${ }^{428}$.

\title{
6.2.4. O conceito da Convenção sobre a eliminação de todas as formas de discriminação contra as mulheres
}

Em 1979, a Assembleia das Nações Unidas firmou uma Convenção internacional para proteção contra a discriminação das mulheres, doze anos após ter declarado os princípios e linhas mestras desta modalidade de discriminação, através da Declaração sobre a Eliminação da Discriminação contra a Mulher $^{429}$. A Convenção recebeu uma significativa influência da OIT nos trabalhos preparatórios, agregando os principais documentos daquela entidade, e teve um foco muito detalhado nas condições e exigências femininas para o trabalho.

O conceito adotado pela referida Convenção é semelhante ao da Convenção para eliminação de todas as formas de discriminação racial, no seguinte sentido:

\begin{abstract}
Artigo $1^{o}$ - Para os fins da presente Convenção, a expressão "discriminação contra a mulher" significará toda a distinção, exclusão ou restrição baseada no sexo e que tenha por objeto ou resultado prejudicar ou anular o reconhecimento, gozo ou exercício pela mulher, independentemente de seu estado civil, com base na igualdade do homem e da mulher, dos direitos humanos e liberdades fundamentais nos campos político, econômico, social, cultural e civil ou em qualquer outro campo. ${ }^{430}$
\end{abstract}

Como pode ser visto, a estruturação do conceito de discriminação é o mesmo da Convenção sobre a discriminação racial. O conceito adotado na referida norma define a expressão "discriminação contra a mulher", enumera condutas que considera como

\footnotetext{
${ }^{428}$ CYFER, Ingrid. Convenção sobre a Eliminação de Todas as Formas de Discriminação Racial (1965). PERRONE-MOISÉS, Claudia; ALMEIDA, Guilherme Assis de (Coord.). Direito internacional dos direitos humanos: instrumentos básicos. 2. ed. São Paulo:Atlas, 2007. p. 17.

${ }^{429}$ ORGANIZAÇÃO DAS NAÇÕES UNIDAS. Declaração sobre a eliminação da discriminação contra a mulher. Proclamada pela Assembleia Geral das Nações Unidas em 7 de novembro de 1967. Disponível em: $<$ http://www.direitoshumanos.usp.br/index.php/Direitos-da-Mulher/declaracao-sobre-a-eliminacao-dadiscriminacao-contra-a-mulher.html>. Acesso em: 20 out. 2009.

${ }^{430}$ ORGANIZAÇÃO DAS NAÇÕES UNIDAS. Convenção sobre a eliminação de todas as formas de discriminação contra a mulher. Biblioteca Virtual de Direitos Humanos da USP. Disponível em: $<$ http://www.direitoshumanos.usp.br/index.php/Direitos-da-Mulher/convencao-sobre-a-eliminacao-detodas-as-formas-de-discriminacao-contra-a-mulher.html>. Acesso em: 21 out. 2009.
} 
discriminatórias, com exclusão da preferência, ao contrário da Convenção racial. Todos os comportamentos noticiados são baseados no sexo e possuem como resultado o prejuízo dos direitos humanos e liberdades fundamentais em qualquer campo, diferentemente da Convenção sobre a discriminação racial, que mencionava qualquer campo da vida pública.

O conceito apresentado pela citada Convenção é mais sintético na sua definição e mais amplo na sua proteção, sem dúvida alguma, impondo considerar que entre a Convenção para a eliminação da discriminação racial e a referida Convenção transcorreram quatorze anos com muita experiência doutrinária e jurisprudencial sobre a discriminação feminina, em especial no âmbito europeu. Traz consigo um dos objetos mais importantes da proteção contra a discriminação, a igualdade entre homens e mulheres, um dos princípios mais importantes do Direito do Trabalho, consolidado desde o Tratado de Versalhes em 1919, e um dos compromissos da OIT. Porém, a referida Convenção é despida de instrumentos e meios mais eficazes de cumprimento de suas disposições. É uma norma com pouco efeito vinculativo e desprovida dos instrumentos habituais de implantação e fiscalização, previstos em outras convenções, em especial a Convenção para eliminação da discriminação racial. Como bem aponta Olga Espinoza, ao comentar a referida Convenção, ainda são necessários sistemas que combatam com maior eficácia a discriminação contra as mulheres, para que imponham aos Estados uma atitude mais definida e uma postura mais ativa ${ }^{431}$.

\subsubsection{O conceito da Declaração sobre a eliminação de todas as formas de intolerância e discriminação fundadas na religião ou nas convicções}

Em 25 de novembro de 1981, a Assembleia Geral das Nações Unidas proclamou a Declaração sobre a eliminação de todas as formas de intolerância e discriminação fundadas na religião ou nas convicções. Trata-se de uma declaração, portanto, possuindo tão somente efeitos políticos, e não estabeleceu caráter vinculativo a seus signatários. No entanto, o conceito de discriminação ali adotado segue a tendência da Convenção para eliminação da discriminação contra as mulheres e o parágrafo $2^{\circ}$ do artigo $2^{\circ}$ da referida declaração. E assim define a discriminação religiosa, conjuntamente com a intolerância religiosa:

\footnotetext{
${ }^{431}$ ESPINOZA, Olga. Convenção sobre a Eliminação de Todas as Formas de Discriminação Contra a Mulher. PERRONE-MOISÉS, Claudia; ALMEIDA, Guilherme Assis de (Coord.). Direito internacional dos direitos humanos: instrumentos básicos. 2. ed. São Paulo:Atlas, 2007. p. 47.
} 
Artigo $2^{\circ} \S 1$. Ninguém será objeto de discriminação por motivos de religião ou convicções por parte de nenhum Estado, instituição, grupo de pessoas ou particulares.

\$2. Aos efeitos da presente declaração, entende-se por "intolerância e discriminação baseadas na religião ou nas convicções" toda a distinção, exclusão, restrição ou preferência fundada na religião ou nas convicções e cujo fim ou efeito seja a abolição ou o fim do reconhecimento, o gozo e $o$ exercício em igualdade dos direitos humanos e das liberdades fundamentais. ${ }^{432}$

A referida declaração também adota a tendência mais sintética da Convenção para eliminação da discriminação feminina, mas com uma posição ainda mais restrita. $\mathrm{O}$ mencionado texto revela uma tendência adotada pelas Nações Unidas no sentido de elaborar normas antidiscriminatórias cada vez mais sintéticas, principalmente seus conceitos.

\subsubsection{O conceito da Declaração sobre o direito e a responsabilidade dos indivíduos, grupos ou órgãos da sociedade de promover e proteger os direitos humanos e liberdades fundamentais universalmente reconhecidas}

Em 9 de dezembro de 1998, através da Resolução 53/144, a Assembleia Geral das Nações Unidas proclamou a Declaração sobre o direito e a responsabilidade dos indivíduos, grupos ou órgãos da sociedade de promover e proteger os direitos humanos e liberdades fundamentais universalmente reconhecidas. A referida declaração não traz propriamente um conceito discriminatório, no entanto reconhece explicitamente a existência de duas modalidades de discriminação, em seu artigo 12. Na referida norma, o texto da Declaração menciona que o Estado signatário deverá adotar todas as medidas adequadas para garantir que as autoridades competentes protejam todas as pessoas de diversos modos de agressão. Entre os modos de agressão, revela a existência de discriminação negativa de fato ou de direito ${ }^{433}$.

\footnotetext{
${ }^{432}$ NAÇÕES UNIDAS. Declaração sobre a eliminação de todas as formas de intolerância e discriminação fundadas na religião ou nas conviçcões. Proclamada pela Assembleia Geral das Nações Unidas a 25 de novembro de 1981 - Resolução 36/55. Biblioteca Virtual de Direitos Humanos. Universidade de São Paulo. Disponível em: http://www.direitoshumanos.usp.br/index.php/Prevenção-contra-a-Discriminação-eProteção-das-Minorias/declaracao-sobre-a-eliminacao-de-todas-as-formas-de-intolerancia-e-discriminacaofundadas-na-religiao-ou-nas-conviccoes.html >. Acesso em: 21 out. 2009. Proclamada pela Assembleia Geral das Nações Unidas a 25 de novembro de 1981 - Resolução 36/55.

${ }^{433}$ ORGANIZAÇÃO DAS NAÇÕES UNIDAS. Declaração sobre o Direito e a Responsabilidade dos Indivíduos, Grupos ou Órgãos da Sociedade de Promover e Proteger os Direitos Humanos e Liberdades Fundamentais Universalmente Reconhecidas. Biblioteca Virtual de Direitos Humanos. Universidade de São Paulo. Disponível em: <http://www.direitoshumanos.usp.br/index.php/Sistema-Global.-Declarações-e-
} 
O conceito citado trata-se de uma novidade entre os textos internacionais. O referido diploma assinala a existência de uma discriminação negativa, portanto reconhecendo expressamente a existência de discriminações positivas. Por outro lado, aponta a existência de discriminações de fato e de direito, podendo ser compreendida a primeira por qualquer atitude discriminatória pública ou privada, mas a segunda, a discriminação ocorrida por meio legislativo ou judicial, contra as pessoas, grupos e entidades defensoras dos direitos humanos, situação infelizmente muito comum.

É uma expressão cunhada já em 1998, portanto bem adiante das normas gerais de discriminação acima relatadas, adotando expressões até então não verificadas nos tratados anteriores.

\subsubsection{Convenção sobre os Direitos da Criança}

Em 20 de novembro de 1989, a Assembleia Geral das Nações Unidas adotou a Convenção sobre os Direitos da Criança, texto voltado a promover diversas formas de sua defesa, atendendo aos princípios da Carta da organização e de outros diplomas já aprovados por aquela entidade, referentes à proteção da infância. A Convenção não expressa um conceito de discriminação, mas adiciona uma nova modalidade de discriminação nas suas previsões.

Com efeito, o artigo $2^{\circ}$ afirma que os Estados-membros respeitarão os termos da Convenção, sem discriminação alguma, por diversos motivos, entre eles raça, cor, sexo, língua, religião, opinião política ou outra, origem nacional, étnica ou social, posição econômica, impedimentos físicos, nascimento ou qualquer outra condição da criança, bem como de seus pais ou de seus representantes legais ${ }^{434}$.

Trata-se do reconhecimento de mais uma forma de discriminação, a discriminação reflexiva. Ela ocorre quando é praticada sobre determinada pessoa, mas reflete nas pessoas que estão em convívio ou próximas com a vítima, situação infelizmente comum também nas relações de trabalho. Portanto, o reconhecimento desta forma de discriminação é

Tratados-Internacionais-de-Proteção/declaracao-sobre-o-direito-e-a-responsabilidade-dos-individuosgrupos-ou-orgaos-da-sociedade-de-promover-e-proteger-os-direitos-humanos.html>. Acesso em: 21 out. 2009.

${ }^{434}$ ORGANIZAÇÃO DAS NAÇÕES UNIDAS. Convenção sobre os Direitos da Criança. Resolução n 44 de 20.11.1989. Biblioteca Virtual de Direitos Humanos. Universidade de São Paulo. Disponível em: $<$ http://www.direitoshumanos.usp.br/index.php/Criança/convencao-sobre-os-direitos-da-crianca.html>. Acesso em: 21 out. 2009. 
extremamente importante, posto que certas modalidades discriminatórias não refletem somente na vítima, mas, também, sobre todas as pessoas que sejam seus dependentes.

\title{
6.2.8. O conceito da Convenção interamericana para a eliminação de todas as formas de discriminação contra as pessoas portadoras de deficiência
}

A Convenção Interamericana para a Eliminação de Todas as Formas de Discriminação Contra as Pessoas Portadoras de Deficiência, aprovada na Cidade de Guatemala, em 7 de junho de 1999, no vigésimo-nono período ordinário de sessões da Assembleia Geral, possui uma definição de discriminação no seu artigo $2^{\circ}$, nos seguintes termos:

\begin{abstract}
2. Discriminação contra as pessoas portadoras de deficiência:
a) o termo "discriminação contra as pessoas portadoras de deficiência" significa toda diferenciação, exclusão ou restrição baseada em deficiência, antecedente de deficiência, consequência de deficiência anterior ou percepção de deficiência presente ou passada, que tenha o efeito ou propósito de impedir ou anular o reconhecimento, gozo ou exercício por parte das pessoas portadoras de deficiência de seus direitos humanos e suas liberdades fundamentais;

b) não constitui discriminação a diferenciação ou preferência adotada pelo Estado Parte para promover a integração social ou o desenvolvimento pessoal dos portadores de deficiência, desde que a diferenciação ou preferência não limite em si mesma o direito à igualdade dessas pessoas e que elas não sejam obrigadas a aceitar tal diferenciação ou preferência. Nos casos em que a legislação interna preveja a declaração de interdição, quando for necessária e apropriada para o seu bem-estar, esta não constituirá discriminação ${ }^{435}$.
\end{abstract}

O texto interamericano busca a defesa das pessoas que possuam alguma forma de deficiência física ou mental. É uma situação especial que demanda um conceito especial diante das peculiaridades da proteção dos deficientes.

A Convenção considera como ato discriminatório a existência de diferenciação, exclusão ou restrição, voltada contra as pessoas portadoras de deficiência e assimilados, e que tais atos tenham o efeito ou propósito de impedir ou anular o reconhecimento, gozo ou

\footnotetext{
${ }^{435}$ ORGANIZAÇÃO DOS ESTADOS AMERICANOS. Convenção Interamericana para a Eliminação de Todas as Formas de Discriminação Contra as Pessoas Portadoras de Deficiência. Biblioteca Virtual de Direitos Humanos. Universidade de São Paulo. Disponível em: $<$ http://www.direitoshumanos.usp.br/index.php/Direito-dos-Portadores-de-Deficiência/convencaointeramericana-para-a-eliminacao-de-todas-as-formas-de-discriminacao-contra-as-pessoas-portadoras-dedeficiencia.html>. Acesso em: 21 out. 2009.
} 
exercício, por parte das pessoas portadoras de deficiência, de seus direitos humanos e liberdades fundamentais. O conceito expresso é muito semelhante aos conceitos adotados pelas Nações Unidas em suas normas antidiscriminatórias, adaptado a uma situação muito especial.

\subsection{Conceitos positivados na ordem interna de outros Estados}

Apresentados alguns conceitos descritivos sobre a discriminação no direito internacional, cabe neste momento, passar a analisar alguns conceitos de discriminação laboral contidos nos ordenamentos dos Estados que possuem este tipo de norma descritiva. As normas serão apresentadas através da indicação dos respectivos Estados.

\subsection{1. África do Sul}

A África do Sul é uma grande nação fundada em um complexo arranjo político que ainda vivencia os reflexos da nefasta política conhecida como apartheid, uma política segregacionista vigente até o fim da dominação branca naquele país. Apesar de todos os esforços governamentais, o antigo regime ainda deixará um profundo e triste legado. Com a ascensão do governo da maioria negra a partir de 1994, o país viveu uma nova era nas relações do trabalho. O Employment Equity $A c t^{436}$, de 1998, veio regular as relações de trabalho e a complexa questão da discriminação, principalmente em um país com vasto território e uma população composta por várias etnias com várias línguas.

A norma, em seu segundo capítulo, não adota nenhum conceito descritivo de discriminação; no entanto, tece uma série de considerações para apontar situações que não podem ser consideradas como práticas discriminatórias laborais por meio de excludentes. Entre as excludentes de uma atitude discriminatória arbitrária (unfair discrimination), a norma aponta a adoção de ações afirmativas, bem como a distinção, exclusão ou preferência de alguma pessoa por algum requisito inerente ao emprego. Por outro lado, pró́be a adoção de testes médicos não justificáveis (com expressa proibição do teste de portador do vírus HIV da SIDA/AIDS) e testes psicométricos não justificáveis. A norma

\footnotetext{
${ }^{436}$ ÁFRICA DO SUL. Employment Equity Act. $\quad \mathrm{N}^{\mathrm{o}}$ 55, of 1998. Disponível em: $<$ http://www.labour.gov.za/downloads/legislation/acts/employment-equity/Act\%20-

\%20Employment\%20Equity.pdf> Acesso em: 21 out. 2009.
} 
menciona, expressamente, em seu artigo 6 (3), que a prática do assédio pelos motivos constantes no caput desse artigo é reconhecida como uma forma de discriminação.

A norma sul-africana não define exatamente o que seja discriminação, mas adota alguns conceitos sobre situações específicas, muito provavelmente atendendo a situações comuns ou normalmente encontradas nos seus tribunais. Importante destacar que o próprio conceito legal já traz dentro de suas definições a noção de uma situação muito próxima do arbítrio, como elemento de caracterização da discriminação laboral.

\subsubsection{Austrália}

A Austrália possui um sistema de governo constituído por uma comunidade federal de Estados, sob a proteção da coroa britânica, presidido por um sistema parlamentarista, com um congresso bicameral (Senado e Casa dos Representantes). O Congresso possui competência legislativa sobre uma série de matérias estabelecidas na Constituição daquele país $^{437}$, no entanto não possui competência específica para matérias trabalhistas, o que cabe ao parlamento de cada Estado. Somente alguns assuntos que envolvam matéria de direitos humanos e, reflexivamente, matéria laboral correlata, podem ser regulados pelo parlamento federal.

Em termos de legislação federal, quatro diplomas que regulam situações de direitos humanos também tratam de discriminação laboral. O mais antigo deles é o Racial Discrimination Act, de 1975. Esta norma, resumidamente, descreve a discriminação laboral no seu artigo 15, como sendo as seguintes condutas praticadas por parte de um empregador ou alguém agindo em seu nome, por motivo de raça, cor ou origem nacional, seja da própria pessoa envolvida ou de parente, ou a ela unido ${ }^{438}$ :

a) recusar-se ou deixar de empregar alguma pessoa qualificada para determinado emprego disponível;

b) recusar ou não oferecer recursos para que uma pessoa, nas mesmas condições de emprego, condições de trabalho e oportunidades para a formação e promoção, mas que

\footnotetext{
${ }^{437}$ AUSTRÁLIA. Constituição. Parliament of Australia. Senate. Disponível em: <http://www.aph.gov.au/SEnate/general/constitution/chapter1.htm>. Acesso em: 26 out. 2009.

${ }^{438}$ AUSTRÁLIA. Racial Discrimination Act. Act $\mathrm{n}^{\circ} 52$ of 1975 as amended. Comlaw - Commonwealth of Australia Law. Disponível em: <http://www.comlaw.gov.au/comlaw/Legislation/ActCompilation1.nsf/0/A413ADB46D5CC9B2CA25760 7000EBE58?OpenDocument>. Acesso em: 25 out. 2009.
} 
esteja disponível para outras pessoas com as mesmas qualificações e as mesmas circunstâncias no trabalho, venha a ser admitida ou promovida;

c) dispensar uma pessoa pelos motivos apontados;

d) dispensar tratamento menos favorável para uma pessoa que procure emprego para si ou para outros.

A norma acima tem uma destacada preocupação com as situações discriminatórias ocorridas antes da contratação, situações extremamente comuns, infelizmente. E esta será uma tendência comum às normas antidiscriminatórias australianas, o que não deixa de ser um substancial avanço, principalmente tratando-se de uma época na qual a discriminação laboral ainda não possuía um tratamento específico tão avançado.

O segundo diploma federal australiano que trata reflexivamente da discriminação no trabalho é o Sex Discrimination Act, de 1984, diploma que possui uma seção específica para regular a proteção da discriminação no trabalho bem como no caso de aposentadorias $^{439}$. É uma norma extremamente detalhista, possuindo em seu início um extenso glossário dos termos utilizados na referida norma, com descrição específica das principais expressões utilizadas no diploma legal. $\mathrm{Na}$ sua segunda parte, cuida da discriminação em geral e, na sua $1^{a}$ divisão, da discriminação laboral em particular. A referida norma abrange, especificadamente, as discriminações nas relações de emprego, como também nas atividades de agentes comissionados, prestadores de serviços, organizações profissionais, participações societárias, organizações sindicais e agências de empregos, apresentando um artigo específico para cada atividade.

No caso das relações de emprego, em seu artigo 14, a norma proíbe a discriminação na oferta dos empregos, prevendo discriminação, por motivo do sexo, estado civil, gravidez ou potencial gravidez, nas seguintes situações:

a) na escolha das pessoas para as quais será oferecido emprego, bem como sobre as condições estabelecidas para a oferta e recrutamento;

b) nos termos da contratação e suas limitações estabelecidas, oportunidades de promoção, transferência ou treinamento, ou a quaisquer outros benefícios do emprego;

\footnotetext{
${ }^{439}$ AUSTRÁliA. Sex Discrimination Act. Act $\mathrm{n}^{\circ} 4$ of 1984 as amended. Comlaw - Commonwealth of Australia Law. Disponível em: <http://www.comlaw.gov.au/comlaw/Legislation/ActCompilation1.nsf/0/99327A010C648560CA25760700 2370CF?OpenDocument>. Acesso em: 25 out. 2009.
} 
c) dispensa;

d) sujeição a outras situações prejudiciais;

e) responsabilidades familiares;

f) diferenciação nos pagamentos de pensões e benefícios, bem como acesso a benefícios ou aos respectivos fundos.

De acordo com a análise, a norma abrange muitas situações específicas em um contrato de trabalho, passíveis de serem consideradas como discriminatórias em uma norma muito rica em detalhes. Certamente, é uma das normas mais detalhistas sobre a discriminação por gênero já concebida, exatamente destinada a prever situações pontuais consagradas. Como exemplo de atitude discriminatória, esta norma prevê situações discriminatórias na admissão do agente comissionado, na estipulação de condições de trabalho, limitações de acesso a determinadas vendas, limitações de comissões, negação de promoções, transferências e outras atitudes prejudiciais. É uma norma extremamente importante para o estudo das discriminações por gênero, com uma amplitude ímpar na previsão de situações discriminatórias contra a mulher.

A terceira norma federal australiana que merece destaque é o Disability Discrimination Act, de $1992^{440}$, que regula uma série de situações discriminatórias dos deficientes, inclusive nas relações laborais. Ela acompanha a tendência detalhista das demais normas, e apresenta previsões específicas muito precisas sobre a casuística das discriminações laborais por motivo de deficiência. Esta norma já apresenta conceitos distintos para discriminação direta ou indireta, e adota a terminologia europeia, refletindo o reconhecimento das duas modalidades de discriminação naquele continente. Por outro lado, outra novidade importante é o reconhecimento, no seu quinto artigo ${ }^{441}$, de que a

\footnotetext{
${ }^{440}$ AUSTRÁLIA. Disability Discrimination Act. Act n ${ }^{\circ} 135$ of 1992 as amended. Comlaw - Commonwealth of Australia Law. Disponível em: <http://www.comlaw.gov.au/comlaw/Legislation/ActCompilation1.nsf/0/02E50FC08E783ED7CA2576090 00288E1?OpenDocument>. Acesso em: 25 out. 2009.

${ }^{441}$ Direct disability discrimination. For the purposes of this Act, a person (the discriminator) discriminates against another person (the aggrieved person) on the ground of a disability of the aggrieved person if, because of the disability, the discriminator treats, or proposes to treat, the aggrieved person less favourably than the discriminator would treat a person without the disability in circumstances that are not materially different. (2)For the purposes of this Act, a person (the discriminator) also discriminates against another person (the aggrieved person) on the ground of a disability of the aggrieved person if: $(a)$ the discriminator does not make, or proposes not to make, reasonable adjustments for the person; and $(b)$ the failure to make the reasonable adjustments has, or would have, the effect that the aggrieved person is, because of the disability, treated less favourably than a person without the disability would be treated in circumstances that are not materially different. (3) For the purposes of this section, circumstances are not
} 
discriminação direta contra o deficiente ocorre quando o discriminador trata ou possui a intenção de tratar a pessoa agravada de modo menos favorável que trataria qualquer outra pessoa não deficiente. Por outro lado, a mesma norma ainda destaca que haverá discriminação quando o discriminador não tomar medidas razoáveis para adaptar as condições de trabalho para as necessidades do deficiente. Por fim, a supracitada norma, em seu artigo $6^{\circ}$, aponta que há discriminação indireta quando o discriminador requerer ou propuser alguma exigência que a pessoa deficiente não possa cumprir com tal obrigação, ou que tenha o efeito de impedir que o deficiente possa superar tais exigências.

É uma norma extremamente detalhista, que guarda certas semelhanças com a norma antidiscriminatória norte-americana conhecida como Americans with Disabilities Act, que será oportunamente tratada.

Por fim, entre as normas antidiscriminatórias federais australianas, merece destaque o Age Discrimination Act, de $2004^{442}$, uma norma bem mais recente, que incorpora tendências das normas anteriores, bem como tendências das normas da União Europeia, principalmente as tendências das diretivas de 2000 e 2002. A mencionada norma indica como conceito de discriminação direta, em seu artigo 14, o tratamento ou propósito de tratar a pessoa agravada menos favoravelmente que o discriminador trata uma pessoa por motivo de idade, em circunstâncias diversas ou materialmente diferentes, bem como pela característica aparente de uma idade ou que geralmente é imputada a pessoas de idade. Já no seu artigo 15, define discriminação indireta como a imposição ou proposição de condição exigência ou prática, a condição, que não seja razoável nas circunstâncias devidas; bem como a condição, exigência ou prática que possui, ou possa parecer ter, e o efeito desvantajoso sobre as pessoas da mesma idade da pessoa prejudicada.

O panorama australiano é riquíssimo, não somente pelo detalhismo das normas antidiscriminatórias, cunhadas com base na casuística específica de cada motivo diverso de discriminação, mas pelos detalhados conceitos incorporados. Por outro lado, o federalismo australiano permite a concepção de muitas outras normas antidiscriminatórias em cada Estado, formando um corpo de normas antidiscriminatórias extremamente avançado e concebido como um arsenal cuidadosamente planejado para atuar em situações comuns da

materially different because of the fact that, because of the disability, the aggrieved person requires adjustments.

${ }^{442}$ AUSTRÁliA. Age Discrimination Act. Act $N^{\circ} 68$ of 2004 as amended. Comlaw - Commonwealth of Australia Law. Disponível em: <http://www.comlaw.gov.au/comlaw/Legislation/ActCompilation1.nsf/0/C4293494A0BD921DCA257604 0020C9EB?OpenDocument>. Acesso em: 25 out. 2009. 
discriminação laboral. Um estudo para a concepção de normas antidiscriminatórias, deve, sem sombra de dúvidas, visitar as diversas normas australianas sobre a discriminação laboral.

\subsubsection{Nova Zelândia}

A Nova Zelândia possui uma das mais detalhadas normas antidiscriminatórias do planeta. O Human Rights Act, de $1993^{443}$, com suas posteriores emendas, é o diploma que regula as questões da discriminação laboral naquele país. Trata-se de uma norma extremamente extensa, com um grande rol de definições de condutas discriminatórias. A $2^{\mathrm{a}}$ parte desse diploma trata das discriminações ilegais e, no seu artigo 21 , dos motivos da discriminação. Neste aspecto, a norma é extremamente detalhista e indica uma série de opções aplicáveis aos motivos descritos.

Com efeito, ela menciona a proibição de discriminação por sexo, e assim qualifica as situações de gravidez e situação puerperal. No caso de discriminação por estado civil, a norma enumera diferentes formas de estado civil, como ser solteiro; ser formalmente casado ou unido de fato mediante união estável; viúvo ou viúva de um relacionamento formalizado ou por união estável; separado de um cônjuge que foi casado ou civilmente unido; ou integrante de uma relação de união estável que atualmente se encontre encerrada.

No tópico da religião, menciona o credo religioso, bem como o respeito ao ateísmo ou o respeito a outras religiões. Menciona a cor da pele separadamente da raça, bem como origem étnica ou nacional, na qual incluiu nacionalidade e cidadania. Na situação de deficiência aponta, como tal, deficiência física ou incapacidade física, doenças físicas ou psiquiátricas, deficiências ou limitações de ordem intelectual ou psicológica, qualquer outra anormalidade psicológica, anormalidade da estrutura anatômica ou funcional, dependência de um cão guia, uso de cadeira de rodas ou outro meio equivalente, presença de fatores que podem causar doenças, idade ou tratamento médico. Além disso, a norma ainda menciona como motivos proibidos a opinião política, inclusive a sua falta; a situação empregatícia, mesmo desempregado ou beneficiário do sistema de seguridade social; situação familiar, assim considerada a responsabilidade por cuidados parciais ou totais de crianças e outros dependentes; não ter responsabilidade do cuidado de crianças e outros

\footnotetext{
${ }^{443}$ NOVA ZELÂNDIA. Human Rights Act. Parliamentary Counsel Office - New Zealand Legislation. Disponível em: <http://www.legislation.govt.nz/act/public/1993/0082/latest/viewpdf.aspx>. Acesso em: 25 out. 2009.
} 
dependentes; ser casado ou civilmente unido com alguém, manter união estável com alguma pessoa, ser parente de determinada pessoa; orientação sexual, o que significa ser heterossexual, homossexual, lésbica ou bissexual.

A norma ainda aponta que cada um dos motivos apresentados na referida seção, para os efeitos daquela lei, podem ser considerados em relação à vítima, um parente dela, ou alguém associado a ela por algum motivo. Por outro lado, reconhece que o motivo pode ser atual, efetivamente existiu no passado, ou mesmo suspeito de existir ou ter existido no passado.

O conceito de discriminação laboral adotado pela referida norma consiste em afirmar que ocorre discriminação quando houver recusa ou deixar de conceder emprego a um candidato ou a um empregado qualificado para determinado trabalho específico que esteja disponível. Também não poderá o empregador determinar ao empregado ou ao candidato situações menos favoráveis de trabalho, bem como recusar pensões ou quaisquer outros benefícios, oportunidades de treinamento, promoção e transferências, que estejam disponíveis para candidatos ou empregados de similar condição de emprego nas funções envolvidas dentro do cargo. Ainda aponta a norma que dispensar o trabalhador ou sujeitálo a qualquer situação prejudicial em comparação com outro empregado dentro nas mesmas funções, é considerada como atitude discriminatória. Do mesmo modo, prevê que aposentar o trabalhador ou exigir sua aposentadoria, provocar a aposentadoria, induzir seu pedido de dispensa, por qualquer um dos motivos proibidos, é considerada prática discriminatória. Será também considerada prática discriminatória os atos diferenciadores voltados contra qualquer pessoa que esteja obtendo emprego para outras pessoas ou esteja obtendo emprego a mando de um determinado empregador. E, também, é considerada como prática discriminatória o tratamento diferenciado de qualquer pessoa que esteja procurando emprego, em comparação com outras pessoas que estejam na mesma circunstância ou em situação substancialmente similar à circunstância envolvida.

Após a definição acima, a citada norma aponta um extenso rol de exceções à regra da proteção contra a discriminação laboral, entre elas tripulações de navios e aeronaves neozelandesas, motivos de segurança nacional, trabalhos no exterior, exigências específicas de trabalho no exterior, autenticidade do trabalho executado, genuínas necessidades do trabalho solicitado, algumas motivações para o trabalho doméstico, bem como várias outras situações. 
A norma neozelandesa é, certamente, uma das mais detalhadas e minuciosas sobre a discriminação laboral. Ela propicia ao julgador preciosos elementos para proferir uma decisão mais ajustada com a realidade dos casos que envolvam discriminação.

\subsubsection{Canadá}

O Canadá possui um sistema jurídico centralizado, com um rico corpo de normas antidiscriminatórias e uma destacada jurisprudência sobre o tema.

Sua principal previsão normativa contra a discriminação laboral está no Canadian Human Rights Act, norma inicialmente aprovada em 1977. Ela vem sofrendo sucessivas alterações desde então, com a última ocorrida em agosto de 2009. Esta norma traz uma série de previsões para a normatização dos direitos humanos naquele país. Do artigo $7^{\circ}$ ao $11^{\circ}$ a norma prevê, descritivamente, as situações de discriminação no trabalho, aborda a questão dos formulários de admissão e publicidade para determinado emprego, discriminação por parte de organizações de empregados, prática de salários diferenciados, separação de instalações, exceções e políticas antidiscriminatórias ${ }^{444}$.

Em seu artigo $7^{\circ}$, a norma aponta que é uma prática discriminatória, direta ou indireta, recusar-se a empregar ou não manter empregado com base em um motivo proibido de discriminação. Em seu artigo $8^{\circ}$, aponta a norma que é prática discriminatória utilizar ou circular qualquer formulário de admissão em conexão com o emprego ou sobre a perspectiva de emprego, publicar anúncio ou promover indagações orais ou escritas que impliquem em qualquer limitação, especificação ou preferência baseadas em qualquer motivo proibido de discriminação. Em seu artigo $9^{\circ}$, a norma procura qualificar a discriminação praticada pelas entidades de empregados, procurando abranger várias situações peculiares de discriminação no ambiente sindical.

A referida norma, no seu artigo $10^{\circ}$, prevê a existência de práticas discriminatórias por um empregador, organização de empregados ou de empregadores, para estabelecer uma política ou prática, ou mesmo para obter ajustes, que afete o recrutamento, referência, contratação, promoção, treinamento, aprendizado, transferência ou qualquer outra matéria relativa ao emprego ou sua perspectiva, desde que baseada em um motivo proibido de discriminação e que possa privar um empregado ou um grupo de empregados de

\footnotetext{
${ }^{444}$ CANADÁ. Canadian Human Rights Act. Department of Justice. Laws. Disponível em: <http://laws.justice.gc.ca/eng/H-6/page-2.html\#anchorbo-ga:1_I-gb:s_5>. Acesso em: 25 out. 2009.
} 
oportunidades de emprego. No artigo $10^{\circ}$, a referida norma ainda aponta que será considerada como prática discriminatória estabelecer diferenças remuneratórias entre homens e mulheres, no mesmo estabelecimento, e desempenhando trabalho de igual valor. Mas prevê, expressamente, que não será considerada prática discriminatória entre homens e mulheres estabelecer remuneração distinta baseada em fatores previstos pelas diretrizes estabelecidas pela Comissão Canadense de Direitos Humanos, para que um fator razoável justifique a diferença.

\subsubsection{Estados Unidos da América}

Como já visto anteriormente, em especial no quinto capítulo da presente investigação, a preocupação com a discriminação nos Estados Unidos da América é muito intensa, uma tendência muito comum nos países de colonização britânica. No caso dos EUA, a preocupação é ainda mais destacada pela discriminação racial explícita ocorrida no passado, cujos efeitos ainda persistem com grande intensidade e impulsionam a criação de vários conceitos positivados, doutrinários e jurisprudenciais sobre o tema. Assim como na Austrália, o panorama federativo dos EUA permite o surgimento de inúmeras normas antidiscriminatórias, cujo aprofundamento fica prejudicado pela vastidão do objeto de pesquisa. Serão, portanto, apreciados os conceitos das principais normas antidiscriminatórias federais.

Em primeiro lugar, é importante assinalar que a principal norma federal antidiscriminatória nas relações laborais é o Civil Rights Act, de 1964, doravante tratada como Lei dos direitos civis, tal qual é conhecida naquele país. Esse diploma vem sendo submetido a diversas alterações e emendas desde então. Trata-se de uma norma extremamente abrangente, que possui uma seção específica para o tratamento das discriminações laborais, em sua sétima seção, frequentemente abordada pela jurisprudência como o "Título VII". Esta norma faz a descrição de algumas práticas discriminatórias por parte de empregadores, agências de empregos e sindicatos, no seu artigo 703, inserido dentro do Código Federal sob o número $2000 \mathrm{e}-2^{445}$.

A referida norma aponta como prática discriminatória por parte do empregador a recusa de empregar alguém, discriminar relativamente a indenizações, condições ou

\footnotetext{
${ }^{445}$ ESTADOS UNIDOS DA AMÉRICA. Civil Rights Act. Equal Employment Opportunity Comission. Title VII of the Civil Rights of 1964. Disponível em: <http://www.eeoc.gov/policy/vii.html>. Acesso em: 25 out. 2009.
} 
privilégios de emprego pelos motivos ali expostos. Também aponta como prática discriminatória limitações, segregações ou classificações de empregados ou candidatos a um emprego, de modo que venha a privá-los ou tenda a privá-los das oportunidades de emprego, bem como de qualquer modo afete sua condição de empregado. A citada norma também regula práticas discriminatórias das agências de empregos e das organizações sindicais. Ela ainda reconhece práticas discriminatórias como políticas diferenciadoras na formação, aprendizado ou reciclagem, incluindo-se os programas de treinamento, pelos motivos ali expostos.

O Título VII aponta algumas exceções para a sua aplicação, em especial quando se refere a empresas e empreendimentos voltados para determinadas atividades que dependam da contratação de pessoal integrante das características necessárias para seu desempenho. Também exclui práticas contra membros do partido comunista, situações que envolvam a segurança nacional, sistemas promocionais de mérito por antiguidade, testes de habilidade, a Bona Fide Occupational Qualification - BFOQ, tratamentos preferenciais para nativos americanos e tratamentos diferenciados para balancear percentuais de minorias, entre outras.

Já o artigo 704 (Sec. 2000e-3) também reconhece como práticas discriminatórias promover acusações, testes, represálias pela assistência ou participação em procedimentos de efetivação das leis antidiscriminatórias, imprimir ou publicar notícias ou publicidade indicando preferências proibidas, limitações, especificações ou discriminações, com exceção das qualificações necessárias e da Bona Fide Occupational Qualification $\mathrm{BFOQ}^{446}$.

A lei de discriminação no emprego por motivo de idade conhecida como Age Discrimination of Employment Act - ADEA, de 1967, procura promover a proibição da discriminação por idade nas relações de trabalho e auxiliar empregadores e empregados a encontrar meios para resolver os problemas emergentes do impacto da idade no emprego $^{447}$.

O artigo 623 tem uma extensa redação, com inúmeras disposições sobre a proibição da discriminação por idade, cujos conceitos são bastante interessantes. A norma aponta que há ilegalidade por parte do empregador que, por motivo de idade, deixar de ou recusar-se a

\footnotetext{
${ }^{446}$ Id., loc. cit.

${ }^{447}$ ESTADOS UNIDOS DA AMÉRICA. The Age Discrimination in Employment Act of 1967. Equal Employment Opportunity Comission. Disponível em http://www.eeoc.gov/policy/adea.html. Acesso em 26.10.2009.
} 
contratar, despedir qualquer pessoa, discriminar contra qualquer pessoa com respeito à sua indenização, termos, condições, ou privilégios do emprego. Também o referido artigo aponta que são consideradas práticas discriminatórias limitar, segregar ou classificar seus empregados de qualquer modo que prive ou tenda a privar qualquer pessoa das oportunidades de emprego ou, de outro modo, afetar adversamente seu status como empregado, por motivo de sua idade. Por fim, ainda registra que a redução do valor da remuneração de qualquer empregado, para adequá-la aos termos da norma em questão, também é considerada uma prática discriminatória.

Suas previsões são extremamente extensas e detalhadas, merecendo destacar a consideração, como atitudes discriminatórias por motivo de idade, as práticas de exclusão sindical de discriminação por idade, obstar a participação de empregados em ações investigativas para apuração da discriminação por idade e publicar anúncios ou documentos indicando preferências ou limitações relacionadas à idade. A norma ressalta as exceções de qualificação ocupacional, outros fatores razoáveis, leis externas para trabalho no exterior, sistema de antiguidade de boa-fé, planos de benefício e dispensa por bons motivos, Bona Fide Occupational Qualification - BFOQ, planos de desligamento voluntário que não tenham relação com a norma em questão, procedimentos de união de gerências, centralização de recursos humanos, fusões, planos de benefícios, entre outras.

A lei Americans of Disabilities Act, conhecida pela sigla ADA, foi sancionada em 26 de julho de 1990. Não se trata de uma norma contra a discriminação laboral, mas, sim, aborda as questões relativas às relações de trabalho e, também, discriminação nos transportes, habitação, serviços públicos, acomodações públicas, entre outros temas de crucial importância para os deficientes. A lei ADA é dividida em cinco títulos, sendo que o primeiro trata da discriminação nas relações de trabalho. Os empregadores, os empregados, as agências e os envolvidos são praticamente os mesmos que o Título VII estipula, e sua definição de discriminação merece ser transcrita pela especificidade de sua abrangência:

Art. 12112. [Artigo 102] (a) Regra geral. Nenhum abrangido por este diploma deverá discriminar contra uma pessoa considerada como portadora de deficiência em função de procedimentos para candidatura a um emprego, na contratação, desenvolvimento, ou dispensa de empregados, nas indenizações de empregados, treinamento profissional e outros termos, condições e privilégios do emprego.

(a)Interpretação - Como usado na subseção (a) deste artigo, o termo "discriminar" inclui também: 
1. limitar, segregar ou classificar um candidato a emprego ou empregado de modo que afete adversamente as oportunidades ou a condição do referido candidato ou empregado;

2. participar de um contrato ou organização ou relacionamento que tenha o efeito de subordinar um candidato ou empregado qualificado como portador de deficiência de uma entidade abrangida pelo diploma, a uma discriminação proibida por este sub-capítulo, com uma agência de emprego ou de referência, sindicato profissional ou organização que promova benefícios contratuais para um empregado de uma entidade abrangida, ou uma organização que promova programas de treinamento ou de aprendizado.

3. Utilizando padrões, critérios ou métodos de administração:

(a) que tenham o efeito de discriminação com base na deficiência;

(b) que perpetuem a discriminação de outros que estejam sujeitos ao controle administrativo comum.

4. Excluindo ou, de outro modo, negando iguais empregos ou benefícios para uma pessoa qualificada por causa de sua reconhecida deficiência de uma pessoa com a qual o indivíduo qualificado é conhecido por possuir uma relação ou associação;

5.(a) não provendo razoáveis acomodações para as conhecidas limitações físicas ou mentais, ou de outro modo, que qualificam o indivíduo com uma deficiência, o qual é candidato ou empregado, ao menos que esta entidade abrangida possa demonstrar que a acomodação irá impor um excessivo encargo na operação do negócio exercido pela entidade abrangida; ou

(b) negando oportunidades de emprego a um candidato ou empregado que, por outro meio, qualifique a pessoa com deficiência, se esta recusa é baseada na necessidade desta referida entidade para prover razoável acomodação para os prejuízos físicos ou mentais do empregado ou candidato.

6. Utilizando padrões de qualificação, testes de emprego ou outros critérios de seleção que exponham ou tendam a expor uma pessoa portadora de deficiência ou uma classe de pessoas portadoras de deficiência, a menos que o padrão, teste ou outro critério de seleção, seja utilizado pela entidade abrangida demonstrando como relacionado ao desempenho das necessidades do cargo em questão, e consistente com a necessidade do negócio. ${ }^{448}$

A lei tem uma extensa previsão de discriminação no emprego por motivos de porte de deficiência de qualquer natureza (física ou psíquica). Tal qual verificado na norma australiana, a discriminação de deficientes em face da prestação laboral pressupõe uma regulação muito detalhada e agrega um ponto comum às normas de discriminação por deficiência: a questão da acomodação do deficiente e os esforços que o empregador deverá

\footnotetext{
${ }^{448}$ ESTADOS UNIDOS DA AMÉRICA. The Americans with Disabilities Act. Equal Employment
} Opportunity Comission. Disponível em: <http://www.eeoc.gov/policy/ada.html>. Acesso em: 26 out. 2009. 
realizar para que seja possível a relação de emprego do deficiente. Um ponto interessante do conceito de discriminação da referida norma é o critério de efeito de subordinação do trabalhador deficiente a uma determinada entidade empregadora ou abrangida pela norma em questão. É uma novidade baseada na doutrina verificada no $2^{\circ}$ capítulo, item 2.6, que pretende reprimir tratamentos que venham a promover situações de subordinação social.

As normas federais norte-americanas sobre a discriminação laboral recebem, constantemente, emendas em suas definições, agregando às suas descrições situações peculiares da rica casuística daquele país. Assim, as normas não possuem conceitos sintéticos, mas vão agregando ações discriminatórias específicas e excludentes, tornandose bastante extensas e detalhistas, diferentemente de outros países que preferem conceitos mais sintéticos, em especial os europeus.

\subsubsection{Espanha}

A legislação antidiscriminatória espanhola segue os traços das diretivas Europeias 2000/43, 2000/78 e 2002/73, já referidas no início deste capítulo. Tais normas de origem comunitária induziram a uma nova regulação das normas antidiscriminatórias dos países europeus. As novas diretivas definem os conceitos de discriminação direta, discriminação indireta, assédio e assédio sexual de forma descritiva, com uma redação relativamente simples. No caso espanhol, a tendência foi seguida, definindo, a Lei Orgânica 3/2007449, relativamente à igualdade entre homens e mulheres, os seguintes conceitos:

Artigo 6. Discriminação direta e indireta.

1. É considerada como discriminação direta por razão de sexo a situação em que se encontra uma pessoa que seja, tenha sido, ou pudera ser tratada, em atenção a seu sexo, de maneira menos favorável que outra em situação comparável.

2. É considerada como discriminação indireta por razão de sexo a situação em que uma disposição, critério ou prática aparentemente neutra põe pessoas de um sexo em desvantagem particular a respeito a pessoas de outro sexo, salvo que a referida disposição, critério ou prática podem jusitificar-se objetivamente em atenção a uma finalidade legítima e que os meios para alcançar a referida finalidade sejam necessários e adequados.

3. Em qualquer caso, se considera discriminatória toda a ordem para discriminar, direta ou indiretamente, por razão de sexo.

\footnotetext{
${ }^{449}$ ESPANHA. Boletin Oficial del Estado. Ley Orgânica no $\mathrm{n}^{\text {o }}$ 3/2007. Disponível em:
} <http://www.boe.es/boe/dias/2007/03/23/pdfs/A12611-12645.pdf>. Acesso em: 25 out. 2009. 
No caso da norma acima, ela traz as definições de discriminação direta ou indireta, bem como a ordem para realizar uma discriminação. $\mathrm{O}$ conceito de discriminação direta adotado pela norma espanhola, derivado da norma Europeia, possui um formato simplificado, baseado no tratamento menos favorável que o tratamento dispensado a outra pessoa, em situação comparável. Já no caso da discriminação indireta, a norma menciona sobre a desvantagem que determinada medida, ainda que seja neutra ou não intencional, possa provocar sobre uma pessoa ou determinado grupo, desde que não justificável.

Por outro lado, a definição de assédio sexual e assédio por razão de sexo merece um tópico isolado da norma, cuja definição merece ser transcrita, diante da importância de sua definição:

Artigo 7. Assédio sexual e assédio por razão de sexo. 1. Sem prejuízo do estabelecido no Código Penal aos efeitos desta lei constitui assédio sexual qualquer comportamento verbal ou físico de natureza sexual, que tenha o propósito ou produza efeitos de atentar contra a dignidade de uma pessoa, em particular quando é criado um ambiente intimidatório, degradante ou ofensivo.

2. Constitui assédio por razão de sexo qualquer comportamento realizado em função do sexo de uma pessoa, com o propósito ou o efeito de atentar contra a sua dignidade e de criar um ambiente intimidatório, degradante ou ofensivo.

3. Se considera em todo o caso como discriminatórios o assédio sexual e o assédio por razão de sexo.

4. $O$ condicionamento de um direito ou de uma expectativa de direito a aceitação de uma situação constitutiva de assédio sexual ou de assédio por razão de sexo se considerará também ato de discriminação por razão de sexo.

A norma em questão faz uma definição bastante precisa do que seja assédio sexual e assédio por sexo, bem como formas reconhecidas de assédio sexual, ao reprimir tanto a conduta ativa da ameaça como, também, a percepção de vantagens obtidas em face do assédio praticado.

Por fim, a referida norma ainda descreve em seu artigo $8^{\circ}$, de forma simples, mas com extrema clareza que, qualquer trato desfavorável em função da gravidez será reconhecido como discriminação por gravidez ou maternidade. E, no seu artigo $9^{\circ}$, prevê que qualquer represália implicará em igual consideração de atitude discriminatória.

Artigo 8. Discriminação por gravidez ou maternidade.

Constitui discriminação direta por razão de sexo todo trato desfavorável às mulheres relacionados com a gravidez ou à maternidade. 
Artigo 9. Garantia frente a represálias.

Também se considerará discriminação por razão de sexo qualquer trato adverso ou efeito negativo que se produza contra uma pessoa como consequência da apresentação, por sua parte, de queixa, reclamação, denúncia, demanda ou recurso, de qualquer tipo, destinados a impedir sua discriminação e a exigir o cumprimento efetivo do princípio de igualdade de trato entre mulheres e homens.

A referida norma espanhola advém das definições do direito comunitário europeu, atendendo, principalmente, à descrição da Diretiva 2002/73. Outro ponto interessante da lei é a expressa referência da ordem da discriminação como prática discriminatória, o que traduz em uma importante base positivada para punições mais severas da discriminação operada por terceiros a mando do empregador.

$\mathrm{Na}$ Espanha, a Lei 51/2003 450 aborda a igualdade de oportunidades e a discriminação das pessoas deficientes, seguindo as determinações da Diretiva 2000/78, da União Europeia, sobre o trato de pessoas com deficiência. A conceituação de discriminação é semelhante à da Lei 3/2007, com a definição precisa do que seja discriminação direta, indireta e o assédio. O conteúdo descritivo da norma é semelhante ao da Diretiva 2000/78, e das demais normas europeias, ou seja, receber tratamento menos favorável que o destinado a outra pessoa.

\subsubsection{Portugal}

O conceito adotado pela lei portuguesa atualmente vigente, o Código do Trabalho atualizado pela Lei $7 / 2009^{451}$, é aquele utilizado em diversos países da União Europeia, com algumas peculiaridades. Essa lei adota os critérios de discriminação direta, discriminação indireta, trabalho igual e trabalho de igual valor, estabelecidos no artigo 23 daquele diploma. $\mathrm{O}$ mesmo artigo também considera a ordem para a discriminação como medida discriminatória.

O artigo 24 traz uma descrição detalhada de todas as situações possíveis de discriminação no acesso a emprego e no trabalho, como na promoção, formação e igualdade de oportunidades, não permitindo privilégios, benefícios, prejuízos ou privações

\footnotetext{
${ }^{450}$ ESPANHA. Boletin Oficial del Estado. Ley Orgânica $\mathrm{n}^{\circ}$ 51/2003. Disponível em: <http://www.boe.es/boe/dias/2003/12/03/pdfs/A43187-43195.pdf>. Acesso em: 25 out. 2009.

${ }^{451}$ PORTUGAL. Código do Trabalho. Atualizado pela Lei 7 de 12 de fevereiro de 2009. Diário da República Eletrônico. Disponível em: <http://dre.pt/pdf1sdip/2009/02/03000/0092601029.pdf>. Acesso em: 26 out. 2009.
} 
de direitos ou isento de qualquer dever em face dos vinte e um motivos ali listados de forma expressamente exemplificativa. No entanto, a citada norma aponta expressamente que a proibição respeita os critérios de seleção e as condições de contratação, o acesso a todos os tipos de orientação, formação e reconversão profissionais de qualquer nível, incluindo-se a aquisição de experiência prática. A norma também menciona o respeito à retribuição e outras prestações patrimoniais, promoção e critérios de seleção, filiação e participação em estruturas de representação coletiva ou qualquer outra organização.

O artigo 25 da referida Lei indica que estão excluídas como discriminatórias as situações do comportamento baseado em fator de discriminação que constitua um requisito justificável e determinante para o exercício da atividade profissional, em virtude da sua natureza em causa ou do contexto da sua execução, devendo o objetivo ser legítimo e o requisito proporcional. Também exclui a situação das diferenças de tratamento baseadas na idade, que sejam necessárias e apropriadas à realização de um objetivo legítimo, designadamente de política de emprego, mercado de trabalho ou formação profissional. Tais autorizações devem ser revistas periodicamente. $\mathrm{O}$ mesmo artigo ainda relata que são aplicáveis para as situações de gravidez, trabalhadora puérpera ou lactante, licenças por parentalidade ou faltas para assistência a menores, coibindo os atos de retaliação.

O artigo 29 da referida lei traz a definição de assédio e assédio sexual, nos mesmos termos das diretivas europeias sobre o tema, só que não relacionada a qualquer motivo, por se tratar de uma norma geral do direito do trabalho. No seu artigo 30, a norma prevê uma série de práticas discriminatórias em função do sexo, como ofertas de emprego ou publicidades de pré-seleção ou recrutamento, que não poderão conter referências sobre o sexo. A norma também menciona um critério de preferencialidade, em favor do sexo de menor representação, em situações de formação profissional dirigida a profissão predominantemente exercida por trabalhadores de outro sexo.

$\mathrm{O}$ artigo 32 exige o registro de todos os processos de recrutamento pelo prazo de cinco anos, com um rol específico de elementos documentados e relatados sobre o sexo dos convidados para o preenchimento de lugares; anúncios de oferta de emprego; número de candidaturas para apreciação curricular; número de candidatos presentes em entrevistas de pré-seleção; número de candidatos aguardando ingresso; resultados de testes ou provas de admissão ou seleção; e balanços sociais relativos a dados que permitam analisar a existência de eventual discriminação de pessoas de um dos sexos no acesso ao emprego, formação e promoção profissionais e condições de trabalho. 
Não obstante a legislação portuguesa manter estreitíssima relação com o direito comunitário a respeito da proibição da discriminação, ela opta em certos termos, por uma legislação bastante detalhada e precisa. A legislação portuguesa não somente se preocupa com a proibição da discriminação, mas, sim, formula exigências ao empregador para que este tenha como demonstrar em Juízo, quando for acionado sobre uma prática discriminatória.

\subsubsection{Brasil}

No Brasil, somente existe uma norma antidiscriminatória laboral descritiva, a redação do artigo 373-A dada pela Lei 9.799/99 ${ }^{452}$, que acrescentou ao artigo 373 original da Consolidação das Leis do Trabalho o item “A”. Essa norma não menciona a expressão discriminação somente no seu título; no entanto, menciona uma série de condutas discriminatórias como proibidas, na seguinte forma:

Art. 373- A. Ressalvadas as disposições legais destinadas a corrigir as distorções que afetam o acesso da mulher ao mercado de trabalho e certas especificidades estabelecidas nos acordos trabalhistas, é vedado:

I - publicar ou fazer publicar anúncio de emprego no qual haja referência ao sexo, à idade, à cor ou situação familiar, salvo quando a natureza da atividade a ser exercida, pública e notoriamente, assim o exigir;

II - recusar emprego, promoção ou motivar a dispensa do trabalho em razão de sexo, idade, cor, situação familiar ou estado de gravidez, salvo quando a natureza da atividade seja notória e publicamente incompatível;

III - considerar o sexo, a idade, a cor ou situação familiar como variável determinante para fins de remuneração, formação profissional $e$ oportunidades de ascensão profissional;

IV - exigir atestado ou exame, de qualquer natureza, para comprovação de esterilidade ou gravidez, na admissão ou permanência no emprego;

$V$ - impedir o acesso ou adotar critérios subjetivos para deferimento de inscrição ou aprovação em concursos, em empresas privadas, em razão de sexo, idade, cor, situação familiar ou estado de gravidez:

VI - proceder o empregador ou preposto a revistas íntimas nas empregadas ou funcionárias.

Parágrafo único. $O$ disposto neste artigo não obsta a adoção de medidas temporárias que visem ao estabelecimento das políticas de igualdade entre homens e mulheres, em particular as que se destinam a corrigir as

\footnotetext{
${ }^{452}$ BRASIL. Lei 9.799/1999. Presidência da República. Legislação. Disponível em:
} <http://www.planalto.gov.br/ccivil_03/Leis/L9799.htm>. Acesso em: 26 out. 2009. 
distorções que afetam a formação profissional, o acesso ao emprego e as condições gerais de trabalho da mulher.

Não se trata de norma específica para atuar como proibitória geral da discriminação laboral, senão atender a uma necessidade pontual, que seria regular as discriminações por motivo de gênero. No entanto, por não existir qualquer outra que regule a discriminação laboral, esta norma acaba por ficar isolada no panorama jurídico laboral, sendo a única referência descritiva da discriminação laboral vigente no país, além da Convenção 111 da OIT. Tal situação é lamentável e demonstra claramente a carência legislativa em termos da discriminação laboral, principalmente em comparação com as normas antidiscriminatórias internas de outros países.

\subsection{Conceitos doutrinários}

Se nos sub-capítulos anteriores foi possível constatar um grande número de diferentes conceitos sobre a discriminação, em termos doutrinários, a diversidade de conceitos não deixa de ser diferente. É necessário destacar também que, algumas vezes, os conceitos doutrinários são voltados para definir discriminação por determinada motivação e abandonam um conceito geral.

Assim, é necessária a promoção de uma distinção entre os conceitos, distinguindoos em um primeiro grupo compostos por conceitos doutrinários gerais de discriminação, emanados em outros ramos do direito, em especial no direito internacional e direito constitucional. O segundo grupo será composto pelas definições de discriminação dentro das relações laborais, compreendendo-se os conceitos genéricos de discriminação laboral.

\subsubsection{Conceitos doutrinários de outros ramos do direito}

Neste sub-capítulo, a investigação irá tratar dos conceitos doutrinários de outros ramos do direito, em especial do direito internacional e do direito constitucional. Tais conceitos são importantíssimos para formar um alicerce sólido, voltado a edificar um conceito de discriminação nas relações do trabalho.

O primeiro conceito de discriminação a ser analisado vem do direito internacional e é da célebre obra de Marc Bossuyt, que estabelece em suas conclusões que a 
discriminação, para o direito internacional, é a diferenciação arbitrária ${ }^{453}$, definindo que o arbítrio ocorre quando é suficientemente demonstrado que a diferença de tratamento é fundada sobre um motivo que não é relevante para o direito subjetivo referido ${ }^{454}$.

Trata-se de um conceito extremamente interessante para o direito do trabalho, na medida em que a questão do arbítrio é matéria fundamental a ser analisada nas discriminações laborais, em face do princípio das justificativas para uma diferenciação laboral. O conceito de Bossuyt põe lado a lado o motivo e uma eventual justificação que possa vir com ele, como elementos nucleares da discussão sobre a existência de uma conduta discriminatória.

Warwick McKean destaca que, para o direito internacional, as discriminações devem ser compreendidas como tão somente distinções não razoáveis, arbitrárias ou injustas, sem incluir medidas de proteção especial para determinados grupos ${ }^{455}$.

O conceito do jurista neozelandês é unicamente centrado na noção da justificação da distinção e abandona, definitivamente, qualquer noção de motivo para a discussão da discriminação, como ele ressalta em outra passagem ${ }^{456}$.

Por seu turno, Danièle Lochak adota um conceito mais simples, apontando que o significado atual de discriminação explica um comportamento ou um ato que tende a distinguir um grupo humano ou uma pessoa das outras, de forma prejudicial. E no mesmo texto, um pouco mais adiante, assevera que a discriminação é a distinção ou a diferença de tratamento ilegítima - ilegítima por ser arbitrária e proibida por ser ilegítima ${ }^{457}$.

A jurista francesa especializada em direitos humanos apresenta um conceito bastante genérico, no entanto é também baseado na questão do arbítrio e sua relação com o motivo da discriminação. A noção especial do conceito de Lochak é exatamente a descrição de exclusão de determinada pessoa ou grupo das demais, recebendo um tratamento desfavorável por conta desta distinção.

Luigi Ferrajoli assinala que as discriminações são as desigualdades antijurídicas que importam em tratamento desigual das diferenças tuteladas e valorizadas pelo princípio da igualdade estabelecido no artigo 3.1 da Constituição italiana, e que são produtos

\footnotetext{
${ }^{453}$ BOSSUYT, Marc. op. cit., p. 221.

${ }^{454}$ Id. Ibid., p. 222.

${ }^{455}$ MCKEAN, Warwick. op. cit., p. 288.

${ }^{456}$ Id. Ibid., p. 287.

${ }^{457}$ LOCHAK, Daniele. op. cit., p. 778.
} 
ilegítimos dos obstáculos de ordem social e cultural previstos no artigo 3.2 da referida Constituição, e que limitam de fato a liberdade e a igualdade dos cidadãos ${ }^{458}$.

O conceito de Ferrajoli é realizado com lastro no texto da Constituição italiana, sendo que o artigo 3.1. do texto constitucional diz expressamente que todos os cidadãos são detentores da mesma dignidade social e são iguais perante a lei, sem distinções pelos motivos ali apontados ${ }^{459}$. Já o artigo 3.2 fala da obrigação da República italiana de remover os obstáculos de ordem econômica e social que limitam de fato a liberdade e a igualdade dos cidadãos, impedindo o pleno desenvolvimento da pessoa humana e a efetiva participação de todos os trabalhadores na organização política, econômica e social daquele país.

Claramente, o conceito de Ferrajoli é fundado no referido texto constitucional italiano, que possui uma feliz redação no sentido de que a desigualdade real ataca não somente o direito de um tratamento igual, mas também a liberdade, e prejudica o desenvolvimento da pessoa humana.

Roger Raupp Rios, por sua vez, estabelece que discriminação é qualquer distinção, exclusão, restrição ou preferência que tenha o propósito ou o efeito de anular ou prejudicar o reconhecimento, gozo ou exercício em pé de igualdade de direitos humanos e liberdades fundamentais nos campos econômico, social, cultural ou em qualquer campo da vida pública ${ }^{460}$.

O conceito do referido constitucionalista possui um contexto bastante abrangente em relação às definições dos atos discriminatórios, bem como de seus efeitos; no entanto, não se refere ao motivo envolvido, bem como não adentra à questão da justificação dos atos diferenciadores. Trata-se de um conceito muito semelhante ao definido pela Convenção para eliminação de todas as formas de discriminação contra a mulher, das Nações Unidas, que foi positivado e muito bem elaborado.

Jesús Rodríguez Zepeda formula um conceito sobre a discriminação, apontando que a não discriminação é o direito de toda pessoa ser tratada de maneira homogênea, sem exclusão, distinção ou restrição arbitrária, de tal modo que seja possível o aproveitamento

\footnotetext{
${ }^{458}$ FERRAJOLI, Luigi. Igualdad y diferencia: derechos y garantias: la ley del más débil, cit., p. 83.

${ }^{459}$ ITÁLIA. Costituzione della Repubblica Italiana. Senato della Repubblica. Disponível em: $<$ http://www.senato.it/documenti/repository/costituzione.pdf>. Acesso em 27 out. 2009.

${ }^{460}$ RIOS, Roger Raup. Direito da antidiscriminação: discriminação direta, indireta e ações afirmativas, cit., p. 20 .
} 
de seus direitos e liberdades fundamentais e o livre acesso às oportunidades socialmente disponíveis $^{461}$.

O conceito do filósofo político mexicano é extremamente interessante e deve ser muito bem observado. Com efeito, Zepeda assinala, inicialmente, a existência de um direito a não ser discriminado e aponta as principais ações de uma discriminação. Por fim, aborda os efeitos da discriminação de uma forma muito clara, abrangendo decisivamente os resultados da prática discriminatória, com uma aplicação de extrema utilidade para o direito do trabalho, na medida em que converge com os objetivos da Convenção 111 da OIT.

Os conceitos acima são extremamente variados, mas podem apresentar boas noções gerais para auxiliar a formulação de um conceito sobre a discriminação nas relações laborais.

\subsubsection{Conceitos doutrinários no direito do trabalho}

Os conceitos sobre discriminação no direito do trabalho possuem algumas diferenças daqueles gerais de discriminação, na medida em que são voltados para a realidade laboral, que possui algumas diferenças específicas com os demais conceitos discriminatórios. Convém lembrar que o direito laboral foi o precursor na definição da discriminação no direito internacional, mediante a Convenção 111 da OIT. Inicialmente, será feita uma passagem por conceitos doutrinários domésticos, para depois ser realizada a análise de alguns conceitos doutrinários do exterior.

Amauri Mascaro Nascimento prefere utilizar a definição de discriminação dada pela Convenção 111 da OIT, esclarecendo que é qualquer tratamento com distinção, exclusão ou referência embasada em motivo de raça, cor, sexo, opinião política, ascendência nacional ou origem social, que tenha por fim anular ou alterar a igualdade de oportunidades no emprego. Ressalta o jurista que, havendo justificações como as exigências necessárias para determinado emprego ou como medida especial de proteção do trabalhador, as medidas diferenciadoras não serão consideradas como discriminação ${ }^{462}$.

\footnotetext{
${ }^{461}$ RODRÍGUEZ ZEPEDA, Jesús. Una idea teórica de la no discriminación. Instituto de Investigaciones Jurídicas. Universidad Autónoma de México. Biblioteca Juridica Virtual. Disponível em: <http://www.bibliojuridica.org/libros/5/2312/7.pdf>. Acesso em: 27 out. 2009.

${ }^{462}$ NASCIMENTO, Amauri Mascaro. Princípios do direito do trabalho e direitos fundamentais do trabalhador. Revista LTr, São Paulo, ano 67, n. 8, p. 908, ago. 2003.
} 
Alice Monteiro de Barros traz um conceito voltado para a discriminação feminina no entanto, passível de ajustes para aplicações em outros ramos do direito laboral. A autora mineira aponta que a discriminação pressupõe um tratamento diferenciado comparativamente desfavorável, que nem sempre advém de preconceito contra as mulheres, mas do fato de que sua contratação poderá elevar os custos da empresa ${ }^{463}$.

Jorge Luiz Souto Maior ressalta que a palavra discriminação não tem efeito pejorativo, somente assim apontando que o modo não pejorativo seria o de distinguir coisas, pessoas, ideias, em conformidade com suas características próprias e mediante critérios bem definidos $^{464}$. Aponta o jurista que o problema existe quando é feita uma discriminação de pessoas quando esta não poderia ser feita ou, quando fosse necessária e não foi feita ${ }^{465}$.

O conceito de Souto Maior é interessante na medida em que toma como base a história da expressão discriminação, que nunca foi pejorativa, mas somente passa a ser quando é proibida. Por outro lado, a noção apontada pelo mencionado jurista revela que um ato discriminatório pode ser o tratamento diferenciado de iguais ou o tratamento igual de diferentes, sem contar a explícita possibilidade da constituição de diferenciações promocionais.

Maurício Godinho Delgado afirma que discriminação é a conduta pela qual é negada à pessoa tratamento compatível com o padrão jurídico assentado para a situação concreta por ela vivenciada ${ }^{466}$. O conceito do jurista mineiro é bastante interessante ao ressaltar um padrão jurídico assentado que deverá ser observado para cada pessoa. O referido conceito tem muito mais foco na sua antijuridicidade do que propriamente procurar descrever o fenômeno discriminatório.

Rodolfo Pamplona Filho discorre que a discriminação consiste no tratamento desigual ou preferencial de alguém, prejudicando outrem ${ }^{467}$. O conceito do ilustre jurista baiano revela uma situação muitas vezes despercebida pelas discussões sobre a

\footnotetext{
${ }^{463}$ BARROS, Alice Monteiro de. Discriminação no emprego por motivo de sexo. In: VIANA, Márcio Túlio; RENAULT, Luiz Otávio Linhares (Coords.). Discriminação. São Paulo: LTr, 2000. p. 40.

${ }^{464}$ MAIOR, Jorge Luiz Souto. O direito do trabalho e as diversas formas de discriminação. Revista TST, Brasília, v. 68, n. 2, p. 97, abr/jun 2002.

${ }^{465}$ Id., loc. cit.

${ }^{466}$ DELGADO, Maurício Godinho. Proteções contra discriminação na relação de emprego. In: VIANA, Márcio Túlio; RENAULT, Luiz Otávio Linhares (Coords.). Discriminação. São Paulo: LTr, 2000. p. 97.

${ }^{467}$ PAMPLONA FILHO, Rodolfo. Orientação sexual e discriminação no emprego. Revista do Instituto Goiano de Direito do Trabalho, ano 8, n. 9, p. 54, nov. 2001.
} 
discriminação - a promoção indevida de alguém em detrimento dos demais, o que merece ser destacado.

José Cláudio Monteiro de Brito Filho aponta que discriminar é atentar contra o princípio da igualdade, muito embora não só contra ele, como também contra o princípio da dignidade do ser humano ${ }^{468}$. A definição do jurista paraense será extremamente importante para a definição de um conceito sobre a discriminação, mormente quando a jurisprudência sul-africana e canadense vêm caminhando no mesmo sentido.

No direito laboral externo, as definições do que seja discriminação também são bastante variadas.

Guilherme Machado Dray aponta que discriminar, em termos da formação de um contrato de trabalho, consistirá na distinção, exclusão ou preferência feita por uma entidade empregadora em detrimento ou em favor de algum trabalhador, em função dos fatores de diferenciação categoriais, com o objetivo de comprometer ou destruir o reconhecimento, o gozo ou o exercício de direitos do lesado em condições de igualdade e desde que dela resulte, por esse motivo, a destruição ou o desvirtuamento do princípio geral da igualdade de oportunidades no acesso ao emprego ${ }^{469}$. Trata-se de um conceito particularmente extenso e que empresta uma base conceitual da Convenção 111 da OIT, mas que nada aborda sobre a questão da justificação do ato diferenciador.

Laetitia Bonnard-Plancke e Pierre-Yves Verkindt estabelecem um conceito de discriminação laboral pelo qual um grupo social ou uma pessoa (em função de pertencer a este grupo) recebem tratamento menos favorável. Os autores apontam que, no direito francês, o conceito sobre a discriminação é de difícil assentamento, no entanto traz a ideia de um tratamento preferencialmente fundado sobre critérios proibidos, destinados a certas categorias ou certos grupos sociais, entrando em choque com a base da democracia, que é a igualdade de direitos entre todos os homens ${ }^{470}$. Trata-se de um conceito mais simplificado, na esteira daqueles estabelecidos pelas diretivas europeias dos anos 2000 e 2002 e que de modo geral influenciaram sobremaneira a doutrina europeia no que tange aos conceitos descritivos da discriminação, pela fórmula do tratamento menos favorável.

\footnotetext{
${ }^{468}$ BRITO FILHO, José Cláudio Monteiro de. Discriminação no trabalho. São Paulo: LTr, 2002. p. 42.

${ }^{469}$ DRAY, Guilherme Machado. op. cit., p. 36.

${ }^{470}$ BONNARD-PLANCKE, Laetitia; VERKINDT, Pierre-Yves. La lute contre la discrimination syndicale Millésime 2005. Droit Social, Paris, n. 4, p. 393, abr. 2006.
} 
Antoine Lyon-Caen, por seu turno, afirma que a discriminação é uma distinção ilegítima entre duas pessoas ou dois grupos quando a razão da distinção for juridicamente proibida $^{471}$. Marie Thérèse Lanquetin estabelece uma definição sobre a discriminação, no sentido de que é uma distinção, exclusão, preferência ou restrição, que pode ser traduzida como uma diferença de tratamento, fundada em um motivo proibido, que tem por efeito ou por objetivo levar uma violação ao princípio da igualdade ${ }^{472}$.

Luis Gabriel Matínez Rocamora assinala que o conceito de discriminação, apesar de possuir certa elasticidade, possui dois elementos definidores: é constituído por uma diferença de trato com respeito a alguém e, depois, por fundamento ou apoio em determinados motivos ou razões específicas, não considerando a questão intencional como relevante ${ }^{473}$.

Julio J. Martínez Vivot descreve que existe discriminação laboral quando, arbitrariamente, é efetuada uma distinção, exclusão, restrição que afeta o direito igualitário que tem toda a proteção das leis, e, também, quando, injustificadamente, é afetada uma pessoa, um grupo de pessoas ou uma comunidade, no exercício de algumas das liberdades fundamentais expressadas pela Constituição Nacional Argentina pelos motivos ali apontados, ou de qualquer natureza possível ${ }^{474}$.

A definição do jurista argentino é uma das mais completas e precisas definições de discriminação laboral, posto que se atenta para as situações das ofensas à igualdade de trato e às liberdades fundamentais de um ser humano ou de uma comunidade.

Por fim, cabe apontar a definição de Eduardo Goldstein que, ao concluir sobre o que seja discriminação, assinala que nas relações laborais, tanto o empregador como os trabalhadores em respeito àquele e a seus iguais, têm vedado qualquer tipo de trato, diferenciação, descarte ou favoritismo baseado em motivos ilícitos e, entre eles, a diferenciação motivada pelas razões ali enumeradas ${ }^{475}$. A definição conceitual de Goldstein chama a atenção pela obrigação imposta não somente ao empregador, mas também a todos os trabalhadores do mesmo empregador e a seus semelhantes no ambiente

\footnotetext{
${ }^{471}$ LYON-CAEN, Antoine. op. cit., p. 73.

${ }^{472}$ LANQUETIN, Marie-Thérèse. La discrimination à raison du sexe en droit international et communautaire, cit., p. 807.

${ }^{473}$ MARTÍNEZ ROCAMORA, Luis Gabriel. op. cit., p. 166.

${ }^{474}$ MARTÍNEZ VIVOT, Julio J. La discriminación laboral: despido discriminatorio. Buenos Aires:Ciudad Argentina; Universidad del Salvador, 2000. p. 27.

${ }^{475}$ GOLDSTEIN, Eduardo. La discriminación racial por origen nacional y etnia en las relaciones laborales. Montevideo: Fundación de Cultura Universitaria, 2009. p. 68.
} 
de trabalho. É uma preocupação importantíssima, mas que raramente é mencionada nas obras que tratam da discriminação laboral, levando para a situação da discriminação entre trabalhadores, situação extremamente comum e complexa.

Analisados os conceitos mais significativos da discriminação dentro da doutrina laboral, foi possível constatar com certa facilidade a diversidade dos conceitos, bem como a sua dinamicidade. Como aponta Jorge Cavalcanti Boucinhas Filho, conceituar discriminação não representa tarefa das mais simples, apesar de assim parecer, a primeira vista $^{476}$. Manuela Tomei aponta que o conceito de discriminação tem perfis brumosos, podendo surgir discrepâncias sobre o significado da igualdade e as suas consequências nos planos normativo e político ${ }^{477}$.

\subsection{Conceitos jurisprudenciais}

A jurisprudência, sem sombra de dúvidas, é a fonte mais rica de conceitos sobre discriminação laboral em todo o planeta. É facilmente constatada uma ampla evolução do conceito de discriminação laboral na jurisprudência de muitos países e de tribunais internacionais, com destaque para o Tribunal da Comunidade Europeia, em particular, conceitos esses que, efetivamente, moldaram as normas antidiscriminatórias. A riqueza da jurisprudência sobre a discriminação laboral é tão grande que comportaria uma investigação exclusiva somente para destacar alguns conceitos jurisprudenciais que foram incorporados nas normas antidiscriminatórias posteriores.

O exemplo da discriminação indireta no direito europeu é patente. Através de uma jurisprudência audaciosa e atenta para a realidade feminina, a Corte da Comunidade Europeia cunhou uma nova forma de discriminação. Ela foi incorporada não somente em várias diretivas daquela comunidade, como ganhou ares planetários para influenciar várias outras normas antidiscriminatórias laborais, como no caso da Austrália e Nova Zelândia.

Infelizmente, as limitações da presente investigação somente autorizam o destaque de algumas decisões, posto que o universo de conceitos de discriminação cunhados pelas decisões judiciais é extremamente amplo. Os conceitos serão classificados pelos respectivos tribunais prolatores das decisões.

\footnotetext{
${ }^{476}$ BOUCINHAS FILHO, Jorge Cavalcanti. Discriminação por sobrequalificação. São Paulo: LTr, 2009.

${ }^{477}$ TOMEI, Manuela. Análises de los conceptos de discriminación y de igualdade $\mathrm{n}$ el trabajo. Revista Internacional del Trabajo, Genebra, v. 122, n. 4, p. 457, 2003.
} 


\subsubsection{Suprema Corte dos Estados Unidos da América}

Sem sombra de dúvida, a Suprema Corte dos Estados Unidos da América foi, certamente, uma das grandes precursoras dos conceitos jurisprudenciais sobre a discriminação laboral, inclusive formulando teorias amplamente aceitas, não somente pela doutrina daquele país, como externamente. O período da Corte Warren, assim conhecido pela direção do Chief Justice Earl Warren, compreendido entre 1953 e 1969, bem como o período subsequente, comandado pelo Chief Justice Warren Earl Burger, entre 1969 e 1986, foram marcados por uma interpretação audaciosa da cláusula de igual proteção dos cidadãos, prevista pela Emenda 14 da Constituição norte-americana. É necessário recordar que aquela Corte já havia decretado o fim do regime segregacionista nas escolas, em 1954, com a célebre decisão do caso Brown v. Board of Education. Posteriormente, aquela Corte tomou importantes decisões que tiveram e ainda têm um grande impacto naquele país.

A Corte Warren abriu espaço para uma compreensão mais atualizada da cláusula de igualdade estabelecida na Emenda 14 da Constituição norte-americana ${ }^{478}$, com importantes precedentes em favor do igual tratamento dos norte-americanos, especialmente na proteção dos negros, como no caso Loving v. Virginia. A Corte Burger, por seu turno, foi extremamente importante ao interpretar o título VIII do Civil Rights Act - a Lei federal que regulou as questões sobre a discriminação laboral naquele país. O período Burger foi caracterizado pelo que foi chamado de ativismo judicial, sofrendo pesadas críticas de vários doutrinadores de peso ${ }^{479}$, ao afirmarem que a Corte teria extrapolado seus limites de atuação jurisdicional, especialmente no célebre caso Roe v. Wade, de 1974, que entendeu como lícita a prática do aborto, ainda que dentro de certas condições.

Três decisões merecem destaque como fontes de conceitos sobre a discriminação laboral, propugnando algumas teorias discriminatórias. As referidas teorias construídas pela jurisprudência são amplamente reconhecidas pela doutrina daquele país e referenciadas por diversos autores sobre a discriminação laboral por todo o mundo.

A primeira delas, talvez a mais importante decisão daquela Corte sobre a discriminação laboral e uma das mais importantes em todo o mundo, é o caso Griggs v.

\footnotetext{
${ }^{478}$ TRIBE, Laurence H. op. cit., p. 1476. O referido autor cita na nota $\mathrm{n}^{\mathrm{o}} 12$ que a decisão foi amplamente apoiada por autoridades modernas, incluindo o estudo de sete sociólogos.

${ }^{479}$ APPIO, Eduardo. op. cit., p. 162-165.
} 
Duke Power $\mathrm{Co}^{480}$. Trata-se de uma ação movida por empregados negros contra uma empresa geradora de energia, com base no título VIII da Lei de direitos civis, questionando alguns procedimentos da empresa como a exigência de diplomas de ensino médio para determinadas funções, ou a aprovação em testes de inteligência como condições de emprego dentro daquela unidade. Tais exigências não eram relacionadas ou dirigidas ao desempenho de determinadas atividades, apontando os autores que os resultados dos procedimentos adotados, ainda que não contivessem propósitos discriminatórios, estariam limitando o acesso dos trabalhadores negros a postos mais elevados.

A decisão da Corte afirmou que a Lei dos direitos civis requer a eliminação de todas as barreiras artificiais, arbitrárias e desnecessárias ao emprego, que venham a discriminar de forma injusta com base na raça. A decisão destacou que se uma prática de emprego que exclua negros não possa ser demonstrada como relacionada ao desempenho do emprego, deve ser proibida, não obstante desprovida de intenção discriminatória. Joaquim Barbosa Gomes expõe que a referida decisão promoveu o reconhecimento da discriminação de resultados ou estrutural ${ }^{481}$ e reconheceu a teoria do Disparate Impact, ou seja, práticas de empregadores que sejam neutras, despidas de conteúdo ou intenção discriminatória, se demonstradas como prejudiciais a determinado grupo e não possuírem relação com as necessidades do emprego, devem ser consideradas como discriminatórias $^{482}$.

A mencionada teoria ganhou melhores contornos na decisão do caso Teamsters $v$. United States $^{483}$, de 1977, que é um caso extremamente interessante, eis que o próprio governo federal dos EUA moveu a ação com base no título VII contra uma empresa que possui dimensão nacional no setor de transportes, com uma representação sindical muito ampla. Nesta ação, o governo alegou que a empresa adotou uma prática que discriminava negros e pessoas com sobrenomes hispânicos, que eram contratados para trabalhar em serviços de entrega urbanos, com menores salários, ao passo que os cargos de motoristas

\footnotetext{
${ }^{480}$ SUPREMA CORTE DOS ESTADOS UNIDOS DA AMÉRICA. Griggs v. Duke Power Co. 401 U.S. 424 (1971). Justia - US Supreme Court Center. Disponível em: <http://supreme.justia.com/us/401/424/>. Acesso em: 28 out. 2009.

${ }^{481}$ GOMES, Joaquim Barbosa. Ação afirmativa e princípio constitucional da igualdade. Rio de Janeiro: Renovar, 2001. p. 180.

${ }^{482}$ BELTON, Robert; AVERY, Dianne. op. cit., p. 161.

${ }^{483}$ SUPREMA CORTE DOS ESTADOS UNIDOS DA AMÉRICA. Teamsters v. United States, 431 U. S. 424 (1977). Justia - US Supreme Court Center. Disponível em: <http://supreme.justia.com/us/431/324/case.html>. Acesso em: 28 out. 2009.
} 
de longo percurso, que recebiam melhor remuneração, eram ocupados por desproporcional maioria branca.

A referida decisão reconheceu em uma de suas notas que o disparate impact se refere a práticas empresariais que são aparentemente neutras no seu tratamento com diferentes grupos, porém, na realidade, causam maior prejuízo a um grupo do que a outro e não podem ser justificadas pela necessidade da atividade empresarial ${ }^{484}$.

Outro caso que merece destaque é a decisão do caso Price Waterhouse $v$. Hopkins $^{485}$. A Corte reconheceu a teoria dos motivos mistos, na situação em que a empresa acionada considerou tanto o gênero sexual, como fatores legítimos. Quanto tomou a decisão que não aceitou a candidatura da autora, foi tomada por causa do gênero, ainda que outras considerações legítimas tivessem sido levadas em conta. A decisão foi extremamente polêmica, não somente por conta desta importante definição, como também pela questão do ônus da prova, provocando até alterações legislativas do Congresso norteamericano em 1991.

Atualmente, aquela Corte perdeu o arrojo de suas decisões proferidas especialmente nos anos setenta, procurando manter uma postura mais conservadora em relação aos temas da discriminação laboral. No entanto, as decisões anteriores - principalmente aquelas proferidas no período da Corte Burger, quando se afirmava a lei dos direitos civis abriram um caminho importantíssimo para a fixação de conceitos sobre a discriminação.

\subsubsection{Corte Constitucional da África do Sul}

A situação sul-africana é ímpar, por ser um país que vive uma profunda transformação social, saída do regime do apartheid tão somente em 1994, para viver em um regime democrático, com uma grande preocupação no combate à discriminação, conforme observado no item 6.3.1. A jurisprudência sobre a discriminação laboral naquele país é muito interessante, na medida em que adota conceitos derivados de uma legislação bastante abrangente e que procura se livrar de um histórico de opressão explícita de vários

\footnotetext{
${ }^{484}$ The latter (disparate impact) involve employment practices that are facially neutral in their treatment of different groups, but that, in fact, fall more harshly on one group than another, and cannot be justified by business necessity.

${ }^{485}$ SUPREMA CORTE DOS ESTADOS UNIDOS DA AMÉRICA. Price Waterhouse v. Hopkins, 490 U. S. 228 (1989). Cornell University Law School - Legal Information Institute. Disponível em: <http://www.law.cornell.edu/supct/html/historics/USSC_CR_0490_0228_ZS.html>. Acesos em: 28 out. 2009.
} 
grupos. Uma decisão em especial merece destaque, pela riqueza da sua fundamentação, no que concerne à proteção contra a discriminação e seu efetivo significado.

Trata-se do caso Hoffmann v. South African Airways ${ }^{486}$, no qual foi discutida a constitucionalidade da prática da empresa aérea de recusar a contratação de comissários de bordo que possuam o vírus HIV, da SIDA/AIDS. O autor foi aprovado nos exames de seleção da empresa, no entanto a empresa o considerou "inadequado" e recusou sua contratação. Justificou sua recusa ao afirmar que possuía uma política interna motivada por exigências médicas e de segurança, dentro da qual não poderia admitir o autor. Afirmou que o portador do vírus HIV enfrenta problemas na vacinação, com risco de ir para países com problemas endêmicos de doenças, ainda mais correndo o risco de transmitir a doença para outros passageiros, eis que a síndrome de imunodeficiência facilita contrair doenças oportunísticas e repassá-las aos passageiros.

A Corte sul-africana acolheu opinião médica no sentido de que o portador do vírus HIV poderia desempenhar normalmente suas funções de comissários de bordo, com riscos insignificantes para os passageiros. Com base neste entendimento, a Corte proferiu decisão entendendo que a política da empresa em questão violou a igualdade garantida no nono artigo da Constituição daquele país e obrigou a empresa a admiti-lo como comissário de bordo, conforme a legislação antidiscriminatória de 1998 já mencionada.

Aprovada por unanimidade, a decisão apontou expressamente que o âmago da Constituição daquele país proíbe a discriminação injusta ao reconhecer que sob seu manto todos os seres humanos, independentemente de sua posição na sociedade, devem ter reconhecida a mesma dignidade. Quando um cidadão é discriminado, esta dignidade sobre um menoscabo, sendo que o fator que determina a injustiça da discriminação é seu impacto na pessoa que foi discriminada ${ }^{487}$. A decisão ainda afirma, em outra passagem, que a era democrática da República sul-africana é caracterizada pelo respeito à dignidade de todos os seres humanos, sendo que os preconceitos e estereótipos não poderiam ser admitidos.

\footnotetext{
${ }^{486}$ CORTE CONSTITUCIONAL DA ÁFRICA DO SUL. Southern African Legal Information Institute. Hoffmann v. South African Airways - CCT 17/00. Disponível em: <http://www.saflii.org/za/cases/ZACC/2000/17.pdf>. Acesso em: 28 out. 2009.

${ }^{487}$ At the heart of the prohibition of unfair discrimination is the recognition that under our Constitution all human beings, regardless of their position in society, must be accorded equal dignity. The determining factor regarding the unfairness of the discrimination is its impact on the person discriminated against. Relevant considerations in this regard include the position of the victim of the discrimination in society, the purpose sought to be achieved by the discrimination, the extent to which the rights or interests of the victim of the discrimination have been affected, and whether the discrimination has impaired the human dignity of the victim.
} 
Ainda que algumas pessoas não possam ser aptas a laborar como comissárias, portando o vírus HIV, não se justifica a exclusão de todas nesta condição, concluiu a referida decisão.

Esta definição jurisprudencial é extremamente importante, ao reconhecer o respeito à mesma dignidade humana para serem coibidas as práticas discriminatórias, como fundamento da igualdade entre os seres humanos. E a decisão foi clara ao determinar a admissão e o trabalho como comissário, estabelecendo um prazo de trinta dias para o autor assumir a função. Como se observa, a conceituação da discriminação no caso em tela foi extremamente precisa, posto que não havia razoabilidade para a prática discriminatória geral. $\mathrm{O}$ autor do questionamento foi considerado apto para a função, sendo que a política da empresa, ao discriminá-lo, violou o dever de trato digno de qualquer ser humano.

\subsubsection{Alta Corte da Austrália}

Como já mencionado no item 6.3.2 deste capítulo, a legislação australiana é bastante preocupada com a discriminação laboral. Aquele país possui um sistema misto de leis federais e estaduais que procuram fornecer a maior proteção contra atos discriminatórios, inclusive de forma extremamente minuciosa.

A jurisprudência australiana é muito rica, posto que deve enfrentar um verdadeiro cipoal de normas antidiscriminatórias em um ambiente federativo e sua compatibilidade com a Constituição daquele país. Uma decisão merece destaque pela sua definição sobre o que sejam as linhas gerais de uma discriminação conforme a Constituição daquele país, ainda que não seja uma questão laboral.

Trata-se do caso Castlemaine Tooheys Ltd. v. South Australia ${ }^{488}$, no qual é discutida uma questão mercantil de operacionalidade de determinado ramo de atividade de transportes em outro Estado daquele país, por meio de uma lei estadual. Esse diploma restringia a atividade empresarial da autora naquele Estado. Merece destaque determinada passagem da decisão, na qual o voto profere uma conceituação sobre a discriminação praticada por um determinado diploma legal. A decisão afirma que uma norma legal é discriminatória se atua por referência a uma distinção que alguma lei primordial decreta ser irrelevante ou que é irrelevante em relação ao objeto a ser atingido. Afirma a decisão que uma norma legal é discriminatória se, embora atue por referência a uma distinção

\footnotetext{
${ }^{488}$ ALTA CORTE DA AUSTRÁLIA. Castlemaine Tooheys Ltd. v. South Australia [1990] HCA 1; (1990) 169 CLR 436. $\quad$ F.C. $40 / 001.4$ Disponível em: <http://www.austlii.edu.au/au/cases/cth/high_ct/169clr436.html>. Acesso em: 28 out. 2009.
} 
relevante, o tratamento diferenciado assim designado não é apropriado e adaptado à diferença estabelecida ou diferenças que apoiam essa distinção. E, por outro lado, uma norma é discriminatória também se, embora haja uma diferença relevante, age como se não houvesse nenhuma diferença, nem, em outras palavras, trata igualmente coisas que são iguais, a menos que, talvez, não haja nenhuma base prática para diferenciação ${ }^{489}$.

A definição acima revela uma preocupação muito detalhada com o contexto meiofim do juízo de razoabilidade e proporcionalidade que a medida questionada judicialmente deva possuir, reconhecendo esta inquirição como um conceito universalizado, como revela Amelia Simpson ${ }^{490}$.

\subsubsection{Tribunal de Justiça da União Europeia}

As decisões do Tribunal de Justiça da Comunidade Europeia são marcantes na elaboração de conceitos sobre a discriminação laboral. Uma vez estabelecida, no artigo 119, a proibição de tratamento diferenciado sobre salários entre homens e mulheres, pelo Tratado de Roma, celebrado em 1957, que criou a Comunidade Europeia do Carvão e Aço, aquela Corte teve a oportunidade de decidir várias vezes sobre casos envolvendo discriminação laboral feminina. Muitas vezes, a Corte construiu conceitos sobre discriminação que influenciaram o direito antidiscriminatório em todo o planeta. A jurisprudência da referida Corte é riquíssima e bastante audaciosa para uma época em que floresciam as primeiras discussões sobre igualdade laboral feminina. Catherine Barnard aponta para a força dos precedentes do Tribunal comunitário sobre matéria constitucional, nos quais se solidificou o entendimento de que há, efetivamente, um princípio de não discriminação no direito comunitário ${ }^{491}$.

O primeiro caso judicial comunitário em que o artigo 119 teve seu significado interpretado pelo Tribunal de Justiça da Comunidade foi o caso Defrenne ${ }^{4 I^{42}}$. Gabrielle Defrenne foi comissária de bordo da empresa belga estatal Societé Anonyme Belge de

\footnotetext{
${ }^{489}$ A law is discriminatory if it operates by reference to a distinction which some overriding law decrees to be irrelevant or by reference to a distinction which is in fact irrelevant to the object to be attained; a law is discriminatory if, although it operates by reference to a relevant distinction, the different treatment thereby assigned is not appropriate and adapted to the difference or differences which support that distinction. A law is also discriminatory if, although there is a relevant difference, it proceeds as though there is no such difference, or, in other words, if it treats equally things that are unequal -- unless, perhaps, there is no practical basis for differentiation.

${ }^{490}$ SIMPSON, Amelia. op. cit., p. 268.

${ }^{491}$ BARNARD, Catherine. EC employment law. Chichester: John Wiley \& Sons, 1998. p. 10.

${ }^{492}$ Assunto 43/75 [1976] ECR 455, in BARNARD, Catherine. Op. cit., p. 171.
} 
Navegation Aérienne - Sabena, entre os anos de 1951 a 1968 e durante seu contrato, como as demais comissárias, recebeu salário inferior aos salários praticados para os comissários masculinos, postulando a diferença de remuneração percebida.

O Tribunal de Justiça decidiu que, pelo seu caráter peculiar e fundamental, o artigo 119 do Tratado tinha efeitos verticais e horizontais, podendo ser invocado contra empresários privados perante os tribunais nacionais e contra o Estado. A decisão também reconheceu que o artigo 119 atua mesmo onde exista desigualdade de retribuição entre homens e mulheres pelo mesmo trabalho, tanto para um empregador público como para o privado $^{493}$. A decisão também entendeu que as provisões do Tratado têm efeito direto e podem ser utilizadas por pessoas físicas ou jurídicas.

Outra decisão de grande relevo daquela Corte foi no caso Garland v. British Rail Engineering Limited, cuja decisão reconheceu os efeitos da aplicação da igualdade após o término do contrato de trabalho. Ela foi proferida em uma demanda promovida pela autora, questionando uma política da empresa em conceder reduções de tarifas ferroviárias a seus ex-empregados homens e mulheres, mas somente estendia estes benefícios aos familiares dos homens aposentados, não contemplando os familiares das mulheres aposentadas. Neste caso, o Tribunal decidiu que as prestações voluntariamente fornecidas pelo empregador estão incluídas na proteção do artigo 119 do Tratado, e sua natureza legal pouco importa, tornando ilegal qualquer diferença por razão de sexo ${ }^{494}$.

Marcante também é a decisão proferida no caso Bilka-Kaufhaus ${ }^{495}$, decidido em 13 de maio de 1986 (assunto 170/84). Neste caso, a empresa Bilka Kaufhaus GmbH, composta de grandes lojas com milhares de empregados na então Alemanha Ocidental, decidiu implementar alterações no seu sistema de pensões de seguridade social, sendo que uma das medidas adotadas foi excluir os trabalhadores em tempo parcial do plano, a menos que tivessem trabalhado em tempo integral por, pelo menos, quinze anos. A Sra. Karin Weber von Hartz, que trabalhou para a empresa por quinze anos, sendo quatro anos no regime de tempo parcial, requereu sua inclusão ao plano empresarial; o requerimento foi denegado e a recusa empresarial foi judicialmente questionada.

A decisão da Corte Europeia foi no sentido de que o tratamento dado pela empresa infringe a proibição de discriminação remuneratória do artigo 119 do Tratado de Roma e

\footnotetext{
${ }^{493} \mathrm{HEIDE}$, Ingeborg. Medidas supracionales contra la discriminación sexual: igualdad salarial y de trato en la Unión Europea. Revista Internacional del Trabajo, Genebra, v. 118, n. 4, p. 439, 1999.

${ }^{494}$ Id. Ibid., p. 441.

${ }^{495}$ Id. Ibid., p. 445.
} 
da Diretiva 75/117. Segundo a Corte, a prática questionada afeta, de maneira prejudicial, um número muito maior de mulheres do que de homens que trabalham em tempo parcial, a menos que a empresa demonstre que exclusão se baseie em fatores objetivamente justificados e não relacionados com nenhuma discriminação por sexo. A referida decisão veio assentou, com este precedente, o conceito de discriminação indireta, conceito este que acabou sendo universalizado.

No mesmo sentido, aquela Corte constituiu um importante precedente no caso Handels-og Kontorfunktionaerernes Forbund $i$ Danmark contra Dansk Arbejdgiverforening (Assunto 109/88) ${ }^{496}$, julgado em 1988. Nesse feito, a Corte reconheceu que havia nos autos provas estatísticas que as empregadas recebiam menos que seus colegas varões e a empresa não logrou justificar adequadamente a disparidade constatada. A decisão apontou que se o sistema da empresa não é transparente e se uma queixa possui indícios razoáveis de discriminação salarial, ainda que não concludentes, o ônus da prova é do empregador para refutar as provas apresentadas e demonstrar que seu sistema é neutro em termos de disparidades por razões de sexo.

\footnotetext{
${ }^{496}$ HEIDE, Ingeborg. op. cit., p. 449.
} 


\section{MODALIDADES DE DISCRIMINAÇÃO}

No presente capítulo, a investigação pretende apresentar algumas condutas discriminatórias laborais mais comuns. As modalidades de discriminação laboral serão apresentadas com base nas classificações realizadas pela jurisprudência e pela doutrina. Outras classificações serão desenvolvidas tomando por base alguns componentes específicos da discriminação já descritos nos capítulos anteriores, em especial nos critérios de prejudicialidade, dos motivos e das posições das partes envolvidas. Também, será importante uma classificação baseada no momento da relação contratual em que o ato é praticado. Esse fator, ainda que não seja um elemento do ato discriminatório, é importantíssimo para distinguir os tipos de atitudes discriminatórias, principalmente para apontar as reparações envolvidas.

\subsection{Classificação das discriminações pela intencionalidade}

Uma grande evolução no estudo das discriminações no trabalho ocorreu no reconhecimento de práticas de empregadores, que são despidas de intenção discriminatória, mas que demonstraram efeitos discriminatórios.

Houve um grande avanço no estudo da discriminação laboral ao reconhecer tais práticas discriminatórias, o que passou a ocorrer durante os anos setenta, pouco mais de treze anos depois da primeira norma descritiva da discriminação laboral. O ponto nuclear desta modalidade discriminatória foi o resultado efetivo da prática adotada, que passou a ter uma importância incomum no estudo dos atos discriminatórios, levando ao abandono do elemento intencionalidade. A partir do reconhecimento de tais práticas como discriminatórias, uma nova fase tem início no direito antidiscriminatório em geral, e no direito antidiscriminatório laboral em particular. Como já mencionado no item 6.1, a terceira fase das normas antidiscriminatórias tem início com o reconhecimento desta nova modalidade de discriminação, despida de intenção, porém com efeitos discriminatórios, quebrando o unitarismo do conceito de discriminação laboral. Com tal reconhecimento, dois conceitos distintos de discriminação passaram a ser utilizados em vários ordenamentos. 
O ponto chave da diferenciação entre uma forma discriminatória então já reconhecida pela jurisprudência, com uma nova forma da discriminação ainda não reconhecida, foi o elemento intencionalidade. Muitos autores fazem esta distinção, sendo um deles Roger Raupp Rios, que expressamente adota tal distinção ${ }^{497}$. Com esta evolução, a análise da situação discriminatória deixava de dar atenção à atitude discriminatória e sua intenção. Este novo conceito passou a focar mais o efeito discriminatório, avaliando com maior atenção o resultado das práticas de empregadores e contratantes de serviços, para determinados grupos de trabalhadores.

A referida evolução teve seu surgimento nos anos setenta, com surgimento de duas denominações diversas, mas que caminharam no mesmo sentido.

Nos Estados Unidos da América, o julgamento do caso Griggs v. Duke Power Co. $^{498}$, em 1971, reconheceu esta modalidade de discriminação e teria sido a decisão pioneira neste sentido segundo Sandra Fredman ${ }^{499}$. O termo discriminação por impacto adverso foi utilizado inicialmente no julgamento do caso Teamsters $v$. United States ${ }^{500}$, na célebre nota $\mathrm{n}^{\mathrm{o}} 15$ daquela decisão, quando aquela Corte passou a adotar definitivamente a referida expressão. No entanto, ela ficou restrita ao uso daquele país, em face da insularidade e das características peculiares do ordenamento jurídico norte-americano.

Por seu turno, o direito comunitário europeu passou a reconhecer tal modalidade de discriminação pouco tempo depois. Também por iniciativa jurisprudencial, as primeiras decisões sobre o tema, proferidas pela Corte de Justiça da então Comunidade Econômica Europeia, preferiram adotar a expressão discriminação indireta. Esta nova modalidade induziu ao reconhecimento da tradicional modalidade de discriminação como discriminação direta. No entanto, pela abrangência e pela importância do direito comunitário europeu em tantos países de relevância global, em especial o Reino Unido, a expressão discriminação indireta ganhou adeptos dentro e fora do velho continente, em especial pelos países da Commonwealth britânica, consolidando internacionalmente a referida expressão.

\footnotetext{
${ }^{497}$ RIOS, Roger Raup. Direito da antidiscriminação: discriminação direta, indireta e ações afirmativas, cit., p. 89.

${ }^{498}$ SUPREMA CORTE DOS ESTADOS UNIDOS DA AMÉRICA. Griggs v. Duke Power Co. 401 U.S. 424 (1971).

${ }^{499}$ FREDMAN, Sandra. Discrimination law, cit., p. 106.

${ }^{500}$ SUPREMA CORTE DOS ESTADOS UNIDOS DA AMÉRICA. Teamsters v. United States. 431 U. S. 324 (1977).
} 
As questões terminológicas são complexas e deverão ser enfrentadas eis que, as duas expressões, infelizmente, não são muito precisas em espelhar o que seja, efetivamente, esta complexa modalidade de discriminação laboral. O elemento nuclear que distingue as duas modalidades é a intencionalidade do sujeito ativo da conduta discriminatória. Em uma modalidade ela está presente e em outra não. Assim, parece ser mais adequado que a terminologia correta deva se basear exatamente no elemento diferenciador, para melhor expressar o conceito de cada uma delas. Assim, a presente investigação irá promover a sua classificação entre discriminação intencional e discriminação não intencional. É possível que seja uma audaz proposição reformar uma terminologia consolidada ao longo de mais de trinta anos. No entanto, é encontrado um critério tecnicamente mais adequado, em um elemento de distinção importantíssimo entre as duas modalidades, que melhor expresse o seu diferencial. Nesse sentido, George Rutherglen parcialmente adota a expressão discriminação intencional ${ }^{501}$, apesar de, na mesma obra, adotar a expressão cunhada pela Suprema Corte dos EUA. Já Joel Friedman e George Strickler Jr. adotam a diferenciação entre discriminação intencional e não intencional, ainda que façam referência às duas modalidades nos termos adotados pela Suprema Corte dos EUA ${ }^{502}$.

Cabe agora analisar as principais características de cada uma das modalidades discriminatórias apontadas. É, sem dúvida, a mais importante classificação das modalidades discriminatórias, reconhecida em muitas normas antidiscriminatórias positivadas.

\subsubsection{Discriminação intencional}

Como a denominação é clara, a discriminação intencional é aquela em que o agente tem a intenção de promover um ato diferenciador que, de algum modo, cause a um trabalhador ou a um grupo um tratamento menos favorável que outra pessoa ou outro grupo. Nesta situação, o elemento intencionalidade deverá estar presente e constatado, algo não tão simples de ser satisfeito, principalmente em aspectos processuais.

Tal modalidade discriminatória foi mais comum no passado e, com a evolução dos mecanismos antidiscriminatórios, ela foi se tornando cada vez menos aparente ou, muitas

\footnotetext{
${ }^{501}$ RUTHERGLEN, George. Employment discrimination law. New York: Foundation Press, 2001. p. 30.

${ }^{502}$ FRIEDMAN, Joel W.; STRICKLER Jr., George M. op. cit., p. 58.
} 
vezes, escamoteada. Com efeito, as atitudes discriminatórias explícitas encontradas no passado paulatinamente cederam espaço a atitudes mais discretas e sofisticadas, algumas de difícil reconhecimento, sem perder, no entanto, o elemento intencionalidade.

A questão do ônus da prova nesse tipo de discriminação emerge dentro da Suprema Corte dos EUA como um elemento de colossal importância em tais discussões, sendo que muitas doutrinas já foram estabelecidas sobre a alocação do fardo, para uma das partes, de provar a intencionalidade, conforme assegura George Rutherglen ${ }^{503}$. Este importante autor norte-americano cita que o termo discriminação intencional revela certa redundância, na medida em que toda a atitude discriminatória, em certa parte, é intencional, quando opera uma distinção que não poderia ocorrer de forma acidental.

O referido autor aponta que duas previsões na Lei dos Direitos Civis levam a diferentes situações interpretativas ${ }^{504}$. Em uma delas, citando o artigo 706, alínea "g" da referida norma, menciona que somente seria intencional uma discriminação para autorizar a aplicação de remédios gerais equitativos contra um réu que "tenha intencionalmente se engajado em ou tenha intencionalmente dirigido uma prática ilegal empregatícia" ${ }^{505}$. Neste caso poderiam ser consideradas decisões empresariais como intencionais no sentido de afetarem os termos e condições de emprego.

Rutherglen, no entanto, afirma que outro sentido de discriminação intencional refere-se ao motivo que caracteriza como discriminatória determinada decisão empresarial, assim entendendo como alguma característica proibida e as limitações da indenização devida diante de tal circunstância ${ }^{506}$. O referido autor aponta que a intenção do ato deverá ser baseada em alguma característica proibida, resultando no dever de indenizar, além de outras medidas equitativas. Este componente não abrangeria a situação de discriminação não intencional, que possui remédios jurídicos diferenciados e menos abrangentes.

Roger Raupp Rios faz uma sub-classificação das modalidades da discriminação intencional (o autor adota a terminologia discriminação direta e indireta), afirmando que a doutrina $^{507}$ e a jurisprudência norte-americanas visualizaram três hipóteses genéricas desta modalidade de discriminação: a discriminação explícita (facial discrimination), a

\footnotetext{
${ }^{503}$ RUTHERGLEN, George. Employment discrimination law , cit., p. 30.

${ }^{504}$ Id. Ibid., p. 31.

${ }^{505}$ ESTADOS UNIDOS DA AMÉRICA. Civil Rights Act. 42 U.S.C. § 2000e-5(g)(1) (1994).

${ }^{506}$ Id. Ibid., p. 32.

${ }^{507} \mathrm{O}$ referido autor cita Allan Ides e Cristopher N. May (Constitutional Law - Individual Rights, New York: Aspen Law \& Business, 1998, p. 170 e seguintes), sem deixar claro, no entanto, se eles seriam os autores desta divisão.
} 
discriminação na aplicação da legislação (discriminatory application) e a discriminação na elaboração da legislação ou da medida (discrimination by design $)^{508}$.

Na primeira hipótese (facial discrimination), o citado constitucionalista menciona como a "mais clara e manifesta hipótese de discriminação direta" clara de que a medida diferencia expressamente determinado grupo baseado em um critério proibido (atenta a definição para a restrição de motivos existente na Lei dos Direitos Civis dos EUA). São situações de discriminação clara e inequívoca, havendo explícita exclusão de determinado grupo, baseado em um critério proibido, mesmo que ainda não afete todos seus integrantes.

Para a segunda hipótese (discriminatory application), Rios aponta que a discriminação na aplicação da legislação ocorre quando, independentemente da intenção do legislador não ter sido discriminatória, sua aplicação acaba ocorrendo de forma diferenciada para determinado grupo, com ônus desfavoráveis em comparação a outro grupo, seja nos meios administrativos ou judiciais ${ }^{510}$.

E na terceira hipótese (discrimination by design), Rios aponta a existência de uma situação na qual a discriminação pode ocorrer na concepção da legislação, ainda que o seu texto não possa inferir, literal e diretamente, uma diferenciação ${ }^{511}$. Para demonstrar essa situação, o autor exemplifica a exigência infundada de determinados níveis de escolaridade para funções que não as necessitem, ou a exigência de candidatos de "boa aparência", como forma de serem evitadas as contratações de pessoas negras ${ }^{512}$. Apesar de aparentemente serem consideradas situações neutras, a concepção da regra tem propósitos discriminatórios não aparentes.

Nos Estados Unidos da América, tal forma de discriminação recebe a denominação de disparate treatment, que poderia ser traduzido como tratamento diferenciado. Esta expressão é mencionada na famosa nota $\mathrm{n}^{\circ} 15$ da decisão do célebre caso Teamsters, que reconheceu que esta forma de discriminação é a mais comum. A aludida decisão menciona uma definição simples, porém eficiente, no sentido de que ocorre discriminação nesta modalidade quando o empregador simplesmente trata alguma pessoa menos

\footnotetext{
${ }^{508}$ RIOS, Roger Raup. Direito da antidiscriminação: discriminação direta, indireta e ações afirmativas, cit., p. 91.

${ }^{509}$ Id., loc. cit.

${ }^{510}$ Id. Ibid., p. 92.

${ }^{511}$ Id. Ibid., p. 96.

${ }^{512}$ Id. Ibid., p. 96.
} 
favoravelmente que outra em função de sua raça, cor, religião, sexo ou origem nacional $^{513}$.

Esta simples definição, ao esclarecer o que seja uma discriminação intencional, foi utilizada pelas definições adotadas pela trilogia das Diretivas 2000/43, 2000/78 e 2002/73, com a expressão discriminação direta, conforme já demonstrado no item 6.1 da presente investigação. Em tais normas comunitárias, foi adotada como definição de discriminação direta a situação descrita como ser objeto de tratamento menos favorável comparativamente com outra pessoa ou grupo. Por outro lado, tais definições são utilizadas por diversas normas antidiscriminatórias em vários ordenamentos jurídicos, tanto dentro como fora do continente europeu.

Como se observa, neste tipo de discriminação a intencionalidade assume um papel fundamental na discussão sobre a permissibilidade ou não da conduta diferenciadora. Nos Estados Unidos foram erigidas várias construções jurisprudenciais sobre a questão do ônus da prova nas questões discriminatórias, posto que, em função da vasta proibição contra a discriminação, as atitudes discriminatórias passaram a se tornar cada vez mais discretas e sutis. A solução da questão estará centrada na prova, se negada a prática discriminatória, ou na prova de alguma justificativa, caso admitida a prática, mas alegada alguma justificação. A questão do ônus da prova nesses casos será adiante debatida, posto que depende de uma complexa fundamentação sobre as obrigações processuais de cada parte em um processo que trate de tais assuntos.

A decisão do célebre caso Price Waterhouse v. Hopkins ${ }^{514}$ assinalou que, nos casos de discriminação intencional por motivos mistos, cabe ao autor trazer a juízo uma prova sólida no sentido de que um motivo proibido tenha sido um fator substancial na decisão que o prejudicou. Esta decisão foi um duro golpe contra as queixas por discriminação intencional. Com efeito, a exigência da Suprema Corte, no sentido de ser demonstrada uma prova sólida da intenção discriminatória de um empregador em um caso envolvendo motivos legítimos e não legítimos para a recusa de uma participação societária da autora daquele feito demonstrou um grande retrocesso. Aquela corte voltou atrás da posição

\footnotetext{
${ }^{513}$ SUPREMA CORTE DOS ESTADOS UNIDOS DA AMÉRICA. Teamsters v. United States. 431 U. S. 324 (1977). Justia. United States Supreme Court Center. Disponível em: $<$ http://supreme.justia.com/us/431/324/case.html>. Acesso em: 09 nov. 2009. The employer simply treats some people less favorably than others because of their race, color, religion, sex, or national origin.

${ }^{514}$ SUPREMA CORTE DOS ESTADOS UNIDOS DA AMÉRICA. Price Waterhouse v. Hopkins, 490 US 298 (1989). Cornell University Law School. Supreme Court Collection. Disponível em: $<\mathrm{http}: / /$ www.law.cornell.edu/supct/html/historics/USSC_CR_0490_0228_ZS.html $>$. Acesso em: 10 nov. 2009.
} 
tomada no caso McDonnell Douglas v. Green, no sentido de que, havendo uma prova facial de existência de situação discriminatória, caberia ao empregador demonstrar os justos motivos do tratamento menos favorável.

Martin Katz aponta que a teoria do disparate treatment nos EUA vive um momento muito confuso nos dias atuais, eis que existem três modelos processuais para este tipo de discriminação. O primeiro seria baseado na decisão do caso Price Waterhouse v. Hopkins, o segundo, ainda nos moldes da decisão do caso McDonnell Douglas Corp. v. Green e outro baseado nas alterações formuladas na Lei de Direitos Civis em $1991^{515}$. O referido autor propugna que as três formas atualmente existentes devem ser unificadas para evitar os problemas atuais da fragmentação da teoria, que é custosa e problemática ${ }^{516}$. Vários autores alcunharam esta questão como sendo um autêntico terreno pantanoso, entre eles Jamie Prenkart ${ }^{517}$, que defende que o modelo estabelecido pelo caso McDonnell Douglas Corp. v. Green ainda permanece o caminho melhor estruturado para este tipo de questionamento judicial, por poder atender a diversas questões envolvendo a discriminação intencional, mesmo diante das mais recentes decisões e das alterações legislativas de $1991^{518}$.

A situação nos Estados Unidos sobre tal modelo de questionamento judicial ainda é um tanto quanto confusa e complexa, na medida em que uma postura conservadora domina a Suprema Corte nos últimos vinte e cinco anos. No entanto, apesar de conservadora, esta postura não consegue assentar um padrão mais razoável no que tange ao ônus da prova, para decidir sobre os casos de discriminação intencional. A exigência de intransponíveis barreiras no campo das provas sobre a intenção discriminatória é um gigantesco empecilho no sentido de implementar efetivamente a ordem constitucional de promoção da igualdade material.

\footnotetext{
${ }^{515}$ KATZ, Martin J. Unifying disparate treatment (really). Hastings Law Journal. Fev. 2008, no 59, p. 643. Lexis Nexis. Disponível em: http://www.lexisnexis.com/us/lnacademic/results/docview/docview.do?docLinkInd=true\&risb=21_T78333 $22973 \&$ format=GNBFI\&sort=BOOLEAN\&startDocNo=1\&resultsUrlKey=29_T7833322978\&cisb=22_T7 $833322977 \&$ treeMax=true\&treeWidth=0\&csi=7341\&docNo=1>. Acesso em: 09 nov. 2009.

${ }^{516}$ Id. Ibid., p. 681.

${ }^{517}$ PRENKERT, Jamie Darin. The role of second-order uniformity in disparate treatment law: McDonnell Douglas's longevity and the mixed-motives mess. American Business Law Journal. Outono/2008, $\mathrm{n}^{\circ}$ 45, p. 512. Lexis Nexis. Disponível em: <http://www.lexisnexis.com/us/lnacademic/results/docview/docview.do?docLinkInd=true\&risb=21_T7833 430638\&format=GNBFI\&sort=BOOLEAN\&startDocNo=1\&resultsUrlKey=29_T7833430645\&cisb=22_T $7833430644 \&$ treeMax $=$ true $\&$ treeWidth $=0 \& c s i=166252 \&$ docNo=2>. Acesso em: 09 nov. 2009.

${ }^{518}$ Id. Ibid., p. 564.
} 


\subsubsection{Discriminação não intencional}

O reconhecimento doutrinário e jurisprudencial da existência de uma modalidade discriminatória que não dependa de um critério intencional para sua caracterização foi um dos grandes e mais importantes avanços na construção de uma teoria da discriminação em geral, e na discriminação laboral em particular.

Como já foi possível demonstrar anteriormente, a exigência de uma efetiva e substancial igualdade é algo ainda muito difícil de ser alcançado em todo o mundo, conforme demonstram os mais recentes relatórios da OIT sobre a implementação da igualdade no trabalho.

Robert Alexy define que os princípios são mandados de otimização no que tange às possibilidade jurídicas e fáticas ${ }^{519}$, ou seja, devem ser realizados na sua mais extensa e ampla possibilidade. A determinação jurídica no sentido de que todos os seres humanos são iguais e devem ser tratados com a mesma dignidade, está juridicamente consolidada. No entanto, torná-la efetiva para não permitir que sejam aceitas diferenciações que não sejam absolutamente necessárias, é um grande desafio.

Crer que as atitudes discriminatórias fiquem restritas somente ao campo da intencionalidade é, no mínimo, uma demonstração ingênua da capacidade de o ser humano dominar seus semelhantes através de diferenciações. A história da civilização humana é fundada em dominações baseadas em diferenciações. A determinação jurídica do mesmo respeito e igual tratamento a todo e qualquer ser humano é recente. Ela vem sendo conquistada mediante uma árdua luta, que somente adquiriu contornos jurídicos mais claros nos últimos sessenta anos, depois de milênios de disparidades e diferenças estruturais das civilizações humanas. Pôr fim a um longo histórico de diferenciações entre os seres humanos é um esforço hercúleo que deve ser realizado em todas as frentes possíveis, cuja previsão de êxito não pode ser ainda sequer estimada.

A missão de implementar a efetiva igualdade entre os homens encontra uma enorme resistência, muitas vezes sem consciência de que diversas ações resistem a um vetor de igualdade geral. Por outro lado, as estruturas sociais atualmente existentes foram concebidas e são mantidas com base na dominação humana, em que pessoas e grupos são subordinados a outras pessoas e outros grupos. Nosso sistema político é ainda concebido na prevalência de uma maioria sobre uma minoria e o sistema econômico capitalista que

\footnotetext{
${ }^{519}$ ALEXY, Robert. op. cit., p. 112.
} 
dominou o planeta é um sistema subordinativo no qual o capital domina o trabalho. Nos dias atuais, a eficiência econômica é mais importante que qualquer outro valor humanista, lamentavelmente. Os valores culturais, religiosos, educacionais, sociais, econômicos, filosóficos e de toda e qualquer natureza vigente foram construídos e edificados muito antes do reconhecimento ético e jurídico de que todos os seres humanos devem ser tratados com a mesma igualdade.

Ainda que fossem removidas todas as intenções discriminatórias, tudo o que cerca a vida de um ser humano neste planeta, no seu meio e nas suas relações sociais, principalmente no que tange às formas de prestação do trabalho humano, foi construído sob o manto da dominação e da desigualdade. Os resquícios dessa estruturação irão operar efeitos por muito tempo, mesmo que de forma inercial. Situações de dominação mais violenta e radical consolidadas na humanidade ao longo de tantos anos, como a escravidão, o racismo e o colonialismo, entre tantas outras, ainda que sejam efetivamente banidas, produzirão efeitos por séculos. Dentro do próprio Século $\mathrm{XX}$, tais práticas dizimaram a vida de milhões de pessoas, mesmo após o seu reconhecimento. Esperar que os seus efeitos sejam removidos instantaneamente, mediante a aplicação de normas jurídicas meramente proibitivas, seria uma posição extremamente ingênua.

Mais ainda, inconscientemente agimos como se todos os seres humanos não são iguais, por mais preparadas e educadas que sejam as sociedades modernas. A discriminação inconsciente tão bem mencionada pelo jurista Charles Lawrence III, em um texto considerado um clássico no direito antidiscriminatório, nos transmite que todo e qualquer comportamento humano está permeado de racismo, na maior parte inconsciente, eis que criado dentro do ambiente que cercou a formação do ser humano ${ }^{520}$. O autor aponta que as decisões empresariais, e mesmo as decisões judiciais, acabam de alguma forma sendo permeadas pelo racismo inconsciente, baseadas em uma descrição freudiana das ações e reações humanas envolvendo este tema ${ }^{521}$. Vinte anos após seu célebre texto, o autor ainda menciona maior criticismo em face da postura da Suprema Corte dos EUA, apoiado em decisões que revertam o que já foi construído no passado e não permitam que os norte-americanos tenham consciência de seu racismo ${ }^{522}$.

\footnotetext{
${ }^{520}$ LAWRENCE III, Charles R. The id, the ego, and equal protection: reckoning with unconscious racism. Stanford Law Review, n. 39, p. 322, Jan. 1987.

${ }^{521}$ Id. Ibid., p. 324.

${ }^{522}$ LAWRENCE III, Charles R. Unconscious racism revisited: reflections on the impact and origins of " The id, the ego, and equal protection". Connecticut Law Review. Maio/2008, n 40, p. 977. Lexis Nexis. Disponível
} 
Para constatação dessa teoria basta encontrar uma pessoa de um grupo majoritário em um momento de descontrolada raiva, na qual toda a carga cultural e de valores passada pela sociedade a respeito de um determinado grupo social, ao longo de tantos anos inconscientemente acumulada, é facilmente externada como forma de agressão contra outro ser humano integrante de um grupo minoritário. Em tantos outros momentos, principalmente dentro das decisões do mundo laboral, a discriminação inconsciente se manifesta por outras formas também.

O que pode ser extraído é que toda a estrutura social atual, de um modo ou outro, converge para a aceitação de posturas desiguais tal qual ocorria no passado, ainda que atualmente sejam reprimidas. Entender que, em um quadro deste naipe, não deva haver mais discriminação é uma postura inaceitável, por ser condescendente com a perpetuação de tais práticas.

Rosemary C. Hunter and Elaine W. Shoben indicam que a teoria da discriminação não intencional é uma inovação norte-americana ${ }^{523}$. Como já foi apontado anteriormente, a Lei dos Direitos Civis que introduziu o Título VII no ordenamento jurídico dos Estados Unidos da América, somente entrou em vigor em 1964. Robert Belton e Dianne Avery relatam que as cortes federais do sul dos Estados Unidos já vinham construindo uma jurisprudência a partir do impactante julgamento do caso Brown v. Board of Education em 1954 e atuaram nas primeiras causas naquela turbulenta região do país, com graves questões raciais ocorridas mesmo após a promulgação da referida lei federal ${ }^{524}$. Nesse período, segundo os referidos autores, foi construída uma jurisprudência mais arrojada e progressista. Os autores destacam que após a edição da referida lei federal as atitudes empresariais passaram a ser menos explícitas, em favor de práticas mais discretas, com o mesmo efeito discriminatório ${ }^{525}$. Alfred W. Blumrosen destaca que, no mencionado período, as decisões das cortes sulistas foram importantes para a formação de uma jurisprudência sobre a discriminação, em função da experiência dos Juízes daquela região

$<$ http://www.lexisnexis.com/us/lnacademic/results/docview/docview.do?docLinkInd=true \&risb=21_T7838 520840\&format=GNBFI\&sort=BOOLEAN\&startDocNo=1\&resultsUrlKey=29_T7838520843\&cisb=22_T $7838520842 \&$ treeMax $=$ true $\&$ treeWidth $=0 \&$ selRCNodeID=2\&nodeStateId=411en_US, $1,2 \&$ docsInCategor $\mathrm{y}=27 \& \mathrm{csi}=138398 \&$ docNo=7>. Acesso em: 10 nov. 2009.

${ }^{523}$ HUNTER, Rosemary C.; SHOBEN, Elaine W. op. cit., p. 109.

${ }^{524}$ BELTON, Robert; AVERY, Dianne. op. cit., p. 64-65.

${ }^{525}$ Id. Ibid., p. 66. 
com as práticas empresariais em um ambiente de aberta e notória segregação no emprego $^{526}$.

Robert Belton e Dianne Avery apontam que a jurisprudência sulista desenvolveu uma nova tendência jurisprudencial em resposta às atitudes discriminatórias que persistiam em excluir negros e mulheres, com o reconhecimento dos efeitos presentes de uma discriminação passada. Através do mencionado conceito, as cortes sulistas passaram a considerar em suas decisões a existência de um teste de duas questões sobre a intencionalidade discriminatória: (1) se as práticas empresariais questionadas anteriores à promulgação do Título VII se baseavam em intenções subjetivas para tratar candidatos e empregados diferentemente por conta de sua raça ou sexo e (2) se assim fosse, ainda que a prática fosse aparentemente neutra, trariam os mesmos efeitos que persistiam mesmo depois do novo diploma entrar em vigor $^{527}$.

O posicionamento jurisprudencial sulista, mais em contato com a dura realidade de uma segregação explícita, observou que não bastaram proibir as condutas discriminatórias. Elas se perpetuavam por outros meios, não pelas atitudes, mas pelos efeitos de uma sociedade segregacionista. As cortes do sul dos EUA constataram que o mandamento da igualdade humana dependia de outras atitudes, mais ativas e não limitadas às provas de uma intencionalidade muitas vezes bem omitida. A efetiva igualdade seria verificada nos resultados de práticas que perpetuavam os resultados de séculos de discriminação e dominação.

A consolidação desta teoria sulista na Suprema Corte ocorreu na decisão do caso Griggs v. Duke Power Co. ${ }^{528}$, em 1971. No item 6.5.1. já foi formulado um comentário essa decisão, na qual um grupo de empregados afrodescendentes questionou judicialmente a política de uma empresa geradora de energia, com base no título VIII da Lei de Direitos Civis, como a exigência de diplomas de ensino médio para determinadas funções ou a aprovação em testes de inteligência. Os autores daquela ação mencionaram que as exigências não eram relacionadas ou dirigidas ao desempenho de determinadas atividades. Eles também apresentaram que os resultados dos procedimentos adotados, ainda que não

\footnotetext{
${ }^{526}$ BLUMROSEN, Alfred W. The law transmission system and the Southern Jurisprudence of Employment Discrimination. Industrial Relations Law Journal, vol. 6, 1984. In: DONOHUE III, John J. (Coord.). Foundations of employment discrimination law. 2. ed. New York: Foundation Press, 2003. p. 96.

${ }^{527}$ Id., loc. cit.

${ }^{528}$ SUPREMA CORTE DOS ESTADOS UNIDOS DA AMÉRICA. Griggs v. Duke Power Co. 401 U.S. 424 (1971). Justia - US Supreme Court Center. Disponível em: <http://supreme.justia.com/us/401/424/>. Acesso em: 28 out. 2009.
} 
intencionais, construíam barreiras para que os trabalhadores negros, com menor qualificação educacional, atingissem postos mais elevados dentro da empresa.

A ação não teve sucesso em primeiro grau, que não vislumbrou qualquer violação do título VII por parte da empresa. A Corte de Apelações preferiu se debruçar sobre o tratamento diferenciado de empregados contratados no mesmo ano e se posicionou em favor da violação legal tão somente em relação a este grupo.

A decisão da Suprema Corte reverteu as decisões anteriores e declarou as práticas da empresa ré como atentatórias ao título VII. Como fundamento, a decisão unânime, com voto condutor do Juiz Burger, apontou que a Lei dos direitos civis requer a eliminação de todas as barreiras artificiais, arbitrárias e desnecessárias ao emprego, que venham a discriminar de forma injusta com base na raça. A decisão destacou que se uma prática de emprego que exclua negros não possa ser demonstrada como relacionada ao desempenho do emprego, deve ser proibida, não obstante desprovida de intenção discriminatória. Menciona também que a prática das exigências de testes e qualificações da empresa era neutra em sua face, assim como em termos de intencionalidade, no entanto, atuava de forma discriminatória perpetuando o status quo de antigas práticas discriminatórias no emprego.

A decisão teve um grande impacto naquele país. Proibiu testes que não tinham relação com as necessidades de trabalho, contrariando uma prática extremamente comum nos EUA, que é seu o uso para avaliação de aptidões de trabalhadores. Paul R. Sackett and Steffanie L. Wilk demonstram, com dados estarrecedores, o uso desta prática naquele país, com cerca de 19 milhões de pessoas passando anualmente por testes de aptidão, somente no ano de $1994^{529}$. A proibição judicial causou grande apreensão no meio empresarial.

As críticas contra a decisão não tardaram. Hunter e Shoben relatam os duros comentários utilizados por diversos juristas de renome nos EUA, geralmente baseando-se no entendimento de que a Lei dos Direitos Civis não permitia a interpretação extremamente extensiva realizada pela Corte. As expressões utilizadas contra a decisão, segundo as autoras, partiram de importantes autores norte-americanos e variaram desde

\footnotetext{
${ }^{529}$ SACKETT, Paul R.; WILK, Steffanie L. Within-group norming and other forms of score adjustment in preemploying testing. American Psychologist, v. 49, 1994. In: DONOHUE III, John J. (Coord.). Foundations of employment discrimination law. 2. ed. New York: Foundation Press, 2003. p. 103.
} 
uma insensatez da legislação vigente, até uma decisão que perverteu a literalidade e a história legislativa da Lei dos Direitos Civis ${ }^{530}$.

O certo é que, com o tempo, tais reações tiveram efeito sobre a Suprema Corte. Cinco anos após proferir a decisão do caso Griggs, a Corte aplicou novamente tal fundamentação no controvertido caso Washington v. Davis ${ }^{531}$, mas rejeitou a pretensão do feito ao apontar que o impacto desproporcional do teste colocado sob discussão judicial não garante a conclusão que ele operou discriminatoriamente. A corte definiu que o rigor legislativo do Título VII deveria ser atenuado contra atos administrativos, com percepção maior da razoabilidade do ato, ainda que tenha impacto racial mas que não tenha propósito discriminatório. E também assentou, para maior espanto após o precedente do caso Griggs, que não houve demonstração da intenção discriminatória do teste, não obstante tenha reprovado quatro vezes mais negros que brancos.

Um ano após, a Corte decidiu o caso Teamsters v. United States, já mencionado, no qual estabeleceu a descrição da teoria do impacto adverso, definida na famosa nota $\mathrm{n}^{\circ} 15$. Tal decisão utilizou amplamente estatísticas de ocupação de cargos de uma determinada empresa de transportes por negros e brancos para proferir sua decisão. No mesmo ano, também proferiu decisão no caso Hazelwood School District v. United States, uma espécie de ação civil pública que também tratou de situação de discriminação não intencional governamental, adotando-se estatísticas da representatividade das comunidades minoritárias na localidade e dentro do distrito educacional, para reconhecimento de práticas discriminatórias.

William Gordon divide em duas as fases de desenvolvimento desta teoria ${ }^{532}$. A primeira, integrada pelos entendimentos das decisões dos casos Griggs - Albermale Dothard, denominando-a "era Griggs", na qual o autor faria a alegação de discriminação não intencional mediante uma prova facial, o empregador deveria justificar sua prática e ainda o empregado poderia questionar a justificativa como pretexto. O segundo período mais recente, chamado "era moderna", o autor de uma ação desta natureza necessita

\footnotetext{
${ }^{530}$ HUNTER, Rosemary C.; SHOBEN, Elaine W. op. cit., p. 143.

${ }^{531}$ SUPREMA CORTE DOS ESTADOS UNIDOS DA AMÉRICA. Washington v. Davis. 426 U.S. 229 (1976). Cornell University Law School. Supreme Court Collection. Disponível em: <http://www.law.cornell.edu/supct/html/historics/USSC_CR_0426_0229_ZS.html>. Acesso em: 10 nov. 2009.

${ }^{532}$ GORDON, William. The evolution of the disparate impact theory of Title VII: A hypothetical case study. President and Fellows of Harvard College Journal. Verão 2007, no 44, p. 529-551. Lexis Nexis. Disponível $<$ http://www.lexisnexis.com/us/lnacademic/results/docview/docview.do?docLinkInd=true\&risb=21_T7843 595871\&format=GNBFI\&sort=BOOLEAN\&startDocNo=1\&resultsUrlKey=29_T7843595878\&cisb=22_T $7843595877 \&$ treeMax $=$ true $\&$ treeWidth $=0 \& c s i=143841 \&$ docNo=3 > . Acesso em: 30 ago. 2008.
} 
identificar a prática do empregador que resultou na disparidade. Além disso, o autor da ação terá que demonstrar que tal prática afetou desproporcionalmente um determinado grupo protegido. Uma vez demonstrada a prova facial mais complexa, o empregador terá maiores facilidades para demonstrar a necessidade da prática ou algum motivo de defesa. O autor aponta que a "ponte" entre uma fase e outra se deu na decisão do caso Washington v. Davis.

A Corte consolidou sua marcha mais conservadora em relação à sua posição original na decisão do caso Wards Cove Packing Co. v. Atonio ${ }^{533}$, que foi extremamente marcante por redefinir o ônus da prova. Nesta decisão, a Corte decidiu em uma apertada maioria de cinco, entre nove juízes votantes, para entender que a Corte havia interpretado equivocadamente em seus pronunciamentos anteriores sobre a alocação do ônus da prova em casos de discriminação não intencional, em especial no caso Griggs. A Suprema Corte definiu, no caso Wards Cove, que o ônus do empregador deveria ser limitado à produção de prova, mas não ao ônus de persuasão que deva ser do empregado autor, que deverá demonstrar o impacto adverso da ação neutra do empregador. A Corte de 1989, já com significativa influência em sua composição das nomeações republicanas dos governos Reagan e Bush, ao invés de reverter a teoria, criou graves empecilhos processuais à sua aplicação, através de novas exigências de prova e de persuasão impostas aos empregados.

Esta profunda mudança de posicionamento da Suprema Corte, além de outras decisões igualmente com tendência conservadora, motivou o Congresso, de maioria democrata, a modificar as disposições do título VII, procurando positivar o que a Suprema Corte havia deixado para trás. Conhecida como a Lei dos Direitos Civis de 1991, tal diploma legal passou a reconhecer expressamente os casos de disparate impact, estabelecendo regras processuais sobre o ônus da prova no artigo 703 (Sec. 2000e-2 [Section 703]), alínea "k", bem como proibiu expressamente o uso de testes sem relação com a função exigida na alínea "l" e definiu que a prática de discriminação por motivos mistos também é ilegal na alínea "m" "534. A referida regulação pelo Congresso Nacional, segundo Rutherglen, teria encerrado qualquer discussão anteriormente existente, se a

\footnotetext{
${ }^{533}$ SUPREMA CORTE DOS ESTADOS UNIDOS DA AMÉRICA. Wards Cove Packing Co. v. Atonio. 490 US 642109 S. Ct. 2115, 104, L.Ed. 2d. 733 (1989). Findlaw - For Legal Professionals. Disponível em: $<$ http://caselaw.lp.findlaw.com/scripts/getcase.pl?court=US\&vol=490\&invol=642>. Acesso em: 10 nov. 2009.

${ }^{534}$ ESTADOS UNIDOS DA AMÉRICA. Civil Rights Act 1991. Equal Employment Opportunity Comission. Disponível em: <http://www.eeoc.gov/laws/statutes/titlevii.cfm>. Acesso em: 10 nov. 2009.
} 
referida teoria possuía amparo legislativo e se o título VII efetivamente proibia discriminação em face dos efeitos de determinada prática ${ }^{535}$.

Este foi o desenvolvimento do reconhecimento da discriminação não intencional, no conhecido berço de tal modalidade discriminatória. No entanto, logo após o reconhecimento da modalidade pela decisão Griggs, em 1971, esta modalidade ganhou o outro lado do Oceano Atlântico rapidamente, tendo encontrado no ambiente europeu um velocíssimo desenvolvimento e um amplo reconhecimento, inclusive fora da Europa, influenciando as leis da Austrália, Nova Zelândia e Canadá.

Ricardo de Paula Alves aponta que a discriminação não intencional, mencionada pela doutrina europeia como discriminação indireta, já era esboçada pela Corte de Justiça da então Comunidade Econômica Europeia, em 17.07.1963, através do acórdão CJCE 13/63 no assunto Itália v. Comissão, rec. 1963.335, item 4.a ${ }^{536}$. Nesta decisão, o autor afirma que os dizeres da decisão apontavam que "o tratamento diferente de situações não comparáveis não permite concluir automaticamente pela existência de uma discriminação. A aparição de uma discriminação na forma poderá, doravante, corresponder de fato a uma ausência de uma discriminação material, que irá consistir no tratamento de situações idênticas diferentemente ou diferentes situações identicamente" ${ }^{\text {"537. }}$.

Eram tempos em que a definição do que efetivamente seria discriminação era baseada em um conceito unificado, com uma notória escassez de conceitos descritivos vigentes. No entanto, a decisão lança algumas bases sobre a relevância da substancialidade da discriminação em detrimento de sua forma, aspecto fundamental para o reconhecimento de uma discriminação não intencional. No entanto, o conceito da discriminação não intencional, assim como no caso Griggs, deveria ser cunhado pela jurisprudência.

O primeiro caso mencionado por diversos autores como o precursor do reconhecimento da discriminação não intencional pela Corte de Justiça da CEE foi o caso Giovanni Maria Sotgiu v. Deutsche Bundespost ${ }^{538}$, de 12.02.1974. Aqui, a referida Corte

\footnotetext{
${ }^{535}$ RUTHERGLEN, George. op. cit., p. 88.

${ }^{536}$ ALVES, Ricardo de Paula. op. cit., p. 113.

${ }^{537}$ CORTE DE JUSTIÇA DA COMUNIDADE ECONÔMICA EUROPÉIA. Decisão caso República da Itália v. Comissão da Comunidade Econômica Européia. Assunto no 13/63. EUR-Lex. Disponível em: $<$ http://eur-lex.europa.eu/LexUriServ/LexUriServ.do?uri=CELEX:61963J0013:EN:HTML>. Acesso em: 10 nov. 2009.

${ }^{538}$ CORTE DE JUSTIÇA DA COMUNIDADE ECONÔMICA EUROPEIA. Decisão caso Giovanni Maria Sotgiu $v$ Deutsche Bundespost. Assunto $\mathrm{n}^{\circ}$ 152/33. EUR-Lex. Disponível em: <http://eurlex.europa.eu/LexUriServ/LexUriServ.do?uri=CELEX:61973J0152:EN:HTML>. Acesso em: 10 nov. 2009.
} 
entendeu como ilegais as exigências de domicílio formuladas pela parte acionada. A decisão considerou que as regras concernentes à igualdade de tratamento, tanto no tratado como no artigo $7^{\circ}$ do regulamento $n^{o} 1612 / 68$, proíbem não somente discriminação explícita pelos motivos de nacionalidade, como também todas as formas ocultas de discriminação as quais, pela aplicação de outros critérios de diferenciação, levam ao fato do mesmo resultado.

O foco da mencionada decisão está voltado para os resultados da conduta diferenciadora, destacando que reconhece formas abertas $\mathrm{e}$ formas ocultas de discriminação, sendo que as últimas possuem resultados discriminatórios não obstante pareçam ser neutras. Há de ser considerado que a referida decisão foi proferida quase três anos após a decisão do caso Griggs nos Estados Unidos.

Um fato importante no direito europeu de um modo geral foi a promulgação, no Reino Unido, do Sex Discrimination $A c t^{539}$, uma norma de proteção contra a discriminação por gênero naquele reino, no ano de 1975. A norma apresenta um conceito um tanto quanto rudimentar de discriminação não intencional, mas que expressa situações de desproporcionalidade de homens e mulheres admitidos ou laborando em determinada atividade empresarial, que não possa ser justificada em razão do sexo e que cause situação prejudicial para as mulheres. Rosemary C. Hunter e Elaine W. Shoben também informam que o conceito de discriminação não intencional partiu do Reino Unido em direção das suas ex-colônias, sendo adotado alguns anos após na Austrália, Nova Zelândia e Canadá ${ }^{540}$.

A primeira norma em caráter comunitário a tratar da discriminação por gênero na Comunidade Econômica Europeia foi a Diretiva 75/117 $7^{541}$ de 10.02.1975. Ela proíbe qualquer tipo de discriminação por razões de sexo, sem estabelecer conceitos diferenciados descritivos sobre a discriminação. No entanto, a Diretiva 76/207 de 09.02.1976 ${ }^{542}$ teve a iniciativa de estabelecer um princípio de igualdade de tratamento. No seu artigo 2.1 expõe que o princípio da igualdade de tratamento, na acepção das disposições adiante referidas, implica a ausência de qualquer discriminação em razão do sexo, quer direta, quer

\footnotetext{
${ }^{539}$ REINO UNIDO. Sex Discrimination Act. Office of Public Sector Information. Disponível em: <http://www.opsi.gov.uk/acts/acts1975/PDF/ukpga_19750065_en.pdf>. Acesso em: 10 nov. 2009.

${ }^{540}$ HUNTER, Rosemary C.; SHOBEN, Elaine W. op. cit., p. 116-119.

${ }^{541}$ COMUNIDADE ECONÔMICA EUROPEIA. Diretiva 75/117. EUR-Lex. Disponível em: <http://eurlex.europa.eu/LexUriServ/LexUriServ.do?uri=CELEX:31975L0117:PT:HTML>. Acesso em: 10 nov. 2009.

${ }^{542}$ COMUNIDADE ECONÔMICA EUROPEIA. Diretiva 76/207. EUR-Lex. Disponível em: <http://eurlex.europa.eu/smartapi/cgi/sga_doc?smartapi!celexapi!prod!CELEXnumdoc\&numdoc=31976L0207\&mod el=guichett\&lg=pt. $>$. Acesso em: 10 nov. 2009.
} 
indiretamente, nomeadamente pela referência à situação matrimonial ou familiar. Esta norma foi a precursora no direito comunitário europeu que reconheceu a discriminação sem intencionalidade, utilizando-se das expressões diretamente ou indiretamente.

A jurisprudência da Corte de Justiça da Comunidade Econômica Europeia deu outro importante passo favoravelmente ao reconhecimento desta modalidade de discriminação. O julgamento do caso Jenkins v. Kingsgate Ltd (assunto 96/80) ${ }^{543}$ foi marcante, na medida em que a jurisprudência se preocupou em descrever uma atitude discriminatória não intencional (reconhecendo a discriminação como indireta). O referido caso envolvia a prática de uma empresa que pagava aos trabalhadores em tempo parcial, hora de trabalho com valor dez por cento inferior ao da hora paga aos trabalhadores por tempo integral. A autora, que laborava em regime parcial, apresentou uma reclamação de equiparação salarial com um trabalhador do sexo masculino que trabalhava em tempo integral. A empresa reconheceu em sua defesa que o trabalho de ambos era idêntico, diferindo somente do tipo de regime praticado. A decisão da Corte de Justiça reconheceu que existe discriminação quando uma prática diferenciadora de pagamento de salários for uma forma indireta de reduzir a retribuição de um grupo de trabalhadores, exclusiva ou predominantemente composto por mulheres, como no caso do trabalho por tempo $\operatorname{parcial}^{544}$.

Outro importantíssimo passo dado pela jurisprudência da Corte de Justiça da Comunidade Econômica Europeia, talvez o caso mais marcante e que melhor expressa a situação de discriminação não intencional, foi a decisão proferida no caso Bilka Kaufhaus GmbH v Karin Weber von Hartz (assunto 170/84), decidido em 13 de maio de $1986^{545}$. A empresa alemã Bilka Kaufhaus GmbH, com grandes lojas e com milhares de empregados na então Alemanha Ocidental, decidiu implementar alterações no seu sistema de pensões de seguridade social. Uma das medidas adotadas foi excluir os trabalhadores em tempo parcial do plano de complementação de aposentadoria oferecido aos empregados da empresa, a menos que tivessem trabalhado em tempo integral por, pelo menos, quinze

\footnotetext{
${ }^{543}$ HEIDE, Ingeborg. op. cit., p. 443.

${ }^{544}$ CORTE DE JUSTIÇA DA COMUNIDADE ECONÔMICA EUROPEIA. Decisão caso $J$. $P$. Jenkins and Kingsgate (Clothing Productions) Ltd. Assunto $\mathrm{n}^{\circ}$ 96/80. EUR-Lex. Disponível em: <http://eurlex.europa.eu/LexUriServ/LexUriServ.do?uri=CELEX:61980J0096:EN:HTML>. Acesso em: 10 nov. 2009.

${ }^{545}$ CORTE DE JUSTIÇA DA COMUNIDADE ECONÔMICA EUROPÉIA. Decisão caso Kaufhaus GmbH v Karin Weber von Hartz Assunto $\mathrm{n}^{\circ}$ 170/84. EUR-Lex. Disponível em: <http://eurlex.europa.eu/LexUriServ/LexUriServ.do?uri=CELEX:61984J0170:EN:HTML>. Acesso em: 10 nov. 2009.
} 
anos. A Sra. von Hartz trabalhou para a referida empresa por quinze anos, com quatro anos no regime de tempo parcial e os demais no regime integral. Ela requereu sua inclusão ao plano empresarial de complementação de aposentadoria e teve seu requerimento negado, com base no referido regulamento. Ela questionou judicialmente a recusa e a decisão da Corte Europeia, após provocação da corte alemã nesse sentido, foi no sentido de que o tratamento dado pela empresa infringe a proibição de discriminação remuneratória do artigo 119 do Tratado de Roma, bem como da Diretiva 75/117. A decisão destacou que o plano de benefícios da empresa afeta, de maneira prejudicial, um número muito maior de mulheres do que de homens que trabalham em tempo parcial, a menos que a empresa demonstre que a existência da exclusão se baseie em fatores objetivamente justificados e não relacionados com nenhuma discriminação por sexo, o que não foi efetuado ${ }^{546}$.

A decisão da Corte de Justiça aponta que, não obstante a prática da empresa fosse uma atitude despida de qualquer conotação intencional, afetava desproporcionalmente as mulheres que trabalhavam em número muito superior no regime de tempo parcial. Assim, tendo em vista os efeitos danosos da política empresarial, sua conduta foi considerada discriminatória por motivos de sexo, proibida pelo artigo 119 do Tratado de Roma. Talvez, a apreciação do caso Bilka seja o melhor exemplo do que consiste uma discriminação não intencional. A referida decisão adota a expressão "discriminação indireta", entre aspas, reconhecendo que o termo foi utilizado pela Corte alemã de origem, a qual suscitou a decisão da Corte de Justiça da Comunidade Europeia, por se tratar de questão interpretativa do artigo 119 do Tratado de Roma. No item 15, a Corte de Justiça menciona que o artigo 119, em seu primeiro parágrafo, fala da igualdade de remuneração. No entanto, no segundo parágrafo, aquela norma constitutiva comunitária fala em remuneração, assim considerando tanto os pagamentos diretos como os indiretos, do qual a Corte de Justiça entendeu como seu integrante.

Em 1997, a Comunidade Europeia promove a primeira diretiva que apresentou um conceito descritivo da discriminação não intencional, não obstante ser uma norma que tratava da questão do ônus da prova em casos de discriminação laboral. A Diretiva 97/80, de 15 de dezembro de $1997^{547}$, apresentou o conceito de discriminação indireta, fixando a terminologia neste sentido em uma norma positivada.

\footnotetext{
${ }^{546} \mathrm{HEIDE}$, Ingeborg. op. cit., p. 445.

${ }^{547}$ UNIÃO EUROPEIA. Diretiva 97/80. EUR-Lex. Disponível em: <http://eurlex.europa.eu/LexUriServ/LexUriServ.do?uri=CELEX:31997L0080:PT:HTML>. Acesso em: 11 nov. 2009.
} 
O conceito adotado para discriminação indireta pelo artigo $2^{\circ}$, item 2 , estabelece que:

Art. $2^{o}$ - 2. Para efeitos do princípio da igualdade de tratamento referido do $n^{o} 1$, verifica-se uma situação de discriminação indireta sempre que uma disposição, critério ou prática aparentemente neutra afete uma proporção consideravelmente mais elevada de pessoas de um sexo, salvo quando essas disposições, critérios ou práticas sejam adequadas e necessárias e possam ser justificadas por fatores objetivos não relacionados com o sexo.

No ano de 2000, a União Europeia apresentou duas novas Diretivas ajustando a política de combate à discriminação laboral aos motivos previstos no Tratado de Amsterdam, do ano anterior. Assim, adotou as Diretivas 2000/43 $3^{548}$, de 29.06.2000, e a 2000/78 $8^{549}$, de 27.11.2000.

A Diretiva 2000/43 apresentou um conceito de discriminação indireta no sentido de que ela ocorre sempre que uma disposição, critério ou prática aparentemente neutra coloque pessoas de uma dada origem racial ou étnica numa situação de desvantagem comparativamente com outras pessoas, a não ser que essa disposição, critério ou prática seja objetivamente justificada por um objetivo legítimo e que os meios utilizados para tanto sejam adequados e necessários. Tal conceito foi adaptado para uso, em 2002, na Diretiva $2002 / 73^{550}$, de 23 de setembro, e veio a promover alterações na Diretiva 76/207, adaptando-a aos conceitos estabelecidos nas duas Diretivas de 2000. A Diretiva 2002/73 estabelece diferentes conceitos para a discriminação direta, discriminação indireta, assédio e assédio sexual. No que tange à discriminação indireta, a norma define em termos extremamente semelhantes com a definição da Diretiva 97/80 e com redação praticamente idêntica à do conceito emanado pela Diretiva 2000/43, apenas alterando a motivação.

O conceito adotado pela Diretiva 2000/78 é um pouco diverso, eis que a referida norma trata da discriminação por diversos motivos, inclusive a religião, deficiência, idade e orientação sexual, sendo uma norma mais genérica ao contrário das demais diretivas que

\footnotetext{
${ }^{548}$ UNIÃO EUROPEIA. Diretiva 2000/78. EUR-Lex. Disponível em: <http://eurlex.europa.eu/LexUriServ/LexUriServ.do?uri=OJ:L:2000:303:0016:0022:PT:PDF., Acesso em: 11 nov. 2009.

${ }^{549}$ Id. Ibid.

${ }^{550}$ UNIÃO EUROPEIA. Diretiva 2002/73. EUR-Lex. Disponível em: <http://eurlex.europa.eu/LexUriServ/LexUriServ.do?uri=OJ:L:2002:269:0015:0020:PT:PDF>. Acesso em: 11 nov. 2009.
} 
são fundadas em motivos específicos. Seu conceito de discriminação indireta é apresentado da seguinte forma:

Considera-se que existe discriminação indireta sempre que uma disposição, critério ou prática aparentemente neutra seja susceptível de colocar numa situação de desvantagem pessoas com uma determinada religião ou convicções, com uma determinada deficiência, pessoas de uma determinada classe etária ou pessoas com uma determinada orientação sexual, comparativamente com outras pessoas, a não ser que:

i)essa disposição, critério ou prática sejam objetivamente justificados por um objetivo legítimo e que os meios utilizados para o alcançar sejam adequados e necessários, ou que,

ii)relativamente às pessoas com uma determinada deficiência, a entidade patronal, ou qualquer pessoa ou organização a que se aplique a presente diretiva, seja obrigada, por força da legislação nacional, a tomar medidas adequadas, de acordo com os princípios previstos no artigo $5^{\circ}$, a fim de eliminar as desvantagens decorrentes dessa disposição, critério ou prática.

A legislação comunitária europeia foi bastante feliz em procurar positivar um conceito descritivo da discriminação não intencional, adotando os conceitos jurisprudenciais. Em função de a referida Diretiva ser um diploma normogenético para os Estados Membros, difundiu por todo o continente europeu um padrão conceitual elevado.

A discriminação não intencional foi uma criação jurisprudencial arrojada, cuja jurisprudência percebeu que não bastava apenas proibir a prática de atos discriminatórios intencionais, mas deveria coibir qualquer tipo de resultado discriminatório. A própria descrição de discriminação feita pela Convenção 111 da OIT dá uma importância muito destacada aos resultados dos atos discriminatórios e, em nenhum momento, menciona a intencionalidade. O reconhecimento jurisprudencial de que certas atitudes, ainda que completamente neutras, levam a resultados discriminatórios, foi um grande avanço no direito antidiscriminatório.

O conceito jurisprudencial apresentado pelo caso Griggs procura coibir medidas discriminatórias excludentes, como as vividas pelos trabalhadores afrodescendentes da empresa demandada. As medidas da empresa, apesar de absolutamente neutras, causavam exclusão dos empregados aos melhores cargos dentro da empresa, demonstrando que havia desigualdade real, ainda que sem qualquer iniciativa por parte da empresa nesse sentido. A decisão do caso Bilka igualmente foi sensível para compreender que a política da empresa causava maiores danos às trabalhadoras, em sua grande maioria laborando em tempo 
parcial, sendo elas as maiores prejudicadas com a diferenciação feita no plano de complementação de aposentadoria.

Como aponta a socióloga Manuela Tomei, o conceito de discriminação não intencional (pela autora considerada como indireta) demonstra que o mesmo tratamento dado a pessoas diferentes causa desvantagens significativas para alguns ${ }^{551}$. Segundo a mesma autora, o conceito de discriminação não intencional também permite um trabalho de valoração crítica e reformulação das práticas estabelecidas e dos princípios arraigados no mundo do trabalho. E como terceira consequência deste conceito, a autora afirma que o conceito de discriminação não intencional permite o uso de estatísticas para apurar se um critério efetivamente neutro tem provocado efeitos discriminatórios ${ }^{552}$.

A questão da terminologia desta modalidade de discriminação é tormentosa, uma vez que vários termos são adotados. Não parece ser o termo discriminação indireta o mais correto, pois na medida em que ele transmite a sensação de que se trata de uma modalidade de discriminação realizada por intermédio de alguém, dá a impressão da existência de alguma interface entre o sujeito ativo e o passivo. Por outro lado, a expressão discriminação indireta tem uma correlação muito distante da principal característica desta modalidade de discriminação, que é a neutralidade do sujeito ativo e a preponderância do resultado da conduta.

Não se pode adotar também a expressão discriminação oculta. Esta expressão pode revelar intencionalidade, e das mais nefastas. Na discriminação oculta, determinado empregador age deliberadamente com propósitos discriminatórios; no entanto, sua intenção é camuflada ou escamoteada. Pinho Pedreira aponta que, na discriminação oculta, o motivo proibido e não confessado é realmente o determinante, embora disfarçado de outra roupagem $^{553}$.

A terminologia impacto adverso pode parecer ser mais apropriada que a terminologia europeia, mas ainda traduz a ideia de uma ação que cause impacto, o que não é exatamente o caso dessa modalidade. Na maior parte dos casos, tal modalidade de discriminação ocorre por condutas omissivas de sujeitos ativos, principalmente ao tratarem igualmente situações desiguais, provocando resultados desvantajosos para alguns grupos. A canadense Denise Reaumé prefere a adoção da terminologia discriminação por efeito

\footnotetext{
${ }^{551}$ TOMEI, Manuela. op. cit., p. 443.

${ }^{552}$ Id. Ibid., p. 445.

${ }^{553}$ PEDREIRA, Luiz de Pinho. Discriminação indireta, cit., p. 403.
} 
adverso $^{554}$, terminologia mais adequada, por demonstrar uma noção da discriminação não intencional. No entanto, tal expressão peca porque a modalidade intencional de discriminação também possui efeito adverso, como demonstrado no quarto capítulo.

A terminologia adotada por Regina Maria Vasconcelos Dubugras já é bem mais feliz que a adoção da expressão discriminação indireta. A autora adota a expressão discriminação reflexiva ${ }^{555}$ como aquela situação onde determinada política do empregador reflete mais em um grupo que outro, sem justificativa adequada. No entanto, a definição da jurista paulista ainda não consegue superar o alcance da expressão discriminação não intencional, na medida em que esta última expressão traz muito maior proximidade com a noção efetiva desta modalidade de discriminação e sua diferenciação com a forma oposta. Assim, por tal motivo, é a terminologia escolhida na presente investigação.

No caso da discriminação não intencional, a prova de uma necessidade do empregador ou mesmo de um critério de proporcionalidade pode eximi-lo de ser responsável pelos resultados discriminatórios. As diretivas europeias acima citadas mencionam tal situação, principalmente os conceitos elaborados na trilogia das Diretivas de 2000 e 2002. No caso especial da Diretiva 2000/78, os conceitos excludentes da consideração da discriminação não intencional são mais detalhados, uma vez que esta norma também trata das questões de discriminação de deficientes. Esta modalidade, especificamente, traz consigo uma complexa noção na qual o empregador deve adotar e ajustar todas as formas de trabalho, dentro de um critério de razoabilidade, para que o deficiente possa exercer seu trabalho.

\subsection{Classificação das discriminações pela prejudicialidade}

Como foi visto no quarto capítulo, item 4.2.1., a prejudicialidade é um componente dos atos discriminatórios, posto que traduz uma noção de prejuízo, de adversidade ou de tratamento desvantajoso em relação a alguém ou determinado grupo. A definição mais

\footnotetext{
${ }^{554}$ REAUMÉ, Denise. Constitutional law: harm and fault in discrimination law: the transition from intentional to adverse effect discrimination. Theoretical Inquiries in Law. Jan. 2001, p. 380. Lexis Nexis. Disponível em:

<http://www.lexisnexis.com/us/lnacademic/results/docview/docview.do?docLinkInd=true\&risb=21_T7854 381486\&format=GNBFI\&sort=BOOLEAN\&startDocNo=1\&resultsUrlKey=29_T7854381494\&cisb=22_T 7854381493\&treeMax=true \& treeWidth=0\&csi=246886\&docNo=12>. Acesso em: 11 nov. 2009.

${ }^{555}$ DUBUGRAS, Regina Maria Vasconcelos. Discriminação no emprego: formas, defesas e remédios jurídicos. LTr: revista legislação do trabalho, São Paulo, ano 66, n. 11, p. 1335, nov. 2002.
} 
aceita de discriminação intencional nos dias atuais, como demonstrado no sexto capítulo, é no sentido de ser tratado de maneira menos favorável que outra em situação comparável.

Certas modalidades de discriminação, no entanto, ao invés de promoverem tratamento desvantajoso, procuram tratar certos grupos de modo mais favorável, em relação aos demais. É necessário ponderar que em toda a prática discriminatória haverá alguém que será tratado mais favoravelmente. Quando alguns são tratados de modo mais favorável, outros não têm a mesma sorte. Mas existe a possibilidade de que certas medidas venham deliberadamente a tratar de modo mais favorável determinados grupos. Esta situação resulta em uma grande polêmica, na medida em que certas situações discriminatórias são condenadas pelo direito e outras não - ao contrário, devem ser incentivadas.

Como foi visto no tópico anterior, ao tratar da discriminação não intencional, foi possível constatar que, mesmo proibindo atitudes discriminatórias intencionais, situações discriminatórias não intencionais atingirão resultados semelhantes, por uma série de fatores já alinhavados. Combater a discriminação tão somente proibindo-a é uma atitude jurídica extremamente passiva, posto que as relações humanas, nas formas que se encontram atualmente estruturadas, continuarão a promover efeitos discriminatórios.

As ideias relatadas no segundo capítulo sobre a igualdade apontam que não basta apenas proibir atitudes discriminatórias. Somente outras atitudes, fundadas em artifícios que venham a gerar outras desigualdades em sentido inverso, poderão atingir resultados no sentido da igualdade real. A manutenção de uma posição essencialmente neutra e passiva diante de fenômenos discriminatórios não atingirá a ordem de promover a igualdade social, como já foi demonstrado no tópico anterior. A igualdade não é somente um princípio, mas possui uma função axiológica fundamental na edificação de todo o sistema jurídico, em especial no direito constitucional brasileiro. A sua realização não pede somente proibições, mas, sim, atitudes positivas em favor dos menos favorecidos. Luiz Alberto David Araújo destaca que o mandamento de igualdade contém a tarefa de inclusão social, na medida em que devem ser constituídas desigualdades como forma de proteção de determinados grupos que se encontram em situação de inferioridade, para equiparar as situações ou, pelo menos, atenuar as diferenças desses grupos com os demais ${ }^{556}$.

\footnotetext{
${ }^{556}$ ARAÚJO, Luiz Alberto David. Buscando significados a partir de critérios de interpretação constitucional e, muitas vezes, encontrando um desconcertante preconceito. In: (Coord.). Defesa dos direitos das pessoas portadoras de deficiência. São Paulo:Editora Revista dos Tribunais, 2006. p. 208.
} 
O próprio direito do trabalho já deixou claro em sua evolução que não basta as partes serem consideradas iguais, elas deverão ser de fato iguais, cabendo ao direito atuar desigualmente em favor do lado mais débil para se buscar a igualdade substancial entre as partes contratantes. Desigualdades somente serão corrigidas com outras desigualdades, porém em sentido inverso, tentando promover um vetor compensatório em favor do equilíbrio.

O papel do direito no combate à discriminação será o de equalizar as relações sociais e, para tanto, deverá ter um papel ativo. Cabe ao direito, como instrumento de combate do longo histórico de discriminações contra determinados grupos, promover desigualdades em sentido inverso para se busque uma melhor equalização dos efeitos sociais das desigualdades que são praticadas por tanto tempo.

Não cabe aqui, em função das limitações da investigação, formular uma defesa mais sólida das discriminações positivas, posto que ensejaria uma complexa e profunda investigação, desviando-se totalmente do foco inicial. No entanto, cabe um posicionamento favorável à sua existência, mormente quando elas são colocadas em cheque por diversos atores sociais, formulando um intenso debate em torno de seus conceitos.

Nos Estados Unidos da América, seu berço, tais políticas recebem duros questionamentos judiciais nos dias atuais. As mais recentes decisões da Suprema Corte daquele país, principalmente aquelas que tratam de ações afirmativas no campo da educação e das relações de trabalho, tendem a restringir decisivamente esta forma de equalização social, pelo crivo da inconstitucionalidade e do rigoroso exame estrito a que são submetidas naquela Corte. Christopher Peters aponta que a Corte Roberts, dirigida pelo Juiz John Glover Roberts Jr., indicado como chefe da Corte pelo ultraconservador Presidente George W. Bush, em 2005, tem se caracterizado por apresentar resultados que agradam aos conservadores, com particular interesse em decisões constitucionais e infraconstitucionais favorecendo empresas sobre consumidores e empregados ${ }^{557}$. Girardeau Spann possui uma visão mais sombria das futuras tendências da Suprema Corte, com maiores chances de prevalência do conservadorismo nas decisões sobre integração racial

\footnotetext{
${ }^{557}$ PETERS, Christopher J. The Roberts Court at age three: under-the-table overruling. The Wayne Law Review. $\quad N^{\mathrm{o}} 54$, outono 2008, p. 1067. Lexis Nexis. Disponível em: http://www.lexisnexis.com/us/lnacademic/results/docview/docview.do?docLinkInd=true\&risb=21_T78649 93532\&format=GNBFI\&sort=RELEVANCE\&startDocNo=1\&resultsUrlKey=29_T7864993537\&cisb=22 _T7864993536\&treeMax=true\&treeWidth=0\&csi=145282\&docNo=16>. Acesso em: 12 nov. 2009.
} 
escolar, caracterizado pela neutralidade e por uma "cegueira racial" preconizada pelo atual chefe da Corte ${ }^{558}$.

Feitas tais considerações, podemos realizar a classificação das discriminações de acordo com a sua prejudicialidade em dois grupos principais - as discriminações negativas e as discriminações positivas.

\subsubsection{Discriminações negativas}

Discriminações negativas são aquelas modalidades de discriminação que podem tratar alguém de maneira menos favorável que outra pessoa ou grupo, bem como implicam em exclusão ou prejuízo acentuado para determinada pessoa ou grupo. Elas carregam consigo uma noção de prejudicialidade, como demonstrado no quarto capítulo da presente investigação, prejudicialidade esta que pode ser constatada por diversos modos. Por tal motivo, podemos classificá-la de discriminação negativa. A questão não importa maiores aprofundamentos, posto que, praticamente, toda a investigação está centrada nesta modalidade de discriminação.

\subsubsection{Discriminações positivas}

Quando a OIT adotou a Convenção $\mathrm{n}^{\mathrm{o}} 111^{559}$, teve a preocupação de inserir um artigo, que se tornou o quinto daquela norma antidiscriminatória, e que diz o seguinte:

Artigo $5^{\circ}$

1. Medidas especiais de proteção ou de assistência dispostas em outras Convenções ou Recomendações adotadas pela Conferência Internacional do Trabalho não deverão ser consideradas como discriminação.

2. Todo Membro, após consulta a organizações representativas de empregadores e de trabalhadores, se as houver, pode definir que outras medidas especiais destinadas a atender a necessidades particulares de pessoas que, por motivo de sexo, idade, invalidez, responsabilidades familiares ou nível social ou cultural, são geralmente reconhecidas como

\footnotetext{
${ }^{558}$ SPANN, Girardeau A. The future of school integration in America: disintegration. University of Louisville Law Review. $\mathrm{N}^{\mathrm{o}}$ 46, verão 2008, p. 629. Lexis Nexis. Disponível em: $<$ http://www.lexisnexis.com/us/lnacademic/results/docview/docview.do?docLinkInd=true\&risb=21_T7864 993532\&format=GNBFI\&sort=RELEVANCE\&startDocNo=1\&resultsUrlKey=29_T7864993537\&cisb=2 2_T7864993536\&treeMax $=$ true \& treeWidth $=0 \& c s i=148538 \& d o c N o=17>$. Acesso em: 12 nov. 2009.

${ }^{559}$ ORGANIZAÇÃO INTERNACIONAL DO TRABALHO. Convenção $\mathrm{n}^{\mathrm{o}}{ }^{111}$. Sítio do escritório da OIT em Brasília. Disponível em: $<$ http://www.ilo.org/public/portugue/region/ampro/brasilia/info/download/convencao111.pdf >. Acesso em: 20 out. 2009.
} 
requerendo proteção ou assistência especial, não devem ser consideradas discriminação.

Na confecção da norma antidiscriminatória, a OIT teve a preocupação de configurar expressamente, como não discriminatórias, certas medidas de proteção ou de assistência de outras normas daquela entidade. Por outro lado, ao deixar a critério dos países membros, a norma reconhece que determinadas formas de medidas especiais que venham promover proteção ou assistência especial, não podem ser consideradas discriminatórias. Warwick McKean destaca que a principal realização da Convenção 111 foi a formulação de um conceito que permitisse entender o que era discriminação. E dentro da definição apresentada, uma das suas principais virtudes está no reconhecimento inequívoco que medidas especiais de proteção que visam promover igualdade substancial não podem ser consideradas como discriminatórias ${ }^{560}$.

Não somente a Convenção 111, como também outras normas internacionais posteriores, passaram a reconhecer um grupo de medidas promocionais da igualdade como não integrantes dos conceitos de discriminação. Entre elas, a Convenção para eliminação de todas as formas de discriminação racial, conforme seu parágrafo $4^{\circ}$ do artigo $1^{\circ}$, nos seguintes termos:

§4. Não serão consideradas discriminação racial as medidas especiais tomadas com o único objetivo de assegurar o progresso adequado de certos grupos raciais ou étnicos ou de indivíduos que necessitem da proteção que possa ser necessária para proporcionar a tais grupos ou indivíduos igual gozo ou exercício de direitos humanos e liberdades fundamentais, contanto que tais medidas não conduzam, em consequência, à manutenção de direitos separados para diferentes grupos raciais e não prossigam após terem sido alcançados os seus objetivos. ${ }^{561}$

McKean qualifica o item $4^{\circ}$ do artigo $1^{\circ}$ da referida Convenção, não como uma exceção, mas, sim, como sendo um corolário necessário da definição de discriminação ${ }^{562}$. O autor neozelandês aponta que o trabalho da subcomissão preparatória foi ampliado dentro da comissão redatora daquela Convenção, para atender aos conceitos de

\footnotetext{
${ }^{560}$ MCKEAN, Warwick. op. cit., p. 128.

${ }^{561}$ ORGANIZAÇÃO DAS NAÇÕES UNIDAS. Convenção para a eliminação de todas as formas de discriminação racial. Adotada pela Assembléia Geral das Nações Unidas em 21 de dezembro de 1965. Disponível em: <http://www.direitoshumanos.usp.br/index.php/Prevenção-contra-a-Discriminação-eProteção-das-Minorias/convencao-internacional-sobre-a-eliminacao-de-todas-as-formas-de-discriminacaoracial-1968.html>. Acesso em: 20 out. 2009.

${ }^{562}$ MCKEAN, Warwick. op. cit., p. 159.
} 
discriminação e de proteção de minorias, a serem fundidos dentro do princípio de igualdade $^{563}$. A mesma fórmula é adotada na Convenção para eliminação de todas as formas de discriminação contra a mulher em 1979, consolidando-se um princípio internacional de que, medidas diferenciadoras que visam proteger e promover grupos discriminados não podem ser consideradas como atitudes discriminatórias.

As discriminações positivas são aquelas deliberadamente adotadas, em caráter temporário para, através de atitudes diferenciadoras, procurar promover socialmente determinados grupos historicamente prejudicados, conferindo-lhe maior igualdade de oportunidades. Devem ser consideradas discriminações positivas pelo fato de promover uma equalização social de grupos historicamente excluídos ou sub-representados dentro das esferas de poder na sociedade.

Sandra Fredman prefere a adoção da expressão discriminação reversa, apontando, como tal, as atitudes de beneficiar determinado grupo que tenha sido previamente sofrido desvantagem ou exclusão, com base nos motivos por ela mencionados (raça e gênero, atendendo aos desígnios da legislação britânica) ${ }^{564}$. Thilo Ramm também menciona que a expressão discriminação reversa é adotada nos Estados Unidos, expondo que são medidas designadas para remediar discriminações adversas passadas ou presentes, concedendo deliberadamente tratamento preferencial para um grupo em desvantagem ${ }^{565}$.

Resta claro que, promovendo discriminações em favor de um grupo, outro certamente será prejudicado. Resta saber por qual motivo tal forma de discriminação não é condenada pelo direito, apesar de seus efeitos danosos a determinados grupos. As pessoas ou grupos que sofreram desvantagens desta natureza chegam a questionar judicialmente tais formas de discriminações positivas, traduzindo-se em questões extremamente controvertidas. Um vívido exemplo desta tendência ficou consagrada no célebre processo Regents of The University of California v. Bakke ${ }^{566}$, cuja decisão é ainda marcante naquele país em favor de tais ações. Nesse processo, um candidato a estudante na faculdade de medicina da Universidade da Califórnia questionou judicialmente sua admissão preterida

\footnotetext{
${ }^{563}$ MCKEAN, Warwick. op. cit., p. 159.

${ }^{564}$ FREDMAN, Sandra. Discrimination law, cit., p. 126.

${ }^{565}$ RAMM, Thilo. Introduction, cit., p. 17.

${ }^{566}$ SUPREMA CORTE DOS ESTADOS UNIDOS DA AMÉRICA. Regents of The University of California v. Bakke. 438 US 265 (1978). Cornell University Law School. Supreme Court Collection. Disponível em: <http://www.law.cornell.edu/supct/html/historics/USSC_CR_0438_0265_ZS.html>. Acesso em: 12 nov. 2009.
} 
em favor de candidatos negros, os quais lograram obter menor qualificação, mas foram admitidos em função de políticas de ações afirmativas adotadas pela Universidade.

A Suprema Corte dos EUA julgou o caso e decidiu invalidar o procedimento adotado pela universidade. O voto do Juiz Powell entendeu que a questão racial impunha a aplicação do escrutínio estrito, não tendo sido demonstrado pela Universidade que havia interesse irresistível para manutenção do programa, sendo este considerado ilegal. No entanto, apesar de dar ganho de causa ao autor, proferiu decisão no sentido de que as preferências raciais são permissíveis se sua finalidade for aumentar a diversidade racial entre os alunos, e se não estipularem cotas fixas para as minorias, mas levarem em consideração a raça como um dos fatores, entre vários outros.

Em 2003, a Corte julgou dois outros casos que ganharam dimensão nacional, com a participação de quase uma centena de amicus curiae em defesa de ambos os lados. Os casos Grutter v. Bollinger ${ }^{567}$ e Grantz v. Bollinger ${ }^{568}$ mobilizaram o país a favor e contra as ações afirmativas. A Corte considerou como constitucional o uso da raça como critério de seleção (caso Grutter), no entanto derrubou o sistema de pontuação favorável às minorias, o qual foi considerado pela Corte como um sistema de cotas (caso Gratz). Ambas as decisões tomaram como base a decisão proferida no caso Bakke, com algumas pequenas divergências.

Em situações laborais, os precedentes da Suprema Corte dos EUA também reconhecem a discriminação positiva. O julgamento do caso United Steelworkers of America v. Weber ${ }^{569}$ confirmou a constitucionalidade de um programa voluntário de ação afirmativa estabelecido por uma empresa em determinado ambiente de trabalho, afirmando que tal prática não fere a cláusula da igual proteção das leis. A referida Corte examinou detalhadamente os debates para a aprovação da Lei de Direitos Civis de 1964 e concluiu que o programa voluntário de ação afirmativa da empresa em questão foi adotado para eliminar modalidades tradicionais de segregação racial. A decisão afirmou que qualquer proibição de uma ação afirmativa seria exatamente contrária ao propósito da lei posta em

\footnotetext{
${ }^{567}$ SUPREMA CORTE DOS ESTADOS UNIDOS DA AMÉRICA. Grutter v. Bollinger. 539 US 306 (2003). Cornell University Law School. Supreme Court Collection. Disponível em: <http://www4.law.cornell.edu/supct/html/02-241.ZS.html>. Acesso em: 12 nov. 2009.

${ }^{568}$ SUPREMA CORTE DOS ESTADOS UNIDOS DA AMÉRICA. Gratz v. Bollinger. 539 US 244 (2003). Cornell University Law School. Supreme Court Collection. Disponível em: $<$ http://www4.law.cornell.edu/supct/html/02-516.ZS.html>. Acesso em: 12 nov. 2009.

${ }^{569}$ SUPREMA CORTE DOS ESTADOS UNIDOS DA AMÉRICA. United Steelworkers of America v. Weber. 443 US 193 (1979). Findlaw - Law for legal professionals. Disponível em: $<$ http://caselaw.lp.findlaw.com/scripts/getcase.pl?court=US\&vol=443\&invol=193>. Acesso em: 12 nov. 2009.
} 
cheque, o que impôs a rejeição da inconstitucionalidade alegada. A decisão afirmou claramente que as disposições da lei foram concebidas para estimular os empregadores e sindicatos a reverem suas práticas empregatícias e eliminar os vestígios de uma infeliz $e$ ignominiosa página na história do país. A decisão do caso também foi rumorosa e causou manifestações em todos os sentidos.

Recentemente, a Suprema Corte dos EUA proferiu uma decisão em apertada maioria de cinco votos favoráveis contra quatro votos contra, em uma polêmica decisão envolvendo ações afirmativas. Trata-se do caso Ricci v. DeStefano ${ }^{570}$, no qual os autores (bombeiros) ingressaram com uma ação contra a cidade de New Haven alegando discriminação por parte da municipalidade em relação a promoções não consolidadas. Os autores, na maioria brancos e dois hispânicos, passaram nos testes de promoção para cargos superiores. No entanto, os administradores da municipalidade invalidaram o teste em face de que nenhum dos aprovados era negro, temendo uma ação por discriminação não intencional contra uma minoria protegida. Os autores questionaram a invalidação afirmando que a municipalidade negara as promoções por motivo de raça.

A Corte entendeu, pela apertada maioria de votos obtida no seu braço mais conservador, que a decisão da municipalidade que ignorou os resultados do teste aplicado violou o Título VII da Lei dos Direitos Civis. O voto condutor apontou que somente pode ser válida a desclassificação se houver demonstração extremamente segura no sentido de que tais ações afirmativas são válidas se vierem a ser demonstradas como absolutamente necessárias para corrigir efeitos discriminatórios do passado, o que não teria sido demonstrado no mencionado processo.

Como se vê, a decisão proferida em 29 de junho de 2009 demonstra claramente que as discriminações positivas laborais estão sendo vistas cada vez com maiores restrições pela Suprema Corte dos EUA, somente as aceita mediante uma prova irrefutável de sua necessidade para corrigir situações pretéritas.

Assim, é possível constatar que, não obstante sejam importantíssimas as discriminações positivas, elas são vistas com olhos muito restritos pelas visões mais conservadoras. Elas se apoiam em questões processuais, como o uso do escrutínio estrito, para reprovarem as ações afirmativas diante da dificuldade de provar que tais medidas são

\footnotetext{
${ }^{570}$ SUPREMA CORTE DOS ESTADOS UNIDOS DA AMÉRICA. Ricci et al. v. DeStefano et al.. 07-1428 (2009). Supreme Court of United States. Disponível em: <http://www.supremecourtus.gov/opinions/08pdf/07-1428.pdf>. Acesso em: 12 nov. 2009.
} 
absolutamente necessárias e cujo interesse estatal seja irresistível. Salvo uma mudança no perfil decisório daquela Corte, a tendência atual demonstra que as conquistas obtidas nos anos setenta vão sendo paulatinamente minadas mediante argumentos que não preferem enfrentar frontalmente os objetivos de tais ações afirmativas, mas tangenciá-los ou criar empecilhos para que ações de cunho reparador não tenham viabilidade judicial.

\subsection{Classificação em relação aos motivos}

No quinto capítulo, mais precisamente no item 5.4., foi mencionada a divisão dos motivos discriminatórios em dois grupos principais, conforme classificação de Thilo Ramm. A classificação divide os motivos baseados em fatores naturais ou fatores sociais, além da possibilidade de um ato discriminatório envolver motivos mistos. Os motivos de um ato discriminatório repercutem decisivamente na forma da discriminação praticada, impondo uma divisão.

No que tange aos fatores naturais, eles são teoricamente imutáveis, já que para certas situações os avanços da medicina desafiam o seu caráter como definitivos. Formase, assim, uma modalidade de discriminação laboral que não permite à vítima nenhuma opção, ou seja, nada pode ela fazer contra a atitude discriminatória, já que o fator envolvido não depende de sua vontade. $\mathrm{O}$ ato discriminatório se consuma imediatamente.

Por outro lado, a discriminação fundada em fatores sociais é uma situação completamente diversa, na medida em que é fundada sobre critérios optativos da vítima do ato discriminatório. $\mathrm{O}$ bem a ser protegido nesta situação discriminatória é a liberdade de a pessoa humana adotar determinada conduta. A discriminação, nesse caso, tende a ser mais delicada e a situação discriminatória merece uma atenção especial. Com efeito, é possível que uma pressão do empregador ou tomador de serviços anterior ao ato discriminatório possa macular a liberdade de conduta da vítima.

O exemplo clássico de tal modalidade discriminatória nas relações do trabalho é a postura de um empregador não aceitar em seus quadros trabalhadores sindicalizados. Um empregado sindicalizado, necessitando do emprego, poderá perfeitamente, em face de sua necessidade, desfiliar-se do seu sindicato profissional para conseguir sua admissão. Neste caso, a discriminação ocorreu, não pela recusa, mas pela política da empresa em não aceitar trabalhadores sindicalizados, praticamente obrigando o trabalhador a abandonar sua filiação sindical em troca da sua admissão. O prejuízo do empregado não ocorreu na perda 
do emprego, mas na violência que sofreu contra a sua liberdade de filiação sindical, um direito humano internacionalmente consagrado. Do mesmo modo ocorrerá na discriminação por filiação política, crença religiosa e outros fatores opcionais.

A discriminação por motivos sociais é totalmente diferente da discriminação por motivos naturais, eis que a última pode promover reflexos fora do ambiente de trabalho, sem provocar qualquer alteração nas condições de trabalho. Muitas vezes, a discriminação por motivos sociais não traduz uma desvantagem para a vítima no ambiente de trabalho, mas situação de complexa gravidade fora dele, prejudicando o exercício de liberdades sociais e políticas. Portanto, a citada modalidade discriminatória baseada em motivos sociais, pede uma análise extremamente diversa da discriminação por fatores naturais, ingressando no debate sobre sua existência, ou não, o peso da liberdade mitigada pela atitude discriminatória. Esta, por sua vez, pode não estar consolidada em uma atitude nem em um resultado, mas tão somente em uma ameaça, que, sem sombra de dúvida, também é atitude ilícita e deve ser proibida.

No caso da discriminação por motivos mistos, outro equacionamento deve ser adotado para solução do conflito. Em primeiro lugar, deverão ser identificados os motivos, para saber se existe uma discriminação por motivos mistos, bem como se o ato supostamente discriminatório a ser discutido deva ser composto de motivos legítimos e ilegítimos, bem como a natureza dos motivos ilegítimos (naturais e/ou sociais). A apreciação desta complexa situação pede uma apreciação separada dos motivos ilegítimos e legítimos. Será necessário saber se os motivos ilegítimos tiveram influência relevante na atitude apresentada como suposta discriminação para sua configuração.

\subsection{Classificação em relação à posição das partes envolvidas}

Uma classificação apresentada pelo jurista uruguaio Eduardo Goldstein indica uma diversidade de atitudes discriminatórias baseada na posição das partes envolvidas no ato discriminatório $^{571}$. Em sua classificação, apresenta as modalidades de discriminação vertical, vertical invertida e horizontal.

Goldstein assinala que discriminação vertical nas relações laborais é aquela em que o empregador atua, bem como alguma pessoa dentro da estrutura da empresa com poderes

\footnotetext{
${ }^{571}$ GOLDSTEIN, Eduardo. La discriminación racial por origen nacional y etnia en las relaciones laborales. Montevideo: Fundación de Cultura Universitaria, 2009. p. 120-121.
} 
de direção, frente a seus subordinados. $\mathrm{O}$ autor aponta que esta é a forma mais comum de discriminação. Seria interessante ampliar o conceito de Goldstein, para apontar que a discriminação vertical seria aquela modalidade discriminatória praticada por um empregador, tomador de serviços ou pessoa por ele autorizada para atuar com poderes de direção, contra um trabalhador ou candidato, vinculado a este agente, em razão de uma relação de trabalho existente, potencial ou já encerrada. A ampliação se justifica uma vez que a discriminação pode ser praticada pelo empregador, pelo tomador de serviços ou por terceiros autorizados em nome do empregador para tomar decisões em seu nome. Um exemplo desta situação são os agentes de recrutamento, que podem praticar atos discriminatórios.

Goldstein aponta que discriminação vertical invertida é aquela praticada pelos trabalhadores subordinados ante seus empregadores ou dirigentes médios da empresa. Tal situação, apesar de parecer incomum, ocorre com certa frequência quando um trabalhador ou grupo de trabalhadores age de forma prejudicial contra sua chefia. Um modelo desta discriminação é o assédio invertido, situação que ocorre com certa frequência em clubes esportivos, praticadas por atletas profissionais de futebol. São comuns situações de certos atletas de futebol que deixam de atuar da forma esperada, para que os maus resultados acarretem na dispensa do técnico da equipe que, por algum motivo não é do agrado do grupo de atletas. Ou, por exemplo, determinados vendedores que atuem de forma menos rentável ou com resultados menos favoráveis, procurando prejudicar seu gerente ou forçar sua dispensa por algum motivo. A situação acima poderá ocorrer também em relações de trabalho não subordinadas, tal qual a discriminação vertical comum.

Por fim, Goldstein aponta um fenômeno cada vez mais crescente e preocupante, a discriminação horizontal. Segundo o mencionado jurista esta forma de discriminação ocorre quando um ou vários companheiros de trabalho, que não detêm poder de mando dentro da organização empresarial, exteriorizam um trato discriminatório a outro companheiro similar ou de inferior categoria. O conceito de Goldstein pode ser ampliado para caracterizar os atuais fenômenos empresariais como a terceirização, por exemplo. Assim, podemos concluir que a discriminação horizontal ocorre quando um trabalhador ou grupo de trabalhadores, sem qualquer poder ou autorização para agir em nome do empregador ou tomador de serviços, exteriorizam um trato discriminatório a um companheiro de trabalho ou a um trabalhador de algum modo ligado por uma relação de trabalho aos autores, em situação similar ou inferior. 
Esta modalidade de discriminação vem se tornando muito comum, principalmente com o fenômeno do bullying, já descrito no quarto capítulo, no qual integrantes de determinado um grupo passam a hostilizar um trabalhador com atitudes isolacionistas, ofensivas ou humilhantes, sendo uma forma de assédio. Por outro lado, as discriminações horizontais podem ocorrer entre trabalhadores empregados e trabalhadores terceirizados dentro da mesma unidade produtiva, situação mais comum do que se imagina, principalmente pela precariedade da contratação dos terceirizados.

Por fim, podemos adicionar a situação de discriminação reflexiva. Esta modalidade de discriminação ocorre não pelo fato de uma pessoa possuir determinado fator que venha a se tornar um motivo discriminatório, mas que alguém próximo a ela possua tal fator e, reflexivamente, por essa proximidade, acabe sendo vítima de uma discriminação. Trata-se de uma forma de discriminação odiosa e gravíssima, de difícil apuração e demonstração, mas recorrente.

É possível citar como exemplo a discriminação contra empregadas domésticas quando o empregador toma conhecimento que seu companheiro é ou foi presidiário ou possua registros de antecedentes criminais. Por outro lado, é muito comum em casos de conflitos armados, que determinado trabalhador seja cônjuge de uma pessoa da nacionalidade do país beligerante. Ou mesmo pais de filhos que necessitem de cuidados especiais em função de alguma anormalidade física ou mental, que tenham limitações com horários de trabalho e viagens. Pais nessas circunstâncias, tem dificuldades para obterem colocações em funções gerenciais ou mesmo em altos cargos em função das restrições que as condições especiais de seus filhos lhe impõem.

\subsection{Classificação quanto ao momento da prática do ato discriminatório}

Uma importante classificação das discriminações deve ser realizada com base no momento da relação jurídica. Tais situações discriminatórias se distinguem exatamente pelo momento contratual que ocorrem e, diante deste critério, têm características completamente distintas. Assim, a classificação deverá tomar como base o momento em que a relação jurídica material de trabalho se encontra quando praticado o ato discriminatório. 


\subsubsection{Discriminação pré-contratual}

Trata-se de uma modalidade extremamente comum de discriminação, com extremas dificuldades de demonstração e complexas situações de prova. Nesse momento não há ainda qualquer relação jurídica constituída entre a empresa e o trabalhador. De alguma forma as partes começam a manter um relacionamento que visa ajustar uma relação de trabalho que ainda não existe, e forma, tão somente, um vínculo extremamente precário.

O relacionamento nasce com a oferta de trabalho por parte do futuro empregador ou tomador de serviços, como também pode ocorrer pela procura de trabalho por parte de um candidato a determinado trabalho. A última prática atualmente é comum mediante o envio de currículos, tanto para empregadores como para agências de emprego, recrutamento ou seleção de empregados, com entrega direta ou envio por meio eletrônico.

As formas de discriminação são as mais variadas possíveis, e eles podem ter início nos próprios anúncios. Um bom exemplo da discriminação em tais situações são os anúncios onde consta "necessária boa aparência". Tal exigência não permite uma definição prévia, abrindo uma grande possibilidade para uma discriminação contra minorias. O que seria "boa aparência" é, efetivamente, um requisito amplo e ilimitado, abrindo margens para discriminações das mais variadas espécies.

Tais situações discriminatórias também passam pelas formas de apresentação ao emprego. Nos Estados Unidos da América, a prática local adota que o candidato preencha um formulário de solicitação de emprego, que pode ter as mais variadas indagações. Preocupada com esta ampla possibilidade discriminatória, a Equal Employment Opportunity Comission, agência do governo norte-americano encarregada de combater a discriminação laboral conforme a Lei dos Direitos Civis, estabelece uma série de diretrizes que os empregadores deverão cumprir, para não incorrerem em situações discriminatórias. Diretrizes como proibir anúncios apontando determinadas categorias como preferidas, uso de testes não relacionados com o trabalho, recrutamento dirigido, utilizar-se de dados nos formulários que induzam à discriminação por um dos motivos proibidos ${ }^{572}$, entre outras práticas, são condenadas pela comissão que procura orientar os empregadores a não adotálas, como também são auxiliares nas decisões judiciais.

\footnotetext{
${ }^{572}$ ESTADOS UNIDOS DA AMÉRICA. Equal Employment Opportunity Comission. Prohibited Employment Pratices/Policies. Disponível em: <http://www.eeoc.gov/laws/practices/index.cfm>. Acesso em: 13 nov. 2009.
} 
A discriminação pré-contratual é muito ampla nos dias atuais, eis que tal fase pode ser estendida por longos períodos, inclusive envolvendo testes, treinamentos, visitas, viagens e tantos outros procedimentos durante os quais, ainda que não haja uma relação de trabalho, existe uma grande possibilidade de práticas discriminatórias.

No fim de todos os procedimentos preparatórios, a recusa a determinado trabalho normalmente não é divulgada de forma aberta, mas dirigida ao candidato e, muitas vezes, sem qualquer informação mais detalhada da fundamentação da escolha. Por tal motivo, o artigo 32 do Código do Trabalho português exige o registro dos atos de recrutamento e sua manutenção por um prazo de cinco anos ${ }^{573}$. Com a exigência de manutenção de registro por parte do diploma legal, é possível concluir que cabe ao empregador demonstrar os motivos pelos quais determinado empregado não foi admitido naquele país, sendo ônus do empregador a prova de um motivo razoável para tanto.

Chama a atenção o triste mas comum fenômeno das "listas sujas", uma grave prática discriminatória. Muitos empregadores não desejam possuir empregados que já tenham aforado algum processo trabalhista e, para saber esta situação, contratam profissionais especializados em proceder tais levantamentos. Algumas entidades patronais são acusadas de formar uma relação de trabalhadores como personas non gratas. A lista circula dentro de determinada atividade econômica de forma bastante restrita ou mesmo de modo secreto. Uma vez que determinado candidato é adicionado à referida lista, ele praticamente não tem como obter novo emprego dentro daquele ramo de atividade econômica. A utilização de tal artifício por parte do empregador, bem como induzir trabalhadores a encerrarem seus processos para que não tenham reclamações pendentes, configura grave prática discriminatória e deve ser punida com extremo rigor. Tais formas de discriminação são extremamente difíceis de serem demonstradas, prejudicando seu combate e sua erradicação.

São muitas as situações que envolvem a discriminação pré-contratual, o que, infelizmente, quase nada é tratado no Brasil em termos legislativos a respeito desta complexa matéria. Tais posturas são muitas vezes fomentadas por uma grande criatividade dos empregadores para adoção de práticas discriminatórias.

\footnotetext{
${ }^{573}$ PORTUGAL. Código do Trabalho. Atualizado pela Lei 7 de 12 de fevereiro de 2009. Diário da República Eletrônico. Disponível em: <http://dre.pt/pdf1sdip/2009/02/03000/0092601029.pdf>. Acesso em: 26 out. 2009.
} 


\subsubsection{Discriminação durante o contrato}

Durante o desenvolvimento de uma relação de trabalho pode ocorrer um grande número de práticas discriminatórias. As situações mais comuns são as questões envolvendo promoções e, principalmente, as situações de dispensa discriminatória. Ainda mais no Brasil, onde a dispensa imotivada é plenamente aceita por omissão legislativa do Congresso Nacional, a possibilidade de uma dispensa discriminatória é ampliada.

Durante uma relação de trabalho, o empregador deve tomar uma série de decisões envolvendo seus empregados ou trabalhadores não subordinados. Situações de promoção, transferências, designação de funções, ocorrências internas, cortes de trabalhadores, questões disciplinares e tantas outras possibilidades podem ser permeadas por atitudes discriminatórias. Muito mais ainda em tempos de dificuldades que a atividade econômica vem enfrentando, medidas como fusões, terceirizações, downsizings podem carregar muitas características discriminatórias.

Algumas atitudes chegam a ser mais severas, como as que configuram assédio moral vertical, punições como rebaixamentos de função ou situações onde o empregado é colocado como trabalhador sem importância para a atividade funcional perante os demais colegas. Infelizmente, tais situações começam a emergir com maior frequência nas lides trabalhistas, revelando a existência de constantes práticas de atitudes deploráveis, principalmente no caso de assédio moral.

Situações em que o empregador, ou tomador de serviços, deixe de conceder os mesmos benefícios a alguns trabalhadores, bem como a aplicação de cargas de ônus desproporcionalmente distribuídas, são atitudes que podem ser consideradas discriminatórias se o empregador ou tomador de serviços não demonstrar a necessidade de tais medidas, bem como sua proporcionalidade.

Assim, por ser a modalidade mais comum de discriminação, não há nenhuma dificuldade em reconhecê-la, de acordo com uma classificação temporal.

\subsubsection{Discriminação pós-contratual}

As situações de discriminação laboral pós-contratual vêm configurando uma modalidade extremamente perversa, que tem encontrado um número crescente na casuística dos tribunais laborais. São atitudes discriminatórias praticadas por exempregadores ou ex-tomadores de serviços, realizadas após o término do contrato de trabalho. 
A mais comum delas é a prática de prestar más referências a outros futuros empregadores, situação extremamente comum, porém de quase impossível constatação. Em mercados de trabalho competitivos, empregadores e tomadores de serviço procuram obter o máximo de informações dos candidatos que se apresentam para um trabalho. Atualmente, com os meios da tecnologia de informação, uma informação negativa sobre um ex-empregado pode ter efeito devastador em determinada atividade ou localidade, cerceando-lhe a possibilidade de obter novo emprego.

Algumas vezes, o pretenso empregador, ao verificar os registros de exempregadores ou ex-contratantes em uma proposta de emprego ou em uma folha curricular, entra em contato informal com esses ex-empregadores, na busca de referências sobre o candidato. Nessas situações, um ex-empregador inescrupuloso poderá prestar informações falsas ou somente as notícias desabonadoras, ou mesmo informações que constituam dados sensíveis sobre o candidato, que podem, decisivamente, prejudicá-lo na obtenção de novos contratos de trabalho. Em algumas situações, o ex-empregador poderá lançar o nome desse ex-empregado em uma "lista suja" que, se for de interesse do futuro empregador sua verificação, pode fechar definitivamente as portas de qualquer colocação dentro de uma atividade negocial, ou mesmo dentro de uma área territorial mais restrita. São situações extremamente difíceis de serem combatidas, eis que tais informações são prestadas informalmente, sem a presença de testemunhas. Tais dificuldades prejudicam demasiadamente a vítima para demonstrar em juízo um nexo de causalidade entre determinada informação e a sua rejeição em determinado emprego a que se candidatou.

\subsection{Modalidades discriminatórias específicas}

Algumas modalidades discriminatórias possuem um reconhecimento específico por força de normas positivadas ou por parte da doutrina especializada. Em função de características peculiares, não são possíveis classificações, mas, tão somente, um destaque das suas mais importantes formas. A investigação tratará de duas modalidades específicas - o assédio e a discriminação retaliatória - situações que já são comuns e que merecem algumas considerações especiais. 


\subsubsection{Discriminação por assédio}

A discriminação por assédio é um fenômeno muito conhecido dentro das relações laborais. No entanto, recentemente passou a ser considerado o assédio como atitude discriminatória, inclusive por normas positivadas. O assédio sempre foi uma prática comum dentro das relações de trabalho, mormente dentro das relações de emprego onde a vinculação subordinativa do empregado junto ao seu empregador e a necessidade da manutenção do emprego o torna extremamente dependente das vontades de seus chefes. Atualmente, questões envolvendo assédio têm sido procuradas com maior intensidade na Justiça do Trabalho brasileira, inclusive com a formação de uma importante jurisprudência a respeito.

O artigo 29 da Lei de Contrato de Trabalho de Portugal, de $n^{\circ} 7 / 2009$, qualifica o assédio como sendo o comportamento indesejado, nomeadamente o baseado em fator de discriminação, praticado quando do acesso ao emprego ou no próprio emprego, trabalho ou formação profissional, com o objetivo ou o efeito de perturbar ou constranger a pessoa, afetar a sua dignidade, ou de lhe criar um ambiente intimidativo, hostil, degradante, humilhante ou desestabilizador ${ }^{574}$. A norma legal portuguesa trata do assédio como uma modalidade única, fazendo uma distinção entre o assédio de modo geral e o assédio por conotação sexual, no item 2 do referido artigo 29.

O conceito português é derivado dos conceitos apresentados pelas Diretivas 2000/43, 2000/78 e 2002/73, que tratam o assédio como um modo discriminatório em termos gerais. A Diretiva 2002/73 considera separadamente o assédio quando motivado por alguma conotação sexual, sempre que ocorrer um comportamento indesejado de caráter sexual, sob forma verbal, não-verbal ou física, com o objetivo ou o efeito de violar a dignidade da pessoa, em particular pela criação de um ambiente intimidativo, hostil, degradante, humilhante ou ofensivo ${ }^{575}$.

Duas modalidades principais de assédio são definidas pela doutrina e pelo ordenamento jurídico de vários países - o assédio moral e o assédio sexual.

\footnotetext{
${ }^{574}$ PORTUGAL. Código do Trabalho. Atualizado pela Lei 7 de 12 de fevereiro de 2009. Diário da República Eletrônico. Disponível em: <http://dre.pt/pdf1sdip/2009/02/03000/0092601029.pdf>. Acesso em: 26 out. 2009.

${ }^{575}$ UNIÃO EUROPEIA. Diretiva 2002/73. EUR-Lex. Disponível em: <http://eurlex.europa.eu/LexUriServ/LexUriServ.do?uri=OJ:L:2002:269:0015:0020:PT:PDF>. Acesso em: 11 nov. 2009.
} 
Ocorre assédio moral, segundo a psiquiatra francesa Marie-France Hirigoyen ${ }^{576}$, quando é praticada toda e qualquer conduta abusiva manifestada sobretudo por comportamentos, palavras, atos, gestos, escritos que possam trazer dano à personalidade, à dignidade ou à integridade física ou psíquica de uma pessoa, colocando em perigo o seu emprego ou degradando o ambiente de trabalho. Trata-se de uma postura ativa de um determinado agente pela qual passa a hostilizar determinada pessoa, ocorrendo uma situação de maus tratos progressivo e acumulativo, normalmente procurando acuar ou fragilizar a situação de determinada pessoa dentro do ambiente laboral. Candy Florêncio Thome destaca que o assédio moral também pode ocorrer também por omissão da empresa, e não somente pela extrapolação de poder diretivo do empregador ${ }^{577}$.

A referida prática também é conhecida pela expressão prevalecente no Reino Unido como mobbing, assim derivada do verbo to mob da língua inglesa, que tem vários significados, entre eles tumultuar, amotinar, a ação de uma grande multidão que pode ser ruidosa ou violenta ou o cerco de uma multidão por interesse ou admiração ${ }^{578}$. Também a prática pode ser conhecida como "psicoterror social" na Suécia e bullying nos Estados Unidos da América, como relatam Carlos Alberto Toselli, Pablo Martín Grassis e Juan Ignacio Ferrer ${ }^{579}$. Os autores revelam muitas formas desta prática, podendo ser de uma forma aberta ou muito sutil, por diversos atos típicos ou bastante incomuns.

Já o assédio sexual possui definição e até tipificação penal no direito brasileiro, conforme o artigo 216-A do Código Penal, conforme redação dada pela Lei 10.224, de 15 de maio de 2001. O artigo aponta que assédio sexual, para finalidades criminais, é constranger alguém com o intuito de obter vantagem ou favorecimento sexual, prevalecendo-se o agente da sua condição de superior hierárquico ou ascendência inerentes ao exercício de emprego, cargo ou função ${ }^{580}$.

\footnotetext{
${ }^{576}$ HIRIGOYEN, Marie-France. Assédio moral: a violência perversa no cotidiano. Trad. Maria Helena Kühner, 5. ed. Rio de Janeiro: Bertrand Brasil, 2002. p. 65.

${ }^{577}$ THOME, Candy Florencio. O assédio moral nas relações de emprego. São Paulo: LTr, 2008. p. 102.

${ }^{578}$ LONGMAN DICTIONARY OF AMERICAN ENGLISH. White Plains:Longman, 1983. p. 432.

${ }^{579}$ TOSELLI, Carlos Alberto; MARTÍN GRASSIS, Pablo; FERRER, Juan Ignacio. Violencia en las relaciones laborales. Córdoba: Alveroni Ediciones, 2007. p. 395.

${ }^{580}$ BRASIL. Lei 10.224 , de 15 de maio de 2001. Palácio do Planalto. Legislação. Disponível em: <http://www.planalto.gov.br/ccivil_03/Leis/LEIS_2001/L10224.htm>. Acesso em: 16 nov. 2009.
} 
Denise Pasello Valente Novais, com apoio no escólio de Dolores de la Fuente Vásquez, afirma que para a configuração do assédio sexual é necessária a presença dos seguintes elementos ${ }^{581}$ :

a) comportamento do agente com caráter ou conotação sexual;

b) repulsa a este comportamento por parte da vítima;

c) comportamento com incidência negativa na situação laboral da vítima.

A Equal Employment Opportunity Comission destaca que o assédio sexual possui os seguintes componentes em especial:

a) a vítima e o assediador podem ser um homem ou uma mulher e a vítima não deve ser, necessariamente, do sexo oposto;

b) o assediador pode ser um supervisor da vítima, um agente do empregador, um supervisor em outra área, um colega de trabalho ou um não-empregado;

c) a vítima não necessita estar em contato direto com o assediador mas deverá, de algum modo, ser afetado pela conduta;

d) o assédio sexual ilegal poderá ocorrer sem danos econômicos para a vítima ou dispensa da vítima;

e) a conduta do assediador não poderá ser bem-vinda por parte da vítima ${ }^{582}$.

As condutas de assédio sexual se apresentam de várias formas. Elas podem se manifestar mediante uma chantagem, quando um superior, ou qualquer pessoa com controle sobre a situação do empregado atacado solicita um relacionamento sexual em troca de um benefício tangível, como também no caso de a vítima subordinada não ser contratada, promovida, transferida ou demitida, ou não receber o benefício em face da rejeição da proposta sexual oferecida. Também o assédio sexual poderá ser configurado pela existência de ambiente hostil, mediante uma conduta sexual indesejável na forma de aproximações, pedido de favores sexuais, exposição de material de natureza ou orientação sexual, contínuas ofensas ou uso indevido de linguagem inapropriada, contato físico indesejado, propostas ou questões sobre a vida sexual. É uma postura que cria uma conduta suficientemente grave e suficientemente intensa para alterar as condições de emprego ou

\footnotetext{
${ }^{581}$ NOVAIS, Denise Pasello Valente. Discriminação da mulher e direito do trabalho. São Paulo: LTr, 2005. p. 94.

${ }^{582}$ ESTADOS UNIDOS DA AMÉRICA. Equal Employment Opportunity Comission. Disponível em: $<$ http://www.eeoc.gov/eeoc/publications/fs-sex.cfm>. Acesso em: 16 nov. 2009.
} 
para criar ambiente hostil no trabalho. Por fim, o assédio sexual pode decorrer da influência de elementos assediadores vindos de terceiros, sendo que a vítima não está diretamente envolvida com nenhuma conduta sexual e não participa de nenhuma atividade ou mesmo brincadeiras com orientação sexual, porém, por tal motivo, é uma empregada qualificada que deixa de ser beneficiada com promoções e oportunidades em favor de pessoas menos qualificadas, principalmente quando os favorecidos corresponderam a solicitações sexuais do responsável pela decisão ou têm sido participantes voluntários de comportamentos sexuais ofensivos.

A Diretiva 2002/73 deixa claro nas suas considerações e fundamentações em especial no item de $n^{\circ} 8$, que o assédio sexual é uma forma de discriminação por motivo de sexo, por ser contrário ao princípio da igualdade de tratamento entre homens e mulheres ${ }^{583}$. A consideração ainda aponta que tal forma de discriminação pode ocorrer não somente no ambiente de trabalho e na sua execução, como também no acesso ao emprego e na formação profissional.

Por outro lado, o item "9" das considerações sobre a Diretiva deixa claro que tanto os empregadores como os responsáveis pela formação profissional devem ser incentivados a tomar medidas para combater todas as formas de discriminação sexual, em especial medidas contra o assédio e o assédio sexual. $\mathrm{O}$ artigo $3^{\circ}$ da referida diretiva deixa claro, como integrante do texto normativo, que o assédio e o assédio sexual são modalidades discriminatórias e, portanto, proibidas ${ }^{584}$.

\subsubsection{Discriminação por retaliação}

Uma modalidade de discriminação com raras menções na doutrina nacional, mas extremamente comum, é a discriminação por retaliação. Trata-se de uma modalidade discriminatória que ocorre quando o empregado se opõe a uma prática ilegal discriminatória solicitada pelo empregador ou quando o empregado promove alguma reclamação, queixa, testemunho ou participou de alguma investigação de qualquer forma, conforme explica Rebecca White ${ }^{585}$. A autora aponta que a Lei de Direitos Civis dos Estados Unidos da América, em seu artigo 704, garante proteção contra a discriminação

\footnotetext{
${ }^{583}$ ESTADOS UNIDOS DA AMÉRICA. Equal Employment Opportunity Comission, cit. ${ }^{584}$ Id., loc. cit.

${ }^{585}$ WHITE, Rebecca Hanner. Employment law and employment discrimination. New York: Aspen Law \& Business, 1998. p. 99.
} 
por retaliação, baseado em duas cláusulas importantes: a de oposição a atos discriminatórios e a cláusula de livre acesso.

O artigo 704 da Lei dos Direitos Civis de 1964 aponta as seguintes condutas retaliatórias como proibidas $^{586}$ :

a) discriminação pela apresentação de queixas, testemunhos, assistência ou participação em procedimentos de efetivação de medidas antidiscriminatórias, audiências ou por ter participado de qualquer forma em um dos procedimentos indicados;

b) a discriminação a ser considerada envolve empregados e candidatos a emprego;

c) os agentes discriminadores podem ser a empresa, uma agência de empregos, um comitê de controle de aprendizado ou qualquer outra forma de treinamento ou retreinamento, organizações sindicais;

d) publicação de notícias, anúncios indicando preferências proibidas, limitações, especificações de trabalho, que indiquem qualquer preferência, limitação, especificação ou discriminação de qualquer natureza, salvo se houver uma razão específica para tanto, uma qualificação ocupacional de boa-fé ou necessidade do serviço prestado.

A Lei de Direitos Humanos do Canadá, em seu artigo 14, considera como prática discriminatória a retaliação, ou a ameaça de retaliação, contra qualquer pessoa que tenha apresentado queixa, ou tenha agido em nome da vítima, declarando que essa pessoa tem proteção no seu emprego $^{587}$.

No entanto, melhor parece agir a legislação portuguesa, no artigo 25, item 7 , no qual torna inválido qualquer ato de retaliação que prejudique o trabalhador em consequência de rejeição ou submissão a ato discriminatório ${ }^{588}$. A legislação portuguesa é bastante interessante, na medida em que ataca diretamente o efeito da retaliação, um grande fator de inibição para sua prática.

A importância da proibição da discriminação retaliatória está na defesa dos direitos trabalhistas em geral, bem como da proteção contra a discriminação em particular. Ninguém terá segurança para propor uma queixa ou mesmo uma ação judicial, se não tiver

\footnotetext{
${ }^{586}$ ESTADOS UNIDOS DA AMÉRICA. Civil Rights Act. Equal Employment Opportunity Comission. Disponível em: <http://www.eeoc.gov/laws/statutes/titlevii.cfm>. Acesso em: 16 nov. 2009.

${ }^{587}$ CANADÁ. Canadian Human Rights Act. Department of Justice of Canada. Disponível em: $<$ http://laws.justice.gc.ca/PDF/Statute/h/h-6.pdf>. Acesso em: 21 nov. 2009.

${ }^{588}$ PORTUGAL. Código do Trabalho. Atualizado pela Lei 7 de 12 de fevereiro de 2009. Diário da República Eletrônico. Disponível em: <http://dre.pt/pdf1sdip/2009/02/03000/0092601029.pdf>. Acesso em: 21 nov. 2009.
} 
uma proteção contra a dispensa. No caso brasileiro, a situação de retaliação também é facilitada pela falta de regulação da dispensa imotivada, diante da omissão legislativa do Congresso Nacional em regular o inciso I, do artigo $7^{\circ}$ de nossa Constituição Federal.

Nesse tipo de discriminação, é importante que seja estabelecida uma situação de causa e efeito entre uma conduta por parte da vítima que não traria bons resultados para o empregador ou tomador de serviços, bem como uma ação desvantajosa por parte do empregador sobre a vítima. A demonstração das duas situações configura a existência de uma discriminação retaliatória, a menos que o empregador justifique adequadamente a conduta desvantajosa praticada, demonstrando sua necessidade e sua proporcionalidade com a necessidade alegada. Porém, ao existir uma conduta por parte da vítima que seja prejudicial ao empregador, ainda que potencialmente, qualquer atitude contra a vítima ganha contornos de suspeição.

David Rutter ${ }^{589}$ aponta que, nesses casos, a prova deverá seguir o mesmo modo procedimental estabelecido no caso McDonnell Douglas v. Green. Esse modelo de prova no direito norte-americano estabelece que o empregado deverá demonstrar a verossimilhança da alegação de discriminação e, uma vez demonstrada, inverte-se o ônus da prova ao empregador para demonstrar uma justificativa à diferenciação praticada. Uma vez demonstrados os fatos da justificativa pelo empregador, cabe ao autor o ônus da prova para demonstrar que as alegações empresariais não passam de um pretexto.

\footnotetext{
${ }^{589}$ RUTTER, David Anthony. Title VII Retaliation, a Unique Breed. The John Marshall Law Review. $\mathrm{n}^{\mathrm{o}}$ 36, verão de 2003. p. 927. Lexis Nexis. Disponível em: <http://www.lexisnexis.com/us/lnacademic/results/docview/docview.do?docLinkInd=true\&risb=21_T7893 727195\&format=GNBFI\&sort=RELEVANCE\&startDocNo=1\&resultsUrlKey=29_T7893729918\&cisb=2 2_T7893729917\&treeMax $=$ true $\&$ treeWidth $=0 \& c s i=145279 \&$ docNo=3 > . Acesso em: 16 nov. 2009.
} 


\section{PRINCÍPIOS DE COMBATE À DISCRIMINAÇÃO}

O presente capítulo irá abordar os princípios de combate à discriminação nas relações laborais. Como já foi apresentado no terceiro capítulo, a proibição da discriminação é constituída por um corpo de normas de caráter especial dentro do direito internacional e do direito constitucional. Recebe destaque especial no nosso texto constitucional, como um dos objetivos do Estado brasileiro. Igualmente, naquele capítulo, foi demonstrado que a proibição da discriminação é um dos direitos fundamentais nas relações do trabalho, bem como um dos princípios do direito do trabalho.

Esta posição singular das normas antidiscriminatórias dentro do direito internacional, bem como no direito constitucional e, por fim, no direito do trabalho, permite concluir que a proibição da discriminação tem uma influência destacada nas normas laborais. A proibição de discriminação como um princípio do direito laboral constitui alguns princípios de ordem material e processual no âmbito das relações de trabalho.

O capítulo pretende apresentar alguns desses princípios, que são componentes do direito antidiscriminatório em geral e do direito antidiscriminatório laboral em particular. Os mencionados princípios alicerçam o combate à discriminação nas relações de trabalho, principalmente, para assegurar a percepção de todos os demais direitos em igualdade de condições. Assim, serão inicialmente demonstrados os princípios de ordem material e, em seguida, os princípios processuais como instrumentos de realização da proibição da discriminação nas relações do trabalho.

\subsection{A proibição da discriminação nas relações do trabalho}

Como já foi visto no terceiro capítulo, a proibição da discriminação é um dos princípios mais importantes do direito do trabalho, não somente porque visa proteger o igual tratamento e iguais oportunidades a todos os trabalhadores, bem como pretende defender e efetivar os direitos fundamentais dos trabalhadores. O reconhecimento pela OIT da importância de igualdade de tratamento, desde a Convenção de Versalhes até a consolidação da declaração dos direitos fundamentais do trabalho de 1998, demonstra a histórica preocupação daquela entidade com a igualdade de trato e de oportunidades no 
trabalho. Como bem coloca Joaquim Augusto Domingos Damas, o princípio da igualdade de tratamento dos trabalhadores na empresa é reconhecido como um importante princípio na generalidade dos sistemas jurídico-laborais ${ }^{590}$. E não poderia ser diferente, posto que sua não observância seria uma porta escancarada para a violação dos demais direitos trabalhistas e fundamentais do trabalhador.

É uma proibição de direito fundamental voltada contra o Estado e, também, contra os empregadores e contratantes de trabalho humano, com a mesma intensidade e rigor. Aplica-se o princípio conhecido como Drittwirkung der Grundrechte, decorrente da intersecção do direito do trabalho com o direito constitucional geral.

A exigência da igualdade de tratamento interfere nos processos decisórios do empregador ou contratante de serviços, o que torna evidente a existência de um antagonismo entre o direito de não ser discriminado e a liberdade contratual do empregador, como bem lembra Luciano Ventura. Segundo o autor, a aplicação exagerada do princípio da igualdade leva inevitavelmente à completa anulação da autonomia privada $^{591}$. Amauri Mascaro Nascimento lembra muito bem que os direitos fundamentais também significam deveres entre particulares, na defesa do empregado contra a exacerbação de poder do empregador ${ }^{592}$.

Paulo Bonavides assevera que os princípios são superiores e hegemônicos na pirâmide normativa, encontrando-se no seu ápice, como norma das normas, de fonte das fontes, a viga-mestra do sistema ${ }^{593}$. Como norma, ele impõe determinadas condutas, principalmente quando são de natureza especial, tanto no aspecto material como no aspecto instrumental, que é o igual trato em dignidade e direitos de todos os seres humanos.

A proibição da discriminação está umbilicalmente ligada ao princípio maior do direito do trabalho que é o princípio da proteção do trabalhador, como forma de compensação de sua inferioridade e dependência em relação ao empregador ou contratante de serviços. Como bem apontava Plá Rodriguez, o princípio da proteção tem como preocupação central alcançar uma igualdade substancial e verdadeira entre as partes ${ }^{594}$. A proteção contra a discriminação e o princípio protetor, efetivamente, possui objetivos muito próximos, com uma integração de propósitos. Martínez Rocamora, no entanto,

\footnotetext{
${ }^{590}$ DAMAS, Joaquim Augusto Domingos. O princípio da igualdade na relação jurídica de trabalho. Revista Jurídica do Trabalho, ano 1, v. 1, p. 118, abr./jun. 1988.

${ }^{591}$ VENTURA, Luciano. op. cit., p. 19.

${ }^{592}$ NASCIMENTO, Amauri Mascaro. op. cit., p. 906.

${ }^{593}$ BONAVIDES, Paulo. op. cit., p. 294.

${ }^{594}$ PLÁ RODRIGUEZ, Américo. Princípios de direito do trabalho, cit., p. 28.
} 
solicita uma proteção mais acentuada para as situações que envolvem uma discriminação, em comparação com os casos de quebra da igualdade. Segundo o autor, nas atitudes discriminatórias não somente são verificadas violações a interesses individuais, como também violações de interesses coletivos ${ }^{595}$.

Portanto, não resta dúvida que, na condição de princípio do direito do trabalho, ainda mais na qualidade de mandamento de caráter destacado entre os demais direitos humanos, a proibição da discriminação permeia todos os aspectos de uma relação de trabalho. Todo e qualquer componente de uma relação de trabalho deverá observar a proibição da discriminação, gerando reflexos importantes e profundos, impondo sua aplicação efetiva em qualquer situação laboral. Com destaque especial, tal proibição atinge também as normas coletivas, posto que a autonomia coletiva privada não pode se sobrepor a uma obrigação geral de trato igual. Assim, a proibição da discriminação demonstra possuir um grande efeito reflexivo sobre todos os demais princípios e normas laborais.

Essa destacada preocupação implica no surgimento de alguns outros princípios dentro do direito antidiscriminatório laboral, derivados da proibição da discriminação. Tais princípios emergem tanto no direito material como também no direito processual laboral.

\subsection{O princípio da igualdade como presunção de medida justa}

Um dos mais importantes princípios do direito antidiscriminatório é o reconhecimento da igualdade como demonstração de uma medida de justiça. O objetivo nuclear da norma antidiscriminatória é preservar e promover a igualdade substancial, com o pleno respeito à igual dignidade entre os seres humanos. O trato de pessoas em condições de igualdade, com base em tal princípio, faz presumir um tratamento mais justo. Como presunção, não é absoluta, mas, sim, traduz uma noção muito mais próxima da ideia de justiça. Tal princípio tem origem no postulado aristotélico de que a igualdade não pede justificativas ao contrário da desigualdade, como já foi mencionado no segundo capítulo, item 2.7.

O trato igual recebe uma característica intuitiva de tratamento justo, que conduz o intérprete a presumi-lo como atitude mais correta. Uma vez que a igualdade é uma noção mais próxima de justiça, uma situação de tratamento diferenciado induz a uma característica inversa, ou seja, uma noção intuitiva de comportamento inadequado. Trata-se

${ }^{595}$ MARTÍNEZ ROCAMORA, Luis Gabriel. op. cit., p. 165. 
de uma mera noção intuitiva, que não permite deduzir, automaticamente, que havendo tratamento desigual há tratamento discriminatório.

A adoção deste princípio conduz ao entendimento de que, verificada uma situação de tratamento diferenciado, este tende a se distanciar da noção de tratamento justo. Assim, a existência de um tratamento diferenciado pede justificações que, se não forem apresentadas nem suficientemente justificadas, poderão induzir ao entendimento de que o tratamento diferenciado esteja em desacordo com o mandamento geral de igualdade. Porém, somente poderá ser considerado tratamento discriminatório se constatada na diferenciação analisada a presença de outros componentes discriminatórios necessários para sua configuração.

Para o direito antidiscriminatório, toda a situação de tratamento diferenciado, principalmente as diferenciações fundadas em motivos historicamente reconhecidos na nossa sociedade, deve receber contra si uma suspeição de antijuridicidade. A Suprema Corte dos Estados Unidos da América tem mantido por longo tempo um entendimento no sentido de que, havendo uma classificação por motivo de raça, a medida se torna "suspeita", adotando-se tal expressão, aplicando-se o mais rigoroso exame sobre a sua constitucionalidade (strict scrutiny), como já visto no item 5.2.2 da presente investigação. Laurence Tribe aponta que a adoção do referido sistema de investigação da violação dos direitos fundamentais pretende, mediante um rigoroso exame, preservar os valores da igualdade e da autonomia ${ }^{596}$.

Na ocorrência de determinada conduta com efeitos diferenciados, este princípio atrai a suspeição de sua inadequação diante do mandamento de igualdade. Isso não significa que a conduta seja reconhecida imediatamente como discriminatória. A existência de uma postura diferenciadora atrai um exame mais detalhado e profundo para saber se pode ser juridicamente aceita. Martínez Rocamora designa como "categoria suspeita" a existência de uma diferenciação.

Essa suspeição da conduta diferenciadora terá importantes reflexos sobre o direito antidiscriminatório, por ser um princípio constitutivo deste. Em primeiro lugar, quando discutida a existência de uma questão discriminatória, este princípio conduzirá o intérprete a presumir um ato diferenciador como ilegítimo. Se a diferenciação tiver fundamento em um dos motivos expressos pela norma proibitória, bem como os motivos que o sistema

${ }^{596}$ TRIBE, Laurence H. op. cit., p. 1465. 
jurídico tenciona proteger com maior intensidade, a suspeição da medida será proporcionalmente mais intensa. Ela demandará justificativas proporcionalmente mais robustas para fundamentar a disparidade estabelecida e afastar a presunção de violação do tratamento igual.

As implicações deste princípio levarão a duas importantes repercussões: nas questões materiais, havendo um tratamento diferenciado a determinada pessoa ou grupo, a referida diferenciação necessitará de uma justificativa para que não seja considerada como ilegítima. Dependendo do motivo e da gravidade dos danos infligidos pela conduta diferenciadora, a intensidade da justificativa irá, proporcionalmente, ser mais elevada. A proibição da discriminação fortalece e complementa a eficácia dos direitos fundamentais; por tal motivo, uma justificativa adequada e proporcional deve ser exigida para que não seja a diferenciação classificada como discriminatória.

Já no aspecto processual, uma vez constatada alguma conduta diferenciadora, terá efeitos significativos na questão do ônus da prova, principalmente da justificativa. Assim, verificado o tratamento diferenciado, caberá à parte que a ele deu causa justificá-lo, bem como provar a existência da necessidade da conduta diferenciadora, com importantes reflexos sobre o ônus da prova.

Mas é preciso estar bem atento para qual a situação de igualdade ou desigualdade deve ser demonstrada. Certas condutas de cunho igualitário aplicadas sobre situações distintas, devem ser analisadas especialmente. A desigualdade necessita de uma precisa verificação na atitude comparativa para avaliar se a potencial vítima e o modelo de comparação possuem situações iguais que tenham recebido tratamento diferenciado, como também, sendo desiguais, recebam tratamento idêntico, com impacto diferenciado. Caberá ao intérprete proceder com bastante cuidado a avaliação comparativa, para que não venham ocorrer, em nome de uma aparente igualdade, efeitos discriminatórios.

\subsection{A imprescritibilidade das violações discriminatórias}

Um aspecto fundamental que toda violação discriminatória irá envolver, principalmente nas relações laborais, é a existência da prescrição do direito de postular judicialmente uma reparação contra uma atitude discriminatória. Uma prática discriminatória é um dos mais graves atentados contra a dignidade e os direitos do ser humano. Ela não trata a vítima na plenitude de sua condição humana, retirando-lhe os 
mesmos direitos de todos os demais seres humanos, inserindo-a em uma situação de inferioridade diante de outro ser humano ou grupo social. A gravíssima ofensa a todo o corpo de direitos humanos é inequívoca.

As graves violações de direitos humanos não podem estar sujeitas a prazos prescricionais, muito menos ainda no caso das relações laborais. As características dos direitos humanos e do direito de proteção contra a discriminação não permitem aceitar limitações temporais, mormente quando o trabalhador estiver economicamente dependente do empregador ou do contratante de serviços.

Como direito fundamental, a proibição da discriminação não pode sofrer limitações de ordem temporal. José Afonso da Silva destaca que os direitos fundamentais são imprescritíveis na medida que nunca deixam de ser exigíveis, por não serem direitos patrimoniais, mas personalíssimos, sendo sempre exercidos e exercíveis, não havendo intercorrência temporal de não exercício que fundamente a perda da exigibilidade pela prescrição $^{597}$.

Luigi Ferrajoli, no mesmo sentido, indica que os direitos fundamentais são diferentes dos direitos patrimoniais, no sentido de que os primeiros são indisponíveis, não podendo ser expropriáveis ou limitáveis por outros sujeitos, muito menos pelo Estado ${ }^{598}$. Tanto que a própria igualdade de tratamento é inalienável, como também os direitos fundamentais cerceados por uma prática discriminatória, cuja natureza torna-os incompatíveis com uma visão patrimonialista que os permita dispor.

Caio Mário da Silva Pereira ressalta que a prescritibilidade de direitos somente alcança os direitos subjetivos patrimoniais de caráter privado, não podendo ser admitidos como prescritíveis os direitos personalíssimos, como a vida, a honra, a liberdade, a integridade física ou moral. O referido civilista aponta que tais direitos poderão ser reclamados, não sendo possível um estado que lhe seja contrário ${ }^{599}$.

Várias normas internacionais, das quais o Brasil é signatário, reconhecem a inexistência de prescrição contra diversos atos desumanos, inclusive situações de discriminação ostensiva e sistemática. A Convenção contra os crimes de guerra e os crimes contra a humanidade faz menção expressa à imprescritibilidade de determinados atos contra a humanidade. No seu artigo $1^{\circ}, \S 2$, reconhece como imprescritíveis uma série de

\footnotetext{
${ }^{597}$ SILVA, José Afonso. op. cit., p. 181.

${ }^{598}$ FERRAJOLI, Luigi. Igualdad y diferencia: derechos y garantias: la ley del más débil, cit., p. 47.

${ }^{599}$ PEREIRA, Caio Mario da Silva. Instituições de direito civil. Rio de Janeiro: Forense, 2004. v. 1, p. 687.
} 
atos graves contra a pessoa humana, inclusive os atos desumanos resultantes da política de Apartheid ${ }^{600}$.

O Estatuto de Roma, que criou o Tribunal Penal Internacional, faz uma detalhada previsão dos crimes contra a humanidade. Em seu artigo $7^{\circ}$, define uma série de crimes desta natureza, entre eles perseguição de um grupo ou coletividade que possa ser identificado, bem como crime de apartheid e outros atos desumanos que causem grande sofrimento, ou afetem gravemente a integridade física ou a saúde física ou mental ${ }^{601}$.

Fica claro que, dentro do direito internacional, a previsão de atos de discriminação sistemática como o apartheid são medidas consideradas como graves crimes contra a humanidade e, de acordo com a citada convenção, considerados imprescritíveis.

Portanto, a afirmação da imprescritibilidade das reparações dos atos discriminatórios tem forte amparo no direito constitucional e internacional. Tal posicionamento reflete decisivamente na esfera laboral, cujas relações são sempre marcadas por regimes de subordinação e dependência econômica.

As lides envolvendo situações discriminatórias enfrentam grandes discussões sobre limites prescricionais, principalmente aquelas que envolvem diferenças salariais em face de práticas discriminatórias, ocorridas continuamente durante a relação de trabalho. Tais diferenças emergem por um longo período, sem que a vítima tenha condições de reunir elementos materiais e provas suficientes para seu questionamento administrativo ou judicial. Os efeitos da discriminação ocorridos no passado podem ser percebidos continuamente, por muito tempo, sem que, na realidade, a vítima possa exercer livremente seu direito de ação. Nesse sentido, lastreado em sua experiência como magistrado trabalhista, Pedro Paulo Teixeira Manus aponta a correção da aplicação parcial da prescrição contra os atos do empregador que se repetem no tempo, como nos casos de diferenças salariais, uma vez que o proceder do empregador se renova a cada pagamento $^{602}$.

\footnotetext{
${ }^{600}$ ORGANIZAÇÃO DAS NAÇÕES UNIDAS. Convenção contra os crimes de guerra e dos crimes contra a humanidade. Biblioteca Virtual de Direitos Humanos da USP. Disponível em: $<$ http://www.direitoshumanos.usp.br/index.php/Sistema-Global.-Declara\%C3\%A7\%C3\%B5es-e-TratadosInternacionais-de-Prote $\% \mathrm{C} 3 \% \mathrm{~A} 7 \% \mathrm{C} 3 \% \mathrm{~A} 3 \mathrm{o} /$ convencao-sobre-a-imprescritibilidade-dos-crimes-de-guerrae-dos-crimes-contra-a-humanidade.html>. Acesso em: 23 nov. 2009.

${ }^{601}$ ORGANIZAÇÃO DAS NAÇÕES UNIDAS. Ministério das Relações Exteriores. Decreto $n^{\circ}$ 4.388/2002. Disponível em: <http://www2.mre.gov.br/dai/tpi.htm>. Acesso em: 23 nov. 2009.

${ }^{602}$ MANUS, Pedro Paulo Teixeira. A prescrição no direito do trabalho. Revista do Tribunal Regional do Trabalho da $15^{a}$ Região, v. 1, p. 148, 1991.
} 
O caso Ledbetter v. Goodyear Tire \& Rubber Co. ${ }^{603}$ é um destacado exemplo, posto que foi um impactante processo nos Estados Unidos, que resultou em uma reação do Congresso Nacional daquele país. Lilly Ledbetter começou a trabalhar para a mencionada empresa em 1979, e atingiu cargos de gerência intermediária na unidade onde desempenhava suas atividades, mas recebia salários significativamente inferiores a seus pares do sexo masculino, fato incontroverso naquele processo. A autora reclamou da situação perante a empresa, que não reviu sua situação. Próximo de sua saída, em 1998, por aposentadoria antecipada, a funcionária apresentou uma queixa administrativa perante a EEOC - Equal Employment Opportunity Comission, agência governamental responsável pela implementação das disposições trabalhistas da Lei de Direitos Civis, alegando discriminação por motivo de gênero, requisito essencial para mover uma ação judicial contra o empregador de acordo com o Título VII. A autora obteve autorização da entidade e moveu a ação judicial contra a empresa, questionando as diferenças salariais decorrentes da prática discriminatória. Após sucesso em primeiro grau, a decisão favorável à autora foi revertida em grau de apelação. A autora apresentou um recurso perante a Suprema Corte, que admitiu seu apelo e decidiu a questão.

A decisão da Suprema Corte dos EUA, em apertada maioria de cinco votos a quatro, entendeu que a limitação de 180 dias prevista no título VII é aplicável, sendo que a pretensão da referida autora estaria prescrita, uma vez que o ato discriminatório ocorreu muito antes do prazo legal estabelecido e, que cada ato de pagamento não significava uma renovação da prática discriminatória. O voto vencedor da lavra do Juiz Samuel Alito tomou como base o precedente da decisão do caso United Airlines v. Evans ${ }^{604}$, cujo voto do Juiz Stevens afirmou que um ato discriminatório que não seja oportunamente questionado passa a ser um mero evento infeliz na história que não possui consequências legais atuais $^{605}$.

No julgamento do caso Ledbetter, a Juíza Ruth Ginsburg apresentou um voto divergente lido na sessão de julgamento, fato incomum, acompanhada por outros três

\footnotetext{
${ }^{603}$ SUPREMA CORTE DOS ESTADOS UNIDOS DA AMÉRICA. Ledbetter v. Goodyear Tire \& Rubber Co. 550 U.S. 618 (2007). Cornell University Law School - Legal Information Institute. Disponível em: $<$ http://www.law.cornell.edu/supct/html/05-1074.ZS.html>. Acesso em: 23 nov. 2009.

${ }^{604}$ SUPREMA CORTE DOS ESTADOS UNIDOS DA AMÉRICA. United Airlines v. Evans 431 U.S. 553 (1977). Justia.com United States Supreme Court Center. Disponível em: <http://supreme.justia.com/us/431/553/case.html.. Acesso em: 24 nov. 2009.

${ }^{605}$ Destaque do referido voto: It may constitute relevant background evidence in a proceeding in which the status of a current practice is at issue, but separately considered, it is merely an unfortunate event in history which has no present legal consequences.
} 
colegas, apresentando ponderações importantíssimas em sentido contrário à tese vencedora. A autora do voto dissidente apontou que não deveria ser aplicada a limitação prescricional de 180 dias, tendo em vista que a discriminação ocorre em pequenas parcelas, com efeitos durante longo período de tempo. Igualmente, o voto dissidente destacou a dificuldade de a autora obter dados sobre os salários dos colegas, já que são mantidos com cláusula de confidencialidade, sendo difícil reconhecer a discrepância salarial dentro do prazo fixado e que a finalidade do estatuto é bem diversa do que foi interpretado pela Corte. A Juíza apontou que este tipo de discriminação produz efeitos ao longo do tempo, mesmo que tenha origem no passado, produzindo efeitos danosos em cada pagamento, atraindo a responsabilidade da empresa.

Tal qual ocorreu nos célebres julgamentos de 1989 (Price Waterhouse v. Hopkins e Wards Cove Packing Co. v. Atonio), o Congresso Nacional reagiu rapidamente e aprovou uma lei que recebeu o nome da autora da ação (Lilly Ledbetter Fair Pay Act), sancionada pelo Presidente Barack Obama, em 29 de janeiro de 2009, um de seus principais defensores, enquanto senador e candidato a Presidente. O novo diploma reconhece que práticas anteriores ocorridas antes dos 180 dias previstos na legislação podem ser apreciadas se produzirem efeitos futuros, renovando-se o prazo a cada novo pagamento ${ }^{606}$.

O citado processo demonstrou que a observância de limites prescricionais favorece demasiadamente o autor de práticas discriminatórias, com o grave risco de perpetuá-las. As notórias situações da dificuldade na obtenção de provas, o estado de subordinação do empregado ao empregador, seu estado de dependência econômica e a trágica possibilidade de dispensa imotivada no direito brasileiro pela falta de regulação do artigo $7^{\circ}$, I, são inquestionáveis. São situações que espelham muito aquelas específicas de submissão e dependência pessoal, previstas no Código Civil vigente, no seu artigo 197, não permitindo a fluidez de prazo prescricional em tais circunstâncias. Cabe ainda destacar o reconhecimento de Pedro Paulo Teixeira Manus que a Justiça do Trabalho brasileira é, como regra, uma justiça de desempregados ${ }^{607}$, o que acentua ainda mais os riscos de perecimento dos direitos de reparações ao longo do tempo.

Assim, diante dos aspectos acima ponderados, principalmente com o apoio da melhor doutrina sobre os direitos fundamentais, não há como entender que possam ser

\footnotetext{
${ }^{606}$ ESTADOS UNIDOS DA AMÉRICA. Lilly Ledbetter Fair Pay Act. The U. S. Equal Employment Opportunity Comission notice. Disponível em: <http://frwebgate.access.gpo.gov/cgibin/getdoc.cgi?dbname=111_cong_public_laws\&docid=f:publ002.111>. Acesso em: 24 nov. 2009.

${ }^{607}$ MANUS, Pedro Paulo Teixeira. op. cit., p.145.
} 
aplicadas limitações prescricionais sobre as questões envolvendo discriminação laboral. A qualidade dos direitos ameaçados ou violados, como direitos fundamentais do mais alto relevo, aliada com as naturais dificuldades da vítima de uma prática discriminatória tornam os limites prescricionais instrumentos de perpetuação de situações discriminatórias. Reconhecer a prescrição contra o direito de reparação de tais atos é atitude que caminha em sentido oposto ao propósito do mandamento geral de igualdade entre os homens.

\subsection{Os aspectos processuais mais importantes nas questões discriminatórias nas relações do trabalho}

A importância do combate à discriminação nas relações do trabalho demanda não somente princípios de ordem material como também de ordem processual. $O$ drama verificado no caso Ledbetter é exemplar, diante de uma inquestionável e injustificável disparidade salarial; questões de ordem prescricional tornaram as disposições do Título VII como letra morta e ajudaram a perpetuar situações de grave discriminação ocorridas por muito tempo, em face de requisitos de ordem formal.

O processo é um instrumento em favor da realização efetiva da vontade do direito material e, assim, deve servir seus propósitos e nunca dificultar sua realização. As dificuldades de ordem processual que dificultam, ou mesmo anulam a realização da igualdade em direitos e dignidade dos seres humanos, devem ser superadas para que possa ser efetivada a realização do próprio direito. Neste aspecto, o direito antidiscriminatório clama por um diálogo muito tenso a ser travado entre os princípios do direito material a ser defendido e os direitos fundamentais do processo, principalmente sobre seus limites.

As dificuldades da prova para os casos de discriminação são evidentes. Estevão Mallet ressalta que as regras processuais relativas ao ônus da prova, para que não constituam obstáculo à tutela processual dos direitos, deverão levar em conta as possibilidades reais e concretas de cada litigante poder demonstrar suas alegações ${ }^{608}$. É a capacidade de produzir prova que é levada em conta e, no caso da discriminação, esta vantagem é inquestionavelmente do empregador ou contratante de serviços. Eles possuem todos os dados, documentos, recursos pessoais para investigar fatos, facilidade de arregimentar prova testemunhal, além do pleno conhecimento dos reais fatos que

\footnotetext{
${ }^{608}$ MALLET, Estevão. Discriminação e processo do trabalho. Revista do Tribunal Superior do Trabalho, Brasília, v. 65, n. 1, p. 153, out/dez 1999.
} 
envolveram uma decisão empresarial. As condições de realização da prova por parte do empregador ou contratante de serviços são infinitamente superiores às condições do empregado ou ex-empregado, possuindo inequívoca aptidão superior para produzir prova de suas alegações.

Cristiane Maria Sbalqueiro Lopes sustenta, com muita propriedade e acerto, que o papel do Juiz no processo que envolva discriminação não poderá ser um papel de neutralidade ${ }^{609}$. A mencionada jurista destaca que tais processos devem receber uma atenção peculiar pela natureza da matéria envolvida, necessitando uma investigação com a profundidade que for possível obter das próprias partes.

Sandra Fredman ressalta que as condutas discriminatórias não são somente violações individuais, mas atentados contra todo um grupo social, necessitando de medidas processuais capazes de favorecer todo o grupo afetado ${ }^{610}$. A autora sul-africana radicada no Reino Unido propugna pela existência de meios que façam atuar nos processos sobre discriminação, participações representativas de grupos coordenados por sindicatos, grupos de pressão, centros legais, entre outras entidades que devam agregar seus esforços em processos dessa natureza.

A situação peculiar da discriminação laboral pede, em muitos casos, medidas processuais atípicas, alinhadas com a particularidade das questões discriminatórias nas relações do trabalho. As medidas processuais devem estar conscientes das dificuldades encontradas, e voltadas a realizarem da melhor forma possível o mandamento de trato e de oportunidades iguais a todos. O direito processual, nesta situação, não pode estar amarrado ao excessivo formalismo, sem desrespeitar as garantias mínimas dos litigantes, pois deverá ser o instrumento de realização de um direito fundamental de difícil concretização na nossa sociedade.

O polimorfismo das atitudes discriminatórias reconhecido por Miguel RodríguezPiñero e Maria Fernanda Fernandez López ${ }^{611}$, demonstram, sem sombra de dúvida, a dificuldade da demonstração das práticas discriminatórias, principalmente as mais recentes. Por seu turno, Ignacio Garcia-Perrote Escartin apresenta uma lúcida fotografia do panorama da prova em tais casos, ao retratar que as discriminações e as violações de

\footnotetext{
${ }^{609}$ LOPES, Cristiane Maria Sbalqueiro. Discriminação no processo do trabalho: dificuldades de prova de sua ocorrência. Revista LTr, São Paulo, v. 68, n. 12, p. 1445, dez. 2004.

${ }^{610}$ FREDMAN, Sandra. Discrimination law, cit., p. 166.

${ }^{611}$ RODRIGUEZ-PIÑERO, Miguel; FERNANDEZ LOPEZ, Maria Fernanda. op. cit., p. 300.
} 
direitos fundamentais são condutas habitualmente mascaradas e ocultas, vestidas sob uma aparência de legitimidade ou mediante o uso de formas dissimuladas ${ }^{612}$.

Assim, os processos que envolvem discriminação laboral possuem algumas peculiaridades de caráter instrumental para sua correta apreciação, que serão mencionadas separadamente, para melhor discussão. Situações como a complexa questão do ônus da prova, meios de prova especiais como estatísticas, avaliações técnicas e sociológicas, uso de presunções e os meios especiais de reparação dos danos passam a ser tratados separadamente neste tópico.

\subsubsection{O ônus da prova nas questões discriminatórias}

A questão do ônus da prova nas questões discriminatórias é de crucial importância para a solução das respectivas lides que envolvam tais atos, em muitos casos, decisiva. Basta somente recordar o caminho percorrido pela jurisprudência das questões envolvendo o título VII dentro da Suprema Corte dos EUA, para verificar que as controvérsias sobre o ônus da prova são fundamentais para o sucesso de uma demanda naquele país.

Esta posição crucial da prova nas questões discriminatórias não deveria ter um papel tão destacado de influência na solução do litígio. No entanto, a realidade das lides discriminatórias se mostra tão dramática quanto os efeitos de uma prática discriminatória. Em todas as fases da relação laboral, principalmente antes e depois do término da relação de trabalho, a parte que foi discriminada possui enormes dificuldades para demonstrar em juízo as suas alegações. Tratando-se de um valor fundamental para a pessoa humana, o combate à discriminação induz aos inescrupulosos empregadores e contratantes de serviços o uso de meios sofisticados, muitas vezes quase imperceptíveis, para promover seleções não autorizadas com o intuito de melhorar sua rentabilidade. No caso das discriminações não intencionais, então, a dificuldade é redobrada, posto que caberá à parte que alega a prática desta delicada situação discriminatória a prova dos efeitos de uma prática não intencional, situação muito mais complexa que a prova da discriminação intencional.

Adicione-se a este complexo panorama as múltiplas formas discriminatórias e a sua dinamicidade, sempre com novas faces, muitas surpreendentes. Esta dificuldade é bem revelada na construção de normas jurídicas suficientemente ágeis e flexíveis, capazes de

\footnotetext{
${ }^{612}$ GARCIA-PERROTE ESCARTIN, Ignacio. Prova y proceso laboral. Derecho Privado y Constitución, n. 4 , p. 217, set./dez. 1994.
} 
detectar e reprimir uma conduta discriminatória. A constante alteração dos conceitos positivados sobre a discriminação laboral, desde a Convenção 111 da OIT, em 1958, até as recentes Diretivas europeias de 2002, demonstram, com feliz precisão, a dinâmica das formas da discriminação laboral.

Não se age de modo discriminatório às claras; em algumas situações peculiares, como no assédio sexual, são práticas visíveis somente ao agente e à vítima. Esta dificuldade de prova é, efetivamente, um incentivo aos agentes e inibem queixas das vítimas, que ainda sofrem indesejável exposição e riscos, mormente quando carecem de elementos de prova.

No direito processual trabalhista brasileiro, em especial, as toscas e ultrapassadas regras de prova do artigo 818 consolidado não se adaptam, de forma alguma, às necessidades de uma complexa prova demandada pela natureza especial das lides discriminatórias, ainda mais envolvendo diversas facetas. Guilherme Guimarães Feliciano assinala que as referidas regras são inaptas para regular, de um modo absoluto, a dinâmica do processo laboral, geralmente tratando de pretensões vinculadas à violação de direitos fundamentais $^{613}$.

Para uma melhor apreciação de uma questão que envolva situações discriminatórias, o direito processual deve seguir, no mínimo, o mesmo ritmo evolutivo do direito material. São necessárias soluções muito além daquelas encontradas nas clássicas fórmulas, para superar os naturais obstáculos de uma tarefa processual tão importante, em algumas vezes existente para ambas as partes, assim como para o julgador.

A primeira questão que emerge na discussão sobre a prova de uma prática discriminatória recai sobre o ônus, uma vez que a dificuldade da realização da prova é amplamente reconhecida pela doutrina e jurisprudência. A questão do ônus da prova, como uma barreira processual que a parte deva superar para alcançar o reconhecimento de seu direito, é muito valorizada e importante. Isso porque há inegável dificuldade na obtenção e na apresentação de prova capaz de convencer o Juízo das alegações formuladas. Se sabidamente será difícil a obtenção de prova a corroborar as alegações de ambas as partes, a decisão da questão material dependerá, em muitos casos, do posicionamento do julgador para definir quem é o responsável por esta incumbência processual. Em grande número dos

\footnotetext{
${ }^{613}$ FELICIANO, Guilherme Guimarães. Distribuição dinâmica do ônus da prova no processo do trabalho : critérios e casuística. Revista do Tribunal Regional do Trabalho da $15^{a}$ Região, Campinas, v. 32, n. 32, p. 104, jan./jun. 2008.
} 
casos envolvendo discriminação, reconhecer quem seja o responsável pela produção da prova passa a ser a própria solução do litígio, lamentavelmente.

As discussões são muito complexas a respeito da prova dos atos discriminatórios e demandam uma análise mais profunda sobre os aspectos que envolvem a discriminação. Em síntese, um processo que envolva uma alegação de discriminação poderá ter dois momentos importantes, não sendo uma única fase probante, mas duas.

A primeira questão orbita sobre a existência de um tratamento diferenciado. Caso negado, este será o primeiro ponto a ser demonstrado, o que não é algo tão simples de ser realizado. Nos casos de discriminação não intencional, por seu turno, a percepção da existência de tratamento desproporcional é uma prova muito difícil de ser concretizada.

Segundo nosso direito processual laboral, mais especificadamente no caso do artigo 818 consolidado, o ônus da prova desta situação seria do empregado. Afigura-se demasiadamente cruel exigir que o trabalhador discriminado, portanto em situação de desvantagem material, geralmente desempregado ou que não teve sua admissão efetivada, estando fora do local de trabalho, tenha condições de reunir elementos probantes suficientes a demonstrar que tenha recebido tratamento diferenciado de conteúdo discriminatório. Tal exigência processual, exigida sem ponderação da realidade, mostra-se diabólica, com resultado tendente a preservar as situações discriminatórias no Brasil, que notoriamente não são poucas.

No entanto, inverter-se totalmente o ônus da prova ao empregador ou contratante de serviços, de forma automática, para este demonstrar que não ocorreu tratamento diferenciado, não parece ser a medida mais correta também, afigurando-se demasiadamente desproporcional. Tal situação abriria um fértil campo a todo o tipo de abusos processuais despidos de quaisquer risco. Tais abusos, infelizmente, ocorrem na Justiça Laboral brasileira e de outros países. Serve como exemplo a atual banalização de postulações envolvendo danos morais que inundaram as pautas dos Tribunais trabalhistas, várias delas verdadeiras aventuras em busca de significativas indenizações, mesmo tendo contra o autor o fardo da prova.

As facilidades que são concedidas aos demandantes laborais, em face do desequilíbrio de posições entre trabalhadores e empregadores, não podem vir a se tornar estímulo a aventuras processuais. Tal atrativo certamente prejudicaria aqueles que necessitam de uma tutela laboral rápida e efetiva, causando desnecessário 
congestionamento judiciário. Por outro lado, a total inversão do ônus da prova nesta situação traz ao empregador uma difícil missão - a constituição e demonstração de prova negativa da existência de um fato. Martínez Rocamora aponta que tal situação corre o risco de gerar um efeito boomerang, ou seja, voltar-se contra a própria intenção de defesa da igualdade entre os seres humanos, motivo pelo qual o Tribunal Constitucional Espanhol reconsiderou sua posição inicial de pura e simples inversão do ônus da prova ${ }^{614}$.

Nesta situação, a virtude aristotélica da solução no meio de dois extremos se impõe. Não se pode exigir uma prova cabal do empregado, mas também não se pode exigir a inversão total do ônus da prova da conduta diferenciadora. Resta então atenuar a exigência sobre o lado da vítima do ato discriminatório, aceitando-se modelos alternativos para comprovação de fatos, ao invés de uma prova consolidada e indestrutível.

Guilherme Feliciano destaca a importância da figura de constelações de indícios reconhecidos pela doutrina germânica como anscheinsbeweis e, pelo autor, como a verossimilhança das alegações formuladas ${ }^{615}$. Luis Guilherme Marinoni aponta que podem existir outras situações de direito substancial que exijam a inversão do ônus da prova ou mesmo requeiram uma atenuação do rigor na aplicação da regra do ônus da prova, contentando-se com a verossimilhança ${ }^{616}$. E com o apoio do magnífico escólio de Leo Rosenberg e de sua Normentheorie, deixa claro que tais procedimentos não dependem de expressa previsão no ordenamento processual ${ }^{617}$.

Por outro lado, a força das presunções e suspeições superam a exigência pura e simples do ônus da prova. As máximas de experiência, por exemplo, permitem ao Juiz deduzir que determinadas pessoas se encontram em situações costumeiras, que se sujeitam a sofrer tratamentos diferenciados prejudiciais. Serve o exemplo da trabalhadora gestante, que nunca é sempre bem vista pelo empregador ou contratante de serviços, na medida em que irá interromper a prestação laboral e aumentar custos, além de possuir proteção contra a dispensa arbitrária até cinco meses após o parto. Ou o caso do dirigente sindical, ou mesmo daquele trabalhador que promoveu uma reclamação trabalhista. Tais pessoas se encontram em situações delicadas, nas quais a experiência mostra que podem estar muito

\footnotetext{
${ }^{614}$ MARTÍNEZ ROCAMORA, Luis Gabriel. op. cit., p. 174.

${ }^{615}$ FELICIANO, Guilherme Guimarães. op. cit., p. 104.

${ }^{616}$ MARINONI, Luis Guilherme. Formação da convicção e inversão do ônus da prova segundo as peculiaridades do cso concreto. BDJur - Biblioteca Digital Jurídica do Superior Tribunal de Justiça. Mar. $2006 . \quad$ p. $2 . \quad$ Disponível em: http://bdjur.stj.gov.br/xmlui/bitstream/handle/2011/2201/Forma\%c3\%a7\%c3\%a3o_da_Convic\%c3\%a7\%c 3\%a3o_e_Invers\%c3\%a3o.pdf? sequence=1>. Acesso em: 24 nov. 2009.

${ }^{617}$ Id. Ibid., p. 3.
} 
mais sujeitas a atitudes retaliatórias por parte de seus empregadores, do que qualquer outro trabalhador. Não custa recordar que a retaliação também é uma atitude discriminatória, assim reconhecida em normas positivadas em face da notória situação de risco.

Anna Puleo destaca que caberá ao trabalhador demonstrar os fatos que constituam as fontes de construção de uma presunção, que será apresentada ao magistrado, ficando ao controle deste ${ }^{618}$. Ele apreciará a suficiência e a capacidade persuasiva dos elementos trazidos à luz da precisão e da concordância, bem como a existência de outras presunções e elementos que venham a convergir com a proposta da inicial.

No direito antidiscriminatório, as suspeições são respeitadas como demonstração de atitudes discriminatórias. Determinadas categorias de pessoas humanas, em função de práticas discriminatórias ocorridas no passado e que se perpetuam, quando sofrem um tratamento diferenciado podem levar o julgador a situações de suspeição do ato discriminatório. Quando um integrante de um grupo reiteradamente prejudicado, cuja prática discriminatória é reconhecida, seja por parte da vítima ou do agente, pode levar o julgador a superar a prova da existência da diferenciação, fazendo-se presumir a conduta discriminatória pela ocorrência de pertinência a um grupo historicamente prejudicado. $\mathrm{O}$ simples pertencer a determinado grupo já torna toda e qualquer atitude desvantajosa contra esta pessoa suspeita, servindo como exemplo a motivação mais discutida nos tribunais laborais brasileiros - o trabalhador ser portador do vírus HIV da SIDA/AIDS.

Outra possibilidade que afasta os rigores da exigência do ônus de provar determinado fato, como bem destaca Gisela Hildegard Kern no direito laboral português, como meio de aligeirar o ônus da prova (Beweiserlechterung) ${ }^{619}$ é a mera fundamentação da alegação. A autora destaca a legislação laboral portuguesa (Lei 18/2004 ${ }^{620}$ ), em seu artigo $6^{\circ}$, que implementou naquele país a Diretiva $n^{\circ} 2000 / 43$, porém foi além de seus dizeres. Essa norma estabelece que quem alega uma discriminação deve tão somente fundamentar sua alegação apresentando elementos de fato suscetíveis de a indiciarem. Menciona também que tal previsão no direito português vem albergar exatamente uma

\footnotetext{
${ }^{618}$ PULEO, Anna. Discriminazioni di sesso nel mercato del lavoro: novità e aporie di um modello processuale. Rivista Trimestrale di Diritto e Procedura Civile. Milano, ano 50, n. 1, p. 105, mar. 1996.

${ }^{619}$ KERN, Gisela Hildegard. As Directivas 2000/78/CE e 2000/43/CE e a sua transposição no direito privado português. Boletim da Faculdade de Direito da Universidade de Coimbra, Coimbra, v. 80, p. 784, 2004.

${ }^{620}$ PORTUGAL. Lei 18/2004 - 11 de maio de 2004. Faculdade de Direito da Universidade de Coimbra. Enciclopédia Portuguesa de Direitos Humanos. Disponível em: $<$ http://www.fd.uc.pt/hrc/enciclopedia/portugal/legislacao/igualdade/118_2004.pdf>. Acesso em: 27 nov. 2009.
} 
suspeita, bastando apresentar elementos constitutivos de uma alegação de discriminação ${ }^{621}$. Tal posicionamento não é novidade, como já visto no item 5.2.2, no qual os testes de constitucionalidade de normas realizados pela Suprema Corte dos EUA, dependendo do motivo envolvido, colocam sob máxima ou média suspeita as diferenciações tomadas com base em fatores proibidos.

José Fernando Lousada Arochena destaca a jurisprudência da Corte Constitucional da Espanha, no sentido de aceitar as presunções, fatos comuns, suspeitas e, até mesmo a demonstração de um clima de discriminação no ambiente laboral ${ }^{622}$. No entanto, o autor e Juiz espanhol aponta que a jurisprudência oscilou até encontrar um padrão no sentido de que seja encontrado um indício razoável de que a lesão tenha sido produzida, ou um princípio de prova que venha a colocar como manifesto o motivo oculto do ato.

Tais possibilidades permitem suplantar a exigência da prova da diferenciação, adotando-se formas que permitem concluir, mediante elementos probantes menos intensos, que seja muito grande a possibilidade de um tratamento diferenciado praticado por um empregador ou contratante de serviços contra um trabalhador. Ocorrendo tal posição, pode-se, assim, passar para uma segunda fase da prova, que é a justificativa do fato. Nesta nova fase, caberá ao empregador demonstrar os fatos que alega em sua defesa, caso sejam controversos.

José Antonio Ribeiro de Oliveira Silva aponta, com um comentário restritivo sobre a expressão inversão do ônus da prova, que não pode ser considerada uma inversão a situação que não seja aquela na qual o ônus pertença a determinada parte e o Juiz, motivadamente, a transfira para outra ${ }^{623}$. Não há como discordar do insigne processualista mas, no caso das situações discriminatórias, um ônus que seria do empregado é substituído por algum elemento probante menos intenso. Ultrapassada esta exigência, aí sim é invertido para o empregador o ônus de provar que aquele fato verossímil, ou mesmo a suspeição, não seja considerado como atitude diferenciadora e muito menos

\footnotetext{
${ }^{621}$ KERN, Gisela Hildegard. op. cit., p. 785.

${ }^{622}$ LOUSADA AROCHENA, José Fernando. La prueba de la discriminación y del acoso sexual y moral en el proceso laboral. Revista Âmbito Jurídico. Publicado em 30/04/2007, No 40 - Ano X - ABRIL/2007 - ISSN 1518-0360. Disponível em: <http://www.ambitojuridico.com.br/site/index.php?n_link=revista_artigos_leitura\&artigo_id=3974>. Acesso em: 27 nov. 2009.

${ }^{623}$ SILVA, José Antonio Ribeiro de Oliveira. O ônus da prova e sua inversão no processo do trabalho. BDJur - Biblioteca Digital Jurídica do Superior Tribunal de Justiça. Disponível em: <http://bdjur.stj.gov.br/jspui/bitstream/2011/18561/2/O_\%c3\%94nus_da_Prova_e_sua_Invers\%c3\%a3o.pd f>. Acesso em: 27 nov. 2009.
} 
discriminatória, pois cabe ao empregador provar os fatos decorrentes de sua justificativa. Aí, verifica-se claramente que houve uma inversão do ônus da prova.

Adotando-se tais métodos alternativos para considerar a existência da diferenciação como fato, não sendo este reconhecimento derrubado pela contraprova que o empregador ou tomador de serviços esteja obrigado a fazer, passa-se à demonstração de um segundo fato, caso seja objeto de controvérsia: a existência dos fatos que corroboram a justificativa alegada pelo empregador.

Na situação desta alegação, Marzia Barbera assevera que, por ser o empregador o detentor do poder de estabelecer distinções, estas deverão estar condicionadas a justificações, exigindo do empregador a prova primária da existência de pressupostos de fato que permitam o exercício desse poder $^{624}$. Claramente, a aptidão para a prova neste caso é exclusivamente do empregador, cabendo ao trabalhador o direito de formular contraprova, ou demonstrar que a alegação empresarial não passa de um pretexto. Não se desvencilhando deste ônus, a presunção de discriminação é manifesta em face do princípio material exposto no item 8.2. do presente capítulo.

Claramente, temos duas fases bem distintas: uma na qual o trabalhador tem uma obrigação de apresentar fatos que permitam concluir ou suspeitar da existência de uma atitude discriminatória, que cabe contraprova do empregador ou tomador de serviços, conforme colocação precisa de Marie-Thérèse Lanquetin ${ }^{625}$. Por outro lado, existe uma segunda fase processual na qual uma vez reconhecida a existência de uma diferenciação caberá ao empregador provar suficientemente que tal medida tem uma justificativa razoável e proporcional. No mesmo sentido, Miguel Rodríguez-Piñero e Maria Fernanda Fernandez López expressam a existência de uma nova fase processual $^{626}$.

A evolução jurisprudencial sobre o ônus da prova é extremamente interessante, muitas vezes adotando contornos que interferiram drasticamente no próprio direito material, como já apresentado.

Nos EUA, a tendência de restritividade da Suprema Corte daquele país em aceitar postulações alegando discriminação laboral tem sido externalizada pelas restrições do ônus da prova. Desde os anos 80, com destaque para o ano de 1989, os posicionamentos mais

\footnotetext{
${ }^{624}$ BARBERA, Marzia. op. cit., p. 243.

${ }^{625}$ LANQUETIN, Marie-Thérèse. Um tournant en matière de prevue des discriminations. Droit Social, Paris, n. 6, p. 590, jun. 2000.

${ }^{626}$ FERNANDEZ LOPEZ, Maria Fernanda. op. cit., p. 292.
} 
restritivos daquela Corte têm se baseado em incremento das exigências sobre o ônus da prova dos autores. Em alguns casos, foi exigida dos empregados discriminados a superação de barreiras praticamente intransponíveis sobre a prova de suas alegações. Sem adentrar ao tema material com maior profundidade, as decisões da referida Corte têm sido mais restritivas ao reconhecimento dos direitos previstos no Título VII e nos demais diplomas antidiscriminatórios daquele país, por meio das restrições do ônus da prova, ensejando reações do Congresso Nacional.

O Título VII da Lei dos Direitos Civis dos EUA nada previu, originalmente, sobre o ônus da prova nos casos de discriminação laboral. A interpretação veio a ser dada pelo judiciário e o primeiro caso marcante, no qual foi concebida uma importante teoria sobre o ônus da prova nas questões discriminatórias, emergiu na decisão do célebre caso McDonnell Douglas v. Green ${ }^{627}$, decidido em 14 de maio de 1973. A Corte não economizou esforços em propor uma complexa teoria na decisão do referido caso de discriminação intencional. Foi uma decisão marcante no direito antidiscriminatório norteamericano, mencionada por alguns autores como a mais importante até os presentes dias.

Percy Green era afrodescendente e um empregado com qualificação técnica na referida empresa aeroespacial. Como ativista na luta contra a discriminação racial participou de atividades de protesto consideradas ilegais contra a sua dispensa e contra as práticas gerais de discriminação racial nas suas contratações. A empresa abriu vagas para a função de Green, que se candidatou a uma das vagas, no entanto não foi admitido; a empresa o rejeitou em face das suas graves práticas anteriores. Green apresentou queixa perante a EEOC (Equal Employment Opportunity Comission), agência federal responsável pelo cumprimento do Título VII, que entendeu como razoável a queixa e que houve recusa na contratação, com base em motivo ilícito do artigo 704 do Título VII, no sentido de que seria retaliatória, mas negou a queixa na situação de discriminação racial.

Green aforou ação contra a empresa em uma corte federal distrital, que entendeu que as atividades praticadas pelo autor não eram protegidas pelo artigo 704, e arquivou a reclamação com base na discriminação racial em face de a EEOC não ter vislumbrado violação. A Corte Federal superior manteve a decisão em relação ao artigo 704, no entanto afirmou que a aprovação da EEOC não é pré-requisito para propositura da ação judicial. A

\footnotetext{
${ }^{627}$ SUPREMA CORTE DOS ESTADOS UNIDOS DA AMÉRICA. McDonnell Douglas v. Green 411 U.S. 792 (1973). Findlaw - cases and codes. Disponível em: $<$ http://caselaw.lp.findlaw.com/scripts/getcase.pl?court=US\&vol=411\&invol=792>. Acesso em: 24 nov. 2009.
} 
Suprema Corte manteve a decisão da Corte Federal e negou provimento ao recurso da empresa, mantendo a decisão intermediária.

No entanto, a decisão da Suprema Corte promoveu a regulação das questões do ônus da prova, em uma complexa teoria. O voto do Juiz Powell apontou que em uma ação que não seja coletiva, baseada no Título VII, por envolver discriminação racial, o autor tem o ônus de apresentar uma situação de prova aparente ou uma verdade interina (prima facie case), capaz de trazer razoável conclusão em favor de suas alegações. Para tanto, deverá apresentar prova aparente no sentido de que existiram as seguintes situações: 1) que ele pertença a uma minoria racial; 2) que tenha se candidatado a um cargo ao qual estava devidamente qualificado e que o empregador procurava preenchê-lo; 3) de que apesar de qualificado não foi aceito; e 4) o empregador continuava procurando candidatos com as mesmas qualificações do candidato rejeitado.

A decisão definiu que, uma vez apresentada a questão e demonstrada esta prova razoável, o ônus é transferido para o empregador articular e provar que houve alguma razão não discriminatória para a rejeição do empregado, desde que haja uma base razoável para recusar a sua contratação. O voto da Suprema Corte acolheu a decisão intermediária, pois compreendeu que o autor havia apresentado esta prova.

Não obstante a Corte tenha estabelecido essa obrigação, ainda assinalou que se a empresa apresentar uma razão para não ter efetivado a contratação, caberá ao empregado demonstrar, mediante uma nova oportunidade probante, que a alegação do empregador é um pretexto para uma intenção discriminatória. Com a decisão, a Suprema Corte ordenou que a Corte inferior prosseguisse no julgamento do caso.

Ao proferir a decisão, a Suprema Corte estabeleceu um importante parâmetro para apreciação das causas envolvendo discriminação intencional. A decisão foi proferida em um período em que as causas envolvendo alegações de discriminação racial no trabalho eram melhor recebidas (Período da Corte Burger), sendo um período de construção de conceitos. Assim como no caso Griggs, julgado em 1971, e no caso Teamsters, apreciado em 1977, a Suprema Corte inovou bastante no seu poder de interpretar, vinculando as demais cortes inferiores a seu posicionamento, dentro de uma tradição jurídica mista de direito escrito e common law.

George Rutherglen afirmou que a decisão do caso Green, além de ser a mais citada no direito antidiscriminatório laboral daquele país, introduziu a questão da inversão do 
ônus da prova como um tema dominante dentro do direito antidiscriminatório nas relações do trabalho $^{628}$. Sem sombra de dúvida, a decisão foi marcante na medida em que transfere o ônus da prova em um sistema de três passos. Mack Player aponta que a decisão do caso Green cria uma presunção de motivação ilegal, através de uma prova razoável que levará o empregador a apresentar razões suficientes para demonstrar que não houve prática discriminatória, bem como demonstrar que não há razão discriminatória para a distinção formulada ${ }^{629}$.

O caso Green estabeleceu um parâmetro de ônus da prova a ser seguido pelas cortes norte-americanas, o que perdurou por vários anos. Foi um período no qual se consolidou uma tendência em que parecia que a Corte desejava abolir os séculos de discriminação perpetrada contra negros e mulheres. No julgamento do caso Albermale Paper Co $v$. Moody, em 1975, a Suprema Corte confirmou a posição do caso Green, mas gerou certo conflito entre as cortes federais sobre a aplicabilidade deste padrão sobre os processos envolvendo motivos mistos, conforme aponta Robert Belton ${ }^{630}$.

O referido conflito teria sido solvido com a decisão do caso Texas Department of Community Affairs v. Burdine $e^{631}$, em que a Corte teria adotado um sistema mais claro, pelo qual o autor tem o ônus de provar a existência da verossimilhança da alegação por prova preponderante e, se provado, o ônus fica invertido ao empregador para articular as razões da recusa do empregado que não sejam consideradas discriminatórias. Cabe ao empregado, no entanto, caso apresentada esta justificativa, o ônus de provar indiretamente que tais razões não são verdadeiras, mas sim um pretexto para a discriminação. A questão somente passou a ser aplicada aos casos de motivação única para a discriminação alegada, no entanto não havia uma definição para os casos de motivos mistos.

Dezesseis anos depois da decisão do caso Green, a Suprema Corte profere uma decisão bem menos acolhedora, envolvendo uma situação de motivos mistos, já relatada no capítulo $5^{\circ}$, mais precisamente no item 5.4., quando decidiu o rumoroso caso Price Waterhouse v. Hopkins ${ }^{632}$. Esse processo envolveu a discussão judicial da recusa da promoção, como sócia da empresa, da funcionária Ann Hopkins, que moveu uma ação

\footnotetext{
${ }^{628}$ RUTHERGLEN, George. op. cit., p. 35.

${ }^{629}$ PLAYER, Mack. op. cit., p. 329.

${ }^{630}$ BELTON, Robert. op. cit., p. 1362.

${ }^{631}$ SUPREMA CORTE DOS ESTADOS UNIDOS DA AMÉRICA. Findlaw. Texas Department of Community Affairs v. Burdine 450 US 248 (1981). Disponível em: $<$ http://caselaw.lp.findlaw.com/scripts/getcase.pl?court=US\&vol=450\&invol=248>. Acesso em: 25 nov. 2009.

${ }^{632}$ SUPREMA CORTE DOS ESTADOS UNIDOS DA AMÉRICA. Cornell University Law School. Supreme Court Collection. Price Waterhouse v. Hopkins. 490 U.S. 228, 1989. Disponível em: $<$ http://www.law.cornell.edu/supct/html/historics/USSC_CR_0490_0228_ZC.html>. Acesso em: 09 out. 2009.
} 
contra a empresa alegando discriminação por gênero. A empresa, por seu turno, alegou que outros motivos, que não os previstos no título VII, fundamentaram a recusa, tornando-se uma questão sobre motivos mistos. A decisão entendeu que se a prova demonstrar a existência de bons e maus motivos como fatores motivadores da decisão alegada como discriminatória, caberá ao autor demonstrar que um motivo discriminatório tenha parcialmente influenciado a decisão questionada como motivo atuante. Porém, o voto concorrente da Juíza Sandra Day O’Connor, que integrou a decisão, aponta que a referida demonstração deverá ser feita mediante uma prova direta, assim compreendida como aquela que possa demonstrar um fato importante para a questão, sem que haja interferência de outro fato. Prova direta é uma modalidade na qual existe um testemunho direto, vindo de alguém que tenha visto ou ouvido o fato de interesse da causa, ou mesmo um reconhecimento expresso do fato por parte do demandado. Robert Belton e Dianne Avery comentam que este tipo de exigência poderia ser exemplificada como uma confissão em uma queixa, uma declaração do empregador que reconheça a prática ou qualquer outro tipo de prova cabal que demonstre que o empregador teve intenção no ato prejudicial contra a vítima em face do critério proibido ${ }^{633}$.

A decisão do caso Hopkins difere muito do posicionamento do caso Green, na medida em que solicita uma prova muito mais contundente, portanto, bem mais difícil de ser obtida. Não obstante a Corte tenha reconhecido que a prova deva ser feita exclusivamente sobre o fator proibido, ainda que outros tenham influenciado a decisão questionada, a qualidade da prova exigida foi um grande obstáculo levantado, antes de ser procedida a inversão do ônus da prova. No caso Green exigia-se uma prova circunstancial, ao passo que no caso Price a prova passou a ser muito mais qualificada, uma prova cabal. Steven Kaminishine aponta que este tipo de exigência tornou-se atraente para as cortes inferiores, um ponto crítico para as questões envolvendo motivos mistos ${ }^{634}$. A adesão a este entendimento criou, indiscutivelmente, uma barreira para a apreciação de casos de motivos mistos, normalmente situações envolvendo discriminação de extrema complexidade.

No mesmo ano de 1989, outra decisão impactante demonstrou mais ainda a inclinação da Suprema Corte para a restrição da aplicabilidade do Título VII, proferida no

\footnotetext{
${ }^{633}$ BELTON, Robert; AVERY, Dianne. op. cit., p. 69. Os autores mencionam que esta prova pode ser as modalidades acima ou qualquer outra que tenha o caráter óbvio de uma situação que chamam de smoking gun, ou seja, aquela em que o autor de um disparo de arma de fogo criminoso é flagrado imediatamente após sua ação.

${ }^{634}$ KAMINSHINE, Steven J. op. cit., p. 8.
} 
caso Wards Cove Packing Co. v. Atonio ${ }^{635}$. A decisão cuidou de um complexo caso de discriminação intencional e não intencional, em uma ação coletiva movida por um grupo de empregados de uma empresa enlatadora de pescados no Estado do Alaska. A ação questionou as políticas de promoção da empresa que não permitiam que os trabalhadores menos qualificados, em sua maioria integrantes de minorias, ascendessem para cargos mais qualificados.

A decisão de primeiro grau rejeitou o pedido, e a discussão orbitou somente em face da situação da discriminação não intencional, que motivou o recurso dos autores. A Corte de Apelações acolheu o recurso, para reconhecer que havia prova da verossimilhança das alegações formuladas. A decisão intermediária reconheceu que, uma vez determinada classe de autores tenha demonstrado a existência de um impacto desproporcional por meio de estatísticas, cabe ao empregador provar que a prática era necessária ao desempenho da atividade empresarial.

A Suprema Corte dos EUA entendeu que uma demonstração estatística, de que os cargos menos qualificados eram predominantemente preenchidos por minorias, não era capaz de inverter o ônus da prova como um prima facie case. A Corte entendeu que, além da prova estatística, era necessário demonstrar que os seus resultados tinham algum nexo de causalidade com alguma prática específica da empresa, demonstrando que cada prática tem um impacto diverso para brancos e minorias. E, dentro deste parâmetro, também afirmou que cabe aos autores o ônus de persuasão sobre a relação de causalidade entre os efeitos discriminatórios e as práticas do empregador acionado, em qualquer situação.

Segundo Robert Belton, foi a primeira vez que a Suprema Corte apontou a necessidade desta relação de causalidade em casos envolvendo a aplicação do Título VII $^{636}$. Quatro Juízes dissentiram da decisão tomada, em apertada maioria, relembrando o precedente do caso Griggs, que teria rejeitado demonstrações de relação de causalidade. Claramente, a exigência da prova desta relação foi mais um significativo obstáculo para o reconhecimento das ações envolvendo discriminação não intencional, revertendo em parte a doutrina estabelecida durante dezoito anos de vigência dos parâmetros do caso Griggs.

\footnotetext{
${ }^{635}$ SUPREMA CORTE DOS ESTADOS UNIDOS DA AMÉRICA. Cornell University Law School. Supreme Court Collection. Wards Cove Packing Co. v. Atonio 490 US 642 (1989). Disponível em: $<$ http://www4.law.cornell.edu/supct/html/historics/USSC_CR_0490_0642_ZD1.html>. Acesso em: 09 out. 2009.

${ }^{636}$ BELTON, Robert. op. cit., p. 1376.
} 
Como anteriormente mencionado no quinto capítulo, a reação do Congresso foi imediata. Em 1991, promulgou uma alteração na Lei dos Direitos Civis que prescreveu no artigo $703(\mathrm{~m})$ ou 2000e-2(m) ${ }^{637}$ que uma prática ilegal é estabelecida quando a parte demonstrar que os motivos ali listados desencadearam a prática empresarial questionada, ainda que outros fatores também a tenham motivado. A norma aprovada em 1991 revogou em parte o precedente exarado no voto da referida Juíza no caso Hopkins. Por outro lado, passou a reconhecer expressamente a discriminação não intencional como modalidade discriminatória.

No entanto, somente em 2003, doze anos após a promulgação da referida alteração legal, a Suprema Corte reformou parcialmente as exigências formuladas na decisão do caso Hopkins. Através da decisão do caso Desert Palace Inc. v. Costa ${ }^{638}$, a Corte, fundamentando-se expressamente na alteração legislativa do referido artigo $2000 \mathrm{e}-2(\mathrm{~m})$, apontou que nos casos de motivos mistos, não mais era necessária uma prova direta da intenção discriminatória em um dos motivos proibidos. A Corte manteve a decisão plenária do nono circuito federal de apelações, no sentido de que o artigo legal em questão não pede mais uma prova direta da intenção discriminatória e que, demonstrada circunstancialmente a situação discriminatória, inverte-se o ônus da prova para o empregador demonstrar que o fator proibido não influenciou a conduta questionada.

A grande discussão atual nos meios acadêmicos e judiciais é se o parâmetro estabelecido no caso Green ainda permanece válido, ou se a decisão do caso Desert Palace o teria sepultado ao criar um novo modelo. Muitas cortes inferiores ainda adotam o parâmetro do caso Green e sua complexa sistemática, mesmo após a decisão do caso Desert Palace. Jamie Darin Prenkert sustenta vigorosamente que os parâmetros do caso Green ainda resistem, posto que depois da confusão da controvérsia dos motivos mistos em 1989 com o caso Hopkins e a intervenção parcial do Congresso norte-americano, o modelo do caso Green ainda continua o mais consistente e unitário modelo de distribuição do ônus da prova aplicável a todos os casos de discriminação intencional ${ }^{639}$.

Por outro lado, Charles A. Sullivan aponta o atraso do parâmetro do caso Green, qualificando-o como de difícil operação. O autor propõe o uso de estruturas de provas mais

\footnotetext{
${ }^{637}$ ESTADOS UNIDOS DA AMÉRICA. Civil Rights Act. Equal Employment Opportunity Comission. Disponível em: <http://www.eeoc.gov/policy/vii.html>. Acesso em: 09 out. 2009.

${ }^{638}$ SUPREMA CORTE DOS ESTADOS UNIDOS DA AMÉRICA. Cornell University Law School. Supreme Court Collection. Desert Palace Inc. v. Costa. 539 U.S. 90 (2003). Disponível em: $<$ http://www.law.cornell.edu/supct/html/02-679.ZS.html>. Acesso em: 09 out. 2009.

${ }^{639}$ PRENKERT, Jamie Darin. op. cit., p. 564.
} 
simples e práticas, como a do sistema de modelo comparativo, pelo qual se adota um paradigma e procura-se apresentar a questão da discriminação pelas disparidades encontradas no tratamento do paradigma e do autor da ação em uma comparação direta ${ }^{640}$. A questão do ônus da prova nas causas que envolvem discriminação laboral nos EUA depende de um posicionamento mais firme do Congresso Nacional para regular a questão e elaborar uma regra processual específica e definitiva. Tal postura evitaria que as Cortes inferiores dependessem tanto da jurisprudência para firmar parâmetros de inversão do ônus da prova. No contexto europeu, a atitude positiva da Comissão da Comunidade Econômica Europeia para regular aspectos processuais da questão do ônus da prova foi decisiva para pacificar discrepâncias jurisprudenciais sobre o tema.

Em 15 de dezembro de 1997, o Conselho da União Europeia adotou uma diretiva de $n^{\circ}$ 97/80, muito importante para o direito antidiscriminatório por diversos motivos, inclusive por reconhecer por meio de norma positivada a ser implementada nos Estadosmembros, a discriminação não intencional (discriminação indireta), como é conhecida naquele continente.

A norma estabeleceu em seu artigo $4^{\circ}$, item 1, a seguinte regra:

1. Os Estados-membros tomarão as medidas necessárias, em conformidade com os respectivos sistemas jurídicos, para assegurar que quando uma pessoa que se considere lesada pela não aplicação, no que lhe diz respeito, do princípio da igualdade de tratamento apresentar, perante um tribunal ou outra instância competente, elementos de fato constitutivos da presunção de discriminação direta ou indireta, incumba à parte demandada provar que não houve violação do princípio da igualdade de tratamento.

2. A presente diretiva não obsta a que os Estados-membros imponham um regime probatório mais favorável à parte demandante.

3. Os Estados-membros poderão não aplicar o disposto no $n^{o} 1$ aos processos em que a averiguação dos fatos incumba ao tribunal ou a outra instância competente. ${ }^{641}$

\footnotetext{
${ }^{640}$ SULLIVAN, Charles A. The phoenix from the ash: proving discrimination by comparators. Alabama Law Review. $\quad \mathrm{N}^{\mathrm{o}} 60,2009$, p. 192-239, p. 238. Lexis Nexis. Disponível em: $<$ http://www.lexisnexis.com/us/Inacademic/results/docview/docview.do?docLinkInd=true\&risb=21_T7994 650750\&format=GNBFI\&sort=BOOLEAN\&startDocNo=1\&resultsUrlKey=29_T7994650753\&cisb=22_T $7994650752 \&$ treeMax=true $\&$ treeWidth $=0 \&$ selRCNodeID $=2 \&$ nodeStateId=411en_US, $1 \&$ docsInCategory $=2091 \&$ csi $=144191 \&$ docNo=19>. Acesso em: 25 nov. 2009.

${ }^{641}$ CONSELHO DA UNIÃO EUROPEIA. Diretiva 97/80. EUR-Lex. Disponível em: <http://eurlex.europa.eu/LexUriServ/LexUriServ.do?uri=OJ:L:1998:014:0006:0008:PT:PDF>. Acesso em: 25 nov. 2009.
} 
A regra aceita pela União Europeia e a ser adotada pelos Estados-membros é clara no sentido de que, havendo elementos de fato nos autos capazes de fazer presumir uma discriminação, deve ocorrer a inversão do ônus da prova ao empregador. A referida diretiva estabelece esta regra como padrão mínimo, sendo que outros padrões mais favoráveis ao demandante poderão ser adotados pelo Estado-membro.

Marie-Thérèze Lanquetin relata que a referida diretiva tomou por base uma jurisprudência bem construída pela Corte de Justiça das Comunidades Europeias, traduzindo-se em uma efetiva contribuição sobre a difícil questão da prova da discriminação $^{642}$. Segundo a autora, o texto foi elaborado após muitos anos de estudo e pesquisa desde 1992 até 1997, quando aprovado e adotado o texto final.

As considerações sobre a diretiva apontam para alguns detalhes extremamente importantes. No item 17 afirma que as partes poderiam ficar desamparadas de um instrumento eficaz para obterem a proteção da igualdade, principalmente ao impor ao demandante o ônus de provar a discriminação ocorrida. No item 18, das considerações sobre a referida norma, aponta que o Tribunal de Justiça das Comunidades Europeias já definiu que nos casos de presunção de discriminação o ônus da prova pertence ao demandado. Ressaltou no item 19 que, quanto mais indireta é a discriminação mais difícil é apresentar provas da mesma; que, como tal, é importante definir a noção de discriminação indireta.

A trilogia das diretivas dos anos 2000 e 2002 retornou a mencionar o mesmo critério de inversão do ônus da prova, ou seja, havendo um fato que leve a uma presunção de discriminação, o ônus da prova é invertido para o empregador demonstrar que não houve a prática discriminatória.

No caso da legislação sul-africana, os termos de inversão do ônus da prova são claros, conforme o artigo 11 do Equity Employment Act, que diz claramente que:

Sempre que a discriminação injusta é alegada nos termos desta lei, cabe ao empregador contra quem a alegação é feita, provar que é justa. ${ }^{643}$

\footnotetext{
${ }^{642}$ LANQUETIN, Marie-Thérèze. Discriminations à raison du sexe. Droit Social, Paris, n. 7/8, p. 695, jul./ago. 1998.

${ }^{643}$ REPÚBLICA SUL-AFRICANA. Equity Employment Act. Department of Labour - Republic of South Africa. Disponível em: <http://www.labour.gov.za/downloads/legislation/acts/employment-equity/Act\%20\%20Employment\%20Equity.pdf>. Acesso em: 26 nov. 2009. Tradução livre.
} 
A Lei Federal da Austrália sobre discriminações sexuais de 1984 possui regra específica sobre o ônus da prova, no sentido de que em qualquer procedimento judicial envolvendo aquela norma protetiva, o ônus de provar que uma atitude não constitui discriminação não intencional (menciona discriminação indireta), conforme o disposto no artigo anterior, recai sobre a pessoa que cometeu o ato ${ }^{644}$.

No caso da Nova Zelândia, a legislação não é diferente, sendo que o artigo $92 \mathrm{~F}(2)$ do Human Rights Act, de $1993^{645}$, no que tange aos procedimentos que envolvem discriminação no trabalho, aponta que o ônus da prova recai sobre o réu, com exceção de algumas situações específicas.

Marie-Thérèze Lanquetin sustenta a existência de um princípio da inversão do ônus da prova, com base nas reiteradas decisões da jurisprudência da Corte de Justiça da União Europeia, bem como na Diretiva $n^{\circ}$ 97/80. Diante do que restou demonstrado em termos jurisprudenciais e doutrinários, não há dúvida de que a afirmação da jurista francesa deva ser plenamente acolhida.

Assim, é possível reconhecer a existência de um princípio da inversão do ônus da prova nas questões discriminatórias, porém restrito a um complexo modelo de incumbências processuais em diferentes fases. Superada uma primeira etapa, que seria a apresentação e fundamentação da distinção, caberá ao empregador ou tomador de serviços a obrigação de provar que a presunção ou suspeita é infundada. Ultrapassada esta questão e não tendo sido desvencilhado o ônus do empregador em rebater a presunção ou a verossimilhança das alegações, aí sim emerge um novo ônus da prova, relativamente a um segundo fato distinto do primeiro: o da justificação da medida diferenciadora.

Para encerrar este complexo tema, é possível assentar o seguinte posicionamento por parte da presente investigação: havendo motivos suficientes para presumir-se a existência de uma atitude diferenciadora, bem como apresentar indícios razoáveis ou, até mesmo, a adoção de categorias suspeitas, reconhece-se a existência de uma prática diferenciadora. Uma vez reconhecido este fato, cabe ao empregador ou contratante de serviços a contraprova. Ultrapassado este primeiro ônus do empregador ou tomador de

\footnotetext{
${ }^{644}$ AUSTRÁliA. Sex Discrimination Act. Act $\mathrm{n}^{\mathrm{o}} 4$ of 1984 as amended. Comlaw - Commonwealth of Australia Law. Disponível em: <http://www.comlaw.gov.au/comlaw/Legislation/ActCompilation1.nsf/0/99327A010C648560CA25760700 2370CF?OpenDocument>. Acesso em: 26 out. 2009.

${ }^{645}$ NOVA ZELÂNDIA. Human Rights Act. Parliamentary Counsel Office - New Zealand Legislation. Disponível em: <http://www.legislation.govt.nz/act/public/1993/0082/latest/viewpdf.aspx>. Acesso em: 26 out. 2009.
} 
serviços, emerge um novo ônus para ele, em que deve provar os fatos que embasam a justificativa do tratamento diferenciado, caso haja esta alegação. Não cumprido o ônus do empregador ou tomador de serviços pode-se considerar que houve prática discriminatória na situação em análise. Uma vez apresentada uma justificativa, cabe à vítima demonstrar que se trata de um pretexto para uma conduta discriminatória.

No entanto, tal questão é bastante complexa para ser administrada em um processo trabalhista, que tem como um de seus princípios o da concentração das provas. Todas as fases de prova acima explicitadas devem ser enfrentadas, caso sejam necessárias, até mesmo para possibilitar uma ampla apreciação da matéria probante pela instância superior. O trancamento prematuro de uma das fases da prova, diante do convencimento do Juízo de primeiro grau da desnecessidade das demais, em certas situações, pode configurar um cerceamento do direito de defesa de qualquer uma das partes. Os processos trabalhistas envolvendo uma alegação de discriminação demandam audiências com horário diferenciado dos processos comuns, posto que todos os elementos fáticos colhidos serão decisivos na solução do litígio, com uma duração mais prolongada.

\subsubsection{Meios de prova especiais}

As dificuldades com a prova dos atos discriminatórios são notórias, como visto no tópico anterior. Certas modalidades discriminatórias não podem ser provadas pelos meios comuns utilizados no processo trabalhista, em face de sua ineficácia para demonstrar certos fatos específicos. A prova mais comum no processo trabalhista, a prova oral, em muitos casos é totalmente imprecisa de demonstrar certos fatos como, por exemplo, a existência de disparidades na contratação de minorias raciais ou disparidades gerais de tratamento remuneratório. Por outro lado, como já visto, a prova documental pode consagrar práticas discriminatórias que na aparência são neutras; no entanto, escamoteiam dados importantes que podem demonstrar, por exemplo, uma discriminação não intencional.

O julgador de tais questões não pode ter nenhuma postura passiva, muito pelo contrário, o princípio diretivo do processo exige do julgador uma postura ativa, muitas vezes criativa, para procurar averiguar determinados fatos, alguns deles imperceptíveis pelos meios de prova mais comuns.

Dois meios de prova em especial, incomuns para as demais lides trabalhistas, já são consagradas na jurisprudência constituída na União Europeia e nos Estados Unidos da 
América sobre a discriminação: as análises sociológicas e as análises estatísticas. Ricardo de Paula Alves menciona o contexto da jurisprudência da Corte de Justiça da União Europeia, que possui um método pelo qual utiliza os referidos meios de prova ${ }^{646}$.

A primeira modalidade de prova, por meio de análises sociológicas, é extremamente importante para avaliação de contextos discriminatórios, principalmente nas situações de discriminação não intencional. A finalidade de tal modalidade de prova serve, principalmente, para demonstrar cientificamente que os impactos de uma atitude empresarial que seja neutra em sua origem venha a gerar efeitos perversos na sua execução.

A decisão do célebre caso Bilka Kaufhaus GmbH v Karin Weber von Hartz (assunto 170/84), pela Corte de Justiça da então Comunidade Econômica Europeia, em 13 de maio de $1986^{647}$, teve como base um fato social. Naquele feito, relatado no item 7.1.2. da presente investigação, um fato social foi crucial para aquela decisão: o impacto desproporcional causado pela política da empresa de complementação de aposentadoria que atingia muito mais as mulheres que os homens, posto que as primeiras tinham muito mais procura pelos empregos com jornada de meio período, conforme suas necessidades familiares.

Por outro lado, a situação da discriminação interseccional apontada no item 5.4. desta investigação, somente terá uma real avaliação dos efeitos através de uma apurada análise sociológica. Esta será fundamental para averiguar os efeitos de cada motivo perante determinado grupo em termos de oportunidades, de igual dignidade e igual tratamento social. Do mesmo modo, somente tal investigação terá condições de dimensionar o impacto da conjunção de motivos que gera a interseccionalidade, após a análise isolada, para descrever ao julgador os resultados da atuação conjunta dos dois fatores.

O exame dos impactos sociais de uma determinada atitude, ainda que despida de intenções discriminatórias, dependerá essencialmente de uma aproximação muito grande do julgador com a situação real da vítima. A análise ideal de uma situação discriminatória, por parte do julgador, é procurar se colocar na situação social da alegada vítima e perceber os impactos das atitudes do empregador ou contratante de serviços, dentro do trabalho e

\footnotetext{
${ }^{646}$ ALVES, Ricardo de Paula. op. cit., p. 119.

${ }^{647}$ CORTE DE JUSTIÇA DA COMUNIDADE ECONÔMICA EUROPÉIA. Decisão caso Kaufhaus $G m b H v$ Karin Weber von Hartz Assunto $\mathrm{n}^{\circ}$ 170/84. EUR-Lex. Disponível em: <http://eurlex.europa.eu/LexUriServ/LexUriServ.do?uri=CELEX:61984J0170:EN:HTML>. Acesso em: 10 nov. 2009.
} 
fora dele, inserindo-se naquele contexto social. Não deverá vislumbrar a situação real com os olhos de um julgador comum. Sem tal atitude, ele poderá ter uma percepção equivocada do impacto da atitude alegada como discriminatória.

Para a análise de tal contexto, principalmente em face das relações humanas das vítimas com o mundo exterior, somente uma avaliação sociológica adequada permite mensurar os efeitos da prática questionada. Daí sua importância, principalmente nos casos em que se discute se uma determinada atitude afeta desproporcionalmente as pessoas de um determinado grupo, elemento essencial da compreensão da discriminação não intencional, como bem cita John J. Donohue III $^{648}$. Os estudos sociológicos são extremamente importantes não somente nos casos concretos, como também na avaliação das políticas públicas e privadas em torno do tema da discriminação.

Devah Pager aponta que o método de auditagem social é a abordagem mais eficaz para medir a discriminação em contextos reais, ainda que não possa responder a todos os aspectos importantes da desvantagem no mercado de trabalho ${ }^{649}$. No entanto, cita o cientista social que tal prática oferece medições precisas e diretas da discriminação no momento da contratação, um mecanismo poderoso na regulação das oportunidades de emprego. O estudo sociológico feito por Frank Dobbin, John R. Sutton, John W. Meyer e W. Richard Scott aponta que, desde o surgimento da Lei dos Direitos Civis nos EUA, os administradores de pessoal procuram vislumbrar o processo de seleção formal e práticas promocionais como meios de proteger os direitos dos empregados e, ao mesmo tempo, racionalizar a alocação de trabalhadores ${ }^{650}$.

O segundo método, trabalhando conjuntamente com o primeiro, ou mesmo isoladamente, é o uso de provas estatísticas para comprovação de práticas discriminatórias. A aliança entre métodos sociológicos e estatísticos é mencionada por muitos autores, em especial por Robin Stryker, socióloga que aponta a importância do trabalho sociológico

\footnotetext{
${ }^{648}$ DONOHUE III, John J. Foundations of employment discrimination law. 2. ed. New York: Foundation Press, 2003. p. 297.

${ }^{649}$ PAGER, Devah. Medir a discriminação. Trad. de Norberto Guarinello e João Henrique Costa. Tempo Social: revista de sociologia da USP, São Paulo, n. esp., v. 18, n. 2, p. 83, nov. 2006.

${ }^{650}$ DOBBIN, Frank; SUTTON, John R.; MEYER, John W.; SCOTT, W. Richard. Equal opportunity law and the construction of internal labor markets. American Journal of Sociology, vol. 99, 1993. In DONOHUE III, John J. Foundations of employment discrimination law. 2. ed. New York: Foundation Press, 2003. p. 292.
} 
conjugado com o estatístico para demonstração de condutas discriminatórias em diversos setores, desde as escolas até o próprio mercado de trabalho ${ }^{651}$.

O uso de estatísticas nos processos judiciais envolvendo alguma forma de discriminação não é novidade, onde o tema é frequente nas cortes, em especial nos Estados Unidos da América e na Europa. A principal vantagem da estatística é a demonstração de situações de discriminação não intencional, sendo que este tipo de prova permite, com o uso de sua técnica, demonstrar que determinado grupo de pessoas portadoras de alguma característica que as destaque tenha sofrido mais duramente os impactos de determinada postura ou política.

Nos Estados Unidos, vários casos envolvendo o uso de estatísticas foram apreciados pela Suprema Corte, que referendou o método como válido, merecendo destaque dois casos. O primeiro deles - o International Brotherhood of Teamsters $v$. United States $^{652}$ foi o mais importante processo judicial em que se tenha utilizado estatísticas para comprovação de uma política discriminatória promovida por uma empresa. Ele ficou célebre pelo fato de a Suprema Corte aceitar a comprovação de uma discriminação sistêmica por meio de dados estatísticos, tratados em conjunto com outras provas e, neste mesmo processo, cunhou a teoria do disparate impact, como denominação da discriminação não intencional. O uso das estatísticas demonstrou que uma determinada empresa contratava preponderantemente motoristas brancos para linhas de transporte de caminhão intermunicipais, que eram melhor remunerados. Por outro lado, a mesma prova demonstrou que a empresa contratava motoristas negros para as linhas de transporte de caminhão locais, com menor remuneração. O governo federal acusou a existência de um sistema de promoções por antiguidade, estabelecido por meio de negociação coletiva com o sindicato profissional, como perpetuador dos efeitos de discriminação racial existentes no passado.

Os dados estatísticos foram fundamentais para demonstrar que em todas as unidades da empresa no país ocorria disparidade entre a população negra qualificada e a população admitida pela empresa. Apenas como parte da demonstração das práticas discriminatórias, na cidade de Memphis, as linhas de percurso intermunicipal tinham,

\footnotetext{
${ }^{651}$ STRYKER, Robin. Disparate Impact and the Quota Debates: Law, Labor Market Sociology, and Equal Employment Policies. The Sociological Quarterly, v. 42, No. 1 Inverno 2001, p. 16. JSTOR. Disponível em: <http://www.jstor.org/stable/4120924>. Acesso em: 30 nov. 2009.

${ }^{652} 431$ U.S. 324, 97 S.Ct. 1843, 52 L. Ed. 2d. 396 (1977). Find law for legal professionals. Disponível em: <http://laws.findlaw.com/us/431/324.html>. Acesso em: 30 nov. 2009.
} 
respectivamente, $0,4 \%$ de negros e $0,3 \%$ de hispânicos, nos seus quadros, quando somente o índice de negros qualificados para a função na cidade atingia $30 \%$ do mercado de trabalho específico.

A Corte entendeu que as estatísticas demonstraram disparidades inaceitáveis para a função de motoristas de linhas de percursos intermunicipais, não conseguindo a empresa provar motivos justificáveis para tal medida. A defesa alegou que a prova baseada em estatísticas jamais poderia, sozinha, ser considerada uma prima facie case e inverter o ônus da prova. Mas a decisão reafirmou que a prova estatística era de verossimilhança, além do fato de o governo federal basear-se também em testemunhos dos envolvidos, além de outros dados, registrando na célebre nota de rodapé nº 20 a seguinte passagem:

desde a aprovação da Lei dos Direitos Civis as Cortes têm frequentemente acreditado em provas de estatísticas como demonstração de uma violação da lei e ainda poderem ser uma única forma de prova a ser utilizada em casos de estatísticas demonstrarem discriminação encoberta ${ }^{653}$.

E mais adiante concluiu:

as estatísticas são igualmente competentes em provar discriminação no emprego. Nós somente tomamos cuidado no sentido de que as estatísticas não são irrefutáveis, elas vêm em enorme variedade e, como qualquer outro meio de prova, podem ser desafiadas. Sua utilidade depende de todos os fatos e circunstâncias que cercam o caso ${ }^{654}$.

O uso de estatísticas depende de muitos cuidados. A veracidade e a contundência da prova estatística dependerá, em grande parte, da metodologia estatística a ser utilizada, bem como o foco que sua análise irá promover. No caso Hazelwood School District $v$. United States $^{655}$, vários problemas com estatísticas emergiram do referido processo judicial. Trata-se de um processo muito interessante, pelo qual foi ajuizada uma ação pelo governo federal contra uma escola distrital nas proximidades de Saint Louis, Missouri. Em síntese, o governo alegava que o distrito educacional adotava um padrão de prática de discriminação no emprego de professores, em plena violação do Título VII, estando as minorias sub-representadas no corpo docente daquela instituição de ensino.

\footnotetext{
${ }^{653}$ Id. Ibid. "Since the passage of the Civil Rights Act of 1964, the courts have frequently relied upon statistical evidence to prove a violation. In many cases the only available avenue of proof is the use of racial statistics to uncover clandestine and covert discrimination by the employer or union involved." ${ }^{654}$ Id. Ibid.

${ }^{655} 433$ U.S. 299, 97 S.Ct. 2736, 52 L. Ed. 2d. 768 (1977). Find law for legal professionals Disponível em: <http://laws.findlaw.com/us/433/299.html>. Acesso em: 30 nov. 2009.
} 
A ação não foi aceita no Juízo de primeiro grau federal, por entender que o governo não demonstrou o padrão de prática de discriminação, conforme as estatísticas demonstradas no processo. A decisão de primeiro grau foi reformada pela Corte de apelações federais, que entendeu que a análise de dados estatísticos feita pelo juízo de $1^{\circ}$ grau resultou em uma irrelevante comparação de professores negros com alunos negros da comunidade, ao invés de comparar professores negros em Hazelwood com professores negros em todo o Condado de Saint Louis, onde 15,4\% dos professores disponíveis eram negros, mas na escola, nos anos de 1972-1973 e 1973-1974, somente 1,4\% e 1,8\% dos professores, respectivamente, eram afrodescendentes. Os fatos acima, adicionados a práticas anteriores comprovadas nos autos, demonstravam ser um caso prima facie levando à inversão do ônus da prova.

A comparação feita pela Corte revisora foi mantida pela Suprema Corte, entendendo-a como correta, quando foi promovida a comparação entre os professores da escola e o universo profissional qualificado para desempenhar a atividade de professor no mercado de trabalho do condado. A Suprema Corte entendeu que a Corte de Apelações equivocou-se apenas na consideração do feito como prima facie case, posto que poderiam ser cotejados outros dados anteriores e posteriores à época envolvida, cabendo a possibilidade de produção de uma contraprova pela escola.

A referida decisão da Suprema Corte afirmou a importância das estatísticas, apontando que a forma na qual a Corte distrital comparou a força de trabalho de Hazelwood com a população estudantil trouxe um equivocado conceito do papel das estatísticas nos casos de discriminação no trabalho ${ }^{656}$. A Suprema Corte apontou que a Corte de apelações fez a comparação adequada, entre a composição racial dos professores de Hazelwood e a composição racial da população de professores qualificada em um relevante mercado de trabalho.

O caso em questão deixa muito claro o problema da metodologia e da interpretação das estatísticas. Com um pouco de habilidade e, dependendo da ótica do julgador, as estatísticas poderão revelar dados que possam distorcer a situação real de trabalho. Portanto, é uma prova que requer extremos cuidados na sua elaboração e apresentação em

\footnotetext{
${ }^{656}$ Id. Ibid., that the District Court's comparison of Hazelwood's teacher work force to its student population fundamentally misconceived the role of statistics in employment discrimination cases. The Court of Appeals was correct in the view that a proper comparison was between the racial composition of Hazelwood's teaching staff and the racial composition of the qualified public school teacher population in the relevant labor market.
} 
Juízo. Por outro lado, exigirá do julgador uma acuidada percepção em saber se aquela apresentação numérica efetivamente reflete a realidade.

A jurisprudência europeia também tem se baseado neste tipo de prova por um longo tempo. No caso Handels-og Kontorfunktionaerernes Forbund i Danmark contra Dansk Arbejdgiverforening ${ }^{657}$ a Corte de Justiça da União Europeia reconheceu que as provas estatísticas demonstravam que as empregadas recebiam menos que os empregados, e a empresa não logrou demonstrar o motivo desta disparidade. A decisão baseou-se nos fatos demonstrados nas estatísticas no sentido de que a remuneração dos trabalhadores masculinos era 6,85\% maior, comparativamente com a remuneração das trabalhadoras femininas, ainda que não estivesse claro o motivo da diferença; caberia ao empregador demonstrar os motivos da disparidade.

Kingsley R. Browne aponta uma série de motivos para afirmar que as estatísticas não podem ser utilizadas como meio de prova capaz de inverter o ônus da prova para os empregadores em casos de discriminação intencional, devendo ser abandonado como meio de prova primário ${ }^{658}$. O autor critica a forma de interpretação dada às estatísticas, afirmando a existência de uma "falácia estatística", baseando-se em uma série de motivos que possam distorcer seus resultados, como a base de amostragem adotada, a metodologia, além de as estatísticas basearem-se em probabilidades.

Em que pesem os argumentos do jurista, este modelo de prova deve ser aceito, muitas vezes como o único meio capaz de demonstrar algumas alegações importantes e de difícil apresentação pelos meios comuns. No entanto, cabe tomar certos cuidados em função de como esta prova será realizada e apresentada, na medida em que distorções intencionais ou não intencionais poderão transmitir falsos dados. Não faltam críticos contra este sistema de prova. No sistema processual brasileiro, tais provas devem ser aceitas, eis que somente são proibidas provas ilícitas e as moralmente inaceitáveis, o que não seria o caso das provas sociológicas ou estatísticas.

\footnotetext{
${ }^{657}$ TRIBUNAL DE JUSTIÇA DA COMUNIDADE ECONÔMICA EUROPÉIA. Eur-lex. Assunto 109/88. Disponível em: <http://eurlex.europa.eu/LexUriServ/LexUriServ.do?uri=CELEX:61988J0109:PT:HTML>. Acesso em: 30 nov. 2009. ${ }^{658}$ BROWNE. Kingsley R. Statistical proof of discrimination:beyond "Damned Lies". Washington Law Review, vol. 68, 1993. In: DONAHUE, John J. Foundations of employment discrimination law. 2. ed. New York: Foundation Press, 2003. p. 313.
} 


\subsubsection{Meios de reparação dos atos discriminatórios}

As situações discriminatórias, quando constatadas e judicialmente reconhecidas, ainda enfrentam outra situação não menos complexa: como podem ser reparadas as práticas discriminatórias, bem como quais os meios de reparação que podem ser adotados em face dos danos causados pela prática discriminatória.

Dois meios de reparação podem ser facilmente visualizados quando reconhecida uma prática discriminatória - a declaração de nulidade dos atos praticados com base em atitude reconhecidamente discriminatória e a restituição da situação anterior ao ato discriminatório.

A noção de reparação pela restituição da situação como se não houvesse ocorrido a prática discriminatória é uma atitude positiva em favor da vítima, mas que, em alguns casos, pode gerar efeitos negativos para terceiros de boa-fé. Nos casos de admissão ou promoção de trabalhadores, reparar a situação de forma que a admissão ou a promoção não tivesse ocorrido poderá ser situação que venha prejudicar outros trabalhadores que estejam ocupando o cargo de boa-fé, muitas vezes por longo tempo.

Por outro lado, a declaração de nulidade do ato discriminatório poderá levar ao mesmo efeito, ou a outros mais danosos ainda. Os exemplos acima demonstram a dificuldade da reparação da situação discriminatória. Esta reparação não pode ter uma previsão rígida para que se adote uma determinada atitude reparatória. Dependendo da situação, outros remédios devem ser adotados. Por outro lado, as formas acima somente vêm reparar danos ocorridos no passado, sem grandes consequências diretas para o futuro. Certas situações pessoais poderão ser reparadas, muitas vezes sem uma forma adequada, principalmente quando o fator tempo atuar decisivamente nas soluções judiciais. Mas tais meios somente podem atuar de forma individual, sem uma consistência que procure evitar situações coletivas para o futuro.

Assim, a reparação dos atos discriminatórios depende, caso a caso, de medidas especialmente tomadas e ajustadas para cada situação. O julgador deverá dispor de uma ampla possibilidade de medidas que venham não somente reparar danos de uma discriminação passada mas, principalmente, evitar que os mesmos danos venham se repetir no futuro. O tradicional conceito de reparação de danos fundados nos meios de restituição integral da situação anterior, ou na indenização dos prejuízos caso não seja possível a restituição, não devem ser os únicos meios aplicados aos processos envolvendo 
discriminação laboral. O julgador precisa ter em suas mãos outros instrumentos de reparação, bem como deverá ter liberdade em adequar o meio de reparação ao caso concreto.

O artigo 2000e-5 (originalmente $§ 706)^{659}$, da Lei de Direitos Civis dos Estados Unidos da América, pressupõe uma série de medidas para reparação da atitude discriminatória, mas, antes de tudo, um poder especial ao julgador: o poder discricionário para aplicar as penalidades cabíveis previstas naquele diploma, apontando-as de modo exemplificativo, podendo aplicar outras medidas que entender cabíveis e apropriadas ao caso em tela. As possibilidades ali previstas estão entre a determinação da realização de uma ação afirmativa, reintegração, contratação de empregados, poder ou não determinar o pagamento de salários vencidos (limitados a dois anos do ajuizamento da queixa), cuja responsabilidade pode ser do empregador, agência de emprego ou o respectivo sindicato, bem como qualquer outra medida jurídica equitativa, ficando ao critério do juiz, de acordo com o caso concreto.

A supracitada norma legal pressupõe que o julgador tenha amplos poderes para fixar o meio e modo de reparação dos danos causados pela prática discriminatória, garantindo ao Poder Judiciário amplos poderes para flexibilizar a aplicação de medidas, sempre procurando dar a melhor forma de reparação possível à situação peculiar de cada processo. Mack Player destaca que o amplo poder concedido ao julgador ainda é revestido pela possibilidade de emitir ordens proibitivas de conduta, emitir ordens de obrigações de fazer que pedem dos empregadores o cumprimento de diversas etapas para obtenção de efeitos positivos, concedendo às cortes o poder de agir como uma corte equitativa ${ }^{660}$.

George Rutherglen afirma que a referida modalidade de reparação foi adotada pelo Congresso norte-americano, para evitar-se a condenação de indenizações por perdas, as quais, dentro do direito daquele país, levariam as partes à possibilidade de exigirem julgamento da questão por meio de um júri, o que não era interessante nos anos sessenta, principalmente nos Estados do sul daquele país ${ }^{661}$. O autor destaca que as questões raciais ainda eram muito preocupantes nessa época e o legislador temeu que reiteradas nulidades de júris pudessem dificultar a efetivação da lei material, principalmente naquela conturbada região.

\footnotetext{
${ }^{659}$ ESTADOS UNIDOS DA AMÉRICA. Equal Employment Opportunity Comission. Title VII. Disponível em: <http://www.eeoc.gov/laws/statutes/titlevii.cfm>. Acesso em: 30 nov. 2009.

${ }^{660}$ PLAYER, Mack. op. cit., p. 436.

${ }^{661}$ RUTHERGLEN, George. op. cit., p. 174.
} 
No entanto, a lei norte-americana foi reformada diversas vezes, e não obstante sejam mantidas as possibilidades de medidas equitativas, a Lei de Direitos Civis de 1991 autorizou o pagamento de indenizações com valores limitados até US\$ 50.000,00 para empresas de 15 a 100 empregados, e de até de US\$300.000,00, quando o empregador tiver mais de 500 empregados. Atualmente, é possível a condenação em medidas equitativas, mais o pagamento da indenização, além de outras medidas, como pagamento de diferenças salariais e valores futuramente devidos quando não se afasta empregado que teria ocupado o lugar da vítima, pagamento este conhecido como front pay. As medidas de cumprimento de obrigações de fazer ou não fazer também são autorizadas, além de multas e a penalidades mais severas no caso de desrespeito à ordem judicial.

No mesmo sentido de previsão de remédios equitativos, a legislação sul-africana adota os mesmos termos da legislação norte-americana, para que o Poder Judiciário e a autoridade administrativa tenham poderes equitativos. No artigo 50 da Lei de Igualdade no Emprego, o Juízo recebe do diploma legal os poderes de aplicar medidas como pagamento de indenizações, reparações, ordens para evitar futuras discriminações, ordens para ajuste de conduta, registros de práticas e quaisquer outras ordens que o julgador entender como necessárias para cumprimento, inclusive multas ${ }^{662}$.

No Canadá, o mesmo sistema de liberdade de aplicação das penalidades é conferido para a autoridade administrativa apreciar questões discriminatórias. O artigo 50 da Lei Canadense de Direitos Humanos prescreve uma série de medidas, desde a adoção de planos para a cessação de atitudes discriminatórias, restabelecimento de direitos, oportunidades e privilégios negados para a vítima como consequência da prática discriminatória, indenização de todos os prejuízos sofridos pela vítima, custos adicionais para a contratação de serviços e bens necessários para a reparação dos direitos negados, qualquer despesa realizada pela vítima em função da prática discriminatória, danos morais não superiores a vinte mil dólares canadenses pelos sofrimentos emocionais em decorrência da discriminação, indenização no mesmo valor em caso de resistência de cumprimento, possibilidade de multas administrativas até o valor acima, além de previsão expressa de juros de mora ${ }^{663}$.

\footnotetext{
${ }^{662}$ ÁFRICA DO SUL. Employment Equity Act. $\mathrm{N}^{\mathrm{o}} 55$, of 1998. Disponível em: <http://www.labour.gov.za/downloads/legislation/acts/employment-equity/Act\%20\%20Employment\%20Equity.pdf>. Acesso em: 30 nov. 2009.

${ }^{663}$ CANADÁ. Canadian Human Rights Act. Department of Justice. Laws. Disponível em: <http://laws.justice.gc.ca/eng/H-6/page-2.html\#anchorbo-ga:1_I-gb:s_5>. Acesso em: 30 nov. 2009.
} 
Já a Lei Portuguesa do Contrato de Trabalho autoriza, em seu artigo 28, com base nas formas previstas no direito comum, a concessão à vítima de uma indenização por danos patrimoniais e não patrimoniais ${ }^{664}$. Já a Lei 18/2004 prevê, além das medidas acima, a declaração de nulidade dos atos retaliatórios e quaisquer outras medidas neste sentido ${ }^{665}$. Guilherme Machado Day indica os artigos aplicáveis do Código Civil português aos casos de discriminação, declarando-se nulos os atos praticados, reparando-se na maior parte dos casos as despesas efetuadas com a candidatura e, em casos pontuais, os danos sofridos com situações específicas de perda de outro emprego para candidatura ao emprego em que tenha sido discriminado ${ }^{666}$.

Fica claro, pelos exemplos acima citados, que as medidas de reparação dos atos discriminatórios são bem variadas, desde medidas punitivas até mesmo reparatórias, como a instituição de ações afirmativas, bem como multas, condenações em indenizações e outras medidas de obrigação de fazer e de não fazer. $O$ princípio geral que pode ser extraído, portanto, é que tais medidas são aplicáveis de forma discricionária pelo julgador ou pela entidade administrativa, na forma que entender mais apropriada, sendo conferido ao julgador um amplo poder discricionário.

Verifica-se, também, que algumas normas antidiscriminatórias não são taxativas para aplicação de penalidades, ficando a critério do julgador a adoção de outras medidas. Tal poder discricionário é importante, posto que o maior interesse da norma é dar efetividade à ordem legal de tratamento igualitário. Para tanto, deverá o julgador ou autoridade administrativa adequar sua medida ao caso concreto, devendo, portanto, inteirar-se bastante da situação para dosar as medidas que venham melhor restituir direitos e vantagens, posto que algumas medidas, ainda que previstas em lei, possam ser de difícil execução ou que cause desnecessário constrangimento às partes.

\footnotetext{
${ }^{664}$ PORTUGAL. Código do Trabalho. Atualizado pela Lei 7 de 12 de fevereiro de 2009. Diário da República Eletrônico. Disponível em: <http://dre.pt/pdf1sdip/2009/02/03000/0092601029.pdf>. Acesso em: 30 nov. 2009.

${ }^{665}$ PORTUGAL. Lei 18/2004, de 11 de maio de 2004. Diário da República Eletrônico. Id., loc. cit. nota 28.

${ }^{666}$ DRAY, Guilherme Machado. op. cit., p. 285.
} 


\section{DISCRIMINAÇÕES CONTRA OS TRABALHADORES MIGRANTES}

O presente capítulo irá tratar de uma modalidade de discriminação, extremamente comum, que é aquela voltada contra os trabalhadores migrantes, como talvez a mais complexa e intrincada situação discriminatória atualmente. A proteção contra a discriminação não tem demonstrado resultados eficazes na defesa dos trabalhadores que exercem atividade laboral em território estrangeiro.

Luigi Ferrajoli classifica que as discriminações entre cidadãos e não cidadãos não somente sobreviveram, como têm se aprofundado dramaticamente, ressaltando que, enquanto certos direitos são atribuídos a todos como pessoas, outros são atribuídos somente aos cidadãos ${ }^{667}$. O referido autor afirma que a cidadania entra em contradição com a igualdade jurídica, sendo que a cidadania em países ricos tem se tornado um privilégio de status ligado a um accident de naissance. Ferrajoli afirma que a cidadania é um fator de discriminação jurídica, com resultados excludentes, como um dos resíduos pré-modernos das diferenciações pessoais existentes no passado, contrariando a universalidade e igualdade de todos os direitos fundamentais ${ }^{668}$.

Essa complexa e lamentável situação merece um destaque da investigação. Não obstante todos os esforços já apresentados para a eliminação da discriminação laboral, nitidamente tal preocupação é voltada com muito maior intensidade para proteção dos nacionais. Em relação aos estrangeiros, o cenário é extremamente desolador, assumindo contornos dramáticos, e com tendências de intensificação dos tratamentos diferenciados, em alguns casos permeados pelo racismo. A proteção contra a discriminação se encontra diante de um grande dilema. A falta de um tratamento adequado contra a discriminação de trabalhadores migrantes pode desestruturar, completamente, a construção de uma sofisticada proteção global contra a discriminação laboral. Essa situação coloca em risco todas as importantes conquistas obtidas até os dias atuais, anunciando uma atmosfera mais sombria na proteção dos direitos fundamentais da pessoa humana.

\footnotetext{
${ }^{667}$ FERRAJOLI, Luigi. La igualdad y sus garantías, cit., p. 15.

${ }^{668}$ Id., loc. cit.
} 


\subsection{Breve histórico e atualidades dos fenômenos migratórios}

A história da humanidade é profundamente marcada por deslocamentos humanos de diversas origens e motivações, segundo Christian Nguyen Van Yen ${ }^{669}$. Desde uma época de grandes movimentações humanas até a fixação do ser humano com o conhecimento de técnicas agrícolas e o estabelecimento de territórios delimitados, a história registrou grandes movimentações de populações inteiras, fossem espontâneas ou forçadas, sendo que as últimas foram mais comuns. Fatores como catástrofes naturais, guerras, invasões ou mesmo aprisionamentos maciços de seres humanos para escravização são elementos históricos da civilização humana.

Essa prática comum da antiguidade é registrada na ópera "Nabucco", em uma imortal melodia da ária "Va pensiero, sull'alli dorate", composta por Giuseppe Verdi. Com o passar dos tempos, os movimentos migratórios perderam a mesma intensidade, mas sua ocorrência prosseguiu em grande número, principalmente em razão de conflitos e conquistas. A idade moderna marcou um diferente sentido de movimentação, desta vez com destino para fora da Europa, principalmente para os novos territórios descobertos pelas grandes navegações. Constitui-se um importante vetor migratório do centro para a periferia do poder mundial da época, que intensificou-se no século XIX, durando até meados do Século XX. Louis Dollot afirma que este período da independência das colônias latino-americanas entre 1810 e 1815 inaugura a era contemporânea das migrações ${ }^{670}$.

Um grande movimento migratório forçado também ocorreu entre os Séculos XVI e XIX, da África para a América, Europa e Oriente Médio, uma autêntica diáspora forçada. Cerca de 40 milhões de africanos ${ }^{671}$ foram aprisionados em sua terra natal e trazidos em condições totalmente subhumanas para diversos destinos. $\mathrm{O}$ mais comum deles foram as colônias da América, as quais se emanciparam entre o final do Século XVIII e metade do Século XIX, locais nos quais foram vendidos como escravos. Foi um maciço contingente humano que alterou, definitivamente, a composição étnica do continente americano. Outras diásporas também são importantes, como aquelas ocorridas com os hebreus na antiguidade e os armênios mais recentemente.

Com o final da segunda grande guerra, novos vetores migratórios começaram a surgir exatamente em sentido inverso, partindo dos Estados periféricos para os Estados

\footnotetext{
${ }^{669}$ VAN YEN, Christian Nguyen. Droit de l'immigration. Paris: Presses Universitaires de France, 1986. p. 19. ${ }^{670}$ DOLLOT, Louis. Les migrations humanaines. Paris: Presses Universitaires de France, 1970. p. 10.

${ }^{671}$ MUNANGA, Kabengele; GOMES, Nilma Lino. O negro no Brasil de hoje. São Paulo: Ed. Global, 2006. p. 19.
} 
centrais. A consagração da hegemonia norte-americana e a melhoria das condições socioeconômicas do continente europeu, principalmente dos seus países mais evoluídos, foram fatores de atração migratória. Durante os anos cinquenta e sessenta, a migração nos países europeus mais adiantados foi muito bem recebida, principalmente para suprir necessidades de mão de obra barata, recebendo grandes contingentes migratórios dos países do sul do continente, bem como das extintas colônias europeias espalhadas pelo mundo $^{672}$.

A crise do petróleo dos anos setenta e o fim do sonho do welfare state europeu desencadeou uma grave situação econômica, principalmente o desemprego. Ele alimentou as tendências restritivas da migração nos países mais desenvolvidos, com políticas progressivamente mais fechadas para admissão ${ }^{673}$. O fantasma do desemprego massivo dos anos 80 fomentou um sentimento xenófobo em muitos países europeus contra os migrantes, principalmente contra aqueles com cor de pele, religiões e costumes diferentes.

Os Estados Unidos atualmente possuem aproximadamente $12 \%$ de sua população não nascida naquele território. No entanto, nas últimas décadas, especialmente após os anos setenta, passou a restringir, muitas vezes de forma extremamente enérgica, a imigração para seu território. A preocupação com a migração passou a integrar as agendas sociais dos países desenvolvidos.

A globalização e a crescente exclusão social vivida nos países periféricos e semiperiféricos impulsiona um grande vetor imigratório de países mais pobres para países mais desenvolvidos e, também, para os países emergentes. O vetor mudou sua direção, agora da periferia para o centro. Por sua vez, os nacionais dos países em desenvolvimento ou emergentes, aliados com os nacionais de países menos desenvolvidos, procuram atingir os países mais desenvolvidos, em muitos casos sem autorização do país receptor. A intensa pressão migratória de países periféricos e semiperiféricos, auxiliados por uma grande indústria de tráfico de pessoas, estimula os países desenvolvidos a adotarem políticas progressivamente restritivas de admissão de migrantes, algumas delas explicitamente contrárias à proteção dos direitos humanos.

A atual situação brasileira não deixa de ser curiosa. Nosso país é destino de imigrações clandestinas que partem de nossos vizinhos e possui muitos emigrantes,

\footnotetext{
${ }^{672}$ MESSINA, Anthony M. The not so silent revolution. World Politics, Baltimore, v. 49, n. 1, p. 131, Oct. 1996.

${ }^{673}$ CHOLEWINSKI, Ryszard. The protection of the right of economic migrants to family reunion in Europe. International and Comparative Law Quarterly, Cambridge, v. 43, pt. 3, p. 571, July 1994.
} 
principalmente nos Estados Unidos, Europa e Japão, com um significativo contingente de migração não autorizada.

As atuais hostilidades contra os movimentos migratórios são um fenômeno político nos países desenvolvidos, com forte apoio popular, principalmente em face do desemprego e de outras mazelas sociais. Os imigrantes nesses países são vislumbrados como os causadores dos problemas enfrentados. Por tal motivo, a discriminação contra eles cresce assustadoramente, sendo a xenofobia integrante até mesmo de plataformas políticas, conforme o relato do diplomata e jurista J.A. Lindgren Alves ${ }^{674}$. A referida pressão política resulta em um sistema fortemente excludente, demasiadamente perigoso e que forma um círculo vicioso, sem perspectiva de solução a curto ou médio prazo.

Para complicar ainda mais a situação dos migrantes de países periféricos, as políticas contra o terrorismo estabelecidas por países que sofreram graves atentados terroristas produzem efeitos dramáticos. Os trágicos eventos de 11 de setembro de 2001 nos Estados Unidos da América potencializaram muito mais tais efeitos. As políticas antiterrorismo classificam determinadas categorias de pessoas, como os muçulmanos. Eles são tratados naquele país como um grupo próximo ao da suspeição, recebendo inaceitáveis restrições direcionadas a esse povo, com situações absolutamente constrangedoras e humilhantes da pessoa humana, servindo como exemplo os cadastros especiais exclusivamente a eles destinados ${ }^{675}$.

A discriminação contra trabalhadores migrantes é uma questão que preocupa cada vez mais o combate à discriminação em todo o mundo. São crescentes os registros de violações de direitos sofridos por trabalhadores migrantes em muitos lugares do planeta, uma grave situação que cresce a cada dia. A dificuldade do enfrentamento do tema pede soluções além dos limites das políticas estatais, com uma nova conceituação de proteção antidiscriminatória para um alcance global. As políticas repressoras da migração estão propiciando agressivas e sistemáticas violações de direitos, levando, em alguns casos, à perda da condição humana por parte do trabalhador migrante. Tal situação põe sob alto risco todos os sistemas de proteção antidiscriminatória construídos nos últimos sessenta anos.

\footnotetext{
${ }^{674}$ ALVES, J. A. Lindgren. op. cit., p. 201.

${ }^{675}$ PADEN, John N.; SINGER, Peter W. America slams the door (on its foot). Foreign Affairs, New York, v. 82, n. 3, p. 8, May/June 2003.
} 


\subsection{As condições especiais dos diversos tipos de trabalhadores migrantes}

Os movimentos migratórios não espontâneos da antiguidade tinham, em grande parte, o objetivo de obter mão de obra escrava para atender a atividades produtivas dos vencedores. Na idade moderna, houve a constituição de um amplo sistema mercantil para o tráfico de pessoas humanas, realizado por grandes organizações, destinado a aprisionar nativos para comercializá-los como escravos em outros continentes. Essa tragédia dos povos africanos ocorreu até a metade do Século XIX, com maior intensidade, mas ainda perdurou no século XX em algumas localidades. O Brasil foi um dos países que mais se serviu desta nefasta forma de suprimento de mão de obra, tendo sido o último país americano a abolir a escravidão.

Tais fatos revelam que, durante muito tempo, na humanidade, o trabalho do estrangeiro, em grupamentos ou de forma coletiva, fora de sua localidade habitual foi realizado sob o manto da escravidão. Essa realidade produz reflexos até a presente data, pois o trabalho prestado pelo estrangeiro ainda está impregnado pela nefasta associação do migrante com o trabalho de menor qualidade, de menor valor, com menor respeito à pessoa e à família do trabalhador.

Desde que existe trabalho humano existe migração para outros países para tais finalidades. Christian Nguyen Van Yen aponta que o desenvolvimento dos meios de transporte e de comunicação no século XIX possibilitou essa grande movimentação partindo da Europa. As migrações para suprir mão de obra tiveram início no começo da era industrial $^{676}$. A pobreza, as dificuldades de subsistência humana e a falta de perspectivas são as razões mais comuns para a migração de trabalhadores. Não é uma peculiaridade dos países pobres; mesmo nos países mais ricos existem movimentos internos de migração para finalidades de trabalho, partindo de áreas menos privilegiadas para áreas onde estão concentradas as melhores oportunidades de trabalho. Insta lembrar os movimentos migratórios internos forçados, determinados por Josef Stalin na União Soviética, que deslocaram milhares de pessoas dentro daquele país para finalidades econômicas. Por outro lado, guerras, conflitos internos, insegurança, perseguições de diversos matizes são fatores importantes que também fomentam os fluxos migratórios de trabalhadores. É possível, portanto, admitir a existência de migrações espontâneas e forçadas.

${ }^{676}$ VAN YEN, Christian Nguyen. op. cit., p. 20. 
Muitos europeus vieram para a América em busca de novas oportunidades inexistentes na conturbada Europa do Século XIX e início do Século XX. Na América Latina a chegada maciça de estrangeiros para suprir as necessidades de mão de obra trouxe uma profunda alteração da forma das relações capital-trabalho. A chegada dos novos trabalhadores implementou novas formas de trabalho, desde a substituição da mão de obra na agricultura como também no incipiente processo de industrialização do final do Século XIX e no Século XX. Não bastasse a rejeição natural que todo migrante sofre, muitos desses imigrantes trouxeram ideias políticas absolutamente contrastantes com as sociedades agrárias e extremamente conservadoras como as latino-americanas, pouco após o término da escravidão. Não obstante tais dificuldades, os migrantes europeus constituíram o germe da classe operária latino-americana.

A chegada em outro país, com clima, língua, cultura, organização política, religião, costumes, geografia e tantos outros aspectos diversos de suas terras de origem, posicionavam os imigrantes em condições de extrema dificuldade. Os nacionais dos países receptores receberam com desconfiança a presença de estrangeiros entre os seus, pois há uma natural rejeição inicial do ser humano aos que não falam a mesma língua, não professam as mesmas crenças e não têm os mesmos costumes.

Qualquer trabalhador possui grande dificuldade para ser incluído na nova sociedade que escolheu ou foi obrigado a se deslocar, mesmo aqueles cuja migração foi incentivada pelo Estado receptor. As mais dramáticas situações de discriminação interseccional são experimentadas por trabalhadores migrantes em face de sua condição de estrangeiro, seu desconhecimento da língua, sua aparência física que pode ser muito distinta, agregados a outros fatores discriminatórios como o gênero, a religião e os costumes. A soma de todos esses fatores permite concluir que o trabalhador migrante recebe um impacto muito mais negativo e hostil da discriminação, em comparação com aquela experimentada por um trabalhador nacional.

As necessidades de trabalho no novo território que recebe o trabalhador migrante exigem que ele tenha bom domínio da língua, o que, em muitos casos, somente irá ocorrer após um período considerável. O aprendizado de uma nova língua fica muito mais dificultado se o trabalhador migrante não possui um nível de instrução mínimo na sua origem. A língua é uma barreira que facilita bastante a exploração do trabalho humano de forma inescrupulosa. 
Em sua grande maioria, os migrantes atuais são trabalhadores não qualificados, que procuram trabalho em mercados saturados, detentores de significativas taxas de desemprego. Nos dias atuais, o trabalhador migrante volta para os grandes centros como um sub-produto da exclusão social dos países periféricos ou emergentes. Naturalmente, acabam por obter trabalho em funções geralmente não muito desejadas pelos nacionais, decorrente da baixa remuneração, péssimas condições de trabalho e falta de qualificação profissional. São alcunhados como os "trabalhos 3-D" (demanding, dirty and dangerous) árduos, sujos e perigosos - não atraentes para os trabalhadores domésticos dos países mais desenvolvidos. Esse sentido de inclinação para o exercício de trabalhos precários promove mais ainda situações de destruição do senso de solidariedade entre locais e migrantes conforme aponta Robin Cohen ${ }^{677}$, na medida em que os empregos precários acabam sendo o destino natural dos migrantes e prejudicam o nível de remuneração do mercado de trabalho geral.

Mas se ainda consegue um trabalho, a grande dificuldade será conseguir um trabalho formal, que observe corretamente a legislação vigente. Muitos Estados exigem autorização legal para ingresso de trabalhadores, associada à qualificação para determinada atividade laboral, como o caso do Brasil. Ainda que o trabalhador migrante consiga uma colocação formal, a sua fragilidade em face de ameaças e práticas discriminatórias é infinitamente superior. A possibilidade de ser vítima de assédio moral, tanto vertical descendente como horizontal, que venha de seus próprios colegas, é muito grande. Nas decisões mais drásticas e nas dispensas, o estrangeiro tende a ser escolhido em primeiro lugar.

Mas as políticas imigratórias dos países centrais também têm outro critério perverso, o da seletividade, que acaba fomentando mais ainda situações discriminatórias. $\mathrm{O}$ fenômeno do brain drain norteia muitas políticas migratórias governamentais dos países mais adiantados, ou daqueles em desenvolvimento acelerado, que necessitam ainda mais de aquisição de tecnologias. A expressão indica, literalmente, uma "drenagem de cérebros" que transforma os países menos desenvolvidos em verdadeiras vítimas. Trabalhadores originários de países periféricos com baixas taxas de desenvolvimento, detentores de um excelente histórico educacional, e altamente qualificados em termos profissionais são atraídos para países mais evoluídos para lá residirem e desenvolverem suas atividades profissionais ou pesquisas. Tal política é um meio rentável de aquisição e detenção de

\footnotetext{
${ }^{677}$ COHEN, Robin. Global diasporas. Seattle: University of Washington Press. 1997. p. 176.
} 
tecnologias. Ao invés de colaborarem com o desenvolvimento de seus países de origem, geralmente carentes em tais aspectos, irão colaborar com o desenvolvimento de países centrais, favorecendo o acúmulo de tecnologia e, assim, o aumento das desigualdades em todo o mundo.

E com o desenvolvimento das tecnologias da informação, a procura por tais cérebros tem aumentado, principalmente em países orientais. $\mathrm{O}$ apetite das indústrias da tecnologia da informação tem sido cada vez mais voraz atrás desses talentos ${ }^{678}$. Investigações da OIT apontam que muitos países em desenvolvimento perdem de cinco até trinta por cento da mão de obra qualificada para os países desenvolvidos ${ }^{679}$, em uma estimativa de 12,9 milhões de imigrantes nessa situação. Inicialmente, eles deixam seus países de origem para uma formação educacional, e depois, dependendo do seu resultado, recebem ofertas e a possibilidade de permanência no seu território e, em alguns casos, até a nacionalidade.

As dificuldades dos trabalhadores migrantes são inúmeras e começam pela procura do primeiro trabalho, principalmente os menos qualificados. Se não há uma contratação previamente ajustada, a incerteza da chegada em novo território é um enorme desafio para o trabalhador migrante. Esse desafio é muito mais potencializado se não existir uma estrutura preparada para recebê-lo. Essa dificuldade acaba encaminhando muitas vezes o imigrante ao sub-emprego ou ao emprego totalmente clandestino, em muitas situações, para atividades laborais ligadas a atividades ilícitas. Jagdish Bhagwati citou a impactante pesquisa feita por Guillermina Jasso and Mark Rosenzweig, no sentido de que, nos EUA, quase $30 \%$ dos novos imigrantes legalmente admitidos tiveram alguma experiência no mundo da ilegalidade ${ }^{680}$.

Apesar de todos os problemas verificados, a migração para trabalho também apresenta um outro aspecto de crucial importância, o impacto econômico global. A análise econômica de tais movimentos apresenta uma nova faceta que revela o interesse de alguns Estados em enviar trabalhadores além de suas fronteiras. De acordo com os dados do

\footnotetext{
${ }^{678}$ BAGHWATI, Jagdish. Borders beyond control. Foreign Affairs. New York, v. 82, n. 1, p. 100, Jan./Feb. 2003.

${ }^{679}$ WICKRAMASEKARA, Piyasiri. Organização internacional do trabalho. Perspectives in labour migration. policy responses to skilled migration: retention, return and circulation. p. 9. Disponível em: $<$ http://www.ilo.org/public/english/protection/migrant/download/pom/pom5e.pdf>>. Acesso em: $16 \mathrm{dez}$. 2009.

${ }^{680}$ BHAGWATI, Jagdish. Illegal immigrants deserve to be treated with decency. The Financial Times, Londres, 25 July 2007.
} 
Banco Mundial referentes ao ano de $2007^{681}$, cerca de 318 bilhões de dólares foram registrados como remessas a países de origem de migrantes. A lista dos países que mais recebem remessas monetárias registradas de migrantes no mundo foram, respectivamente, em bilhões de dólares, Índia (27 bilhões), China (25,7 bilhões), México (25 bilhões), Filipinas (17 bilhões) e França (12,5 bilhões). Os países mais pobres ou não desenvolvidos receberam cerca de 240 bilhões de dólares em remessas no mesmo período (75\% dos valores remetidos). Fica claro que, para certos países, a migração se torna uma forma de captação de divisas. Por outro lado, a emigração, do ponto de vista do Estado de origem, não somente desafoga os problemas sociais existentes dentro do seu território, como também reduz custos públicos.

Os números mundiais atuais impressionam. A entidade International Organization for Migration, uma organização intergovernamental que trata de assuntos relativos à migração, estima que em 2005 havia 191 milhões de migrantes em todo o globo, compreendendo cerca de $3,0 \%$ da população mundial, o que se tornaria a $5^{\mathrm{a}}$ mais populosa nação do mundo. Desse contingente humano, entre 30 e 40 milhões de pessoas são migrantes não autorizados. Setenta e cinco por cento dos migrantes de todo o mundo estão reunidos somente em $12 \%$ dos países do globo. O número de refugiados no mundo é estimado em 11,4 milhões de pessoas ${ }^{682}$. Em outro relatório da referida entidade, disponível no mesmo sítio, os migrantes internacionais totalizavam $2,5 \%$ da população mundial em 1960, notando-se uma tendência cada vez maior de crescimento da população migrante no mundo ${ }^{683}$. Alguns pesquisadores e especialistas em migração internacional, como Demetrios Papademetriou ${ }^{684}$, contrariam esta posição de crescimento ao afirmar que tal acréscimo nos percentuais de migrantes se deu em face do esfacelamento da União Soviética em vários Estados, nos quais 20 milhões de pessoas passaram a ser consideradas imigrantes sem nunca terem mudado de local de moradia. $\mathrm{O}$ autor aponta que tal fato

\footnotetext{
${ }^{681}$ THE WORLD BANK. News and broadcasts. Disponível em: <http://web.worldbank.org/WBSITE/EXTERNAL/NEWS/0, contentMDK:21692926 pagePK:34370 piP K:34424 theSitePK:4607,00.html>. Acesso em: 27 nov. 2008.

${ }^{682}$ INTERNATIONAL ORGANIZATION FOR MIGRATION. Facts and Figures. Disponível em: $<$ http://www.iom.int/jahia/Jahia/about-migration/facts-and-figures/global-estimates-and-trends>. Acesso em: 26 nov. 2008.

${ }^{683}$ INTERNATIONAL ORGANIZATION FOR MIGRATION. International Migration and Data Statistics. Disponível em: <http://www.iom.int/jahia/Jahia/lang/en/cache/offonce/pid/8>. Acesso em: 26 nov. 2008.

${ }^{684}$ ALTO COMISSARIADO PARA A IMIGRAÇÃO E MINORIAS ÉTNICAS. Congresso Imigração em Portugal: Diversidade - Cidadania - Integração.1.Lisboa.2003 - Actas do I Congresso Imigração em Portugal: Diversidade-Cidadania-Integração, [org.] Alto Comissariado para a Imigração e Minorias Étnicas, ISBN 972-98959-9-6, 1-Portugal. P. 22. OBSERVATÓRIO DA IMIGRAÇÃO. Disponível em: $<$ http://www.oi.acidi.gov.pt/modules.php?name=Content\&pa=showpage \&pid=15>. Acesso em: 26 nov. 2008.
} 
alterou substancialmente o critério de avaliação, permanecendo em termos reais atuais o percentual de 2,5\% desde os anos 60. No entanto, os especialistas da OIT estimam que cerca de 500 milhões de pessoas estarão vivendo fora de seus países em 2050, principalmente em face do envelhecimento da força laboral de países industrializados. Estima o referido estudo que a mão de obra estrangeira passe a ser um fator de extrema importância, principalmente para sustentar economicamente os sistemas de seguridade social desses países, segundo a previsão de Patrick A. Taran, principal especialista em migração da OIT $^{685}$. Assim, se afigura mais consistente a afirmação de que a tendência atual é o crescimento das migrações.

Em alguns países, o número de imigrantes existentes dentro de determinado território supera o índice de $10 \%$ da população local, como os exemplos dos Estados Unidos da América, Canadá, Austrália, Nova Zelândia, França, Líbia, Arábia Saudita, Emirados Árabes, Ucrânia, Bielorússia e Suécia ${ }^{686}$.

A migração é uma situação bastante complexa. Se por um lado traz uma série de problemas individuais a um número muito significativo de seres humanos e também a um grupo de países que maciçamente recebem imigrantes, não deixa de ser para outros uma atividade que apresenta aspectos atraentes, vulnerando ainda mais a defesa dos direitos dos migrantes no mundo. O que pode ser notado em alguns casos é a existência de uma complexa rede internacional de migração, composto por Estados de origem, de destino e de trânsito, alguns ocupando as três posições, como o Brasil.

O economista Jagdish Bhagwati aponta três tendências de migração nos tempos mais recentes: 1) migração de trabalhadores altamente qualificados de países periféricos para países centrais; 2) grande número de trabalhadores não qualificados ingressando ilegalmente em países centrais e procurando por trabalho; e 3 ) movimentação involuntária ou forçada de pessoas, qualificadas ou não, em busca de asilo ${ }^{687}$.

Stephen Castles e Mark J. Miller ${ }^{688}$ enunciam as seguintes tendências mundiais sobre uma importante obra sobre a migração global: 1) a globalização da migração, pois ela está se espalhando por mais países do globo; 2) a aceleração da migração, que se

\footnotetext{
${ }^{685}$ TARAN, Patrick A. Migración y solidariedad laboral. Educación Obrera, Genebra, n. 129, p. 31, 2002.

${ }^{686}$ NAÇÕES UNIDAS. UN Population Division: International Migration 2002 (New York, 2002). Disponível em: <http://www.un.org/esa/population/publications/ittmig2002/2002ITTMIGTEXT2211.pdf>. Acesso em: 01 dez. 2008.

${ }^{687}$ BHAGWATI, Jagdish. op. cit., p. 99.

${ }^{688}$ CASTLES, Stephen; MILLER, Mark J. The age of migration. 3. ed. New York: The Gilford Press, 2003. p. 1.
} 
encontra crescente em todas as regiões do mundo; 3) a diversificação da migração, na medida em que ela passa a assumir cada vez mais diferentes formas; 4) a feminilização da migração, na medida em que as mulheres cada vez assumem papel mais importante nos movimentos migratórios; e 5) a crescente politização da migração, quando as relações políticas internas e externas estão sendo cada vez mais afetadas pelos movimentos migratórios.

A humanidade se depara com uma situação crescente de migração para o trabalho, mas cada dia está menos preparada para enfrentar seus resultados catastróficos. A situação da migração não autorizada é uma verdadeira tragédia humana de proporções globais, minando completamente o sistema de proteção de direitos humanos.

\subsection{O desastre da permanência não autorizada}

Muitos Estados desejados como destinos pelos migrantes adotam políticas restritivas para sua recepção e condutas enérgicas contra a permanência irregular em seu território para finalidade de trabalho. É o caso do Brasil, cujo ordenamento prevê que a permanência irregular importa em imediata deportação. Tal posição pode fomentar uma situação gravíssima, que abre as portas para a adoção de práticas de exploração de mão de obra em condições subhumanas, ou até mesmo a exploração de trabalho em condições análogas à de escravo.

A permanência de um imigrante dentro de um território estranho, quando não desejado pelo país receptor e sem autorização de permanência, gera uma situação terrível para o migrante. Essa pessoa passa a viver na total clandestinidade, encontrando-se em situação de tensão constante e sujeita a uma série de violações de direitos humanos. Se for detectado pelas autoridades locais, corre o risco da deportação. Em muitos casos, o tráfico internacional de pessoas acaba promovendo meios de inserir migrantes de outros países para dentro de territórios cuja aceitação é extremamente restrita, em inúmeros casos, colocando em risco a vida dessas pessoas. O sonho de atingir determinados Estados desenvolvidos para tentar a vida, em especial os EUA, tem construído uma rede internacional de tráfico de pessoas que adotam os mais diversos - e muitas vezes perigosos - meios de inserção de migrantes dentro do território desejado. Os famosos "coiotes" atuam no aliciamento e transporte clandestino com o ingresso irregular em determinada fronteira, frequentemente de forma extremamente precária e arriscada. O migrante, 
desejoso de chegar ao território sonhado, muitas vezes aceita esse meio de transporte, adquirindo um "pacote" onde está incluso o transporte, a estadia e a colocação no novo território. No entanto, esse tipo de atividade tem revelado grandes armadilhas aos migrantes e, em muitas delas, o migrante irregular está fadado à mais grave situação de um trabalhador, a exploração desumana de sua capacidade de trabalho.

O tráfico de pessoas é cada vez maior e está superando as resistências dos sistemas de imigração dos Estados receptores. O fluxo de trabalhadores migrantes irregulares vem aumentando gradativamente, pois é uma atividade altamente lucrativa. O tráfico de pessoas é uma atividade ilícita que somente perde, nos dias atuais, em faturamento, para os tráficos de drogas e de armas. Essa atividade é cada vez mais fomentada pela demanda de mão de obra barata, em condições de trabalho muito abaixo do mínimo legal exigido, segundo Patrick A. Taran ${ }^{689}$. Apesar dos esforços de muitos governos para policiar melhor suas fronteiras, com um mundo globalizado e com o incremento do acesso às informações em tempo real, as fronteiras vão sofrendo uma violenta corrosão. Nesse sentido, Jürgen Habermas chama a atenção para os processos globalizantes, os quais estão tornando as fronteiras mais porosas, ao indicar que:

uma incontrolável maré invasora que vem de fora, evoca a vontade política de fechamento das comportas. $O$ afeto protecionista volta-se do mesmo modo contra os traficantes de armas e de drogas que põem em perigo a segurança interna, bem como o transbordamento de informação, o capital estrangeiro, os imigrantes em busca de trabalho e as ondas de fugitivos que supostamente destroem a cultura local e o nível de vida ${ }^{690}$.

Porém, já dentro de um território em condições irregulares, a mais drástica situação resulta no fato de que o trabalhador migrante irregular perde, de fato, sua capacidade jurídica. O imigrante ilegal não pode exercer os mínimos atos de uma vida civil normal. Tal situação viola frontalmente os artigos $6^{\circ}$ e $7^{\circ}$ da Declaração Universal dos Direitos do Homem (direito de ser, em todos os lugares, reconhecido como pessoa perante a Lei) ${ }^{691}$. O

\footnotetext{
${ }^{689}$ TARAN, Patrick A. op. cit., p. 32-33.

${ }^{690}$ HABERMAS, Jürgen. A constelação pós-nacional: ensaios políticos. Trad. Márcio Seligmann Silva. São Paulo: Littera Mundi, 2001. p. 103.

${ }^{691}$ ORGANIZAÇÃO DAS NAÇÕES UNIDAS - Declaração Universal dos Direitos do Homem UNIVERSIDADE DE SÃO PAULO. Biblioteca Virtual de Direitos Humanos. Disponível em: $<$ http://www.direitoshumanos.usp.br/counter/Onu/Sist_glob_trat/texto/texto_1.html>. Acesso em: 28 nov. 2008. - Artigo $6^{\circ}$ : Todo o homem tem o direito de ser, em todos os lugares, reconhecido como pessoa perante a lei. - Artigo $7^{\circ}$ : Todos são iguais perante a lei e têm direito, sem qualquer distinção, a igual proteção da lei. Todos têm direito a igual proteção contra qualquer discriminação que viole a presente Declaração e contra qualquer incitamento a tal discriminação.
} 
Pacto Internacional de Direitos Civis e Políticos e o Pacto Internacional de Direitos Econômicos, Sociais e Culturais, ambos da ONU, instrumentos com força vinculante para os seus signatários, também enunciam que nenhuma pessoa pode ser privada dos direitos ali estabelecidos, inclusive vários deles que permitam uma existência digna. Porém, a entrada irregular acaba por propiciar exatamente o contrário.

$\mathrm{O}$ imigrante ilegal passa a ser tratado sem o necessário respeito à sua dignidade como pessoa humana, pois se encontra despojado dos direitos mais básicos. Hannah Arendt menciona a importância do que qualificou como uma "calamidade", ao citar a situação dos apátridas e apontar que a privação fundamental dos direitos humanos manifesta-se, na privação do direito à ação, bem como no direito a pertencer a uma comunidade organizada, para que possa perceber a existência de um direito a ter direitos $^{692}$. Sem essa possibilidade, toda a natureza humana do migrante está gravemente comprometida. Um exemplo da assertiva é demonstrado na perda do direito de reivindicar direitos trabalhistas perante um juízo ou tribunal. Tão logo o faça, as autoridades de imigração do território onde ele se encontra providenciarão sua saída imediata, o que inviabiliza seu direito de ação.

É importante destacar a decisão do célebre caso Trop. Vs. Dulles ${ }^{693}$, julgado pela Suprema Corte dos Estados Unidos da América em 1958. O referido processo discutiu a constitucionalidade de uma lei norte-americana que estabelecia a privação da cidadania norte-americana por motivos de deserção militar. Um dos argumentos utilizados pelo Juiz Warren, em seu voto, ao negar a constitucionalidade da lei desafiada, foi no sentido de que a retirada da cidadania não poderia ser uma sanção aceitável, por mais reprovável que seja a conduta do cidadão, por se tratar de um direito fundamental. A retirada da cidadania, segundo o voto condutor, extrapola os limites constitucionais porque incorre na total destruição do status de um indivíduo em uma sociedade organizada. É uma forma de punição mais primitiva que a tortura, ao destruir a existência política consolidada em séculos de desenvolvimento, despojando a pessoa de seu status na comunidade política nacional e internacional, e perdendo o direito a ter direitos, o que não seria permitido pela oitava emenda da Constituição dos Estados Unidos da América. E o referido voto aponta

\footnotetext{
${ }^{692}$ ARENDT, Hannah. As origens do totalitarismo. Trad. Roberto Raposo. São Paulo: Cia. Das Letras, 1989. p. 330.

${ }^{693}$ Trop v. Dulles, 356 U.S. 86 (1958) (USSC). Cornell University Law School. Legal Information Institute. disponível em: <http://www.law.cornell.edu/supct/html/historics/USSC_CR_0356_0086_ZS.html,>. Acesso em: 30 dez. 2009.
} 
que a supressão da nacionalidade e da capacidade de direitos ofende a dignidade da pessoa humana.

A punição recebida por um imigrante irregular guarda semelhanças com a lei discutida no referido caso, uma gravíssima situação que o atinge desproporcionalmente. Tudo o que for realizar e que dependa de atos formais, corre riscos de ser detectado pelas autoridades de imigração ao se identificar. A maioria dos ordenamentos dos Estados que adotam políticas restritivas à imigração determinam a deportação em tais casos, incluindo o Brasil ${ }^{694}$, também um centro de recepção de imigrantes em âmbito regional. Em alguns Estados, o ingresso irregular é considerado crime pelas leis locais, passível de sanções penais.

Não possui o migrante qualquer direito político ou social nesta situação de clandestinidade $^{695}$, não pode se expressar politicamente e não tem qualquer direito de representação social formal, muito menos política. Sente-se inibido a tomar qualquer atitude na defesa de seus direitos ou no respeito como pessoa humana, pois ainda que lhe seja favorável a pretensão, certamente será denunciado às autoridades de imigração. Não pode demonstrar livremente seus valores culturais e religiosos, pois estaria sujeito a perseguição dos próprios habitantes locais, com risco de chegar ao conhecimento das autoridades. Não pode, também, receber assistência médica e social regular em muitos casos, senão aquela mais elementar e preparatória para o ato de deportação e retorno ao país de origem, quando não correr risco de sofrer uma pena restritiva de liberdade. $O$ tenebroso cenário para atitudes discriminatórias está montado para que a capacidade de trabalho desse migrante esteja sujeito a toda a sorte de explorações.

\footnotetext{
${ }^{694}$ BRASIL. Lei 6.815/80: Art. 57. Nos casos de entrada ou estada irregular de estrangeiro, se este não se retirar voluntariamente do território nacional no prazo fixado em Regulamento, será promovida sua deportação. (Renumerado pela Lei $n^{\circ}$ 6.964, de 09/12/81). \$ $1^{\circ}$ Será igualmente deportado o estrangeiro que infringir o disposto nos artigos $21, \S 2^{\circ}, 24,37, \S 2^{\circ}, 98$ a 101, $\$ \S 1^{\circ}$ ou $2^{\circ}$ do artigo 104 ou artigo 105. (Renumerado pela Lei $n^{\circ}$ 6.964, de 09/12/81). \$ $2^{\circ}$ Desde que conveniente aos interesses nacionais, a deportação far-se-á independentemente da fixação do prazo de que trata o caput deste artigo. Art. 58. A deportação consistirá na saída compulsória do estrangeiro. (Renumerado pela Lei $\mathrm{n}^{\circ}$ 6.964, de 09/12/81). Parágrafo único. A deportação far-se-á para o país da nacionalidade ou de procedência do estrangeiro, ou para outro que consinta em recebê-lo.

${ }^{695}$ SAYAD, A. O retorno. Revista Travessia, 2000 - in A MOBILIDADE DE TRABALHADORES DO E PARA O JAPÃO. ESTUDO DE CASO DE LONDRINA, PR - BRASIL. Lirian Melchior - Scripta Nova. Revista Electrónica de Geografía y Ciencias Sociales. Universidad de Barcelona [ISSN 1138-9788] No 94 (54), 1 de agosto de 2001. Disponível em: <http://www.ub.edu/geocrit/sn-94-54.htm>. Acesso em: 27 dez. 2008. Os imigrantes por serem considerados apenas portadores da força de trabalho para o capital, são revestidos de uma neutralidade política perdendo o direito de exercer sua cidadania em qualquer lugar onde estejam. Isto ocorre porque as pessoas, enquanto seres sociais, quando rompem com seu grupo, com os seus pares, assumem um caráter individualista, e no outro país não são consideradas como parte legítima da sociedade, e só recuperam sua identidade política quando retornam ao seu país.
} 
O trabalhador migrante irá procurar uma atividade remunerada para subsistir, mas não pode ser admitido formalmente em um emprego regular. Em vários países, o emprego de trabalhadores clandestinos incorre em severas sanções aos empregadores, desde administrativas, pecuniárias e até criminais. Mas em muitos, não há esta caracterização, ou quando há, os sistemas internos de repressão são demasiadamente brandos com o empregador inescrupuloso. Somente lhes restará o ramo informal da economia, sujeitandose, em alguns casos, às mais cruéis situações de exploração humana. Infelizmente não é incomum a redução do trabalhador migrante à condução análoga de escravo, ou completo desrespeito aos direitos trabalhistas mais elementares como proteção contra jornadas excessivas e acidentes de trabalho. É um fenômeno que ocorre no Brasil, no centro da Cidade de São Paulo, com muitos trabalhadores bolivianos e paraguaios. Esses migrantes irregulares se encontram completamente desamparados, já que não poderão oferecer qualquer queixa ou ajuizar qualquer remédio jurisdicional para a reparação de direitos trabalhistas violados, pelos riscos mencionados.

Os empregadores inescrupulosos que atuam na informalidade se aproveitam dessa situação de extrema inferioridade jurídica do imigrante irregular. Em muitos casos, o empregador é alguém ligado à mesma origem nacional, religiosa ou étnica e já vivenciou esse drama. Ao contratar tais pessoas, obtém inegável redução de custos, causando um grande desequilíbrio no mercado que atua e alcança uma viabilidade econômica de seu negócio, que seria inexistente caso praticasse os salários e encargos regularmente previstos na legislação local. O especialista Patrick A. Taran, da Organização Internacional do Trabalho, revela que muitos Estados que reprimem o ingresso de imigrantes ilegais acabam por tolerar cada vez mais o trabalho em situação irregular, que é extremamente atrativo para sua economia ${ }^{696}$. Nesse sentido, o referido autor lembra que, no ano de 2000, o Serviço de Imigração e Naturalização dos EUA (INS) suspendeu silenciosamente suas incursões repressivas, salvo na fronteira mexicana, na medida em que o país não poderia ter inflação pressionada por aumentos salariais e a melhor maneira de reter tais aumentos seria através do uso de mão de obra estrangeira irregular, que impulsiona a diminuição dos patamares salariais dos nacionais, no mercado de trabalho interno ${ }^{697}$.

Em Estados nos quais a repressão ao trabalho irregular é branda ou ineficiente, o empregador irregular se aproveita da situação, causando desequilíbrio econômico contra

\footnotetext{
${ }^{696}$ TARAN, Patrick A. op. cit., p. 29.
}

${ }^{697}$ Id. Ibid., p. 32. 
seus concorrentes. Em alguns casos, para não pagar sequer a contraprestação mínima pelo trabalho executado e terminado, os próprios empregadores acabam denunciando os migrantes irregulares, que são imediatamente deportados, para eliminarem os custos de uma recisão contratual ou mesmo o pagamento de salários. Em outras situações, os próprios empregadores criam o estado de terror sobre os migrantes, ameaçando-os de delação às autoridades, obtendo, assim, maior domínio sobre os migrantes explorados.

Diante da clandestinidade, o trabalho informal somente pode ser buscado na economia não formalizada. Ou seja, o país anfitrião, ao proibir a obtenção de oportunidades de trabalho para os trabalhadores migrantes, provoca a sua exclusão social. O migrante excluído, sem outras opções, acaba não encontrando outra alternativa senão atuar no mercado informal, algumas vezes relacionado com alguma atividade ilícita. Ao assim proceder, sua imagem fica mais agregada à criminalidade e ao mundo da informalidade, instigando ainda mais a hostilidade dos nacionais contra os migrantes, em um perigosíssimo círculo vicioso. O referido círculo faz explodir a xenofobia e a postura discriminatória da sociedade receptora floresce rapidamente, muitas vezes com atitudes agressivas e atentatórias da segurança física dos migrantes.

Como bem mencionam Chris Nwachukwu Okeke e James A.R. Nafziger ${ }^{698}$, além de os migrantes serem recebidos com hostilidade e rejeição, podem ser tratados como bodes expiatórios para os desacertos da sociedade receptora, estando sujeitos a atitudes discriminatórias e violentas. Do mesmo modo, sua situação de precariedade fica mais acentuada quando o desemprego atinge o Estado receptor. Havendo aumento das taxas de desemprego, a população local tenderá a ser mais restritiva contra os migrantes. Quando tais atitudes não partem da população, podem partir dos governos, desesperados com o fenômeno ou, em busca de atitudes com finalidade eleitoral, promovem políticas atentatórias contra os direitos fundamentais. Como exemplo, pode ser citada a famosa proposta legislativa do Governador Pete Wilson do Estado norte-americano da Califórnia, conhecida como proposta 187, pela qual seriam cortados diversos atendimentos sociais para imigrantes ilegais ${ }^{699}$. A referida proposta legislativa foi aprovada em ambas as casas legislativas daquele Estado norte-americano, porém foi suspensa sua aplicação diante de uma ordem judicial. Por outro lado, algumas medidas são pouco efetivas, mas

\footnotetext{
${ }^{698}$ OKEKE, Chris Nwachukwu; NAFZIGER, James A.R. United States migration law: essentials for comparison. The American Journal of Comparative Law. Ann Arbor, v. 54 (supplement), p. 532, 2006.

${ }^{699}$ ESPÓSITO, Carlos. The European Union response towards Racism. Revue des Affaires Européennes, Paris, n. 1-2, p. 125, avr. 2000.
} 
extremamente impactantes em termos simbólicos, como levantar grandes muros. Eles são mais que paredes basicamente erigidas para impedir o ingresso da pobreza e dos excluídos, são símbolos físicos agressivos da exclusão. Tais construções, caras e pouco eficazes, acabam estigmatizando ainda mais os migrantes dentro do território receptor.

Assim, é possível verificar com facilidade que o sistema de punições severas para os migrantes irregulares tem faces opostas. Por um lado, pode desestimular muitos deles a não procurar adentrar um território, mas, por outro, incentivam a criação de uma situação catastrófica para aqueles que desafiam violar suas imposições, ou mesmo aqueles que são vítimas do tráfico internacional de pessoas. As situações a que são submetidas muitos migrantes compõem um verdadeiro desastre da humanidade e pedem uma proteção jurídica adequada e eficaz.

A associação entre a exclusão, discriminação e exploração se faz mais presente no caso dos trabalhadores irregulares. A Conferência Mundial Contra o Racismo e a Xenofobia de Durban, realizada em 2001, incluiu na sua Declaração e Programa de Ação nada menos que 40 parágrafos sobre o trato dos trabalhadores migrantes, refugiados e outros não nacionais. A mencionada declaração concluiu que a união da discriminação racial e xenofobia está umbilicalmente associada ao trabalho do migrante. O referido documento assinala ainda que não são proporcionadas condições mínimas de trabalho e há falta de aplicação da legislação trabalhista do Estado receptor tal qual se faz para os nacionais, mesmo para os irregulares, segundo o interessante registro de J.A. Lindgren Alves $^{700}$. Isso porque os trabalhadores migrantes irregulares não têm outra opção senão procurar o caminho da exploração nos países em que escolheram viver, inclusive, em muitos casos, com a compreensão, por parte do trabalhador, como "um mal necessário". Para ser coibida a violência aos direitos humanos dos imigrantes irregulares, seria necessário um equacionamento da limitação do direito de cada Estado estabelecer políticas restritivas à migração, para que estas não venham, direta ou indiretamente, violar direitos humanos.

Tratados ou convenções internacionais atuais já apresentam medidas protetivas e garantias mínimas dos imigrantes, ainda que irregulares. Contudo, pouca tem sido a adesão dos Estados de um modo geral a tais convenções, principalmente os tradicionalmente considerados receptores de imigrantes, que vislumbram nesses tratados uma limitação de sua soberania, como um grande risco para seus interesses.

${ }^{700}$ ALVES, J. A. Lindgren. op. cit., op. cit., p. 215. 


\subsection{Proteção internacional do trabalhador migrante}

Não é recente a preocupação do direito internacional com a condição dos trabalhadores migrantes. Vários são os esforços internacionais para resolver, ou pelo menos atenuar, o sofrimento de estrangeiros trabalhando em outros países. No entanto, tais esforços contam com pouco apoio dos governos, entre eles, lamentavelmente, o Brasil. Alguns tratados internacionais, entretanto, têm procurado dar apoio aos trabalhadores migrantes, sendo importante analisar, ainda que sucintamente, os mais importantes.

\subsubsection{A Convenção $n^{\circ} 97$ da OIT}

O primeiro documento internacional que trata o tema é a Convenção $n^{\circ} 97$ da OIT, inicialmente aprovada em 1939, pela $26^{\text {a }}$ sessão da Conferência da entidade. Ela foi revisada em 1949, na sua $32^{\mathrm{a}}$ sessão, após várias propostas nesse sentido e, assim, aprovada como "Convenção no 97 (revisada)". Ela entrou em vigor em 22.01.1952, já na atmosfera de pós-guerra e dentro do panorama de novos diplomas internacionais sobre direitos humanos, em especial após a Declaração Universal dos Direitos do Homem de 1948. O Brasil ratificou a mencionada Convenção em 18.06.1965, estando em plena vigência em nosso território.

A definição de trabalhador migrante advém do artigo 11 da referida convenção, assim considerado aquele que emigra de um país para outro com vista a ocupar um emprego que não seja por conta própria, incluindo-se todas as pessoas recebidas como trabalhador migrante. Estão excluídos de sua proteção os trabalhadores fronteiriços, os que ingressarem por curto período exercendo uma profissão liberal, artistas e trabalhadores marítimos. A mencionada Convenção dispõe que os Estados que a ratificarem deverão manter um serviço gratuito apropriado para ajudar os trabalhadores migrantes; atuar contra propaganda enganosa relativa à emigração ou imigração; na medida do possível facilitar a partida, viagem e acolhimento de trabalhadores migrantes; assegurar condições de saúde e proteção para os familiares, entre outros direitos.

$\mathrm{O}$ artigo $6^{\circ}$ visa proteger os trabalhadores migrantes de discriminações por vários fatores, devendo entender-se este rol como exemplificativo e compreendido em uma situação de discriminação por motivos mistos. É uma providência necessária, mas ainda tímida, eis que, de fato, possuem uma abrangência restrita e não atingem os casos de subemprego ou trabalho informal. Também a referida Convenção aponta, em seu artigo $8^{\circ}$, 
que os trabalhadores migrantes admitidos em título permanente não podem ser enviados de volta ao país de origem, salvo em situações específicas. O artigo $9^{\circ}$ trata da remessa e recepção de divisas do exterior, permitindo sua regulação pela legislação local, que definirá os limites para o exercício desse direito implicitamente reconhecido. A convenção ainda possui dois anexos que tratam do recrutamento de trabalhadores, bem como a migração coletiva acordada e controlada pelos governos. Os anexos definem o que é recrutamento, introdução em determinado território e colocação.

Trata-se de uma norma muito bem construída para atuar em situações de trabalho formal. No entanto, a prática revela que a referida norma se torna branda em face da carência de instrumentos para sua efetivação, principalmente nas situações de contratos precários ou informais.

\subsubsection{A Convenção $n^{\circ} 118$ da OIT}

A segunda norma elaborada pela OIT é a Convenção 118, destinada ao tratamento de trabalhadores migrantes, que aborda a igualdade de tratamento dos nacionais e não nacionais em matéria de Previdência Social. Ela foi adotada na 46 ${ }^{a}$ Sessão da Conferência em Genebra, em 1962. No Brasil, essa norma foi aprovada pelo Decreto Legislativo n. ${ }^{\circ}$ 31, de 20 de agosto de 1968.

A Convenção trata das prestações previdenciárias concedidas por determinado Estado, com a finalidade de prestar igual tratamento previdenciário aos trabalhadores migrantes, para concessão de diversas prestações previdenciárias, e que ficam a critério do Estado definir ao ratificar o tratado. As prestações previstas na referida Convenção são, basicamente, as mesmas previstas no sistema de Seguridade Social brasileiro atual. A norma convencional prevê uma série de regras de transitoriedade, carências e a adequação dos sistemas internos para proteção dos trabalhadores migrantes. Não deixa de ser um importante instrumento, mas é necessário que o trabalhador migrante esteja em atividade mediante um contrato formal de trabalho. 


\subsubsection{A Convenção n ${ }^{0} 143$ da OIT}

O terceiro instrumento normativo aprovado pela OIT que trata do trabalhador migrante é a Convenção $n^{\circ} 143^{701}$, aprovada na $60^{\text {a }}$ Sessão, em 24.06.1975, entrando em vigor na ordem internacional em 09.12.1978, mas que ainda não foi ratificada pelo Brasil. O Ministério do Trabalho, através da sua Comissão Tripartite de Relações Internacionais aprovou um novo encaminhamento da Convenção para aprovação e ratificação pelo Congresso Nacional, ainda em tramitação. Em 14.12.1989, o Congresso Nacional, através do Decreto Legislativo $n^{\circ} 86 / 89$, rejeitou a ratificação da supracitada Convenção ${ }^{702}$.

A Convenção é extremamente importante para a defesa dos trabalhadores migrantes em territórios estrangeiros. Uma de suas considerações afirma dois aspectos importantes da Declaração de Filadélfia: o primeiro no sentido de que o trabalho não é mercadoria e que a pobreza, onde quer que exista, constitui uma ameaça à prosperidade coletiva. A segunda consideração importante reside na declaração de que é obrigação da OIT apoiar a realização de programas capazes de levar ao pleno emprego, especialmente em face de meios adequados à facilitação das transferências de trabalhadores, incluindo as migrações de mão de obra.

As considerações da referida Convenção possuem fundamento no programa mundial do emprego da OIT, bem como a necessidade de evitar o aumento excessivo, não controlado ou não assistido, dos movimentos migratórios, em virtude de suas consequências negativas do ponto de vista social e humano. Um aspecto importantíssimo é o reconhecimento da existência de um direito humano de sair de um país e se estabelecer em outro.

A preocupação da Convenção está voltada para movimentos migratórios não assistidos por entidades governamentais, bem como a existência de tráficos ilícitos ou clandestinos de mão de obra, ao entender como conveniente novas medidas contra tais práticas. Fica claro, comparando-se com a Convenção $n^{\circ} 97$, que a entidade debruçou especial atenção sobre os movimentos migratórios clandestinos.

\footnotetext{
${ }^{701}$ ORGANIZAÇÃO INTERNACIONAL DO TRABALHO. Convenção no 143 , de 24.06.1975. Biblioteca Virtual de Direitos Humanos da USP. Disponível em: <http://www.direitoshumanos.usp.br/index.php/OITOrganização-Internacional-do-Trabalho/convencao-no-143-da-oit-relativo-as-migracoes-em-condicoesabusivas-e-a-promocao-da-igualdade-de-oportunidades-e-de-tratamento-dos-trabalhadoresmigrantes.html>. Acesso em: 07 dez. 2009.

${ }^{702}$ DEPARTAMENTO INTERSINDICAL DE ASSESSORIA PARLAMENTAR - DIAP. Disponível em: <http://diap.ps5.com.br/file/1416.pdf>. Acesso em: 27 nov. 2008.
} 
A norma em questão trata, inicialmente, das migrações em condições abusivas. Ela considera que é dever de todos os membros o respeito aos direitos fundamentais do homem de todos os trabalhadores migrantes, como um ponto fundamental. $\mathrm{O}$ artigo $2^{\circ}$ afirma que os países signatários devem assumir o compromisso de detectar, sistematicamente, a existência de migrantes ilegalmente empregados no seu território, em trânsito do seu território para outro, ou em condições contrárias aos instrumentos e acordos internacionais aplicáveis. Os Estados signatários ainda se comprometem a tomar as medidas necessárias para suprimir as migrações clandestinas, atuar contra os organizadores de movimentos ilícitos ou clandestinos de migrantes, provenientes de seu território ou que a eles se destinam, bem como passagem de trânsito e, ainda, sancionar empregadores que contratem trabalhadores em condições ilegais. Deverão também os Estados signatários promover a troca de informações com outros Estados para combate do tráfico de trabalhadores, bem como consultar as entidades de empregados e empregadores para tal finalidade. Os autores de tráfico de mão de obra clandestina deverão ser processados onde for possível, segundo o texto convencionado.

Um aspecto muito importante dessa convenção encontra-se assinalado no artigo $6^{\circ}$, no qual deverão ser tomadas medidas para detecção eficaz de emprego ilegal de trabalhadores migrantes e aplicação de diversas sanções, inclusive civis e penais, cabendo ao empregador processado o direito de provar que agiu de boa fé. A norma repete disposição da Convenção $n^{\circ} 97$ sobre a possibilidade de não ser deportado, diante do fato de ter residido legalmente em determinado país com fim de emprego. Afirma a mencionada norma que não poderá ser considerado irregular e suspensa sua autorização caso venha a perder o emprego, possuindo chance como qualquer nacional de procurar outro emprego. Trata-se de um aspecto extremamente importante em termo da igualdade de oportunidades, que fragiliza, demasiadamente, a situação do trabalhador migrante.

Também o texto convencionado aponta que o trabalhador migrante, cuja relação não respeitar a legislação, e cuja situação não possa ser regularizada, deve usufruir dos mesmos benefícios dos nacionais referentes a empregos anteriores, em relação à remuneração, à segurança social e outras vantagens. Por outro lado, a Convenção aponta, em seu artigo $9^{\circ}$, que nenhuma disposição do texto convencionado impedirá que os Estados que a aderirem possam conceder às pessoas que residem ou trabalhem ilegalmente no país o direito de nele permanecer ou serem empregadas. Ou seja, a norma convencional não 
impede que o Estado receptor, de algum modo, isente o trabalhador migrante de qualquer punição e permita a manutenção, mesmo em caso de trabalho ilegal.

$\mathrm{O}$ artigo $10^{\circ}$ é crucial no combate à discriminação dos trabalhadores migrantes, uma vez que trata das políticas a serem adotadas pelos Estados que aderirem ao texto. Ela estipula o dever de promover a igualdade de oportunidades em matéria de emprego e profissão, assegurar a segurança social, o respeito aos direitos sindicais e culturais, bem como assegurar liberdades individuais e coletivas para aqueles que se encontram legalmente nos seus territórios na qualidade de imigrantes ou de familiares.

$\mathrm{O}$ artigo $11^{\circ}$ refere-se à definição do trabalhador migrante como sendo aquele que emigra ou emigrou de um país para outro com o fim de ocupar um emprego que não seja por conta própria e compreende todo e qualquer indivíduo regularmente admitido como trabalhador migrante. A referida norma exclui, com um rol mais extenso que o previsto na Convenção $\mathrm{n}^{\circ}$ 97, os casos de trabalhadores fronteiriços, artistas e os indivíduos que exerçam uma profissão liberal por curto período, trabalhadores marítimos, migrantes com perspectivas de formação ou de educação, empregados por organizações e empresas por período determinado. Nesse sentido, a norma aponta a proteção diferenciada daqueles que migram com contrato de trabalho ajustado, e daqueles sem contratação prévia acertada, deixando claro que os últimos merecem proteção mais intensa que os primeiros, reconhecendo explicitamente sua situação de desvantagem.

O artigo 12 aponta que o Estado participante da Convenção terá determinadas obrigações como o diálogo social com as entidades de empregados e empregadores para dar cumprimento às medidas de igualdade de oportunidades, promover programas de educação, amplo conhecimento da política adotada, conhecimento dos direitos e obrigações dos migrantes e iniciativas para uma assistência efetiva. Deverá o Estado signatário revogar as disposições legais em sentido contrário e aplicar uma política social para que os trabalhadores migrantes possam se beneficiar das mesmas vantagens que os trabalhadores nacionais, reconhecendo necessidades especiais que possam ter, até que a sua adaptação à sociedade seja uma realidade, sem lesar o princípio da igualdade de oportunidades e de tratamento. Deverá o Estado receptor, ainda, tomar medidas no sentido de os trabalhadores migrantes e suas famílias preservarem suas identidades nacionais e étnicas, assim como os laços culturais, possibilitando as crianças com o ensino de sua língua materna, um dado fundamental. Por fim, a norma impinge ao Estado aderente a garantia da igualdade de tratamento em matéria de condições de trabalho entre todos os 
trabalhadores migrantes que exerçam a mesma atividade, sejam quais forem as condições específicas dos respectivos empregos.

\subsubsection{A Convenção no 157 da OIT}

A Convenção $n^{\circ} 157$ foi adotada na $66^{\mathrm{a}}$ Sessão da Conferência da entidade, em 21.06.1982, e complementa a Convenção 118 ao abordar a igualdade de tratamento para efeitos de seguridade social e sobre a preservação de direitos em curso de aquisição e dos direitos adquiridos para efeito da seguridade social. Tal diploma também trata da situação dos refugiados e apátridas, membros de família e sobreviventes.

Este diploma não foi ratificado pelo Brasil, tendo-o sido apenas por quatro Estados até a presente data ${ }^{703}$.

\subsubsection{A Convenção sobre Direitos dos Trabalhadores Migrantes e de suas Famílias da Organização das Nações Unidas}

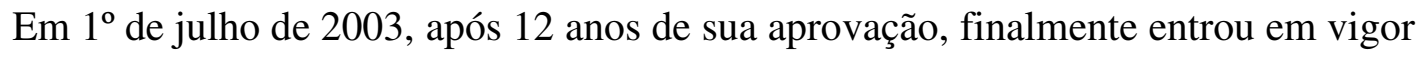
a Convenção Internacional de Proteção de Todos os Trabalhadores Migrantes e os Membros de suas famílias, da Organização das Nações Unidas, uma vez que a Guatemala ratificou o tratado e conferiu o número mínimo necessário para que o diploma entrasse em vigência (vinte ratificantes). A convenção é um ambicioso tratado que pretende ser um poderoso instrumento de prevenção e eliminação da exploração de trabalhadores migrantes e de suas famílias, em todas as fases do processo migratório. A Convenção, atualmente, tem 30 signatários e 39 partes, segundo os registros da Organização das Nações Unidas ${ }^{704}$. É um número reduzido de adesões $(20,31 \%)$ dentro da comunidade das Nações Unidas, atualmente com 192 Estados participantes, demonstrando o desinteresse de muitos Estados, principalmente os centrais, na ratificação da Convenção.

Essa Convenção foi adotada pela Assembleia Geral daquela entidade em 18 de dezembro de 1990, com base na Declaração Universal dos Direitos do Homem, no Pacto de Direitos Políticos e Civis e o Pacto de Direitos Econômicos, Sociais e Culturais de

\footnotetext{
${ }^{703}$ ORGANIZAÇÃO INTERNACIONAL DO TRABALHO. Ilolex. Disponível em: <http://www.ilo.org/ilolex/spanish/newratframeS.htm>. Acesso em: 26 nov. 2008.

${ }^{704}$ ORGANIZAÇÃO DAS NAÇÕES UNIDAS. United Nations Treaty Collection. Disponível em:<http://treaties.un.org/Pages/ViewDetails.aspx?src=TREATY\&id=137\&chapter=4\&lang=en $>$. Acesso em: 26 nov. 2008.
} 
1966. Também procurou ela observar as convenções de eliminação de todas as formas de discriminação racial, contra as mulheres e contra as crianças, além de basear-se, em grande parte, nas Convenções 97, 143 e 151 da OIT, entre outras, bem como em vários princípios firmados pelas Nações Unidas contra tratamentos desumanos ou ofensivos à dignidade humana.

O referido diploma procura atacar os recrutamentos ilegais e clandestinos, desencorajar empregadores a admitirem imigrantes em situação irregular e estabelecer uma série de padrões e tratamentos necessários para o bem-estar e a preservação de direitos humanos de migrantes regulares ou irregulares, bem como de suas famílias, além de obrigações por parte de Estados que enviem ou recebam migrantes. A preservação dos direitos humanos dos migrantes e suas famílias é o principal objetivo do tratado, tanto para imigrantes autorizados a ingressar em determinado país, como não autorizados. A convenção também pretende reconhecer várias qualidades de migrantes, como aqueles que trabalham em fronteiras, aqueles que residem em estados vizinhos, trabalhadores sazonais, empregados marítimos, em estruturas marítimas, trabalhadores itinerantes, migrantes para trabalhos específicos e trabalhadores independentes.

São várias as obrigações impostas aos Estados aderentes para promover condições mais humanas no trato da migração internacional de trabalhadores e os membros de suas famílias. Este é um aspecto fundamental e diferenciador em relação às Convenções da OIT, uma vez que prevê vários direitos dos trabalhadores, bem como de suas famílias. A mencionada ampliação é um aspecto crucial na defesa dos direitos ali previstos, posto que a extensão da proteção vai além do trabalhador para dentro da esfera familiar, principalmente ao observar o direito à reunião familiar, bem como além das fronteiras do Estado de aplicação.

No entanto, o maior foco do texto convencionado é dado ao combate e a eliminação da discriminação contra os trabalhadores migrantes e suas famílias. Do mesmo modo, a norma dedica especial atenção às violações de direitos humanos que constantemente afligem os trabalhadores migrantes e suas famílias pelo mundo afora, um aspecto intensamente abordado. $\mathrm{O}$ outro ponto que a norma deixa muito claro é o combate aos problemas experimentados pelos trabalhadores que são contratados em condição irregular. Ela se preocupa com o estabelecimento de um patamar mínimo de direitos que devem ser observados pelos Estados ratificantes, como forma de desestimular o uso de mão de obra contratada irregularmente. 
A norma é bastante extensa, muito detalhada, e possui muitas definições. No seu artigo $2^{\circ}$, a norma se preocupa em definir trabalhador migrante como aquele que vai exercer, exerce ou exerceu uma atividade remunerada em determinado Estado no qual não é nacional. No mesmo artigo, traz uma série de especificações de trabalhadores migrantes especiais, caracterizando expressamente as situações do trabalhador fronteiriço, trabalhador sazonal, marítimo, trabalhador numa estrutura marítima, trabalhador itinerante, trabalhador vinculado a um projeto, trabalhador com emprego específico e trabalhador independente.

$\mathrm{O}$ artigo $3^{\circ}$ também tem uma preocupação muito detalhada em afirmar os casos em que a norma não é aplicável. O artigo $4^{\circ}$ define os membros da família do trabalhador migrante. $\mathrm{O}$ artigo $5^{\circ}$ define a condição de trabalhadores documentados e não documentados ou irregulares, bem como o artigo $6^{\circ}$ define as expressões "Estado de origem", "Estado de emprego" e "Estado de trânsito", uma condição muito peculiar dos atuais movimentos migratórios.

A parte II do Tratado, no artigo $7^{\circ}$, trata da proibição de discriminação dos trabalhadores migrantes dentro dos territórios dos Estados signatários. A parte III, do artigo $8^{\circ}$ ao artigo 35 , possui uma extensa e detalhada relação dos direitos humanos dos trabalhadores migrantes e membros de suas famílias, que deverão ser observados pelos Estados participantes. A parte IV, do artigo 36 ao 56, trata de outros direitos dos trabalhadores migrantes e suas famílias. A partir do artigo 57, até o artigo 63, na parte V, a referida norma passa a tratar das disposições aplicáveis às categorias especiais de trabalhadores e suas famílias e, na parte VI, aborda a promoção de condições saudáveis, equitativas, dignas e justas em matéria de migração internacional de trabalhadores migrantes e suas famílias, estabelecendo uma série de obrigações aos Estados participantes. Ao final, nas partes VII e VIII, o texto convencionado trata da aplicação da convenção e dos seus mecanismos de efetivação, bem como as disposições gerais e finais, totalizando, ao final, 93 detalhados artigos.

O artigo 10 da Convenção dos Trabalhadores Migrantes e suas Famílias afirma claramente que nem os trabalhadores nem suas famílias podem estar sujeitos a torturas, bem como a tratamentos e punições cruéis, desumanos ou degradantes. Os artigos 11 e seguintes apontam também proteção contra a escravidão, trabalhos forçados, liberdade de expressão e pensamento, religião, privacidade de correspondência, propriedade e segurança das pessoas, entre outros direitos. 
Dentro da esfera trabalhista, a própria Convenção dos Trabalhadores Migrantes e suas Famílias estabelece, em seu artigo 26, um tratamento equânime entre o migrante trabalhador e o residente local, para livre atuação sindical. Igualmente, é aplicável para direitos da Seguridade Social, conforme o artigo 27 da mencionada Convenção.

Verifica-se que a Convenção é um instrumento importantíssimo na defesa dos direitos humanos dos migrantes em território estrangeiro. No entanto, em face da grande interferência e contrariedade que ela impõe às políticas de imigração de vários Estados, principalmente os centrais e receptores de migrantes, constata-se um baixíssimo número de adesões à Convenção. Vários países latino-americanos aderiram às suas disposições, inclusive todos os integrantes do Mercosul, com exceção do Brasil. Há uma intensa discussão a respeito em nosso país, inclusive com o fomento da ratificação pela Secretaria Nacional de Direitos Humanos, cujo secretário Paulo Vanucchi está empenhado na sua aprovação, ainda que tema resistências dentro do Congresso Nacional ${ }^{705}$.

O ponto mais positivo desta Convenção é, sem dúvida, a preocupação e a determinação em favor de situações atuais envolvendo trabalhadores migrantes e, principalmente, suas famílias. Ela estipula uma série de direitos para os últimos, e uma série de obrigações para os Estados participantes, principalmente nos casos de trabalhadores com permanência irregular. Resta aguardar uma maior conscientização mundial do problema, para que os Estados centrais, principalmente aqueles que têm maior vocação para recepção de trabalhadores migrantes, incluam nas suas agendas políticas a ratificação deste importante instrumento de defesa dos trabalhadores migrantes em todo o mundo.

\subsubsection{Declaração Sócio Laboral do Mercosul}

Em 10 de dezembro de 1998, os chefes de Estado dos quatro Estados integrantes da Comunidade do Mercado Comum do Sul, conhecida como Mercosul, assinaram uma declaração pela qual constituíram os princípios e os direitos laborais reconhecidos na referida comunidade internacional para a efetivação da integração regional. Entre elas, o $\operatorname{artigo} 4^{\circ}$ da referida norma estipula que:

\footnotetext{
${ }^{705}$ REPÓRTER DA AGÊNCIA BRASIL. 18 de março de 2008. Disponível em: <http://www.agenciabrasil.gov.br/noticias/2008/03/18/materia.2008-03-18.0853368466/view>, Acesso em: 27 nov. 2008.
} 
ARTIGO $4^{o}$ - Trabalhadores Migrantes e Fronteiriços

1.- Todo trabalhador migrante, independentemente de sua nacionalidade, tem direito à ajuda, informação, proteção e igualdade de direitos e condições de trabalho reconhecidos aos nacionais do país em que estiver exercendo suas atividades, em conformidade com a legislação profissional de cada país.

2. - Os Estados Partes comprometem-se a adotar medidas tendentes ao estabelecimento de normas e procedimentos comuns relativos à circulação dos trabalhadores nas zonas de fronteira e a levar a cabo as ações necessárias para melhorar as oportunidades de emprego e as condições de trabalho e de vida destes trabalhadores ${ }^{706}$.

A referida norma não tem efeito vinculante no nosso ordenamento por se tratar de uma declaração, porém possui grande peso político na fixação de diretrizes de tratamento das relações do trabalho. E nesse caso, procurando estabelecer diretrizes para uma integração regional, o valor da norma em questão fica muito mais intensificado, pois no segundo item abre a possibilidade de circulação de trabalhadores nas zonas de fronteira.

\subsection{O ordenamento jurídico brasileiro e o trabalhador migrante}

O Estado brasileiro não tem demonstrado boa vontade em tratar adequadamente a questão do trabalhador migrante, sendo estabelecida uma política pública caracterizada pela extrema seletividade de ingresso de trabalhadores migrantes no nosso território.

O Brasil é um país com contornos especiais na questão do trabalho em território estrangeiro. Recebe um grande número de migrantes dos países vizinhos menos desenvolvidos, como Bolívia, Paraguai e Peru, possuindo cerca de 510 mil estrangeiros residindo no nosso território ${ }^{707}$. No entanto, atualmente, estima-se a presença de dois milhões de brasileiros vivendo no exterior, cerca de 800 mil nos EUA e, os demais, em grande maioria, na Europa e no Japão. Segundo dados do Banco Interamericano de Desenvolvimento, a estimativa de remessas de divisas ao nosso país em 2007 é de US\$ 7,075 bilhões $^{708}$. Traduzindo os dados acima, somos um país receptor em menor escala,

\footnotetext{
${ }^{706}$ MERCOSUL. Declaração sociolaboral do Mercosul. Supremo Tribunal Federal. Disponível em: $<$ http://www.stf.jus.br/arquivo/cms/forumCorteSupremaNorma/forumCorteSupremaNorma_AP_75320.pdf >. Acesso em: 07 dez. 2009.

${ }^{707}$ INSTITUTO BRASILEIRO DE GEOGRAFIA E ESTATÍSTICA. Censo Demográfico de 2000. Disponível

<http://www.ibge.gov.br/home/estatistica/populacao/censo2000/migracao/Brasil_mig_Censo2000.pdf>. Acesso em: 12 dez. 2008.

${ }^{708}$ BANCO INTERAMERICANO DE DESENVOLVIMENTO. Global Link. Disponível em: <http://www.iadb.org/gl/index_esp.html>. Acesso em: 01 dez. 2008.
} 
cerca de 4 vezes menor que o número de brasileiros residindo no exterior, em termos comparativos. Nossa tendência predominante é enviar migrantes para o exterior, fluxo que vem crescendo em ritmo extremamente acelerado nas últimas décadas. Segundo os dados do IBGE, o número de pessoas que se declararam residentes no exterior em 2000 aumentou $181,5 \%$ em relação aos dados obtidos em $1991^{709}$.

Não são poucos os problemas que os brasileiros enfrentam no exterior. No entanto, a massa de trabalhadores migrantes no Brasil é extremamente significativa, posto que é uma população com o tamanho de algumas capitais de Estado. As situações de exploração de estrangeiros no Brasil são reiteradamente divulgadas pela imprensa, com amplo conhecimento público. Em muitos centros urbanos, em especial na cidade de São Paulo e em outras cidades do interior paulista, há um grande contingente de trabalhadores migrantes de países vizinhos. Eles é que vêm tentar melhores dias por aqui, já que em seus países a situação socioeconômica é muito grave, principalmente no contexto andino.

A legislação brasileira ainda é insensível em relação aos direitos humanos dos estrangeiros, possuindo uma visão extremamente limitada e desatualizada dos fenômenos migratórios mundiais. Dispomos hoje das previsões constitucionais sobre os estrangeiros no país, mais especificamente no artigo $5^{\circ}$, caput (igualdade de direitos entre brasileiros e estrangeiros em relação a alguns direitos), e as previsões do artigo 12 da Carta Política, relativamente à condição de brasileiro nato e naturalizado. Além da nossa Constituição, o artigo $3^{\circ}$ do atual Código Civil aponta que "a lei não distingue entre nacionais e estrangeiros quanto à aquisição e ao gozo dos direitos civis" $" 710$.

O principal diploma que regula a situação do estrangeiro no país é a Lei 6.815 , de 19 de agosto de 1980, promulgada durante o regime militar, e também conhecida como "Estatuto do Estrangeiro". O artigo $2^{\circ}$ da referida norma deixa claro que a preocupação das suas disposições está em atender precipuamente à segurança nacional, à organização institucional, aos interesses políticos, socioeconômicos e culturais do Brasil, bem assim à defesa do trabalhador nacional. Ou seja, o último aspecto deixa muito claro que o trabalhador estrangeiro estará sempre em desvantagem comparativamente ao trabalhador nacional, o que não se coaduna com os diplomas internacionais vigentes, mesmo com a Convenção $n^{\circ} 97$ da OIT, ratificada pelo Brasil. Nela fica claro que há flagrante intenção

\footnotetext{
${ }^{709}$ BANCO INTERAMERICANO DE DESENVOLVIMENTO. Global Link. Disponível em: <http://www.iadb.org/gl/index_esp.html>. Acesso em: 01 dez. 2008.

${ }^{710}$ BRASIL. Código Civil. Lei 10.402 , de 10 de janeiro de 2002. Palácio do Planalto. Disponível em: <www.planalto.gov.br>. Acesso em: 01 dez. 2008.
} 
de tratamento diferenciado do trabalhador nacional em relação ao estrangeiro, contrariando o artigo $6^{\circ}$ da referida norma internacional.

Adotando este princípio expresso, a referida norma define critérios extremamente rígidos para a admissão de trabalhadores estrangeiros no país, inclusive ao formular exigência de um contrato de trabalho prévio, que deve ser apresentado na concessão de visto para trabalho no país na condição de "temporário" (art. 13). Este contrato tem prazo determinado não superior a dois anos, prorrogáveis por mais dois, conforme as disposições da Consolidação das Leis do Trabalho no seu artigo 445. Além disso, a citada norma exige prévia aprovação do Ministério do Trabalho através do Conselho Nacional de Imigração, que irá analisar os benefícios do trabalho do estrangeiro para nossa atividade produtiva. É uma condição extremamente burocrática, muitas vezes difícil de ser obtida, que dificulta, e muito, a atividade laboral do estrangeiro em nosso território.

A política adotada pela Lei 6.815/80 acompanha as disposições da Consolidação das Leis do Trabalho que, nos idos dos anos quarenta, se preocupava com uma condição de predominância de trabalho de brasileiros sobre estrangeiros nas empresas nacionais, instituindo a figura da proporcionalidade, com regra geral de $2 / 3$ de brasileiros (art. $354^{711}$ ). Esta regra poderá ser flexibilizada se houver interesse avaliado pelo Ministério do Trabalho, caso seja de interesse nacional, a diminuição da proporcionalidade mediante maior admissão de estrangeiros quando não encontrado o correspondente número de trabalhadores brasileiros. Trata-se de uma situação completamente anacrônica, principalmente para um mundo globalizado como o atual. Os dados estatísticos acima apontados deixam claro que tal exigência é totalmente inócua, na medida que longe está de chegar a $1 / 3$, em termos gerais, a presença de trabalhadores estrangeiros no Brasil. A origem desta separação está nos primórdios da industrialização no país, na qual uma grande massa operária especializada era estrangeira, ou pelo menos não naturalizada. Aos olhos dos governantes da época, esse grupo de operários estrangeiros constituía uma ameaça à segurança nacional ao trazer ideias revolucionárias de seus países de origem. Assim, a proporcionalidade era um instrumento de maior controle, por parte do Estado, de possíveis "atividades subversivas".

\footnotetext{
${ }^{711}$ BRASIL. Consolidação das Leis do Trabalho. Decreto-Lei 5.452, de $1^{\circ}$ de maio de 1943. Disponível em: <www.planalto.gov.br>. Acesso em: 01 dez. 2008. Art. 354. A proporcionalidade será de dois terços de empregados brasileiros, podendo, entretanto, ser fixada proporcionalidade inferior, em atenção às circunstâncias especiais de cada atividade, mediante ato do Poder Executivo, e depois de devidamente apurada pelo Departamento Nacional do Trabalho e pelo Serviço de Estatística de Previdência e Trabalho a insuficiência do número de brasileiros na atividade de que se tratar.
} 
O nosso Estatuto do Estrangeiro caminha nos mesmos trilhos do passado. Vislumbra o trabalho estrangeiro como um fato extremamente excepcional, dependente de uma permissão mediante ampla investigação da sua necessidade para os interesses nacionais e a preservação de uma proporcionalidade que não há mais razão de existir. $\mathrm{O}$ artigo 98 veda a qualquer estrangeiro, na condição de turista, de temporário, conforme item IV do artigo 13 (estudante), ou na condição de trânsito, qualquer atividade remunerada. No caso de jornalista ou correspondente, não pode ser este contratado por fonte brasileira. E o artigo 100 do referido diploma afirma textualmente que o estrangeiro admitido na condição de temporário, sob regime de contrato, somente pode exercer atividade perante a empresa pela qual foi contratado, na oportunidade da concessão de visto, salvo autorização expressa do Ministério da Justiça, depois de ouvido o Ministério do Trabalho.

Como facilmente se vislumbra nas disposições do referido diploma legal, a possibilidade de o estrangeiro exercer atividade remunerada no Brasil é extremamente restrita. A admissão somente é possível mediante a prévia contratação, como requisito essencial para a concessão do visto temporário, observados os rigores da Consolidação das Leis do Trabalho e mediante aprovação expressa do Ministério do Trabalho. Como se vê, os anseios da Lei são completamente distintos dos anseios dos trabalhadores que buscam nossas fronteiras, geralmente com pouca qualificação. Se não possuírem qualquer qualificação profissional e contrato de trabalho previamente celebrado, não terão a menor chance de obter uma aprovação do Ministério do Trabalho para uma qualificação não encontrada no mercado nacional.

Esse aparato legal-burocrático, sem razão alguma de persistir nos dias atuais, somente encaminha o trabalhador migrante para uma situação: o ingresso no país para trabalho em situação irregular. A referida norma veda expressamente o exercício de atividade remunerada para atividades não qualificadas, encaminhando automaticamente o trabalhador não qualificado para a clandestinidade laboral. Soma-se a este fato a deficiência da estrutura de vigilância das nossas fronteiras terrestres, o que leva a uma branda repressão do ingresso irregular no país. Assim, torna-se muito fácil o ingresso de trabalhadores irregulares em nosso território até os grandes centros urbanos. Neles, a detecção de atividade irregular fica bastante dificultada, mormente diante da ínfima estrutura da fiscalização do Ministério do Trabalho.

Mas a situação catastrófica não termina aí. A Lei 6.815/80 garante alguns direitos que são aqueles reconhecidos aos brasileiros, conforme a Constituição e as leis (art. 95), 
sem se preocupar com qualquer definição, sendo uma norma extremamente genérica. Não há qualquer preocupação, muito menos de ordem humanitária, por parte do referido artigo. E, por fim, a referida norma possui um rol taxativo das penalidades aplicáveis aos estrangeiros, em caso de irregularidades. O trabalho irregular acarreta a deportação, ou seja, a devolução do estrangeiro ao exterior ${ }^{712}$. A penalidade também incide no ingresso irregular em nosso território, ao aí permanecer além do permitido ou no exercício de trabalho não autorizado. No entanto, ao empregador que admitir trabalho em condição irregular, somente é aplicável uma multa de 30 vezes o maior valor de referência por trabalhador (art. 125, VI), ou seja, uma penalidade completamente desproporcional em função da gravidade da pena de deportação aplicada ao estrangeiro, praticamente sem qualquer efeito repressor diante do baixo valor da multa. $\mathrm{O}$ trabalho prestado sem registro em carteira profissional importa em penalidade criminal prevista no artigo 337-A do Código Penal, no entanto, como é de amplo conhecimento, são muito raras tais punições.

Como é possível verificar, a situação jurídica do trabalho irregular no nosso país é extremamente difícil para o migrante, e de reduzidíssimo risco para o empregador. As complexas exigências burocráticas dificultam a obtenção de trabalho regularizado e a branda penalidade prevista no artigo 125, VI, estimula o empregador inescrupuloso a admitir imigrantes irregulares para obter maior rentabilidade pela informalidade. A dificuldade de fiscalização, a branda pena e a passagem do maior ônus para o trabalhador irregular configuram-se verdadeiros estímulos a trabalhos informais para estrangeiros, em vários casos em condições análogas a de um escravo. Não se verifica na atual legislação qualquer intenção mais destacada de proteção da pessoa humana do estrangeiro no nosso país, muito menos do trabalhador irregular. Ao contrário, a intenção da norma é priorizar o trabalho do nacional sobre o trabalho estrangeiro, encaminhando-o para uma situação de exclusão social, principalmente o irregular, gerando um cenário ideal para violações de direitos humanos de forma sistemática e impune.

O sistema legal vigente de admissão do trabalho estrangeiro no Brasil não atende às necessidades de uma política mais humana de tratamento ao trabalhador migrante, com maior permissibilidade e com penalidades maiores e mais efetivas para a exploração de trabalho irregular. Nosso sistema de admissão de trabalho estrangeiro não está adequado a uma política internacional de proteção da pessoa humana em nosso território, tal qual exigem os incisos II e IX do artigo $4^{\circ}$ da atual Constituição, menos estatocêntrica e mais

${ }^{712}$ AMARAL JÚNIOR, Alberto do. op. cit., p. 335. 
voltada para a defesa da pessoa humana do trabalhador migrante. O reiterado reconhecimento dos direitos dos trabalhadores migrantes em diversos documentos internacionais, de cunho geral ou específico, vem inserir a proteção humana do migrante no rol de direitos humanos que integram uma consciência jurídica universal. A referida qualificação formulada por Antonio Augusto Cançado Trindade emerge como um novo paradigma jurídico que abandona o conceito estatocêntrico e situa o ser humano como o centro da atenção de uma ordem jurídica internacional. Ela é voltada para o valor da solidariedade humana ${ }^{713}$, sendo que nenhum Estado pode se sobrepor ao corpo de direitos pertencentes à humanidade.

\subsection{A tensão crescente entre dois direitos: o direito individual de ir e vir e o direito dos Estados de restringir a imigração}

Um dos aspectos jurídicos mais controvertidos sobre a migração humana é a discussão da existência de um direito humano de imigração. Ela pressupõe a existência de um direito universal pertencente a cada ser humano que lhe permita circular livremente de um território para outro, principalmente em busca do exercício de determinada atividade remunerada.

A questão se torna controvertida diante da assimetria de tratamento normativo dado à questão da entrada e da saída de trabalhadores. É reconhecido muito amplamente o direito de deslocamento internacional em relação à saída de determinado território como um direito explícito em diversos documentos internacionais de grande importância. No entanto, o direito de ingresso ou permanência em Estado que não é o do indivíduo não goza da mesma visibilidade normativa. Na prática, sofre uma restrição intensa, diante da reiterada prática de muitos Estados, ao quais ampliam demasiadamente outro direito a eles pertencente.

Nguyen Quoc Dihn, Patrick Dailler e Alain Pellet ${ }^{714}$ apontam que a proteção dos estrangeiros segue alguns princípios gerais do direito das gentes especificando a soberania permanente sobre os recursos naturais e as atividades econômicas, a competência pessoal, a proteção dos direitos do homem e proteção diplomática. Os mesmos autores assinalam

\footnotetext{
${ }^{713}$ TRINDADE, Antonio Augusto Cançado. A humanização do direito internacional. Belo Horizonte: Ed. Del Rey, 2006. p. 91.

${ }^{714}$ DIHN, Nguyen Quoc; DAILLER, Patrick; PELLET, Alain. Direito internacional público. Trad. de Vítor Marques Coelho. 4. ed. Lisboa: Fundação Calouste Gulbenkian, 1999. p. 611.
} 
que, apesar das proclamações muito gerais consolidadas em certos instrumentos relativos à proteção dos direitos do homem, a liberdade de circulação das pessoas de um Estado para outro e mesmo sobre o território de um dado Estado é muito imperfeitamente assegurada na atualidade ${ }^{715}$.

É facilmente verificado um paradoxo. As políticas públicas de muitos Estados são extremamente permissivas no que tange à saída de nacionais. No entanto, na maioria dos casos, a política dos mesmos países são extremamente restritivas no que tange à autorização para ingresso de estrangeiros, seja em caráter temporário ou definitivo.

Thelma Thais Cavarzere enuncia a existência de um direito à livre circulação de pessoas reconhecido pelo direito internacional e as restrições impostas a este direito, desde que justas e cabíveis pela própria comunidade internacional, possuindo cada Estado um direito de controlar as migrações como meio de defesa ${ }^{716}$. É o direito individual internacional de ir e vir, previsto no artigo 13 da Declaração Universal dos Direitos do Homem, e no artigo 12 do Pacto Internacional de Direitos Civis e Políticos ${ }^{717}$, além da Convenção Americana sobre Direitos Humanos, em seu artigo $22^{718}$. Nele, estão compreendidos os direitos de emigração e imigração.

No entanto, esse direito de ir e vir sempre se encontra condicionado ao critério de estadia legal estabelecido por cada Estado, de acordo com o seu ordenamento interno. Os Estados possuem um direito de estabelecer restrições ao direito individual de ir e vir. As expressas limitações diretas ao referido direito estão contidas no parágrafo $3^{\circ}$ do artigo 12 do Pacto Internacional de Direitos Civis e Políticos, nos casos de segurança nacional, ordem pública, saúde pública, moral pública, direitos e liberdades de terceiros e compatibilidade com os demais direitos reconhecidos neste diploma. Além deles, são

\footnotetext{
${ }^{715}$ DIHN, Nguyen Quoc; DAILLER, Patrick; PELLET, Alain op. cit., p. 613.

${ }^{716}$ CAVARZERE, Thelma Thais. Direito internacional da pessoa humana: a circulação internacional de pessoas. Rio de Janeiro: Renovar, 1995. p. 38.

${ }^{717}$ ORGANIZAÇÃO DAS NAÇÕES UNIDAS. Pacto Internacional de Direitos Civis e Políticos. UNIVERSIDADE DE SÃO PAULO. Biblioteca Virtual de Direitos Humanos. Disponível em:<http://www.direitoshumanos.usp.br/counter/Onu/Sist_glob_trat/texto/texto_3.html $>$. Acesso em: 08 dez. 2008. Artigo 12 \$1. Toda pessoa que se encontre legalmente no território de um Estado terá o direito de nele livremente circular e escolher sua residência. \$2. Toda pessoa terá o direito de sair livremente de qualquer país, inclusive de seu próprio país. 3 . Os direitos supracitados não poderão constituir objeto de restrições, a menos que estejam previstas em lei e no intuito de proteger a segurança nacional e a ordem, saúde ou moral públicas, bem como os direitos e liberdades das demais pessoas, e que sejam compatíveis com os outros direitos reconhecidos no presente Pacto. \$4. Ninguém poderá ser privado arbitrariamente do direito de entrar em seu próprio país.

${ }^{718}$ ORGANIZAÇÃO DOS ESTADOS AMERICANOS. Convenção Americana de Direitos Humanos. UNIVERSIDADE DE SÃO PAULO. Biblioteca Virtual de Direitos Humanos. Disponível em:<http://www.direitoshumanos.usp.br/counter/Sistema_inter/texto/texto_5.html>. Acesso em: 08 dez. 2008.
} 
reconhecidas duas situações especiais como a incapacidade legal e o conhecimento profissional, de acordo com os comentários de Thelma Thais Cavarzere sobre a referida norma $^{719}$.

No mesmo sentido aponta Graciela R. Salas, que reconhece a existência de um direito básico à livre circulação e à emigração e com reconhecimento progressivo ${ }^{720}$. A Convenção $n^{\circ} 143$ da OIT deixa clara a existência de um direito humano de abandonar qualquer país, inclusive o próprio e, de retornar a seu próprio país.

Esse direito veio a ser paulatinamente construído durante a evolução do direito internacional público. Christian Nguyen Van Yen $^{721}$ afirma que juristas como Vattel sustentavam que cada Estado tinha uma competência exclusiva e discricionária para determinar as leis e regulamentos que governariam a admissão de estrangeiros em seu território. Celso D. Albuquerque de Mello destaca, no entanto, que a existência de um direito de caráter universalista remonta ao jus communicationes, como um direito de emigração e imigração no plano internacional, conforme formulação de Francisco de Vitória. O teólogo afirmou ainda que se não fosse ilimitado este direito, os Estados somente poderiam restringi-lo em face de um motivo importante ${ }^{722}$.

Desde o período entre guerras, os princípios gerais reconhecidos pelas nações civilizadas consagradas pela Sociedade das Nações deveriam se impor sobre os ordenamentos aplicáveis aos estrangeiros. Esse direito veio a ser paulatinamente reconhecido no sentido de constituir limitações aos poderes estatais na regulação da admissão. E Christian Nguyen Van Yen $^{723}$ conclui sua explanação no sentido de que, diante do direito positivo existente, da doutrina e das orientações políticas formuladas, é possível constituir um verdadeiro direito de imigração, o qual não tem sido um objeto de construção global, permanecendo, de certo modo, um direito frágil. Chris Nwachukwu Okeke e James A.R. Nafziger ${ }^{724}$ apontam para a existência de uma opinio juris da comunidade internacional no sentido da existência de uma abertura regulada para a migração. E os mesmos autores asseguram que os regulamentos aprovados pelo Instituto de Direito Internacional em 1892 sobre a admissão e expulsão de estrangeiros, com certa

\footnotetext{
${ }^{719}$ CAVARZERE, Thelma Thais. op. cit., p. 59-60.

${ }^{720}$ SALAS, Graciela R. Prospectiva de las migraciones. Anuario Argentino de Derecho Internacional, Córdoba, v.4, p. 209, 1990-1991.

${ }^{721}$ VAN YEN, Christian Nguyen. op. cit., p. 30.

${ }^{722}$ MELLO, Celso Duvivier de Albuquerque. Curso de direito internacional público. 14. ed. Rio de Janeiro: Renovar, 2002. v. 2, p. 1043.

${ }^{723}$ VAN YEN, Christian Nguyen. op. cit., p. 32.

${ }^{724}$ OKEKE, Chris Nwachukwu; NAFZIGER, James A.R. op. cit., p.534.
} 
especificidade, apontaram para o princípio histórico do direito de os migrantes ingressarem em determinado território de um Estado estrangeiro, desde que de modo compatível com a segurança deste.

Uma simples análise de todos os documentos internacionais relativos à proteção do trabalhador migrante permite constatar a inequívoca existência de direito de livre saída do território do qual é nacional e seu retorno. Mas a permanência em determinado território que não seja aquele de sua nacionalidade não possui a mesma explicitude normativa, tal qual a saída, constatando-se, assim, uma assimetria de tratamento jurídico para as duas situações. Mesmo a Convenção Internacional da ONU sobre os trabalhadores migrantes e suas famílias, documento que possui uma tendência detalhista e posições extremamente arrojadas em comparação aos textos da OIT, não prevê, de modo claro e em momento algum, a existência de um direito à imigração. O próprio reconhecimento de uma situação regular, e de ingresso irregular, pressupõe, por parte da norma, o direito de o Estado receptor regulamentar, dentro do exercício de sua soberania, as condições para que o estrangeiro adentre seu território e nele permaneça para fins de trabalho. Frise-se que tal Convenção não proscreve esse direito de cada Estado restringir, ou até mesmo proibir, o ingresso em seu território.

Nguyen Quoc Dihn, Patrick Dailler e Alain Pellet ${ }^{725}$ comentam que numerosos Estados adotam uma concepção singularmente ampla dos motivos explicitados no parágrafo $3^{\circ}$ do artigo 12 , a ponto de inverterem o princípio, que deveria ser a liberdade de circular. Segundo os autores, as exceções passam a ser a regra dominante, submetendo a liberdade de circulação a limitações consideráveis, na verdade, a uma proibição total.

O estabelecimento de um exercício de soberania mediante critérios existentes dentro do ordenamento interno, para admitir ou recusar a presença de algum trabalhador estrangeiro em seu território, decorre do exercício de soberania, como um direito reconhecido formalmente por meio de tratados. Com efeito, a Convenção de Havana sobre os estrangeiros de 1928, vigente no nosso país por força do Decreto $\mathrm{n}^{\circ} 18.956$, de 22 de outubro de 1929, estabelece em seu artigo $1^{\circ}$ que "os Estados têm o direito de estabelecer, por meio de leis, as condições de entrada e residência dos estrangeiros em seus territórios"726. A Carta das Nações Unidas, implicitamente, traz este direito de os Estados

\footnotetext{
${ }^{725}$ DIHN, Nguyen Quoc; DAILLER, Patrick; PELLET, Alain. op. cit., p. 611-612.

${ }^{726}$ CONVENÇÃO SOBRE OS ESTRANGEIROS. Ministério das Relações Exteriores. Divisão de atos internacionais. Disponível em: <http://www2.mre.gov.br/dai/estrangeiros.htm>. Acesso em: 16 dez. 2008.
} 
regularem questões internas, inclusive a imigração ${ }^{727}$, somente sujeito a interferências externas quando um Estado, através de sua política interna, ameaçar a paz ou outros Estados. Assim, o exercício de um direito individual de transferência está sempre condicionado aos critérios estabelecidos por cada Estado para admissão e manutenção de estrangeiros trabalhando em seu território, na visão de Celso D. de Albuquerque Mello ${ }^{728}$. Como fundamento para essas restrições, a inexistência desta possibilidade poderia ser uma séria ameaça à segurança da existência do próprio Estado, por motivos óbvios.

Em posição oposta, Thomas Kleven expõe que somente duas normas podem limitar o direito dos Estados de restringir o ingresso em seu território: a primeira é o Pacto Internacional de Direitos Civis e Políticos, quando reconhece o direito ao devido processo legal do indivíduo antes de ser expelido de determinado território, quando admitido legalmente. E o segundo é o direito reconhecido na Declaração Universal dos Direitos do Homem que dá o direito de procurar e usufruir de asilo político em face de alguma perseguição de outro Estado ${ }^{729}$.

A limitação do direito de transferência e permanência pelo direito de regular o ingresso em seu território insere o trabalhador migrante em uma posição de extrema fragilidade jurídica. E o fundamento deste direito dos Estados é reforçado por um costume internacional de reconhecimento da soberania de os outros Estados regularem o ingresso de estrangeiros em seus territórios. No entanto, esse direito teve origem nos interesses das grandes potências econômicas e militares. Isso ocorreu porque muitos Estados dependeram essencialmente das imigrações para atingirem estágios de crescimento econômico elevado, como os Estados Unidos no Século XIX e XX e a Europa após a Segunda Grande Guerra. Esses Estados adotaram uma política de fronteiras abertas enquanto essa abertura era interessante para suas economias, mas depois passaram a adotar políticas seletivas quando a carga de imigração deixou de ser necessária. Foi, basicamente, uma política liberal,

ARTIGO $1^{\circ}$ Os Estados têm o direito de estabelecer, por meio de leis, as condições de entrada e residência dos estrangeiros nos seus territórios.

${ }^{727}$ ORGANIZAÇÃO DAS NAÇÕES UNIDAS. Carta Geral das Nações Unidas. UNIVERSIDADE DE SÃO PAULO. Biblioteca Virtual de Direitos Humanos. Disponível em: <http://www.direitoshumanos.usp.br/counter/Onu/Carta_Geral/carta_geral.html>. Acesso em: 08dez. 2008. Artigo 2 A Organização e seus Membros, para a realização dos propósitos mencionados no Artigo 1, agirão de acordo com os seguintes Princípios: 7. Nenhum dispositivo da presente Carta autorizará as Nações Unidas a intervirem em assuntos que dependam essencialmente da jurisdição de qualquer Estado ou obrigará os Membros a submeterem tais assuntos a uma solução, nos termos da presente Carta; este princípio, porém, não prejudicará a aplicação das medidas coercitivas constantes do Capítulo VII.

${ }^{728}$ MELLO, Celso Duvivier de Albuquerque. op. cit., p. 1044.

${ }^{729}$ KLEVEN, Thomas. Why international law favors emigration over immigration. The University of Miami Inter-American Law Review. Florida, v. 33. n.1. p. 71, 2002. 
sendo que Anthony Messina expõe que nesse período, na Europa, adotava-se uma enorme expansão e integração crescente da economia internacional após a Segunda Grande Guerra e também começava a se formar um mercado de trabalho internacional ${ }^{730}$.

E, nesse ponto, a discussão sobre a conduta contraditória de posições internas dos Estados atinge seu ponto mais relevante. A limitação do direito à imigração possui uma natureza extremamente utilitarista para o Estado receptor, típica de uma filosofia neoliberal inserida em uma economia globalizada e cujo objetivo maior é a eficiência econômica como elemento justificador de todas as políticas governamentais.

O tratamento da imigração e da emigração é profundamente distinto. O primeiro é restrito, sujeito ao poder discricionário de cada Estado receptor ao sabor de suas políticas sobre o tema. O tratamento da emigração, em muitos textos constitucionais, como o português, por exemplo, é um direito constitucionalmente assegurado como o direito de emigrar e retornar quando bem entender ${ }^{731}$. Também, vários documentos de direitos humanos, em especial os principais (Declaração Universal dos Direitos do Homem e o Pacto Internacional de Direitos Civis e Políticos) definem muito claramente o direito de sair de determinado Estado. Contudo, tais diplomas não afirmam com a mesma eloquência e visibilidade o direito de ingressar em outro Estado, salvo em condições especiais, geralmente em situações transitórias e por questões humanitárias.

Thomas Kleven assinala esse diferencial, apontando que as normas de direito internacional muito mais protegem o direito de emigrar (normas de autodeterminação de caráter individual) de seu país de origem que o direito de imigrar para outro país (normas de autodeterminação de caráter coletivo - voltado ao interesse do Estado proteger-se de estrangeiros indesejáveis) ${ }^{732}$. A construção dessa ambiguidade dentro do direito internacional tem grande fundamento no próprio capitalismo. Funda-se um direito de caráter liberal, de conduta abstencionista, de modo geral, ou seja, não proibir, mas isso nas atitudes administrativas para saída. Porém, para a imigração, arquitetam-se barreiras fundadas por questões internas do Estado, justificadas por necessidades estratégicas quando existente alguma ameaça. Em tempos de paz, possuem um caráter muito mais

\footnotetext{
${ }^{730}$ MESSINA, Anthony M. op. cit., p. 139.

${ }^{731}$ PORTUGAL. Constituição da República Portuguesa.Portal do Governo Português. Disponível em: $<$ http://www.portugal.gov.pt/Portal/PT/Portugal/Sistema_Politico/Constituicao/constituicao_p03.htm>. Acesso em: 01 dez. 2008. Artigo 44. ${ }^{\circ}$ (Direito de deslocação e de emigração) 1. A todos os cidadãos é garantido o direito de se deslocarem e fixarem livremente em qualquer parte do território nacional. 2. A todos é garantido o direito de emigrar ou de sair do território nacional e o direito de regressar.

${ }^{732}$ KLEVEN, Thomas. op. cit., p. 70.
} 
utilitarista a limitar o direito de ir e vir. Algumas políticas são estabelecidas sem qualquer observação da proteção dos direitos da pessoa humana, que deveria reger o direito internacional dos direitos humanos.

Este, talvez, seja o aspecto mais delicado do estudo das discriminações contra os trabalhadores migrantes. Eles estão em uma situação jurídica extremamente precária e em condição demasiadamente fragilizada. Não podem exercer adequadamente um direito fundamental, nem ao menos possuem um direito de natureza humana, a ponto de exigir do Estado receptor sua admissão ou permanência, salvo em situações especialíssimas. A precariedade reside no fato de que os trabalhadores migrantes estão sujeitos ao poder discricionário e assimétrico do Estado receptor, muitas vezes exercido de forma arbitrária, sem limites precisos e definidos. Os Estados receptores também não sofrem a exigência da fundamentação de seus atos, principalmente os de recusa na admissão ou cancelamento da autorização de permanência.

Joaquim José Gomes Canotilho observa com muita propriedade que este pretenso direito de imigração está posicionado em uma situação de insularidade nos planos dogmático e científico. Antes de ser um direito dos estrangeiros, é uma questão de polícia centrado no direito administrativo especial e dependente de atos de governo, nos quais a intervenção jurídica revelava apenas uma soberba indiferença e marginalização ${ }^{733}$. O célebre constitucionalista lusitano lembra ainda que esse deslocamento do direito de imigração para o direito administrativo de polícia implicou, direta ou indiretamente, que o direito constitucional e o direito internacional se ocupassem de um problema de direito interno de um Estado, quando se trata, efetivamente, de um problema internacional de direitos humanos ${ }^{734}$.

As discussões sobre o direito de imigração passam de forma inexorável, portanto, por essa tensão entre dois direitos: o de livre deslocamento, de caráter individual, um direito de natureza humana; e o direito de caráter governamental, de cada Estado, em estabelecer políticas que venham a restringir o exercício do referido direito individual.

\footnotetext{
${ }^{733}$ CANOTILHO, Joaquim José Gomes. Enquadramento jurídico da imigração. ALTO COMISSARIADO PARA A IMIGRAÇÃO E MINORIAS ÉTNICAS. Congresso Imigração em Portugal: Diversidade Cidadania - Integração.1. Lisboa.2003 - Actas do I Congresso Imigração em Portugal: DiversidadeCidadania-Integração (Org.). Alto Comissariado para a Imigração e Minorias Étnicas, ISBN 972-98959-96, 1-Portugal, $\quad$ p. $153-154$ D 150 Disponível em: $<$ http://www.oi.acidi.gov.pt/modules.php?name=Content\&pa=showpage\&pid=15>. Acesso em: 26 nov. 2008.

${ }^{734}$ Id. Ibid., p. 154.
} 
Os Estados revelam uma ambiguidade no reconhecimento do direito de ir e vir, eis que a situação recebe um foco estritamente dominado por interesses de cada um deles. A motivação tem origem em razões utilitaristas, interesses edificados ou alicerçados na ordem internacional pelas necessidades do capitalismo internacional dominante. Contra esses interesses, somente se contrapõe o sentido de proteção da pessoa humana mediante o reconhecimento jurídico de uma liberdade humana de estar onde melhor desejar. Nesse ponto é constituída outra forte tensão, cada dia mais crescente, pelos resultados de tais políticas orientadas pelo capitalismo esbarrarem no respeito aos direitos mínimos de cada ser humano.

O referido utilitarismo está cada vez presente nas atuais políticas seletivas de imigração dos países centrais. Eles não querem adotar políticas absolutamente fechadas, apenas querem autorizar a imigração de indivíduos cuja presença no seu território converge para seus interesses econômicos e tecnológicos, surgindo o problema da admissão seletiva, que traz consigo a lamentável figura do brain drain.

Procura-se restringir a imigração indesejada, principalmente aquela que trará custos sociais e, ao mesmo tempo, aproveitar-se da imigração que lhe traga benefícios, o que ocorre em parcela muito inferior. Daí, é possível observar que não há uma justificativa jurídica razoável para permitir, simultaneamente, dois comportamentos tão opostos.

Por tal motivo, o reconhecimento de um direito geral de ingresso em um determinado Estado enfrenta barreiras de difícil superação, ainda que elas sejam discutíveis. O mencionado fenômeno passou a ser demasiadamente ampliado quando o componente "segurança" passou a orientar cada vez mais os critérios de admissão em determinado território, especialmente após a intensificação do terrorismo internacional e com os atentados de 11 de setembro de 2001. A questão de segurança geral é um componente que inviabiliza completamente o reconhecimento de um direito geral de ingresso em outro Estado.

Dentro desta situação, a proteção dos direitos humanos dos migrantes somente obterá ganhos efetivos a partir da ruptura desse modelo utilitarista e estatocêntrico na sua concepção, com a aplicação do direito de ir e vir, para um modelo mais humanista e internacionalmente solidário. A realidade de uma economia globalizada não mais permite que as questões migratórias sejam vistas exclusivamente somente pela ótica interna, mas depende, essencialmente, de uma observação e uma ação internacionalmente coordenada. Ela deverá ser voltada muito mais para o sentido da proteção da pessoa humana, em uma 
perspectiva global. Isso nos leva a entender que não é mais possível admitir este modelo liberal-utilitarista, que realiza, apesar de não possuir justificativa aceitável, uma interpretação ambígua do direito de ir e vir.

Enquanto a construção de um novo modelo não passar de um projeto, somente resta o caminho para atenuar as violências contra o trabalhador migrante dentro do modelo atualmente vigente. Isso leva à visão, como ponto de partida, da intransigente defesa dos direitos humanos do trabalhador migrante se contrapondo cada vez mais contra os poderes desse modelo pernicioso. Para a defesa dos direitos humanos, a proteção contra a discriminação assume papel central. Ela é uma poderosa arma para combater, com maior vigor, a visão administrativa que norteia as questões migratórias na ótica dos Estados receptores, principalmente movidos por interesses econômicos e estratégicos internos.

Ou seja, a proteção contra a discriminação dos trabalhadores migrantes é um objetivo e, também, um fundamento para limitação dos poderes de cada Estado de adotar políticas restritivas não justificadas de ingresso de estrangeiros em seu território.

Como bem assinala Antonio Rodrigues de Freitas Jr., o direito moderno, apesar de seu crescente desapontamento com os limites da racionalidade, consegue sobreviver ao crescimento da incerteza, bem como ao mesmo tempo preserva a oferta de segurança e a certeza do comportamento social ${ }^{735}$. Mas o direito, segundo o autor, deve reconhecer a perda da centralidade do Estado-Nação, aceitar a globalização como um dado de realidade, a avaliação da plausibilidade econômica das medidas e, identificar novos atores jurídicos que atuem além das fronteiras ${ }^{736}$. Por seu turno, Pedro Bohomoletz de Abreu Dallari vislumbra um futuro de convivência de duas tendências simultaneamente antagônicas: a uniformização do direito no plano global e a diferenciação do direito em função das particularidades do Estado ou de ente dotado de poder capaz de substituí-lo ${ }^{737}$. Tais tendências devem reger um novo panorama jurídico internacional para a proteção dos trabalhadores migrantes.

O primeiro objetivo a ser traçado pela defesa dos direitos humanos do trabalhador migrante seria promover a limitação da discricionariedade dos Estados receptores nas escolhas de admissão, proposta extremamente ambiciosa em face das dificuldades

\footnotetext{
${ }^{735}$ FREITAS JR., Antonio Rodrigues de. Globalização, Mercosul e crise do Estado-Nação: perspectivas para o direito numa sociedade em mudança. São Paulo: LTr, 1997. p. 83.

${ }^{736}$ Id. Ibid., p. 84.

${ }^{737}$ DALLARI, Pedro Bohomoletz de Abreu. Desafios da globalização. In: DOWBOR, Ladislau; IANNI, Octavio; RESENDE, Paulo-Edgar A. (Orgs.). Globalização. Petrópolis:Vozes, 2002. p. 255.
} 
apresentadas pela superioridade econômica, política e militar dos Estados centrais. O direito de ir e vir deve ser intensificado em seus dois vetores, tendendo a uma interpretação mais simétrica. Não se almeja extinguir as restrições que cada Estado queira impor porque elas são inquestionavelmente necessárias, no entanto elas devem ser modeladas de acordo com uma visão humanista e de interesse global e não somente estatal.

Esse ponto converge com os documentos internacionais analisados até então, mediante a progressiva estruturação e sedimentação de padrões mínimos de proteção dos trabalhadores migrantes, ainda que de forma insatisfatória, pois as situações de violações continuam a ocorrer em grande escala. Ainda que insuficientes para resolver os problemas vivenciados pelos trabalhadores migrantes, os atuais tratados exprimem um significativo avanço no caminho de quebra da inferioridade jurídica que os trabalhadores migrantes atualmente vivenciam.

O direito dos Estados receptores de negar acesso ou permanência a determinados trabalhadores deve passar cada vez mais pelo crivo da proibição de discriminação, como princípio de abrangência universal, que todo ser humano possui contra qualquer ato discriminatório. Esse princípio proíbe que os Estados receptores venham a limitar o acesso a seu território por medidas de caráter discriminatório, principalmente aquelas fundadas em critérios de raça, etnia, religião ou origem nacional.

Como ponto essencial, para que a proteção contra a discriminação passe a ser mais eficaz, é importante o pleno reconhecimento do dever do Estado receptor de fundamentar objetivamente sua decisão sobre a não permanência de determinada pessoa, cabendo a cada ser humano o direito de ser formalmente informado sobre essa decisão e em linguagem compreensível pelo trabalhador migrante. Stephen H. Legomsky destaca a necessidade de uma fundamentação adequada e objetiva, sendo que cada Estado deve estabelecer critérios específicos, de amplo conhecimento por todos os envolvidos e pela comunidade internacional. No entanto, o referido autor aponta que, assim mesmo, dependendo do critério, a decisão torna-se muito questionável. Ele cita alguns parâmetros da legislação norte-americana sobre imigração, referindo-se aos exemplos das normas que barram o acesso dos candidatos que não possuam ambos os pais quando do nascimento ou se o candidato não nasceu dentro do território de sua nacionalidade, entre tantos outros ${ }^{738}$. Ou seja, ainda que positivados tais critérios objetivos dentro da ordem interna, eles devem ser

\footnotetext{
${ }^{738}$ LEGOMSKY, Stephen H. Immigration, equality and diversity. Columbia Journal of Transnational Law, New York, v. 31, n. 2, p. 323-325, 1999.
} 
razoáveis e proporcionais, para não serem considerados discriminatórios dentro da ótica internacional.

A possibilidade de ocorrer um ato discriminatório na recusa de acesso ou permanência somente pode ser reparada por uma medida judicial baseada em um motivo explícito justificável. Porém, além disso, não é necessário ponderar quão difícil é, senão quase que impossível, efetivar esta medida estando fora do Estado questionado. Não é fácil pensar nesse sentido quando os instrumentos para questionamento de eventuais práticas discriminatórias não estão ao alcance dos envolvidos, sendo um aspecto fundamental para uma defesa mais eficiente dos trabalhadores migrantes, na visão de Ryszard Cholewinski $^{739}$.

Assim, a proteção internacional do trabalhador migrante passa, inicialmente, pelo direito a uma informação consistente a ser fornecida pelo Estado receptor, esclarecendo por qual motivo teve seu acesso ou permanência recusada, sendo esse dado fundamental para o questionamento deste ato. Mas não basta a informação exclusivamente ao interessado. Toda a comunidade internacional deve ter acesso a tais dados, principalmente das estatísticas da proibição de admissão, os motivos e as tendências de cada Estado, para que seja possível que entidades internacionais, públicas ou privadas, possam apurar práticas contra determinados grupos, ainda que por impacto adverso.

Posteriormente, em posse deste dado, poderá tal medida, ou o conjunto de medidas restritivas, ser discutida à luz da proibição universal de discriminação, tratando-se de um direito universal de qualidade especial.

Por outro lado, os tratados internacionais da OIT e da ONU procuram atuar na proteção do trabalhador migrante e de suas famílias, diante do compromisso assumido pelos seus signatários, no sentido dos Estados receptores e seus nacionais se absterem de praticar determinados atos agressivos aos trabalhadores migrantes. E ainda, em alguns deles, está estabelecida a obrigação de assumir e patrocinar políticas públicas de promoção e inclusão de trabalhadores migrantes. Os referidos padrões mínimos constituem, na atualidade, o corpo básico de normas de um direito de proteção do trabalhador migrante, atuando em contraposição ao poder de regulação dos Estados, em especial as Convenções

\footnotetext{
${ }^{739}$ CHOLEWINSKI, Ryszard. Borders and discrimination. Immigration law practitioners'association/ Migration Policy Group, p.V. Sítio de IMMIGRATION LAW PRACTITIONERS' ASSOCIATION. Disponível em: <http://www.ilpa.org.uk/publications/borders_exec_summary.pdf>. Acesso em: 07 dez. 2008, também publicado em In Police and Justice Co-Operation and the New European Borders, The Hague: Ed. Anderson Malcolm, Apap Joanna, p. 81-102, 2002.
} 
da OIT nº 97 e 143, que possuem um número maior de aderentes. As referidas normas constituem um núcleo mínimo de direitos dos trabalhadores migrantes, em especial o direito de não sofrer práticas discriminatórias.

Gradativamente, os tratados da OIT vieram introduzir limitações ao poder administrativo dos Estados receptores. O desafio da Convenção Internacional da ONU é bem maior, pois ela pretende ampliar significativamente tais restrições, demandando, por parte de seus signatários, a renúncia de poderes costumeira e positivamente consagrados como um padrão internacionalmente aceitável de soberania, ainda mais em uma comunidade internacional guiada pelos princípios do liberalismo e da eficiência econômica.

Vários direitos já estão consagrados. No entanto, caberá um desenvolvimento progressivo constante de mecanismos para, pelo menos, atenuar a fragilidade em que se encontram os trabalhadores migrantes além das fronteiras de origem. E em caráter primordial e urgente, o grande desafio que se avizinha é limitar o tratamento dispensado pelos Estados receptores aos imigrantes irregulares. A proteção ideal seria reconhecer que, mesmo irregulares possuem efetivamente todos os direitos reconhecidos tais quais os regulares. É uma situação difícil de ser imaginada na atualidade, cujas políticas contra os irregulares assumem uma clara tendência de endurecimento de posições em todo o globo, especialmente nos últimos tempos na Europa mediterrânea e na América do Norte. No entanto, a melhoria da proteção está na progressiva limitação dos poderes de deportação de seu território, para impedir, definitivamente, a criminalização do ingresso ou permanência irregular. As normas devem garantir aos irregulares pelo menos um tratamento digno antes de serem retirados dos territórios ingressados e que, no mínimo, tenham a garantia de efetivação dos direitos mínimos e essenciais da condição de trabalhador antes da retirada do território. É o caminho mais curto e seguro para a melhoria da proteção dos trabalhadores migrantes irregulares no presente momento.

Concluindo o capítulo, é possível estabelecer, sem sombra de dúvidas, que existe propriamente o direito de transferência de um território a outro, como o direito de ir e vir. Esse direito colide frontalmente com o direito do Estado receptor de recusar a presença, em seu território, das pessoas que lhe possam oferecer alguma espécie de risco. Mas não há dúvidas que o mencionado direito do Estado deve possuir limitações, em face do direito dos migrantes de receberem um tratamento igualitário e digno a todo e qualquer ser humano. Essa proteção deve ser baseada, principalmente, na proibição de discriminação e 
na preservação dos direitos mínimos, independentemente de sua condição no território em que esteja. Os direitos do trabalhador migrante, que progressivamente vão se solidificando na comunidade internacional, importam em uma considerável limitação ao direito do Estado receptor de recusar a presença. Por outro lado, tais direitos procuram agir positivamente na defesa dos demais direitos fundamentais da pessoa humana do trabalhador migrante. Esse é um ponto de partida para uma estratégia de combate às violações cometidas contra os migrantes. Da mesma forma, tais limitações também impõem a ideia de que o direito de recusa não poderá ser exercido arbitraria e ilimitadamente, pois deverá apresentar publicamente justificativas plausíveis e aceitáveis dentro de padrões mínimos aceitos pelo direito internacional. 


\section{CONCLUSÕES}

Durante a maior parte da história da civilização humana, jamais poder-se-ia imaginar a existência de qualquer regra, muito menos uma norma jurídica, que determinasse que todos os homens fossem tratados igualmente, sem promover diferenciações. Qualquer proposição nesse sentido poderia levar seu autor a perder até mesmo a vida. Somente no Século XX foi consolidado um direito da mais alta importância entre todos os direitos humanos - o direito de não ser discriminado. Em quase sessenta anos desde seu primeiro reconhecimento, os conceitos sobre a discriminação em geral, e da discriminação em particular, evoluíram significativamente.

A expressão discriminação adquiriu o sentido da presente investigação nos Estados Unidos da América como descrição de práticas segregacionistas, em meados do Século XIX. Essa expressão foi introduzida no cenário internacional no Século XX, quando passou a ser adotada em muitos documentos internacionais, principalmente após a Segunda Grande Guerra. Posteriormente, a expressão avançou para os ordenamentos internos de diversos países, tornando-se uma universal para exprimir uma distinção desfavorável não autorizada.

A palavra discriminação, em todos os seus sentidos analisados, traz consigo como principal ideia a de separar elementos em face de algumas diferenças. Elas permitem identificar, por meio de características especiais, determinado elemento dentro de um universo. Os sentidos originais da expressão discriminação não continham qualquer contexto pejorativo, descreviam atitudes neutras e perfeitamente aceitáveis dentro de uma realidade jurídica, como separar e distinguir. O significado pejorativo foi consagrado a partir do uso para discussão de práticas segregacionistas.

Assim, a noção primordial que pode ser extraída da existência de uma discriminação é a de que foi estabelecida uma separação com base em alguma diferença encontrada. Ela ocorre mediante o reconhecimento de que não há igualdade entre os elementos que foram distinguidos, servindo este critério de diferenciação como base para formação de distintos grupos.

No Brasil, a expressão discriminação teve um uso muito mais recente, comparativamente com o seu emprego no cenário internacional. Somente a Constituição Federal de 1988 consolidou, definitivamente, o uso da referida expressão no direito 
brasileiro. Até então, eram muito esporádicas suas aparições, algumas surpreendentes, como na Constituição Federal de 1937. No entanto, a Lei 5.473/68, que já havia recebido os reflexos da ratificação e do ingresso no ordenamento jurídico nacional da Convenção 111 da OIT, teve a iniciativa na área laboral de sua utilização com o significado de tratamento diferenciado não autorizado. Com o atual texto constitucional, as normas positivadas doravante existentes passaram a adotar a expressão com maior frequência, e algumas delas demonstram a intenção de apresentar definições de uma conduta discriminatória, ainda que timidamente.

Discriminar, portanto, tem como noção básica o estabelecimento de diferenças de tratamento entre dois ou mais seres humanos, ou mesmo entre grupos de pessoas. Uma averiguação mais profunda sobre a discriminação pede, então, em caráter inicial, uma detalhada análise sobre a existência de um comportamento de diferenciação, que contrasta com o dever de tratamento igual. Assim, discriminar incorre, necessariamente, na quebra do dever de trato igual de seres humanos.

A igualdade é um valor comparativo, ou seja, qualquer análise sobre a possibilidade da existência de uma discriminação dependerá de uma ação comparativa com outra pessoa ou grupo. A averiguação de uma conduta discriminatória passará, necessariamente, por uma apreciação comparativa entre a suposta vítima com um determinado modelo. Somente quando existir um tratamento diferenciado entre a suposta vítima e o modelo, poderá ser possível prosseguir na averiguação da existência de uma discriminação. A simples existência do tratamento diferenciado não significa, necessariamente, que houve uma discriminação. A existência do tratamento diferenciado é um elemento essencial para a consideração de uma conduta discriminatória, mas não o único. Nem toda quebra de igualdade pode ser considerada uma discriminação, sendo que outras modalidades de tratamento desigual, também proibidas pelo direito, não podem ser consideradas discriminatórias, uma vez que envolvem uma diferenciação qualificada.

O dever de tratamento igual não pressupõe que todas as pessoas sejam igualmente consideradas em todos os critérios possíveis, mas somente em um ou mais critérios que realmente sejam relevantes na decisão diferenciadora. Não há como exigir igualdade absoluta entre duas pessoas, pois cada uma possui uma identidade composta por características próprias em uma única combinação. A diversidade humana deve ser respeitada e valorizada pela obrigação de tratamento igual. A discriminação não somente a viola como prejudica o reconhecimento da diversidade humana, pois trará prejuízos à 
vítima em função de uma diferença. A exigência de tratamento igual impõe o igual reconhecimento e consideração de todas as pessoas, mediante o integral respeito da sua identidade, observando e enaltecendo suas diferenças. Deixar de reconhecer a diversidade humana ao impor padrões aos seres humanos também é uma violação do dever de trato igual. O mandamento de igualdade somente é realizado em sua plenitude com o reconhecimento, valorização e garantias das diferenças de cada ser humano. Não é o frio trato igual que decreta a igualdade substancial, mas a blindagem das diferenças para que não sejam fatores motivadores de tratamentos diferenciados e nem constituam obstáculos ao pleno desenvolvimento da pessoa. A dignidade do ser humano somente será efetivamente concretizada no igual respeito do que cada um é, bem como do que deseja ser.

A igualdade é, também, um princípio de justiça. Logo, qualquer situação que venha a demonstrar uma quebra da igualdade de tratamento necessitará de uma justificativa. A diferença de tratamento exige justificativas sem as quais poderá ser considerado tratamento diferenciado proibido. Tal assertiva possui importantíssimas repercussões na constituição de alguns princípios antidiscriminatórios, fundamentando princípios específicos aplicáveis nas questões materiais e processuais que envolvam uma discriminação.

O respeito à igualdade não é obtido, tão somente, pela verificação das circunstâncias individuais de um contexto discriminatório. O exame de uma alegação discriminatória deve focar o cenário dos fatos com uma lente com ângulo mais aberto. Situações discriminatórias envolvendo grupos sociais historicamente vitimizados demandam uma análise da conjuntura social envolvida. Os impactos negativos trazidos pela discriminação devem ser bem observados, principalmente se eles perpetuam situações de dominação social de um grupo por outro. Também, o exame da situação discriminatória demanda uma avaliação especial do julgador, no qual ele deverá se posicionar dentro do contexto social da vítima, procurando se colocar na posição dela, para poder melhor analisar os efeitos da prática discriminatória.

A discriminação vai muito além do trato desigual, posto que não somente a presença desse componente essencial a caracteriza, mas outros igualmente importantes. A vítima de uma discriminação sofre um grave prejuízo na possibilidade de exercício de seus direitos na mesma condição de qualquer outra pessoa humana. A discriminação também implica uma condição de inferioridade social da vítima, não somente perante os modelos 
adotados, mas também perante todos os demais seres humanos, já que sua dignidade como pessoa humana não foi integralmente observada e respeitada.

A proteção jurídica contra a discriminação é consolidada mediante uma norma especial, em comparação com as normas de direitos fundamentais. A sua proteção é realizada como um mecanismo essencial para a efetivação e o gozo de todos os demais direitos, inclusive os direitos da pessoa humana. No direito internacional, a norma antidiscriminatória goza de status especial e qualificação destacada entre as demais normas internacionais. No direito interno, sua situação não é diferente, posto que é uma norma constitucional de valor destacado, exatamente para tornar efetivos todos os direitos fundamentais em caráter universal.

No direito constitucional brasileiro, a norma antidiscriminatória possui uma qualidade destacada e de elevada importância entre as demais normas de direitos fundamentais. A Constituição Federal de 1988 é moldada sobre um eixo igualitário no qual o combate a todas as formas de discriminação é mencionado expressamente como um dos objetivos do Estado brasileiro. Mais ainda, a proibição de discriminação também é renovada em diversas normas de direitos fundamentais, tratando-se de um inequívoco princípio da Carta vigente, que produz efeitos sobre todo o ordenamento jurídico.

Não obstante o caráter abrangente do princípio da proibição da discriminação, ele também não deixa de ser um dos princípios do direito do trabalho. Ele atua, decisivamente, na proteção e efetivação dos demais direitos laborais. É, reconhecidamente, um princípio de caráter fundamental, com grande relevância entre os principais instrumentos de proteção do trabalho humano. A atual Constituição brasileira também prevê a proibição da discriminação como um princípio específico trabalhista, e está em plena sintonia com os da Organização Internacional do Trabalho.

A prática discriminatória é extremamente dinâmica e criativa. Os conceitos da discriminação laboral sofreram profundas alterações desde a aparição da definição da Convenção $\mathrm{n}^{\circ} 111$, a pioneira norma descritiva. Inicialmente concebida como uma relação triangular, dentro de uma relação de emprego clássica (empregador - empregado - modelo de comparação), a discriminação nas relações do trabalho pode assumir formatos mais complexos. Nos dias atuais, um cenário discriminatório pode envolver um número praticamente ilimitado de personagens, em face das substanciais mudanças que as relações trabalhistas sofreram nos últimos anos. Efetivamente, a nova morfologia das relações de trabalho e de emprego estende a possibilidade de uma discriminação laboral para um 
grande número de participantes ativos e passivos, em especial as situações que envolvem a participação de terceiros na relação produtiva e a agregação de novas formas de prestação de trabalho humano. Mesmo diante dos novos formatos, não se perde o sentido de uma discriminação ocorrida dentro de uma relação laboral, muito menos da gravidade de seus efeitos. A atmosfera de mudanças nas formas de prestação do trabalho humano impulsiona, ainda mais, a dinamicidade das formas de discriminação nas relações do trabalho. Novas modalidades da prestação de trabalho humano que venham a surgir trarão novas formas de discriminação, com amplas implicações sociais. Tais situações demandarão novas soluções jurídicas para as formas de discriminação que ainda irão surgir.

Duas tendências em termos de normas antidiscriminatórias podem ser verificadas, quando tratam dos efeitos da discriminação: a primeira tendência se funda em uma descrição bastante simplificada da prática discriminatória, portanto, mais abrangente. A segunda tendência se baseia na adoção de descrições específicas, destinadas a atuar restritivamente em situações discriminatórias fundadas em motivos específicos, com a observância de suas características peculiares. A primeira tendência pode parecer menos eficiente, por não possuir uma definição mais precisa e depender de uma interpretação, que pode tomar rumos incompatíveis com a proteção solicitada.

Por outro lado, definições mais detalhadas possuem uma característica de praticidade na sua aplicação e conduzem a uma maior vinculação jurídica do intérprete, porém restritas a motivações específicas. Em face do caráter dinâmico das práticas discriminatórias e do número indefinido de motivos discriminatórios, as normas mais específicas poderão encontrar mais dificuldades para acompanhar e atuar, futuramente, contra novas práticas discriminatórias.

Os efeitos também possuem outro destacado papel na construção de um conceito de discriminação laboral. Eles importam, inicialmente, no reconhecimento de diferentes condições de ser humano entre determinada pessoa ou grupo e o elemento de comparação. E também demonstram outro efeito da discriminação, a anulação ou menoscabo de determinados direitos, vantagens ou benefícios, assegurados ao trabalhador, como também a intensificação da pressão negativa de medidas prejudiciais gerais. A avaliação dos efeitos do ato discriminatório é etapa de suma importância para uma análise da existência de discriminação, bem como componente fundamental para a idealização de medidas efetivas de combate. $\mathrm{O}$ efeito prejudicial é manifesto na prática discriminatória, mas ele pode ser 
ocorrer com formatos muito variados, inclusive alguns que não sejam facilmente verificáveis.

Importante é ressaltar que os efeitos do ato discriminatório laboral não devem estar circunscritos às manifestações prejudiciais dentro da relação de trabalho. Outras práticas discriminatórias, principalmente aquelas motivadas por fatores sociais opcionais, podem manifestar efeitos na relação de trabalho com repercussões exteriores graves. Elas afetam não somente a igualdade de tratamento dentro da relação de trabalho, como também a fruição e o exercício de direitos fundamentais na vida comum do trabalhador, ao comprometer a plenitude de sua condição humana como detentor de direitos. Portanto, um conceito de discriminação mais moderno não deve estar atrelado somente aos efeitos endógenos de sua prática, mas também focar os efeitos exógenos sobre a pessoa do trabalhador e aqueles que o cercam.

A questão da motivação é um dos temas mais tormentosos no estudo da discriminação laboral. Ela possui crucial importância na definição do que possa, ou não, ser permitido em termos de tratamento diferenciado nas relações do trabalho. É um tema delicado, que pode trazer algumas incertezas sobre a conceituação da discriminação laboral, por introduzir o intérprete em um intrincado e complexo sistema de avaliação de uma determinada prática.

Nas relações laborais, a detecção e o aprofundado estudo de um motivo discriminatório são etapas fundamentais para uma precisa averiguação de uma conduta diferenciadora. Algumas diferenciações no âmbito laboral possuem estreitas possibilidades de serem admitidas, em face da necessidade da atividade do empregador ou contratante, bem como pelo fato de sua proibição gerar prejuízos demasiados a trabalhadores, empregador ou terceiros. O relacionamento entre o motivo do trato diferenciado e a necessidade da medida diferenciadora é componente essencial para o juízo da sua proporcionalidade, com estreitas possibilidades que não podem ser alargadas, com riscos do comprometimento de todo o sistema protetivo. Assim, na discriminação laboral, a identificação do seu motivo é inafastável, passo a ser tomado para sua caracterização. O juízo de proporcionalidade também é uma etapa imprescindível, que deve ser enfrentado quando admitida uma prática diferenciadora pelo agente, com alegação de alguma necessidade ou manifesto risco.

A constatação de um tratamento diferenciado motivado, reconhecido pelo ordenamento positivado como proibido não levará ao reconhecimento automático de uma 
prática discriminatória. Impõe-se a consideração de um princípio antidiscriminatório laboral no qual as necessidades da atividade empresarial, bem como situações de risco ou exigências de proteção do trabalhador, da atividade empresarial ou de terceiros, são justificativas capazes de autorizar práticas diferenciadoras. Nem toda prática diferenciadora deve ser considerada discriminatória, existem algumas situações excepcionais que retiram o seu caráter de antijuridiciadade, uma vez que os direitos fundamentais não são absolutos. Tais situações, fundadas na necessidade do negócio ou em uma exigência imprescindível para que a atividade produtiva não gere outros riscos, permitem adotar certos tratamentos diferenciados como válidos. Tais situações, apesar de constituírem diferenciações explícitas e motivadas, podem ser consideradas juridicamente aceitáveis se demonstrarem sua necessidade, pertinência, a não existência de outro meio e adequação da forma adotada com determinada necessidade essencial. A avaliação de tais critérios será feita adotando-se o juízo de proporcionalidade e os três componentes mencionados. No entanto, a possibilidade da permissão de quebras do dever de trato igual deve ser apreciada de forma muito restrita e sua demonstração deverá ser feita de forma cabal e irrefutável, por parte do autor da prática diferenciadora ou seu beneficiário.

Os motivos da conduta diferenciadora não estão restritos somente ao rol daqueles previstos nas normas positivadas; qualquer motivo pode caracterizar uma postura discriminatória. Trata-se de outro princípio que deve ser considerado, no qual o rol de motivos em qualquer norma antidiscriminatória é exemplificativo, salvo se esta expressamente determinar como taxativo. Para que um motivo não previsto nas normas antidiscriminatórias seja considerado como fundamento da discriminação bastará, tão somente, que ele seja decisivo no tratamento diferenciado e não encontre uma justificativa adequada conforme os parâmetros de proporcionalidade acima explicitados. A falta de proporcionalidade e justificativa aceitável para a medida diferenciadora levará à consideração de sua arbitrariedade, com a possibilidade de ser considerada discriminatória, caso estejam presentes os demais componentes. O motivo envolvido na atitude diferenciadora também será importantíssimo no exame de sua juridicidade, eis que, dependendo da sua natureza e do grau de proteção que o ordenamento procure dar, o rigor no exame da proporcionalidade deverá ser ajustado de forma gradativa à necessidade que o grupo envolvido demande.

Uma das mais graves e complexas formas de discriminação verificadas é aquela que envolve diversos motivos. A interseccionalidade de motivos discriminatórios configura 
uma realidade peculiar, que potencializa os efeitos da prática discriminatória. A interseccionalidade solicita uma análise especial e muito distinta comparativamente com o exame isolado de cada motivo e a soma dos seus efeitos. A realidade tem demonstrado que as discriminações interseccionais são as piores formas de discriminação encontradas na sociedade atual, posto que os motivos se sobrepõem e agravam exponencialmente seus nefastos efeitos prejudiciais.

A intencionalidade da prática discriminatória é um elemento importante tão somente para a finalidade de classificação da discriminação laboral, uma vez que não é componente essencial para a caracterização de uma prática discriminatória. Práticas diferenciadoras não intencionais podem, perfeitamente, ser consideradas como discriminatórias, desde que atinjam desproporcionalmente determinado grupo, causando situação de desvantagem aos seus integrantes.

Uma divisão entre discriminação intencional e discriminação não intencional parece ser a forma mais adequada para ocupar o lugar das expressões discriminação por tratamento adverso ou discriminação direta, como também para discriminação por impacto adverso ou discriminação indireta. As terminologias usualmente adotadas nas cortes europeias e norte-americanas não demonstram ser as mais precisas para a distinção entre as duas modalidades discriminatórias, na medida em que não menciona o elemento nuclear que as distingue - a intencionalidade.

O reconhecimento dos critérios para a consideração de uma discriminação não intencional é um aspecto importantíssimo para o combate à discriminação laboral. Tais critérios são fundamentais para o reconhecimento de situações discriminatórias voltadas contra grupos historicamente prejudicados, que sofrem ao longo dos tempos os efeitos de uma reiterada prática discriminatória. Para tanto, não basta que o direito assuma uma postura meramente proibitiva; a proteção contra a discriminação deverá ir bem além para cumprir a ordem de igualdade substancial entre os seres humanos. São necessárias ações mais arrojadas e focadas na realidade vivida pelos grupos prejudicados, para que o combate à discriminação seja mais efetivo na promoção de oportunidades iguais com igual respeito da dignidade humana de cada componente. As discriminações podem ocorrer mesmo sem qualquer intenção do empregador ou do tomador de serviços. As marcas de uma discriminação sistemática exercida ao longo de tantos anos não serão imediatamente apagadas pela proibição da discriminação em uma realidade social excludente, principalmente no inconsciente das mentes dos integrantes dos grupos dominadores. 
Nesse sentido, as discriminações positivas, incluindo-se as ações afirmativas, são medidas juridicamente reconhecidas para o combate da discriminação, com excelentes propósitos de cessar os efeitos de uma prática discriminatória consolidada no passado. As discriminações positivas são amplamente permitidas pelos diplomas antidiscriminatórios internacionais, como forma de promoção de grupos historicamente prejudicados. A Constituição brasileira de 1988 acolhe perfeitamente tais iniciativas, principalmente no ambiente laboral, como meio efetivo de correção das desigualdades sociais, em plena consonância com os propósitos mais elevados da ordem constitucional nacional. Somente será possível reverter tendências discriminatórias de nossa sociedade contra tais grupos quando forem estabelecidas desigualdades artificiais em favor dos grupos historicamente discriminados. A atual estruturação social, constituída em épocas nas quais a proteção discriminatória sequer era imaginada, tenderá a impulsionar a exclusão das minorias, ainda que inercialmente, sem que haja respeito à sua diversidade e à sua identidade.

As discriminações nas relações de trabalho podem ocorrer desde o período de formação do contrato, durante seu desenvolvimento e mesmo após seu término. O combate às discriminações nas fases pré e pós-contratual também merece a mesma importância que as discriminações verificadas no transcorrer do contrato. Graves violações dos direitos fundamentais são praticadas em tais períodos, em especial na admissão, tendo origem em uma relação de trabalho a ser futuramente concretizada, ou já desfeita, sem perder o nexo de causalidade com o liame laboral.

O assédio e o assédio sexual são formas de discriminação que devem ser duramente combatidas. Sua caracterização como discriminação e a adoção dos mesmos métodos de apuração, bem como dos mesmos remédios para sua reparação, são estratégias fundamentais para sua eliminação. Tais modalidades discriminatórias são praticadas de forma quase imperceptível, dificultando bastante o seu combate e sua prova em Juízo. Seus resultados são extremamente graves, posto que atentam frontalmente contra a liberdade e a dignidade do ser humano.

A discriminação retaliatória deve ser vista com muito maior atenção, posto que é uma prática discriminatória voltada a desconstituir os efeitos da própria proteção antidiscriminatória. A falta de efetividade no combate da discriminação retaliatória é um gravíssimo dano à eficácia da proteção antidiscriminatória. A vítima de uma prática discriminatória deve gozar de proteções adequadas contra uma perseguição de seu empregador ou tomador de serviços, principalmente depois de efetivar alguma queixa ou 
aforar ação por motivos discriminatórios. A declaração da ineficácia de atos retaliatórios praticados pelo empregador ou pelo tomador de serviços é um excelente mecanismo para procurar estancar os efeitos dessa terrível modalidade discriminatória.

O princípio da proibição da discriminação é, também, um princípio do direito do trabalho, com uma importância destacada entre os demais princípios, na medida em que também integra o princípio protetor. Toda e qualquer situação laboral será abrangida pela proibição da discriminação nas relações do trabalho, possuindo um grande efeito reflexivo sobre todas as normas laborais, tal qual foi reconhecido pela Declaração de 1998 da OIT. A proibição da discriminação atinge todas as normas laborais, inclusive as normas coletivas e as normas regulamentares da empresa, que somente poderão adotar práticas diferenciadoras dentro do estreito campo das possibilidades de trato diferenciado.

O tratamento igualitário deve ser presumido como medida justa, gerando uma série de importantes desencadeamentos, após constatada uma prática diferenciadora, tornando-se um princípio do direito antidiscriminatório laboral. $\mathrm{O}$ tratamento desigual gera o dever de justificação adequada dos motivos do comportamento diferenciado pela parte que o instituiu. Uma vez não justificado e presentes os demais componentes, a diferenciação será compreendida como prática discriminatória. Este princípio traz dois reflexos importantes: no campo do direito material, implica a obrigação de o autor da prática justificar proporcionalmente o tratamento diferenciado, caso contrário poderá ser considerado antijurídico se presentes os demais componentes. Já no ramo do direito processual, implicará, ao ser constatado um tratamento diferenciado mediante indícios razoáveis de sua existência, a inversão do ônus da prova tanto para desmanchar os referidos indícios como para provar os fatos controversos que sustentam a justificativa do empregador ou contratante de serviços.

O exercício do direito de ação nas questões que envolvam discriminação não poderá estar sujeito a restrições temporais. A gravidade dos efeitos da discriminação e a natureza dos direitos envolvidos não autorizam que seja consumado qualquer prazo prescricional, tal qual ocorre com os demais direitos fundamentais. As questões discriminatórias devem ser consideradas imprescritíveis, posto que sujeitá-las ao regime prescricional comum é um posicionamento desproporcional que fomenta, demasiadamente, a continuidade das práticas discriminatórias, atuando contra todo o sistema protetivo.

As dificuldades de obtenção de provas são notórias nos processos que envolvem discriminação laboral. Em face da sabida escassez de provas, a sua apreciação deve ser 
realizada com menor rigor formal. O julgador deve utilizar, também, outros meios alternativos de prova, bem como o uso de máximas de experiência, presunções, e a adoção das categorias suspeitas para os casos de discriminação mais comuns. Essas práticas processuais facilitam a apresentação de demandas envolvendo a discriminação no trabalho, para que possa ser mais efetiva a proibição da discriminação e procure fazer cumprir o dever de trato igual entre todos os trabalhadores.

Outras modalidades de prova deverão ser aceitas com maior frequência e força probante, entre elas as avaliações sociológicas e as estatísticas, sem prejuízo de outras provas que venham a ser necessárias, mesmo que envolvam outras esferas de conhecimento humano sobre as relações laborais. A gravidade dos efeitos discriminatórios demanda do julgador uma boa parcela de atenção e criatividade na busca dos fatos que sejam necessários para a apreciação da questão, sem ficar limitado aos meios de prova mais comuns utilizados no processo do trabalho.

Para o julgamento de questões envolvendo uma prática discriminatória, o julgador deverá contar com amplo poder discricionário na aplicação de medidas reparatórias. Ao julgador deve ser disponibilizado um amplo leque de opções para reparações efetivas de práticas discriminatórias. A escolha e a dosagem da aplicação de tais medidas deverão ficar a critério do julgador, conforme o caso concreto exigir. A escolha de medidas corretivas não somente deve reparar danos passados, como também deve evitar que tal prática se repita, como forma mais efetiva de obter a eliminação das práticas discriminatórias.

\section{Um conceito de discriminação nas relações do trabalho}

A investigação procurou destacar e reunir os componentes das práticas discriminatórias, bem como avaliar as normas antidiscriminatórias e os mecanismos de proteção contra tais práticas. A reunião de todos os mencionados componentes teve como objetivo localizar e reunir todos os elementos de uma prática discriminatória para, ao final da pesquisa, como propósito nuclear da tese, formular um conceito de discriminação nas relações do trabalho. É certo que tal propósito não é tarefa das mais singelas, como pode ser visto no sexto capítulo. A demonstração da diversidade dos conceitos demonstra que um conceito de discriminação laboral envolve muitos aspectos.

A investigação procurou destacar cada componente essencial da discriminação laboral, mediante um exame mais profundo e preciso de cada um deles, com a avaliação da 
sua importância e do seu alcance. A diferenciação de tratamento, a quebra da igualdade, a importância da proteção contra a discriminação, os sujeitos e os efeitos da discriminação, bem como os motivos, permitem constituir um conceito de discriminação laboral. As modalidades discriminatórias mais comuns e os princípios da proteção contra a discriminação somente vieram a auxiliar tal propósito.

Inicialmente, um conceito sobre a discriminação laboral deverá refletir a existência de um direito a não ser discriminado. É fundamental que o conceito demonstre a existência de uma obrigação a determinadas pessoas de direito público ou privado de respeitar um direito da pessoa humana do trabalhador.

Ao reunir os componentes é possível observar uma diferença de tratamento entre pessoas ou grupos de pessoas, que pertencem a determinado grupo social caracterizado por determinado fator comum, conhecido como motivo. Qualquer medida que gere tratamento diferenciado deve possuir uma relação de proporcionalidade com as necessidades que justificam sua criação. Assim, o motivo é um aspecto fundamental para o conceito da prática discriminatória.

O conceito de prejudicialidade adotado pelas normas europeias e norte-americanas, expressado pela simples definição da expressão tratamento menos favorável, é razoavelmente capaz de exprimir os reflexos prejudiciais causados tanto na discriminação intencional como na não intencional. A capacidade da expressão para refletir os sintomas das duas mencionadas modalidades afasta qualquer necessidade de conceitos distintos para cada uma delas. E sua característica extremamente abrangente a torna ideal para integrar um conceito de discriminação nas relações do trabalho, por possuir a capacidade de atingir um número muito significativo de resultados desfavoráveis das práticas discriminatórias.

No que tange aos efeitos, a definição dada pelo conceito de discriminação da Convenção para eliminação de todas as formas de discriminação contra a mulher, da ONU, parece ser a melhor indicada para servir de base ao conceito, ainda que mereça pequenos reparos. A proteção à diferença de tratamento originalmente estabelecida na Convenção $\mathrm{n}^{\circ}$ 111 da OIT também não pode ser deixada de lado. A possibilidade de existência de um tratamento segregacionista, sem que traga efeitos prejudiciais perceptíveis, não pode ser permitida de forma alguma. Ainda que não venha prejudicar a fruição de direitos, atenta contra a mesma dignidade que todo o ser humano deve receber. Assim, o conceito de discriminação mais adequado deverá proteger os direitos da vítima, a igualdade de 
oportunidades, e não permitir a diferença de tratamento entre pessoas em condições assemelhadas.

O elemento de justificação da conduta diferenciadora, como princípio antidiscriminatório nas relações do trabalho, não pode ser deixado de lado. Já foi amplamente analisada a possibilidade de justificação de condutas diferenciadoras, ainda que de modo restrito. O conceito deverá, então, agregar essa possibilidade, ainda que sinteticamente, para expressar sua natureza eminentemente restrita. As exceções de uma prática discriminatória podem ser muitas, dependendo do motivo abordado e do grau de proteção que pretenda ser aplicado. Assim, parece ser recomendável que elas não integrem o conceito de discriminação, caso contrário esse poderá ser um conceito demasiadamente alongado.

Em termos de efeitos, esses podem ser voltados contra a vítima, bem como contra as pessoas que a cercam ou que mantêm convívio próximo a ela, por algum motivo. A Convenção dos direitos da criança da ONU aponta, com muito acerto, que a discriminação pode ser reflexiva, ou seja, ela também ocorre contra as demais pessoas que convivem com a pessoa a ser protegida por um diploma específico. Nas relações de trabalho, tal situação assume crucial importância, na medida em que parentes ou agregados do trabalhador poderão constituir fatores discriminatórios por parte de um empregador ou contratante, em prejuízo dos interesses da pessoa humana do trabalhador que não integre o grupo relacionado a um fator que motive a conduta discriminatória. Assim, o conceito de discriminação no trabalho deve acolher os efeitos reflexos da discriminação por afinidade ou proximidade.

É importante frisar que um conceito sobre discriminação laboral deverá abranger a questão temporal, ou seja, abordar todas as possibilidades de discriminação em uma relação de trabalho. Assim, o conceito deve abranger as práticas discriminatórias antes da formação da relação, durante a sua realização, até seu desfazimento, e mesmo após o término da relação de trabalho. As possibilidades de ocorrência de discriminação précontratual e pós-contratual são tão importantes como as questões ocorridas no transcurso do contrato de trabalho.

Assim, ao reunir os elementos anteriormente apontados, é possível afirmar que todo trabalhador tem o direito a não sofrer tratamento diferenciado menos favorável que o dispensado a outra pessoa ou grupo, em decorrência de uma relação de trabalho, praticado por qualquer pessoa ou resultante de uma situação de afinidade pessoal de 
qualquer natureza, antes de sua celebração, durante seu transcurso ou depois de seu término, por qualquer motivo que não possa ser justificado mediante os critérios de proporcionalidade e que tenha por objeto ou resultado prejudicar ou anular o reconhecimento, gozo ou exercício dos direitos laborais ou os direitos humanos e liberdades fundamentais de qualquer natureza, em qualquer campo e aspecto da vida laboral, privada ou pública.

Trata-se de um conceito extenso e amplo, sem dúvida alguma. No entanto, apesar de amplo, não é minucioso, e suficientemente flexível, para que possa acolher o maior número de práticas discriminatórias nas relações do trabalho. A proposta da investigação não é moldar um conceito definitivo, mas tão somente estabelecer um ponto de partida para outros estudos sobre o tema. Sua contribuição reside em propiciar algumas linhas gerais para definir o que seja uma prática discriminatória mediante a análise de algumas situações mais comuns. A definição de um conceito pretende auxiliar o combate dessa terrível e nefasta prática, ainda muito comum.

Todo o trabalho de pesquisa foi sustentado e incentivado pela esperança de que, parafraseando Martin Luther King, sonhamos, um dia, que todos os seres humanos sejam igualmente respeitados e cujas diferenças não sejam mais motivo para sofrimento. A riqueza e a beleza da diversidade humana deverão ser celebradas como o marco inicial da realização da fraternidade e da solidariedade entre os homens, o único caminho rumo a uma existência pacífica e feliz. 


\section{REFERÊNCIAS BIBLIOGRÁFICAS}

ACKERMAN, Mario E. La Negociacion colectiva como instrumento para la aplicación del Convenio 111 de la OIT. Revista do Ministério Público do Trabalho, Brasília, ano 10, n. 19, p. 37-54, mar. 2000.

ALEXY, Robert. Teoria de los derechos fundamentales. 3. reimpr. Trad. para o espanhol de Ernesto Garzón Valdés. Madrid:Centro de Estúdios Políticos e Constitucionales, 2002.

ALTLAW. Barbara ZAMLEN; Charleen Cuffari; Sharon Pirosko; Leana Adkins; Jennifer Garuccio; Concetta K. Zingale; and Diane Horne, Plaintiffs-Appellants, v. The CITY OF CLEVELAND, Defendant-Appellee, George V. Voinovich, Defendant. 53 Fair Empl.Prac.Cas. 70; 906 F.2d 209; 59 USLW 2026; 30 Fed. R. Evid. Serv. 555. Disponível em: <http://www.altlaw.org/v1/cases/499660>. Acesso em: 13 out. 2009.

ALVES, J. A. Lindgren. A conferência de Durban contra o racismo e a responsabilidade de outros. Revista Brasileira de Política Internacional, Rio de Janeiro, ano 45, n. 2, p. 198223, 2002.

ALVES, Ricardo de Paula. Considerações sobre o princípio de não-discriminação em direito comunitário: novas perspectivas em relação ao direito laboral. Revista de Direito do Trabalho. São Paulo, n. 101, p. 108-126, jan./mar. 2001.

AMARAL JÚNIOR, Alberto do. Introdução ao direito internacional público. São Paulo: Atlas, 2008.

AMERICAN HERITAGE DICTIONARY. Rev. ed. of American Heritage dicitionary of english language. New College ed. 1976.

ANDRADE, José Carlos Vieira de. Os direitos fundamentais na Constituição portuguesa de 1976. 2. ed. Coimbra: Almedina, 2001.

APPIO, Eduardo. Direito das minorias. São Paulo: Ed. Revista dos Tribunais, 2008.

ARAÚJO, Luiz Alberto David. Buscando significados a partir de critérios de interpretação constitucional e, muitas vezes, encontrando um desconcertante preconceito. In:

(Coord.). Defesa dos direitos das pessoas portadoras de deficiência. São Paulo:Editora Revista dos Tribunais, 2006. p. 207-220.

ARENDT, Hannah. As origens do totalitarismo. Trad. Roberto Raposo. São Paulo: Cia. Das Letras, 1989.

ARISTÓTELES. Ética a Nicômacos. Trad. Mário da Gama Kury. 4. ed. Brasília: Ed. Universidade de Brasília, 2001. 
BAGHWATI, Jagdish. Borders beyond control. Foreign Affairs. New York, v. 82, n. 1, p. 98-104, Jan./Feb. 2003.

BAMFORTH, Nicholas. Conceptions of anti-discrimination law. Oxford Journal of Legal Studies, v. 24, n. 4, p. 693-716, Dec. 2004.

BARBAGELATA, Hector-Hugo. Los Convenios 100, 111 e 156 ratificados por la Ley n ${ }^{\circ}$ 16.063 e a eliminação da discriminação na matéria de emprego e ocupação. Cuadernos. Facultad de Derecho y Ciencias Sociales, Montevideo, n. 15, 1990.

BARBERA, Marzia. Discriminazione ed eguaglianza nel diritto del lavoro. Milano: Giuffré, 1991.

BARNARD, Catherine. EC employment law. Chichester: John Wiley \& Sons, 1998.

BARROS, Alice Monteiro de. Discriminação no emprego por motivo de sexo. In: VIANA, Márcio Túlio; RENAULT, Luiz Otávio Linhares (Coords.). Discriminação. São Paulo: LTr, 2000. p. 36-76.

BARROSO, Luis Roberto. Razoabilidade e isonomia no direito brasileiro. In: VIANA, Márcio Túlio; RENAULT, Luiz Otávio Linhares (Coords.). Discriminação. São Paulo: LTr, 2000. p. 28-35.

BASTOS, Celso Ribeiro. Curso de direito constitucional. 17. ed. São Paulo: Saraiva, 1996. BEFORT, Stephen F. BFOQ Revisited: Johnson Controls Halts the Expansion of the Defense to Intentional Sex Discrimination. Ohio State Law Journal, n. 52, 1991, p. 5-47, 1991. Lexis Nexis. Disponível em: $<$ http://www.lexisnexis.com/us/lnacademic/search/journalssubmitForm.do>. Acesso em: 04 out. 2009.

BELTON, Robert. Causation and burden-shifiting doctrines in employment discrimination law revisited: some thoughts on Hopkins and Wards Cove. Tulane Law Review, v. 64, n. 6, p. 1359-1406, June 1990.

; AVERY, Dianne. Employment discrimination law. 6. ed. St. Paul: West Publishing Co., 1999.

BHAGWATI, Jagdish. Illegal immigrants deserve to be treated with decency. The Financial Times, Londres, 25 July 2007.

BILBAO UBILLOS, Juan Maria. Prohibición de discriminación y relaciones entre particulares. Teoria y Realidad Constitucional, Madrid, n. 18, p. 147-189, 2006.

BLACK, Henry Campbell. By the publisher's editorial staff. Black's Law Dictionary. 6. ed. St. Paul: West Publishing Co., 1990. 
BLOCH, Oscar. Dictionnaire étymologique de la langue française. 8. ed. Paris: Presses Universitaires de France, 1989.

BLUMROSEN, Alfred W. The law transmission system and the Southern Jurisprudence of Employment Discrimination. Industrial Relations Law Journal, vol. 6, 1984. In: DONOHUE III, John J. (Coord.). Foundations of employment discrimination law. 2. ed. New York: Foundation Press, 2003.

BLUTEAU, Raphael. Vocabulário portuguez e latino. Edição facsimilada. Hildesheim: Georg Olms Verlag, 2002. v. 3.

BOBBIO, Norberto. A era dos direitos. Trad. Carlos Nélson Coutinho. Rio de Janeiro: Campus, 1992.

- Igualdad y libertad. Tradução para o castelhano de Pedro Aragón Rincón. Barcelona: Ed. Paidós Ibérica, 1993.

. Teoria geral da política. Trad. Daniela Beccacia Versiani. Rio de Janeiro: Campus, 2000.

BONAVIDES, Paulo. Curso de direito constitucional. 24. ed. São Paulo: Malheiros, 2009.

BONNARD-PLANCKE, Laetitia; VERKINDT, Pierre-Yves. La lute contre la discrimination syndicale Millésime 2005. Droit Social, Paris, n. 4, p. 393-401, abr. 2006.

BOSSUYT, Marc. L'interdiction de la discrimination dans le droit International des droits d'homme. Bruxelas: Étabilissements Émile Bruylent, 1976.

BOUCINHAS FILHO, Jorge Cavalcanti. Discriminação por sobrequalificação. São Paulo: LTr, 2009.

BRITO FILHO, José Cláudio Monteiro de. Discriminação no trabalho. São Paulo: LTr, 2002.

BROWNE. Kingsley R. Statistical proof of discrimination:beyond "Damned Lies". Washington Law Review, vol. 68, 1993. In: DONAHUE, John J. Foundations of employment discrimination law. 2. ed. New York: Foundation Press, 2003. p. 313-317.

CAMPOS, Sergio J. Subordination and the fortuity of our circumstances. University of Michigan Journal of Law Reform, n. 41, Primavera 2008, p. 585-667. Lexis Nexis. Disponível em: <http://www.lexisnexis.com/us/lnacademic/search/homesubmitForm.do>. Acesso em: 13 set. 2009.

CANOTILHO, Joaquim José Gomes. Direito constitucional. 6. ed. Coimbra: Almedina, 1993.

. Direito constitucional e teoria da Constituição. 6. ed. Coimbra: Almedina, 2002. 
CANOTILHO, Joaquim José Gomes. Enquadramento jurídico da imigração. ALTO COMISSARIADO PARA A IMIGRAÇÃO E MINORIAS ÉTNICAS. Congresso Imigração em Portugal: Diversidade - Cidadania - Integração.1. Lisboa.2003 - Actas do I Congresso Imigração em Portugal: Diversidade-Cidadania-Integração (Org.). Alto Comissariado para a Imigração e Minorias Étnicas, ISBN 972-98959-9-6, 1-Portugal, p. 153-154.

Disponível

em:

$<$ http://www.oi.acidi.gov.pt/modules.php?name=Content\&pa=showpage\&pid=15>.

Acesso em: 26 nov. 2008.

CASTLES, Stephen; MILLER, Mark J. The age of migration. 3. ed. New York: The Gilford Press, 2003.

CASTRO, Carlos Roberto Siqueira. A constituição aberta e os direitos fundamentais: ensaios sobre o constitucionalismo pós-moderno e comunitário. Rio de Janeiro: Forense, 2003.

CAVARZERE, Thelma Thais. Direito internacional da pessoa humana: a circulação internacional de pessoas. Rio de Janeiro: Renovar, 1995.

CHOLEWINSKI, Ryszard. Borders and discrimination. Immigration law practitioners'association/ Migration Policy Group, p.V. Sítio de IMMIGRATION LAW PRACTITIONERS' ASSOCIATION. Disponível em: $<$ http://www.ilpa.org.uk/publications/borders_exec_summary.pdf>. Acesso em: $07 \mathrm{dez}$. 2008 .

CHOLEWINSKI, Ryszard. The protection of the right of economic migrants to family reunion in Europe. International and Comparative Law Quarterly, Cambridge, v. 43, pt. 3, p. 568-598, July 1994.

CIANCIARDO, Juan. El principio de razonabilidad. Buenos Aires: Editorial Ábaco de Rodolfo Depalma, 2004.

COHEN, Robin. Global diasporas. Seattle: University of Washington Press. 1997.

COLKER, Ruth. Anti-subordination above all: sex, race, and equal protection. New York University Law Review, Dec. 1986, nº 61, p. 1003-1066. Lexis Nexis. Disponível em: $<$ http://www.lexisnexis.com/us/lnacademic/results/docview/docview.do?docLinkInd=true $\&$ risb $=21 \_$T7334624754\&format $=$GNBFI\&sort $=$BOOLEAN\&startDocNo $=1 \&$ resultsUrlK ey=29_T7334624759\&cisb=22_T7334624758\&treeMax $=$ true \&treeWidth $=0 \& c s i=7351 \& d$ ocNo=11>. Acesso em: 13 jan. 2009.

COMPARATO, Fábio Konder. A afirmação histórica dos direitos humanos. 3. ed. rev. e atual. São Paulo: Saraiva, 2003.

A afirmação histórica dos direitos humanos. 4. ed. rev. e atual. São Paulo: Saraiva, 2005. 
CRENSHAW, Kimberlé. Mapping the Margins: Intersectionality, Identity Politics, and Violence Against Women of Color. Stanford Law Review. Julho 1991. No 43, p. 12411299. Lexis Nexis. Disponível em: $<$ http://www.lexisnexis.com/us/lnacademic/results/docview/docview.do?docLinkInd=true \&risb=21_T7543680835\&format=GNBFI\&sort=BOOLEAN\&startDocNo=51\&resultsUrl $\mathrm{Key}=29 \_\mathrm{T} 7543680839 \& \mathrm{cisb}=22 \_\mathrm{T} 7543680838 \&$ treeMax $=$ true $\&$ treeWidth $=0 \& \mathrm{csi}=7353$ $\&$ docNo=53>. Acesso em: 18 out. 2009.

CUNHA, Antonio Geraldo da. Dicionário etimológico Nova Fronteira da língua portuguesa. 2. ed. Rio de Janeiro: Nova Fronteira, 1982.

CYFER, Ingrid. Convenção sobre a Eliminação de Todas as Formas de Discriminação Racial (1965). PERRONE-MOISÉS, Claudia; ALMEIDA, Guilherme Assis de (Coord.). Direito internacional dos direitos humanos: instrumentos básicos. 2. ed. São Paulo:Atlas, 2007.

DALLARI, Pedro Bohomoletz de Abreu. Desafios da globalização. In: DOWBOR, Ladislau; IANNI, Octavio; RESENDE, Paulo-Edgar A. (Orgs.). Globalização. Petrópolis:Vozes, 2002. p. 252-255.

DAMAS, Joaquim Augusto Domingos. O princípio da igualdade na relação jurídica de trabalho. Revista Jurídica do Trabalho, ano 1, v. 1, abr./jun. 1988.

DANZAT, Albert; DUBOIS, Jean; MITTERAND, Henri. Dictionnaire étymologique et historique du français. Paris: Larousse, 1993.

DELGADO, Maurício Godinho. Proteções contra discriminação na relação de emprego. In: VIANA, Márcio Túlio; RENAULT, Luiz Otávio Linhares (Coords.). Discriminação. São Paulo: LTr, 2000. p. 97-108.

DIHN, Nguyen Quoc; DAILLER, Patrick; PELLET, Alain. Direito internacional público. Trad. de Vítor Marques Coelho. 4. ed. Lisboa: Fundação Calouste Gulbenkian, 1999.

DOBBIN, Frank; SUTTON, John R.; MEYER, John W.; SCOTT, W. Richard. Equal opportunity law and the construction of internal labor markets. American Journal of Sociology, vol. 99, 1993. In DONOHUE III, John J. Foundations of employment discrimination law. 2. ed. New York: Foundation Press, 2003. p. 282-293.

DOLLOT, Louis. Les migrations humanaines. Paris: Presses Universitaires de France, 1970.

DONOHUE, John J., III. Employment discrimination law in perspective: three concepts of equality. Michigan Law Review, Ann Arbor, v. 92, n.8, p.2583-612, Aug. 1994. Lexis Nexis, Disponível em: $<$ http://www.lexisnexis.com/us/lnacademic/auth/checkbrowser.do?ipcounter=1\&cookieSta te $=0 \&$ rand $=0.7214586677334796 \& b h c p=1>$. Acesso em: 31 ago. 2009. 
DONOHUE, John J., III. Foundations of employment discrimination law. 2. ed. New York: Foundation Press, 2003.

DRAY, Guilherme Machado. O princípio da igualdade no direito do trabalho. Coimbra: Almedina, 1999.

DUBUGRAS, Regina Maria Vasconcelos. Discriminação no emprego: formas, defesas e remédios jurídicos. LTr: revista legislação do trabalho, São Paulo, ano 66, n. 11, p. 1335, nov. 2002.

DWORKIN, Ronald. Sovereign virtue: the theory and practice of equality. Cambridge: Harvard University Press, 2002.

ERMIDA URIARTE, Oscar. Derechos laborales e comércio exterior. Ponencia presentada al V Congreso Regional Americano de Derecho del Trabajo y de la Seguridad Social, Lima 2001. Universidad de la República. Facultad de Derecho. Instituto de Derecho del Trabajo y Seguridad Social. Disponível em: <http://www.rau.edu.uy/universidad/inst_derecho_del_trabajo/derlabermida.htm>. Acesso em: 23 ago. 2008.

ERNOUT, A.; MEILLET, A. Dictionnaire étymologique de la langue latine: histoire de mots. 4. ed. Paris: C. Klincksieck, 1959.

ESPINOZA, Olga. Convenção sobre a Eliminação de Todas as Formas de Discriminação Contra a Mulher. PERRONE-MOISÉS, Claudia; ALMEIDA, Guilherme Assis de (Coord.). Direito internacional dos direitos humanos: instrumentos básicos. 2. ed. São Paulo:Atlas, 2007.

ESPÓSITO, Carlos. The European Union response towards Racism. Revue des Affaires Européennes, Paris, n. 1-2, p. 118-127, avr. 2000.

FARIA, Ernesto. Dicionário escolar latino-português. Revisão de Ruth Junqueira de Faria. 5. ed. Rio de Janeiro:FENAME, 1975.

FELICIANO, Guilherme Guimarães. Distribuição dinâmica do ônus da prova no processo do trabalho : critérios e casuística. Revista do Tribunal Regional do Trabalho da $15^{a}$ Região, Campinas, v. 32, n. 32, p. 103-112, jan./jun. 2008.

FELLMETH, Aaron. Human rights: nondiscrimination as a Universal Human Right. The Yale Journal of International Law, no 34, Verão 2009, p. 588-595. Nexis Lexis. Disponível em:

<http://www.lexisnexis.com/us/lnacademic/results/docview/docview.do?docLinkInd=true $\&$ risb=21_T7498424111\&format=GNBFI\&sort=RELEVANCE\&startDocNo=1\&resultsU rlKey=29_T7498424114\&cisb=22_T7498424113\&treeMax =true\&treeWidth=0\&csi=1728 $60 \&$ docNo=11>. Acesso em: 04 out. 2009. 
FERNANDES, Francisco. Dicionário de sinônimos e antônimos da língua portuguesa. 3. ed. rev. e ampl. por Celso Pedro Luft. Porto Alegre:Globo, 1980.

FERNÁNDEZ LÓPEZ, Maria Fernanda. La prohibición de discriminación en el marco internacional y en el derecho de la Unión Europea. Revista de Derecho Social Latinoamérica, Buenos Aires, n. 2, p. 65-88, 2007.

FERRAJOLI, Luigi. Igualdad y diferencia: derechos y garantias: la ley del más débil. Trad. de Perfecto Andrés Ibañez y Andrea Greppi. 3. ed. Madrid: Trotta, 2002.

La igualdad y sus garantias. In: SARLO, Oscar; BLANCO, Andrés (Coord.). El princípio de igualdad en la teoría del derecho y la dogmática jurídica. Montevideo: Fundación de Cultura Universitaria, 2008.

FERREIRA, Aurélio Buarque de Holanda. Novo Aurélio século XXI: o dicionário da língua portuguesa. 3. ed. Rio de Janeiro: Nova Fronteira, 1999.

FISS, Owen M. Groups and the Equal Protection Clause. Philosophy and Public Affairs, n. 5, p. 107-177, 1976. Yale Law School. Disponível em: http://www.law.yale.edu/faculty/fisspublications.htm>. Acesso em: 13 set. 2009.

FREDMAN, Sandra. Discrimination law. Oxford: Oxford University Press, 2002.

Equality: A new generation? Industrial Law Journal. June 2001, volume 30, Número 2, ILJ 2001.30(145), Oxford: Oxford Journal Press, p. 145-168. Lexis Nexis, Disponível em: $<$ http://www.lexisnexis.com/us/lnacademic/results/docview/docview.do?risb=21_T724446 $1488 \&$ treeMax $=$ true $\&$ sort $=$ BOOLEAN $\&$ docNo=11\&format $=$ GNBFULL $\&$ startDocNo $=1$ $\&$ treeWidth $=0 \&$ nodeDisplayName $=\&$ cisb $=22 \_$T7244461490\&reloadPage $=$false $>$. Acesso em: 31 ago. 2009.

FREEMAN, Alan. Antidiscrimination law: the view from 1989. Tulane Law Review, v. 64, n. 6, June 1990.

FREITAS JR., Antonio Rodrigues de. Globalização, Mercosul e crise do Estado-Nação: perspectivas para o direito numa sociedade em mudança. São Paulo: LTr, 1997.

FRIEDMAN, Joel W.; STRICKLER Jr., George M. The law of employment discrimination. 5. ed. New York: Foundation Press, 2001.

FUGAZZA, Marco. La discriminación racial. Teorias, hechos y planos políticos. Revista Internacional del Trabajo, Genebra, v. 122, n. 4, p. 557-597, 2003.

GARCIA-PERROTE ESCARTIN, Ignacio. Prova y proceso laboral. Derecho Privado y Constitución, n. 4, p. 163-221, set./dez. 1994.

GARMENDIA ARIGÓN, Mario; GAUTHIER, Gustavo. Tercerizaciones. Montevideo; Fundación de Cultura Universtiária, 2008. 
GHIONE, Hugo Barreto. El derecho a la igualdad y la no discriminación en derecho del trabajo: una revisión crítica. Derecho Social Latinoamérica, N. 4-5, p. 37-58, 2008.

GILBERT, Daphne. Time to Regroup: Rethinking Section 15 of the Charter. McGill Law Journal, $\mathrm{N}^{\mathrm{o}}$ 48, p. 627-649, dezembro de 2003. Lexis Nexis. Disponível em: $<$ http://www.lexisnexis.com/us/lnacademic/results/docview/docview.do?docLinkInd=true $\&$ risb=21_T7498557915\&format=GNBFI\&sort=RELEVANCE\&startDocNo=1\&resultsU $\mathrm{rlKey}=29 \_\mathrm{T} 7498557924 \& \mathrm{cisb}=22 \_\mathrm{T} 7498557918 \&$ treeMax $=$ true \&treeWidth $=0 \& \mathrm{csi}=1527$ $38 \& \operatorname{doc} \mathrm{No}=3>$. Acesso em: 04 out. 2009.

GIUGNI, Gino. Political, religious and private-life discrimination. In: AARON, Benjamim et al. Discrimination at employment: a study of six countries by the comparative labour law Group. Stockholm:Almqvist \& Wiksell International, 1978.

GOLDSTEIN, Eduardo. La discriminación racial por origen nacional y etnia en las relaciones laborales. Montevideo: Fundación de Cultura Universitaria, 2009.

GOMES, Joaquim Barbosa. Ação afirmativa e princípio constitucional da igualdade. Rio de Janeiro: Renovar, 2001.

GORDON, William. The evolution of the disparate impact theory of Title VII: A hypothetical case study. President and Fellows of Harvard College Journal. Verão 2007, $\mathrm{n}^{\circ}$ 44, p. 529-551. Lexis Nexis. Disponível $<$ http://www.lexisnexis.com/us/lnacademic/results/docview/docview.do?docLinkInd=true $\&$ risb=21_T7843595871\&format=GNBFI\&sort=BOOLEAN\&startDocNo $=1 \&$ resultsUrlK ey=29_T7843595878\&cisb=22_T7843595877\&treeMax=true \&treeWidth=0\&csi=143841 $\&$ docNo=3>. Acesso em: 30 ago. 2008.

GOVENDER, Karthy. The developing equality jurisprudence in South Africa. Michigan Law Review First Impressions. Janeiro 2009, no 107, p. 120-123. Lexis Nexis. Disponível em:

<http://www.lexisnexis.com/us/lnacademic/results/docview/docview.do?docLinkInd=true \&risb=21_T7510801140\&format=GNBFI\&sort=RELEVANCE\&startDocNo=226\&results UrlKey=29_T7510801147\&cisb=22_T7510801146\&treeMax $=$ true \&treeWidth $=0 \& c s i=73$ $46 \&$ docNo=233>. Acesso em: 05 dez. 2009.

HÄBERLE, Peter. Hermenêutica constitucional. Trad. Gilmar Ferreira Mendes. Porto Alegre: Sérgio Antonio Fabris Editor, 2002.

La libertad fundamental en el Estado constitucional. Trad. Carlos Ramos, Jürgen Saligmann e César Landa. San Miguel: Fondo Editorial de La Pontificia Universidad Catolica del Peru, 1997.

HABERMAS, Jürgen. A constelação pós-nacional.: ensaios políticos. Trad. Márcio Seligmann Silva. São Paulo: Littera Mundi, 2001. 
HEIDE, Ingeborg. Medidas supracionales contra la discriminación sexual: igualdad salarial y de trato en la Unión Europea. Revista Internacional del Trabajo, Genebra, v. 118, n. 4, 1999.

HEIDEGGER, Martin. O que é isto: a filosofia? Identidade e diferença. Trad. Ernildo Stein. Petrópolis: Vozes, 2006.

HEPPLE, Bob. Igualdad, representación y participación para un trabajo decente. Revista Internacional del Trabajo, Genebra, v. 120, n. 1, p. 5-20, 2001.

; COUSSEY, Mary; CHOUDHURY, Tufyal. Equality: a new framework. Portland: Hart Publishing, 2000.

HERNU, Rémy. Principe d'égalité et principe de non-discrimination dans la jurisprudence de la Cour de Justice des Communautés Européennes. Paris: L.G.D.J., 2003.

HIRIGOYEN, Marie-France. Assédio moral: a violência perversa no cotidiano. Trad. Maria Helena Kühner, 5. ed. Rio de Janeiro: Bertrand Brasil, 2002.

THE HISTORY PLACE. The World War I. Text of President Wilson's Speech. Disponível em: <http://www.historyplace.com/worldhistory/firstworldwar/us-wilson-war-decl.htm>. Acesso em: 21 jul. 2009.

HUECK, Alfred; NIPPERDEY, H.C. Compendio de derecho del trabajo. Trad. M. Rodríguez Piñero e Luís Enrique de la Villa. Madrid: Editorial Revista de Derecho Privado, 1963.

HUNTER, Rosemary C.; SHOBEN, Elaine W. Disparate impact discrimination: american oddity or internationally accepted concept? Berkeley Journal of Employment and Labor Law. $\quad \mathrm{N}^{\mathrm{o}} 19,1998$, p. 108-152. Lexis Nexis. Disponível em: $<$ http://www.lexisnexis.com/us/lnacademic/results/docview/docview.do?docLinkInd=true $\&$ risb=21_T7498584904\&format=GNBFI\&sort=RELEVANCE\&startDocNo=1\&resultsU $\mathrm{rlKey}=29 \_\mathrm{T} 7498584911 \& \mathrm{cisb}=22 \_\mathrm{T} 7498584910 \&$ treeMax $=$ true \&treeWidth $=0 \& \mathrm{csi}=2480$ $45 \&$ docNo=4>. Acesso em: 04 out. 2009.

KAMINSHINE, Steven J. Disparate treatment as a theory of discrimination: the need for a restatement, not a revolution. Stanford Journal of Civil Rights \& Civil Liberties. Stanford. $\mathrm{N}^{\mathrm{o}}$ 1. Novembro 2005, p. 2-61. Lexis Nexis. Disponível em: $<$ http://www.lexisnexis.com/us/lnacademic/results/docview/docview.do?docLinkInd=true $\&$ risb=21_T7509823010\&format=GNBFI\&sort=RELEVANCE\&startDocNo=1\&resultsU rlKey=29_T7509823022\&cisb=22_T7509823021\&treeMax $=$ true \&treeWidth $=0 \&$ selRCNo deID $=25 \&$ nodeStateId $=411$ en_US, $1 \&$ docsInCategory $=850 \& \operatorname{csi}=303824 \&$ docNo $=2>$. Acesso em: 06 out. 2009. 
KATZ, Martin J. Unifying disparate treatment (really). Hastings Law Journal. Fev. 2008, $\mathrm{n}^{\mathrm{o}} \quad 59, \quad$ p. 643-681. Lexis Nexis. Disponível em: http://www.lexisnexis.com/us/lnacademic/results/docview/docview.do?docLinkInd=true\&r isb=21_T7833322973\&format=GNBFI\&sort=BOOLEAN\&startDocNo=1\&resultsUrlKey $=29 \_$T7833322978\&cisb=22_T7833322977\&treeMax $=$true $\&$ treeWidth $=0 \&$ csi $=7341 \&$ doc No=1>. Acesso em: 09 nov. 2009.

KELSEN, Hans. A justiça e o direito natural. Trad. João Baptista Machado. Coimbra: Almedina, 2001.

KERN, Gisela Hildegard. As Directivas 2000/78/CE e 2000/43/CE e a sua transposição no direito privado português. Boletim da Faculdade de Direito da Universidade de Coimbra, Coimbra, v. 80, p. 767-796, 2004.

KLEVEN, Thomas. Why international law favors emigration over immigration. The University of Miami Inter-American Law Review. Florida, v. 33. n.1. p. 69-100, 2002.

LAFER, Celso. A reconstrução dos direitos humanos: um diálogo com o pensamento de Hannah Arendt. São Paulo: Cia das Letras, 1988.

LANQUETIN, Marie-Thérèse. La discrimination à raison du sexe en droit international et communautaire. Droit Social, Paris, n. 12, p. 806-818, dez. 1998.

Discriminations à raison du sexe. Droit Social, Paris, n. 7/8, p. 688-695, jul./ago. 1998.

La preuve de la discrimination:l'apport du droit communautaire. Droit Social, Paris, n. 5, p. 435-441, maio 1995.

. Um tournant en matière de prevue des discriminations. Droit Social, Paris, n. 6, p. 589-593, jun. 2000.

LAWRENCE III, Charles R. The id, the ego, and equal protection: reckoning with unconscious racism. Stanford Law Review, n. 39, p. 317-388, Jan. 1987.

. Unconscious racism revisited: reflections on the impact and origins of "The id, the ego, and equal protection". Connecticut Law Review. Maio/2008, n 40, p. 931-977. Lexis Nexis.

Disponível

$<$ http://www.lexisnexis.com/us/lnacademic/results/docview/docview.do?docLinkInd=true $\&$ risb=21_T7838520840\&format=GNBFI\&sort=BOOLEAN\&startDocNo=1\&resultsUrlK ey=29_T7838520843\&cisb=22_T7838520842\&treeMax $=$ true $\&$ treeWidth $=0 \&$ selRCNodeI $\mathrm{D}=2 \&$ nodeStateId=411en_US, $1,2 \&$ docsInCategory $=27 \& \operatorname{csi}=138398 \&$ docNo=7>. Acesso em: 10 nov. 2009.

LEGOMSKY, Stephen H. Immigration, equality and diversity. Columbia Journal of Transnational Law, New York, v. 31, n. 2, p. 319-336, 1999. 
LEWIS, Charlton T. A latin dictionary: founded on Andrew's edition of Freund's Latin Dictionary. Oxford:Clarendon Press. First Edition 1879 - Impression 1984.

LOCHAK, Daniele. Réflexions sur la notion de discrimination. Droit Social, Paris, n. 11, nov. 1987.

LONGMAN DICTIONARY OF AMERICAN ENGLISH. White Plains:Longman, 1983.

LOPES, Cristiane Maria Sbalqueiro. Discriminação no processo do trabalho: dificuldades de prova de sua ocorrência. Revista LTr, São Paulo, v. 68, n. 12, p. 1437-1445, dez. 2004.

LOUSADA AROCHENA, José Fernando. La prueba de la discriminación y del acoso sexual y moral en el proceso laboral. Revista Âmbito Jurídico. Publicado em 30/04/2007, No 40 - Ano X - ABRIL/2007 - ISSN - 1518-0360. Disponível em: <http://www.ambitojuridico.com.br/site/index.php?n_link=revista_artigos_leitura\&artigo_id=3974>. Acesso em: 27 nov. 2009.

LYON-CAEN, Antoine. L'égalité et la loi en droit du travail. Droit Social, Paris, n. 1, p. 68-75 janv. 1990.

MACHADO, José Pedro. Dicionário etimológico da língua portuguesa. 6. ed. Lisboa: Livros Horizonte, 1990. v. 2.

MAIOR, Jorge Luiz Souto. O direito do trabalho e as diversas formas de discriminação. Revista TST, Brasília, v. 68, n. 2, p. 97-102, abr/jun 2002.

MALLET, Estevão. Discriminação e processo do trabalho. Revista do Tribunal Superior do Trabalho, Brasília, v. 65, n. 1, p. 148-159, out/dez 1999.

MANLEY, Katie. The BFOQ Defense: Title VII's Concession to Gender Discrimination. Duke Journal of Gender Law \& Policy. Janeiro 2009, n 16, p. 169-210. Lexis Nexis. Disponível em: $<$ http://www.lexisnexis.com/us/lnacademic/search/journalssubmitForm.do>. Acesso em: 29 set. 2009.

MANSUETI, Hugo Roberto. Discriminación Laboral e integración normativa. Revista de Direito do Trabalho, São Paulo, ano 33, n. 125, p. 257-266, jan/mar. 2007.

MANUS, Pedro Paulo Teixeira. A prescrição no direito do trabalho. Revista do Tribunal Regional do Trabalho da 15ª Região, v. 1, p. 145-149, 1991.

MARINONI, Luis Guilherme. Formação da convicção e inversão do ônus da prova segundo as peculiaridades do cso concreto. BDJur - Biblioteca Digital Jurídica do Superior Tribunal de Justiça. Mar. 2006. p. 2. Disponível em: http://bdjur.stj.gov.br/xmlui/bitstream/handle/2011/2201/Forma\%c3\%a7\%c3\%a3o_da_Co nvic\%c3\%a7\%c3\%a3o_e_Invers\%c3\%a3o.pdf?sequence=1>. Acesso em: 24 nov. 2009. 
MARTÍNEZ ROCAMORA, Luis Gabriel. Decepciones empresariais y principio de igualdade. Barcelona:Sedes Editorial, 1998.

MARTÍNEZ VIVOT, Julio J. La discriminación laboral: despido discriminatorio. Buenos Aires:Ciudad Argentina; Universidad del Salvador, 2000.

MCKEAN, Warwick. Equality and discrimination under international law. Oxford:Clarendon Press, 1983.

MELlO, Celso Duvivier de Albuquerque. Curso de direito internacional público. 14. ed. Rio de Janeiro: Renovar, 2002. v. 2.

MENDES, Gilmar Ferreira. Direitos fundamentais e controle de constitucionalidade. 2. ed. São Paulo: Celso Bastos, 1999.

MESSINA, Anthony M. The not so silent revolution. World Politics, Baltimore, v. 49, n. 1, p. 130-154, Oct. 1996.

MIRANDA, Francisco Cavalcanti Pontes de. Comentários à Constituição de 1967, com a Emenda $n^{o} 1$ de 1969. 2. ed. São Paulo: Ed. Revista dos Tribunais, 1970. t. 4.

MIRANDA, Jorge. Manual de direito constitucional. 3. ed. Coimbra: Coimbra Ed., 2000. t. 4.

MIZE, Selene. Indirect discrimination reconsidered. New Zealand Law Review. $N^{\mathbf{o}}$, 2007, p.27-79. Lexis Nexis. Disponível em: $<$ http://www.lexisnexis.com/us/lnacademic/results/docview/docview.do?docLinkInd=true \&risb=21_T7456070051\&format $=$ GNBFI\&sort=RELEVANCE\&startDocNo=26\&results UrlKey=29_T7456070057\&cisb=22_T7456070056\&treeMax $=$ true \&treeWidth $=0 \& c s i=24$ $1402 \&$ docNo=44 2909.2009>. Acesso em: 29 set. 2009.

MUNANGA, Kabengele; GOMES, Nilma Lino. O negro no Brasil de hoje. São Paulo: Ed. Global, 2006.

NASCIMENTO, Amauri Mascaro. Princípios do direito do trabalho e direitos fundamentais do trabalhador. Revista LTr, São Paulo, ano 67, n. 8, p. 903-916, ago. 2003.

NIELSEN, Henrik Karl. The concept of discrimination in ILO Convention $\mathrm{N}^{\mathrm{o}} 111$. International and Comparative Law Quarterly, v. 43, n. 4, p.827-856, out. 1994.

NOVAIS, Denise Pasello Valente. Discriminação da mulher e direito do trabalho. São Paulo: LTr, 2005. 
NOWICKI, Marek Antoni The European Convention of Human Rights: prohibition of discrimination. Saint Louis-Warsaw Transatlantic Law Journal, 1999, p. 17-35. Lexis Nexis. Disponível

em: $<$ http://www.lexisnexis.com/us/lnacademic/results/docview/docview.do?docLinkInd=true \&risb=21_T7498643639\&format=GNBFI\&sort=RELEVANCE\&startDocNo=26\&results UrlKey=29_T7498643642\&cisb=22_T7498643641\&treeMax $=$ true \&treeWidth $=0 \& c s i=15$ 6973\&docNo=34>. Acesso em: 04 dez. 2009.

OKEKE, Chris Nwachukwu; NAFZIGER, James A.R. United States migration law: essentials for comparison. The American Journal of Comparative Law. Ann Arbor, v. 54 (supplement), p. 531-552, 2006.

ONLINE Etimology Dictionary. Disponível em: $<$ http://www.etymonline.com/index.php?search=discrimination\&searchmode=none $>$. Acesso em: 20 jul. 2009.

OXFORD UNIVERSITY PRESS. Oxford dictionary of business english. Oxford: Oxford University Press, 1994.

PADEN, John N.; SINGER, Peter W. America slams the door (on its foot). Foreign Affairs, New York, v. 82, n. 3, p. 8-14, May/June 2003.

PAGER, Devah. Medir a discriminação. Trad. de Norberto Guarinello e João Henrique Costa. Tempo Social: revista de sociologia da USP, São Paulo, n. esp., v. 18, n. 2, p. 65-88, nov. 2006.

PALOMEQUE LÓPEZ, Manuel Carlos. O direito constitucional à igualdade e à não discriminação por razão de gênero nas relações de trabalho em Espanha. Revista do Instituto Goiano de Direito do Trabalho, Goiânia, ano 7, n. 9, p. 95-107, nov. 2001.

PAMPLONA FILHO, Rodolfo. Orientação sexual e discriminação no emprego. Revista do Instituto Goiano de Direito do Trabalho, ano 8, n. 9, p. 41-57, nov. 2001.

PASCO COSMÓPOLIS, Mario. Tendências constitucionais em matéria trabalhista. Associação de Magistrados da Justiça do Trabalho da $4^{a}$ Região - AMATRA IV. Disponível em: <http://www.amatra4.org.br/Comunicacao/Artigos/1460>. Acesso em: 23 nov. 2008.

PEDREIRA, Luiz de Pinho. Discriminação indireta. LTr: revista legislação do trabalho, São Paulo, ano, 65, n. 4, p. 402-406, abr. 2001.

O princípio da igualdade de tratamento. LTr: revista legislação do trabalho, São Paulo, ano 60, n. 4, abr. 1996.

PEREIRA, Caio Mario da Silva. Instituições de direito civil. Rio de Janeiro: Forense, 2004. v. 1. 
PERELMAN, Chaïm. Égalité et valeurs. L'Égalité. Bruxelas: Bruylant, 1971. Ética e direito. Trad. Maria Ermantina Galvão. São Paulo:Martins Fontes, 1996.

PÉREZ LUÑO. Antonio E. Derechos humanos, Estado de derecho y Constitución. 7. ed. Madrid: Tecnos, 2001.

PESSI, Roberto. Lavoro e discriminazione femminile. In: LAVORO e discriminatione: Atti dell'XI Congresso Nazionale de Direito Del Lavoro Gubbio, 3-5 Giugno 1994. Milano: Giuffrè, 1996.

PETERS, Christopher J. The Roberts Court at age three: under-the-table overruling. The Wayne Law Review. No 54, outono 2008, p. 1067-1103. Lexis Nexis. Disponível em: http://www.lexisnexis.com/us/lnacademic/results/docview/docview.do?docLinkInd=true\&r isb=21_T7864993532\&format=GNBFI\&sort=RELEVANCE\&startDocNo=1\&resultsUrlK ey $=29 \_$T7864993537\&cisb=22_T7864993536\&treeMax $=$true $\&$ treeWidth $=0 \& c s i=145282$ $\&$ docNo=16>. Acesso em: 12 nov. 2009.

PLÁ RODRIGUEZ, Américo. Nuevos aportes sobre la proteción a la intimidad del trabajador. In: RIBEIRO, Lélia Guimarães Carvalho; PAMPLONA FILHO, Rodolfo (Coords.). Direito do trabalho: estudos em homenagem ao Prof. Luiz de Pinho Pedreira da Silva. São Paulo: LTr, 1998.

. Princípios de direito do trabalho. Trad. de Wagner D. Giglio. 3. tir. São Paulo: LTr; Ed. da Universidade de São Paulo, 1994.

PLAYER, Mack. Employment discrimination law. St. Paul:The West Group, 1988.

PRENKERT, Jamie Darin. The role of second-order uniformity in disparate treatment law: McDonnell Douglas's longevity and the mixed-motives mess. American Business Law Journal. Outono/2008, $\mathrm{n}^{\mathrm{o}}$ 45, p. 511-564. Lexis Nexis. Disponível em: $<$ http://www.lexisnexis.com/us/lnacademic/results/docview/docview.do?docLinkInd=true \&risb=21_T7833430638\&format=GNBFI\&sort=BOOLEAN\&startDocNo=1\&resultsUrlK ey $=29 \_$T7833430645\&cisb=22_T7833430644\&treeMax $=$true $\&$ treeWidth $=0 \& c s i=166252$ $\&$ docNo=2>. Acesso em: 09 nov. 2009.

PULEO, Anna. Discriminazioni di sesso nel mercato del lavoro: novità e aporie di um modello processuale. Rivista Trimestrale di Diritto e Procedura Civile. Milano, ano 50, $\mathrm{n}$. 1, p. 89-137, mar. 1996.

QUEIROZ, Cristina M. M. Direitos fundamentais. Coimbra: Coimbra Ed., 2002.

RAMM, Thilo. Discrimination: international development and remarks of legal theory. In: AARON, Benjamim et al. Discrimination at employment: a study of six countries by the Comparative Labour Law Group. Stockholm:Almqvist \& Wiksell International, 1978. 
RAMM, Thilo. Introduction. In: AARON, Benjamim et al. Discrimination at employment: a study of six countries by the Comparative Labour Law Group. Stockholm:Almqvist \& Wiksell International, 1978.

RAMOS, André de Carvalho. Teoria geral dos direitos humanos na ordem internacional. Rio de Janeiro: Renovar, 2005.

RATTI, Luca. Agency work and the idea of dual employership: a comparative perspective. Comparative Labor Law \& Policy Journal. No 30, Verão 2009, p. 835-874, p. 869. Lexis Nexis. Disponível em: $<$ http://www.lexisnexis.com/us/lnacademic/results/docview/docview.do?docLinkInd=true $\&$ risb=21_T7498438386\&format=GNBFI\&sort=RELEVANCE\&startDocNo=1\&resultsU $\mathrm{rlKey}=29 \_\mathrm{T} 7498438398 \& \mathrm{cisb}=22 \_\mathrm{T} 7498438397 \&$ treeMax $=$ true \&treeWidth $=0 \& \mathrm{csi}=7381$ $\&$ docNo=1>. Acesso em: 04 out. 2009.

RAWLS, John. Uma teoria da justiça. Trad. Almino Pisetta e Lenita M.R. Esteves. 1. ed. 2. tir. São Paulo: Martins Fontes, 2000.

REAUMÉ, Denise. Constitutional law: harm and fault in discrimination law: the transition from intentional to adverse effect discrimination. Theoretical Inquiries in Law. Jan. 2001, p. 350-385. Lexis Nexis. Disponível em: $<$ http://www.lexisnexis.com/us/lnacademic/results/docview/docview.do?docLinkInd=true $\&$ risb $=21 \_$T7854381486\&format $=$GNBFI\&sort=BOOLEAN\&startDocNo $=1 \&$ resultsUrlK ey=29_T7854381494\&cisb=22_T7854381493\&treeMax =true \& treeWidth $=0 \& c s i=246886$ $\&$ docNo=12>. Acesso em: 11 nov. 2009.

REYNOSO, Julissa. Perspectives on intersections of race, ethnicity, gender, and other grounds: Latinas at the Margins. Harvard Latino Law Review. $N^{\circ}$ 7, p. 64-73. Lexis Nexis. Disponível em: <http://www.lexisnexis.com/us/lnacademic/results/docview/docview.do?docLinkInd=true $\&$ risb $=21 \_$T7543680835\&format $=$GNBFI\&sort $=$BOOLEAN\&startDocNo $=1 \&$ resultsUrlK ey=29_T7543680839\&cisb=22_T7543680838\&treeMax=true \&treeWidth=0\&csi=221805 $\&$ docNo=22>. Acesso em: 08 out. 2009.

RIOS, Roger Raup. Direito da antidiscriminação: discriminação direta, indireta e ações afirmativas. Porto Alegre: Livr. do Advogado, 2008.

O princípio da igualdade e a discriminação por orientação sexual. São Paulo: Ed. Revista dos Tribunais, 2002.

RODRIGUEZ-PIÑERO, Miguel; FERNANDEZ LOPEZ, Maria Fernanda. Igualdad y discriminación. Madrid:Tecnos, 1986. 
RODRÍGUEZ ZEPEDA, Jesús. Una idea teórica de la no discriminación. Instituto de Investigaciones Jurídicas. Universidad Autónoma de México. Biblioteca Juridica Virtual. Disponível em: <http://www.bibliojuridica.org/libros/5/2312/7.pdf>. Acesso em: 27 out. 2009.

ROSSILLION, Claude. La OIT y la eliminación de la discriminación en el empleo. Medellin,Revista de la Facultad de Derecho y Ciencias Políticas de la UPB, n. 76, primer semestre, 1987.

ROTHSTEIN, Mark A.; LIEBMAN, Lance. Employment law. 3. ed. New York: The Foundation Press, 1994.

ROUSSEAU, Jean Jacques. Du contrat social. Paris: Éditions Sociales, 1963.

RUPRECHT, Alfredo J. Os princípios do direito do trabalho. Trad. para o português de Edílson Alkmin Cunha. São Paulo: LTr, 1995.

RUTHERGLEN, George. Discrimination and discontents. Virginia Law Review, feb. 1995, $\mathrm{n}^{\mathrm{o}}$ 81, p. 117-147, p. 117. Lexis Nexis. Disponível em: $<$ http://www.lexisnexis.com/us/lnacademic/results/docview/docview.do?docLinkInd=true $\&$ risb=21_T7345684975\&format $=$ GNBFI\&sort=RELEVANCE\&startDocNo=1\&resultsU $\mathrm{rlKey}=29 \_\mathrm{T} 7345684979 \& \mathrm{cisb}=22 \_\mathrm{T} 7345684978 \&$ treeMax $=$ true \&treeWidth $=0 \& \mathrm{csi}=7361$ $\&$ docNo=1>. Acesso em: 08 set. 2009.

Employment discrimination law. New York: Foundation Press, 2001.

RUTTER, David Anthony. Title VII Retaliation, a Unique Breed. The John Marshall Law Review. $N^{\circ} 36$, verão de 2003, p. 925-940, p. 927. Lexis Nexis. Disponível em: $<$ http://www.lexisnexis.com/us/lnacademic/results/docview/docview.do?docLinkInd=true $\&$ risb=21_T7893727195\&format=GNBFI\&sort=RELEVANCE\&startDocNo=1\&resultsU rlKey=29_T7893729918\&cisb=22_T7893729917\&treeMax $=$ true \& treeWidth $=0 \& c s i=1452$ $79 \&$ docNo=3>. Acesso em: 16 nov. 2009.

SACKETT, Paul R.; WILK, Steffanie L. Within-group norming and other forms of score adjustment in preemploying testing. American Psychologist, v. 49, 1994. In: DONOHUE III, John J. (Coord.). Foundations of employment discrimination law. 2. ed. New York: Foundation Press, 2003.

SALAS, Graciela R. Prospectiva de las migraciones. Anuario Argentino de Derecho Internacional, Córdoba, v.4, p. 203-224, 1990-1991.

SARLET, Ingo Wolfgang. Dignidade da pessoa humana e direitos fundamentais. 2. ed. Porto Alegre: Livr. do Advogado, 2002.

SARLO, Oscar. La igualdad y sus garantias. In: SARLO, Oscar; BLANCO, Andrés (Coord.). El princípio de igualdad en la teoría del derecho y la dogmática jurídica. Montevideo: Fundación de Cultura Universitaria, 2008. 
SAYAD, A. O retorno. Revista Travessia, 2000 - in A MOBILIDADE DE TRABALHADORES DO E PARA O JAPÃO. ESTUDO DE CASO DE LONDRINA, PR - BRASIL. Lirian Melchior - Scripta Nova. Revista Electrónica de Geografía y Ciencias Sociales. Universidad de Barcelona [ISSN 1138-9788] No 94 (54), 1 de agosto de 2001. Disponível em: <http://www.ub.edu/geocrit/sn-94-54.htm>. Acesso em: 27 dez. 2008.

SCRIBD. Tratado de Versalhes. Disponível em: $<$ http://www.scribd.com/doc/11553826/Traite-de-Versailles-1919>. Acesso em: 21 jul. 2009.

SILVA, José Afonso. Curso de direito constitucional positivo. 22. ed. São Paulo: Malheiros, 2003.

SILVA, José Antonio Ribeiro de Oliveira. O ônus da prova e sua inversão no processo do trabalho. BDJur - Biblioteca Digital Jurídica do Superior Tribunal de Justiça. Disponível em:

<http://bdjur.stj.gov.br/jspui/bitstream/2011/18561/2/O_\%c3\%94nus_da_Prova_e_sua_Inv ers\%c3\%a3o.pdf>. Acesso em: 27 nov. 2009.

SIMPSON, Amelia. The high court's conception of discrimination: origins, applications, and implications. The Sidney Law Review, n. 29, p. 263-295, Jun. 2007. Lexis Nexis. Disponível em: $<$ http://www.lexisnexis.com/us/lnacademic/results/docview/docview.do?docLinkInd=true $\&$ risb $=21 \_$T7590411324\&format $=$GNBFI\&sort $=$BOOLEAN\&startDocNo $=1 \&$ resultsUrlK ey $=29 \_$T7590411329\&cisb=22_T7590411328\&treeMax =true \&treeWidth $=0 \& c s i=224646$ $\&$ docNo=4>. Acesso em: 31 ago. 2009.

SKEAT, Walter W. An etymological dictionary of english language. Oxford: Clarendon Press, 1961.

SPANN, Girardeau A. The future of school integration in America: disintegration. University of Louisville Law Review. No 46, verão 2008, p. 629. Lexis Nexis. Disponível em:

$<$ http://www.lexisnexis.com/us/lnacademic/results/docview/docview.do?docLinkInd=true \&risb=21_T7864993532\&format=GNBFI\&sort=RELEVANCE\&startDocNo=1\&resultsU $\mathrm{rlKey}=29 \_\mathrm{T} 7864993537 \& \mathrm{cisb}=22 \_\mathrm{T} 7864993536 \&$ treeMax $=$ true $\&$ treeWidth $=0 \& \mathrm{csi}=1485$ $38 \&$ docNo=17>. Acesso em: 12 nov. 2009.

STRYKER, Robin. Disparate Impact and the Quota Debates: Law, Labor Market Sociology, and Equal Employment Policies. The Sociological Quarterly, v. 42, No. 1 Inverno 2001, p. 13-46. JSTOR. Disponível em: <http://www.jstor.org/stable/4120924>. Acesso em: 30 nov. 2009. 
SULLIVAN, Charles A. The phoenix from the ash: proving discrimination by comparators. Alabama Law Review. $\mathrm{N}^{\circ}$ 60, 2009, p. 192-239, p. 238. Lexis Nexis. Disponível em: $<$ http://www.lexisnexis.com/us/lnacademic/results/docview/docview.do?docLinkInd=true $\&$ risb=21_T7994650750\&format=GNBFI\&sort=BOOLEAN\&startDocNo=1\&resultsUrlK ey=29_T7994650753\&cisb=22_T7994650752\&treeMax $=$ true \&treeWidth $=0 \&$ selRCNodeI $\mathrm{D}=2 \&$ nodeStateId=411en_US, $1 \&$ docsInCategory=2091\&csi $=144191 \&$ docNo=19>.

Acesso em: 25 nov. 2009.

SÜSSEKIND, Arnaldo. Convenções da OIT. São Paulo: LTr, 1994.

TARAN, Patrick A. Migración y solidariedad laboral. Educación Obrera, Genebra, n. 129, p. 29-38, 2002.

THATCHER, Virginia S.; McQUEEN, Alexander. The new webster encyclopedic dictionary of the english language. New York, Grolier Inc., 1969. v. 1.

THOME, Candy Florencio. O assédio moral nas relações de emprego. São Paulo: LTr, 2008 .

TOMEI, Manuela. Análises de los conceptos de discriminación y de igualdade n el trabajo. Revista Internacional del Trabajo, Genebra, v. 122, n. 4, p. 441-461, 2003.

TOSELLI, Carlos Alberto; MARTÍN GRASSIS, Pablo; FERRER, Juan Ignacio. Violencia en las relaciones laborales. Córdoba: Alveroni Ediciones, 2007.

TRIBE, Laurence H. American constitutional law. 2. ed. Mineola: The Foundation Press, 1988.

TRINDADE, Antonio Augusto Cançado. A humanização do direito internacional. Belo Horizonte: Ed. Del Rey, 2006.

A proteção internacional dos direitos humanos e o Brasil. 2. ed. Brasília: Ed. Universidade de Brasília, 2000.

UNIVERSITÉ DE MONTREAL. LexUM. Canado-American Treaties. Disponível em: <http://www.lexum.umontreal.ca/ca_us/en/cus.1901.147.en.html>.

VAN YEN, Christian Nguyen. Droit de l'immigration. Paris: Presses Universitaires de France, 1986.

VENTURA, Luciano. Il principio di eguaglianza nel diritto del lavoro. Milano: Giuffré, 1984.

VIERDAG, Egbert. W. The concept of discrimination in international law. The Hague: Martinus Nijhoff, 1973. 
WEEKLEY, Ernest. A concise etymological dictionary of modern english. London: Secker \& Warburg, 1952.

WHITE, Rebecca Hanner. Employment law and employment discrimination. New York: Aspen Law \& Business, 1998.

WICKRAMASEKARA, Piyasiri. Organização internacional do trabalho. Perspectives in labour migration. policy responses to skilled migration: retention, return and circulation. Disponível em: $<$ http://www.ilo.org/public/english/protection/migrant/download/pom/pom5e.pdf $>>$. Acesso em: $16 \mathrm{dez} .2009$.

YAMADA, David. C. Human Dignity and American Employment Law. University of Richmond Law Review, $\mathrm{n}^{\circ}$ 43, Janeiro 2009, p. 523-569, p. 531. Lexis Nexis. Disponível em:

<http://www.lexisnexis.com/us/lnacademic/results/docview/docview.do?docLinkInd=true \&risb=21_T7342949468\&format=GNBFI\&sort=RELEVANCE\&startDocNo=1\&resultsU rlKey=29_T7342949472\&cisb=22_T7342949471\&treeMax $=$ true \& treeWidth $=0 \&$ selRCNo deID=46\&nodeStateId=411en_US, $1 \&$ docsInCategory=380\&csi $=143888 \&$ docNo=19>. Acesso em: 15 set. 2009.

\section{DOCUMENTOS - INTERNET}

ÁFRICA DO SUL. Employment Equity Act. $\mathrm{N}^{\mathrm{o}}$ 55, of 1998. Disponível em: $<$ http://www.labour.gov.za/downloads/legislation/acts/employment-equity/Act\%20-

\%20Employment\%20Equity.pdf> Acesso em: 21 out. 2009.

Employment Equity Act. $\quad \mathrm{N}^{\mathrm{o}}$ 55, of 1998. Disponível em: <http://www.labour.gov.za/downloads/legislation/acts/employment-equity/Act\%20\%20Employment\%20Equity.pdf>. Acesso em: 30 nov. 2009.

ALEMANHA. Deutscher Bundestag. Disponível em: $<$ http://www.bundestag.de/dokumente/rechtsgrundlagen/grundgesetz/gg_01.html>. Acesso em 25 ago. 2009.

ALTA CORTE DA AUSTRALIA. Bayside City Council (2004) 216 CLR 595 at 629-30. Disponível em: <http://www.austlii.edu.au/au/cases/cth/HCA/2004/19.html>. Acesso em: 14 set. 2009.

. Castlemaine Tooheys Ltd. v. South Australia [1990] HCA 1; (1990) 169 CLR 436. F.C. 90/001. Disponível em: <http://www.austlii.edu.au/au/cases/cth/high_ct/169clr436.html>. Acesso em: 28 out. 2009. 
ALTO COMISSARIADO PARA A IMIGRAÇÃO E MINORIAS ÉTNICAS. Congresso Imigração em Portugal: Diversidade - Cidadania - Integração.1.Lisboa.2003 - Actas do I Congresso Imigração em Portugal: Diversidade-Cidadania-Integração, [org.] Alto Comissariado para a Imigração e Minorias Étnicas, ISBN 972-98959-9-6, 1-Portugal. P. 22. OBSERVATÓRIO DA IMIGRAÇÃO. Disponível em: <http://www.oi.acidi.gov.pt/modules.php?name=Content\&pa=showpage\&pid=15>. Acesso em: 26 nov. 2008.

AUSTRÁliA. Age Discrimination Act. Act No 68 of 2004 as amended. Comlaw - Commonwealth of Australia Law. Disponível em: <http://www.comlaw.gov.au/comlaw/Legislation/ActCompilation1.nsf/0/C4293494A0BD921DCA 2576040020C9EB?OpenDocument>. Acesso em: 25 out. 2009.

- Constituição. Parliament of Australia. Senate. Disponível em: <http://www.aph.gov.au/SEnate/general/constitution/chapter1.htm>. Acesso em: 26 out. 2009.

. Disability Discrimination Act. Act n ${ }^{\circ} 135$ of 1992 as amended. Comlaw - Commonwealth of Australia Law. Disponível em: $<$ http://www.comlaw.gov.au/comlaw/Legislation/ActCompilation1.nsf/0/02E50FC08E783ED7CA 257609000288E1?OpenDocument>. Acesso em: 25 out. 2009.

. Racial Discrimination Act. Act $\mathrm{n}^{\circ} 52$ of 1975 as amended. Comlaw - Commonwealth of Australia Law. Disponível em: $<$ http://www.comlaw.gov.au/comlaw/Legislation/ActCompilation1.nsf/0/A413ADB46D5CC9B2C A257607000EBE58?OpenDocument>. Acesso em: 25 out. 2009.

. Sex Discrimination Act. Act $\mathrm{n}^{\circ} 4$ of 1984 as amended. Comlaw - Commonwealth of Australia Law. Disponível em: $<$ http://www.comlaw.gov.au/comlaw/Legislation/ActCompilation1.nsf/0/99327A010C648560CA2 57607002370CF?OpenDocument>. Acesso em: 25 out. 2009.

Sex Discrimination Act. Act $\mathrm{n}^{\circ} 4$ of 1984 as amended. Comlaw - Commonwealth of Australia Law. Disponível em: $<$ http://www.comlaw.gov.au/comlaw/Legislation/ActCompilation1.nsf/0/99327A010C648560CA2 57607002370CF?OpenDocument>. Acesso em: 26 out. 2009.

BANCO INTERAMERICANO DE DESENVOLVIMENTO. Global Link. Disponível em: $<$ http://www.iadb.org/gl/index_esp.html>. Acesso em: 01 dez. 2008.

BRASIL. Código Civil. Lei 10.402, de 10 de janeiro de 2002. Palácio do Planalto. Disponível em: <www.planalto.gov.br>. Acesso em: 01 dez. 2008.

. Consolidação das Leis do Trabalho. Decreto-Lei 5.452, de $1^{\circ}$ de maio de 1943. Disponível em: <www.planalto.gov.br>. Acesso em: 01 dez. 2008.

Constituição Federal de 1988. Presidência da República. Legislação. Disponível em: $<$ www.planalto.gov.br>. Acesso em 29 set. 2009. Art. $3^{\circ}$ Constituem objetivos fundamentais da República Federativa do Brasil: IV - promover o bem de todos, sem preconceitos de origem, raça, sexo, cor, idade e quaisquer outras formas de discriminação.

Lei 10.224, de 15 de maio de 2001. Palácio do Planalto. Legislação. Disponível em: <http://www.planalto.gov.br/ccivil_03/Leis/LEIS_2001/L10224.htm>. Acesso em: 16 nov. 2009. 
BRASIL. Lei 7.437, de 20.12.1985. Senado Federal. Disponível em: <www.senado.gov.br>. Acesso em: 22 jul. 2009.

Lei 7.716 de 5 de janeiro de 1989, alterada pela Lei 9.459, de 15 de maio de 1997. Presidência da República. Casa Civil. Subchefia para assuntos jurídicos. Disponível em: <http://www.planalto.gov.br/ccivil_03/Leis/L7716.htm>. Acesso em: 22 jul. 2009.

. Lei 7.853 de 24 de outubro de 1989. Presidência da República. Casa Civil. Subchefia para assuntos jurídicos. Disponível em: <http://www.planalto.gov.br/ccivil_03/Leis/L7853.htm>. Acesso em: 22 jul. 2009.

. Lei 9.029 de 13 de abril de 1995. Presidência da República. Casa Civil. Subchefia para assuntos jurídicos. Disponível em: <http://www.planalto.gov.br/ccivil_03/Leis/L9029.htm>. Acesso em: 22 jul. 2009.

. Lei 9.799/1999. Presidência da República. Legislação. Disponível em:

CANADA. Canadian Human Rights Act. Department of Justice of Canada. Disponível em: $<$ http://laws.justice.gc.ca/PDF/Statute/h/h-6.pdf>. Acesso em: 21 set. 2009.

Canadian Human Rights Act. Department of Justice of Canada. Disponível em: $<$ http://laws.justice.gc.ca/PDF/Statute/h/h-6.pdf>. Acesso em: 21 nov. 2009.

Canadian Human Rights Act. Department of Justice. Laws. Disponível em: <http://laws.justice.gc.ca/eng/H-6/page-2.html\#anchorbo-ga:1_I-gb:s_5>. Acesso em: 25 out. 2009.

Canadian Human Rights Act. Department of Justice. Laws. Disponível em: $<$ http://laws.justice.gc.ca/eng/H-6/page-2.html\#anchorbo-ga:1_I-gb:s_5>. Acesso em: 30 nov. 2009.

CARTA AFRICANA DE DIREITOS HUMANOS E DOS POVOS. Organização da Unidade Africana. Biblioteca de Direitos Humanos da USP. Disponível em: $<$ http://www.direitoshumanos.usp.br/index.php/Documentos-n\%C3\%A3o-Inseridos-nas-

Delibera\%C3\%A7\%C3\%B5es-da-ONU/carta-africana-dos-direitos-humanose-dos-povos-carta-debanjul.html>. Acesso em: 07 out. 2009.

COMUNIDADE ECONÔMICA EUROPEIA. Diretiva 75/117. EUR-Lex. Disponível em: $<$ http://eur-lex.europa.eu/LexUriServ/LexUriServ.do?uri=CELEX:31975L0117:PT:HTML>. Acesso em: 10 nov. 2009.

Diretiva 76/207. EUR-Lex. Disponível em: $<$ http://eurlex.europa.eu/smartapi/cgi/sga_doc?smartapi!celexapi!prod!CELEXnumdoc\&numdoc=31976L020 $7 \&$ model=guichett\&lg=pt.>. Acesso em: 10 nov. 2009.

CONGRESSO NACIONAL. Diário do Congresso Nacional. Brasília, Seção I, 12 out. 1965.

CONSELHO DA UNIÃO EUROPEIA. Diretiva 97/80. EUR-Lex. Disponível em: <http://eurlex.europa.eu/LexUriServ/LexUriServ.do?uri=OJ:L:1998:014:0006:0008:PT:PDF>. Acesso em: 25 nov. 2009.

CONVENÇÃO EUROPEIA DOS DIREITOS HUMANOS. Corte Europeia dos Direitos Humanos. Disponível em: <http://www.echr.coe.int/nr/rdonlyres/d5cc24a7-dc13-4318-b4575c9014916d7a/0/englishanglais.pdf>. Acesso em: 07 out. 2009. 
CONVENÇÃO SOBRE OS ESTRANGEIROS. Ministério das Relações Exteriores. Divisão de atos internacionais. Disponível em: <http://www2.mre.gov.br/dai/estrangeiros.htm>. Acesso em: $16 \mathrm{dez}$. 2008.

CORNELL UNIVERSITY LAW SCHOOL. Legal Information Institute. disponível em: <http://www.law.cornell.edu/supct/html/historics/USSC_CR_0356_0086_ZS.html,>. Acesso em: 30 dez. 2009.

CORTE CONSTITUCIONAL DA ÁFRICA DO SUL. Southern African Legal Information Institute. Hoffmann v. South African Airways - CCT 17/00. Disponível em: <http://www.saflii.org/za/cases/ZACC/2000/17.pdf>. Acesso em: 28 out. 2009.

CORTE DE JUSTIÇA DA COMUNIDADE ECONÔMICA EUROPEIA. Decisão caso Giovanni Maria Sotgiu v Deutsche Bundespost. Assunto no 152/33. EUR-Lex. Disponível em: <http://eurlex.europa.eu/LexUriServ/LexUriServ.do?uri=CELEX:61973J0152:EN:HTML>. Acesso em: 10 nov. 2009.

. Decisão caso J . P . Jenkins and Kingsgate (Clothing Productions) Ltd. Assunto $n^{\circ}$ 96/80.

EUR-Lex. Disponível em: <http://eur-

lex.europa.eu/LexUriServ/LexUriServ.do?uri=CELEX:61980J0096:EN:HTML>. Acesso em: 10 nov. 2009.

Decisão caso Kaufhaus GmbH v Karin Weber von Hartz Assunto nº 170/84. EUR-Lex.

Disponível em: <http://eurlex.europa.eu/LexUriServ/LexUriServ.do?uri=CELEX:61984J0170:EN:HTML>. Acesso em: 10 nov. 2009.

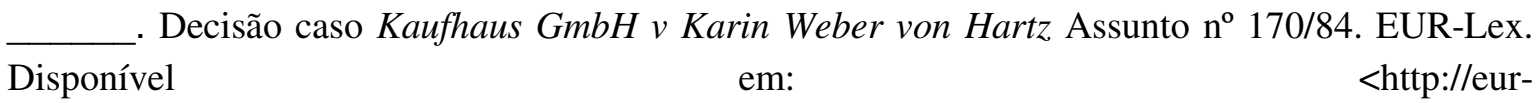
lex.europa.eu/LexUriServ/LexUriServ.do?uri=CELEX:61984J0170:EN:HTML>. Acesso em: 10 nov. 2009.

—. Decisão caso República da Itália v. Comissão da Comunidade Econômica Européia. Assunto $\quad \mathrm{n}^{\mathrm{o}} \quad$ 13/63. $\quad$ EUR-Lex. Disponível em: <http://eurlex.europa.eu/LexUriServ/LexUriServ.do?uri=CELEX:61963J0013:EN:HTML>. Acesso em: 10 nov. 2009.

DECLARAÇÃO AMERICANA DOS DIREITOS E DEVERES DO HOMEM. IX Conferência Internacional Americana em Bogotá. Biblioteca Virtual de Direitos Humanos da USP. Disponível

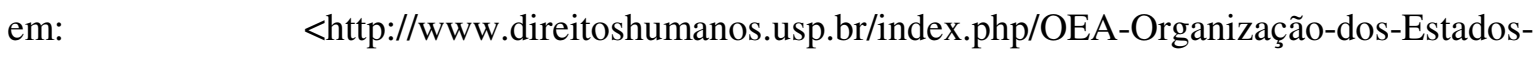
Americanos/declaracao-americana-dos-direitos-e-deveres-do-homem.html>. Acesso em: 20 out. 2009.

DECLARAÇÃO DA OIT sobre os Princípios e Direitos Fundamentais no Trabalho e seu Seguimento. Tradução de Edílson Alkmin Cunha. Brasília: Escritório da OIT.

DECLARAÇÃo E PROGRAMA DE AÇÃO DE VIENA. Conferência Mundial sobre Direitos Humanos. Organização das Nações Unidas. Ministério Público Federal. Procuradoria Federal dos Direitos do Cidadão. Legislação. Disponível em: <http://pfdc.pgr.mpf.gov.br/legislacaopfdc/direitos-humanos/Declarac255eo\%20e\%20Plano\%20de\%20Ac255eo\%20-\%20Viena.pdf>. Acesso em: 07 out. 2009. 
DECLARAÇÃO UNIVERSAL DOS DIREITOS DO HOMEM. Biblioteca Virtual de Direitos Humanos da USP. Disponível em: <http://www.direitoshumanos.usp.br/index.php/SistemaGlobal.-Declarações-e-Tratados-Internacionais-de-Proteção/declaracao-universal-dos-direitoshumanos.html>. Acesso em: 12 dez. 2009.

DEPARTAMENTO INTERSINDICAL DE ASSESSORIA PARLAMENTAR - DIAP. Disponível em: <http://diap.ps5.com.br/file/1416.pdf>. Acesso em: 27 nov. 2008.

EQUAL EMPLOYMENT OPPORTUNITY COMISSION. Harassment. Disponível em: $<$ http://www.eeoc.gov/types/harassment.html>. Acesso em: 09 set. 2009.

ESPANHA. Boletin Oficial del Estado. Ley Orgânica $\mathrm{n}^{\circ}$ 3/2007. Disponível em: <http://www.boe.es/boe/dias/2007/03/23/pdfs/A12611-12645.pdf>. Acesso em: 25 out. 2009.

Boletin Oficial del Estado. Ley Orgânica $\mathrm{n}^{\circ}$ 51/2003. Disponível em: <http://www.boe.es/boe/dias/2003/12/03/pdfs/A43187-43195.pdf>. Acesso em: 25 out. 2009.

Constitución Española. Ministerio de la Presidencia. Boletim Oficial del Estado.

Disponível

em:

$<$ http://www.boe.es/aeboe/consultas/enlaces/documentos/ConstitucionCASTELLANO.pdf>.

Acesso em 25 ago. 2009.

Lei Orgânica 3/2007. Boletin Oficial del Estado. Disponível em: <http://www.boe.es/aeboe/consultas/bases_datos/doc.php?coleccion=iberlex\&id=2007/06115>. Acesso em: 21 set. 2009.

ESTADO DE SÃO PAULO. Lei 13.541/2009. Sítio Lei Antifumo. Disponível em: <http://www.leiantifumo.sp.gov.br/usr/share/documents/legislacao.pdf>. Acesso em: 16 out. 2009.

ESTADOS UNIDOS. Declaração de independência. "Nós temos por evidentes em si mesmas as seguintes verdades: todos os homens foram criados iguais e dotados pelo criador de certos direitos inalienáveis.". Embaixada dos Estados Unidos da América no Brasil. Disponível em: $<$ http://www.embaixada-

americana.org.br/index.php?action $=$ materia $\&$ id $=645 \&$ submenu $=106 \&$ itemmenu $=110>. \quad$ Acesso em: 04 ago. 2009.

ESTADOS UNIDOS DA AMÉRICA. Civil Rights Act 1991. Equal Employment Opportunity Comission. Disponível em: <http://www.eeoc.gov/laws/statutes/titlevii.cfm>. Acesso em: 10 nov. 2009.

Civil Rights Act. Equal Employment Opportunity Comission. Disponível em: <http://www.eeoc.gov/policy/vii.html>. Acesso em: 09 out. 2009.

. Civil Rights Act. Equal Employment Opportunity Comission. SEC. 2000e-2. [Section 703]. Disponível em: <http://www.eeoc.gov/policy/vii.html>. Acesso em: 13 out. 2009

. Civil Rights Act. Equal Employment Opportunity Comission. Title VII of the Civil Rights of 1964. Disponível em: <http://www.eeoc.gov/policy/vii.html>. Acesso em: 25 out. 2009.

. Civil Rights Act. Equal Employment Opportunity Comission. Disponível em: <http://www.eeoc.gov/laws/statutes/titlevii.cfm>. Acesso em: 16 nov. 2009.

Civil Rights Act. Equal Employment Opportunity Comission. Disponível em: $<$ http://www.eeoc.gov/policy/vii.html>. Acesso em: 09 out. 2009. 
ESTADOS UNIDOS DA AMÉRICA. Clayton Antitrust Act. St. Olaf College - legal texts. Disponível em: <http://www.stolaf.edu/people/becker/antitrust/statutes/clayton.html>. Acesso em: 20 jul. 2009.

Código Federal. Título 42, Capítulo 21, Subcapítulo I, § 1981. Disponível em: <http://uscode.law.cornell.edu/uscode/html/uscode42/usc_sec_42_00001981----000-.html>. Acesso em: 21 jul. 2009.

Constituição, 14 a Emenda Constitucional, 1866, no sítio FINDLAW - For legal professionals. Disponível em: <http://caselaw.lp.findlaw.com/data/constitution/amendment14/>. Acesso em: 21 jul. 2009.

. Declaração dos direitos do homem e do cidadão - 1789. Biblioteca Virtual de Direitos

Humanos, Universidade de São Paulo. Disponível em: $<$ http://www.direitoshumanos.usp.br/index.php/Documentos-anteriores-à-criação-da-Sociedadedas-Nações-até-1919/declaracao-de-direitos-do-homem-e-do-cidadao-1789.html>. Acesso em: 04 ago. 2009.

Equal Employment Opportunity Comission. Prohibited Employment Pratices/Policies. Disponível em: <http://www.eeoc.gov/laws/practices/index.cfm>. Acesso em: 13 nov. 2009.

Equal Employment Opportunity Comission. Disponível em: <http://www.eeoc.gov/eeoc/publications/fs-sex.cfm>. Acesso em: 16 nov. 2009.

Equal Employment Opportunity Comission. Title VII. Disponível em: <http://www.eeoc.gov/laws/statutes/titlevii.cfm>. Acesso em: 30 nov. 2009.

. Lilly Ledbetter Fair Pay Act. The U. S. Equal Employment Opportunity Comission notice. Disponível em: <http://frwebgate.access.gpo.gov/cgibin/getdoc.cgi?dbname=111_cong_public_laws\&docid=f:publ002.111>. Acesso em: 24 nov. 2009.

The Age Discrimination in Employment Act of 1967. Equal Employment Opportunity Comission. Disponível em http://www.eeoc.gov/policy/adea.html. Acesso em 26.10.2009.

The Americans with Disabilities Act. Equal Employment Opportunity Comission. Disponível em: <http://www.eeoc.gov/policy/ada.html>. Acesso em: 26 out. 2009.

The Civil Rights Act. Equal Employment Opportunity Comission. SEC. 2000e-2. [Section 703]. Disponível em: <http://www.eeoc.gov/policy/vii.html>. Acesso em: 13 out. 2009.

EUROPEAN CENTRAL BANK. Home Page. Legal framework. Tratado de Amsterdão. Disponível em: <http://www.ecb.europa.eu/ecb/legal/pedf;Amsterdam_pt.pdf>. Acesso em: 20 out. 2009.

Foram nomeados por Ronald Reagan os Juízes O’Connor, Scalia, Rehnquist e Kennedy.

FRANÇA. Código do Trabalho. Lei 2008-496. Lexinter.net. Disponível em: $<$ http://www.lexinter.net/Legislation5/JURISOC2/chapitre_ii_principe_de_non_discrimination.htm >. Acesso em: 21 set. 2009.

THE HISTORY PLACE. The World War I. Text of President Wilson's Speech. Disponível em: $<$ http://www.historyplace.com/worldhistory/firstworldwar/us-wilson-war-decl.htm>. Acesso em: 21 jul. 2009. 
INSTITUT DE DROIT INTERNATIONAL. Déclarations. Disponível em: <http://www.idiiil.org/idiF/resolutionsF/1929_nyork_03_fr.pdf $>$. Acesso em: 20 jul. 2009. L'égalité prévue ne devra pas être nominale mais effective. Elle exclut toute discrimination directe ou indirecte.

INSTITUTO BRASILEIRO DE GEOGRAFIA E ESTATÍSTICA. Censo Demográfico de 2000. Disponível em: <http://www.ibge.gov.br/home/estatistica/populacao/censo2000/migracao/Brasil_mig_Censo2000.p df>. Acesso em: 12 dez. 2008.

INTERNATIONAL ORGANIZATION FOR MIGRATION. Facts and Figures. Disponível em: $<$ http://www.iom.int/jahia/Jahia/about-migration/facts-and-figures/global-estimates-and-trends $>$. Acesso em: 26 nov. 2008.

- International Migration and Data Statistics. Disponível em: <http://www.iom.int/jahia/Jahia/lang/en/cache/offonce/pid/8>. Acesso em: 26 nov. 2008.

ITALIA. Costituzione della Reppublica Italiana. Corte Costituzionale. Disponível em: $<$ http://www.cortecostituzionale.it/istituzione/lacorte/fontinormative/lacostituzione/costituzione_pri ncipii.asp>. Acesso Acesso em: 25 ago. 2009.

Decreto legislativo n. 219, de 9 de julho de 2003. La Consiglieri di Paritá Provinciale di Torino. Disponível em: <http://www.consiglieraparitatorino.it/allegati/2003_DL216.pdf>. Acesso em: 21 set. 2009.

- Lei 67/2006. Webacessibile.org. Disponível em: <http://webaccessibile.org/normative/legge-67-2006/>. Acesso em: 21 set. 2009.

MERCOSUL. Declaração sociolaboral do Mercosul. Supremo Tribunal Federal. Disponível em: $<$ http://www.stf.jus.br/arquivo/cms/forumCorteSupremaNorma/forumCorteSupremaNorma_AP_75 320.pdf>. Acesso em: 07 dez. 2009.

NAÇÕES UNIDAS. Convenção internacional sobre a eliminação de todas as formas de discriminação racial (1968). Biblioteca Virtual de Direitos Humanos. Universidade de São Paulo. Disponível em: $<$ http://www.direitoshumanos.usp.br/counter/Onu/Minorias_discriminacao/texto/texto_1.html>. Acesso em: 22 jul. 2009.

. Convenção internacional sobre a eliminação de todas as formas de discriminação contra a mulher. Biblioteca Virtual de Direitos Humanos. Universidade de São Paulo. Disponível em: $<$ http://www.direitoshumanos.usp.br/index.php/Direitos-da-Mulher/convencao-sobre-a-eliminacaode-todas-as-formas-de-discriminacao-contra-a-mulher.html>. Acesso em: 21 set. 2009.

. Convenção sobre a eliminação de todas as formas de discriminação contra as mulheres (1979). Biblioteca Virtual de Direitos Humanos. Universidade de São Paulo. Disponível em: <http://www.direitoshumanos.usp.br/counter/Onu/Mulher/texto/texto_3.html>. Acesso em: 22 jul. 2009. Adotada pela Resolução n..$^{\circ}$ 34/180 da Assembleia das Nações Unidas, em 18 de dezembro de 1979. Aprovada pelo Decreto Legislativo n. ${ }^{\circ}$ 93, de 14.11.1983. Ratificada pelo Brasil em $1^{\circ}$ de fevereiro de 1984 (com reservas). Promulgada pelo Decreto n. ${ }^{\circ}$ 89.460, de 20.3.1984. 
NAÇÕES UNIDAS. Declaração sobre a eliminação de todas as formas de intolerância e discriminação fundadas na religião ou nas convicções. Proclamada pela Assembleia Geral das Nações Unidas a 25 de novembro de 1981 - Resolução 36/55. Biblioteca Virtual de Direitos Humanos. Universidade de São Paulo. Disponível em: http://www.direitoshumanos.usp.br/index.php/Prevenção-contra-a-Discriminação-e-Proteção-dasMinorias/declaracao-sobre-a-eliminacao-de-todas-as-formas-de-intolerancia-e-discriminacaofundadas-na-religiao-ou-nas-conviccoes.html>. Acesso em: 21 out. 2009. Proclamada pela Assembleia Geral das Nações Unidas a 25 de novembro de 1981 - Resolução 36/55.

UN Population Division: International Migration 2002 (New York, 2002). Disponível em: $<$ http://www.un.org/esa/population/publications/ittmig2002/2002ITTMIGTEXT22-11.pdf>. Acesso em: 01 dez. 2008.

NOVA ZELÂNDIA. Human Rights Act. Parliamentary Counsel Office - New Zealand Legislation. Disponível em: $<$ http://www.legislation.govt.nz/act/public/1993/0082/latest/viewpdf.aspx>. Acesso em: 25 out. 2009.

. Human Rights Act. Parliamentary Counsel Office - New Zealand Legislation. Disponível em: <http://www.legislation.govt.nz/act/public/1993/0082/latest/viewpdf.aspx>. Acesso em: 26 out. 2009.

OPEN JURIST. 475 F2d 216 Spurlock v. United Airlines Inc 475 F.2d 2165 Fair Empl.Prac.Cas. 17, 5 Empl. Prac. Dec. P 7996. Disponível em: <http://openjurist.org/475/f2d/216>. Acesso em: 13 out. 2009.

ORGANIZAÇÃO DAS NAÇÕES UNIDAS. Declaração Universal dos Direitos do Homem UNIVERSIDADE DE SÃO PAULO. Biblioteca Virtual de Direitos Humanos. Disponível em: $<$ http://www.direitoshumanos.usp.br/counter/Onu/Sist_glob_trat/texto/texto_1.html>. Acesso em: 28 nov. 2008. - Artigo $6^{\circ}$ : Todo o homem tem o direito de ser, em todos os lugares, reconhecido como pessoa perante a lei. - Artigo $7^{\circ}$ : Todos são iguais perante a lei e têm direito, sem qualquer distinção, a igual proteção da lei. Todos têm direito a igual proteção contra qualquer discriminação que viole a presente Declaração e contra qualquer incitamento a tal discriminação.

. Carta Geral das Nações Unidas. UNIVERSIDADE DE SÃO PAULO. Biblioteca Virtual de Direitos Humanos. Disponível em: $<$ http://www.direitoshumanos.usp.br/counter/Onu/Carta_Geral/carta_geral.html>. Acesso em: 08dez. 2008.

. Convenção contra os crimes de guerra e dos crimes contra a humanidade. Biblioteca Virtual de Direitos Humanos da USP. Disponível em: $<$ http://www.direitoshumanos.usp.br/index.php/Sistema-Global.-Declara\%C3\%A7\%C3\%B5es-eTratados-Internacionais-de-Prote $\% \mathrm{C} 3 \% \mathrm{~A} 7 \% \mathrm{C} 3 \% \mathrm{~A} 3 \mathrm{o} /$ convencao-sobre-a-imprescritibilidade-doscrimes-de-guerra-e-dos-crimes-contra-a-humanidade.html>. Acesso em: 23 nov. 2009.

Convenção Internacional para Eliminação de todas as formas de Discriminação Racial.

Biblioteca Virtual de Direitos Humanos da USP. Disponível em: $<$ http://www.direitoshumanos.usp.br/index.php/Prevenção-contra-a-Discriminação-e-Proteção-dasMinorias/convencao-internacional-sobre-a-eliminacao-de-todas-as-formas-de-discriminacao-racial1968.html>. Acesso em: 21 set. 2009. 
ORGANIZAÇÃO DAS NAÇÕES UNIDAS. Convenção para a eliminação de todas as formas de discriminação racial. Adotada pela Assembléia Geral das Nações Unidas em 21 de dezembro de 1965. Disponível em: http://www.direitoshumanos.usp.br/index.php/Prevenção-contra-aDiscriminação-e-Proteção-das-Minorias/convencao-internacional-sobre-a-eliminacao-de-todas-asformas-de-discriminacao-racial-1968.html>. Acesso em: 20 out. 2009.

. Convenção relativa à luta contra as discriminações na esfera do ensino. Biblioteca Virtual de Direitos Humanos da USP. Disponível em: $<$ http://www.direitoshumanos.usp.br/index.php/Direito-a-Educação/convencao-relativa-a-lutacontra-as-discriminacoes-na-esfera-do-ensino.html>. Acesso em: 21 set. 2009.

. Convenção Relativa à Luta Contra as Discriminações na Esfera do Ensino. Adotada pela Assembleia Geral em 14.12.1960. Disponível em: $<$ http://www.direitoshumanos.usp.br/index.php/Direito-a-Educação/convencao-relativa-a-lutacontra-as-discriminacoes-na-esfera-do-ensino.html>. Acesso em: 20 out. 2009.

Convenção sobre a eliminação de todas as formas de discriminação contra a mulher. Biblioteca Virtual de Direitos Humanos da USP. Disponível em: $<$ http://www.direitoshumanos.usp.br/index.php/Direitos-da-Mulher/convencao-sobre-a-eliminacaode-todas-as-formas-de-discriminacao-contra-a-mulher.html>. Acesso em: 21 out. 2009.

. Convenção sobre os Direitos da Criança. Resolução no 44 de 20.11.1989. Biblioteca Virtual de Direitos Humanos. Universidade de São Paulo. Disponível em: $<$ http://www.direitoshumanos.usp.br/index.php/Criança/convencao-sobre-os-direitos-dacrianca.html>. Acesso em: 21 out. 2009.

Declaração sobre a eliminação da discriminação contra a mulher. Proclamada pela Assembleia Geral das Nações Unidas em 7 de novembro de 1967. Disponível em: $<$ http://www.direitoshumanos.usp.br/index.php/Direitos-da-Mulher/declaracao-sobre-a-eliminacaoda-discriminacao-contra-a-mulher.html>. Acesso em: 20 out. 2009.

Declaração sobre o Direito e a Responsabilidade dos Indivíduos, Grupos ou Órgãos da Sociedade de Promover e Proteger os Direitos Humanos e Liberdades Fundamentais Universalmente Reconhecidas. Biblioteca Virtual de Direitos Humanos. Universidade de São Paulo. Disponível em: <http://www.direitoshumanos.usp.br/index.php/Sistema-Global.Declarações-e-Tratados-Internacionais-de-Proteção/declaracao-sobre-o-direito-e-aresponsabilidade-dos-individuos-grupos-ou-orgaos-da-sociedade-de-promover-e-proteger-osdireitos-humanos.html>. Acesso em: 21 out. 2009.

Ministério das Relações Exteriores. Decreto $n^{\circ}$ 4.388/2002. Disponível em: <http://www2.mre.gov.br/dai/tpi.htm>. Acesso em: 23 nov. 2009.

- Pacto Internacional de Direitos Civis e Políticos. UNIVERSIDADE DE SÃO PAULO. Biblioteca Virtual de Direitos Humanos. Disponível em: $<$ http://www.direitoshumanos.usp.br/counter/Onu/Sist_glob_trat/texto/texto_3.html>. Acesso em: 08 dez. 2008.

Pacto Internacional dos Direitos Civis e Políticos. Biblioteca de Direitos Humanos da USP. Disponível em: <http://www.direitoshumanos.usp.br/index.php/Sistema-Global.Declarações-e-Tratados-Internacionais-de-Proteção/pacto-internacional-dos-direitos-civis-epoliticos.html>. Acesso em: 07 out. 2009. 
ORGANIZAÇÃO DAS NAÇÕES UNIDAS. United Nations Treaty Collection. Disponível em:<http://treaties.un.org/Pages/ViewDetails.aspx?src=TREATY\&id=137\&chapter=4\&lang=en>. Acesso em: 26 nov. 2008.

ORGANIZAÇÃO DOS ESTADOS AMERICANOS. Convenção Americana de Direitos Humanos. UNIVERSIDADE DE SÃO PAULO. Biblioteca Virtual de Direitos Humanos. Disponível em:<http://www.direitoshumanos.usp.br/counter/Sistema_inter/texto/texto_5.html>. Acesso em: 08 dez. 2008.

Convenção Americana dos Direitos Humanos. Biblioteca de Direitos Humanos da USP. Disponível em: <http://www.direitoshumanos.usp.br/index.php/OEA-Organização-dos-EstadosAmericanos/convencao-americana-de-direitos-humanos-1969-pacto-de-san-jose-da-costarica.html>. Acesso em: 07 out. 2009.

. Convenção Interamericana para a Eliminação de Todas as Formas de Discriminação Contra as Pessoas Portadoras de Deficiência. Biblioteca Virtual de Direitos Humanos. Universidade de São Paulo. Disponível em: <http://www.direitoshumanos.usp.br/index.php/Direito-dos-Portadores-deDeficiência/convencao-interamericana-para-a-eliminacao-de-todas-as-formas-de-discriminacaocontra-as-pessoas-portadoras-de-deficiencia.html>. Acesso em: 21 out. 2009.

ORGANIZAÇÃO INTERNACIONAL DO TRABALHO. Constituição Sítio do Escritório no Brasil. Disponível em: <http://www.oitbrasil.org.br/info/download/constituicao_oit.pdf>. Acesso em 08 set. 2009.

Convenção 111. Sítio do escritório no Brasil. Disponível em: $<$ http://www.ilo.org/public/portugue/region/ampro/brasilia/info/download/conv_111.pdf >. Acesso em: 16 set. 2009.

Convenção $\mathrm{n}^{0}$ 111. Sítio do escritório da OIT em Brasília. Disponível em: <http://www.ilo.org/public/portugue/region/ampro/brasilia/info/download/convencao111.pdf>. Acesso em: 20 out. 2009.

Convenção $n^{\circ}$ 143, de 24.06.1975. Biblioteca Virtual de Direitos Humanos da USP. Disponível em: <http://www.direitoshumanos.usp.br/index.php/OIT-Organização-Internacional-doTrabalho/convencao-no-143-da-oit-relativo-as-migracoes-em-condicoes-abusivas-e-a-promocaoda-igualdade-de-oportunidades-e-de-tratamento-dos-trabalhadores-migrantes.html>. Acesso em: 07 dez. 2009.

Convenção $\mathrm{n}^{\mathrm{o}}$ 98. Escritório da OIT Brasil. Disponível em: <http://www.oitbrasil.org.br/download/convencao98.pdf>. Acesso em: 08 out. 2009.

. Equality at work: Tacking the challenges. Global Report under the follow-up to the ILO Declaration on Fundamental Principles and Rights at Work. Disponível em: $<$ http://www.ilo.org/wcmsp5/groups/public/---dgreports/---dcomm/---

webdev/documents/publication/wcms_082607.pdf>. Acesso em: 22 set. 2009.

Equality at work: tackling the challenges. Global Report under the follow-up to the ILO Declaration on Fundamental Principles and Rights at Work. Disponível em: $<$ http://www.ilo.org/wcmsp5/groups/public/---dgreports/---dcomm/---

webdev/documents/publication/wcms_082607.pdf>. Acesso em: 29 dez. 2008.

Ilolex Database of International Labour Standards. Disponível em: <http://www.ilo.org/ilolex/english/convdisp1.htm>. Acesso em: 08 out. 2009. 
INSTITUT DE DROIT INTERNATIONAL. Déclarations. Disponível em: <http://www.idiiil.org/idiF/resolutionsF/1929_nyork_03_fr.pdf>. Acesso em: 20 jul. 2009.

ORGANIZAÇÃO INTERNACIONAL DO TRABALHO. Ilolex. Base de dados de documentos da OIT. Disponível em: <http://www.ilo.org/ilolex/english/newratframeE.htm>. Acesso em: 08 set. 2009.

- Ilolex. Declaração de Filadélfia. Disponível em: <http://www.ilo.org/ilolex/english/constq.htm>. Acesso em: 16 set. 2009.

. Ilolex. Disponível em: <http://www.ilo.org/ilolex/spanish/newratframeS.htm>. Acesso em: 26 nov. 2008.

- Sítio do escritório da OIT em Brasília. Disponível em: http://www.ilo.org/public/portugue/region/ampro/brasilia/info/download/convencao111.pdf>. Acesso em: 20 out. 2009.

OXFORD UNIVERSITY PRESS. Oxford dictionary of business english. Oxford: Oxford University Press, 1994. p. 319, v. price discrimination.

PORTUGAL. Código do Trabalho. Atualizado pela Lei 7 de 12 de fevereiro de 2009. Diário da República Eletrônico. Disponível em: <http://dre.pt/pdf1sdip/2009/02/03000/0092601029.pdf>. Acesso em: 26 out. 2009.

Código do Trabalho. Atualizado pela Lei 7 de 12 de fevereiro de 2009. Diário da República Eletrônico. Disponível em: <http://dre.pt/pdf1sdip/2009/02/03000/0092601029.pdf>. Acesso em: 26 out. 2009.

Código do Trabalho. Atualizado pela Lei 7 de 12 de fevereiro de 2009. Diário da República Eletrônico. Disponível em: <http://dre.pt/pdf1sdip/2009/02/03000/0092601029.pdf>. Acesso em: 26 out. 2009.

Código do Trabalho. Atualizado pela Lei 7 de 12 de fevereiro de 2009. Diário da República Eletrônico. Disponível em: <http://dre.pt/pdf1sdip/2009/02/03000/0092601029.pdf>. Acesso em: 21 nov. 2009.

Código do Trabalho. Atualizado pela Lei 7 de 12 de fevereiro de 2009. Diário da República Eletrônico. Disponível em: <http://dre.pt/pdf1sdip/2009/02/03000/0092601029.pdf>. Acesso em: 30 nov. 2009.

Constituição da República Portuguesa. Tribunal Constitucional. Disponível em: $<$ http://www.tribunalconstitucional.pt/tc/crp.html\#art13>. Acesso em 25 ago. 2009.

Constituição da República Portuguesa.Portal do Governo Português. Disponível em: $<$ http://www.portugal.gov.pt/Portal/PT/Portugal/Sistema_Politico/Constituicao/constituicao_p03.ht m>. Acesso em: 01 dez. 2008.

Lei 18/2004 - 11 de maio de 2004. Faculdade de Direito da Universidade de Coimbra. Enciclopédia Portuguesa de Direitos Humanos. Disponível em: $<$ http://www.fd.uc.pt/hrc/enciclopedia/portugal/legislacao/igualdade/118_2004.pdf>. Acesso em: 27 nov. 2009.

. Lei 18/2004, de 11 de maio de 2004. Diário da República Eletrônico. Id., loc. cit. nota 28. 
PORTUGAL. Lei $\mathrm{n}^{\circ}$ 7/2009. Diário da República Eletrónico. Disponível em: $>$ http://dre.pt/pdf1sdip/2009/02/03000/0092601029.pdf>. Acesso em: 21 set. 2009 Acesso em: 21 set. 2009 Acesso em: 21 set. 2009 Acesso em: 21 set. 2009 Acesso em: 21 set. 2009.

REINO UNIDO. Disability Discrimination Act. OPSI - Office of Public Sector Information. Disponível em: <http://www.opsi.gov.uk/acts/acts1995/ukpga_19950050_en_2\#pt2-pb1-11g4>. Acesso em: 21 set. 2009.

Race Relations Act. OPSI - Office of Public Sector Information. Disponível em: <http://www.opsi.gov.uk/RevisedStatutes/Acts/ukpga/1976/cukpga_19760074_en_2\#pt1-11g1>. Acesso em: 21 set. 2009.

Sex Discrimination Act. Office of Public Sector Information. Disponível em: <http://www.opsi.gov.uk/acts/acts1975/PDF/ukpga_19750065_en.pdf>. Acesso em: 10 nov. 2009.

Sex Discrimination Act. OPSI - Office of Public Sector Information. Disponível em: <http://www.opsi.gov.uk/RevisedStatutes/Acts/ukpga/1975/cukpga_19750065_en_2\#pt1-11g1>. Acesso em: 21 set. 2009.

REPÓRTER DA AGÊNCIA BRASIL. 18 de março de 2008. Disponível em: <http://www.agenciabrasil.gov.br/noticias/2008/03/18/materia.2008-03-18.0853368466/view>, Acesso em: 27 nov. 2008.

REPÚBLICA DA ÁFRICA DO SUL. Constitutional Court of South Africa. Disponível em: $<$ http://www.constitutionalcourt.org.za/site/constitution/english-web/ch2.html>. Acesso em 25 ago. 2009.

REPÚBLICA SUL-AFRICANA. Department of Labour. Employment Equity Act, n. 55 - 1998. Disponível em: <http://www.labour.gov.za/downloads/legislation/acts/employmentequity/Act\%20-\%20Employment\%20Equity.pdf>. Acesso em: 21 set. 2009.

Equity Employment Act. Department of Labour - Republic of South Africa. Disponível em: <http://www.labour.gov.za/downloads/legislation/acts/employment-equity/Act\%20\%20Employment\%20Equity.pdf>. Acesso em: 26 nov. 2009. Tradução livre.

SCRIBD. Tratado de Versalhes. Disponível em: <http://www.scribd.com/doc/11553826/Traite-deVersailles-1919>. Acesso em: 21 jul. 2009.

SUPREMA CORTE DO CANADA. B v. Ontario (Human Rights Commission), [2002] 3 S.C.R. 403, 2002 SCC 66. Université de Montréal. Judgments of the Supreme Court of Canada. Disponível em: <http://csc.lexum.umontreal.ca/en/2002/2002scc66/2002scc66.html>. Acesso em: 08 out. 2009.

. Law v. Canada (Minister of Employment and Immigration) [1999] 1 S.C.R. 497, 170 D.L.R. (4th) 1 [Law]. Université de Montréal. Judgments of the Supreme Court of Canada. Disponível em: <http://csc.lexum.umontreal.ca/en/1999/1999rcs1-497/1999rcs1-497.html>. acesso em: 08 out. 2009.

Law v. Canada (Minister of Employment and Immigration) [1999] 1 S.C.R. 497, 170 D.L.R. (4th) 1 [Law]. Université de Montréal. Judgments of the Supreme Court of Canada. Disponível em: <http://csc.lexum.umontreal.ca/en/1999/1999rcs1-497/1999rcs1-497.html>. Acesso em: 09 out. 2009. 
SUPREMA CORTE DO CANADA. Université du Montréal. Judgments of the Supreme Court of Canada. Disponível em: <http://csc.lexum.umontreal.ca/en/1985/1985rcs2-536/1985rcs2-536.pdf>. Acesso em: 06 out. 2009.

Université du Montréal. Judgments of the Supreme Court of Canada. Canada (Attorney General) v. Mossop, [1993] 1 S.C.R. 554. Disponível em: <http://csc.lexum.umontreal.ca/en/1993/1993rcs1-554/1993rcs1-554.html>. Acesso em: 09 out. 2009.

SUPREMA CORTE DOS ESTADOS UNIDOS DA AMÉRICA. 1991. International Union, United Automobile, Aerospace and Agricultural Implement Workers of America, UAW v. Johnson Controls, Inc. 499 US 187, 111 S. Ct. 1196, 113 L. Ed. 2d. 158. Cornell University Law School. Supreme Court Collection. Disponível em: <http://www.law.cornell.edu/supct/html/historics/USSC_CR_0499_0187_ZS.html>. Acesso em: 13 out. 2001.

_ Cornell University Law School. Supreme Court Collection. Price Waterhouse v. Hopkins. $490 \quad$ U.S. 228, 1989.2 Disponível em: <http://www.law.cornell.edu/supct/html/historics/USSC_CR_0490_0228_ZC.html>. Acesso em: 09 out. 2009.

. Cornell University Law School. Supreme Court Collection. Desert Palace Inc. v. Costa. 539 U.S. 90 (2003). Disponível em: http://www.law.cornell.edu/supct/html/02-679.ZS.html>. Acesso em: 09 out. 2009.

. Cornell University Law School. Supreme Court Collection. Price Waterhouse v. Hopkins. $490 \quad$ U.S. 228, $1989 . \quad$ Disponível em: <http://www.law.cornell.edu/supct/html/historics/USSC_CR_0490_0228_ZC.html>. Acesso em: 09 out. 2009.

. Cornell University Law School. Supreme Court Collection. Wards Cove Packing Co. v. Atonio 490 US 642 (1989). Disponível em: <http://www4.law.cornell.edu/supct/html/historics/USSC_CR_0490_0642_ZD1.html>. Acesso em: 09 out. 2009.

Cornell University Law School. Supreme Court Collection. Desert Palace Inc. v. Costa. 539 U.S. 90 (2003). Disponível em: <http://www.law.cornell.edu/supct/html/02-679.ZS.html>. Acesso em: 09 out. 2009.

Findlaw. Disponível em: $<$ http://caselaw.lp.findlaw.com/scripts/getcase.pl?court=US\&vol=323\&invol=214>. Acesso em: 30 set. 2009.

FindLaw. McDonnell Douglas Corp. v. Green, 411 U.S. 792 (1973). Disponível em: $<$ http://caselaw.lp.findlaw.com/scripts/getcase.pl?court=US\&vol=411\&invol=792>. Acesso em: 13 out. 2009.

Disponível

. Findlaw. Texas Department of Community Affairs v. Burdine 450 US 248 (1981).

$<$ http://caselaw.lp.findlaw.com/scripts/getcase.pl?court=US\&vol=450\&invol=248>. Acesso em: 25 nov. 2009. 
SUPREMA CORTE DOS ESTADOS UNIDOS DA AMÉRICA. Gratz v. Bollinger. 539 US 244 (2003). Cornell University Law School. Supreme Court Collection. Disponível em: <http://www4.law.cornell.edu/supct/html/02-516.ZS.html>. Acesso em: 12 nov. 2009.

. Griggs v. Duke Power Co. 401 US 424, 91 S. Ct. 849, 28 L. Ed.2d 158. Cornell University

Law School. Supreme Court Collection. Disponível em:
$<$ http://www.law.cornell.edu/supct/html/historics/USSC_CR_0401_0424_ZS.html>. Acesso em: 13 out. 2009.

Griggs v. Duke Power Co. 401 U.S. 424 (1971). Justia - US Supreme Court Center. Disponível em: <http://supreme.justia.com/us/401/424/>. Acesso em: 28 out. 2009.

Griggs v. Duke Power Co. 401 U.S. 424 (1971). Justia - US Supreme Court Center. Disponível em: <http://supreme.justia.com/us/401/424/>. Acesso em: 28 out. 2009.

. Grutter v. Bollinger. 539 US 306 (2003). Cornell University Law School. Supreme Court Collection. Disponível em: <http://www4.law.cornell.edu/supct/html/02-241.ZS.html>. Acesso em: 12 nov. 2009.

Ledbetter v. Goodyear Tire \& Rubber Co. 550 U.S. 618 (2007). Cornell University Law School - Legal Information Institute. Disponível em: <http://www.law.cornell.edu/supct/html/051074.ZS.html>. Acesso em: 23 nov. 2009.

. McDonnell Douglas v. Green 411 U.S. 792 (1973). Findlaw - cases and codes. Disponível em: $<$ http://caselaw.lp.findlaw.com/scripts/getcase.pl?court=US\&vol=411\&invol=792>. Acesso em: 24 nov. 2009.

Paul v. Virginia, 75 U.S. (8 Wall.) 168 (1869). Findlaw. Disponível em: $<$ http://caselaw.lp.findlaw.com/scripts/getcase.pl?court=US\&vol=75\&invol=168>. Acesso em: 13 set. 2009.

Price Waterhouse v. Hopkins, 490 U. S. 228 (1989). Cornell University Law School Legal Information Institute. Disponível em: <http://www.law.cornell.edu/supct/html/historics/USSC_CR_0490_0228_ZS.html>. Acesos em: 28 out. 2009.

Price Waterhouse v. Hopkins, 490 US 298 (1989). Cornell University Law School. Supreme Court Collection. Disponível em: <http://www.law.cornell.edu/supct/html/historics/USSC_CR_0490_0228_ZS.html>. Acesso em: 10 nov. 2009.

Regents of The University of California v. Bakke. 438 US 265 (1978). Cornell University Law School. Supreme Court Collection. Disponível em: <http://www.law.cornell.edu/supct/html/historics/USSC_CR_0438_0265_ZS.html>. Acesso em: 12 nov. 2009.

Ricci et al. v. DeStefano et al. 07-1428 (2009). Supreme Court of United States. Disponível em: <http://www.supremecourtus.gov/opinions/08pdf/07-1428.pdf>. Acesso em: 12 nov. 2009.

- Strauder v. West Virginia, 100 US 303 (1880). Disponível em: $<$ http://www.law.cornell.edu/supct/html/historics/USSC_CR_0100_0303_ZS.html>. Acesso em: 21 jul. 2009. 
SUPREMA CORTE DOS ESTADOS UNIDOS DA AMÉRICA. Teamsters v. United States, 431 U. S. 424 (1977). Justia - US Supreme Court Center. Disponível em: <http://supreme.justia.com/us/431/324/case.html>. Acesso em: 28 out. 2009.

Teamsters v. United States. 431 U. S. 324 (1977). Justia. United States Supreme Court Center. Disponível em: <http://supreme.justia.com/us/431/324/case.html>. Acesso em: 09 nov. 2009. The employer simply treats some people less favorably than others because of their race, color, religion, sex, or national origin.

United Airlines v. Evans 431 U.S. 553 (1977). Justia.com United States Supreme Court Center. Disponível em: <http://supreme.justia.com/us/431/553/case.html.. Acesso em: 24 nov. 2009.

United Steelworkers of America v. Weber. 443 US 193 (1979). Findlaw - Law for legal professionals.

Disponível

em:

<http://caselaw.lp.findlaw.com/scripts/getcase.pl?court=US\&vol=443\&invol=193>. Acesso em: 12 nov. 2009.

. Wards Cove Packing Co. v. Atonio. 490 US 642, 109 S. Ct. 2115, 104 L. Ed.2d 733. Cornell University Law School - Legal Information Institute. Disponível em: <http://www.law.cornell.edu/supct/html/historics/USSC_CR_0490_0642_ZO.html>. Acesso em: 13 out. 2009.

Wards Cove Packing Co. v. Atonio. 490 US 642109 S. Ct. 2115, 104, L.Ed. 2d. 733 (1989). Findlaw - For Legal Professionals. Disponível em: $<$ http://caselaw.lp.findlaw.com/scripts/getcase.pl?court=US\&vol=490\&invol=642>. Acesso em: 10 nov. 2009.

Washington v. Davis. 426 U.S. 229 (1976). Cornell University Law School. Supreme Court Collection. Disponível

em: <http://www.law.cornell.edu/supct/html/historics/USSC_CR_0426_0229_ZS.html>. Acesso em: 10 nov. 2009.

TRIBUNAL DE JUSTIÇA DA COMUNIDADE ECONÔMICA EUROPÉIA. Eur-lex. Assunto 109/88. Disponível em: <http://eurlex.europa.eu/LexUriServ/LexUriServ.do?uri=CELEX:61988J0109:PT:HTML>. Acesso em: 30 nov. 2009.

UNIÃO EUROPEIA. Diretiva 2000/43. EURLEX. Disponível em: <http://eurlex.europa.eu/LexUriServ/LexUriServ.do?uri=CELEX:32000L0043:PT:HTML>. Acesso em: 21 set. 2009.

- Diretiva 2000/78. EUR-Lex. Disponível em: <http://eurlex.europa.eu/LexUriServ/LexUriServ.do?uri=OJ:L:2000:303:0016:0022:PT:PDF., Acesso em: 11 nov. 2009.

Diretiva 2000/78. EUR-Lex. Disponível em: <http://eurlex.europa.eu/LexUriServ/LexUriServ.do?uri=OJ:L:2000:303:0016:0022:PT:PDF>. Acesso em: 11 nov. 2009.

Diretiva 2000/78. EURLEX. Disponível em: <http://eurlex.europa.eu/Notice.do?val=237068:cs\&lang=pt\&list=432017:cs, 257961:cs, 237068:cs, \&pos=3\&p age $=1 \& \mathrm{nbl}=3 \&$ pgs $=10 \&$ hwords $=\&$ checktexte $=$ checkbox \&visu=\#texte $>$. Acesso em: 21 set. 2009 . 
UNIÃO EUROPEIA. Diretiva 2002/73. EUR-Lex. Disponível em: <http://eurlex.europa.eu/LexUriServ/LexUriServ.do?uri=OJ:L:2002:269:0015:0020:PT:PDF>. Acesso em: 11 nov. 2009.

Diretiva 2002/73. EUR-Lex. Disponível em: <http://eurlex.europa.eu/LexUriServ/LexUriServ.do?uri=OJ:L:2002:269:0015:0020:PT:PDF>. Acesso em: 11 nov. 2009.

Diretiva 2002/73. EURLEX. Disponível em: <http://eurlex.europa.eu/Notice.do?val=275217:cs\&lang=pt\&list=275217:cs,\&pos=1\&page=1\&nbl=1\&pgs= $10 \&$ hwords $=\&$ checktexte $=$ checkbox $\&$ visu=\#texte $>$. Acesso em: 21 set. 2009.

Diretiva 76/207. EURLEX. Disponível em: <http://eurlex.europa.eu/LexUriServ/LexUriServ.do?uri=CELEX:31976L0207:PT:HTML>. Acesso em: 21 set. 2009.

Diretiva 97/80. EUR-Lex. Disponível em: $<$ http://eurlex.europa.eu/LexUriServ/LexUriServ.do?uri=CELEX:31997L0080:PT:HTML>. Acesso em: 11 nov. 2009.

UNIVERSITÉ DE MONTREAL. LexUM. Canado-American Treaties. Disponível em: <http://www.lexum.umontreal.ca/ca_us/en/cus.1901.147.en.html>.

THE WORLD BANK. News and broadcasts. Disponível em: <http://web.worldbank.org/WBSITE/EXTERNAL/NEWS/0,,contentMDK:21692926 pagePK:3437 0 piPK:34424 theSitePK:4607,00.html>. Acesso em: 27 nov. 2008. 